\title{
EFICIÊNCIA DE ALGUMAS ESTAÇÕES DE TRATAMENTO DE ESGOTOS DE FEIRA DE SANTANA NA REMOÇÃO DE CARGA ORGÂNICA, COLIFORMES, HELMINTOS E PROTOZOÁRIOS E SITUAÇÕES DE RISCO DE USUÁRIOS A JUSANTE DO LANÇAMENTO.
}

\section{ROQUE ANGÉLICO ARAUJO}

Tese apresentada ao Departamento de Saúde Ambiental da Faculdade de Saúde Pública da Universidade de São Paulo para obtenção do Grau de Doutor

Área de Concentração: Saúde Ambiental

ORIENTADORA: PROFESSORA DRA.

WANDA MARIA RISSO GÜNTHER 
A

minha esposa Rita de Cássia, e meus filhos, Lorena, Bruno e Lucas 


\section{AGRADECIMENTOS.}

Os meus sinceros agradecimentos:

A UEFS pela oportunidade para a realização do curso na quase totalidade em Feira de Santana.

A EMBASA por permitir a pesquisa nas plantas de tratamento de esgotos de Feira de Santana.

À Professora Wanda Maria Risso Günther pela orientação e incentivo permanente na realização deste trabalho acadêmico.

Ao Professor Dr. Guido Rummeler e Tânia Lago Coordenador e Secretária, respectivamente, do Curso de Doutorado.

Ao DTEC pelo apoio durante a realização do curso e levantamento de dados.

A Dione Ribeiro S. M. de Araújo - Coordenadora do Laboratório de Saneamento do Departamento de Tecnologia da UEFS pela disponibilidade para coordenar a execução das análises de DBO, DQO e Coliformes.

Aos funcionários do Laboratório de Saneamento da UEFS pela execução das análises.

\section{$>$ Adriano Cosme Pereira Lima - Técnico de Laboratório}

$>$ Elisangela Lisboa de Souza -Técnica de Laboratório

$>$ Antônio Luis Lima -Técnico em Laboratório

$>$ Maria Souza de Almeida - Auxiliar de Laboratório

$>$ Vitor Cavalcante de Carvalho - Estagiário

Ao Professor João Francisco dos Santos - Coordenador do Laboratório de Parasitologia do Departamento de Biologia da UEFS pelo apoio, orientação e disponibilidade para coordenar a execução das análises.

Aos funcionários do Laboratório de Patologia Clínica pela execução das análises.

$>$ Alany Santos Oliveira - Bióloga

> Patrícia Carneiro da Silva - Técnica de Laboratório

$>$ Tahise da Silva Neiva - Estagiária Acadêmica

A José Mário C. Pires - Auxiliar Técnico da EMBASA pelo apoio na coleta, armazenamento, preparo das amostras e transporte até os laboratórios. 
Ao Engenheiro Cícero Carvalho pelo empenho junto à Diretoria da EMBASA para minha liberação para fazer o Curso e liberação das ETEs para desenvolver as pesquisas.

Aos funcionários da EMBASA pela ajuda na busca de relatórios, projetos, levantamento de dados de abastecimento de água e de esgotamento sanitário nos arquivos da EMBASA.

José Roque Santana Pinho - Auxiliar Técnico;

$>$ Gessiara Oliveira Caldas - Assistente Administrativo;

$>$ Ailton Nunes de Almeida - Engo. Civil

> João Marcelo Gonçalves Coelho - Tec. em Quimica 


\section{RESUMO}

Araújo R. A. Estudo da persistência de helmintos e protozoários nos afluentes e efluentes de estações de tratamento de esgotos sanitário em Feira de Santana e levantamento do impacto à saúde de usuários de jusante do lançamento. São Paulo; 2003. [Tese de Doutorado - Faculdade de Saúde Pública da USP].

É comum a ocupação das margens dos recursos hídricos por pessoas que se utilizam das águas desses recursos para vários fins sem qualquer tratamento prévio, estando sujeitas a impactos à saúde devido à poluição causada pelos lançamentos dos esgotos sanitários nesses corpos hídricos.

Essa pesquisa visa caracterizar os afluentes e efluentes de quatro estações de tratamento de esgotos sanitários de comunidades que dispõem dos serviços de abastecimento de água e esgotamento sanitário em Feira de Santana; verificar como ocorre a persistência de parasitas intestinais - helmintos e protozoários - nos esgotos sanitários dessas comunidades; avaliar a eficiência das estações de tratamento estudadas quanto à remoção da carga orgânica e de coliformes; verificar a capacidade de remoção de microorganismos nos sistemas de tratamento de esgotos sanitários estudados; verificar a passagem de microorganismos nos sistemas de tratamento de esgotos estudados e o que isso representa em termos de impacto à saúde dos usuários de jusante dos pontos de lançamentos de efluentes tratados. Tratase de um estudo analítico, constituído de levantamentos de parâmetros: físicos temperatura, $\mathrm{pH}$, vazão -; químicos - $\mathrm{DBO}$ e DQO - e biológicos - coliformes totais e fecais, nove espécies de helmintos e seis espécies de protozoários, parasitos do intestino humano. As coletas de amostras foram realizadas uma vez por semana, durante o período de um ano, em quatro plantas de tratamento de esgotos selecionadas para estudo, em dois pontos - entrada e saída das mesmas. As análises foram executadas no Laboratório de Saneamento do Departamento de Tecnologia e no Laboratório de Parasitologia do Departamento de Biologia, ambos da UEFS Universidade Estadual de Feira de Santana. Os resultados obtidos nos afluentes analisados mostram que nas comunidades pesquisadas há persistência de helmintos e 
protozoários, nas quatro estações do ano; que a eficiência do tratamento nos diferentes sistemas de tratamento de esgotos estudados atende ou se aproxima das exigências previstas em Lei quanto à remoção de $\mathrm{DBO}$ e $\mathrm{DQO}$; que a remoção de coliformes é baixa, embora atenda à exigência prevista em Lei do Estado da Bahia; e que parasitas dos grupos helmintos e protozoários não são retidos pelos sistemas de tratamento e são lançados nos corpos receptores, impactando-os.

Descritores: Tese Acadêmica. Saúde Pública. Esgoto Sanitário. Estudo de avaliação. Parasitos no esgoto. 


\section{SUMMARY}

Araújo R. A. Study of the persistence of helminthes and protozoa in affluent and effluent of sanitary sewer treatment station in Feira de Santana and the evaluation of the impact to the health of launching ebb tide users. São Paulo 2003. [Doctorate Thesis - Public Health School of São Paulo - USP].

The occupation of the margins of water resources by people is a common habit and these people, making use of the water from these resources for many ends without any previous treatment, are subject to health problems due to the pollution caused by the launching of sanitary sewers in these water bodies.

This research aims to characterize the tributaries and effluents of four sanitary sewers treatment stations of communities that make use of sanitation and water supply services in Feira de Santana. It also aims to verify how the persistence of intestinal parasites -helminthes and protozoa -occurs in the sanitary sewers of these communities and to evaluate the efficiency of treatment stations which have been studied in relation to the removal of the organic load and coliformes; to verify the locomotion and removal of microorganisms in the treatment systems of studied sanitary sewers and what impact this represents to the health of the ebb tide users of the launching points of treated effluents. This is an analytical study, consisting of parameters surveys: physical parameters such as temperature, $\mathrm{pH}$, outflow; chemical parameters such as BOD and QOD and biological parameters, such as total and fecal coliformes, nine species of helminthes and six species of protozoa which are parasites of the human intestine. The collect of samples have been carried through once a week, during the period of one year, in four of sewer treatment plants selected for study, in two different points- entrance and exit of the aforesaid plants. The analyses have been made in the Laboratory of Sanitation (in the Technology Department) and in the Laboratory of Parasitology (in the Biology Department), which belong to UEFS - Universidade Estadual of Feira of Santana. The results show that in the researched communities there is persistence of helminthes and protozoa during the four seasons of the year. They also show that the efficiency of the treatment in the different sewer treatment systems which have been studied, fills 
or are next to the requirements stablished by Law, concerning the removal of BOD and QOD, and that the removal of coliformes is reduced and also fits the requirements stablished by the Law of the state of Bahia; that parasites of the helminthes and protozoa groups are not blocked by the treatment system and are launched in the recipient bodies, impacting them.

Describers: Academic Thesis. Public Health. Sanitary sewer. Evaluative study. Parasites on sewer. 


\section{Lista de Figuras.}

Figura 1.1 - Feira de Santana Localização no contesto nacional ................................2

Figura 1.2 - Feira de Santana localização no contesto regional ...................................2

Figura 1.3 - Bacias hidrológicas de Feira de Santana ............................................

Figura 2.1 - Riacho Principal ou Três Riachos ....................................................60

Figura 2.2 - Esquema do lançamento do esgoto sanitário da estação Homero Figueiredo

Figura 2.3 - Esquema da estação de tratamento de esgoto sanitário Homero Figueiredo 69

Figura 2.4 - Esquema do lançamento do esgoto sanitário da estação Viveiros-A......71

Figura 2.5 - Esquema da estação de tratamento de esgoto sanitário Viveiros-A.........73

Figura 2.6 - Esquema do lançamento do esgoto sanitário da estação Viveiros-B......75

Figura 2.7 - Esquema da estação de tratamento de esgoto sanitário Viveiros-B........77

Figura 2.8 - Esquema do lançamento do esgoto sanitário da estação Viveiros-C......79

Figura 2.9 - Esquema da estação de tratamento de esgoto sanitário Viveiros-C........81

Figura 2.10-Esquema do lançamento do esgoto sanitário da estação Lagoa Grande.82

Figura 2.11-Esquema da estação de tratamento de esgoto sanitário Lagoa Grande...85

Figura 2.12 - Esquema do lançamento do esgoto sanitário da estação Feira VII...... 86

Figura 2.13 - Esquema da estação de tratamento de esgoto sanitário Feira VII. ..... 89

Figura 2.14 - Esquema do lançamento do esgoto sanitário da estação Contorno........92

Figura 2.15 - Esquema da estação de tratamento de esgoto sanitário Contorno..........95

Figura 2.16 - Esquema do lançamento do esgoto sanitário da estação Cajueiro...... 96

Figura 2.17 - Esquema da estação de tratamento de esgoto sanitário Cajueiro..........99

Figura 2.18 - Esquema do lançamento do esgoto sanitário da estação Chácara da Mangabeira. 100

Figura 2.19 - Esquema da estação de tratamento de esgoto sanitário Chácara da Mangabeira. 103

Figura 2.20 - Esquema do lançamento do esgoto sanitário da estação Subaé. 105

Figura 5.21 - Esquema da estação de tratamento de esgoto sanitário Subaé. 107 


\section{Lista de Fotos.}

Foto 01 - Lagoa Facultativa da ETE Homero Figueiredo.......................68

Foto 02 - Estação Viveiros-A ...............................................................72

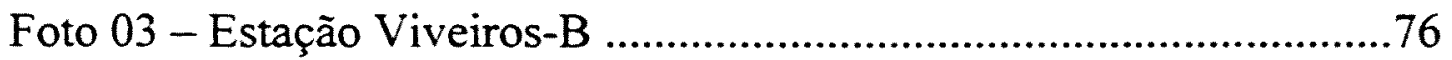

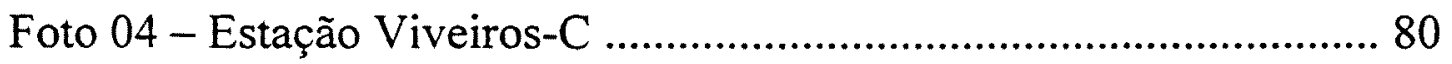

Foto 05 - Estação Lagoa Grande ....................................................... 84

Fotos 06 e 07 _Estação Feira VII ......................................................8

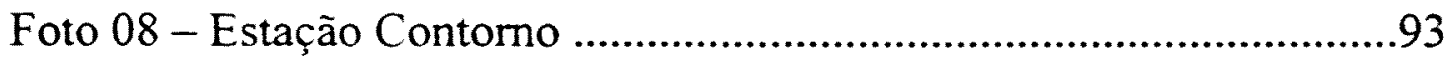

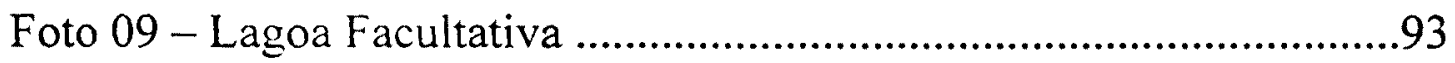

Foto 10 - Decantador, Recirculação de Lodo e Lagoas Aeradas.............94

Foto 11 - Lagoa Aerada ...................................................................94

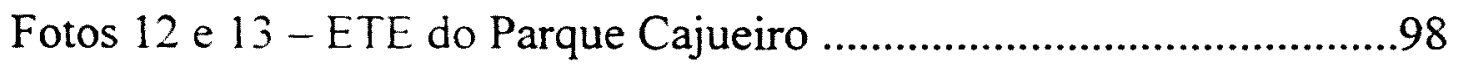

Foto 14 - ETE Chácara da Mangabeira ….........................................102

Foto 15 - ETE Subaé …................................................................106

Foto 16 - Dessedentação de animais (Gado) no Riacho Principal, a jusante da descarga da ETE Contorno ...........................................176

Fotos 17, 18 e 19 - Pescador na área de descarga do Riacho Principal na Bacia da Barragem de Pedra do Cavalo .176

Fotos 20 e 21 - Área de utilização de contato primário, banho, na Bacia da Barragem de Pedra do Cavalo, no ponto da descarga do Riacho Principal .178

Fotos 22 - Área de utilização de contato primário, banho, na Bacia da Barragem de Pedra do Cavalo, junto à BR 116 Sul, adjacente à descarga do Riacho Principal.

Foto 23 - Uma área de plantação irrigada, nos períodos de estiagem, com utilização da água do Riacho Principal, a jusante da descarga da ETE Contorno 


\section{Lista de Tabelas.}

Tabela 2.1 - Tamanho e crescimento da população e disponibilidade de água doce em países com falta d'água

Tabela 2.2 - Tipos e quantidades de microorganismos fecais presentes no afluente e efluente de reatores tipo UASB.

Tabela 2.3 - Tempo de sobrevivência de patogênicos no solo e na superficie com plantas.

Tabela 2.4 - Distribuição do número e porcentagem de óbitos por doenças infecciosas e parasitárias segundo tipos. Brasil e regiões - 1989-1995. Brasil.

Tabela 2.5 - Distribuição do número e porcentagem de óbitos por doenças infecciosas e parasitárias segundo tipos. Brasil e regiões - 1989-1995. Nordeste.. 33 Tabela 2.6 - Distribuição do número e porcentagem de óbitos por doenças infecciosas e parasitárias segundo tipos. Brasil e regiões - 1989-1995. Bahia....... 34 Tabela 2.7 - Resultados de exames parasitológicos de fezes de 2.500 pacientes da Cidade de Belo Horizonte e zonas rurais. 35

Tabela 2.8 - População do Município de Feira de Santana e taxa de crescimento por década, no periodo entre $1940-2000$

Tabela 2.9 - Valor de $\mathrm{DBO}_{5}$ do Riacho Principal entre a descarga da ETE Contorno e o Rio Jacuípe (RP2300) no período de 1989/1992 59

Tabela 2.10 - Valor de $\mathrm{DBO}_{5}$ e Coliformes Fecais no Riacho Principal entre a descarga da ETE Contorno e o Rio Jacuipe (RP2300) em 2000 ......................... 61

Tabela 2.11 - Valor de $\mathrm{DBO}_{5}$ na nascente do Rio Subaé..................................... 62

Tabela 2.12 - Óbitos de Residentes de Feira de Santana segundo causas.......... 66 Tabela 6.1 - Temperatura e pH registrados nos pontos de amostragem, na hora da coleta das amostras, na ETE Homero Figueiredo. 124

Tabela 6.2 - Temperatura e pH registrados nos pontos de amostragem, na hora da coleta das amostras, na ETE Lagoa Grande.

Tabela 6.3 - Temperatura e $\mathrm{pH}$ registrados nos pontos de amostragem, na hora da coleta das amostras, na ETE Viveiros-A. 
Tabela 6.4 - Temperatura e pH registrados nos pontos de amostragem, na hora da coleta das amostras, na ETE Contorno. 126

Tabela 6.5 - Freqüência de amostra com presença de helmintos e protozoários na Comunidade Homero Figueiredo medida no afluente à ETE .128

Tabela 6.6 - Freqüência de amostras com presença de helmintos e protozoários no efluente da ETE Homero Figueiredo.

Tabela 6.7 - Valores médios de $\mathrm{DBO}_{5}$ e DQO encontrados na ETE Homero Figueiredo 131

Tabela 6.8 - Razão da $\mathrm{DQO} / \mathrm{DBO}_{5}$ afluente à ETE Homero Figueiredo. .131

Tabela 6.9 - Valores de Coliformes Totais e Fecais encontrados na ETE Homero Figueiredo 134

Tabela 6.10 - Freqüência de amostra com presença de helmintos e protozoários na Comunidade Lagoa Grande medida no afluente à ETE. 136

Tabela 6.11 - Freqüência de amostras com presença de helmintos e protozoários no efluente da ETE Lagoa Grande. .138

Tabela 6.12 - Valores médios de $\mathrm{DBO}_{5}$ e DQO encontrados no esgoto da ETE Lagoa Grande. .139

Tabela 6.13 - Razão da DQO / $\mathrm{DBO}_{5}$ encontrada no afluente à ETE Lagoa Grande.

Tabela 6.14 - Valores de coliformes totais e fecais encontrados na ETE Lagoa Grande.

Tabela 6.15 - Freqüência de amostras com presença de helmintos e protozoários na Comunidade Viveiros-A medida no afluente à ETE 144

Tabela 6.16 - Freqüência de amostra com presença de helmintos e protozoários no efluente da ETE da Comunidade Viveiros-A.

Tabela 6.17 - Valores médios de $\mathrm{DBO}_{5}$ e DQO encontrados na ETE Viveiros-A...146

Tabela 6.18 - Razão entre DQO / $\mathrm{DBO}_{5}$ para a ETE Viveiros-A............................147

Tabela 6.19 - Valores de Coliformes Totais e Fecais encontrados na ETE Viveiros-A .150

Tabela 6.20 - Frequiência de amostras com presença de helmintos e protozoários na Comunidade Contorno medida no afluente à ETE. 
Tabela 6.21 - Freqüência de amostras com presença de helmintos e protozoários no efluente da ETE da Comunidade Contorno.

Tabela 6.22 - Valores médios de $\mathrm{DBO}_{5}$ e DQO encontrados na ETE Contorno.......154

Tabela 6.23 - Razão da DQO / $\mathrm{DBO}_{5}$ para a ETE Contorno....................................155

Tabela 6.24 -Valores de Coliformes Totais e Fecais encontrados na ETE Contorno....158

Tabela 6.25 - Eficiências das ETEs pesquisadas

Tabela 6.26 - Freqüência de amostras com presença de helmintos e protozoários nos afluentes das ETEs pesquisadas. 163

Tabela 6.27 - Frequeencia de amostras com presença de helmintos e protozoários nos efluentes das ETEs pesquisadas.

Tabela 6.28 - Frequêencia de amostras com presença de helmintos e protozoários no afluente e efluente das ETEs Homero Figueiredo e Lagoa Grande 165

Tabela 6.29 - Freqüência de amostras com presença de helmintos e protozoários no afluente e efluente das ETEs Viveiros-A e Contorno. 166

Tabela 9.1 - Resultados Físico-Químicos da Estação de Tratamento de Esgoto Sanitário Homero Figueiredo. Periodo: Primavera 2001 200

Tabela 9.2 - Resultados Bacteriológicos da Estação de Tratamento de Esgotamento Sanitário Homero Figueiredo. Periodo: Primavera 2001 201

Tabela 9.3 - Resultados das Análises Parasitológicas da Estação de Tratamento Homero Figueiredo. Periodo: Primavera 2001 202

Tabela 9.4 - Resumo dos Resultados das Análises Parasitológicas da Estação de Tratamento Homero Figueiredo. Periodo: Primavera 2001. 203

Tabela 9.5 - Resultados Físico-Químicos da Estação de Tratamento de Esgoto Sanitário Lagoa Grande. Periodo: Primavera 2001 204

Tabela 9.6 - Resultados Bacteriológicos da Estação de Tratamento de Esgotamento Sanitário Lagoa Grande. Período: Primavera 2001 205

Tabela 9.7-Resultados das Análises Parasitológicas da Estação de Tratamento Lagoa Grande. Período: Primavera 2001. 206

Tabela 9.8 - Resumo dos Resultados das Análises Parasitológicas da Estação de Tratamento Lagoa Grande. Período: Primavera 2001 207 
Tabela 9.9 - Resultados Físico-Químicos da Estação de Tratamento de Esgoto Sanitário Viveiros A. Período: Primavera 2001. 208

Tabela 9.10 - Resultados Bacteriológicos da Estação de Tratamento de Esgotamento Sanitário Viveiros A. Período: Primavera 2001 209

Tabela 9.11 - Resultados das Análises Parasitológicas da Estação de Tratamento Viveiros A. Periodo: Primavera 2001. 210

Tabela 9.12 - Resumo dos Resultados das Análises Parasitológicas da Estação de Tratamento Viveiros A. Período: Primavera 2001 211

Tabela 9.13 - Resultados Físico-Químicos da Estação de Tratamento de Esgoto Sanitário Contorno. Período: Primavera 2001

Tabela 9.14 - Resultados Bacteriológicos da Estação de Tratamento de Esgotamento Sanitário Contorno. Periodo: Primavera 2001 213

Tabela 9.15 - Resultados das Análises Parasitológicas da Estação de Tratamento Contorno. Período: Primavera 2001 214

Tabela 9.16 - Resumo dos Resultados das Análises Parasitológicas da Estação de Tratamento Contorno. Período: Primavera 2001 215

Tabela 9.17 - Resultados Físico-Químicos da Estação de Tratamento de Esgoto Sanitário Homero Figueiredo. Período: Verão 2001/2002.

Tabela 9.18 - Resultados Bacteriológicos da Estação de Tratamento de Esgotamento Sanitário Homero Figueiredo. Periodo: Verão 2001/2002. 218

Tabela 9.19 - Resultados das Análises Parasitológicas da Estação de Tratamento Homero Figueiredo. Periodo: Verão 2001/2002

Tabela 9.20 - Resumo dos Resultados das Análises Parasitológicas da Estação de Tratamento Homero Figueiredo. Período: Verão 2001/2002. 220

Tabela 9.21 - Resultados Físico-Químicos da Estação de Tratamento de Esgoto Sanitário Lagoa Grande. Periodo: Verão 2001/2002.

Tabela 9.22 - Resultados Bacteriológicos da Estação de Tratamento de Esgotamento Sanitário Lagoa Grande. Período: Verão 2001/2002. 222

Tabela 9.23 - Resultados das Análises Parasitológicas da Estação de Tratamento Lagoa Grande. Periodo: Verão 2001/2002. 223

Tabela 9.24 - Resumo dos Resultados das Análises Parasitológicas da Estação de Tratamento Lagoa Grande. Periodo: Verão 2001/2002. 224 
Tabela 9.25 - Resultados Físico-Químicos da Estação de Tratamento de Esgoto Sanitário Viveiros A. Período: Verão 2001/2002 ......................................... 225

Tabela 9.26 - Resultados Bacteriológicos da Estação de Tratamento de Esgotamento Sanitário Viveiros A. Periodo: Verão 2001/2002 ............................................. 226

Tabela 9.27 - Resultados das Análises Parasitológicas da Estação de Tratamento Viveiros A. Periodo: Primavera 2001/2002 …....................................................227

Tabela 9.28 - Resumo dos Resultados das Análises Parasitológicas da Estação de Tratamento Viveiros A. Período: Primavera 2001 228

Tabela 9.29 - Resultados Físico-Químicos da Edtação de Tratamento de Esgoto Sanitário Contorno. Periodo: 2001/2002 229

Tabela 9.30 - Resultados Bacteriológicos da Estação de Tratamento de Esgotamento Sanitário Contorno. Período: Verão 2001/2002 .230

Tabela 9.31 - Resultados das Análises Parasitológicas da Estação de Tratamento Contorno. Período: Verão 2001/2002 231

Tabela 9.32 - Resumo dos Resultados das Análises Parasitológicas da Estação de Tratamento Contomo. Período: Verão 2001/2002 .232

Tabela 9.33 - Resultados Físico-Químicos da Estação de Tratamento de Esgoto Sanitário Homero Figueiredo. Período: Outono 2002. .234

Tabela 9.34 - Resultados Bacteriológicos da Estação de Tratamento de Esgotamento Sanitário Homero Figueiredo. Período: Outono 2002. .235

Tabela 9.35 - Resultados das Análises Parasitológicas da Estação de Tratamento Homero Figueiredo. Período: Outono 2002 .....................................................236 Tabela 9.36 - Resumo dos Resultados das Análises Parasitológicas da Estação de Tratamento Homero Figueiredo. Periodo: Outono 2002. 237

Tabela 9.37 - Resultados Físico-Químicos da Estação de Tratamento de Esgoto Sanitário Lagoa Grande. Período: Outono 2002 .238

Tabela 9.38 - Resultados Bacteriológicos da Estação de Tratamento de Esgotamento Sanitário Lagoa Grande. Periodo: Outono 2002. .239

Tabela 9.39 - Resultados das Análises Parasitológicas da Estação de Tratamento Lagoa Grande. Período: Outono 2002. 240

Tabela 9.40 - Resumo dos Resultados das Análises Parasitológicas da Estação de Tratamento Lagoa Grande. Período: Outono 2002. 
Tabela 9.41 - Resultados Físico-Químicos da Estação de Tratamento de Esgoto Sanitário Viveiros A. Período: Outono 2002

Tabela 9.42 - Resultados Bacteriológicos da Estação de Tratamento de Esgotamento Sanitário Viveiros A. Periodo: Outono 2002. 243

Tabela 9.43 - Resultados das Análises Parasitológicas da Estação de Tratamento Homero Viveiros A. Período: Outono 2002. 244

Tabela 9.44 - Resumo dos Resultados das Análises Parasitológicas da Estação de Tratamento Viveiros A. Período: Outono 2002. 245

Tabela 9.45 - Resultados Físico-Químicos da Estação de Tratamento de Esgoto Sanitário Contorno. Periodo: Outono 2002. .246

Tabela 9.46 - Resultados Bacteriológicos da Estação de Tratamento de Esgotamento Sanitário Contorno. Periodo: Outono 2002. 247

Tabela 9.47 - Resultados das Análises Parasitológicas da Estação de Tratamento Contorno. Período: Outono 2002 .248

Tabela 9.48 - Resumo dos Resultados das Análises Parasitológicas da Estação de Tratamento Contomo. Período: Outono 2002 249

Tabela 9.49 - Resultados Físico-Químicos da Estação de Tratamento de Esgoto Sanitário Homero Figueiredo. Período: Inverno 2002. .251

Tabela 9.50 - Resultados Bacteriológicos da Estação de Tratamento de Esgotamento Sanitário Homero Figueiredo. Período: Inverno 2002. .252

Tabela 9.51 - Resultados das Análises Parasitológicas da Estação de Tratamento Homero Figueiredo. Periodo: Inverno 2002. 253

Tabela 9.52 - Resumo dos Resultados das Análises Parasitológicas da Estação de Tratamento Homero Figueiredo. Período: Inverno 2002 .254

Tabela 9.53 - Resultados Físico-Químicos da Estação de Tratamento de Esgoto Sanitário Lagoa Grande. Período: Inverno 2002 .255

Tabela 9.54 - Resultados Bacteriológicos da Estação de Tratamento de Esgotamento Sanitário Lagoa Grande. Periodo: Inverno 2002 .256

Tabela 9.55 - Resultados das Análises Parasitológicas da Estação de Tratamento Lagoa Grande. Período: Inverno 2002 .257

Tabela 9.56 - Resumo dos Resultados das Análises Parasitológicas da Estação de Tratamento Lagoa Grande. Periodo: Inverno 2002 .258 
Tabela 9.57 - Resultados Físico-Químicos da Estação de Tratamento de Esgoto Sanitário Viveiros A. Periodo: Inverno 2002. 259

Tabela 9.58 - Resultados Bacteriológicos da Estação de Tratamento de Esgotamento Sanitário Viveiros A. Periodo: Inverno 2002 260

Tabela 9.59 - Resultados das Análises Parasitológicas da Estação de Tratamento Homero Viveiros A. Período: Inverno 2002 261

Tabela 9.60 - Resumo dos Resultados das Análises Parasitológicas da Estação de Tratamento Viveiros A. Periodo: Inverno 2002. 262

Tabela 9.61 - Resultados Físico-Químicos da Estação de Tratamento de Esgoto Sanitário Contorno. Periodo: Inverno 2002. 263

Tabela 9.62 - Resultados Bacteriológicos da Estação de Tratamento de Esgotamento Sanitário Contomo. Periodo: Inverno 2002 .........................................................264

Tabela 9.63 - Resultados das Análises Parasitológicas da Estação de Tratamento Contorno. Periodo: Inverno 2002 .265

Tabela 9.64 - Resumo dos Resultados das Análises Parasitológicas da Estação de Tratamento Contorno. Periodo: Inverno 2002. 266 


\section{Lista de Siglas.}

ABES - Associação Brasileira de Engenharia Sanitária e Ambiental - Sessão Bahia ANA - Agência Nacional da Água

APEB - Arquivo Público do Estado da Bahia

CEPIS - Centro Pan Americano de Ingenieria Sanitária y Ciências Del Ambiente CEPRAM - Conselho Estadual de Meio Ambiente da Bahia

CETESB - Companhia de Tecnologia em Saneamento Ambiental do Estado de São Paulo

Coli - Coliformes

CONAMA - Conselho Nacional de Meio Ambiente

CRA - Centro de Recursos Ambientais. Órgão da Secretaria de Planejamento do Estado da Bahia

DAFA - Digestor Anaeróbio de Fluxo Ascendente

DATASUS - Dados sobre o Sistema Único de Saúde

DBO - Demanda Bioquímica de Oxigênio

DMAE - Departamento Municipal de Águas e Esgotos. Porto Alegra, RS.

DQO - Demanda Química de Oxigênio

EMBASA - Empresa Baiana de Águas e Saneamento S. A.

EPA - Environmental Protection Agency

ETE - Estação de Tratamento de Esgotos Sanitários

FUNASA - Fundação Nacional de Saúde

IBGE - Instituto Brasileiro de Geografia e Estatística

Inv. - Inverno

IWA - International Water Association

MS - Ministério da Saúde

$\mathrm{N}-\mathrm{Não}$

NMP - Número Máximo Provável

NT002 - Norma Técnica 002 - Padrões de lançamento para efluentes sanitários aprovada através da Resolução $n^{\circ} 2288$ de 24/04/2000 do CEPRAM Bahia.

OD - Oxigênio Dissolvido

OMS - Organização Mundial de Saúde 
OPS -Organização Pan-americana de Saúde

Out. - Outono

pH - Potencial de Hidrogênio

Pri. - Primavera

RP 2300 - Ponto de monitoramento do CRA no Riacho Principal

$\mathrm{S}-\mathrm{Sim}$

SESP - Serviço Especial de Saúde Pública

SABESP - Companhia de Saneamento Básico do Estado de São Paulo

TD - Tempo de Detenção

UASB - Upflow Anaerobic Sludge Blanket

UEFS - Universidade Estadual de Feira de Santana.

UFBA - Universidade Federal da Bahia

UNF - Unidade de Negócio de Feira de Santana

USP - Universidade de São Paulo

Ve. - Verão

WHO - Word Health Organization 


\section{ÍNDICE}

1. INTRODUÇÃO 1

2. REVISÃO BIBLIOGRÁFICA 6

2.1 Recursos hídricos e qualidade das águas $\quad 6$

$\begin{array}{ll}2.2 \text { Esgotamento sanitário } & 14\end{array}$

2.3 Aspectos de saúde e doenças com enfoque em água e esgoto sanitário $\quad 25$

2.3.1 Considerações Gerais 25

2.3.2 Helmintos 36

2.3.3 Protozoários 43

2.4 História Político Administrativa de Feira de Santana 48

2.4.1 O Município de Feira de Santana 48

2.4.2 A Administração de Feira de Santana 51

2.4.3 População de Feira de Santana 53

2.4.4 Recursos hídricos do entorno da cidade de Feira de Santana 54

2.4.5 Abastecimento de água em Feira de Santana 56

2.4.6 Esgotamento sanitário em Feira de Santana 57

2.4.7 Aspectos de saúde e doenças em Feira de Santana 62

2.4.8 Caracterização das estações de tratamento de esgoto de Feira de Santana $\begin{array}{ll}\text { e das comunidades atendidas } & 66\end{array}$

3. HIPÓTESE 109

$\begin{array}{ll}\text { 4. OBJETIVOS } & 109\end{array}$

$\begin{array}{ll}4.1 \text { Objetivo geral } & 109\end{array}$

$\begin{array}{ll}4.2 \text { objetivo específico } & 109\end{array}$

5. METODOLOGIA 111

5.1 Passos da metodologia 111

5.1.1 Levantamento documental 111

$\begin{array}{ll}\text { 5.1.2 Levantamento bibliográfico } & 111\end{array}$

$\begin{array}{ll}5.1 .3 \text { Observações de campo } & 111\end{array}$

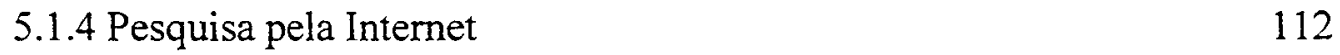

$\begin{array}{ll}\text { 5.1.5 Seleção da amostra } & 112\end{array}$ 
5.1.7 Seleção dos pontos de coleta 114

5.1.8 Definição do período de amostragem $\quad 114$

5.1.9 Definição do tipo e hora da amostragem 114

5.1.10 Definição da quantidade de amostras 115

a) Para as análises de temperatura, vazão e pH 115

b) Para as análises químicas de DBO e DQO 115

c) Para os exames bacteriológicos 115

d) Para os exames de Helmintos e Protozoários 115

5.1.11 Coleta de amostra, armazenamento e transporte 116

a) Para análises de DBO, DQO e Bacteriológica 116

b) Para exames de helmintos e protozoários parasitos do intestino humano 116

5.1.12 Técnica de preparo das amostras para exames de helmintos e protozoários parasitos do intestino humano 117

5.1.13 Determinações e Análises 118

a) Determinação da Temperatura 118

b) Determinação do pH 118

c) Determinação da Vazão 118

d) Análises de DBO e DQO 118

e) Análises de coliformes totais e fecais 119

f) Análises de Helmintos e Protozoários parasitas do intestino humano 119

5.1.14 Avaliação dos resultados $\quad 119$

a) Avaliação das condições de saúde-doença das comunidades estudadas

b) Eficiência em Remoção de Helmintos e Protozoários parasitos do intestino humano

c) Eficiência em Remoção de DBO, DQO e Coliformes e adequação à Legislação e ao projeto

d) Eficiência real e de projeto das estações de tratamento de esgotos estudadas 
f) Levantamento das condiçôes de risco à saúde dos usuários de jusante dos lançamentos das ETEs

6.1.1 Temperatura e pH no ambiente das comunidades e das estações pesquisadas

6.2 Comunidade e ETE Homero Figueiredo

6.2.1 Condição de saúde doença da comunidade

6.2.2 Eficiência de remoção de helmintos e protozoários na ETE Homero Figueiredo

6.2.3 Eficiência de remoção de $\mathrm{DBO}_{5}$ e DQO na ETE Homero Figueiredo e adequação à Legislação e ao projeto

6.2.4 Eficiência de remoção de coliformes na ETE Homero Figueiredo e adequação à Legislação

6.3 Comunidade e ETE Lagoa Grande

6.3.1 Condição de saúde doença da Comunidade

6.3.2 Eficiência de remoção de helmintos e protozoários na ETE Lagoa Grande

6.3.3 Eficiência de remoção de $\mathrm{DBO}_{5}$ e DQO na ETE Lagoa Grande e adequação à Legislação e ao projeto 138

6.3.4 Eficiência de remoção de coliformes na ETE Lagoa Grande e adequação à Legislação

6.4 Comunidade e ETE Viveiros A

6.4.1 Condição de saúde da Comunidade

6.4.2 Eficiência de remoção de helmintos e protozoários na ETE Viveiros-A

6.4.3 Eficiência de remoção de $\mathrm{DBO}_{5}$ e DQO na ETE Viveiros-A e adequação à Legislação e ao projeto

6.4.4 Eficiência de remoção de coliformes na ETE Viveiros-A e adequação à Legislação 
6.5.2 Eficiência de remoção de helmintos e protozoários na ETE Contorno

6.5.3 Eficiência de remoção de $\mathrm{DBO}_{5}$ e DQO na ETE Contorno e adequação à Legislação e ao projeto

6.5.4 Eficiência de remoção de coliformes na ETE Contorno e adequação à Legislação

6.6 Comparação das estações de tratamento

6.6.1 Quanto à remoção de $\mathrm{DBO}_{5}$

6.6.2 Quanto à remoção de coliformes

6.6.3 'Quanto à remoção de helmintos e protozoários

6.7 Levantamento das situações de risco à saúde dos usuários de jusante dos lançamentos das ETEs Homero Figueiredo, Lagoa Grande, Viveiros-A e Contorno

7.1 Estação Homero Figueiredo

7.2 Estação Lagoa Grande 170

7.3 Estação Viveiros-A 172

7.4 Estação Contorno 173

7.5 Geral

8. RECOMENDAÇÕES

Os resultados físico-químicos, bacteriológicos e parasitológicos obtidos na primavera, para a Estação Homero Figueiredo, Lagoa Grande, Viveiros-A e Contorno, estão apresentados nas Tabelas 9.1 a 9.16. 
Os resultados fisico-químicos, bacteriológicos e parasitológicos obtidos no verão, para a Estação Homero Figueiredo, Lagoa Grande, Viveiros-A e Contorno, estão apresentados nas Tabelas 9.17 a 9.32 .

Os resultados físico-químicos, bacteriológicos e parasitológicos obtidos no outono, para a Estação Homero Figueiredo, Lagoa Grande, Viveiros-A e Contorno, estão apresentados nas Tabelas 9.33 a 9.48 .

Os resultados físico-químicos, bacteriológicos e parasitológicos obtidos no inverno, para a Estação Homero Figueiredo, Lagoa Grande, Viveiros-A e Contorno. estão apresentados nas Tabelas 9.49 a 9.64. 


\section{INTRODUÇÃO.}

Feira de Santana é uma cidade do estado da Bahia (Figura 1.1), cortada pelas rodovias: BR - 324 que a liga a Salvador e ao oeste do Estado; BR 116, ligando-a ao Norte e Sul do País; e BA-042 que da acesso a São Gonçalo dos Campos e Conceição da Feira e BR 101 (Figura 1.2). Está localizada nas coordenadas $12^{\circ} 15^{\prime}$ $24^{\prime \prime}$ de latitude S e $37^{\circ} 57^{\prime} 53$ " de longitude, em um platô com altitude média de 242 metros, sendo que seus recursos hídricos alimentam três bacias hidrográficas: Rio Jacuípe (ao Sudoeste); Rio Pojuca (Nordeste); e Rio Subaé (Sudeste). A nascente do Rio Subaé e outras nascentes afluentes deste Rio e dos Rios Pojuca, e Jacuípe ficam na periferia da cidade (Figura 1.3), atualmente ocupada por habitações, indústrias e agroindústrias.

Em Feira de Santana, o abastecimento de água apresenta cobertura de $96 \%$ da população urbana e está avançando para as áreas rurais. Entretanto a coleta e o tratamento dos esgotos sanitários não se desenvolveram da mesma forma que o abastecimento de água. $\mathrm{O}$ atual sistema público de esgotamento sanitário atende somente a $33,5 \%$ da população. Os demais habitantes são potenciais usuários do sistema de esgotamento existente; utilizam-se de fossas sépticas com sumidouros; descarregam os esgotos diretamente nas galerias de drenagem pluvial, ou os lançam a céu aberto, poluindo e contaminando o solo, o aqüífero freático, as nascentes e os córregos que alimentam as bacias hidrográficas citadas.

Ao longo do Rio Subaé e dos afluentes dos Rios Jacuípe e Pojuca, que nascem no perímetro urbano de Feira de Santana, a população ribeirinha faz uso dessas águas para vários fins como: lavar roupas, tomar banho, irrigar hortaliças, dessedentar animais, lazer e, até mesmo, para abastecimento humano, sem que a água sofra qualquer tipo de tratamento prévio. Esta é uma situação comum nas periferias de cidades baianas e às margens dos córregos dessas áreas. No caso de Feira de Santana, a situação se agrava, pois essas águas recebem efluentes de estações de tratamento de esgoto sanitário e/ou contribuições de lançamentos de esgoto sanitário bruto. 


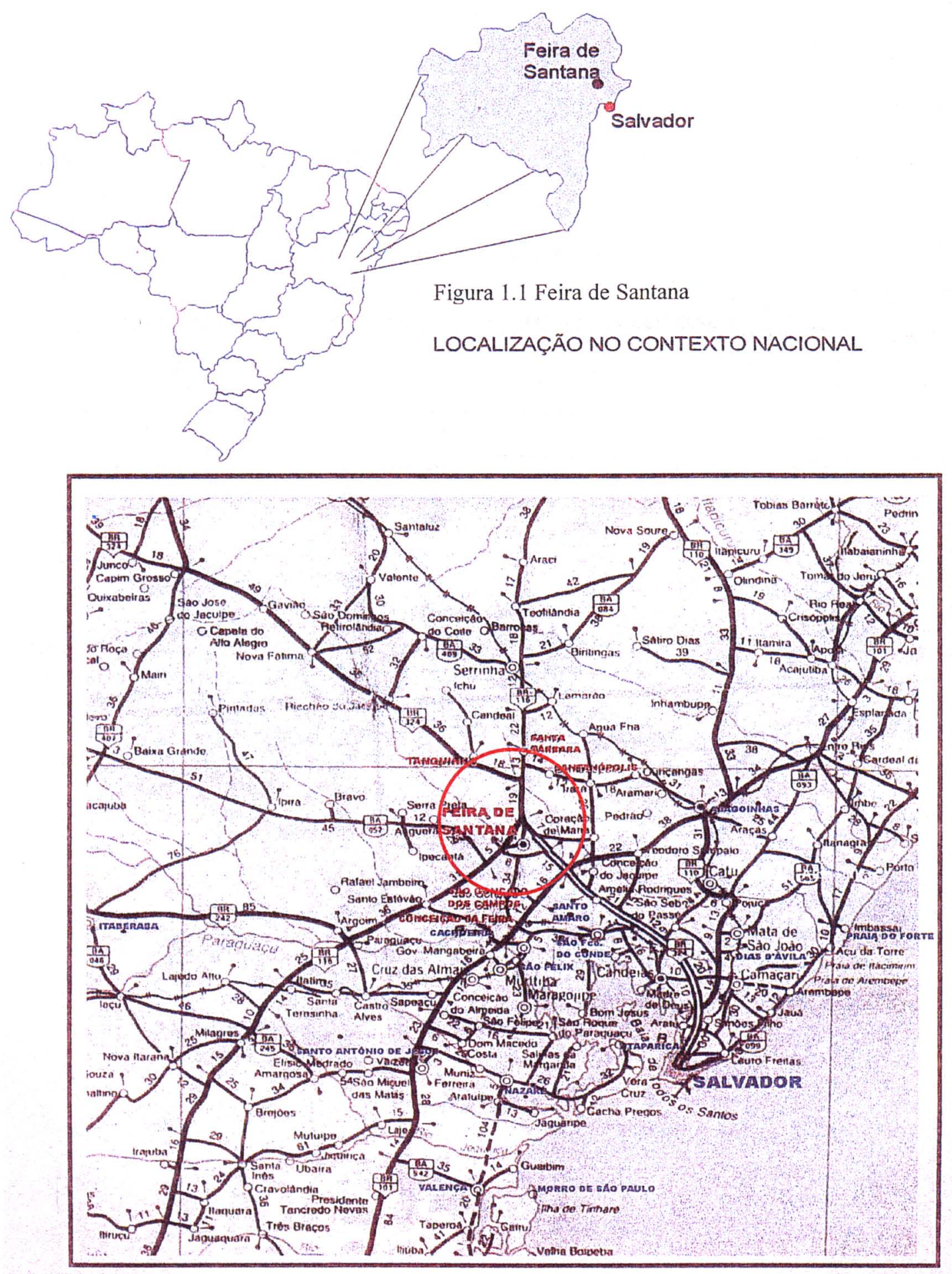

Figura 1.2 Feira de Santana LOCALIZAÇÃO NO CONTEXTO REGIONAL 


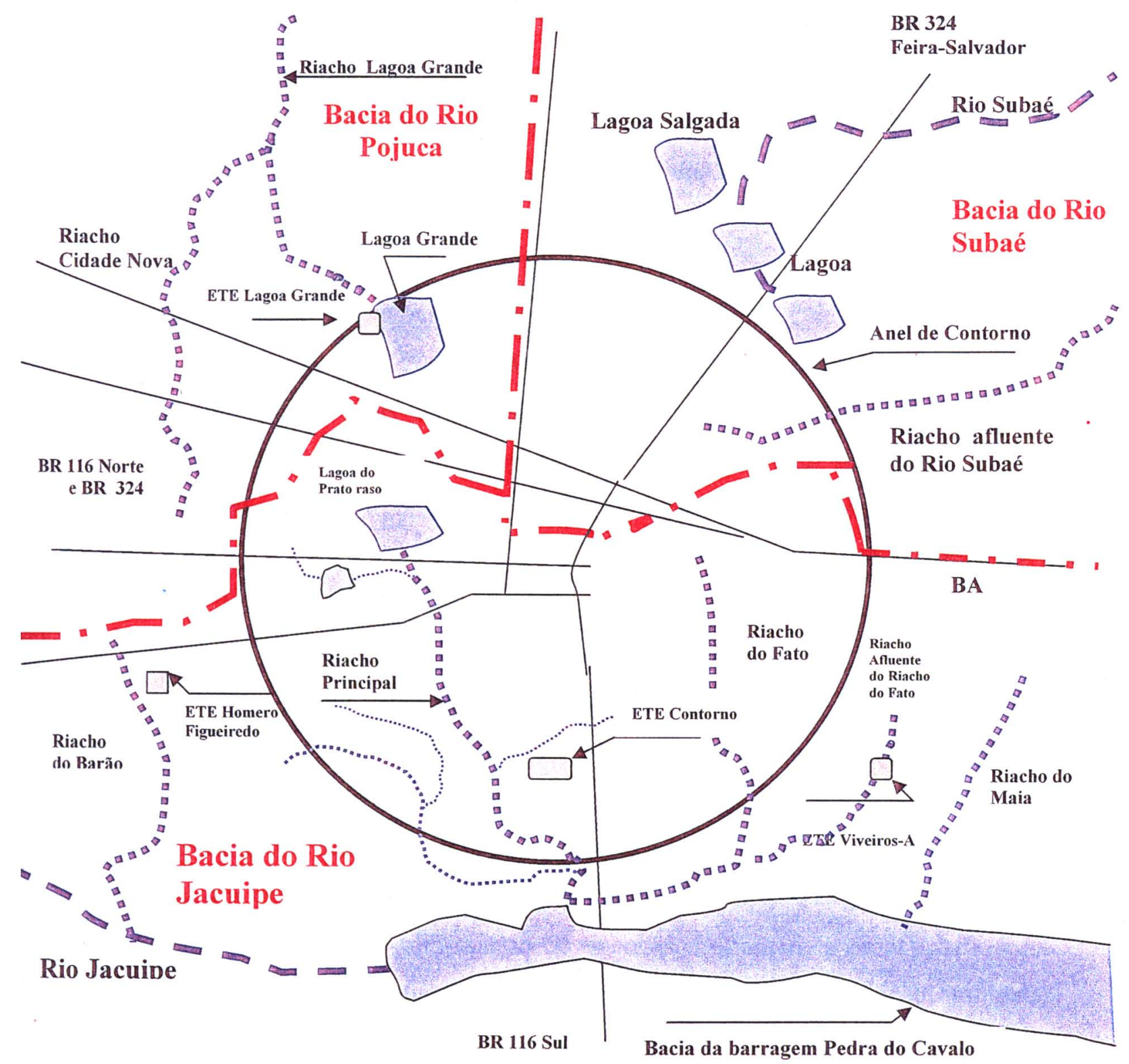

Figura 1.3 Bacias hidrográficas de Feira de Santana

Os padrões de qualidade da água são definidos em função do uso. A Resolução $\mathrm{n}^{\circ} 20$ (CONAMA 1986) classifica as águas do território nacional em doces, salobras e salinas. As águas doces são subdivididas em cinco classes: especial, 1, 2, 3 e 4 . A classe especial é a única que pode ser consumida sem prévia desinfecção, desde que os coliformes totais estejam ausentes em qualquer amostra coletada. A água de classe especial somente é encontrada em mananciais muito protegidos, logo, escassa. Para as demais classes de água doce, faz-se necessário tratamento simples ou completo, dependendo principalmente do número de coliformes presentes. Segundo JULIANO 
(1996) e AISSE (1998), os padrões de qualidade da água são definidos em função dos usos preponderantes dos corpos d'água, que são classificados segundo uma escala de nobreza destes usos, variando do abastecimento doméstico até outros menos exigentes, enquanto que os padrões de lançamento são uniformes e de aplicação geral, independente da natureza do efluente.

Sabe-se, hoje, que a quantidade de água potável no planeta é limitada e tende a se esgotar em futuro próximo. Por falta de alternativa, alguns mananciais poluídos e, às vezes, contaminados estão sendo usados pelo homem sem qualquer tratamento prévio. A forma de preservar os mananciais e garantir sua utilização para as populações presentes e futuras, sem transtornos para o Meio Ambiente e para a Saúde Pública, é assegurar a qualidade dos lançamentos dos esgotos sanitários e efluentes industriais através do tratamento, atendendo tanto à remoção da carga orgânica, quanto à microrganismos e eventuais poluentes químicos.

Sabe-se que os esgotos sanitários são uma grande fonte de microrganismos patogênicos, pois o homem, portador de agentes de doenças e/ou doente, elimina os agentes etiológicos nos excretas. A coleta, o transporte rápido e seguro, e o tratamento dos esgotos sanitários são etapas importantes na melhoria da qualidade de vida e no processo de não transmissão de doenças. Entretanto a preocupação com respeito ao tratamento do esgoto sanitário tem sido atender à legislação ambiental vigente, no que concerne à redução da $\mathrm{DBO}$ a valores considerados aceitáveis pelo corpo receptor, sem um cuidado maior quanto ao limite de descarga de coliformes, salvo situação específica. Os coliformes fecais têm sido utilizados como indicador biológico de poluição das águas, e sua presença caracteriza água como não potável. Na maioria dos casos, a redução desejada e necessária de coliformes, entre a entrada e saída do esgoto na unidade de tratamento, não ocorre. Mesmo quando há uma redução significativa de coliformes durante o tratamento dos esgotos sanitários, não há garantia de que os microorganismos patogênicos remanescentes não ultrapassem os limites físicos da estação de tratamento. SANTOS (1989) afirma que o princípio do saneamento básico está ligado ao conceito da vida, definida como o conjunto de ações e reações entre organismo e o meio, e que só é mantida quando persiste o 
equilíbrio entre um e outro; logo, é de fundamental importância a manutenção de um ambiente salubre.

A preocupação com o tratamento de esgotos sanitários somente no sentido da remoção da DBO não resolve a questão da remoção dos patógenos que, conseqüentemente, são lançados nos corpos receptores. $\mathrm{O}$ uso de água de corpos receptores de esgotos sanitários, mesmo após o seu tratamento pode representar riscos para os usuários, visto que estação de tratamento de água pode não garantir que algumas espécies de microorganismos patogênicos não ultrapassem as barreiras dessa estação. Se o uso da água desse corpo receptor de esgoto sanitário ocorrer sem tratamento o risco do usuário contrair doenças, com certeza, aumenta.

Até 1970, a captação de água para abastecimento da cidade de Feira de Santana ainda era feita apenas através de poços artesianos na bacia do Rio Pojuca e na periferia da cidade. A partir dessa data, pela exaustão da capacidade de produção dos poços artesianos para suprir a demanda de água decorrente do crescimento da cidade, partiu-se para captar água complementar no Rio Paraguassu, a $28 \mathrm{~km}$ de Feira de Santana. O manancial do subsolo da periferia da cidade foi paulatinamente contaminado, chegando ao abandono completo como fonte de captação de água para abastecimento público em 1992. A realidade dos últimos anos permite constatar a obrigatoriedade de suprir sistemas de abastecimento de água com aproveitamento de recursos hídricos situados cada vez mais distantes dos pontos de distribuição, com custos extraordinariamente maiores, decorrentes do sistema de adutoras e elevatórias necessárias (HELLER 1998). Logo, é preciso despertar para essa situação e aceitar o fato de que é menos oneroso proteger os recursos hídricos disponíveis nas proximidades das cidades, para aproveitá-los como fonte de captação de água para os vários usos das populações vizinhas do que buscar novos mananciais, cada vez mais distantes e escassos, ou praticar o re-uso da água. Ignorar a necessidade de preservar os mananciais, fatalmente, provocará um acelerado esgotamento dos recursos hídricos disponíveis. Nessa situação, o re-uso da água, além de mais dificil, será, consideravelmente, mais oneroso (CRESPO 1989). 


\section{REVISÃO BIBLIOGRÁFICA}

\subsection{Recursos hídricos e qualidade das águas.}

Sabe-se que, do total de $1,36 \times 10^{18} \mathrm{~m}^{3}$ de água existente no planeta, $97,0 \%$ são águas salgadas e somente 3,0\% são águas doces, sendo que, desse percentual, 76,7\% (2,3\% do total) estão imobilizadas nas calotas polares e $23,3 \%$ (0,699\% do total) constituem as águas subterrâneas e superficiais. Das águas subterrâneas e superficiais, $0,5 \%$ ( $0,035 \%$ de água doce) estão nos rios, nos lagos e na atmosfera (VON SPERLING 1996a; HELLER 1998).

Segundo BRASIL (2000b; 2000c), indicadores do Banco Mundial mostram que, aproximadamente, 80 países já enfrentam os primeiros problemas com a escassez de recursos hídricos, particularmente os de crescimento populacional acelerado e com carência de água. Essas nações foram divididas em quatro grupos: o primeiro é constituído pelos países que já vêm sofrendo de escassez de água e que, dificilmente, manterão, em 2025, os mesmos níveis de abastecimento de 1990. Fazem parte deste grupo 17 países situados no Oriente Médio, no Sul da África e regiões secas da Índia e China. Nestes paises, vivem um bilhão de habitantes com projeção para 1,8 bilhão em 2025. Na segunda categoria, estão os países que têm recursos potencialmente suficientes, mas que terão que receber recursos técnicos e financeiros para captar água. São 24 nações da África Subsaariana, com uma população de 348 milhões de habitantes, com previsão de chegar em 894 milhões no ano de 2025. Os demais países do planeta Terra estão enquadrados nas categorias 3 e 4, inclusive a América do Norte e Europa, que dispõem de reservas que permitem uma discreta tranqüilidade no abastecimento.

Considera-se que há escassez de água quando uma nação dispõe de menos de 1.000 $\mathrm{m}^{3}$ de água por pessoa por ano, conforme Tabela 2.1, mas quando o valor anual é igual ou inferior a $1.700 \mathrm{~m}^{3}$ de água, o alerta deve ser acionado (BRASIL 2002). 
Tabela 2.1 Tamanho e crescimento da população e disponibilidade de água doce em países com falta de água.

\begin{tabular}{|c|c|c|c|c|}
\hline \multirow[t]{2}{*}{ PAÍS } & \multicolumn{2}{|c|}{1995} & \multicolumn{2}{|c|}{2025} \\
\hline & $\begin{array}{c}\text { População } \\
\left(\times 10^{6)}\right.\end{array}$ & $\mathrm{m}^{3} / \mathrm{hab} / \mathrm{ano}$ & $\begin{array}{c}\text { População } \\
\left(\times 10^{6}\right)\end{array}$ & $\mathrm{m}^{3} / \mathrm{hab} / \mathrm{ano}$ \\
\hline Kuwait & 1,7 & 95 & 2,9 & 55 \\
\hline Irã & 68,4 & 1719 & 128,3 & 916 \\
\hline Emirados Árabes & 2,2 & 902 & 3,3 & 604 \\
\hline Arábia Saudita & 18,3 & 249 & 42,4 & 107 \\
\hline Singapura & 3,3 & 180 & 4,2 & 142 \\
\hline Somália & 9,5 & 1422 & 23,7 & 570 \\
\hline Etiópia & 56,4 & 1950 & 136,3 & 807 \\
\hline Malawi & 9,7 & 1933 & 20,4 & 917 \\
\hline Africa do Sul & 41,5 & 1206 & 71,6 & 698 \\
\hline Egito & 62,1 & 936 & 95,8 & 607 \\
\hline Libia & 5,4 & 111 & 12,9 & 47 \\
\hline Argélia & 28,1 & 527 & 47,3 & 319 \\
\hline Marrocos & 26,5 & 1131 & 39,9 & 751 \\
\hline Haiti & 7,1 & 1544 & 12,5 & 879 \\
\hline Malta & 0,4 & 82 & 0,4 & 71 \\
\hline Israel & 5,5 & 389 & 8,0 & 270 \\
\hline Jordânia & 5,4 & 318 & 11,9 & 144 \\
\hline
\end{tabular}

Fonte: BRASIL 2002.

No caso do Rio Amarelo, na China, a redução, cada vez maior, da vazão, em decorrência das secas, é estarrecedora. Em 1977, a estação de Lijin contabilizou 226 dias de volume de água nulo. O Canadá e os Estados Unidos são exportadores de água para a França e países Asiáticos, mas os EUA proibiram qualquer tipo de extração de água dos Grandes Lagos por período de seis meses, devido à possibilidade de não renovação na mesma proporção da extração. A região dos Grandes Lagos proporciona água potável para mais de vinte e cinco milhões de pessoas do Canadá e Estados Unidos. O norte do México sofre, há mais de oito anos, de seca e está importando água dos Estados Unidos, com necessidade de investimento da ordem de US\$ 1 bilhão para os próximos cinco anos para enfrentar essa dificuldade (BRASIL 2000e; 2001).

É preciso despertar para o fato de que a água é fundamental para a vida, sem ela não há como manter os ecossistemas, sendo básica para o desenvolvimento da humanidade. Para o corpo humano, a água é extremamente importante, pois sua constituição é da ordem de $70 \%$ e, para se manter esta relação, é preciso que se beba, em média, 2 litros de água por dia. Se uma pessoa perder $10 \%$ da água de seu corpo, 
sua vida fica em situação de risco; se perder $20 \%$, a condição é tão grave que pode levá-la à morte (BRANCO 1978; BRASIL 2002).

As condições de escassez de água associadas ao acréscimo do custo de obtenção da mesma conduzem o homem a aceitar o fato de que é mais lógico e mais econômico proteger os recursos hídricos disponíveis nas proximidades dos centros urbanos e aproveitá-los para os mais diversos usos (CRESPO 1989). Lamentavelmente, a água tem se tornado escassa, tanto em quantidade, quanto em qualidade. A realidade das últimas décadas permite constatar que, em toda cidade de porte, o suprimento dos sistemas de abastecimento de água está sendo feito aproveitando-se recursos hídricos situados cada vez mais distantes dos centros de distribuição. Isto se deve não somente ao acréscimo de demanda, mas, principalmente, à deterioração da qualidade da água dos recursos hídricos próximos às cidades, devido aos lançamentos de despejos sem qualquer controle. Essa realidade tem gerado, via de regra, soluções extraordinariamente onerosas em razão das adutoras e elevatórias exigidas. Como recurso natural limitado, a água tem valor econômico, conseqüentemente, papel estratégico e, como recurso ambiental, deve ser preservado e seus mananciais, recuperados (HELLER 1998). A água pode representar divisas, como no caso do Canadá e dos Estados Unidos que exportam para França, México e países asiáticos, ou um bem econômico, conforme modelo mexicano, onde é cobrada. No Brasil, com a implantação da Política Nacional de Recursos Hídricos, que reconhece a água como bem finito e de valor econômico, o uso das águas dos recursos hídricos será cobrado.

A preocupação com a preservação da água no Brasil é antiga. Em 1934, o Código das Águas tratava do assunto, mas só em 1981, através da Lei Federal nº 6938 (BRASIL 1997a), que instituiu a Política Nacional do Meio Ambiente, ficou consagrada a responsabilidade de que o poluidor é obrigado, independentemente da existência de culpa, a indenizar ou a reparar os danos causados ao meio ambiente e a terceiros, afetados por sua atividade. A Lei Federal $n^{\circ}$ 9433, de 08 de janeiro de 1997, (BRASIL 1997b), instituiu a Política Nacional de Recursos Hídricos e, no seu artigo $1^{\circ}$, estabelece os seguintes princípios: adoção da bacia hidrográfica como unidade de 
planejamento; usos múltiplos; reconhecimento da água como um bem finito e vulnerável; reconhecimento do valor econômico da água; e o princípio do sistema de gestão descentralizada e participativa (BRASIL 2002).

Para definição e implantação da Política Nacional de Recursos Hídricos e do Sistema de Gestão, foi criada a ANA - Agência Nacional da Água, através da Lei Federal 9.984, de 17 de julho de 2000 (BRASIL 2003).

Com o funcionamento da ANA, aguarda-se, com certa apreensão, o manejo das bacias hidrográficas, visando garantir a qualidade da água e controlar os usos, embora os recursos hídricos em água doce no Brasil representem 19\% do disponível no mundo. Entretanto. estes recursos, quase sempre, estão localizados distantes dos centros urbanos. Quanto aos disponíveis nas proximidades, verifica-se que estão sendo poluídos continuamente. Segundo BRASIL (2002), dados levantados pelo governo indicam que $90 \%$ dos esgotos urbanos no país ainda não têm tratamento em condições consideradas perfeitamente adequadas. Para melhorar a qualidade dos lançamentos, o governo e a comunidade científica não têm poupado esforços no desenvolvimento de técnicas de tratamento e disposição de esgotos sanitários, visando devolver ao meio ambiente a água em condições semelhantes àquela captada, e assegurar o desenvolvimento sustentável, principalmente, para a sobrevivência humana.

Do ponto de vista da potabilidade, o conceito de água pura é totalmente diverso do conceito químico. A pureza química da água é, não só dispensável, como, até, indesejável para consumo humano. A água é um alimento que, embora não tenha valor energético, contribui fundamentalmente para a edificação do organismo, fazendo parte da composição celular de maneira preponderante (BRANCO 1978). Por essas razões, a água potável é indispensável à vida humana.

Desde a Antiguidade a água potável já era considerada importante para o homem, por isso, usava-se a subterrânea para as necessidades de abastecimento por ser considerada vinda de um manancial de cuja "pureza" não havia dúvidas. A sabedoria 
dos mais velhos já nos ensinava que água de poço é "pura", fresquinha e tem sabor como nenhuma outra. E ainda hoje, muita gente prefere pagar muito mais caro por um copo de água mineral - extraída de fontes do subsolo - julgando que assim estará consumindo um produto de qualidade incontestável (BRASIL 2000c).

O conceito de que a água subterrânea (água de poço) é "pura" começa a ser contestado. Dados divulgados em revista técnicas mostram que água de lençol freático pode não ser segura. Esta situação está sendo comprovada em várias pesquisas realizadas no mundo, e, inclusive em alguns casos, a poluição é irreversivel. Nas últimas décadas, químicos europeus vêm documentando, cada vez com maior freqüência, a contaminação, por fármacos, dos lagos, fontes e água subterrânea. Recentemente, em São Francisco, cientistas norte-americanos e canadenses apresentaram confirmação preliminar de que resíduos de medicamentos, oriundos dos esgotos de clínicas de pessoas e de animais, também poluem as águas. Eles mostraram suas descobertas no primeiro grande simpósio sobre fármacos na água, como parte do encontro anual da Sociedade Americana de Química. Outro relato mostra dados de descoberta, na Alemanha, de resíduos não diluídos de carbamazepine, uma droga anticonvulsiva, e de uma substância a base de iodo usada como contrastante para Raio-X (BRASIL 2000e). A poluição dos corpos d'água subterrâneos e superficiais tem-se acelerado em decorrência da negligência do homem quando do lançamento dos resíduos gerados.

Enquanto a quantidade e tipos de resíduos produzidos pelos homens eram compatíveis com a capacidade de absorção do ambiente natural, conseguia-se garantir qualidade de vida sem que houvesse uma grande preocupação com a sua destinação. Com o crescimento da população, o surgimento dos aglomerados urbanos e o desenvolvimento tecnológico, o homem passou a gerar resíduos líquidos, sólidos e gasosos em tal quantidade que o ambiente não mais os absorve de forma natural. A partir daí, a não geração, ou redução da geração, ou o recolhimento e destinação adequada dos dejetos tornaram-se de grande importância para garantir a qualidade da água é, conseqüentemente, a sobrevivência do próprio homem. 
A descoberta dos microorganismos por Leewenhoek em 1683, e a constatação, por Koch, Pasteur e outros, de que muitos deles são causadores de enfermidades ampliaram os conhecimentos sobre os agentes etiológicos, permitindo formatar, com maior segurança, metodologia para proteção da qualidade da água potável. Doenças são originadas de microorganismos e estes não são gerados espontaneamente na água, mas devem ser levados a ela pelas dejeções de pessoas portadoras dessas mesmas doenças. A associação dessas doenças com caracteres tais como turbidez, cor, odor ou sabor da água perdeu, a partir de então, todo o seu significado. Todas as medidas de controle sanitário da qualidade da água passaram a se basear na proteção dos corpos d'água contra a introdução de elementos tóxicos e patogênicos. $\mathrm{E}$, como o veículo principal dos patogênicos são os dejetos humanos, o seu controle passou a ser realizado através de medidas visando caracterizar e mensurar as concentrações de matéria fecal na água (BRANCO 1978).

A pesquisa de microorganismos patogênicos na água requer procedimentos complexos e longo tempo para obtenção dos resultados. Isto inviabiliza sua aplicação na rotina diária das estações de tratamento e na rede de distribuição, além do que, normalmente, encontram-se em número reduzido, e sua chegada à água é intermitente. Portanto, para avaliação da qualidade da água, do ponto de vista bacteriológico, é imprescindível a utilização de organismos indicadores de contaminação fecal, tais como os coliformes totais, coliformes fecais, E. coli e estreptococos fecais, por estarem presentes na flora intestinal humana e na de animais homeotermos. Outros indicadores foram propostos e todos apresentam vantagens e desvantagens na aplicação prática para a avaliação da qualidade da água para consumo humano. Em âmbito nacional e internacional, a base da indicação de qualidade da água está na deteç̧ão e numeração de coliformes totais, coliformes fecais e E. coli (CONAMA 20 1986; WHO 1987; LIMA et al 1999).

As bactérias indicadoras normais de poluição fecal, coliformes fecais e $E$. coli, ainda são os melhores indicadores, apesar de não preencher as características ideais, visto que existem outros coliformes termotolerantes, como a do gênero klebsiella, que não são de origem exclusivamente excrementícia, comprometendo a especificidade desse 
subgrupo como indicador de contaminação fecal (EDBERG et al. 1986). Observa-se também que a $E$. coli, por ser um microrgnismo presente na flora intestinal humana $\mathrm{e}$ na de animais homeotermos e constituir o principal componente do grupo de coliformes fecais, dela foram reconhecidas cepas como patogênicas, após 1950, pois podem causar diferentes doenças, como enfermidades diarréicas, infecções locais, meningite, septicemia, síndrome urêmica hemolítica e enfermidades imunológicas (SUSSMAN 1985; LIMA et al 1999).

Os organismos indicadores, comumente empregados, servem, apenas, para mostrar a existência da poluição fecal, não podendo ser tomados como medida do grau da poluição ou da presença de microorganismos patogênicos. De modo geral, se for constatada a contaminação fecal de uma água, pode-se supor a presença de elementos patogênicos nessa água (BERNARDE 1973; LEWIS 1986; PAGANINI 1996).

Nos climas tropicais, os usos mais importantes para as águas de superficie são, geralmente, piscicultura, irrigação e abastecimento público. Garantir a qualidade da água em padrões adequados ao consumo humano torna-se demasiadamente dispendioso, mesmo quando os padrões possam ser consideravelmente inferiores às diretrizes estabelecidos pela Organização Mundial de Saúde - OMS. Logo, segundo PESCOD (1974) é menos dispendioso manter um rio em condições adequadas para a piscicultura, irrigação, dessedentação de animais do que se desenvolver fontes alternativas para o abastecimento doméstico.

O padrão brasileiro de qualidade dos mananciais está definido de acordo com a Resolução $n^{\circ} 20$ (CONAMA 1986). De acordo com esse padrão, os corpos d'água de Classe 1 e 2 podem ser utilizados para proteção das comunidades aquáticas, bem como para abastecimento doméstico juntamente com os corpos d'água de Classe 3. Este último ainda pode ser utilizado para dessedentação de animais, entretanto, a utilização dessas águas para consumo humano só é possível se for observada a qualidade conforme prevê a Portaria 1469 de 29 de dezembro de 2000 (MS 2001) que substitui a Portaria 36 de 19 de janeiro de 1990 (MS 1997). 
A Portaria 1469 (MS 2001), quanto à qualidade bacteriológica da água para consumo humano, estabelece que esta, pós-tratada, não deve ter Escherichia coli ou coliformes termotolerantes no sistema de distribuição (reservatórios e rede). Nos sistemas que analisam 40 ou mais amostras de $100 \mathrm{ml}$ por mês só é aceitável a presença de coliformes totais em até $5 \%$ das examinadas nas saidas do tratamento. Nos que analisam menos de 40 amostras por mês, só uma pode apresentar contaminação.

Para compatibilizar as situações estabelecidas na Resolução $n^{\circ} 20$ (CONAMA 1986) e na Resolução 1469 (MS 2001) é indispensável que a água para consumo humano seja precedida de tratamento, seguida de desinfecção. O Ministério da Saúde recomenda teor mínimo de $0,5 \mathrm{mg} / \mathrm{l}$ de cloro residual livre, sendo obrigatória a manutenção de, no mínimo, $0,2 \mathrm{mg} / \mathrm{l}$ em qualquer ponto da rede de distribuição.

Quanto aos lançamentos de despejos nos corpos receptores, não há padrões para coliformes, mas, tão somente para corpos d'água. A quantidade limite de 1000 coliformes fecais por $100 \mathrm{ml}$, água da Classe 2, é extremamente dificil de ser satisfeita, a menos que haja uma etapa específica de remoção de patogênicos no tratamento de esgotos. A cloração de esgotos é raramente praticada no Brasil, a ozonização apresenta custos proibitivos e a radiação ultravioleta é promissora, mas ainda pouco utilizada (VON SPERLING 1998). Logo, as águas residuárias devem ser tratadas antes do lançamento em corpo receptor a fim de evitar disseminação de doenças transmissiveis, causadas pelos organismos patogênicos nela existentes e evitar a poluição das águas subterrâneas e de superfície (SILVA e MARA 1979).

Mais recentemente, algumas estações de tratamento de esgotos sanitários onde os lançamentos podem afetar populações associadas ao turismo, por exemplo, já contam com a desinfecção com ultravioleta, como o caso de Porto Seguro, São Francisco do Conde e Praias do Forte, na Bahia. 


\subsection{Esgotamento sanitário}

$\mathrm{Na}$ flora intestinal do homem, estão presentes microrganismos da espécie coliformes. A quantidade de coliformes presentes nos excretas é muito grande e dá uma boa idéia da matéria fecal provinda dos esgotos domésticos. Um adulto médio expele cerca de dois milhões de coliformes por dia (GELDREICH 1966). Valores altos de coliformes encontrados nos corpos d'água significam grande incidência de esgotos produzidos recentemente. Valores baixos significam baixa incidência de esgotos ou grande diluição ou, ainda, certo tempo após o lançamento porque esses microrganismos da flora intestinal não duram muito no ambiente e decaem exponencialmente (VASCONCELOS 1991).

Excretas de pessoas doentes ou portadoras sãs, além dos coliformes fecais, são fontes de microrganismos patogênicos como: Ascaris, Enterobius, Bacillus anthracis, Brucella, Entamoeba histolytica, Leptospira icterohaemorrhagiae, Mycobacterium tuberculosis, Salmonella paratyphi, Salmonella, Schistosoma, Shigella, Taenia, Vibrio cholerae, Giardia lamblia, Cryptosporidium parvum, e vírus, entre outros (MENDONÇA 1987; MOTA 1997). Esses microrganismos podem chegar ao homem através de vários veículos como água e alimentos contaminados, contato direto, entre outros, podendo causar doenças como Ascaridiose, Verminose, Antrax, Brucelose, Disenteria amebiana, Leptospirose, Tuberculose, Febre tifóide, Febre paratifóide, Envenenamento, Esquistossomose, Disenteria bacilar, Solitária, Cólera, Giardiase, Envenenamento, Poliomielite e Hepatite.

Bactérias do grupo coliformes fecais presentes na água indicam poluição fecal e que, portanto, ele pode conter organismos patogênicos (SILVA e MARA 1979). Logo, para avaliação da qualidade da água para consumo humano ou de um corpo receptor, do ponto de vista bacteriológico, é indispensável utilizar-se um indicador de contaminação fecal visto que os excretas humanos podem ser fontes de microrganismos patogênicos. A Portaria $n^{\circ} 1469$ (MS 2001) estabelece os padrões de qualidade da água para consumo 
humano. Quanto à definição da qualidade bacteriológica para os lançamentos de efluentes de estações de tratamento de águas residuárias, alguns países têm adotado padrões, determinando o número máximo permissivel de coliformes fecais (SILVA e MARA 1979). No Brasil, não existe padrão para lançamento de coliformes, mas sim, padrão de qualidade para os corpos hídricos receptores. Entretanto, alguns estados da Federação instituiram padrão de lançamento de coliformes, como o Estado da Bahia. Na Resolução $n^{\circ} 2288$ (CEPRAM 2000), no item 6 - Disposições Gerais da NT002 (Normas Técnicas 002) sobre padrões de lançamento para efluentes sanitários, consta que os empreendimentos imobiliários habitacionais serão enquadrados em função do padrão de renda familiar e de interesse social, de acordo com as seguintes categorias:

I. Construções Imobiliárias Habitacionais destinadas a famílias com renda mensal de 0 a 12 salários mínimos;

II. Construções Imobiliárias Habitacionais destinadas a famílias com renda mensal superior a 12 salários mínimos;

III. Reurbanização de áreas carentes, tais como: melhorias habitacionais, implantação de infra-estrutura urbana e equipamentos comunitários;

Os sistemas de tratamento adotados para as categorias I e III, mencionadas no item 6 da NT002 da Resolução 2288 (CEPRAM 2000) deverão atender à eficiência mínima para os seguintes parâmetros: $80 \%$ de remoção de $\mathrm{DBO}_{5}-$ Demanda Bioquímica de Oxigênio, $70 \%$ de remoção MS - Material Sólido e redução de coliformes fecais de $10^{7}$ para $10^{6} \mathrm{CF} / 100 \mathrm{ml}$.

Os sistemas de tratamento adotados para as categorias II, mencionadas no item 6 da NT002 da Resolução 2288 (CEPRAM 2000) deverão atender à eficiência mínima para os seguintes parâmetros: $90 \%$ de remoção de $\mathrm{DBO}_{5}$ - Demanda Bioquímica de Oxigênio, $90 \%$ de remoção MS - Material Sólido e redução de coliformes fecais de $10^{7}$ para $10^{6} \mathrm{CF} / 100 \mathrm{ml}$. 
O padrão de efluente de tratamento de esgoto sanitário em coliformes fecais conforme NT002 da Resolução 2288 (CEPRAM 2000) - $10^{6} \mathrm{NMP} / 100 \mathrm{ml}$ - não representa avanço, pois uma ETE com baixa eficiência em remoção de coliformes garante efluente com essa ordem de grandeza em remoção. Na NT002 da Resolução 2288 (CEPRAM 2000), não consta qualquer referência quanto à diluição dessa carga no corpo receptor que, para garantir a Classe 2, conforme Resolução n² 20 (CONAMA 1986), seria necessária vazão do corpo receptor mil vezes maior que a vazão do efluente da ETE $\left(10^{6}\right.$ $/ 10^{3}=10^{3}$ ), não havendo qualquer carga de coliformes a montante do lançamento, situação dificil de ocorrer na prática. Quanto à remoção de $\mathrm{DBO}_{5}$ a NT002 da Resolução 2288 (CEPRAM 2000), faz-se distinção quanto ao grau de tratamento para empreendimentos de classes sociais diferentes, ou seja, exige-se maior eficiência para empreendimentos de classe social não popular. Entretanto, verifica-se que a quantidade de pessoas de classe social popular é bem maior que a não popular. Conseqüentemente, essa classe produz maior volume total de esgoto com menor exigência em eficiência, gerando maior poluição e contaminação, visto que as classes sociais mais baixas têm maior índice de doenças.

$\mathrm{O}$ uso de água contaminada por despejos domésticos pode gerar graves problemas à saúde, em decorrência das doenças possíveis de ocorrer. Assim, o tratamento dos esgotos sanitários passa a ser de grande importância para a saúde pública. O princípio do Saneamento Básico está ligado ao conceito da vida, que é definido como o conjunto de ações e reações entre organismo e o meio, que só é mantido quando persiste o equilíbrio entre um e outro (SANTOS 1989).

Enquanto a quantidade de despejos produzidos pelo homem era compatível com a capacidade de absorção do ambiente natural, conseguia-se garantir a qualidade de vida do homem sem que houvesse uma grande preocupação com a sua destinação. Com o surgimento dos aglomerados urbanos, crescimento da população, o surgimento de novas tecnologias, entre outras causas, o homem passou a gerar despejos, esgotos, em quantidades tais que, dependendo da infra-estrutura sanitária, não mais é possível o 
ambiente absorvê-los naturalmente (BRINGHENTI 1999). Desta forma, torna-se indispensável a adoção de medidas, visando à redução do impacto ambiental. A redução dos resíduos na fonte para valores possíveis de serem absorvidos pelo ambiente, de forma natural, é uma alternativa muito importante, entretanto, só mais recentemente, esta alternativa passou a ser viável na prática, ainda assim, para alguns casos. Anteriormente, a solução possível e viável foi o desenvolvimento de técnicas de tratamento dos despejos seguindo-se o que se verifica na natureza, com melhorias desses processos naturais, instalando-se sistemas de coleta, transporte e tratamento dos esgotos gerados e sua posterior disposição em corpo hídrico receptor.

Para manter o enquadramento dos corpos hídricos, receptores de esgotos sanitários, conforme Resolução $\mathrm{n}^{\circ} 20$ (CONAMA 1986) as águas residuárias devem ser tratadas adequadamente, antes do lançamento no corpo receptor, não só para reduzir a carga orgânica, mas, também, para evitar a disseminação das doenças transmissíveis causadas pelos organismos patogênicos, possivelmente existentes nos despejos, e a poluição das águas subterrâneas e de superficie. Tratar esgotos domésticos é mais barato que cuidar de doentes em clínicas e hospitais. Segundo AL-LAYLA et al (1980), o custo com um alto grau de tratamento de esgotos é menor que o custo para tratar água poluída para uso doméstico, visto que os esgotos sanitários são, em resumo, águas mais impurezas compostas de matéria orgânica de origem fecal, presentes na forma de material suspenso e dissolvido, sendo que o tratamento garante remoção quase que total da matéria orgânica fecal. O propósito do tratamento dos esgotos sanitários é separar a água das impurezas, tratar estas estabilizando a matéria orgânica e dispor ambas, água e matéria orgânica estabilizada no meio ambiente de forma adequada, ou seja, que atenda a legislação ambiental.

Os processos de tratamento de esgotos são formados por uma seqüência de operações unitárias e podem ser classificados de várias maneiras: tratamentos preliminar, primário, secundário e terciário, em função da qualidade esperada para o efluente final. $O$ grau de tratamento a ser adotado em uma estação deve ser em função da capacidade do corpo 
receptor e do tipo de utilização deste após lançamento do efluente tratado, condições estas que, quase sempre, não são observadas na prática. Os processos básicos de tratamento de esgotos podem ser físicos, químicos ou biológicos, em função das características do efluente a ser tratado. $O$ processo biológico será o enfoque básico deste trabalho visto que é o mais utilizado no momento.

O tanque séptico, possivelmente, foi o primeiro sistema de tratamento de esgotos do tipo anaeróbico, inventado ou descoberto. Ocorreu em 1872 na França, quando Juan Louis Mouras percebeu que o volume de sólidos acumulados durante 12 anos em um tanque de alvenaria que havia idealizado e construído para receber esgotos da cozinha de sua residência, antes de lançar o efluente em um poço absorvente, era muito menor do que havia calculado, ou seja, o volume havia reduzido consideravelmente. $O$ invento foi patenteado por Mouras em 1881 (ANDRADE NETO 1997). Esse sistema de tratamento, hoje, é conhecido como tratamento primário.

Segundo AZEVEDO NETO (1975), é praticamente impossível determinar quando surgiu a primeira lagoa de estabilização, pois a simples descarga acidental de matéria orgânica em uma lagoa natural ou artificial põe em marcha os processos de estabilização, que são naturais. Entretanto, têm-se registros de que, durante a II Guerra Mundial, foram construídas as primeiras lagoas, projetadas com vista a uma solução técnica bem definida e, em 1946, foram publicados resultados completos de operação das estações de Camp Hood, Camp Berkley, no Texas e Shoemaker Naval Station na Califórnia, as quais se encontravam em operação desde 1943.

Nas décadas de 70 e 80 , muitas pesquisas foram realizadas no Brasil, visando ao tratamento de esgotos sanitários, bem como ao desenvolvimento de estações de tratamento e sua implantação. Porém, a preocupação com relação ao tratamento do esgoto sanitário sempre esteve centrada na remoção da matéria orgânica e muito pouco ou nada em termos de eliminação de microrganismos patogênicos, ou seja sem nenhuma preocupação com a saúde pública (AZEVEDO NETO 1985a, 1985b; BRITO 1986; 
CAMPOS 1989; FIGUEIREDO 1985; MACEDO 1985; OLIVEIRA 1983; ROCHA 1985; VIEIRA e ALÉM 1983; VIEIRA 1996; WIENDL 1985) entre muitos outros.

Na década de 90 a preocupação com o tratamento de esgotos sanitários deixa de ser somente com relação à remoção de $\mathrm{DBO}_{5}$ e $\mathrm{DQO}$ e amplia-se para a remoção de microrganismos, sendo que várias soluções foram estudadas e concebidas com esse objetivo. Nas alternativas estudadas, incluem-se o aumento do tempo de detenção hidráulica, para o caso de lagoas, e a desinfecção com gás cloro, ozônio, ultravioleta e até uso de microrganismos predadores de Coliformes.

Segundo BARÉA (1994), o tratamento de esgoto sanitário em UASB - Upflow Anaerobic Sludge Blanket apresenta as seguintes desvantagens:

- Eficiência de remoção limitada a $70-80 \%$ de $\mathrm{DBO}_{5}$, em um estágio;

- Processo aplicado somente a esgoto com temperatura >=15 graus centígrados;

- Processo bastante afetado por grande número de compostos químicos;

- Partida das estações levando de 3 a 4 meses para o seu pleno funcionamento;

- Baixa remoção de nutrientes (Nitrogênio, Fósforo e Potássio);

- Baixa remoção de coliformes e patogênicos é baixa.

Segundo GASI (1988, 1991) e VIEIRA (1996) nos reatores UASB, ocorre remoção de coliformes totais e fecais, estreptococos fecais, clostridium perfrigens, Salmonella $s p$. colifagos, ovos e larvas de helmintos e cistos de protozoários. No entanto, a remoção de indicadores bacterianos e virais não é suficiente, do ponto de vista de saúde pública.

Estudos realizados com reatores anaeróbicos de fluxo ascendente e manto de lodo para tratamento de esgotos domésticos mostraram que a remoção de patogênicos - coliformes - ocorria na faixa de 80 a $90 \%$, contra 70 a $80 \%$ de remoção de $\mathrm{DBO}_{5}$ para tempo de detenção de 3 a 5 horas, e que outros tipos de tratamento, como lodos ativados, também não são eficientes na remoção de patogênicos (SOUZA e VIEIRA 1986; VIEIRA 1996; NUNES 1998). 
Os reatores do tipo RALF são amplamente utilizados no Paraná, pela Sanepar, para o tratamento de efluentes. $O$ esgoto sofre o tratamento preliminar no qual se removem os sólidos grosseiros, depois é seguido pelo RALF, resultando em uma eficiência de remoção de $\mathrm{DBO}_{5}$ de aproximadamente $70 \%$. Esta taxa, apesar de alta, requer que o esgoto efluente receba um polimento para a remoção de coliformes ou patogênicos e aumentar a eficiência da remoção de $\mathrm{DBO}_{5}$. A necessidade desse polimento deve-se ao iminente risco de existência de água contaminada com patogênicos e serve para diminuir o impacto no ambiente, decorrente da carga orgânica restante (LEITE e AISSE 1998).

$\mathrm{Na}$ Tabela 2.2, estão listados os tipos e quantidades de microrganismos fecais encontrados nos esgotos afluentes e efluentes de reatores tipo UASB em operação pela SABESP - Companhia de Saneamento Básico do Estado de São Paulo.

Tabela 2.2 - Tipos e quantidades de microrganismos fecais presentes no afluente e efluente de reatores tipo UASB.

\begin{tabular}{l|l|l}
\hline Microorganismo & Afluente & Efluente \\
\hline Coliformes Totais* & $1,1 \times 10^{8}$ & $1,2 \times 10^{7}$ \\
\hline Coliformes Fecais* & $1,6 \times 10^{7}$ & $4,1 \times 10^{6}$ \\
\hline Estreptococos Fecais* & $3,3 \times 10^{6}$ & $6,9 \times 10^{5}$ \\
\hline Clostridium perfrigens & $9,8 \times 10^{4}$ & $3,0 \times 10^{4}$ \\
\hline Salmonellas sp & Presentes & Presentes \\
\hline Colifagos** & $2,7 \times 10^{5}$ & $1,1 \times 10^{5}$ \\
\hline Ovos e Larvas de Helmintos & Presentes & Raros \\
\hline Cistos de Protozoários & Presentes & Ausentes \\
\hline Fonte: (VIEIRA 1996) * NMP/100 ml **UFC/100 ml
\end{tabular}

Nas pesquisas conduzidas por BRITO e ALVES (1984) para tratamento de efluentes sanitários com bacteriófagos, buscando viabilizar o emprego de fagos em condições naturais, verificou-se que a remoção de $E$. coli foi superior a $99,9 \%$ e que os fagos agiram sobre a $E$. coli em relação aos coliformes totais. Os autores, após os testes realizados, concluíram que é viável o uso de fagos em fossas sépticas em condições naturais de utilização por parte da população. O uso de fagos nessas fossas elevou significativamente a eficiência de remoção de $E$. coli, diminuindo desta forma os riscos 
de contaminação por parte da população, porém não é a solução completa para o problema.

No tratamento de esgotos sanitários através de escoamentos à superfície, segundo PAGANINI (1996), bactérias e parasitas são retidas e removidas na superficie do solo por filtração, predação biológica, radiação ultravioleta, alcançando uma eficiência de até $95 \%$ no primeiro centímetro, e podendo chegar a $98 \%$ ou $99 \%$ de remoção destes microrganismos no sistema como um todo. Quanto à remoção de vírus com o sistema de escoamento à superficie, a eficiência apresenta-se, via de regra, pouco melhor que os tratamentos secundários convencionais; isto se deve ao fato de que é um processo que, na maioria dos casos, apresenta efluente líquido coletado das estações de tratamento e, se as taxas de aplicação e o tempo de detenção não forem suficientes, o referido efluente pode ainda carrear quantidades remanescentes de vírus e outros microrganismos (BERNARDE 1973; EPA 1981; PAHREN 1979).

Nos sistemas de disposição por irrigação em solo de textura fina, a remoção de bactérias e parasitas é alta $(99,8 \%)$ e acontece quase que completamente nos primeiros $150 \mathrm{~cm}$ de profundidade. As bactérias são eliminadas em duas fases: durante as primeiras 48 horas após a irrigação, 90\% delas morrem, e a quantidade remanescente de bactérias morre durante as duas semanas seguintes (PAGANINI 1996). Entretanto, para os sistemas de disposição por infiltração, verifica-se remoção da ordem de $99 \%$ para bactérias, protozoários e helmintos (ovos), porém depende da temperatura, tempo de detenção, textura do solo, taxa de aplicação do esgoto, profundidade do lençol freático, etc. (PAGANINI 1996).

No que diz respeito a virus, os sistemas por escoamento à superfície, ou por irrigação, removem 90 a $99 \%$ deles nos primeiros $10 \mathrm{~cm}$ de profundidade, sendo que a redução de $99,99 \%$ é alocada numa distância média de $9 \mathrm{~m}$ abaixo do ponto de aplicação. Os números apresentados anteriormente devem ser considerados com muito cuidado, pois dependem de adequabilidade de diversos fatores favoráveis ocorrendo ao mesmo tempo. 
Num sistema de infiltração em solo de areia e cascalho, em Fort Deveus, Massachusetts - EUA, foram isolados vírus a uma profundidade de $18,3 \mathrm{~m}$ e distância horizontal de 183 m da área de aplicação (PAGANINI 1996; DRIVER et al 1972; EPA 1981).

Quanto às Escherichia coli, Salmonella typhi e Mycobacterium avium, o tempo de sobrevivência tem aumentado quando o lançamento dos esgotos é feito em solos úmidos e em períodos de chuva (ANDRAUS et al 1997). Um fator que reduz o tempo de sobrevivência das bactérias lançadas nesses ambientes é a competição entre os microrganismos naturais do solo. Os protozoários de vida livre são considerados importantes predadores de coliformes (TATE 1978 apud EPA 1985), entretanto, bactérias entéricas aplicadas em solo estéril sobrevivem mais do que aquelas aplicadas em solo não-estéril (ANDRAUS et al 1997).

Na Tabela 2.3 estão listados os tempos de sobrevivência de quatro tipos de organismos patogênicos, no solo e nas estações. Os cistos de protozoários, no solo e nas estações, são, rapidamente, mortos pelos fatores ambientais, portanto a ameaça à saúde pública e de animais, através dos protozoários no lodo de esgoto, fica reduzida em relação a outras condições. As bactérias, vírus e helmintos são de maior preocupação (EPA 1985; ANDRAUS et al 1997).

Tabela 2.3 Tempo de sobrevivência de patogênicos no solo e na superficie com plantas

\begin{tabular}{l|l|l|l|l}
\hline \multirow{2}{*}{ Patogênicos } & \multicolumn{2}{|c|}{ SOLO } & \multicolumn{2}{c}{ ESTACÃO } \\
\cline { 2 - 5 } & $\begin{array}{l}\text { Máximo } \\
\text { Absoluto }\end{array}$ & $\begin{array}{l}\text { Máximo } \\
\text { Comum }\end{array}$ & $\begin{array}{l}\text { Máximo } \\
\text { Absoluto }\end{array}$ & $\begin{array}{l}\text { Máximo } \\
\text { Comum }\end{array}$ \\
\hline Bactéria & 1 ano & 2 meses & 6 meses & 1 mês \\
\hline Vírus & 1 ano & 3 meses & 2 meses & 1 mês \\
\hline Cisto de protozoários & 10 dias & 2 dias & 5 dias & 2 dias \\
\hline Ovos de helmintos & 7 anos & 2 anos & 5 meses & 1 mês \\
\hline
\end{tabular}

Fonte: ANDRAUS et al, 1997.

Segundo LEITE e AISSE (1998), o tempo de sobrevida das Salmonelas e sua remoção nos processos de tratamento ajustam-se à dos coliformes fecais, ou seja, pode-se considerar como equivalente sua redução. 
A remoção de coliformes fecais em lagoas de altas taxas é da ordem de $99,99 \%$ a $99,95 \%$, correspondente à mesma ordem de grandeza observada nas lagoas facultativas convencionais: $5,0 \times 10^{3}$ a $2,3 \times 10^{4} \mathrm{NMP} / 100 \mathrm{ml}$ (PINTO e ONOYAMA 1991).

As estações de tratamento convencionais não são suficientemente eficientes na remoção de $\mathrm{DBO}$ e de coliformes, indicadores de doenças de veiculação hídrica. Assim, para os efluentes serem lançados em rios de Classe 2, com garantia do padrão, são necessárias razões de diluição (Qrio/Qesg) da ordem de 6, para $\mathrm{DBO}_{5}$ e 999, para coliformes fecais, nas situações de montante dos rios não comprometidos previamente (AISSE 1998).

Trabalhos do CEPIS - Centro Pan Americano de Ingenierie Sanitária y Ciencias del Ambiente demonstraram que ocorreu remoção completa de protozoários em duas lagoas em série com 20 dias de detenção, bem como, remoção completa de helmintos em lagoas facultativas com 10 dias de detenção (LEITE e AISSE 1998).

$\mathrm{Na}$ maioria dos países em desenvolvimento, a relativa escassez de recursos e a urgente necessidade de instalações sanitárias asseguram que ainda e durante muitos anos, os investimentos serão destinados, prioritariamente, às medidas de coleta de águas residuárias, controle de vetores etc., ao invés de melhoramento do meio ambiente como um todo (SILVA e MARA 1979).

A Salmonella ssp, S. typhi, S. paratyphi A, B, C e E. coli enteropatogênicas são bactérias patogênicas encontradas em grandes concentrações no lodo de esgoto sanitário. A presença e a quantidade no esgoto dependem dos níveis de infecção da população contribuinte. Em pessoas infectadas, estima-se a presença de $S$. paratyphi e Salmonela ssp em concentração $10^{6} \mathrm{NMP} / \mathrm{g}$ PS e Escherichia coli em $10^{8} \mathrm{NMP}$ por grama de peso seco. (EPA 1985; ANDRAUS et al 1997). A disposição do lodo gerado nas estações de tratamento deve ser realizada adequadamente para preservar o ambiente e não contaminar o corpo receptor com os microrganismos retidos. 
A remoção de coliformes, indicadores de poluição fecal, devido às elevadas concentrações nos esgotos brutos, é, usualmente, de difícil atendimento aos padrões. Elevadíssimas eficiências de remoção são necessárias, da ordem de 99,9 a 99,99\% (3 a 4 unidades logaritmicas) ou mesmo mais (VON SPERLING 1996c), para ser considerada aceitável do ponto de vista de saúde pública.

Dos estudos realizados sobre os diversos processos de tratamento de esgotos sanitários, conclui-se que não existe um sistema ideal de tratamento para as diversas condições, principalmente no que tange à remoção de coliformes. De todos os possíveis tipos estudados, a remoção fica na ordem máxima de $90 \%$, com exceção para a infiltração no solo e escoamento superficial que podem chegar até 99\% (VON SPERLING 1994). Mesmo estes valores percentuais altos não são confiáveis quanto à condição de remoção de patogênicos, considerando-se o surgimento de organismos mais resistentes que o indicador padrão que vêm causando surtos de infecções como os verificados nos EUA por Cryptosporidium, e, conseqüentemente, preocupação para a vigilância sanitária e seqüelas para a saúde pública.

A desinfecção do esgoto tratado para garantir a remoção completa de coliformes, ou quase isso, tem sido questionada, em decorrência do custo para implantação do serviço. A desinfecção com cloro tem custo pouco inferior à com radiação ultravioleta e a com ozônio é, aproximadamente, três vezes superior. Mesmo a desinfecção com cloro, alternativa mais barata, não é prática corrente no Brasil e o custo do $\mathrm{m}^{3}$ fica, aproximadamente, o dobro da desinfecção de água (SAMPAIO e CAMPOS 1985).

Como as estações de tratamento de esgotos sanitários não sạ̃o devidamente eficientes quanto à remoção de microorganismos, e não existe em quantidade suficiente, a situação da saúde pública fica comprometida. 


\subsection{Aspectos de saúde e doenças com enfoque em água e esgoto sanitário}

\subsubsection{Considerações gerais}

$\mathrm{O}$ abastecimento público com água de qualidade, e a coleta, tratamento e disposição adequada dos esgotos sanitários são parte integrante da atenção à saúde pública, cujo reconhecimento e importância remontam às mais antigas culturas. Ruínas de uma grande civilização que se desenvolveu ao norte da Índia há cerca de 4.000 anos atrás, indicam evidências de hábitos sanitários, incluindo a presença de banheiros e de esgotos nas construções, além de drenagem nas ruas (ROSEN 1994; HELLER 1997). O próprio Velho Testamento apresenta diversas abordagens vinculadas às práticas sanitárias do povo judeu como: a importância do uso da água para limpeza; a afirmação de que roupas sujas podem levar a doenças, como escabiose, e de que sujeira pode levar à insanidade. Em função destas visões, são mencionados, na obra, cuidados para que os poços sejam mantidos tampados, limpos e distantes de possíveis fontes de poluição e de árvores (KOTTEK 1995).

Alguns autores chegam a afirmar que a saúde pública iniciou quando o homem se apercebeu de que a vida em comunidade resultava em perigos para a saúde dos indivíduos e foi descobrindo, consciente e inconscientemente, meios de reduzir e evitar esses perigos. A experiência prática evoluiu para medidas e hábitos, posteriormente regras e leis e, finalmente, para a construção do esboço de uma atuação coletiva, constituindo a saúde pública (FERREIRA 1982; HELLER 1997).

Na trajetória mais recente da saúde pública, Snow, em sua histórica pesquisa concluída em 1854, comprovava, cientificamente, a associação entre a fonte de água consumida pela população de Londres e a incidência de cólera. A despeito dessa demonstração, influentes sanitaristas, como Chadwick, já defendiam a importância do saneamento. A investigação de Snow ocorreu cerca de 20 anos antes do início da era bacteriológica, com Pasteur, Kóch e outros cientistas (ROSEN 1994; HELLER 1997).

Segundo SIBIYA (1980), a atenção primária à saúde, além do suprimento de água adequada e segura, e dispositivos de saneamento (esgotamento sanitário) incluem sete 
outros componentes essenciais: 1-Educação geral e eficaz em problemas de saúde; 2Prevenção e controle de doenças endêmicas; 3-Tratamento apropriado de doenças e danos; 4-Cuidados maternos e com a criança, incluindo planejamento familiar; 5-Provisão de drogas essenciais; 6-Imunização contra doenças infecciosas principais; 7-Promoção de alimentação adequada e nutrição natural apropriada.

A Constituição Federal do Brasil, em alguns de seus artigos, conceitua meio ambiente, saúde e saneamento como preocupações voltadas à qualidade de vida das populações. Há, portanto, um reconhecimento da interdependência conceitual e física entre estes assuntos, visto que pretender saúde sem integrar suas respectivas ações significa administrar a doença. Este tem sido o panorama brasileiro, administrar a doença, apesar dos esforços desenvolvidos. As causas básicas estão nas questões educação e desigualdade social que só é ultrapassada por Honduras e Serra Leoa, segundo relatório do Banco Mundial publicado em agosto de 1991. Na avaliação da qualidade de vida, identificou-se, claramente, que os desajustes dos modelos e políticas adotados no Brasil, entre elas os voltados para o controle de vetores de doenças, são as causas básicas para as condições de vida tão ruins. Esses modelos colocam a nona economia do mundo em convivência com a quarta maior taxa de mortalidade infantil da América Latina, visto que $65 \%$ das internações hospitalares, em nosso país, são conseqüências diretas ou associadas a doenças de veiculação hídrica, conseqüentemente, da falta de abastecimento de água e de esgotamento sanitário adequados (ANDREOLI et al 1995). A melhoria da qualidade de vida do povo brasileiro depende da ampliação dos serviços de abastecimento de água e de esgotamento sanitário integrados a ações de educação para a saúde, prevenção e controle de doenças endêmicas, tratamento apropriado de doenças, cuidados maternos e com a criança, planejamento familiar, provisão e facilidade de acesso a drogas essenciais, imunização contra doenças infecciosas, acesso fácil à alimentação adequada, entre outras.

A carência de saneamento básico não é privilégio somente do Brasil. Quase metade da população mundial carece de meios aceitáveis de saneamento e, praticamente, um quinto não dispõe de abastecimento de água adequado, ou seja, 2,4 bilhões de pessoas no mundo não têm esgoto e 1,1 bilhão não recebe água em condições adequadas. Este foi o quadro 
divulgado durante o V Fórum Global 2000 do Conselho Mundial de Colaboradores em Água Potável e Saneamento da Organização Mundial de Saúde, ocorrida em foz do Iguaçu, Paraná. $\mathrm{O}$ déficit em saneamento básico provoca um aumento considerável do número de mortes e de enfermidades relacionadas à falta de higiene e tratamento da água. Segundo os números do relatório divulgado no V Fórum Global 2000, ocorrem 4 bilhões de casos de diarréia por ano no mundo, com 2,2 milhões de mortes. O relatório mostra ainda que $10 \%$ da população mundial têm parasitas intestinais, seis milhões de pessoas são cegas por causa de doenças infecciosas e 200 milhões sofrem de esquistossomose (BRASIL 2000d).

O uso de água contaminada por despejos domésticos para consumo humano gera graves problemas para a saúde. As estações de tratamento de água possuem múltiplas barreiras e é a melhor garantia de proteção quanto à remoção de microorganismos, porém não é absoluto se as estações não forem operadas adequadamente, ou seja, se todas as barreiras disponibilizadas não forem suficientes. As estações de tratamento de água convencionais utilizam os processos unitários de coagulação, sedimentação e filtração em leito de areia, e, mesmo assim, esses podem não ser suficientes para a remoção dos microorganismos presentes. Existem centenas de vírus entéricos, entre outros microorganismos, que podem constituir-se em importantes agentes de doenças veiculadas pela água e, quase sempre, oriundas do esgoto sanitário. Segundo HUFFMAN e ROSE (1998), informações sobre incidências de infecções por vírus entéricos são limitadas tanto nos Estados Unidos, quanto no resto do mundo. Muitos destes organismos ultrapassam as barreiras dos sistemas convencionais de tratamento de água, causando infecções como as verificadas em $1993 \mathrm{em}$ Milwaukee Wisconsin nos Estados Unidos, devido ao Cryptosporidium parvum, que atingiu 400.000 pessoas, levando 100 a óbito. Na Inglaterra, ocorreram 11 casos de infecção por Cryptosporidium parvum entre 1990 a 1997 (Mc CANN 1999) e segundo BENNETT, et al (1987), mais de 20 milhões de casos de infecções ocorrem, por ano, devido a vírus entéricos, dos quais, em média, 2000 resultam em morte. No Brasil não existe registro específico sobre essa questão.

As infecções por Cryptosporidium parvum são em função da localização geográfica. Elas ocorrem entre 0,6 a $20 \%$ da população mundial, com grande prevalência na Ásia, Austrália, 
África e América do Sul. Atualmente, nos Estados Unidos da América, é o mais importante agente de doenças veiculadas pela água. Sua identificação em águas superficiais tem sido confirmada em 4 a 100\% das amostras, conforme relatam LISLE e ROSE (1995) e HUFFMAN e ROSE (1998). Em águas do subsolo, por serem mais protegidas, a ocorrência de Cryiptosporidium parvum tem sido entre 9,5 a $22 \%$ das amostras analisadas (HAMCOCK et al 1998; HUFFMAN e ROSE 1998). No Brasil, segundo HELLER et al (2000) foram encontrados Cripytosporidium parvum e Giardia lamblia nos esgotos sanitários do Ribeirão Arruda (Belo Horizonte, MG), entretanto não foi verificada correlação dos protozoários com presença de indicadores bacterianos e turbidez, nem observado padrão de variação diária ou semanal, mas observada variação sazonal. Estudos realizados pelo DMAE - Departamento Municipal de Águas e Esgotos da Prefeitura de Porto Alegre, entre 1975 e 1987, mostram que foram identificados resultados positivos para enterovirus, caracterizado posteriormente como de origem vacinal, em amostras de esgotos e de água coletadas na bacia do Rio Jacuí (FARIA 1989).

$\mathrm{Na}$ Inglaterra, durante os anos 90 , três experimentos foram realizados quando se verificou que Cryptosporidium parvum passavam pelas barreiras da estação de tratamento de água (Mc CANN 1999). Os experimentos mostram que o Cryptosporidium, um patógeno transportado pela água, sobrevive por longo tempo no meio ambiente aquático e pode passa através do filtro de areia, resistindo à desinfecção com cloro e causando infecção com muito baixa contagem de oocistos, justificando uma série de incidentes ocorridos no mundo. Segundo FRICKER e CLANCY (1998) estes microorganismos devem ser removidos na estação de tratamento de água.

A grande preocupação com o protozoário Cryptosporidium parvum ocorre por diversas razões. Primeiro, o estágio de resistência do oocisto ao meio ambiente é tal que não é destruído por cloração. Segundo, o Cryptosporidium parvum passa pelas barreiras das estações convencionais de tratamento de águas. Terceiro, a $E$ coli, indicador da presença de poluição fecal, não resiste a pequenas concentrações de cloro. A ausência de $E$ coli não caracteriza, portanto, a ausência de Cryptosporidium parvum, que é resistente a baixas 
concentrações de cloro. Quarto, o Cryptosporidium parvum pode ser causa de epidemia levando a óbitos como a verificada nos Estados Unidos, em 1993.

Atualmente, o risco relativo de possiveis doenças decorrentes da veiculação hídrica somase a outros itens, visto que traços de remédios usados em animais domésticos foram encontrados em rios e efluentes de esgotos tratados, conforme estudos realizados por Chris Metcalf da Universidade Canadense de Trent em Peterborough (Ontário), bem como resíduos de remédios para câncer, anti-inflamatórios e de fármacos usados em Psiquiatria (HOFER e VICENTE 1989; BRASIL 2000d). Nas últimas décadas, químicos europeus vêm documentando, cada vez com maior freqüência, a contaminação por fármacos em lagos, fontes e água subterrânea. Recentemente, em São Francisco, cientistas norteamericanos e canadenses obtiveram confirmação de que resíduos de medicamentos, oriundos dos esgotos domésticos de pessoas e animais, também poluem as águas. A origem dos resíduos de medicamentos encontrados nos esgotos e águas pode ser de restos jogados no lixo pela população, consideravelmente aumentado pela força da poluição da indústria farmacêutica, visto que componentes para medicamentos aparecem, até mesmo em países como a Croácia, em concentrações bem elevadas. A poluição da água por medicamentos é o desafio mais emergente, segundo pesquisas desenvolvidas pela Agência de Proteção Ambiental-EPA (BRASIL 2000d).

São comuns, nas vastas áreas rurais e urbanas dos países do terceiro mundo inclusive os muitos povoados, populações com falta de suprimento de água segura e de dispositivos básicos de esgotamento sanitário, resultando em ocorrências de várias doenças devido a microorganismos como bactérias, vírus, protozoários e helmintos. Há pessoas que sofrem pela ausência de suprimento de água potável e de disposição adequada dos excretas humanos porque lhes faltam tão somente os meios para obter tais serviços. Enquanto outras sofrem pela falta dos meios, de conhecimentos e de tecnologia para reduzir o efeito adverso das condições não sanitária das habitações. O problema torna-se particularmente trágico porque as crianças são as mais vulneráveis. 
A população brasileira, em 1990, era de aproximadamente 150 milhões de habitantes, sendo que 113 milhões $(75,3 \%)$ residiam em zonas urbanas e 37 milhões $(24,7 \%)$ em áreas rurais. Da população urbana, 32 milhões de habitantes $(28 \%)$ viviam em condições precárias em todos os aspectos. Em 1995, o abastecimento de água apresentava cobertura de apenas $88 \%$ da população urbana e $35 \%$ da população rural. Da mesma forma, o esgotamento sanitário atendia apenas $35 \%$ da área urbana e $7 \%$ da área rural, valores estes muito aquém do desejado (ANDREOLI et al 1995).

Segundo MELLO JORGE e GOTLIEB (2000), dentre os óbitos verificados em decorrência das DIP-Doenças Infecciosas Parasitárias no Brasil, destacam-se, como primeira causa, as doenças infecciosas intestinais com 57,6\% em 1980, declinando para 30,4\% em 1995, destacando-se que a maioria das mortes foi por gastroenterite, controlada no país em decorrência da elevação da cobertura de abastecimento de água, conforme apresentado na Tabela 2.4. Os autores não fazem qualquer referência à cobertura do esgotamento sanitário. No Nordeste, a causa básica é a mesma, entretanto os índices de óbitos encontrados foram mais altos. Em 1980, o percentual era de 71,4\%, declinando para 47,5\%, em 1995, conforme Tabela 2.5. No Estado da Bahia, os dados encontrados estão entre a situação do Brasil e da Região Nordeste, ou seja, o percentual de óbitos, em 1980, foi de $68,55 \%$, decaindo para 41,4\%, em 1995, conforme Tabela 2.6.

No verão de 1983, ocorreu um surto de esquistossomose entre banhistas das praias de Ubatuba, São Paulo, e a Superintendência de Combate às Endemias - Sucen - do Estado constatou a presença de caramujos contaminados por Schistosoma mansoni nas valetas de drenagem e córregos. Esta situação pode ser desencadeada por apenas uma pessoa doente (PAOLETTI 1984; ZULAUF 1984).

O assessor em Saúde Ambiental da Organização Pan-americana de Saúde, no $19^{\circ}$ Congresso da ABES - Associação Brasileira de Engenharia Sanitária e Ambiental, realizado em Foz do Iguaçu (VILLAR et al 1997), alertou para o fato de que as diarréias são o maior problema da humanidade. Quatro bilhões de casos por ano foram registrados no planeta. Eles poderiam ser evitados com uma desinfecção eficiente e exaustiva da água. 
A melhor forma é a cloração, recomenda a OMS. Nós não podemos comprometer a qualidade bacteriológica da água, mas é preferível ter um caso de câncer entre cem mil habitantes, do que ter dezenas de milhares de casos de diarréia, reconhece o assessor em Saúde Ambiental (VILLAR et al 1997).

Segundo MIM et al (1999), a ingestão de patógenos pode causar diversas infecções que, tanto podem ficar confinados ao trato gastrintestinal, como iniciar no intestino e se disseminar para outros locais do organismo. Para que a infecção ocorra, os patógenos devem ser ingeridos em quantidade adequada e/ou possuir atributos particulares de evasão das defesas do hospedeiro no trato gastrintestinal superior, atingindo, finalmente, o intestino. Neste, ou os patógenos permanecem localizados fazendo com que a doença seja o resultado da multiplicação e/ou produção de tóxicos, ou os organismos podem migrar, através da mucosa intestinal, atingindo os linfáticos ou a corrente sanguínea.

Muitas doenças intestinais são causadas por helmintos e protozoários parasitas do trato gastrintestinal do homem (MIMS et al 1999) como sejam:

\section{Protozoários:}

No intestino delgado: Giardia lamblia, cryptosporidium parvum e Isospera belli.

No intestino grosso: Entamoeba histolytica, Entamoeba coli, Endolimax nana, Iodamoeba butschlii, Dientamoeba fragilis, Balantidium coli e Trichomonas hominis.

\section{Helmintos:}

No intestino delgado: Ascaris lumbricoides, Ancylostoma duodenale, Necator americanus, Strongyloides stercoralis, Taenia saginata, Trichinella spiralis, Capillaria philippinensis, Taenia solium, Diphyllobothrium latum, Hymenolepis nana, Hymenolepis dimunita Fasciolopsis buski, Metagonimus yokogawi, Heterophyes heterophyes, Gastrodiscoides hominis..

No intestino grosso: Enterobius vermicularis e Trichuris trichiura. 
$\approx$

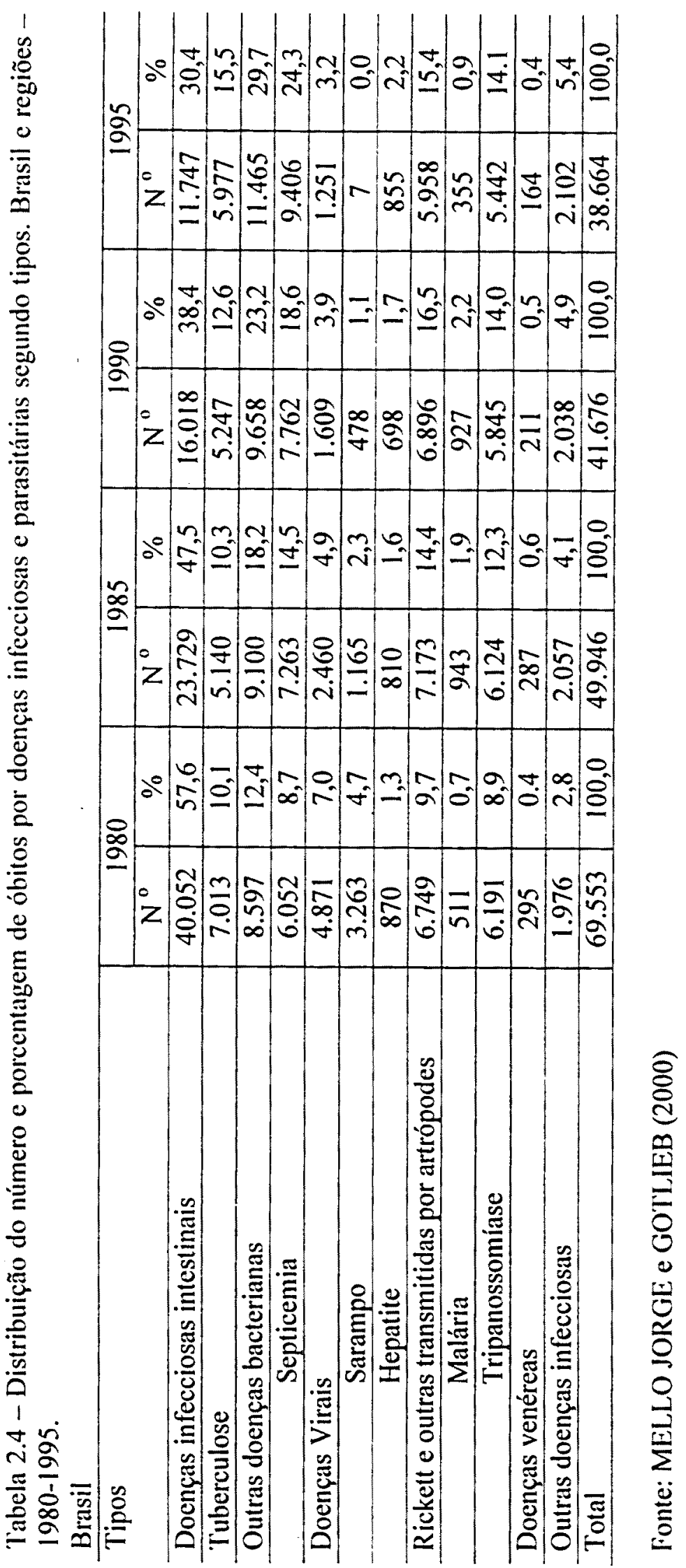




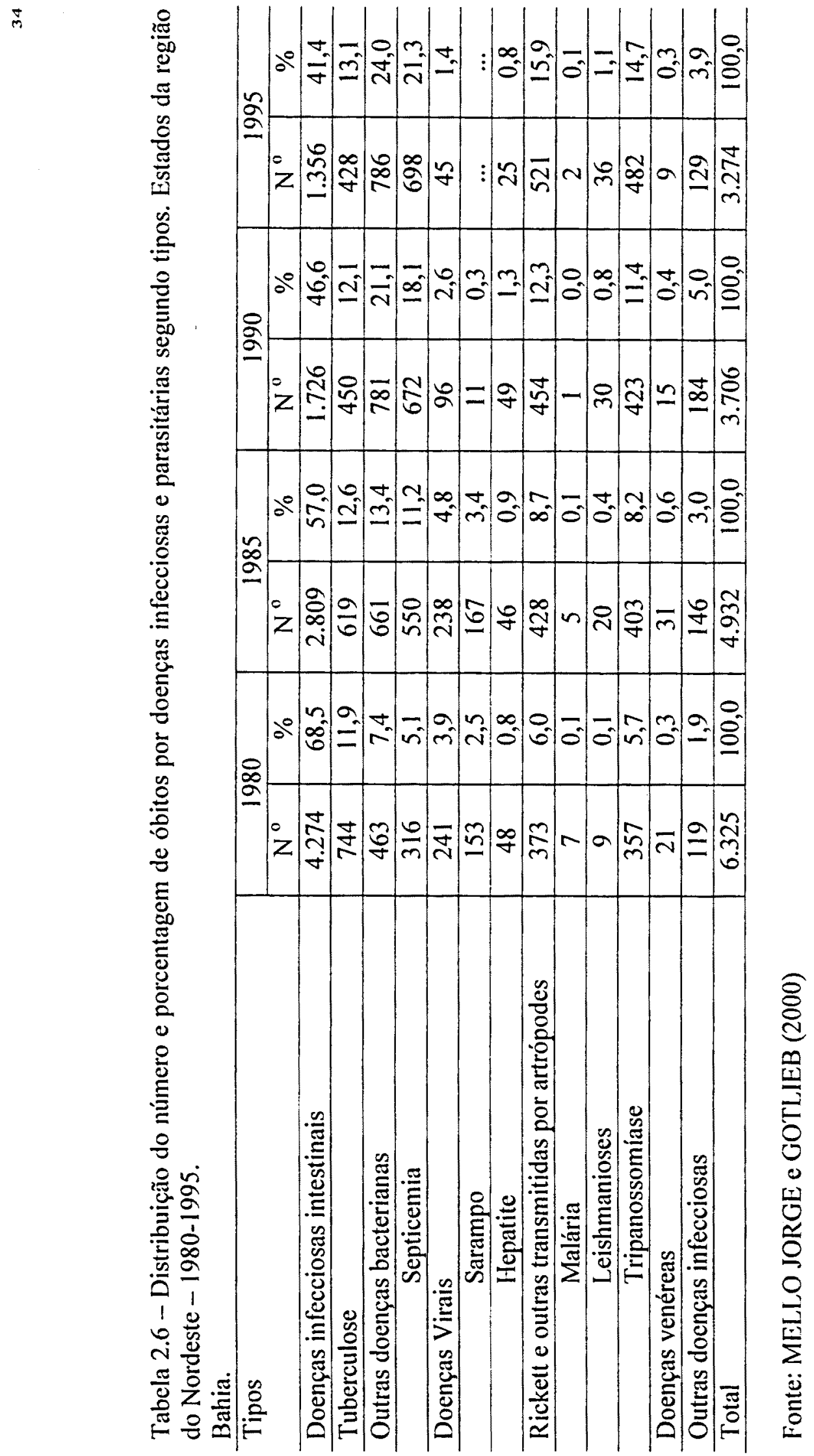


Destes parasitas gastrintestinais, os mais freqüentemente encontrados na população brasileira, e em especial no nordeste, são os helmintos: Ascaris lumbricoides; Trycocephalus trichiurus; Strongyloides stercoralis; Ancylostoma duodenale; Enterobius vermicularis; Schistosoma mansoni; Hymenolepis nana; Hymenolepis dimunita; Taenia saginata; Taenia solium e os protozoários: Entamoeba histolytica; Entamoeba coli; Endolimax nana; Iodamoeba butschlii; Dientamoeba fragilis e Giardia lamblia ${ }^{1}$ e destes parasitas, alguns constituem causa freqüente de patologias graves como os marcados em negrito (MIMS et al 1999).

$\mathrm{Na}$ Tabela 2.7, a seguir, estão registrados alguns tipos mais comuns de parasitas dos intestinos humanos, bem como a percentagem de pacientes infectados. A pesquisa foi realizada em pacientes de todas as idades e das diversas classes sociais com a maior parte de residentes na cidade de Belo Horizonte e os demais em diferentes zonas rurais.

Tabela 2.7 - Resultados de exames parasitológicos de fezes de 2.500 pacientes da Cidade de Belo Horizonte e zonas rurais.

\begin{tabular}{l|c|c}
\hline METAZOA (HELMUNTOS) & Pacientes infectados & Percentagem \\
\hline Ascaris lumbricoides & 489 & 19,5 \\
\hline Necator americanus & 366 & 14,6 \\
\hline Trichuris trichiura & 513 & 20,5 \\
\hline Strongyloides stercolaris & 217 & 8,6 \\
\hline Enterobius vermicularis & 73 & 2,9 \\
\hline Taenia. sp. & 23 & 0,9 \\
\hline Hymenolepis nana & 1 & 0,04 \\
\hline Schistosoma mansoni & 100 & 4,0 \\
\hline PROTOZOA (PROTOZOÁRIOS) & & \\
\hline Endamoeba histolytica & 259 & 10,3 \\
\hline Endamoeba coli & 621 & 24,8 \\
\hline Endolimax nana & 58 & 2,3 \\
\hline Iodamoeba butschlii & 11 & 0,4 \\
\hline Giárdia intestinalis & 251 & 10,0 \\
\hline Chilomastix mesnili & 156 & 6,2 \\
\hline Trichomonas hominis & 36 & 1,4 \\
\hline Balantidium coli & 4 & 0,16 \\
\hline Font (PSSOA & & \\
\hline
\end{tabular}

Fonte: (PESSOA e MARTINS 1982).

Pela Tabela 2.7, verifica-se que, antes de 1982, era alto o percentual de pessoas portadoras de doenças parasitárias do intestino devido a helmintos e protozoários.

\footnotetext{
${ }^{1}$ Informações obtidas com o coordenador do Laboratório de Análise Clínica da UEFS
} 
Apesar das melhorias nos diversos serviços que promovem uma boa qualidade de vida ao homem, implantadas posteriormente a 1982, verifica-se, ainda, a existência destes tipos de doenças, não só nas áreas rurais, como nas urbanas, com incidência maior nas Regiões Norte e Nordeste, em relação ao Sul do País.

\subsubsection{Helmintos}

Os helmintos constituem um grupo numeroso de espécies de vida livre e de espécies parasitas, subdivididas em três filos: Platyhelminthes, Aschelminthes $\mathrm{e}$ Acanthocephala. As ocorrências no homem são muito comuns. Cerca de $20 \%$ da população humana do mundo estão parasitada por ancilostomideos e Ascaris lumbricoides, equivalente a mais de um bilhão de pessoas (COSTA 1998).

Os Platyhelminthes são achatados dorsoventralmente, com ou sem tubo digestivo, sem ânus, sem aparelho circulatório, sem aparelho respiratório, sistema excretor tipo protonefrídico. Podem ser de vida livre ou parasitas. Entre os parasita estão os do homem como a $S$. mansoni, $S$ japonicum, $S$. haematobium, $T$. solium, $T$ saginata, $H$. nana, H. diminuta (COSTA 1998).

Os Aschelminthes têm corpo, em geral, cilíndrico, freqüentemente de pequeno porte, com revestimento externo cuticular e tubo digestivo completo. O sistema nervoso é constituído por uma massa cerebral anterior com nervos-troncos dirigidos para frente e para trás. Incluem formas de vida livre e de parasitas. Entre os parasitas, destacamse os que infectam o homem como $A$. lumbricoides, $A$. duodenali, $A$. braziliense, $N$. americanus, T. trichiura (COSTA 1998).

Os Acanthocephala são helmintos endoparasitos, pseudocelomados, com simetria bilateral, sem tubo digestivo e apresentando, na extremidade anterior, uma armada de ganchos. Apresentam corpo cilíndrico ou ligeiramente comprimido lateralmente. $\mathrm{O}$ tamanho é variável, acima de $1,5 \mathrm{~mm}$, sendo a maioria das espécies em torno de 25 $\mathrm{mm}$. O sistema nervoso consiste de um gânglio central que funciona como cérebro, são de vida livre ou parasita e, em alguns casos, têm sido encontradas parasitando também o homem (COSTA 1998). 
A importância do estudo dos helmintos que parasitam o intestino do homem é grande, não só para os médicos e autoridades sanitárias, mas também para a população em geral, devido às numerosas espécies de helmintos que parasitam o homem brasileiro, pelos males que ocasionam e pela vasta disseminação desses parasitas entre os habitantes de todas as regiões do país (PESSOA e MARTINS 1982). A disseminação das helmintoses intestinais, segundo PELLON e TEIXEIRA apud PESSOA e MARTINS (1982), foi avaliada com base em exame de fezes de cerca de 700 mil escolares, entre 7-14 anos de idade, no periodo de 1948 - 1953, em 17 estados brasileiros das regiões Norte, Leste, Sul e Centro Oeste, quando foi identificado que, dos 70 milhões de brasileiros, 65 milhões estavam parasitados por alguma(s) espécie(s) de helmintos intestinais. Os cinco milhões não-parasitados pelos helmintos intestinais eram constituídos pelas crianças de poucos meses de idade, por uma porcentagem mais ou menos elevada de residentes em locais do sertão semi-árido do Nordeste e pelos componentes das classes ricas de todo o país. Entre 1948 - 1968 esses resultados não foram alterados de forma considerável (PESSOA E MARTINS 1982).

$\dot{E}$ evidente que não podem ser considerados como doentes os 65 milhões de brasileiros que, seguramente, estão parasitados por uma ou mais espécies de helmintos intestinais. Estas infecções diferem das causadas por bactérias, protozoários e vírus porque o agente causador não se multiplica no corpo humano do hospedeiro, salvo exceções. Essas pessoas, com certeza, são portadoras de vermes intestinais e comportam-se como sãs. Essas endemias ocorrem geralmente em populações subdesenvolvidas e/ou com carência alimentar (PESSOA e MARTINS 1982).

Os helmintos dividem-se em várias classes, sendo a Nematoda, a Cestoda e a Trematoda as classes em que se encontram os parasitas humanos mais importantes (BRANCO 1978; SILVA e MARA 1979; METCALF e EDDY 1991; COSTA 2000). 
O Trematóide mais conhecido no Brasil como agente de doença para o homem é o Schistosoma mansoni. O portador são da esquistossomose mansônica, na maioria dos casos, não apresenta sintomas clínicos. De qualquer forma, a tendência é dar sempre importância clínica ao achado de ovos do Schistosoma nas fezes. Os cestóides parasitas do organismo humano são Hymenolepis nana, Hymenolepis diminuta $e$ Taenia solium e Taenia saginata. O portador são adulto comporta-se sem o sintoma clínico, o qual indica que uma criança está contaminada. Alguns dos nematóides parasitas do organismo humano são Ascaris lumbricoides, Trycocephalus trichiura, Ancylostoma duodenale, Strongyloides stercoralis, Enterobius vermicularis (PESSOA e MARTINS 1982; COSTA 2000).

\section{Ascaris lumbricoides}

Ascaris lumbricoides, ou lombrigas, habitam o intestino delgado, em geral, em grande número e são os agentes etiológicos da ascaridiose. As fêmeas fecundadas no aparelho digestivo do homem podem produzir cerca de 12.000 ovos por dia, têm vida média de 12 meses e quando os ovos embrionados encontram um meio favorável podem permanecer viáveis e infectantes durante anos. Os ovos são elípticos, medem cerca de 45 a 50 por 60 a 75 micrômetros, são amarelos ou castanhos e dotados de espessa membrana (LIMA et al 1977; ROTHENBERG 1979; SILVA e MARA 1979).

A ascaridiose, doença parasitária do homem causada pelo Ascaris lumbricoides, não causa sintomatologia mas pode se manifestar por dor abdominal, diarréia, náuseas e anorexia. Tem distribuição em países de clima tropical, subtropical e temperado. As más condições de higiene e saneamento básico, e a utilização de fezes como fertilizantes contribuem para a prevalência da doença nos países do terceiro mundo. Pode causar sintomas nervosos e gastrintestinais. Os seres humanos adultos são menos susceptíveis à infecção do que as crianças (LIMA et al 1977; NEVES et al 1998). O reservatório do agente etiológico é o homem, a transmissão ocorre através da ingestão dos ovos infectantes do parasita, procedente do solo, água ou alimentos contaminados com fezes humanas. A incubação ocorre entre 4 a 8 dias e a transmissibilidade verifica-se durante todo o período em que $o$ indivíduo porte $o$ 
verme e estiver eliminando ovos pelas fezes. O diagnóstico é feito através da confirmação do achado de ovos nos exames parasitológicos de fezes (LIMA et al 1977; NEVES 1998).

\section{Trycocephalus trichiurus}

O Trycocephalus trichiurus ou Trichuris trichiura é o agente da tricurose ou tricocefalose. Mede de 3,5 a $5 \mathrm{~cm}$, vive no intestino grosso, em especial no ceco, com a extremidade delgada introduzida na mucosa. Em geral, a tricurose, ou tricocefalose, é assintomática, embora lhe sejam atribuidos certos sintomas gastrintestinais, distúrbios nervosos e anemia. Como outros parasitos intestinais, lesam a mucosa favorecendo a invasão bacteriana. Há quem pense que o tricocéfalo, talvez, desempenhe algum papel na etiologia da apendicite, da febre tifóide e de outras infecções intestinais. Os ovos são ovóides, castanhos, medindo de 50 a 54 micrômetros de comprimento por cerca de 23 de largura, com um opérculo em cada extremidade (LIMA et al 1977; NEVES 1998).

O portador são da tricurose, com pequeno número de parasitas, não determina qualquer manifestação clínica. Só apresenta sintomas quando o número de ovos expulsos nas fezes ultrapassa 30 mil por gramo, que indica alto grau de parasitismo. O parasita possui evolução direta e fixo no ceco, não tendo tendência a se locomover para outras regiões como ocorre com as Ascaris lumbricoides (LIMA et al 1977).

\section{Strongyloides stercoralis}

O Strongyloides stercoralis é o agente etiológico da estrogiloidiose ou anguilulose. Alguns autores o consideram inofensivo, podendo causar uma enterite catarral benigna. Porém, existem autores que the atribuem grande patogenicidade e existem registros de casos fatais (LIMA et al 1977). Habita, preferencialmente, a porção superior do intestino delgado e, via de regra, nem o verme adulto ou seus ovos aparecem nas fezes, exceto quando ocorrem diarréias acentuadas. Os ovos abrem-se no intestino e, quando a infecção é muito intensa, podem se encontrar larvas em abundância nas fezes e também no líquido duodenal (LIMA et al 1977; NEVES 1998). O portador são da estrongiloidose é encontrado com alta freqüência. As 
infecções são assintomáticas e as lesões discretas, não se exteriorizando por manifestações clínicas. Ocorrem casos de auto-infecção processada através da pele da região perianal. Admite-se também a auto-infecção interna ou hiperinfecção pela invasão da mucosa do ílio ou do cólon, alcançando os pulmões (PESSOA e MARTINS 1982; NEVES 1998).

\section{Ancylostoma duodenale}

O Ancylostoma duodenale é o agente da ancilostomíase, infecção intestinal que pode se apresentar assintomática em casos de infecções leves. Em crianças com parasitismo intenso, podem ocorrer hipoproteinemia e atraso no desenvolvimento fisico e mental. Com freqüência, dependendo da intensidade, acarreta anemia ferropriva, insuficiência cardíaca, anasarca, pneumonite e hemorragia. O reservatório do agente etiológico é o homem e a transmissão não ocorre de pessoa para pessoa. A infecção dá-se quando essas larvas infectantes penetram na pele, geralmente pelos pés, causando uma dermatite característica. As larvas do ancylostoma, após penetrarem através da pele, passam pelos vasos linfáticos, ganham a corrente sangüínea e nos pulmões penetram nos alvéolos. Daí migram para a traquéia e a faringe, são deglutidos e chegam ao intestino delgado, onde se fixam, atingindo a maturidade. A incubação ocorre semanas ou meses após a infecção inicial. $O$ diagnóstico clínico, em geral, é devido ao prurido característico. O diagnóstico laboratorial é realizado através do achado de ovos nos exames parasitológicos de fezes, pelos métodos de Lutz, Willis ou Faust, realizando-se, também, a contagem de ovos pelo Kato-Katz (LIMA et al 1977; PESSOA e MARTINS 1982; LEITE 1998). Não é doença de notificação compulsória.

O Ancylostoma duodenale vive no intestino delgado e tem distribuição universal. No Brasil, predomina na população rural e está associada a áreas sem saneamento. São vermes dos mais perniciosos, produzindo freqüentemente anemia grave, às vezes fatal quando não tratado, e associada à desnutrição. Os ovos que estão nas fezes são depositados no solo onde se tornam embrionários. Em condições favoráveis de umidade e temperatura, as larvas se desenvolvem até chegar ao $3^{\circ}$ estágio, tornando- 
se infectantes. Podem produzir milhares de ovos por dia no intestino delgado, quando atingem a maturidade (LIMA et al 1977; LEITE 1998).

O portador são da ancilostomíase é aquele que libera ovos nas fezes. Entretanto, uma quantidade pequena de ovos pode ter significado muito pequeno ou nulo como medida de infecção do parasitado. Estudiosos sobre o assunto não indicam um padrão comum de medida de infecção. Uns consideram que 25 vermes, por exemplo, não trazem perturbações sobre o estado de saúde do parasitado. Tanto para crianças como para adultos, considera-se limite para infecção quando o parasitismo fica na faixa de 50 a 100 vermes, em média de 75 , ou seja, cerca de 2.600 ovos por grama de fezes. Esses indivíduos apresentam estado de infecção com taxa de hemoglobina normal (PESSOA e MARTINS 1982).

\section{Enterobius vermicularis}

O Enterobius vermicularis é um verme encontrado nas fezes após edema abundante, enquanto que os ovos raramente o são. Medem $0,4 \mathrm{~mm}$ de diâmetro por $10 \mathrm{~mm}$ de comprimento, vivem no ceco, apêndice e anus. Podem ocorrer auto infecção externa e interna (raro), retroinfecção e infecção indireta através da poeira, dos alimentos e da água. Os ovos são incolores, assimetricamente ovais, com um dos lados achatado, têm 50 micrômetros de comprimento por 16 a 25 micrômetros de largura, membrana de duplo contorno e fina. É um parasita cosmopolita, sendo o homem seu único hospedeiro conhecido (NEVES 1998).

\section{Schistosoma mansoni}

A Schistosoma mansoni é o agente da esquistossomose mansoni, amplamente disseminada no Brasil. No ciclo evolutivo deste verme, aparece como hospedeiro intermediário em molusco, em nosso meio, o Australorbis glabnatur. Os ovos são de coloração amarela, medem em média 150 por 60 micrômetros. As fêmeas produzem perto de 300 ovos por dia e, a partir da oviparição, ainda imaturos, os ovos passam por quatro estágios, e no final do sexto dia, tornam-se ovos maduros. $\mathrm{O}$ ovo maduro pode permanecer vivo durante 12 dias no intestino e morrem se não forem expulsos com as fezes (LIMA et al 1977; PEREIRA 1998). 
A forma aguda pode ser assintomática ou apresentar-se como dermatite urticariforme, acompanhada de erupção papilar, eritema, edema e prurido até 5 dias após a infecção. Com 3 a 7 semanas de exposição, pode surgir o quadro de esquistossomose aguda ou febre de Katayama, caracterizado por febre, anorexia, dor abdominal e cefaléia. Estes sintomas podem ser acompanhados de diarréia, náuseas, vômitos ou tosse seca. Após seis dias de infecção, há riscos do quadro clínico evoluir para esquistossomose crônica, de forma clínica: tipo I ou intestinal - caracterizada por diarréias repetidas, mucosanguinolentas, com dor ou desconforto abdominal; tipo II ou hepatointestinal - diarréias, epigastralgia, hepatomegalia, podendo ser detectadas nodulações à palpação de figado; tipo III ou hepatoesplênica compensada - hepatoesplenomegalia, hipertensão com formação de varizes de esôfago; IV ou hepatoesplênica descompensada - forma mais grave, figado volumoso ou contraído devido à fibrose, esplenomegalia, ascite, varizes de esôfago, hematêmase, anemia, desnutrição e hiperesplenismo. O reservatório do agente etiológico principal é o homem. São potencialmente infectados roedores, primatas e marsupiais. $O$ hospedeiro intermediário é o molusco. A transmissão ocorre através do contato do homem com a água infectada pela cercaria, fase intermediária da Schistosoma mansoni. A incubação se dá entre 2 a 6 semanas após a infecção, e a transmissibilidade se inicia através da eliminação de ovos viáveis de $S$. mansoni nas fezes (LIMA et al 1977; PEREIRA 1998). O diagnóstico é feito pelo achado de ovos em fezes ou em fragmentos da mucosa retal ou em tecidos do paciente (COELHO 1998).

\section{Hymenolepis nana}

A Hymenolepis nana evolui normalmente sem hospedeiro intermediário e é um helminto parasito do homem e também muito encontrado no ilio de ratos e camundongos de várias partes do mundo. A Hymenolepis nana é esfacelada no intestino, resultando disto eliminação abundante de ovos. O tamanho é variável, medem de 30 a $50 \mathrm{~mm}$ e os ovos incolores e transparentes medem de 40 a 50 micrômetros. $O$ verme adulto é encontrado no intestino delgado, principalmento no ileo e jejuno do homem. O mecanismo de transmissão mais freqüente é a ingestão de 
ovos presentes nas mãos e em alimentos contaminados (LIMA et al 1977; NEVES 1998)

\section{Hymenolepis diminuta}

A Hymenolepis diminuta é um protozoário parasito comum do rato e, excepcionalmente, do homem. Mede de 30 a 60 centímetros de comprimento e o parasitismo humano normalmente não leva a nenhuma alteração orgânica. Os ovos são de cor amarelada, tem membrana externa transparente, são esféricos ou ovóides, medem de 70 a 80 micra de comprimento e são muito resistentes à dessecação, putrefação e a condições adversas do meio externo. Pode ser expulso do intestino espontaneamente ou através de um purgativo qualquer (NEVES 1998).

\section{Taenia saginata e Taenia solium}

A Taenia saginata e a Taenia solium, popularmente conhecidas como solitárias, são vermes cosmopolitas (largamente distribuído no globo terrestre). Os hospedeiros intermediários são os bovinos e suínos. Microscopicamente, é impossivel diferenciar os ovos das duas espécies. Eles são ovóides ou esféricos e medem 30 micrômetros de diâmetro, amarelos ou castanhos. $\mathrm{Na}$ fase adulta ou reprodutiva, vivem no intestino delgado do homem. $\mathrm{O}$ homem adquire a teniase por ingestão das carnes bovina $\mathrm{e}$ suína cruas ou mal cozidas ( $T$. saginata) e infectadas (LIMA et al 1977; NASCIMENTO 1998).

\subsubsection{Protozoários}

Os protozoários compreendem um grupo de organismos unicelulares extremamente diverso. Muitos são multi-nucleares e poliplóides. Do ponto de vista da evolução eles têm origem polifilética e alguns representam o ramo mais antigo da árvore da família eucariota. Existem, atualmente, aproximadamente, 30.000 espécies reconhecidas com uma grande variedade de propriedades morfológicas e fisiológicas (ROCHELLE 2001; VITOR 2000). Quanto à sua morfologia, os protozoários apresentam variações, conforme sua fase evolutiva e o meio a que estejam adaptados. Podem ser esféricos, ovais ou mesmos alongados. Alguns são revestidos de cílios, outros possuem flagelos, e existem ainda os que não possuem nenhuma organela 
locomotora especializada. Possuem fases bem definidas como: trofozoítos (forma ativa do protozoário), cisto e oocisto (formas de resistência ou inativa). A locomoção dos protozoários é feita com o auxílio de uma ou associações de duas ou mais organelas (VITOR 2000).

Entre os protozoários estão as amebas, a Giardia, o Cryptosporidium, parasitas do intestino humano. Segundo NEVES et al (2000), a classificação das amebas é a seguinte: Sub-reino Protozoa, Philum Sarcomastigophora, Subphilum Sarcodina, Superclasse Rhizopoda, Classe Lobozia, Ordem Aemoebida: Família Entamoebidae e Gêneros Entamoeba, Iodamoeba e Endolimax; e Família Dientamoebidae, Gênero Dientamoeba.

As amebas podem se apresentar segundo as fases trofozoítos e cistos. Os trofozoitos medem de 20 a $50 \mu \mathrm{m}$. mas podem chegar a $60 \mu \mathrm{m}$ em situações específicas. Os cistos são esféricos ou ovais, medindo 8 a $20 \mu \mathrm{m}$ de diâmetro.

As amebas, parasitas naturais do homem, são em número de sete: Entamoeba histolytica; Entamoeba hartemanni; Entamoeba coli; Entamoeba gingivalis; Endolimax nana; Iodamoeba butschlii e Dientamoeba fragilis. Segundo LIMA et al (1977), de todas as amebas, seis são parasitas do intestino humano e a Entamoeba histolytica é a única patogênica para o homem. Entretanto, alguns autores consideram a Entamoeba coli e a Endolimax nana como patogênicas, também.

\section{Endolimax nana}

A Endolimax nana é a menor ameba que vive no homem. O trofozoíto mede $10-20$ $\mu \mathrm{m}$, com o citoplasma claro, membrana nuclear fina e sem grãos de cromatina, cariossoma grande e irregular. O cisto mede $8 \mu \mathrm{m}$, é oval, contendo quatro núcleos pequenos; às vezes podem ser vistos corpos cromatóides pequenos e ovóides (NEVES 2000; LIMA et al 1977).

\section{Entamoeba coli}

O trofozoíto da $E$. coli mede cerca de 20 a 50 micrometros, o citoplasma não é diferenciado em endo e ectoplasma; o núcleo apresenta a cromatina grosseira e 
irregular e o cariossoma grande e excêntrico. A E. coli contem cistos com oito núcleos, e os cistos são maiores que os da $E$. histolytica e se apresenta como uma pequena esfera medindo 15-20 micrômetros.

A forma vegetativa da $E$. coli (trofozoito) diferencia-se da $E$. histolytica por seu tamanho maior, mobilidade reduzida, núcleo muito mais visivel porque seus vacúolos digestivos contêm hemácias. É encontrada, com freqüência, em $25 \%$ dos exames realizados em fezes humanas (SOGAYAR e GUIMARÃES 2000).

\section{Iodamoeba butschlii}

Iodamoeba butschlii é uma pequena ameba bastante encontrada no homem e também no porco, esse com taxa de infecção maior que a daquele. Medem de 10 a 20 micras de diâmetro (LIMA et al 1977)

\section{Entamoeba histolytica}

A amebiase é causada por protozoário, Entamoeba histolytica, que se aloja no aparelho digestivo. As Entamoebas histolyticas são aquelas com cistos de quatro núcleos (NEVES 2000), localizam-se quase, unicamente, no intestino grosso e, raramente, no intestino delgado. Os portadores de cistos da Entamoeba histolytica podem ser divididos em: sãos, que eliminam cistos sem nunca terem apresentado crise de disenteria; convalescentes, que continuam eliminando cistos após a cura da doença; outros, cuja amebíase crônica se apresenta em uma fase latente (LIMA et al 1977).

As formas clínicas subdividem-se em dois grupos: assintomáticos e sintomáticos. Os sintomáticos podem se apresentar na forma de amebíase intestinal, com os sintomas de disenterias, colites não disentéricas, ameboma, apêndice amébica; ou a forma de amebíase extraintestinal, com sintomas hepáticos, cutâneos e em outros órgãos (pulmão, cérebro, baço, etc.). O periodo de incubação pode variar de alguns dias até anos, de modo que na maioria dos casos não se pode definir o período de incubação (LIMA et al 1977). 
E. histolytica, diferente das demais, se apresenta segundo as seguintes fases: trofozoítos ou vegetativas; cistos ou forma de resistência; pré-cisto e metacisto. A infecção por Entamoeba histolytica é cosmopolita, porém a doença é encontrada em suas diversas formas, freqüentemente, nos paises pobres e subdesenvolvidos situados, em geral, nas regiões tropicais. A transmissão é por intermédio de cistos e somente estes são infecciosos para o homem. As formas vegetativa ou trofozoita, se acidentalmente ingeridas, são mortas facilmente pelo suco gástrico no estômago. Alguns autores admitem a transmissão pela forma vegetativa (NEVES 2000).

Os trofozoítos medem de 20 a $40 \mu \mathrm{m}$, mas podem chegar a $60 \mu \mathrm{m}$ nas formas obtidas de lesões tissulares, em culturas ou disenteria. Geralmente, têm um só núcleo, bem nítido quando corado, e pouco visíveis nas formas vivas. O pré-cisto é uma fase intermediária entre o trofozoíto e o cisto, é oval ou ligeiramente arredondado, menor que o trofozoíto e o núcleo é semelhante ao do trofozoíto (NEVES 2000).

Os cistos são esféricos ou ovais, medindo 8 a $20 \mu \mathrm{m}$ de diâmetro. Os núcleos são pouco visíveis. Quando corados pelo lugol ou pela hematoxilina férrica, tornam-se bem visíveis e variam de um a quatro, tomando a cor castanho-escuro, podendo permanecer 9 a 10 dias em fezes úmidas. Em águas com muitas bactérias, os cistos sobrevivem 8 a 9 dias, porém, em águas pobres em bactérias, chegam a resistir durante um mês. Os cistos são mortos, normalmente, à temperatura de $50^{\circ} \mathrm{C}$, e na temperatura entre 2 e $6{ }^{\circ} \mathrm{C}$ morrem em 5 minutos. Os processos de cloração da água não matam os cistos de Entamoeba histolytica; seriam necessárias 100 vezes mais cloro que o normalmente aplicado às águas de abastecimento para se obter efeito letal sobre os cistos. É uma moléstia endêmica (LIMA et al 1977).

O homem é a única fonte de contágio. A transmissão pode ocorrer através de fezes humanas que contenham a forma cística do protozoário, e uma pessoas pode ser contaminada muito tempo depois da defecação. A amebiase surge sob formas intestinais ou extra-intestinais (hepáticas, pleuras pulmonares, urogenitais e outras). Em geral, os sintomas são lentos e progressivos. Diarréia e violentas cólicas abdominais podem vir acompanhadas de náuseas, vômitos e necessidade constante 
de defecar. Más, existem sintomas menos aparentes como emagrecimento lento, fadiga, dores abdominais vagas e alterações psíquicas. Muitos pacientes permanecem sem sintomas por meses e até anos (LIMA et al 1977).

\section{Dientamoeba fragilis}

A Dientamoeba fragilis apresenta, como principal característica, dois núcleos na maioria dos trofozoítos e não possuem cistos. Os trofozoítos medem de 8 a $22 \mu \mathrm{m}$ de diâmetro. Os núcleos não possuem cromatina periférica e a mesma cromática se condensa em quatro a seis grânulos, geralmente com disposição irregular, alguns deles mais densos e grosseiros. Muitos pesquisadores consideram a $D$. fragilis como não patogênica, entretanto, alguns afirmam que são responsáveis por sintomatologia intestinal branda -diarréia - (NEVES et al 2000).

Mastigophora são protozoários que possuem flagelos que servem para a locomoção e apreensão de alimentos. Muitos são animais de vida livre, outros verdadeiramente parasitas, alguns determinam doenças ao homem e outros são considerados simples comensais (PESSOA e MARTINS 1982). Entre os Mastigophora está a Giardia lamblia, um patógeno emergente.

\section{Giardia lamblia}

Giardia lamblia (Lamblia intestinalis) apresenta-se de duas formas: o trofozoíto e o cisto. O trofozoito tem formato de pêra, com simetria bilateral e mede $20 \mu \mathrm{m}$ de comprimento por $10 \mu \mathrm{m}$ de largura. A face dorsal é lisa e convexa, enquanto a face ventral é côncava, apresentando uma estrutura semelhante a uma ventosa, que é conhecida por várias denominações disco veltral, adesivo ou suctorial. O trofozoíto possui, ainda, quatro pares de flagelo que se originam de blefaroplastos ou corpos basais situados nos pólos anteriores dos núcleos, a saber: um par de flagelos anteriores, um par de flagelos ventrais, um par de flagelos posteriores e um par de flagelos caudais. O cisto é oval ou elipsóide, mede cerca de $12 \mu \mathrm{m}$ de comprimento por $8 \mu \mathrm{m}$ de largura. A via normal de infecção do homem é a ingestão de cistos maduros que se transmitem, principalmente através da ingestão de águas superficiais sem tratamento, de águas deficientemente tratadas, de alimentos contaminados 
(verduras cruas e frutas mal lavadas ou por cistos veiculados por moscas, baratas); de pessoa a pessoa por meio das mãos contaminadas, em locais de aglomeração humana ou entre membros familiares, ou por contatos com animais domésticos infectados com Giardia lamblia (SOGAYAR e GUIMARÃES 2000)

Giardia lamblia é um flagelado que vive no intestino delgado, no intestino grosso e, às vezes, no estômago, sendo encontrada com freqüência nas vias biliares. Sua sede de eleição é a parte superior do intestino delgado, principalmente o duodeno (LIMA et al 1977). A giardíase é uma infecção intestinal provocada pela Giardia Lamblia. A infecção manifesta-se quando cistos desse protozoário são ingeridos, e se desenvolvem nos intestinos, causando diarréia; algumas vezes, provocam, também, outras complicações (SILVA e MARA 1979).

\subsection{História Político-Administrativa de Feira de Santana}

\subsubsection{O Município de Feira de Santana}

Em muitos aspectos, a história da pecuária no Estado da Bahia pode ser considerada a história de Feira de Santana. Até 1650, a pecuária foi prejudicada, ao longo da costa, devido às guerrilhas com os holandeses e aos conflitos entre os criadores e os lavradores em defesa das plantações. Não havia o arame, o grande elemento pacificador e protetor da cultura dos campos. Após 1650, vários ranchos de criação de gado foram instalados na vasta sesmaria de Tocós, doada, em 1609, a Antônio Guedes de Brito, um dos maiores criadores de gado da Província. Na época, era fácil comprar ou, tão somente, ocupar as terras da família Brito para criar gado, atividade rentável para quem se dispunha a suprir as necessidades de força motriz dos engenhos de açúcar e de abastecimento de carne de Salvador, sede da Província, que já não podia ser atendida com a produção dos currais de sua periferia (SIMONSEN 1977). 
A ordenação territorial das Províncias durante os primeiros séculos de colonização do país, segundo CÂMARA (1985), desenvolvia-se através das freguesias da Igreja Católica. A Igreja era a instituição que praticamente dava sustentação à criação e à consolidação das freguesias que, quase sempre, serviam como referência para a constituição territorial dos municípios na Bahia. A criação da freguesia de São José das Itapororocas, onde se localizava a Fazenda Olhos d'Água, ocorreu em 1696 e foi o primeiro passo para a criação do território de Feira de Santana.

A fazenda Olhos d'Água, de propriedade do português Domingos Barbosa de Araújo, era um dos diversos ranchos de criação de gado da região. A sede da fazenda estava localizada na bacia do Rio Jacuípe, próxima ao divisor das águas deste Rio com as do Rio Subaé e às nascentes de água, lagoas, riachos e ao leito do próprio Rio Jacuípe. Nas terras da fazenda, existiam excelentes pastagens naturais e várias lagoas e nascentes de água como a de dois outros rios (Pojuca e Subaé), suficientes para dessedentar milhares de cabeças de gado. Sua localização era privilegiada, pois estava no caminho mais direto entre o Recôncavo (faixa litorânea da Bahia próximo a Salvador) e as imensas pastagens do Sertão.

Com essas vantagens de localização, a fazenda Olhos d'Água tornou-se ponto de convergência de boiadas e, consequentemente, local ideal para o surgimento natural da feira de gado e formação de um povoado (elevado à categoria de vila em 1832). Ao redor da capela da fazenda instalou-se um pequeno centro de permuta comercial, tornando-se pouso obrigatório de tropas e viajantes que circulavam entre o alto sertão da Bahia, Minas, Piauí e Goiás e o porto de Nossa Senhora do Rosário de Cachoeira, situado à margem do Rio Paraguaçu, no trecho navegável e mais avançado da sua desembocadura na Bahia de Todos os Santos (CÂMARA 1985).

No porto de Nossa Senhora do Rosário de Cachoeira, ou Cachoeira, localizavam-se grandes estabelecimentos de vendas de tecidos e mercadorias diversas, pertencentes a comerciantes portugueses, onde eram compradas as mercadorias para todo o sertão 
baiano cuja rota, obrigatoriamente, passava pela fazenda Olhos d'Água (CÂMARA 1985). Na época, o transporte fluvial e maritimo era a única forma de comunicação eficiente entre Cachoeira e a sede da Província (Salvador). De Cachoeira para Feira a ligação era realizada através de estrada de boiadas. A ligação entre Feira e Cachoeira era tão importante que, em 1876, foi implantado, inicialmente, um ramal de estrada de ferro, ligando as duas localidades. A ligação entre Feira de Santana e a sede da província também era realizada com mais facilidade através de Cachoeira. Segundo CÂMARA (1985) a abertura da rodovia Salvador-Feira (BR 324), foi inaugurada em 1926, com extensão total de $144 \mathrm{~km}$ e constituiu-se no primeiro e principal passo para a comunicação do sertão baiano com a capital do Estado através de rodovia.

Segundo POPPINO (1968), “.... o povoado, que crescia em torno dos Olhos d'Água, tinha como base o comércio. A grande maioria da população da paróquia constituía-se de lavradores e por isso os habitantes do arraial de Feira de Santana estavam principalmente interessados em negócios. A vida comercial da região centrava-se em torno da feira de gado e só em segundo plano fixava-se na venda de fumo, algodão e gêneros alimentícios, más, desde os primórdios, existiu também um comércio limitado de mercadorias importadas da Cidade de Salvador ou da Europa. O sal de cozinha para o gado e para o preparo do couro ia para Feira de Santana em compridos comboios de tropas da Capital e de Cachoeira. Armas de fogo e pólvora também se importavam (....) $\mathrm{O}$ azeite, o vinagre e vinhos, elementos essenciais na dieta da população portuguesa, eram trazidos das ilhas do Atlântico ou do continente. Durante o periodo analisado ${ }^{(2)}$ tecidos finos vinham da Europa para o corte das roupas das pessoas mais ricas da sociedade local (....) " p.75-76).

O Município de Feira de Santana está situado à nordeste do Estado da Bahia e a noroeste de Salvador, na fronteira do Recôncavo Baiano, tendo $96 \%$ de seu território incluído no "poligono das secas", com sua sede nas coordenadas $12^{\circ} 15^{\prime} 24^{\prime}$ " de latitude $\mathrm{S}$ e $37^{\circ} 57^{\prime}$ 53"de longitude. Segundo CÂMARA (1985), o Município foi criado pelo Decreto de 13

\footnotetext{
${ }^{2} O$ periodo analisado corresponde à origem do povoado até 1860.
} 
de novembro de 1832, com território desmembrado do Município de Cachoeira, em cujo território estava localizada a fazenda Santana dos Olhos d'Água, conhecida por Olhos d'Água. Com o correr dos anos, a cidade de Feira de Santana, sede do Município de mesmo nome, transformou-se na maior e mais próspera cidade do interior do Estado da Bahia.

O territóriọ inicial do município era constituído pelas freguesias de São José das Itapororocas, de Santana do Camisão e do Santíssimo Coração de Jesus do Pedrão, com $2099 \mathrm{~km}^{2}$ (CAMARA 1985). Em 1964, com a conquista de sua emancipação, foram desmembrados de Feira de Santana os distritos de Anguera, Santa Bárbara e Tanquinho, passando a municipios com os mesmos nomes. Segundo HOUAISS (1978), Feira de Santana é uma cidade do Estado da Bahia com $1.344 \mathrm{~km}^{2}$ de território, altitude média de $242 \mathrm{~m}$, uma das maiores feiras de gado do país, importante feira-livre semanal e famosa em todo o Nordeste.

\subsubsection{A Administração de Feira de Santana}

Segundo CÂMARA (1985), a história político-administrativa de Feira de Santana pode ser subdividida em quatro períodos: de sua fundação até 1889 , quando se constituiu a estrutura tributária municipal sob a tutela do Império; de 1889 a 1930, quando se firmou a divisão dos três poderes republicanos e foram construídos os principais prédios da administração; de 1930 a 1950, quando se modernizaram as finanças municipais e o município perdeu grande parte de sua autonomia, tendo sido governado por interventores; e de 1950 até hoje, quando o Município recupera parte de sua autonomia política, mas perde parte de sua autonomia tributária, com as ações centralizadoras do governo federal. É neste último periodo que se inicia o crescimento industrial no Município, além da tradicional transformação de matéria prima e beneficiamento de produtos agrícolas (fabricação doméstica).

Até 1889, as funções executivas eram exercidas pela Câmara Municipal, mas, em assunto de importância, o presidente da Província conservava a autoridade executiva 
dentro do município. A Câmara Municipal coletava os impostos e taxas, aplicava multas e penas, recolhia o foro de terras públicas, gerenciava a construção de prédios municipais, fiscalizava o alinhamento dos prédios, promovia a pavimentação de ruas, preocupava-se com a arborização, abastecimento de água e exercia rigoroso controle dos cidadãos através dos Códigos de Postura (CÂMARA 1985), entretanto, não faz qualquer referência quanto ao esgotamento sanitário local.

No segundo periodo, foi dissolvida a Câmara Municipal e criados os Conselhos Municipais, e surgindo a figura do Intendente, o antepassado dos atuais Prefeitos. Os Conselhos, o Intendente, as Juntas Distritais e os Juizes de Paz, segundo a Constituição Republicana da época, deveriam ser eleitos de uma só vez. A experiência foi modificada em 1915 quando o Intendente passou a ser nomeado pelo Governador da Província. Em 1920, acaba o período de intervenção e passa-se ao regime político, com eleições, a cada dois anos, para os cargos públicos citados. Nesse período, já havia registros de falta d'água, de esgotamento sanitário e de condições insatisfatórias de vida, triste e quase sem animação (CÂMARA 1985). Mesmo nessas condições, havia administradores que divulgavam a cidade de Feira de Santana como a mais linda da Bahia e de excelente clima para se morar.

Na terceira fase de sua história $(1930$ - 1950) a figura do Intendente deu lugar à do Prefeito. Apesar da importância política do Prefeito, foi um período de pouca responsabilidade para o executivo municipal, pois, de quatro Prefeitos que serviram Feira de Santana, no período, apenas dois foram eleitos (CÂMARA 1985).

Após 1950, os Municípios recuperaram parte de sua autonomia política, mas perderam grande parte da tributária, mediante a ação centralizadora do governo federal. Nesse periodo, iniciam as instalações das indústrias de transformação, porém o Município não conseguiu um desenvolvimento industrial autônomo. As bases para a industrialização de maior importância (de fora do Município) foram implantadas a partir da década de 
1970 e, fortemente, orientadas para mercados extralocais, com fontes de suprimento também extraregionais, em sua maior parte (MECCIA 1985).

\subsubsection{População de Feira de Santana}

A primeira informação relativa à população de Feira de Santana de que se tem registro é do ano de 1825, quando José Joaquim de Almeida informa, em seu relatório para o governo do Império, que "Há na distância de oito léguas de Cachoeira e na de quatro de São Gonçalo, o grande e populoso arraial de Santana dos Olhos d'Água, onde, nas terças-feiras de cada semana (dia de feira no arraial àquela época) se juntam de três a quatro mil pessoas" (POPPINO 1968). A população informada era estimada e correspondia ao dia de pico, dia de feira, não era de um dia normal para a localidade.

Segundo SILVA (1997), em 1875, um ano antes da inauguração da estrada de ferro que liga Feira a Cachoeira, a população oficial de Santana dos Olhos d'Água era de 7.995 habitantes distribuída conforme segue: 3327 homens, 3.769 mulheres, 472 menores e 371 escravos (7.959 nacionais e 37 estrangeiros). Em 1889, só no perímetro urbano, Feira de Santana já contava com 4.454 habitantes (1.835 homens e 2.619 mulheres, dos quais 2.232 eram pardos, 1.402 brancos e 821 negros).

A população de Feira de Santana, rural e urbana, para o período de 1940 a 2000 corresponde ao registro na Tabela 2.8 .

Considerando-se a população de 1875 e a população de 1940 (65 anos) verifica-se que Feira de Santana cresceu a uma taxa média anual de 0,88\%. Entre 1875 e 2000 (125 anos) a população de Feira de Santana cresceu mais de 60 vezes, ou seja, a uma taxa média de $3,33 \%$ ao ano. 
A partir da Tabela 2.8 verifica-se que Feira de Santana cresceu muito rapidamente nas décadas de 40, 50 e 60 , praticamente dobrando a população por década. Nas décadas seguintes, 70, 80 e 90 manteve o crescimento alto, porem com taxas menores.

Tabela 2.8 - População do Municipio de Feira de Santana e taxa de crescimento por década, no periodo entre $1940-2000$.

\begin{tabular}{|c|c|c|c|c|c|c|}
\hline \multirow[t]{2}{*}{ ANO } & \multicolumn{3}{|c|}{ POPULAÇÃO URBANA } & \multicolumn{3}{|c|}{ POPULAÇÃO RURAL } \\
\hline & $\begin{array}{l}\text { POPULACÃO } \\
\text { (habitantes) }\end{array}$ & $\begin{array}{c}\text { TAXA DE } \\
\text { CRESCIMENTO } \\
(\%)\end{array}$ & $\begin{array}{c}\text { COEFICIENTE } \\
\text { MULTIPLICADOR }\end{array}$ & $\begin{array}{c}\text { POPULAÇÄO } \\
\text { (habitantes) }\end{array}$ & $\begin{array}{c}\text { TAXA DE } \\
\text { CRESCIMENTO } \\
(\%)\end{array}$ & $\begin{array}{c}\text { COEFICIENTE } \\
\text { MULTIPLICADOR }\end{array}$ \\
\hline 1940 & 14.131 & - & - & 4.665 & - & - \\
\hline 1950 & 26.559 & 6,51 & 1,88 & 8.488 & 6,17 & 1,82 \\
\hline 1960 & 61.612 & 8,78 & 2,32 & 6.984 & $-1,93$ & 0,82 \\
\hline 1970 & 129.412 & 7,71 & 2,10 & 6.816 & $-0,24$ & 0,98 \\
\hline 1980 & 228.751 & 5,86 & 1,77 & 27.568 & 15,00 & 4,04 \\
\hline 1991 & 341.794 & 3,72 & 1,49 & 36.055 & 1,04 & 1,31 \\
\hline 2000 & 431.580 & 2,63 & 1,26 & 49.234 & 3,52 & 1,37 \\
\hline
\end{tabular}

Tabela montada pelo autor a partir de dados de TECNOSAN ENGENHARIA S. A. 1981; META SERVIÇOS DE ENGENHARIA LTDA. 1998a, 1998b; IBGE 2000.

(1) O cálculo da taxa anual de crescimento foi feito através da fórmula $\left[(\mathrm{P} 1 / \mathrm{Po})^{\wedge(1 / \mathrm{n})}\right]-1=\mathrm{i}$

(2) O cálculo do coeficiente multiplicador foi feito com a fórmula $C=P n / P(n-1)$

\subsubsection{Recursos hídricos do entorno da cidade de Feira de Santana}

As terras da Fazenda Santana dos Olhos d'Água eram cortadas, de oeste para sudeste, pelo Rio Jacuipe, com $500 \mathrm{~km}$ de extensão, bastante caudaloso nos períodos de chuvas de invernos e de fortes trovoadas, e intermitente, ou com baixa vazão, em determinados anos secos. Esse rio possui água salobra e imprópria para consumo humano, porém muito utilizada para dessedentação de animais. Nas terras da fazenda, existiam dois outros rios: o Subaé e o Pojuca. O primeiro, com sua nascente na lagoa de mesmo nome, escoa na direção sudeste, no sentido de Feira para o Recôncavo Baiano, de vazão inicial pequena, porém de água doce, usado para abastecimento humano e de animais. $\mathrm{O}$ rio Pojuca nasce a noroeste de Feira de Santana, em terras do Municipio de Tanquinho, 
sendo que seu escoamento se dá para nordeste, depois para leste. O rio é intermitente em seu curso inicial e nos períodos de chuvas, a vazão próxima à nascente é relativamente pequena. Apresenta água pouco salobra, tolerável para consumo humano e de animais. Atualmente a nascente do rio Subaé encontra-se no perímetro de Feira de Santana, enquanto que a nascente do rio Pojuca localiza-se em terras do município de Santa Bárbara. $\mathrm{Na}$ fazenda, havia, além dos rios citados, vários afluentes desses como os riachos: do, Fato, Principal (três riachos), do Maia, do Barão, da Lagoa Grande, da Cidade Nova, etc. e muitas lagoas como do Prato Raso, Lagoa Grande, Lagoa do Subaé, Lagoa Salgada, Lagoa do Berreca, Lagoa da Tabua, Lagoa Pirrixi.

Os recursos hídricos da região foram, inicialmente, a causa básica do surgimento e progresso de Feira de Santana. Entretanto, atualmente, muitos desses recursos não estão sendo utilizados para consumo humano devido à poluição que apresentam, o que prejudica a qualidade das águas, inviabilizando seu uso para abastecimento humano e mesmo para dessedentação de animais.

Parte do território urbano de Feira de Santana pertence à bacia hidrográfica que é drenada para o reservatório do Rio Paraguaçu, barrado por meio da represa de Pedra do Cavalo, utilizada para abastecimento de água de Salvador, de Feira de Santana e de outras cidades do Recôncavo Baiano; para irrigação; e em futuro próximo, para produção de energia. Esta condição determina que a poluição seja minimizada ou eliminada, devido à sua utilização. O Rio Subaé que deságua na Bahia de Todos os Santos, está sendo despoluído desde sua nascente, com a captação dos esgotos sanitários que nele são lançados e aí chegam, tendo em vista a despoluição de praias de Salvador.

Os usos atuais previstos para as águas do rio Subaé são os seguintes: abastecimento de água em pequenas comunidades e vilarejo; irrigação; abastecimento industrial; preservação da fauna e da flora; navegação (trecho de Santo Amaro até a foz); e pesca. (META SERVIÇOS DE ENGENHARIA LTDA 1998a, 1998b). 


\subsubsection{Abastecimento de água em Feira de Santana}

O abastecimento de água sempre foi motivo de preocupação da Câmara Municipal e do Executivo de Feira, e item obrigatório de todos os orçamentos republicanos. Entretanto, apesar de Feira ter se transformado em polo de pecuária, exatamente, pela grande disponibilidade de água, em 1860, o município não dispunha de fonte com água de qualidade e quantidade suficiente para suprir a cidade. Em 1875, comprava-se água de bem longe. No início da década de 40 , já se reclamava de muita falta de água na cidade. Até 1950, com 26.559 habitantes, Feira de Santana não tinha sistema público de abastecimento de água (CÂMARA 1985). Os moradores continuavam no costume secular de captar águas de chuvas nos telhados e armazenar em reservatórios, ou comprar água, por barril ou tina, de fornecedores que a transportavam em animais e carroças, captada em fontes poluídas como o Tanque da Nação e, ainda, de retirar água do subsolo (lençol freático) por meio de cisternas. Mesmo sendo considerado pela Administração um serviço público de importância, a situação de abastecimento de água de Feira era caótica.

Em 1951, foi implantado o primeiro sistema de abastecimento de água de Feira de Santana, cento e dezoito anos depois da criação do Município, através de convênio do SESP - Serviço Especial de Saúde Pública do Ministério da Saúde do Brasil com a Prefeitura Municipal. A captação de água era realizada no aqüífero subterrâneo, por meio de poços tubulares artesianos, localizados nas proximidades da Lagoa Grande, periferia de Feira de Santana. A água captada nos cinco poços era bombeada até um reservatório de reunião nas proximidades da lagoa e daí recalcada para a rede de distribuição na cidade, onde existiam dois reservatórios apoiados, de sobra, construídos com chapa de aço carbono, com $2.500 \mathrm{~m}^{3}$ de capacidade (COPLAN S. A. 1968; LIMA et al 1969; TECNOSAN ENGENHARIA S. A. 1981; ARAUJO 1985).

Em 1970, por exaustão do sistema de abastecimento de água existente, inclusive exaustão do manancial, o Município de Feira, não tendo recurso para investir na construção de um novo sistema com novo manancial, concedeu os serviços de 
abastecimento de água e esgotamento sanitário à SESEB - Superintendência de Engenharia Sanitária do Estado da Bahia, que cuidava do setor no interior do Estado. A Empresa Estatal projetou e construiu o novo sistema, mantendo a captação em poços na área da lagoa grande somente para abastecimento das indústrias e captação no Rio Paraguaçu, no Município de Conceição da Feira a $28 \mathrm{~km}$ de Feira de Santana, para abastecimento público.

O sistema implantado em 1970 operou até 1985 conforme projeto. Entretanto, com a construção da barragem Pedra do Cavalo, a captação, o tratamento e o primeiro recalque do sistema foram inundados e substituídos por captação em outro ponto (no lago de Pedra do Cavalo) junto ao segundo recalque do sistema anterior. Além das modificações citadas, foi ampliada a adução até Feira, com a construção de uma nova adutora em paralelo à existente, e em 1992, a distribuição foi ampliada para atender às novas demandas decorrentes de ter o crescimento da cidade ter ocorrido diferente do previsto no plano diretor de 1969. Esse sistema é o que existe no presente momento, com capacidade para $1500 \mathrm{l} / \mathrm{s}$, operando com $860 \mathrm{l} / \mathrm{s}$ em média, exceto o tratamento que está limitado a $1000 \mathrm{l} / \mathrm{s}$.

\subsubsection{Esgotamento sanitário em Feira de Santana}

O esgotamento Sanitário em Feira de Santana não foi assunto de muita preocupação da administração pública do município, desde sua fundação até metade da década de 1980 , de forma que as fontes naturais, objeto da origem do Município, não foram preservadas. As fontes naturais foram sendo poluídas paulatinamente com esgotos e lixo gerados em Feira de Santana, sendo, conseqüentemente, causas de doenças de veiculação hídrica. Esta realidade é comum nos países latino-americanos, onde a contaminação da água soma-se ao uso irracional, gerando problemas à qualidade de vida das populações.

O primeiro projeto de esgotamento sanitário de Feira de Santana foi contratado em 1966 pela Fundação SESP - Serviço Especial de Saúde Pública do Ministério da Saúde, desenvolvido pelo Escritório Hildalius Cantanhede Engenharia Civil e Sanitária Soc. 
Ltda e revisado, em 1973, através de contrato da Divisão de Saneamento Básico do DNOS - Departamento Nacional de Obras de Saneamento do Governo Federal pelo mesmo projetista (ARAUJO 1985).

O primeiro e atual sistema de esgotamento sanitário de Feira de Santana foi implantado em quatro etapas distintas. A primeira etapa de 1978 a 1982, a segunda de 1983 a 1987, a terceira de 1992 a 1994 e a última de 1997 a 2001. As duas primeiras etapas compreenderam a execução de redes coletoras na bacia, a construção do interceptor do Riacho Principal e da Estação de tratamento na bacia do rio Jacuípe, bem como a incorporação de redes de diversos conjuntos habitacionais. Na terceira etapa, fez-se a substituição da estação de tratamento constituída de três valos de oxidação pela ETE Contorno cujo sistema de tratamento envolve duas lagoas aeradas em paralelo; esse conjunto em série com um decantador (com recirculação de lodo); e uma lagoa de sedimentação. A quarta etapa corresponde à implantação da primeira etapa do sistema de esgotamento sanitário da bacia do Subaé, constituída de rede coletora, duas elevatórias, interceptor e uma estação de tratamento (dois DAFAs em paralelo e esse conjunto em série com uma lagoa aerada e uma facultativa tipo pistão).

A primeira etapa do esgotamento sanitário de Feira de Santana foi inaugurada em 1982, cento e cinqüenta anos após a criação do Município, com atendimento a uma população estimada em 13.500 habitantes, quando Feira já dispunha de 246.078 habitantes aproximadamente. Em 1994 (com 369.428 hab), já atendia a 41.225 habitantes quando foi ampliado para atender uma população de 90.000 habitantes. Hoje, com a implantação da $1^{2}$ etapa do esgotamento sanitário da bacia do rio Subaé, e a população total estimada em 483.748 habitantes, em Feira, o sistema de tratamento de esgoto está preparado para atender a uma população de 297.008 habitantes, que corresponde a $61,4 \%$ da população urbana de Feira. Entretanto, só estão interligados ao sistema 33,5\% da população, ou seja, 162.056 habitantes. A implantação de novas ligações continua sendo efetuada. 
Parte do solo de Feira de Santana possibilita o uso de fossa séptica com sumidouro e esta alternativa é usada por boa parte da população. Logo, a população atendida com esgotamento sanitário é bem maior que o indicado acima. Como o sistema composto de fossa séptica e sumidouro não é operado adequadamente, a fossa enche-se de matéria orgânica decomposta, o material sedimentável passa para o sumidouro e colmata as paredes, impedindo a infiltração do esgoto no solo. Existem, na cidade, cinco empresas privadas com a função de limpar fossa e são utilizadas pela população exatamente para descarte do esgoto que não infiltra no solo.

O riacho Principal ou três riachos Figura 2.1, afluente do rio Jacuípe, nasce na Lagoa do Prato Raso, dentro da área urbana de Feira de Santana, possui vazão natural pequena nos períodos de estiagem, recebe contribuição de outros riachos e é constituído de efluentes de esgoto sanitário da região. Em 1980, a concentração de $\mathrm{DBO}_{5}$ era de $120 \mathrm{mg} / \mathrm{l}$ antes do lançamento do esgoto tratado dos Valos de Oxidação e, posteriormente, essa carga poluidora caiu para $40 \mathrm{mg} / 1$ (ARAUJO 1985). Em 1989, após sete anos da inauguração da primeira etapa do sistema, a carga orgânica no Riacho Principal, entre o ponto de lançamento do esgoto tratado (ETE Contorno) e o rio Jacuípe (hoje Lago de Pedra do Cavalo), está discriminada na Tabela 2.9.

Tabela 2.9 - Valores de $\mathrm{DBO}_{5}$ do Riacho Principal entre a descarga da ETE Contorno e o Rio Jacuipe (RP 2300) ${ }^{3}$, no período de 1989/1992.

\begin{tabular}{c|c|c|c}
\hline ANO & MÊS & $\begin{array}{c}\text { VALOR MÉDIO DE } \\
\text { DBO }_{5}, 20^{\circ} \mathrm{C}(\mathrm{mg} / 1)\end{array}$ & $\begin{array}{c}\text { COLIFORME FECAL } \\
\left(\mathrm{N}^{\circ} \mathrm{de} c o l / 100 \mathrm{ml}\right)\end{array}$ \\
\hline 1989 & Novembro & 140 & - \\
\hline 1990 & Março & 250 & - \\
\hline 1991 & Maço & 310 & - \\
\hline 1992 & Março & 380 & - \\
\hline
\end{tabular}

Tabela montada pelo autor com dados de: CONCREMAT Engenharia e Tecnologia S. A. (1992); EMBASA / POLO DE FEIRA ${ }^{4}$; SANTIAGO et al (2001)

\footnotetext{
${ }^{3}$ RP 2300 - Ponto de monitoramento do CRA no Riacho Principal.

${ }^{4}$ Relatório de Controle de Qualidade das Plantas de Tratamento do esgoto sanitário de Feira de Santana e Corpo Receptor dos anos de 1989, 1990, 1991 e 1992.
} 
Com o início do funcionamento da estação Contorno, a jusante do tratamento e no Riacho Principal, os valores de Demanda Biológica de Oxigênio e Coliformes Fecais foram alterados e estão discriminados na Tabela 2.10 .

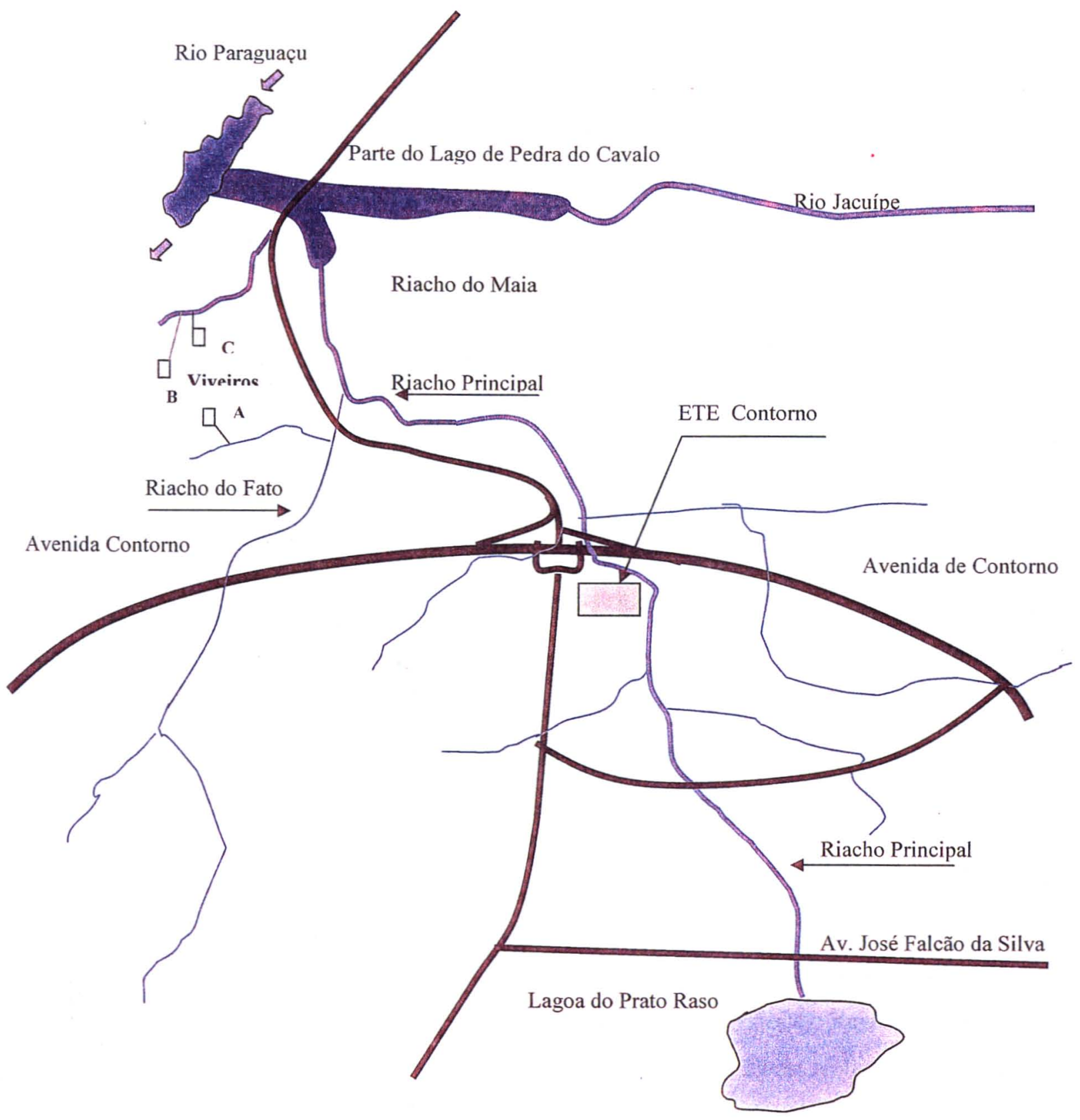

Figura 2.1 Riacho Principal ou Três Riachos 
Tabela 2.10 - Valores de $\mathrm{DBO}_{5}$ e Coliformes Fecais no Riacho Principal, entre a descarga da ETE Contorno e o Rio Jacuípe (RP 2300), em 2000.

\begin{tabular}{c|c|c|c}
\hline ANO & MÊS & $\begin{array}{c}\text { VALOR MEDIO DE } \\
\text { DBO5, } 20^{\circ} \mathrm{C}(\mathrm{mg} / \mathrm{l})\end{array}$ & $\begin{array}{c}\text { COLIFORMES FECAIS } \\
\text { (Nol/100ml) }\end{array}$ \\
\hline 2000 & Junho & 6 & $2,4 \times 10^{4}$ \\
\hline 2000 & Julho & 16 & $3,0 \times 10^{5}$ \\
\hline 2000 & Agosto & 12 & $1,6 \times 10^{5}$ \\
\hline
\end{tabular}

Tabela montada pelo autor com dados de: EMBASA / UNF ${ }^{5}$; SANTIAGO et al (2001).

Como se pode verificar o valor da DBO vinha crescendo até 1992, possivelmente também em 1993, quando entrou em funcionamento a ETE Contorno. A partir daí passou a declinar. Quanto aos coliformes fecais, a redução verificada é de $10^{7}$ para $10^{5}$, valor este superior ao limite máximo estabelecido pela Resolução $n^{\circ} 20$ (CONAMA 1986) que é de $10^{3}$ para rios classe 2 . O ponto de amostragem RP 2300 do CRA Coordenação Regional Ambiental está próximo à descarga do Riacho no Rio Jacuípe. Na saida da ETE Contorno, o valor de coliformes fecais é ainda maior que o verificado no ponto de amostragem, devido à redução que ocorre entre os dois pontos.

O Riacho do Barão, afluente do Rio Jacuípe, nasce à oeste de Feira de Santana e, em seu perímetro urbano, possui vazão natural desprezível nos períodos de estiagem, sendo constituído pelos efluentes de esgoto sanitário da região e recebendo as águas tratadas oriundas da ETE Homero Figueiredo. A história da qualidade da água do riacho do Barão, quanto aos parâmetros de $\mathrm{DBO}_{5}$ e coliformes fecais é desconhecida. Em setembro de 2000 , a $\mathrm{DBO}_{5}$ era de $51 \mathrm{mg} / \mathrm{l}$ na descarga da ETE e os valores de coliformes fecais eram desconhecidos.

O riacho Lagoa Grande nasce no perímetro urbano de Feira, na lagoa de mesmo nome, é afluente do Rio Pojuca, possui vazão natural razoável nos períodos de estiagem, é constituído de efluentes de esgoto sanitário da região e recebe as águas tratadas oriundas da ETE Lagoa Grande. A história da qualidade da água do riacho Lagoa Grande, quanto

\footnotetext{
${ }^{5}$ Relatório de Controle de Qualidade das Plantas de Tratamento do esgoto sanitário de Feira de Santana e Corpo Receptor dos anos de 2001 e 2002.
} 
à $\mathrm{DBO}_{5}$ e coliforme fecais, é desconhecida. Em Setembro de 2000, a $\mathrm{DBO}_{5}$ era $126 \mathrm{mg} / 1$ na descarga da ETE e os valores de coliformes fecais eram desconhecidos.

O riacho do Fato, afluente do Riacho Principal, é o receptor do pequeno córrego que recebe o esgoto tratado da ETE Viveiros-A e certo volume de esgoto bruto da região. Não é monitorado individualmente, só após descarga no Riacho Principal -no RP 2300. Os valores de $\mathrm{DBO}_{5}$ e coliformes fecais conhecidos pós-lançamento da ETE Viveiros-A são os constantes na Tabelas 2.9 e 2.10 .

O rio Subaé, em sua nascente, possui vazão natural desprezível. É constituído de efluentes de esgotos sanitários da região e recebe as águas tratadas da ETE de mesmo nome (ETE Subaé). A qualidade da água do rio Subaé, na sua nascente, está caracterizada na Tabela 2.11 , quanto a DBO.

Tabela 2.11 - Valores de $\mathrm{DBO}_{5}$ na nascente do Rio Subaé.

\begin{tabular}{c|l|c}
\hline ANO & MÉS & VALOR MÉDIO DE DBO, $20^{\circ} \mathrm{C}(\mathrm{mg} / \mathrm{l})$ \\
\hline 1998 & & 276 \\
\hline
\end{tabular}

Fonte: SANTIAGO et al (2001).

\subsubsection{Aspectos de saúde e doença em Feira de Santana}

A fundamentação da questão médico-científica em Feira de Santana, na sua origem, estava intimamente ligada ao paradigma miasmático, idéia segundo a qual as doenças resultavam das emissões de gases e vapores - os miasmas - via de regra, decorrentes da decomposição de matéria orgânica ou, simplesmente, do acúmulo desta (SILVA 1997). Em verdade, não se tinha certeza das causas reais dos miasmas. A definição sempre fora imprecisa. O solo remexido ou escavado, aglomerações de pessoas, principalmente em ambientes fechados, com a conseqüente emanação de vapores e odores (decorrente de suores, ar respirado), decomposição de matéria orgânica, etc poderiam provocar os tão temidos gases. 
A idéia era tão marcante, que, no final do verão de 1844, o juiz e delegado municipal, Vicente Ferreira dos Santos, dirigiu oficio à Câmara Municipal (responsável pela administração pública) solicitando providências para que fossem plantadas grandes árvores nas praças e ruas da cidade, de modo a beneficiar os transeuntes (poupando-os dos rigores do sol), purificando o ar. Observava o juiz, em seu ofício, que a falta de arborização era especialmente sentida nos dias da grande feira de gado, quando a maior parte da população ficava inteiramente desabrigada e suportando sol fortíssimo, o que, talvez, a alguns, já tivesse ocasionado a morte (SILVA 1997).

Acreditavam o juiz e os vereadores, que as árvores, além de amenizar o forte sol, tinham a capacidade de absorver os miasmas. Elas eram especialmente necessárias àquele ambiente - a feira - onde o sol forte e o constante e volumoso acúmulo de pessoas, animais e dejetos criavam o ambiente perfeito à disseminação de toda sorte de males, condições essas agravadas pelas lagoas, alagadiços e olhos d'água existentes nas proximidades, que caracterizavam a região (ANONYMUS, 1923).

No século XIX, as precárias condições sanitárias da Bahia não eram desconhecidas. $\mathrm{O}$ Inimigo Invisível, "os microorganismos patogênicos", já chamava a atenção para a insalubridade dos ambientes urbanos, especialmente em Salvador, mas também em Cachoeira, Santo Amaro e Feira de Santana. A existência de uma legislação específica voltada para a preservação das condições de salubridade do ambiente urbano (como proibição da criação de porcos no perímetro da cidade, regulamentação dos lançamentos de dejetos nas vias públicas - esgotos a céu aberto, focos de águas estagnadas, acúmulo de lixo - utilização das fontes comuns, etc.) mostrava essa condição de insalubridade do ambiente (SILVA 1997).

Feira de Santana, com esse ambiente, foi acometida pela variola, que chegou a atingir proporções epidêmicas em dez ocasiões diferentes: anos $1837 ; 1844 ; 1851 ; 1882 ; 1883$; $1899 ; 1900 ; 1913 ; 1919$ e 1920. A malária, endêmica, era outro mal para a população local e, em algumas situações epidêmicas, como as verificadas nos anos de 1883; 1894; 
1913; 1918 e 1926, bem como a febre amarela em 1849, 1857, 1883, 1894 e 1913. Entretanto, não se verifica o registro das vítimas para cada um dos males, de forma adequada. Outra grande epidemia ocorrida foi registrada em 1919, conhecida como gripe espanhola (SILVA 1997).

Apesar da rapidez e intensidade com que se espalhou a epidemia de colera morbus, em 1855, na Província da Bahia, que implicou na perda de nada menos que 36.000 vidas, Feira de Santana foi pouco atingida, a despeito da sua condição de ser um entreposto comercial de enorme fluxo populacional. Morreram menos de 50 pessoas, quarenta e tantos como afirma o médico Dr José dos Santos Carneiro Pinto designado pelo governo, em oficio ao Presidente da Província (....) A Província, Excelentíssimo Senhor, parece querer proteger os habitantes deste lugar de um mal tão devastador, não isentando-os de serem acometidos dele, mas sim tornando-o muito mais benigno do que em outras lugares, (....) (....)se bem que a Feira até agora deva se considerar felicíssima, visto como o mal não tem feito o estrago que se tem dado em outros lugares atacados, todavia tem perdido dentro da Villa quarenta e tantas pessoas (....), comparadas a 8.200 pessoas em Cachoeira, 8.500 em Vila de Santo Amaro e 3.214 em Nazaré, etc. (APEB; SILVA 1997).

Não pode ser esquecida a presença da peste bubônica, verificada desde o período de colônia e que, só no século XX, se tornou epidêmica, mais especificamente nos anos 1922, 1925 e 1930. Como medida, foi proibida em 1860, por Lei Municipal, a instalação de estábulo no perímetro urbano para evitar acúmulo de sujeira e a conseqüente proliferação de ratos (SILVA 1997).

A população habituou-se a lidar com epidemias, pois 17 diferentes tipos ocorreram em Feira, entre 1837 e 1918. Existem registros da presença de outras doenças como a dracontiase causada por helmintos (bicho da costa) e endêmica na província da Bahia, inclusive em Feira de Santana e região. Na época, com uma população de cerca de 5.000 pessoas, constatavam-se quase 100 doentes do bicho da costa. $O$ ingresso no corpo 
humano dava-se através da água de beber, e o desenvolvimento, através da fonte Tanque da Nação, qualificada como cisterna imunda. Essa fonte era um dos principais pontos de abastecimento d'água da população, sobretudo nos períodos de seca (SILVA 1997).

Se as fontes de água contaminadas eram o principal elemento de propagação da dracontiase (dracunculose), eram, também, para várias outras enfermidades de natureza parasitária intestinal (SILVA 1997). O tratamento da água disponibilizada à população seria a solução mais lógica para o problema, entretanto, só a partir de 1951, a população urbana de Feira de Santana passou a ter sistema de abastecimento de água tratada.

Não se encontram registros históricos do número de pessoas relacionadas com as doenças de natureza parasitária intestinal em Feira de Santana. Dos registros parciais encontrados em livros de cemitérios, constatam que, no período de 1860 a 1889, há registros de mortes de 25 pessoas com disenteria diarréica, 52 com hidropisia e 76 de "jatos" (SILVA 1997). A importância era dada às doenças que matavam com rapidez, como as epidemias do cólera morbus, do sarampo, da varíola, etc. As doenças que causavam morte de forma lenta não tinham a mesma importância, exceto alguns casos estudados como o da dracunculose.

Nos períodos mais recentes, não se encontra registro sobre morbidade em Feira de Santana, entretanto, existe registro de mortalidade, conforme apresentado na Tabela 2.12 .

Em 1980, as doenças infecciosas e parasitárias eram a $3^{\text {a }}$ causa de óbitos em Feira de Santana, inferior apenas a Outras causas e a Sinais, sintomas e afecções mal definidas. Em 1985, passa a ser a $4^{\text {a }}$ causa de óbitos, em 1987 e em 1989 a $5^{2}$. Verifica-se uma queda contínua de óbitos em decorrência da causa morte entre os anos de 1980 e 1989. 
Tabela 2.12 - Óbitos de Residentes de Feira de Santana segundo causas.

\begin{tabular}{|c|c|c|c|c|c|c|c|c|}
\hline CAUSAS / ANO & \multicolumn{2}{|c|}{1980} & \multicolumn{2}{|c|}{1985} & \multicolumn{2}{|c|}{1987} & \multicolumn{2}{|c|}{1989} \\
\hline & No. & $\%$ & No. & $\%$ & No. & $\%$ & No. & $\%$ \\
\hline $\begin{array}{lll}\text { Doenças } & \text { Infecciosas } & \mathrm{e} \\
\text { parasitárias } & & \end{array}$ & 357 & 19,4 & 215 & 11,9 & 127 & 6,4 & 97 & 7,7 \\
\hline $\begin{array}{l}\text { Sinais, Sintomas, Afecções mal } \\
\text { definidas }\end{array}$ & 418 & 22,8 & 460 & 25,6 & 850 & 43,0 & 134 & 10,6 \\
\hline Doenças do aparelho respiratório & 317 & 17,2 & 416 & 23,1 & 323 & 16,3 & 450 & 35,8 \\
\hline Causas Externas & 209 & 11,4 & 140 & 7,8 & 238 & 12,0 & 127 & 10,1 \\
\hline Outras causas & 536 & 29,2 & 568 & 31,6 & 440 & 22,2 & 450 & 35,8 \\
\hline Total & 1837 & 100,0 & 1799 & 100,0 & 1971 & 100,0 & 1258 & 100,0 \\
\hline
\end{tabular}

Fonte: META SERVIÇOS DE ENGENHARIA LTDA (1998a, 1998b).

Nas áreas rurais, e mesmo urbanas de Feira de Santana, onde já existem abastecimento de água e esgotamento sanitário, helmintos e protozoários, parasitos do intestino humano, são responsáveis por uma série de doenças que, em casos extremos, podem levar a óbito se nāo forem tratadas adequadamente. As pessoas portadoras desses microorganismos não apresentam, obrigatoriamente, sintomas da doença, podem ser portadores sãos.

\subsubsection{Caracterização das estações de tratamento de esgotos de Feira de Santana e} das comunidades atendidas

Em Feira de Santana existem dez estações de tratamento de esgotos sanitários: Homero Figueiredo, Viveiros A, B e C, Lagoa Grande, Feira VII, Contorno, Parque Cajueiro, Chácara da Mangabeira e Subaé, conforme seguem.

\section{Comunidade e Estacão de Tratamento Homero Figueiredo.}

As comunidades Homero Figueiredo, Alvorada e Arco Íris localizam-se no bairro Sobradinho, a noroeste da cidade de Feira de Santana e são constituídas de pessoas de renda familiar na faixa de 2 a 4 salários mínimos. Essas comunidades dispõem dos serviços públicos de abastecimento de água tratada e esgotamento sanitário para $100 \%$ da população desde a implantação do sistema, em 1993. A coleta e o transporte do esgoto sanitário são feitos através de coletor predial ligado à rede pública coletora que descarrega na estação de tratamento Homero Figueiredo. Após tratamento na ETE 
Homero Figueiredo, o efluente é lançado no riacho do Barão, afluente do rio Jacuípe, conforme Figura 2.2. As ruas das comunidades citadas não são pavimentadas com paralelo ou asfalto, são em cascalho compactado. A drenagem pluvial é favorecida pela topografia, logo, o escoamento é feito através das calhas das ruas que conduzem as águas pluviais para um canal a céu aberto em alvenaria de pedra, que corta todas as comunidades e contribui para o Riacho do Barão. A coleta do lixo é feita três vezes por semana, mas, mesmo assim, é comum se encontrar lixo jogado nas calhas de drenagem pluvial ou em terrenos baldios.

O sistema de tratamento de esgotos sanitários Homero Figueiredo foi projetado para atender a um equivalente populacional de 9.790 habitantes com tratamento do esgoto a nível secundário. Estão interligadas ao sistema 1.468 residências, correspondendo a 7.340 habitantes ( $75 \%$ do previsto em projeto), gerando uma vazão média de $10,12 \mathrm{l} / \mathrm{s}$ e carga orgânica de $514 \mathrm{~kg}$ de DBO por dia (OYAMA FIGUEIREDO Construções e Empreendimento Ltda. 1992; SANTIAGO et al 2001).

Figura 2.2 Esquema do lançamento do esgoto sanitário da estação Homero Figueiredo.

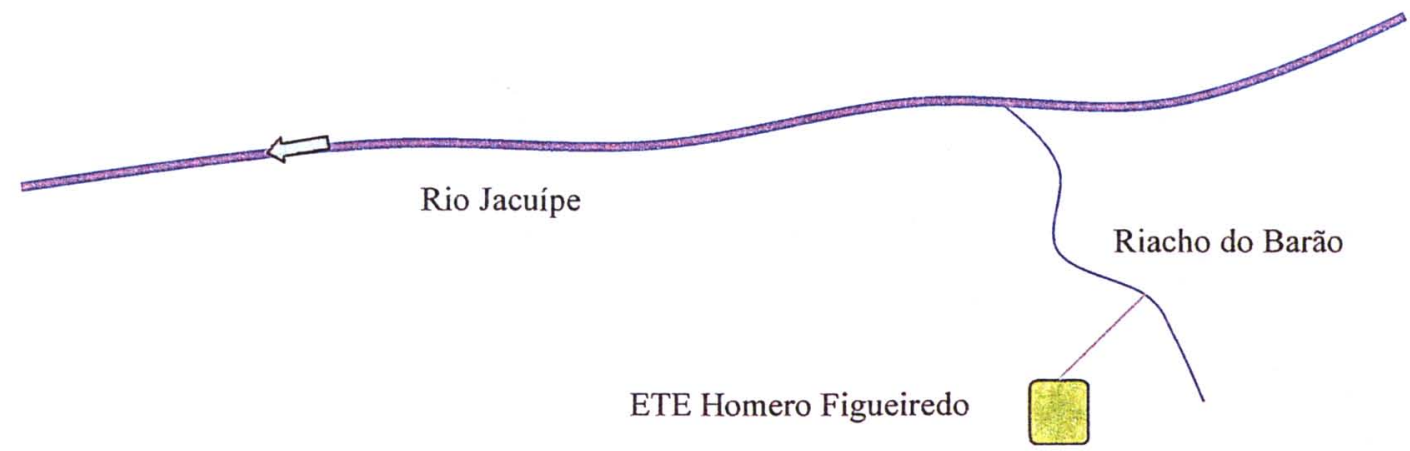

A estação de tratamento de esgotos sanitários Homero Figueiredo é constituída por tratamento preliminar (gradeamento e desarenador), tratamento primário e secundário em dois estágios, sendo composta por quatro DAFA - Digestor Anaeróbico de Fluxo Ascendente, em paralelo, e em série com uma lagoa de estabilização facultativa Foto 01 e Figura 2.3. 
Os parâmetros utilizados no projeto foram:

Carga orgânica: Afluente $\mathrm{Ca}=588,85 \mathrm{mg} \mathrm{DBO} / \mathrm{l}$, equivalente a $514,82 \mathrm{~kg} \mathrm{DBO}_{5} / \mathrm{dia}$;

Efluente $\mathrm{Ca}=40,00 \mathrm{mg} \mathrm{DBO} 5 /$, equivalente a $34,97 \mathrm{~kg} \mathrm{DBO}_{5} / \mathrm{dia}$;

Vazões afluentes: Máxima=17,59 l/s; Média =10,12 1/s; Mínima =6,19 1/s.

Vazões efluentes: Considerou-se as mesmas vazões afluentes.

Eficiência $=93,2$ \% em remoção de DBO;

Tempo de detenção: DAFA=10:00 h; Lagoa=259:12 h; Total=269:12 h = 11 dias e $05: 12 \mathrm{~h}$.

Remoção de coliformes: sem indicação (OYAMA FIGUEIREDO Construções e Empreendimentos Ltda. 1992).

Quanto à operação do sistema, foram previstas limpezas da grade de retenção de sólidos grosseiros diariamente, da caixa de areia a cada 15 dias, remoção de $12,73 \mathrm{~m}^{3}$ de lodo por DAFA a cada 20 dias, observando-se os limites de 0,25 - 1,0 mg/l de sólidos sedimentáveis no efluente da ETE, com descarga em leito de secagem dimensionado para período de limpeza a cada 30 dias. O lodo produzido na ETE está sendo transportado para a ETE Contorno em caminhões Hight Velocity, ou seja não está sendo descarregado no leito de secagem.

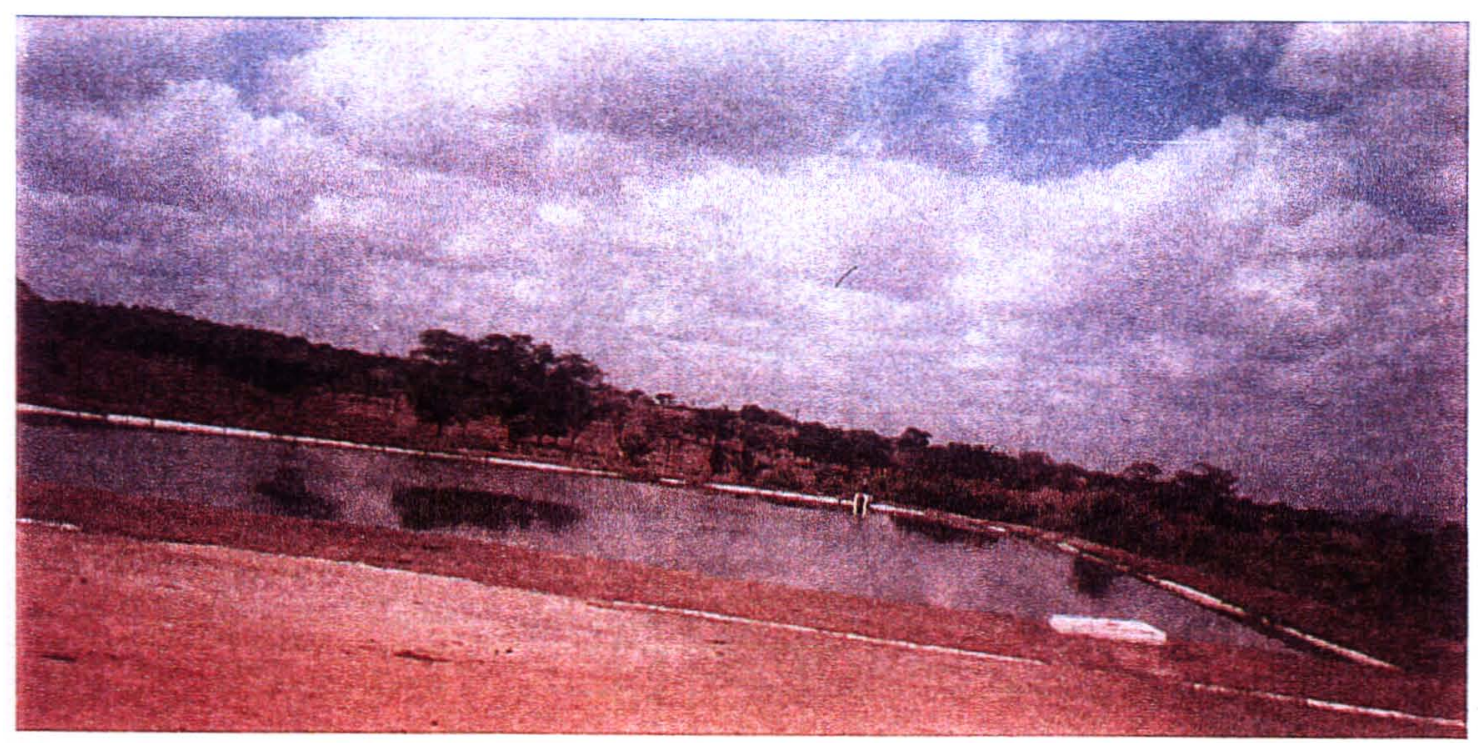

Foto 01. Lagoa Facultativa da ETE Homero Figueiredo 


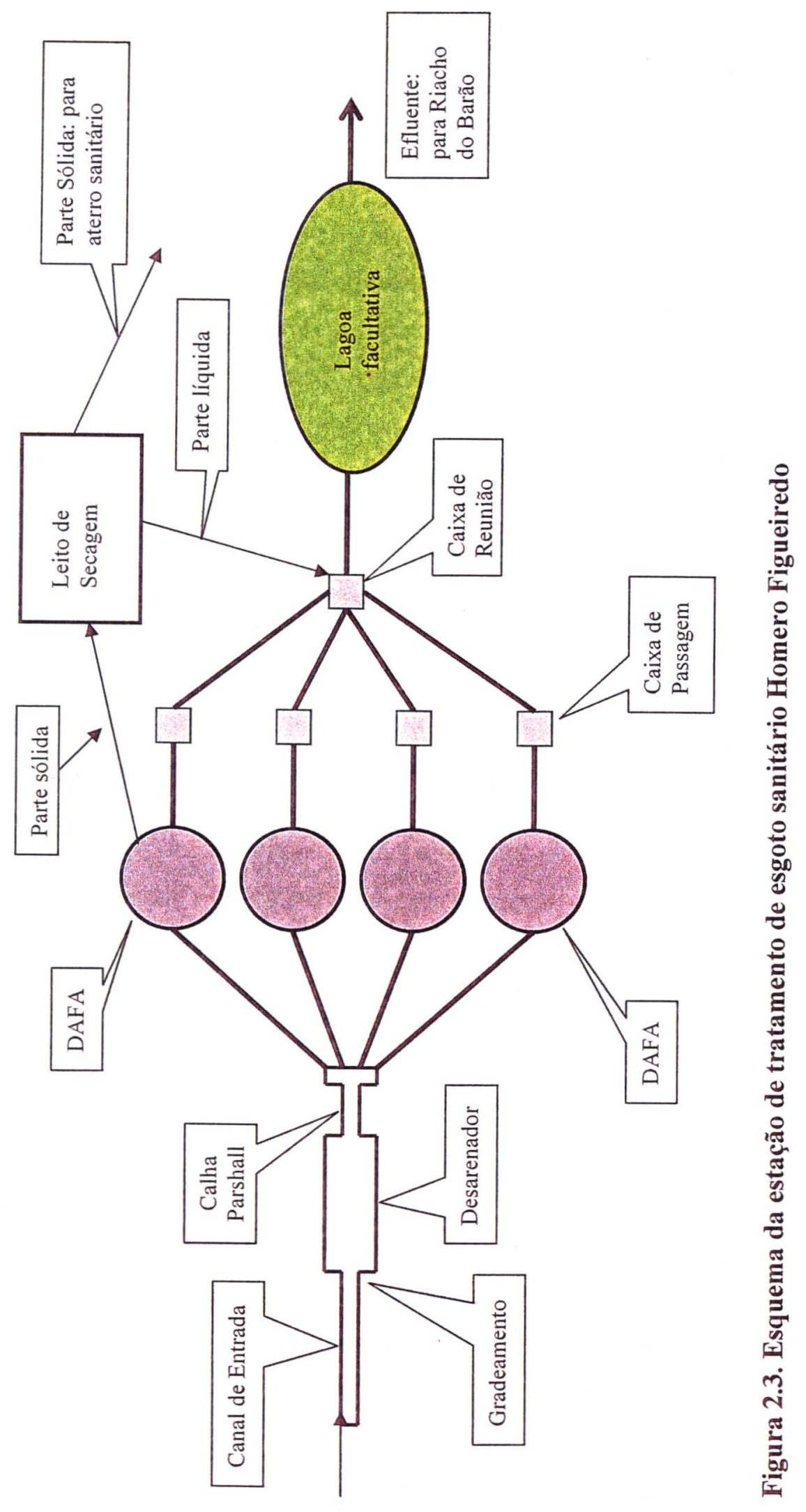




\section{Comunidade e Estacão de Tratamento Viveiros-A}

A comunidade Viveiros-A localiza-se em área da antiga fazenda Viveiros, próximo ao anel rodoviário de Contorno e ao Bairro Feira X, ao sul da cidade de Feira de Santana e é constituída basicamente por populares de baixa renda (sem renda familiar fixa ou na faixa de 1 a 2 salários mínimos) e pequenos comércios. A comunidade dispõe dos serviços públicos de abastecimento de água tratada e esgotamento sanitário desde a implantação do sistema em 1992. A coleta e o transporte do esgoto sanitário são feitos através de coletor predial e rede pública coletora, descarregando na estação de tratamento. O efluente tratado na estação Viveiros-A é lançado em um riacho, afluente do riacho do Fato, que, por sua vez, é afluente do riacho Principal que deságua no rio Jacuípe, conforme Figura 2.4. A drenagem pluvial é favorecida pela topografia, logo, o escoamento é feito através das calhas das ruas que conduzem as águas pluviais para canais a céu aberto que cortam a comunidade e contribuem para o riacho receptor do esgoto sanitário tratado na Estação Viveiros-A. O lixo é coletado pelo Serviço Municipal três vezes por semana, mas, mesmo assim, é comum encontrar lixo jogado nas ruas, calhas de drenagem pluvial ou em terrenos baldios.

O projeto da ETE Viveiros-A foi autorizado pelo parecer técnico AEH N ${ }^{\circ}$ 039/90 do Centro de Recursos Ambientais - CRA, com a recomendação de que a estação de tratamento confira ao efluente final dos esgotos tratados os padrões recomendados de DBO $<=40 \mathrm{mg} / \mathrm{l}$ e Material em Suspensão $<=100 \mathrm{mg} / \mathrm{l}$ (ERGON ENGENHARIA LTDA 1990).

O sistema de esgotamento sanitário Viveiros-A foi projetado para atender a um equivalente populacional de 3.560 habitantes e comércio ( 78 pessoas dia) com tratamento do esgoto a nivel secundário. Estão interligadas ao sistema 712 residências, correspondendo a 3.560 habitantes (100\% do previsto em projeto) e os estabelecimentos comerciais, gerando uma vazão de 3,59 1/s, carga orgânica de $181,90 \mathrm{~kg}$ de DBO por dia e $267,39 \mathrm{~kg}$ de DQO por dia (ERGON ENGENHARIA LTDA 1990; SANTIAGO et al 2001). 
Figura 2.4 Esquema do lançamento do esgoto sanitário da estação Viveiros A

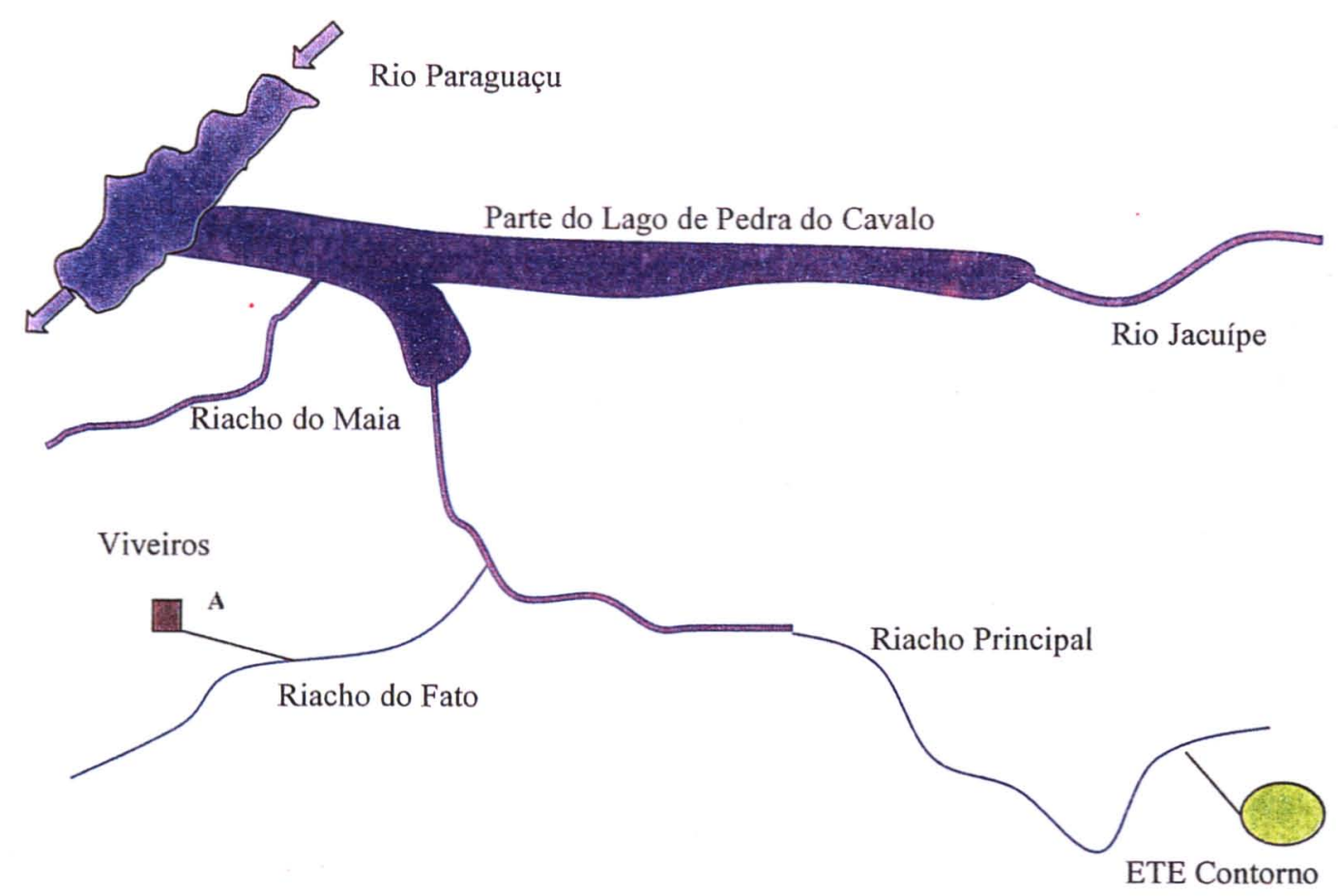

A estação de tratamento de esgoto Viveiros-A é constituída por tratamento preliminar (gradeamento e desarenador), tratamento primário e secundário compostos por seis DAFAs operando em série, dois a dois, conforme Foto 02 e Figura 2.5.

Os parâmetros utilizados no projeto foram:

Carga orgânica: Afluente $\mathrm{Ca}=587,10 \mathrm{mg} \mathrm{DBO}_{5} / \mathrm{l}$, equivalente a $182,10 \mathrm{~kg} \mathrm{DBO} / \mathrm{dia}$

Efluente $\mathrm{Ca}=23,49 \mathrm{mg} \mathrm{DBO}_{5} / 1$, equivalente a $7,29 \mathrm{~kg} \mathrm{DBO}_{5} / \mathrm{dia}$;

Vazões afluentes: Máxima=6,18 1/s; Média=3,59 1/s; Mínima=2,22 1/s.

Vazões efluentes: Considerou as mesmas vazões afluentes.

Eficiência $=96,0 \%$ em remoção de DBO. $80 \%$ em cada etapa do processo, ou seja, $80 \%$ no primeiro DAFA e $80 \%$ no segundo.

Tempo de detenção: DAFA 1 = 10:00 h; DAFA $2=10: 00 \mathrm{~h}$; Total = 20:00 h.

Remoção de coliforme: não há qualquer referência no projeto (ERGON ENGENHARIA LTDA 1990). 
Quanto à operação do tratamento, foram previstas limpezas da grade de retenção de sólidos grosseiros diariamente, da caixa de areia a cada 15 dias, remoção de $6,17 \mathrm{~m}^{3} \mathrm{de}$ lodo em cada DAFA em série a cada 20 dias, com base em análises físico-químicas. $\mathrm{O}$ lodo é removido e transportado para a Estação Contorno em caminhões tipo High Velocity, disponível na Unidade da Embasa em Feira de Santana.

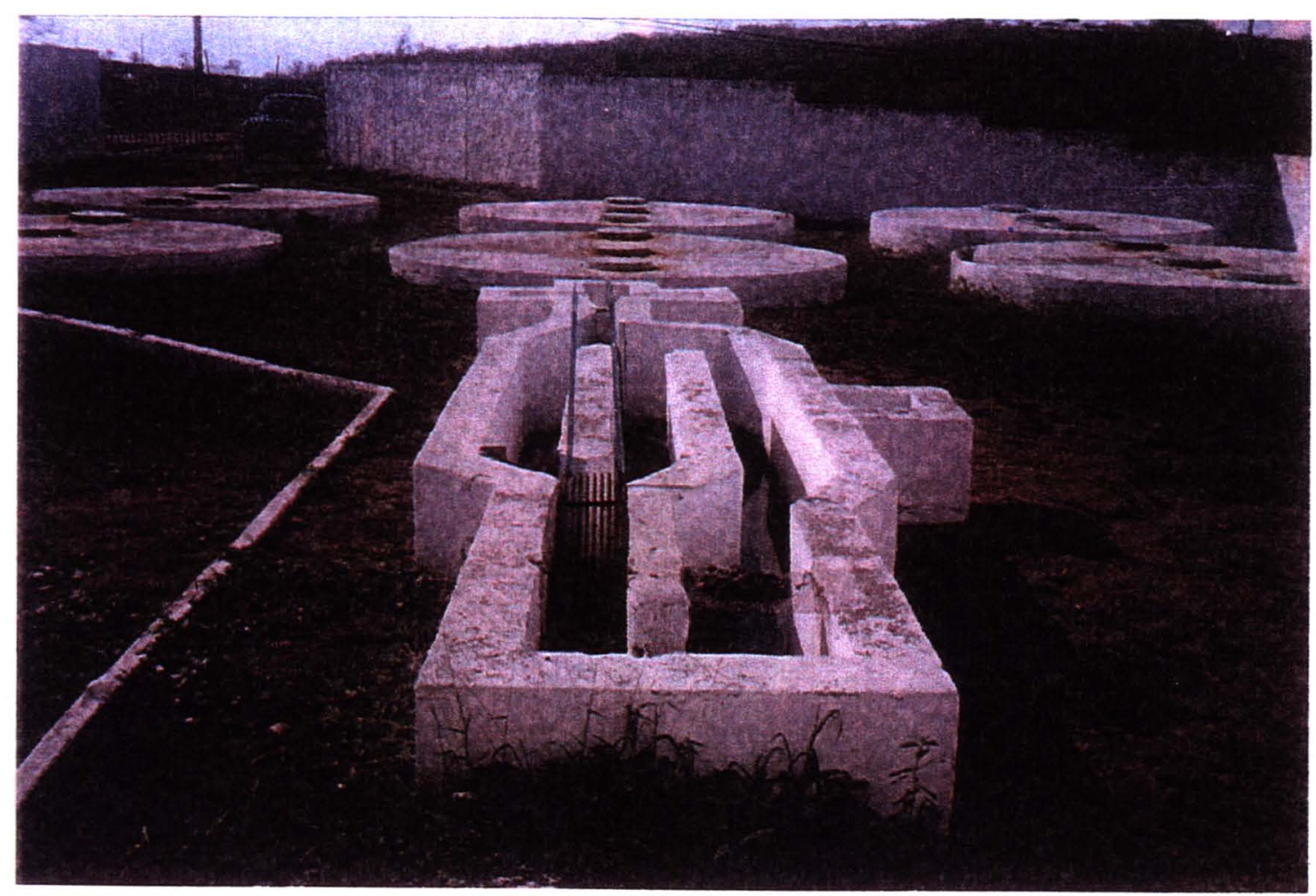

Foto 02. Estação Viveiros-A. 

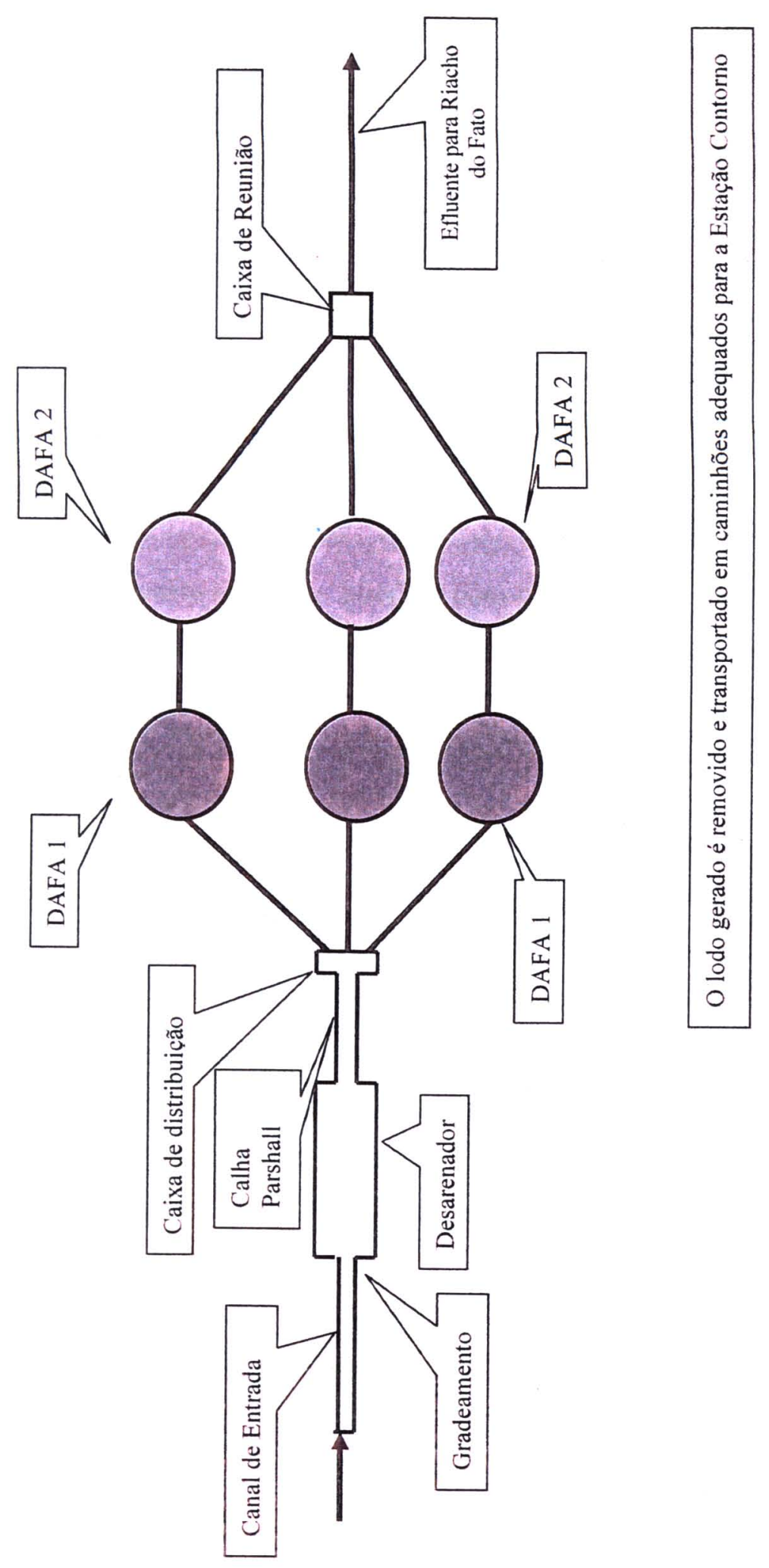

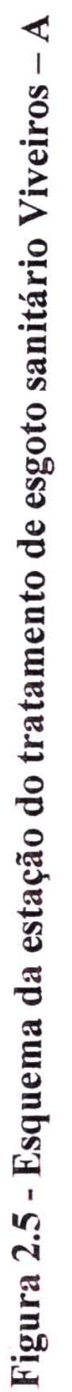




\section{Comunidade e Estação de Tratamento Viveiros - B}

A comunidade Viveiros B localiza-se em área da antiga fazenda Viveiros, vizinho ao Viveiros-A e próximo ao anel rodoviário de Contorno e ao Bairro Feira $\mathrm{X}$, ao sul da cidade de Feira de Santana e é constituída basicamente por populares de baixa renda (sem renda familiar fixa ou na faixa de 1 a 2 salários mínimos), posto policial, pequenos comércios e de um centro comunitário. A comunidade dispõe dos serviços públicos de abastecimento de água tratada e esgotamento sanitário desde a implantação do sistema em 1992. A coleta e o transporte do esgoto sanitário são feitos através de coletor predial e rede pública coletora descarregando na estação de tratamento. $O$ efluente tratado na estação Viveiros-B é lançado em um riacho afluente do riacho do Maia que deságua no rio Jacuipe, conforme Figura 2.6. A drenagem pluvial é favorecida pela topografia, logo, o escoamento é feito através das calhas das ruas que conduzem as águas pluviais para canais a céu aberto que cortam a comunidade e contribuem para o riacho receptor do esgoto sanitário tratado na Estação Viveiros-B. A coleta do lixo é feita, três vezes por semana, pelo serviço de limpeza município, mas, mesmo assim é comum encontrar lixo jogado nas ruas, calhas de drenagem pluvial ou em terrenos baldios.

O sistema de esgotamento sanitário Viveiros-B foi projetado para atender a um equivalente populacional de 3.580 habitantes, comércio (111 pessoas dia), posto policial ( 2 pessoas dia) e centro comunal (54 pessoas dia) com tratamento do esgoto a nível secundário. Estão ligados ao sistema 716 residências, correspondendo a 3.580 habitantes ( $100 \%$ do previsto em projeto), os estabelecimentos comerciais, o posto policial e o centro comunal, gerando uma vazão média de 3,54 l/s, carga orgânica de $185,11 \mathrm{~kg}$ de DBO por dia e $272,11 \mathrm{~kg}$ de DQO por dia (ERGON ENGENHARIA LTDA 1990; SANTIAGO et al 2001).

A estação de tratamento de esgotos Viveiros-B é constituída de tratamento preliminar (gradeamento e desarenador), tratamento primário e secundário composto por seis DAFAs, operando em série, dois a dois, conforme Foto 03 e Figura 2.7. 
Figura 2.6 Esquema do lançamento do esgoto sanitário da estação Viveiros B

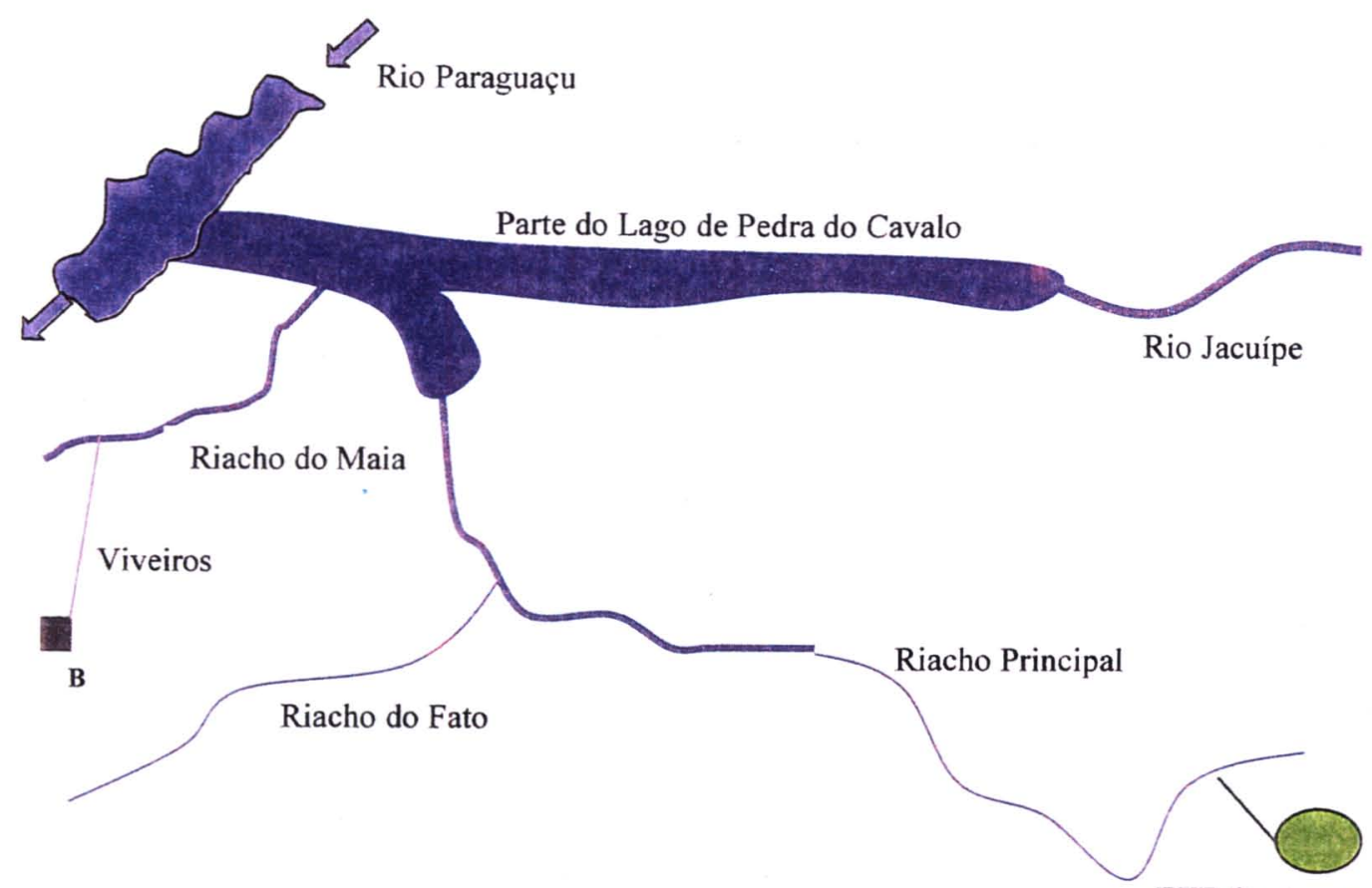

ETE Contorno

Js parâmetros utilizados no projeto foram:

Zarga orgânica: Afluente $\mathrm{Ca}=605,56 \mathrm{mg} \mathrm{DBO} / /$, equivalente a $185,21 \mathrm{~kg} \mathrm{DBO}_{5} / \mathrm{dia}$;

Efluente $\mathrm{Ca}=24,22 \mathrm{mg} \mathrm{DBO}_{5} / \mathrm{l}$, equivalente a $7,41 \mathrm{~kg} \mathrm{DBO}_{5} /$ dia;

Vazões afluentes: Máxima =6,19 1/s; Média = 3,54 1/s; Mínima = 2,14 l/s.

vazões efluentes: Considerou as mesmas vazões afluentes.

活iciência $=96,0 \%$ em remoção de DBO. $80 \%$ em cada etapa do processo, ou seja, $80 \%$ no rimeiro DAFA e $80 \%$ no segundo.

'empo de detenção: DAFA $1=10: 00 \mathrm{~h}$; DAFA $2=10: 00 \mathrm{~h}$; Total $=20: 00 \mathrm{~h}$.

¿uanto à remoção de coliforme não há qualquer referência no projeto (ERGON ingenharia Ltda 1990). 
Quanto à operação do tratamento, foram previstas limpezas da grade de retenção de sólidos grosseiros diariamente, da caixa de areia a cada 15 dias, remoção de lodo em cada DAFA em série a cada 20 dias, fundamentado em análises físico-químicas. O lodo é removido e transportado para a Estação Contorno em caminhões tipo High Velocity, disponível na Unidade da Embasa em Feira de Santana.

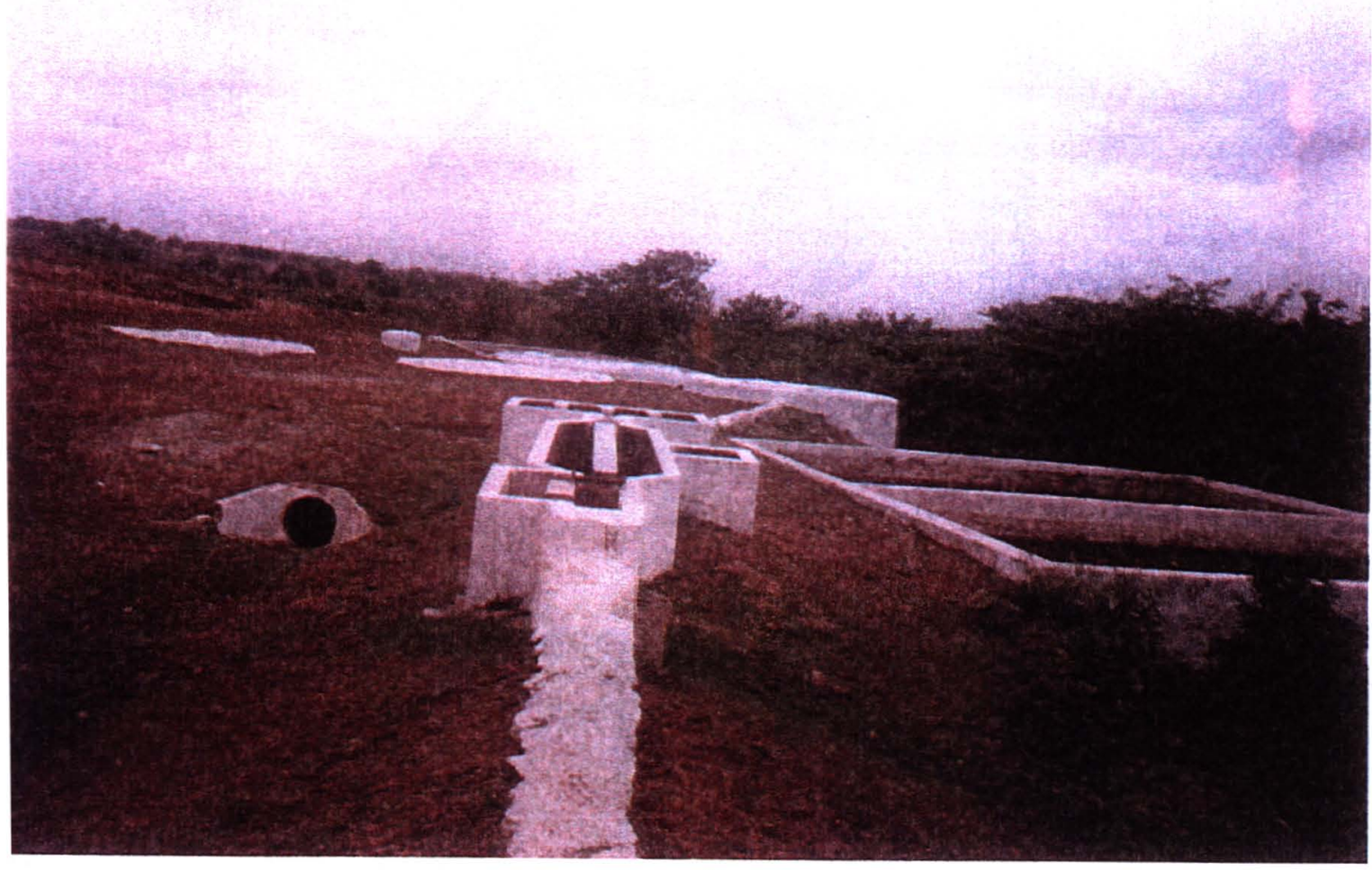

?oto 03. Estação Viveiros-B. 
I

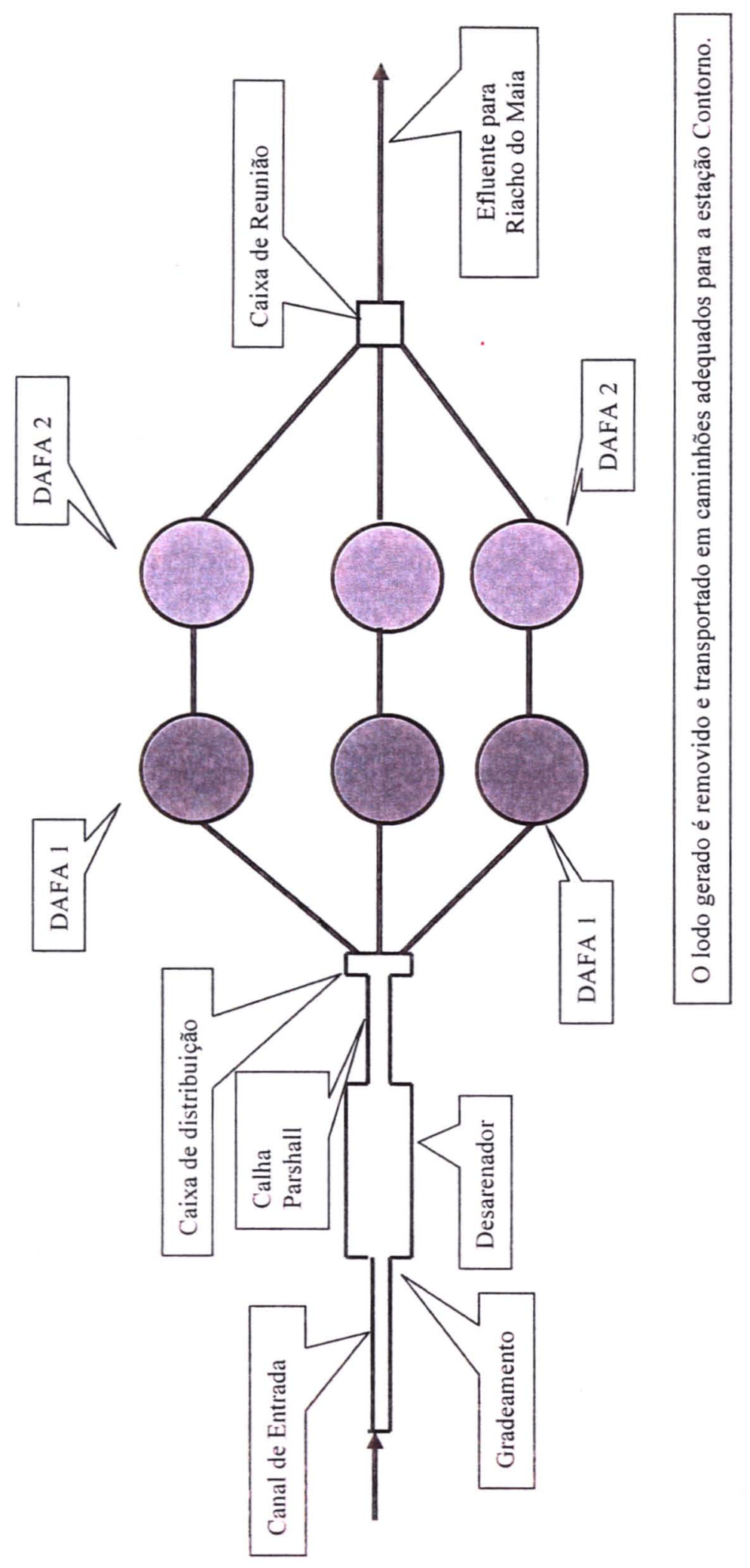

告) 


\section{Comunidade e Estacão de Tratamento Viveiros-C}

A comunidade Viveiros- $C$ localiza-se em área da antiga fazenda Viveiros, ao lado das comunidades viveiros $\mathrm{A}$ e $\mathrm{B}$ e próximo ao anel rodoviário de Contorno e ao Bairro Feira $\mathrm{X}$, ao sul da cidade de Feira de Santana e é constituída por populares de baixa renda (sem renda familiar fixa ou na faixa de 1 a 2 salários mínimos), escola, creche, pequenos comércios e posto médico. A comunidade dispõe dos serviços públicos de abastecimento de água tratada e esgotamento sanitário desde a implantação do sistema em 1992. A coleta e o transporte do esgoto sanitário são feitos através de coletor predial e rede pública coletora, descarregando na estação de tratamento. $O$ efluente tratado na estação Viveiros-C é lançado em um riacho afluente do riacho do Maia que deságua no rio Jacuipe, conforme Figura 2.8. A drenagem pluvial é favorecida pela topografia, logo, o escoamento é feito através das calhas das ruas que conduzem as águas pluviais para canais a céu aberto que cortam a comunidade e contribui para o riacho receptor do esgoto sanitário tratado na estação Viveiros-C. O lixo é coletado pelo serviço de limpeza municipal três vezes por semana, mas, mesmo assim, é comum se encontrar lixo jogado nas ruas, calhas de drenagem pluvial ou em terrenos baldios.

O sistema de esgotamento sanitário Viveiros $C$ foi projetado para atender a um equivalente populacional de 3.680 habitantes, comércio (149 pessoas dia), escola (2164 pessoas dia), creche (541 pessoas dia) e posto médico (216 pessoas dia), com tratamento do esgoto a nível secundário. Estão ligados ao sistema 736 residências, correspondendo a 3.680 habitantes ( $100 \%$ do previsto em projeto), os estabelecimentos comerciais, a creche, a escola e o posto médico gerando uma vazão média de $6,21 \mathrm{l} / \mathrm{s}$ e carga orgânica de $287,48 \mathrm{~kg}$ de DBO por dia e $422,60 \mathrm{~kg}$ de DQO por dia (ERGON ENGENHARLA LTDA 1990) 
Figura 2.8 Esquema do lançamento do esgoto sanitário da estação Viveiros C.

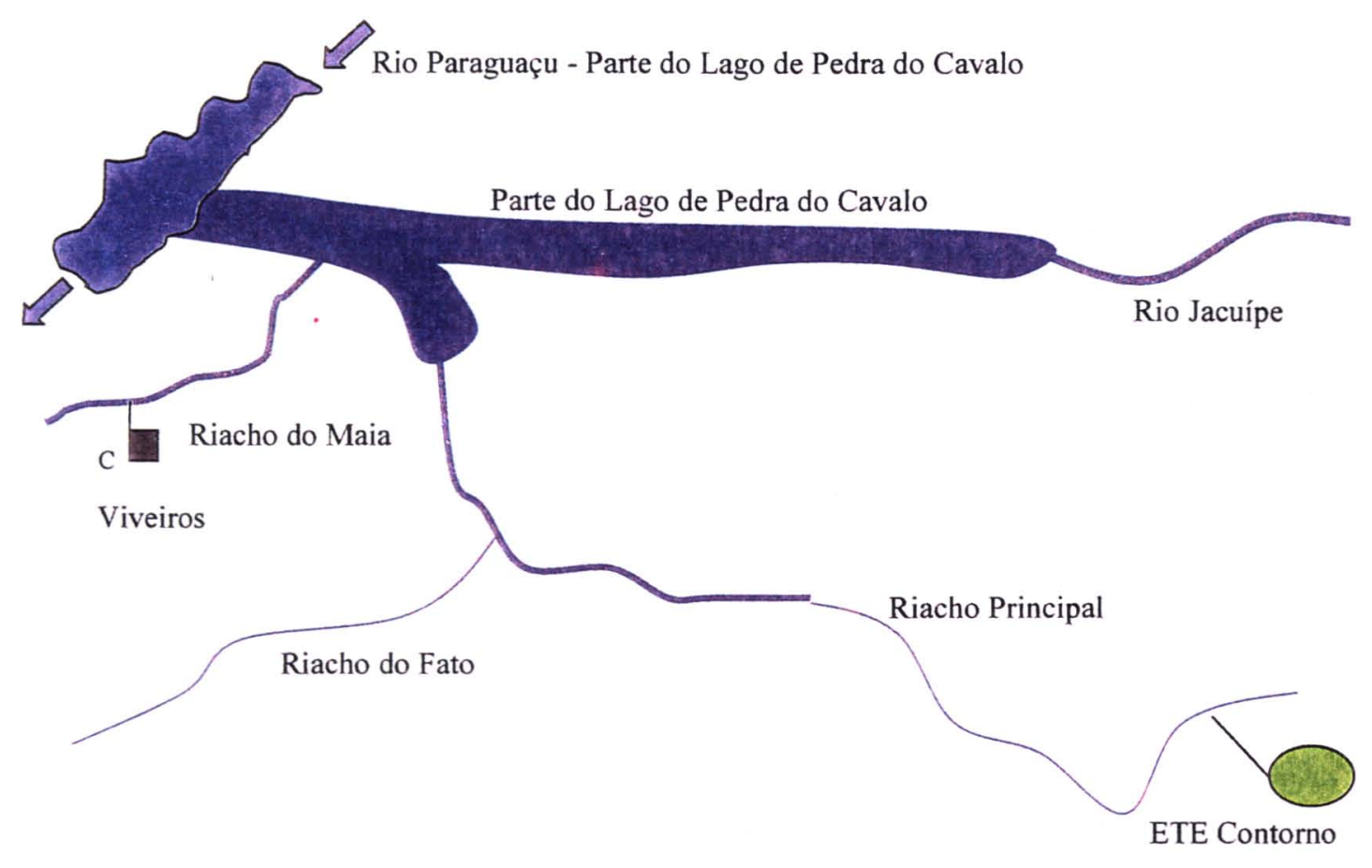

A estação de tratamento de esgotos Viveiros-C é constituída de tratamento preliminar (gradeamento e desarenador), tratamento primário e secundário composto por oito DAFAs, operando em série dois a dois, conforme Foto 04 e Figura 2.9.

Os parâmetros usados em projeto foram:

Carga orgânica: Afluente $\mathrm{Ca}=535,46 \mathrm{mg} \mathrm{DBO}_{5} / \mathrm{l}$, equivalente a $287,30 \mathrm{~kg} \mathrm{DBO} / \mathrm{dia}$;

Efluente $\mathrm{Ca}=21,42 \mathrm{mg} \mathrm{DBO}_{5} / 1$, equivalente a $11,49 \mathrm{~kg} \mathrm{DBO}_{5} / \mathrm{dia}$;

Vazões afluentes: Máxima $=11,18 \mathrm{l} / \mathrm{s}$; Média $=6,21 \mathrm{l} / \mathrm{s}$; Mínima = 3,60 1/s.

Vazões efluentes: Considerou as mesmas vazões afluentes.

Eficiência $=96,0 \%$ em remoção de DBO. $80 \%$ em cada etapa do processo, ou seja, $80 \%$ no primeiro DAFA e $80 \%$ no segundo.

Tempo de detenção: DAFA 1 = 10:00 h; DAFA 2=10:00 h; Total = 20:00 h. 
Quanto à remoção de coliformes não há qualquer referência no projeto (ERGON ENGENHARIA LTDA 1990).

Para a operação do tratamento foram previstas limpezas da grade de retenção de sólidos grosseiros diariamente, da caixa de areia a cada 15 dias, remoção de $4,78 \mathrm{~m}^{3}$ de lodo em cada DAFA em série a cada 20 dias, fundamentado em análises físico-químicas. O lodo é removido e transportado para a Estação Contorno em caminhões tipo High Velocity, disponível na Unidade da Embasa em Feira de Santana.

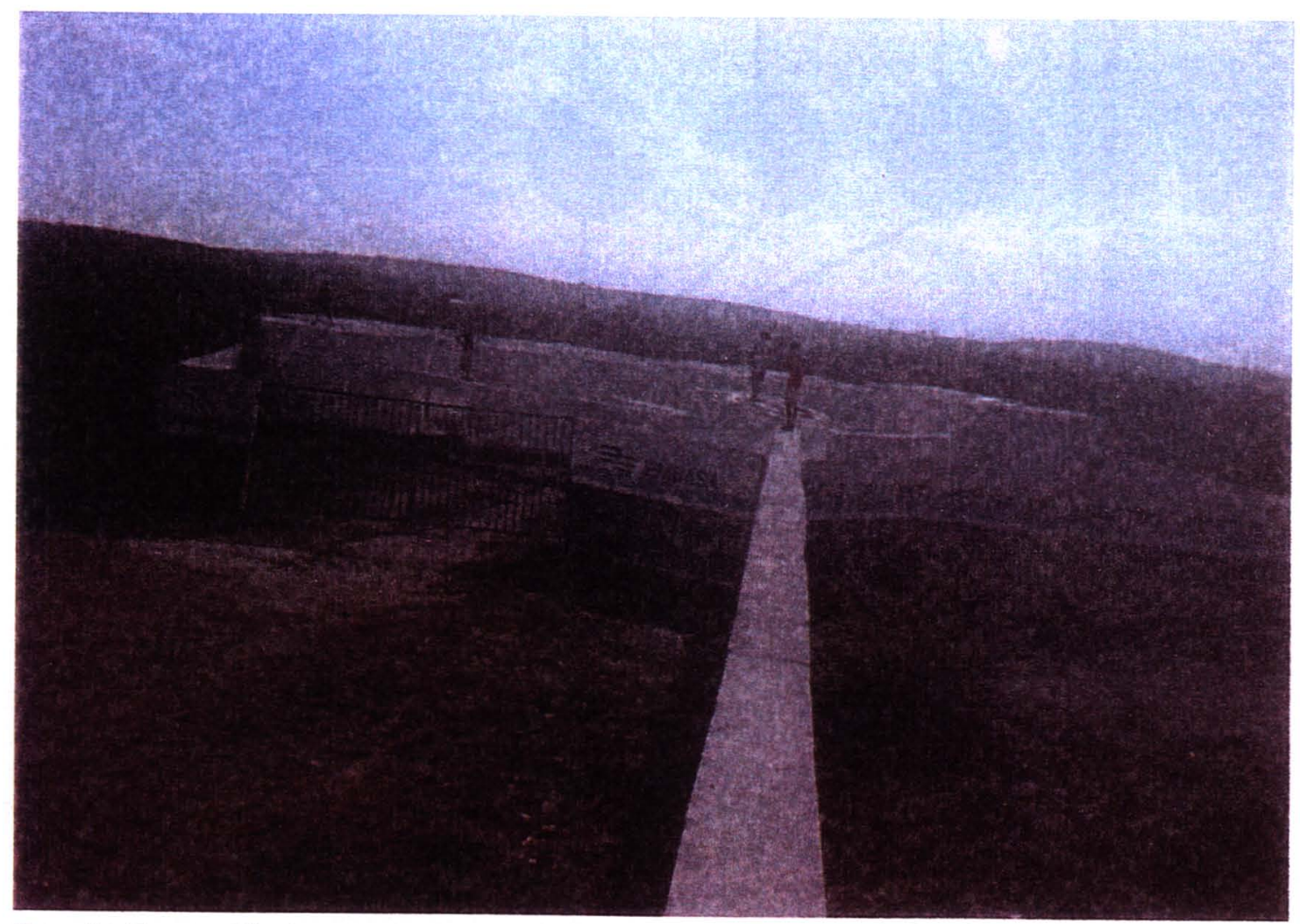

Fotos 04. Estação Viveiros-C 


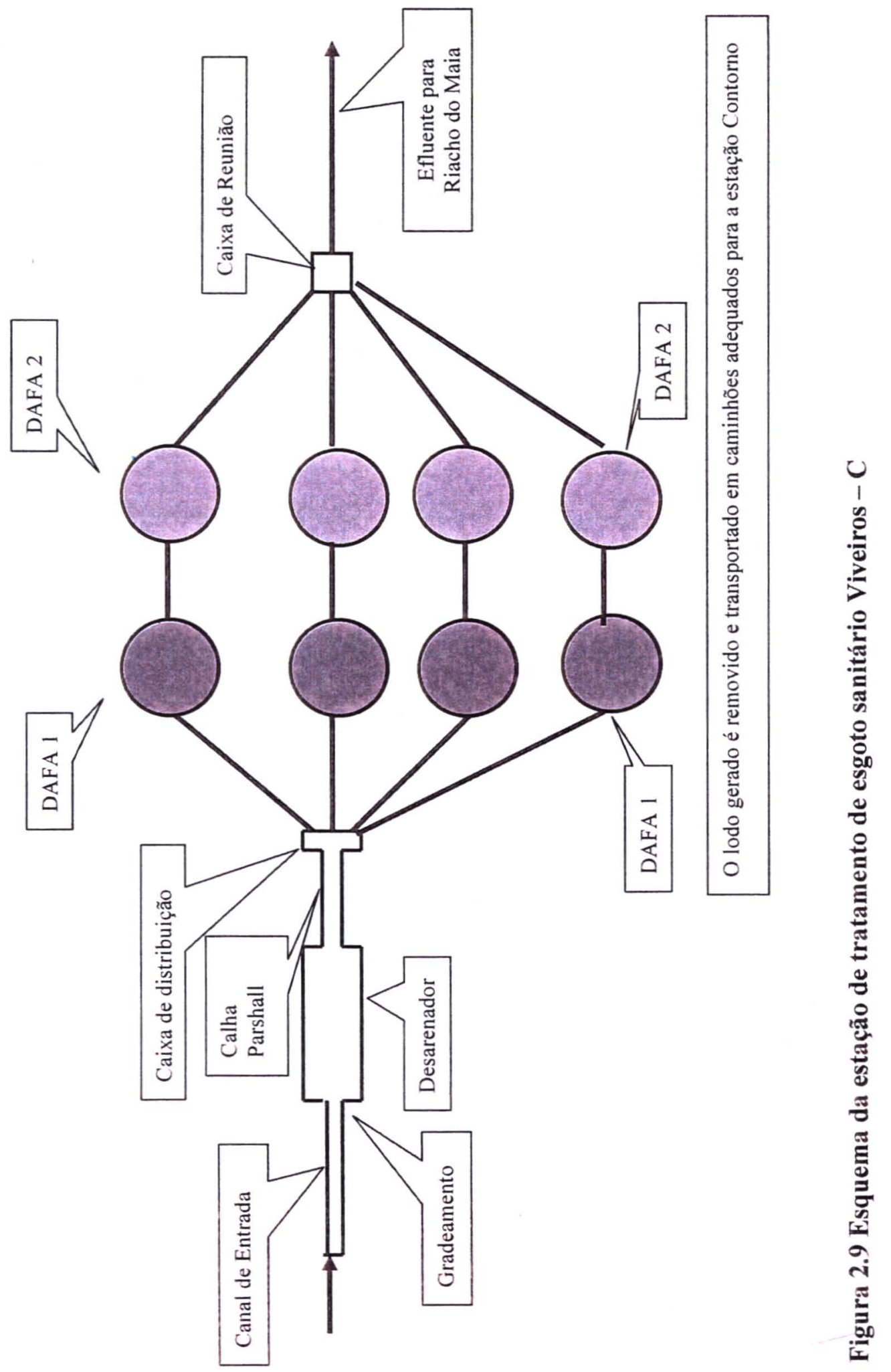




\section{Comunidade e Estação de Tratamento Lagoa Grande}

A comunidade de Lagoa Grande localiza-se em área de expansão, a nordeste de Feira de Santana, no bairro de mesmo nome. Constitui-se por população com renda familiar na faixa de 5 a 12 salários mínimos. A comunidade dispõe dos serviços públicos de abastecimento de água tratada e esgotamento sanitário desde sua implantação em 1991. A coleta e o transporte do esgoto sanitário são feitos através de coletor predial e rede pública coletora. O destino final do efluente tratado é o riacho Lagoa Grande afluente do rio Pojuca, conforme Figura 2.10. A drenagem pluvial é favorecida pela topografia, logo, o escoamento é feito através das calhas das ruas que conduzem as águas pluviais para a Lagoa Grande, nascente do riacho do mesmo nome, afluente do rio Pojuca. Quanto ao lixo existe ponto interno ao condomínio para descarga e o serviço de limpeza municipal faz a coleta três vezes por semana. Não é comum encontrar lixo espalhado.

Figura 2.10 Esquema de lançamento do esgoto sanitário da estação Lagoa Grande

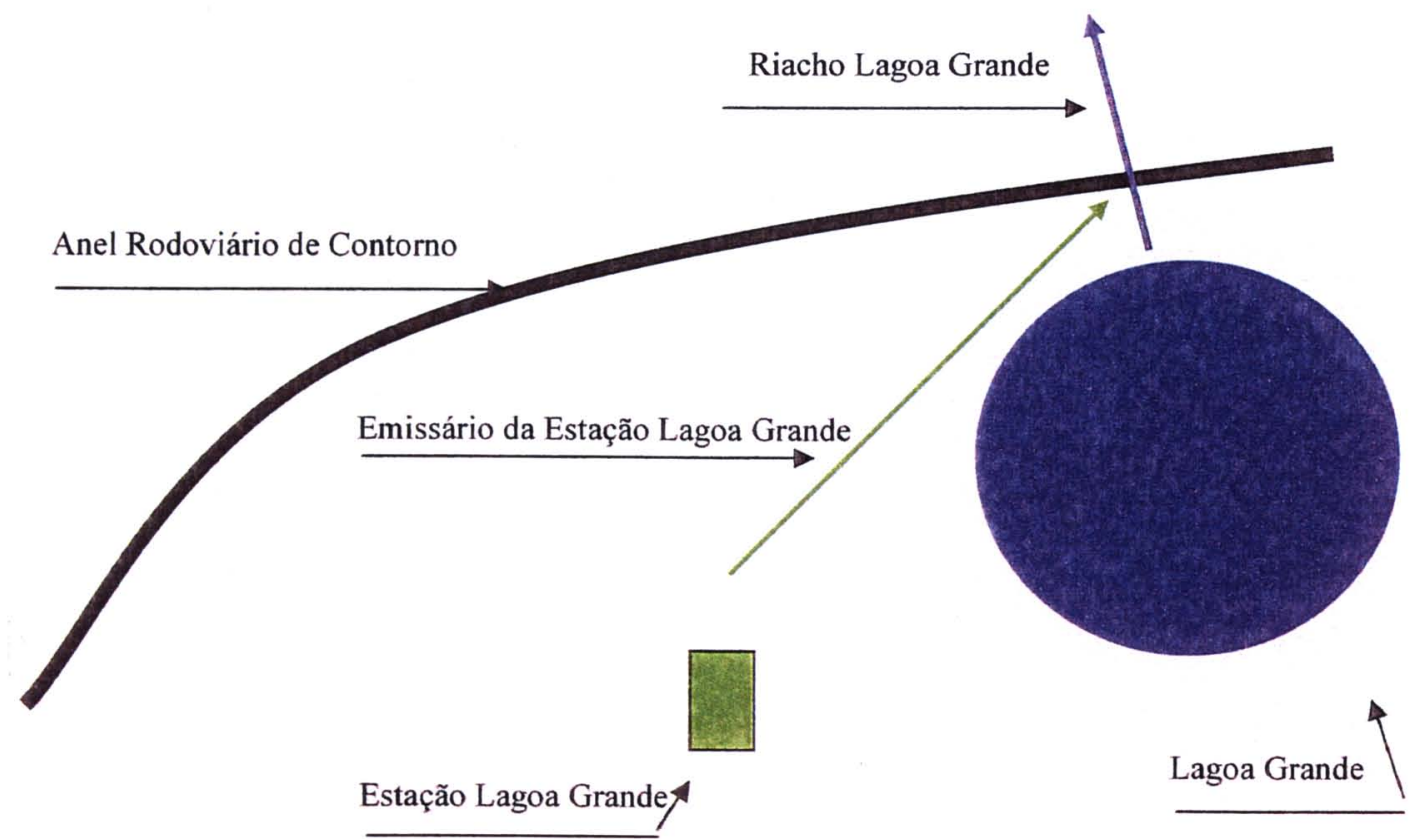


O sistema Lagoa Grande foi projetado para atender a um equivalente populacional de

3.200 habitantes com tratamento do esgoto a nível secundário. Estão ligados ao sistema 640 apartamentos residenciais, correspondendo a 3.200 habitantes (100\% do previsto em projeto), gerando uma vazão média de 4,78 1/s, carga orgânica de $160,00 \mathrm{~kg}$ de DBO e 235,20 kg de DQO por dia (CONSTRUTORA CELI LTDA. 1989;

SANTIAGO et al 2001).

A Estação Lagoa Grande é constituída de tratamento preliminar (gradeamento e desarenador), tratamento primário e secundário constituídos por 2 (dois) DAFAs em série, leito de secagem para o lodo excedente produzido no processo de tratamento, conforme Foto 05 e Figura 2.11.

Os parâmetros usados em projeto foram:

Carga orgânica: Afluente $\mathrm{Ca}=415,77 \mathrm{mg} \mathrm{DBO}_{5} / \mathrm{l}$, equivalente a $171,71 \mathrm{~kg} \mathrm{DBO} / \mathrm{dia}$;

Efluente $\mathrm{Ca}=37,42 \mathrm{mg} \mathrm{DBO}_{5} / 1$, equivalente a $15,45 \mathrm{~kg} \mathrm{DBO}_{5} / \mathrm{dia}$;

Vazões afluentes: Máxima $=8,08 \mathrm{l} / \mathrm{s} ;$ Média $=4,78 \mathrm{l} / \mathrm{s}$; Mínima $=2,71 \mathrm{l} / \mathrm{s}$.

Vazões efluentes: Considerou as mesmas vazões afluentes.

Eficiência $=91,0 \%$ em remoção de $\mathrm{DBO}$;

Tempo de detenção: DAFA $1=06: 06 \mathrm{~h}$; DAFA 2 $=06: 06 \mathrm{~h}$; Total $=12: 12 \mathrm{~h}$.

Remoção de coliformes: sem indicação (CONSTRUTORA CELI LTDA. 1989).

Quanto à operação do tratamento foram previstas limpezas da grade de retenção de sólidos grosseiros diariamente, da caixa de areia a cada 15 dias, remoção de $8,32 \mathrm{~m}^{3}$ de lodo nos DAFAs em série a cada 10 dias, fundamentada em análises fisico-quimicas. Apesar de existir leito de secagem, o lodo é transportado e descarregado na ETE Contorno com tempo de limpeza de 30 dias. 


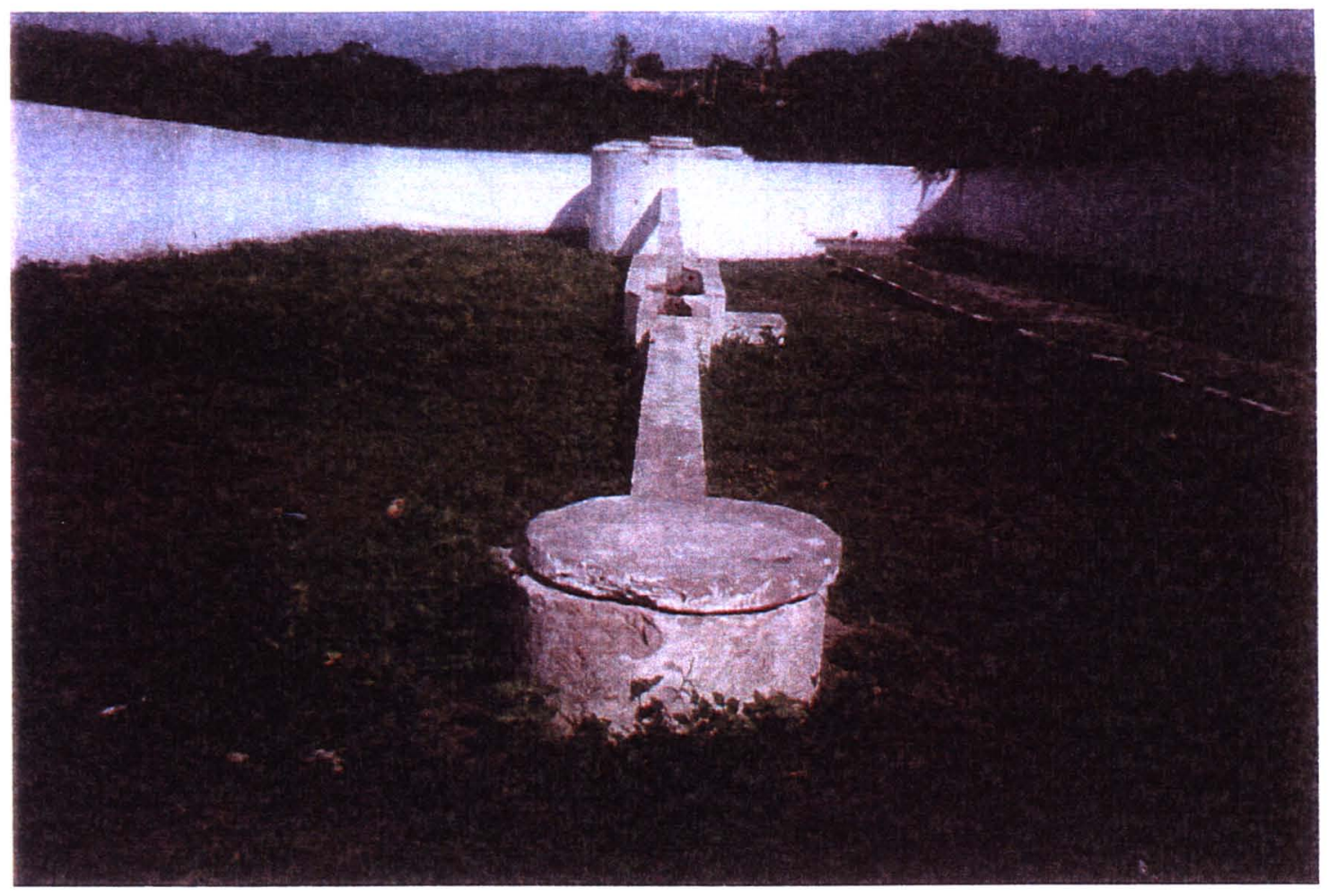

Foto 05. Estação Lagoa Grande. 


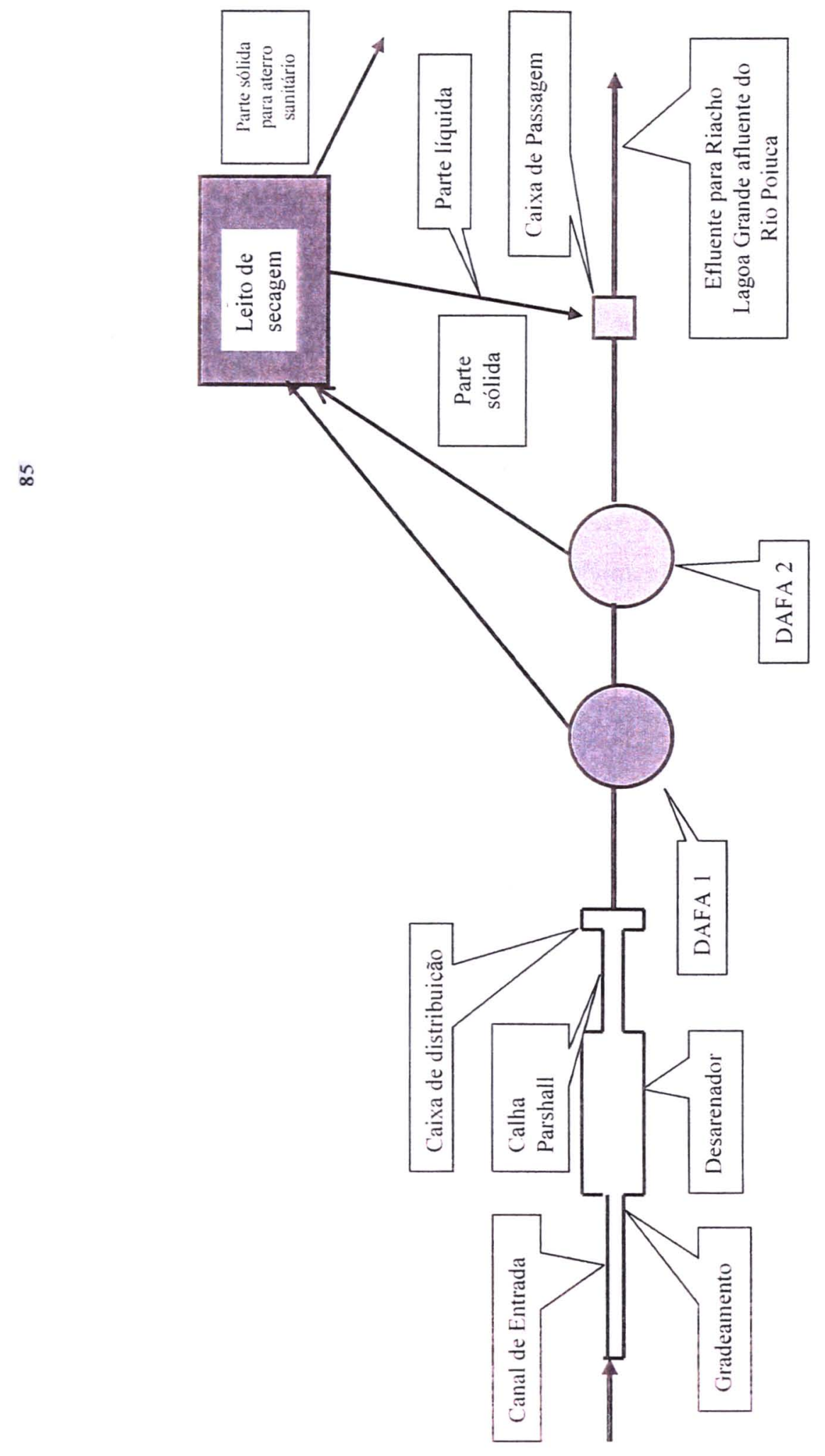

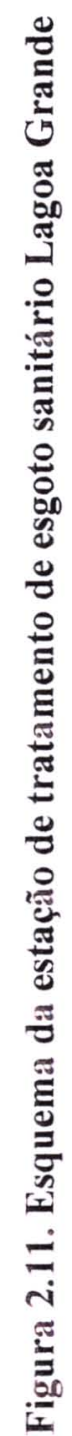




\section{Comunidade e Estação Feira VII}

A comunidade que tem seus esgotos tratados na estação Feira VII localiza-se a sudeste da cidade de Feira de Santana e é constituída de pessoas com renda familiar variando na fixa de 3 a 5 salários mínimos.

A comunidade dispõe dos serviços públicos de abastecimento de água tratada e esgotamento sanitário desde a inauguração dos sistemas em 1995. A coleta e transporte do esgoto são feitos através de coletor predial e rede pública coletora. $\mathrm{O}$ destino final do efluente tratado é um riacho afluente do Rio Subaé, conforme Figura 2.12. A drenagem pluvial é favorecida pela topografia e o escoamento é feito através das calhas das ruas que conduzem as águas pluviais a céu aberto para galeria de drenagem que leva ao Rio Subaé. As ruas desta comunidade são pavimentadas com paralelepípedo e a coleta do lixo é feita pelo Serviço de limpeza municipal três vezes por semana, mas, mesmo assim, é comum o lançamento de lixo nas calhas de drenagem, em terrenos baldios e mesmo nas ruas.

Figura 2.12 Esquema do lançamento do esgoto sanitário da estação Feira VII

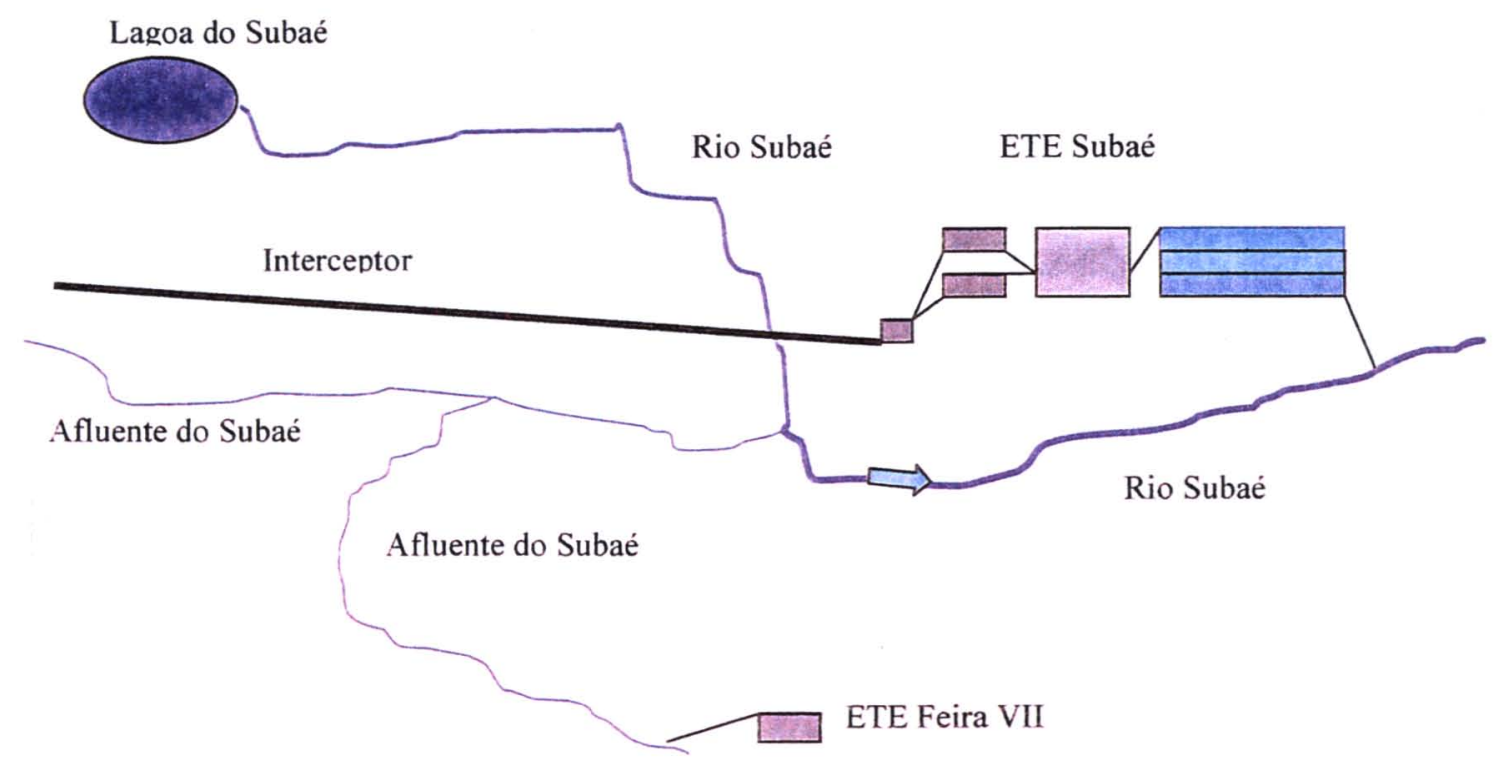


O tratamento de esgoto Feira VII foi projetado para atender a 480 apartamentos e 1896 casas, correspondendo à população de 11.880 habitantes, e 24 unidades de pequenos comércios, uma escola. uma creche e um centro de saúde, com vazão média de $21,92 \mathrm{l} / \mathrm{s}$ (máxima de $39,93 \mathrm{l} / \mathrm{s}$ ) e carga orgânica de esgoto de $684,92 \mathrm{~kg}$ de $\mathrm{DBO} / \mathrm{dia}$ (CONSTRUTORA ERG LTDA. 1992). O tratamento do esgoto sanitário projetado foi a nível secundário e estão ligadas ao sistema 1920 residências correspondentes a 9.600 habitantes, gerando uma vazão média de $16,7 \mathrm{l} / \mathrm{s}$ e carga orgânica de $518 \mathrm{~kg} \mathrm{DBO} / \mathrm{dia}$ (SANTIAGO et al 2001). A diferença entre a ocupação prevista e a real gerou uma desigualdade entre carga orgânica e vazão, do projeto, e a realidade.

A estação de tratamento Feira VIl é constituída de tratamento preliminar (gradeamento e desarenador); seguido de tratamento primário através de dois tanques Imhoff e secundário através de dois DAFAs em série com o Imhoff. O lodo gerado no processo é captado e desidratado em seis Leitos de Secagem. O efluente tratado é lançado em riacho afluente do Rio Subaé, conforme Fotos 06 e 07 e Figura 2.13.

Os parâmetros usados no projeto foram:

Carga orgânica: Afluente $\mathrm{Ca}=363,30 \mathrm{mg} \mathrm{DBO} / \mathrm{l}$, equivalente a $684,92 \mathrm{~kg} \mathrm{DBO} / / \mathrm{dia}$;

Efluente $\mathrm{Ca}=37,42 \mathrm{mg} \mathrm{DBO}_{5} / 1$, equivalente a $70,55 \mathrm{~kg} \mathrm{DBO}_{5} / \mathrm{dia}$.

Vazões afluentes: Máxima $=39,93 \mathrm{l} / \mathrm{s} ;$ Média $=21,82 \mathrm{l} / \mathrm{s}$; Mínima $=12,29 \mathrm{l} / \mathrm{s}$.

Vazões efluentes: Considerou as mesmas vazões afluentes.

Eficiência total $=83,5 \%$ em remoção de DBO;

Tempo de detenção: Tanque Imhoff $=02: 00 \mathrm{~h} ;$ DAFA $=08: 00 \mathrm{~h}$; Total $=10: 00 \mathrm{~h}$. Remoção de coliformes: não informado (CONSTRUTORA ERG LTDA. 1992)

Quanto à operação do tratamento, foram previstas limpezas da grade de retenção de sólidos grosseiros diariamente, da caixa de areia a cada 15 dias, remoção de $15,44 \mathrm{~m}^{3}$ de lodo em cada tanque Imhoff e em DAFA a cada 10 dias e fundamentado em análises fisico-químicas. Apesar da existência de leitos de secagem, o lodo removido é transportado e descarregado na ETE Contorno a cada 30 dias. 

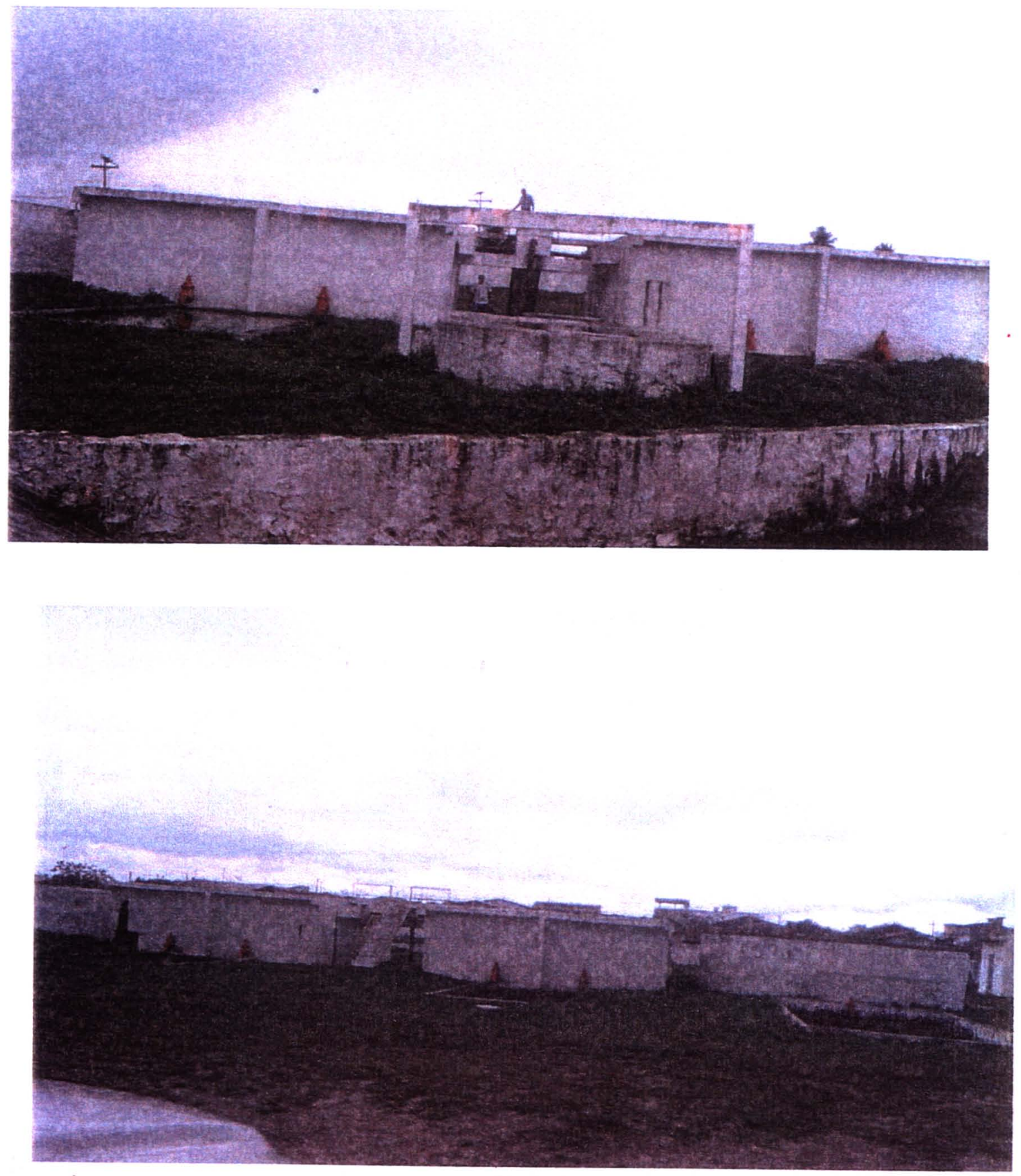

Fotos 06 e 07. Estação Feira VII. 


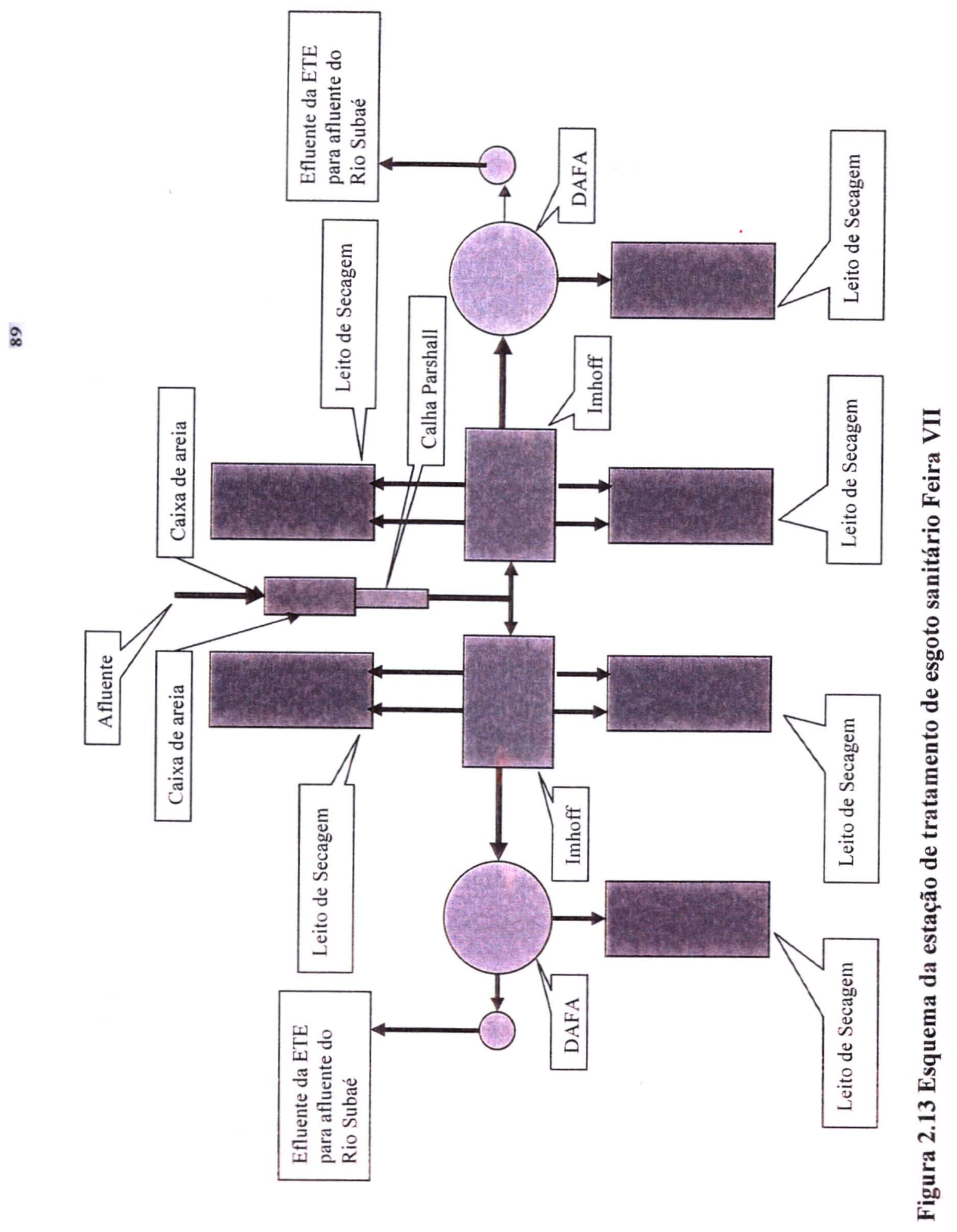




\section{Comunidade e Estação de Tratamento Contorno}

A comunidade que tem seus esgotos tratados na estação Contorno localiza-se, parte no centro da cidade de Feira de Santana, e parte, na periferia, englobando os bairros: Kalilândia; Queimadinha (parte); Pilão; Serraria Brasil (parte); Jardim Cruzeiro; Sobradinho (parte); Barroquinha; Campo Limpo; George Américo, e os conjuntos residências: Parque das Acácias; Feira IV; Morada do Sol; Morada Tropical; Feira IX; Vila Verde; Wilson Falcão; Feira X; José Falcão da Silva; J.J. Lopes de Brito; Magnólia Residencial e Feira VI.

É constituída de pessoas com renda familiar das mais variadas possíveis, entre 1 a 40 salários mínimos, ou mais. A comunidade dispõe dos serviços públicos de abastecimento de água tratada implantado entre mais de três e cinqüenta e três anos, e esgotamento sanitário operando desde três a vinte e um anos. A coleta e o transporte do esgoto são feitos através de coletor predial e rede pública coletora. O destino final do efluente tratado é o riacho Principal, afluente do rio Jacuipe, conforme Figura 2.14. A drenagem pluvial é favorecida, em parte, pela topografia, o escoamento é feito através das calhas das ruas que conduzem as águas pluviais a galerias ou a canais a céu aberto (construídos em alvenaria de pedra ou em terra), que cortam as comunidades citadas e deságuam no rio Jacuípe. As ruas destas comunidades, na sua maioria, são pavimentadas com paralelepípedo ou asfalto. A coleta do lixo é feita três vezes por semana nas áreas residenciais, mas, mesmo assim é comum encontrar lixo jogado nas calhas de drenagem pluvial ou em terrenos baldios. No centro da cidade e nas áreas comerciais, a coleta do lixo é feita diariamente, exceto aos domingos.

A estação de tratamento de esgotos de Contorno foi projetada para atender, em primeira etapa, a um equivalente populacional de 90.000 pessoas, consumo percapita de 150 1/hab/dia, coeficiente de retorno de 0,8 , infiltração de $15 \mathrm{l} / \mathrm{s}$ carga orgânica de esgoto de $4.597 \mathrm{~kg}$ de $\mathrm{DBO} / \mathrm{dia}$, correspondente a uma vazão média de $140 \mathrm{l} / \mathrm{s}$ e DBO de 380 $\mathrm{mg} /$, com tratamento do esgoto sanitário projetado a nível secundário (CONCREMAT 
ENGENHARIA E TECNOLOGIA S. A. 1992, 1993). Em junho de 2001, estavam ligadas ao sistema 108.235 habitantes, hoje, Clínicas Médicas, Hospitais, Casas Comerciais, Órgãos Públicos, etc., gerando uma vazão média de $188 \mathrm{l} / \mathrm{s}$ e carga orgânica de $5.845 \mathrm{~kg} \mathrm{DBO} /$ dia (SANTIAGO et al 2001; EMBASA/UNF ${ }^{6}$ ). Atualmente, estão ligadas 114.412 habitantes, Clínicas Médicas, Hospitais, Casas Comerciais, Órgãos Públicos, etc., gerando uma vazão de $199 \mathrm{l} / \mathrm{s}$, que com DBO média de $404 \mathrm{mg} / \mathrm{l}$ resulta em carga orgânica de $6.937 \mathrm{~kg}$ de DBO por dia.

A estação de tratamento Contorno é constituída de tratamento preliminar (gradeamento e desarenador); seguido de tratamento primário e secundário através de duas lagoas aeradas funcionando em paralelo; esse conjunto opera em série com um decantador (com captação de lodo para recirculação e para o leito de secagem) e uma lagoa facultativa. O efluente tratado é lançado no Riacho Principal, afluente da bacia de acumulação da barragem Pedra do Cavalo, conforme Fotos 08, 09, 10 e 11 e Figura 2.15 .

Os parâmetros usados no projeto foram:

Carga orgânica:Afluente $\mathrm{Ca}=380 \mathrm{mg}$ de $\mathrm{DBO}_{5} / \mathrm{l}$, equivalente a 4.596,5 $\mathrm{kg} \mathrm{DBO}_{5} / \mathrm{dia}$; Efluente $\mathrm{Ca}=20 \mathrm{mg}$ de $\mathrm{DBO}_{5} / \mathrm{l}$, equivalente a $241,9 \mathrm{~kg} \mathrm{DBO} / /$ dia.

Vazões afluentes: Máxima $=240,0 \mathrm{l} / \mathrm{s} ;$ Média $=140,0 \mathrm{l} / \mathrm{s}$; Mínima = 85,0 l/s.

Vazões efluentes: Considerou as mesmas vazões afluentes.

Eficiência $=94,7 \%$ em remoção de $\mathrm{DBO}$;

Tempo de detenção: Lagoa aerada $=36: 00 \mathrm{~h}$; Tanque de Decantação $=02: 00 \mathrm{~h}$; Lagoa Facultativa $=48: 00 \mathrm{~h}$; Total $=86: 00 \mathrm{~h}(3,58$ dias $)$.

Remoção de coliforme: de $10^{7}$ para menos que $10^{3}$ (CONCREMAT - ENGENHARIA E TECNOLOGIA S. A. 1992,1993 )

\footnotetext{
${ }^{6}$ Relatório de Controle de Qualidade das Plantas de Tratamento do esgoto sanitário de Feira de Santana e Corpo Receptor dos anos de 2001 e 2002.
} 
Figura 2.14 Esquema do lançamento do esgoto sanitário da estação Contorno

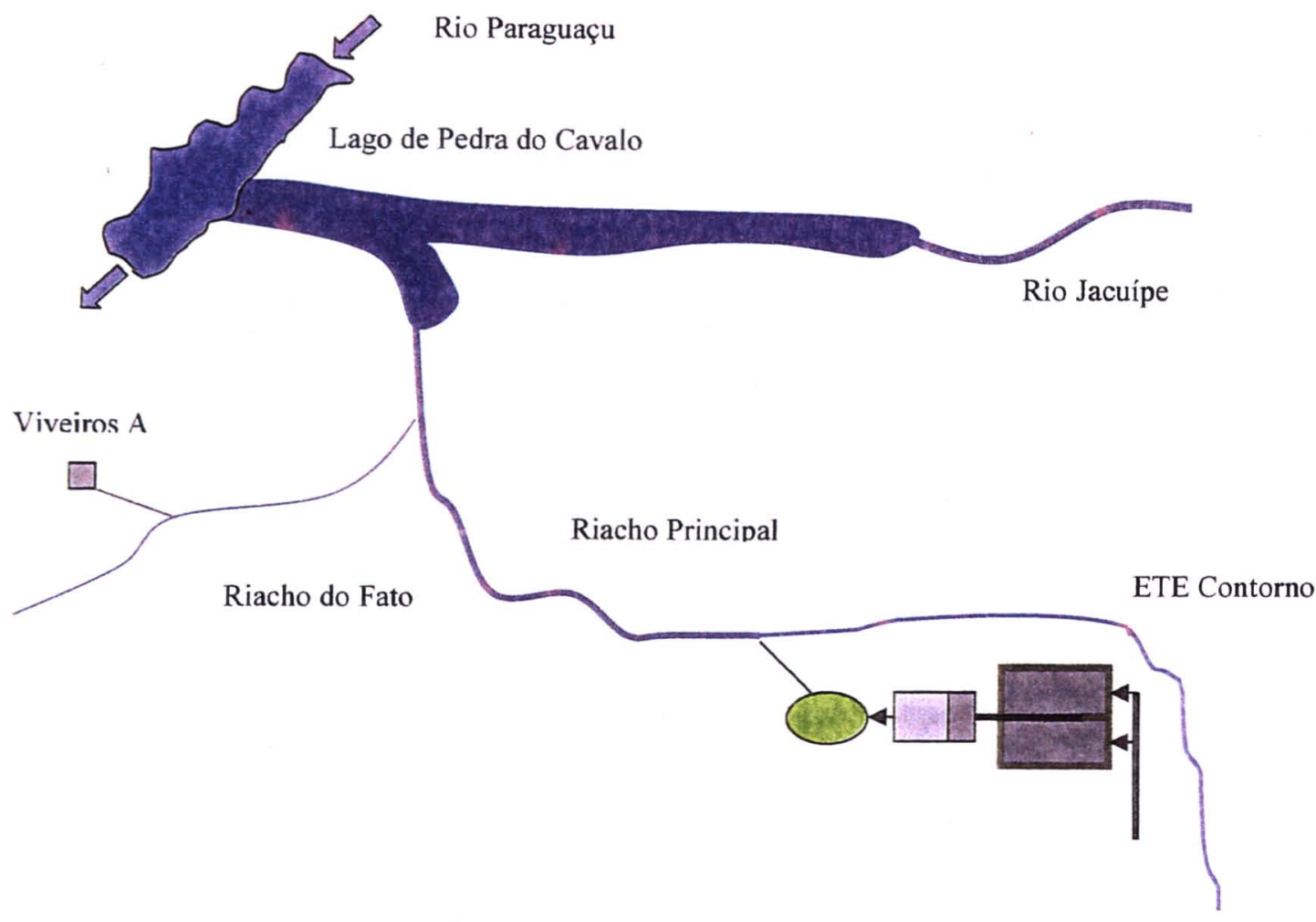

Quanto à operação do tratamento, além do que foi citado no texto acima, foram previstas limpezas da grade de retenção de sólidos grosseiros diariamente, da caixa de areia diariamente ou quando a caixa atingir determinada altura, recirculação de 1/3 do lodo decantado e remoção de $15,6 \mathrm{~m}^{3}$ de lodo por dia, para uma lagoa de lodo ao lado da estação Contorno. O lodo seco na lagoa de lodo é transportado para o aterro sanitário do município. 


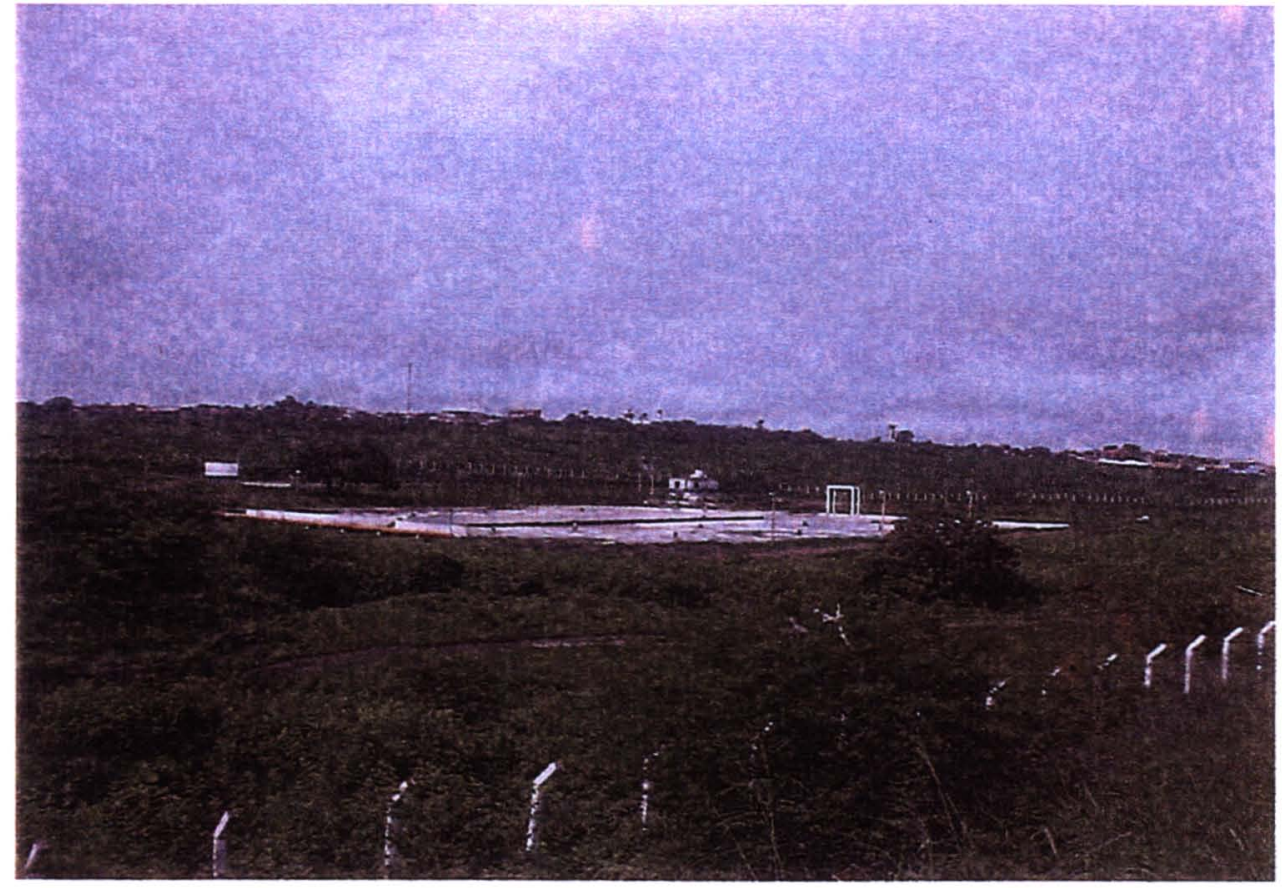

Foto 08. Estação Contorno.

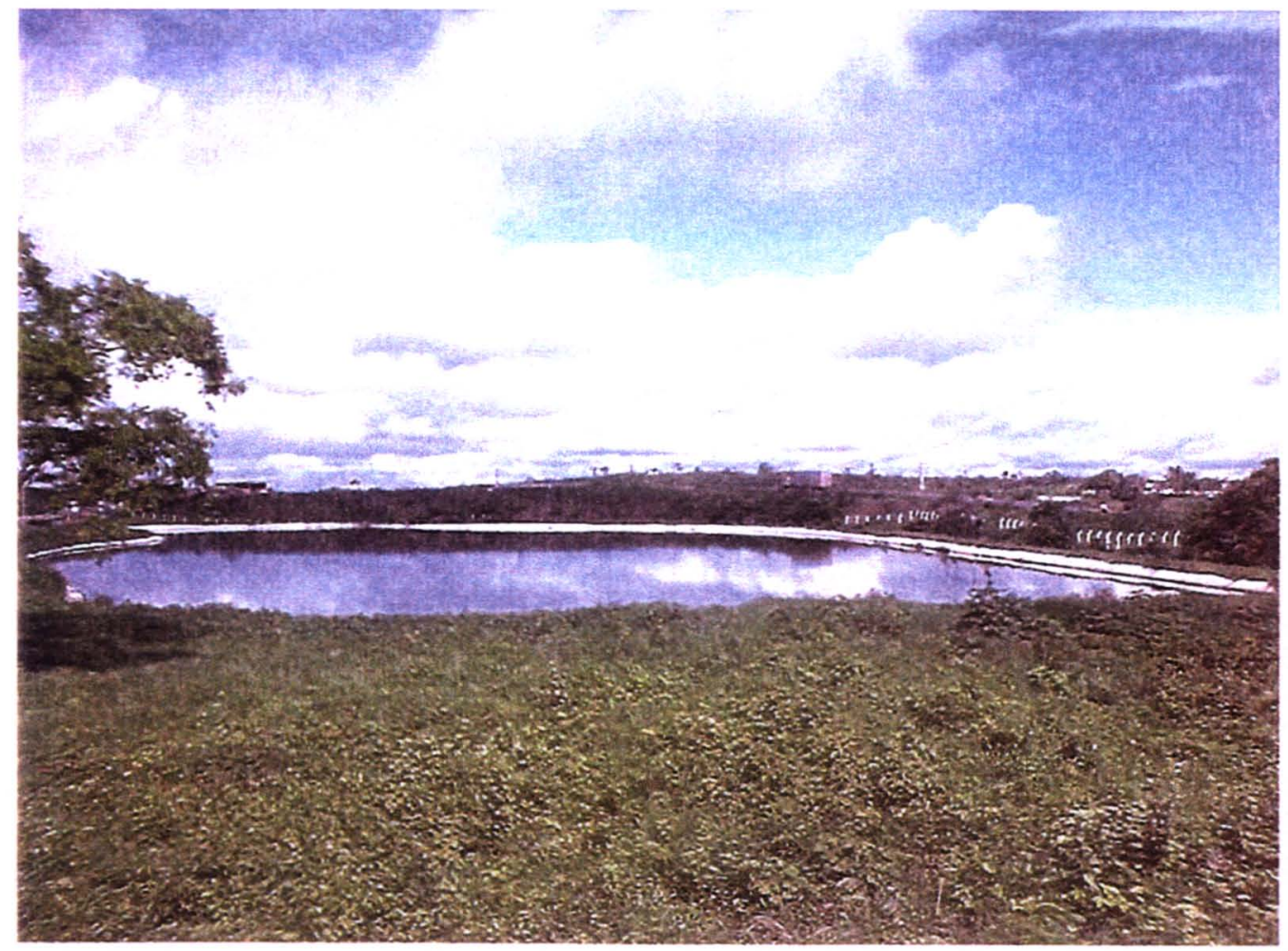

Foto 09. Lagoa Facultativa. 


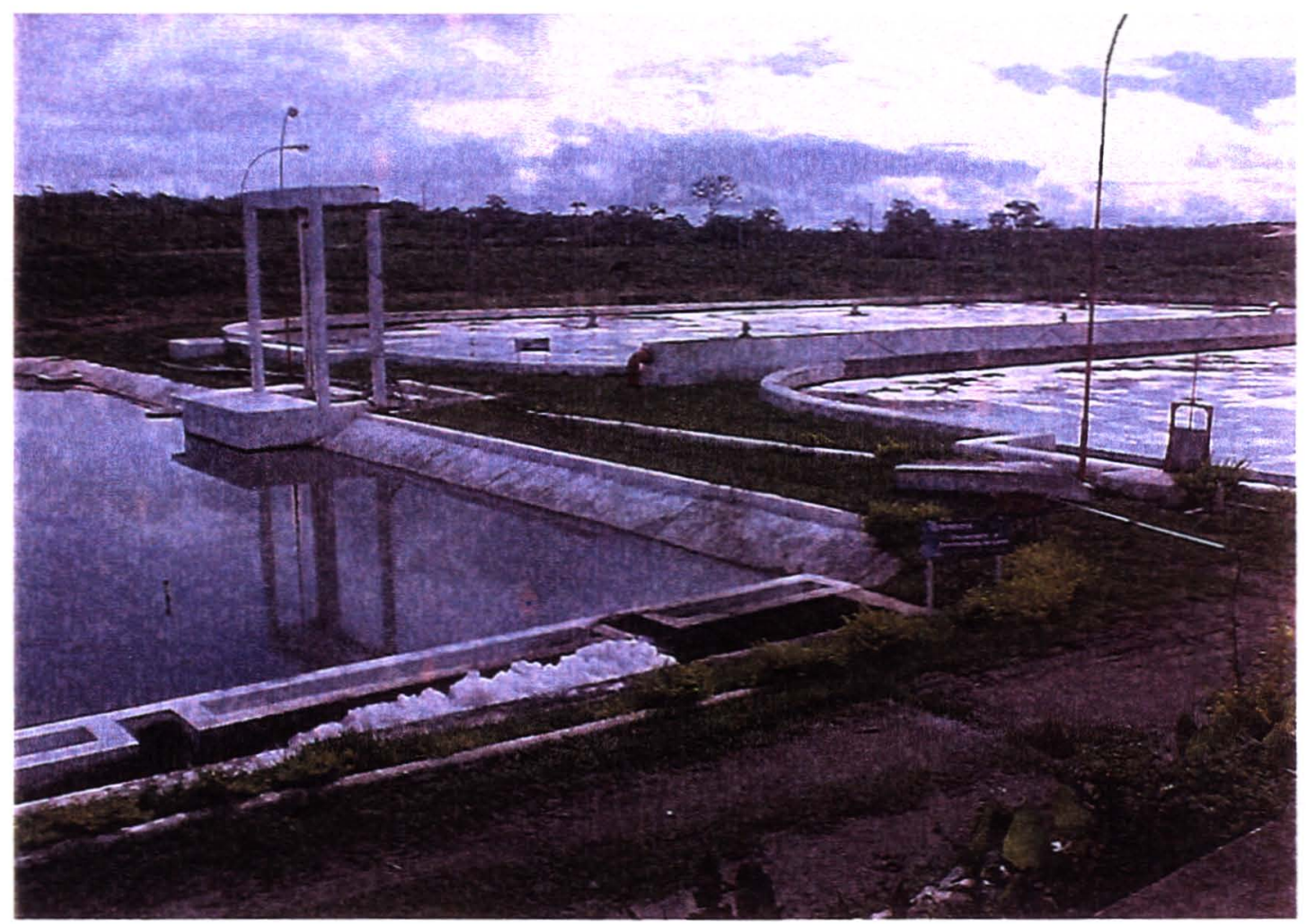

Foto 10. Decantador, Recirculação de Lodo e Lagoas Aeradas.

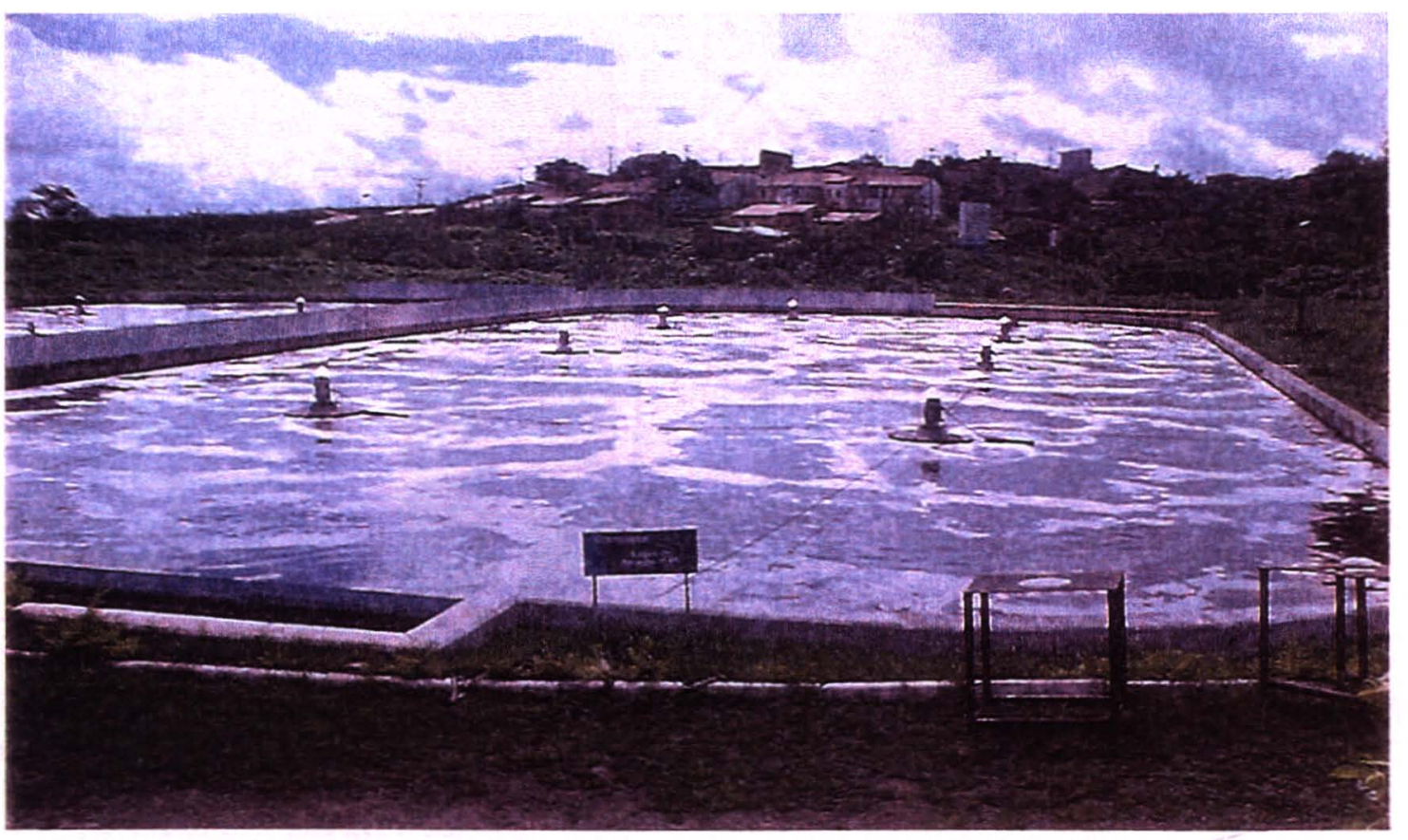

Foto 11. Lagoa Aerada. 


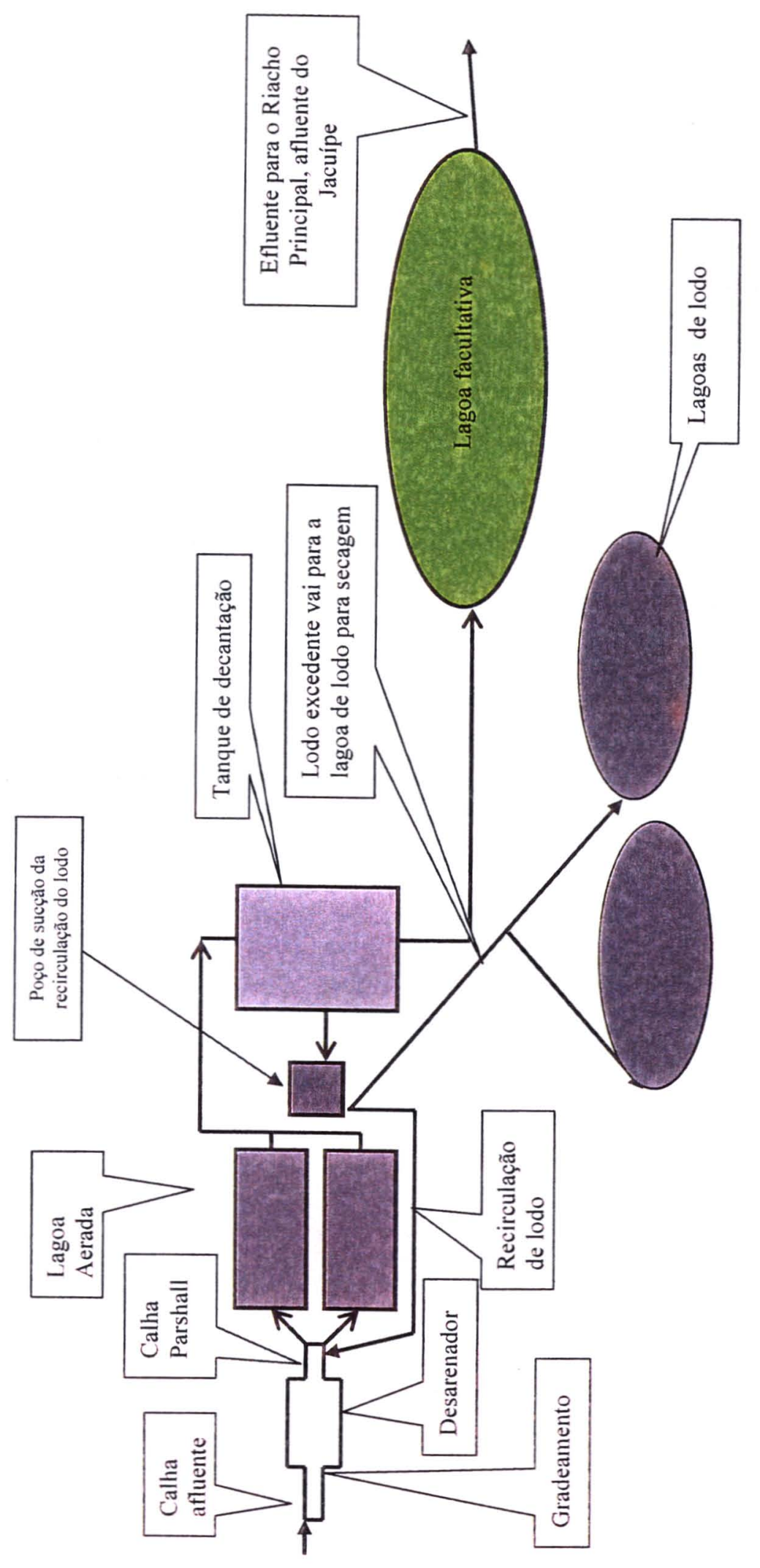

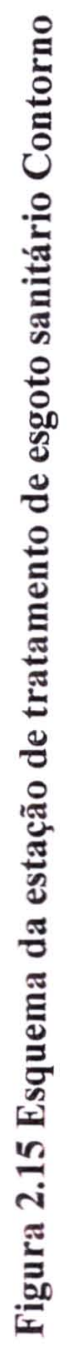




\section{Comunidade e Estação Cajueiro}

A comunidade que tem seus esgotos tratados na estação Cajueiro localiza-se a leste da cidade de Feira de Santana, no Bairro Serraria Brasil, e é constituída de pessoas com renda familiar variando na faixa de 10 a 20 salários mínimos.

A comunidade dispõe dos serviços públicos de abastecimento de água tratada e esgotamento sanitário desde a inauguração dos sistemas em 1992. A coleta e transporte do esgoto são feitos através de coletor predial e rede pública coletora. O destino final do efluente tratado é o riacho do Fato, afluente do rio Jacuípe, conforme Figura 2.16. A drenagem pluvial é favorecida, em parte, pela topografia, o escoamento é feito através das calhas das ruas que conduzem as águas pluviais para a Av. João Durval Carneiro e desta chega ao riacho do Fato. O condomínio dispõe de local para descarte temporário do lixo e o Serviço de limpeza municipal faz a coleta três vezes por semana.

Figura 2.16 Esquema do lançamento do esgoto sanitário da Estação Cajueiro

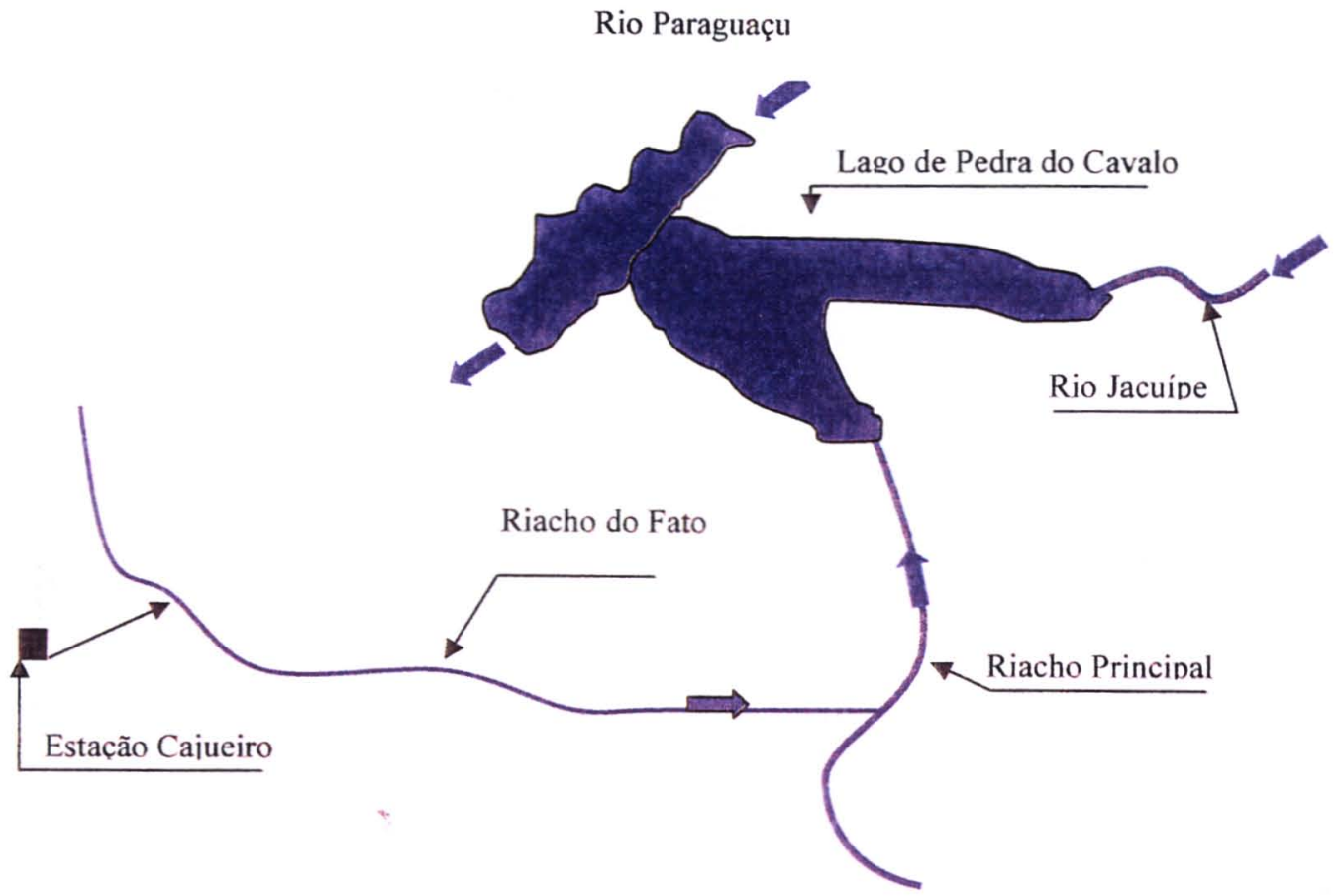


O tratamento de esgoto do Parque Cajueiro foi projetado para atender a 360 apartamentos, correspondendo a uma população de 1.800 habitantes, com vazão média de 4,10 l/s (máxima 7,28 1/s) e carga orgânica de esgoto de $88,56 \mathrm{~kg}$ de $\mathrm{DBO} / \mathrm{dia}$ (HABITACIONAL CONSTRUÇÕES S. A. 1990). O tratamento do esgoto sanitário projetado foi a nivel secundário e estão ligados ao sistema 360 apartamentos e um centro comunitário de 1.800 habitantes, gerando uma vazão média de 4,10 l/s e carga orgânica de $90 \mathrm{~kg}$ DBO/dia (SANTIAGO et al 2001).

A estação de tratamento do Parque Cajueiro é constituída de tratamento preliminar (gradeamento e desarenador); seguido de tratamento primário através de dois tanques Imhoff e secundário através de um DAFAs em série com os Imhoffs. O lodo gerado no processo é removido e transportado para a estação Contorno. Inicialmente era captado e desidratado em leitos de secagem, no local da estação de tratamento. O efluente tratado é lançado em riacho afluente do Rio Jacuipe, conforme Fotos 12 e 13 e Figura 2.17.

Os parâmetros básicos de projeto foram:

Carga orgânica: Afluente $\mathrm{Ca}=250,0 \mathrm{mg} \mathrm{DBO}_{5} / 1$, equivalente a $88,56 \mathrm{~kg} \mathrm{DBO}_{5} /$ dia;

Efluente $\mathrm{Ca}=45,0 \mathrm{mg} \mathrm{DBO}_{5} / 1$, equivalente a $15,94 \mathrm{~kg} \mathrm{DBO}_{5} /$ dia.

Vazões afluentes: Máxima $=7,28 \mathrm{l} / \mathrm{s}$; Média $=4,10 \mathrm{l} / \mathrm{s}$; Mínima $=2,44 \mathrm{l} / \mathrm{s}$.

Vazões efluentes: Considerou as mesmas vazões afluentes.

Eficiência total $=82,8 \%$ em remoção de $\mathrm{DBO}$;

Tempo de detenção: Tanque Imhoff $=02: 00 \mathrm{~h} ;$ DAFA $=06: 00 \mathrm{~h}$; Total $=08: 00 \mathrm{~h}$.

Remoção de coliformes: não informado (HABITACIONAL CONSTRUÇÕES S. A. 1990).

Quanto à operação do tratamento foram previstas limpezas da grade de retenção de sólidos grosseiros diariamente, da caixa de areia a cada 15 dias, remoção de $9,36 \mathrm{~m}^{3}$ de lodo nos Imhoffs e DAFA a cada 20 dias, fundamentado em análisea físico-químicas. Apesar de existir leito de secagem, o lodo é removido e transportado, em caminhões High Velocity, para a estação Contorno. 

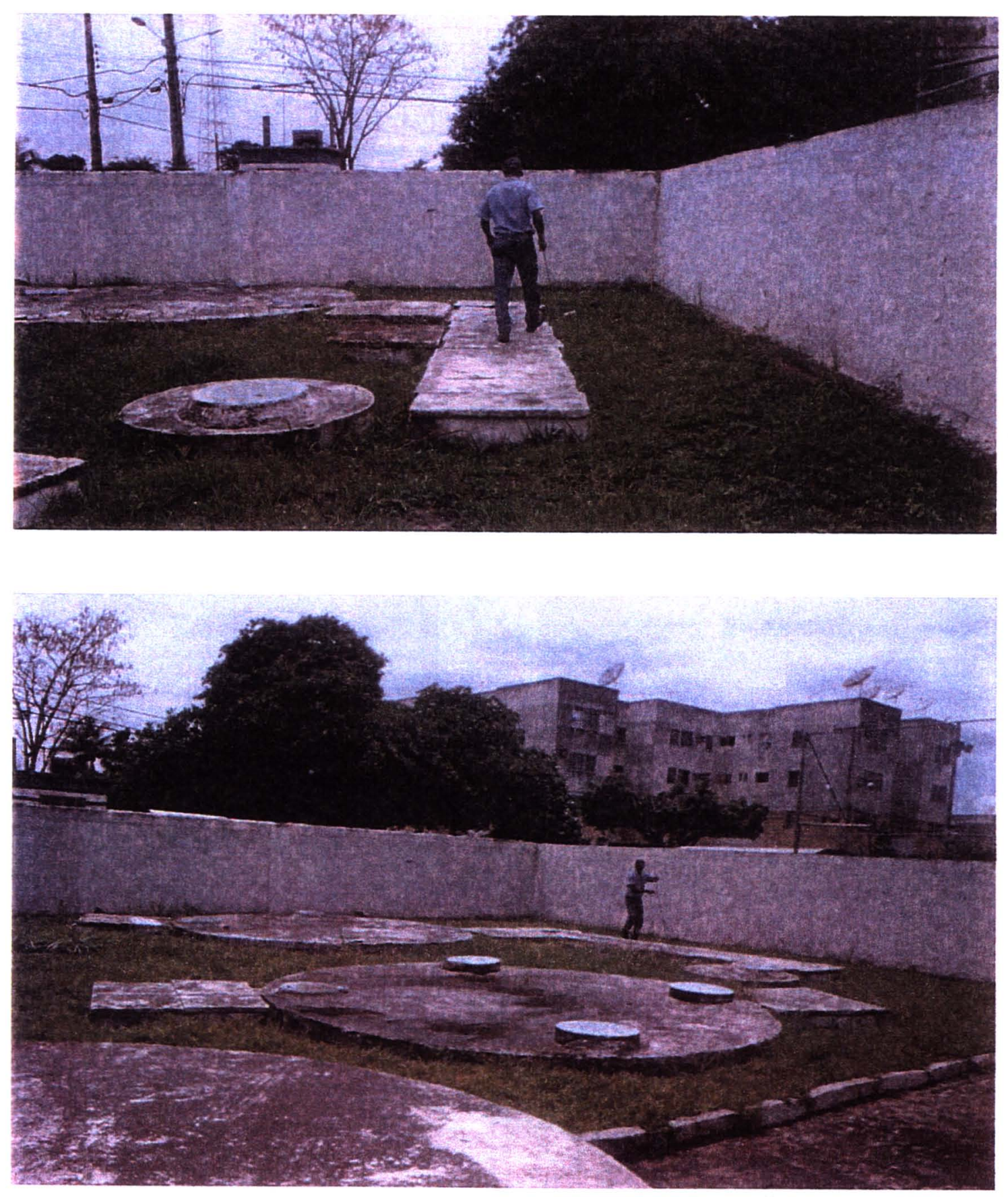

Fotos 12 e 13. ETE do Parque Cajueiro. 


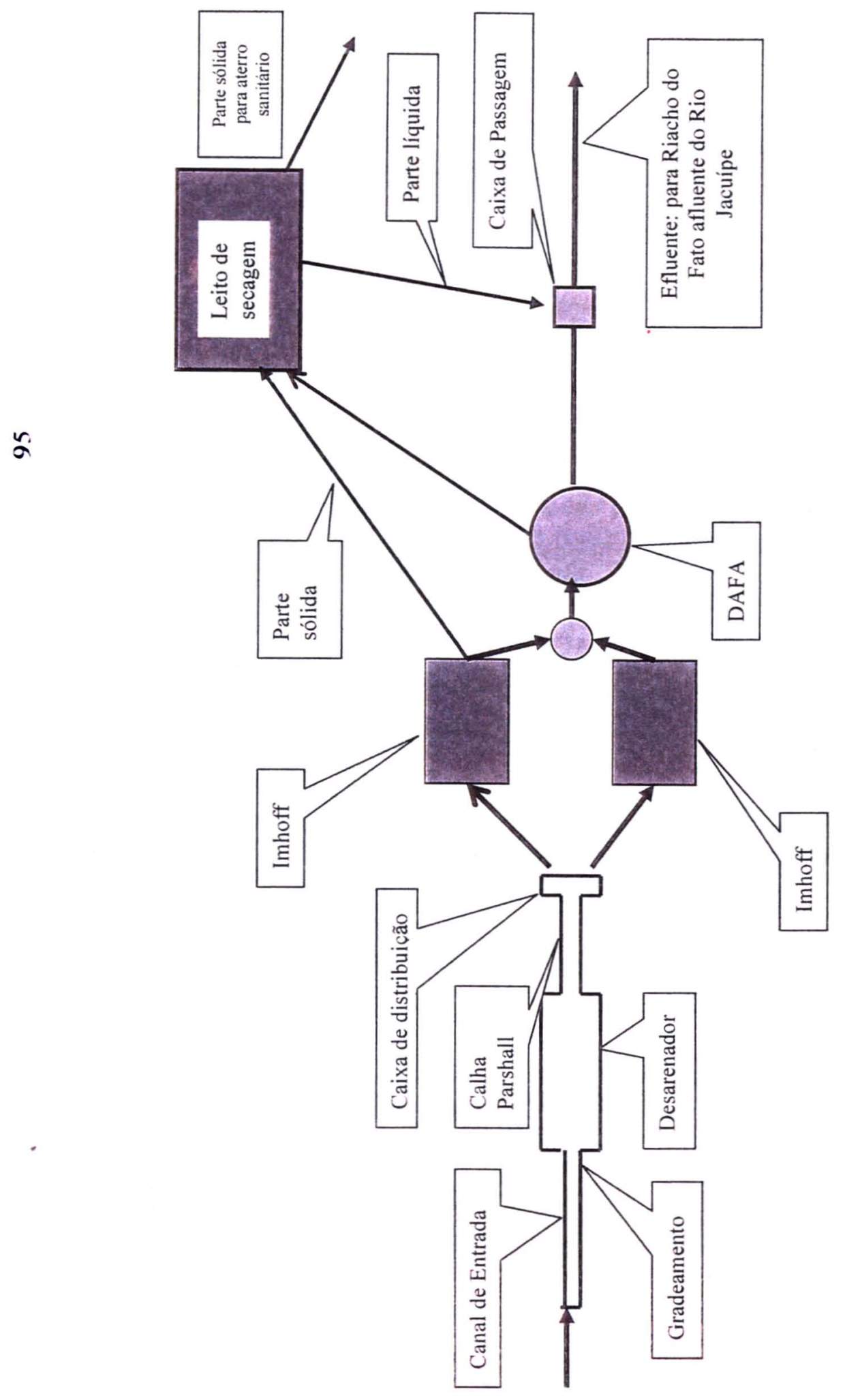

ป 


\section{Comunidade e Estação Chácara da Mangabeira}

A comunidade que tem seus esgotos tratados na estação Chácara da Mangabeira localiza-se ao norte da cidade de Feira de Santana, no bairro da Mangabeira. É constituída de pessoas com renda familiar variando na faixa de 3 a 8 salários mínimos. A comunidade dispõe dos serviços públicos de abastecimento de água tratada e esgotamento sanitário desde sua inauguração em 1991. A coleta e transporte do esgoto são feitos através de coletor predial e rede pública coletora. O destino final do efluente tratado é uma lagoa formada pelo riacho Cidade Nova, afluente do riacho Lagoa Grande, que deságua no Rio Pojuca, conforme Figura 2.18. A drenagem pluvial é favorecida pela topografia, o escoamento é feito através das calhas das ruas que conduzem as águas pluviais a céu aberto para a calha do riacho Cidade Nova. As ruas destas comunidades não são pavimentadas. A coleta do lixo é feita três vezes por semana mas, mesmo assim, é comum encontrar lixo jogado nas calhas de drenagem pluvial ou em terrenos baldios.

Figura 2.18 Esquema do lançamento do esgoto sanitário da estação Chácara da Mangabeira

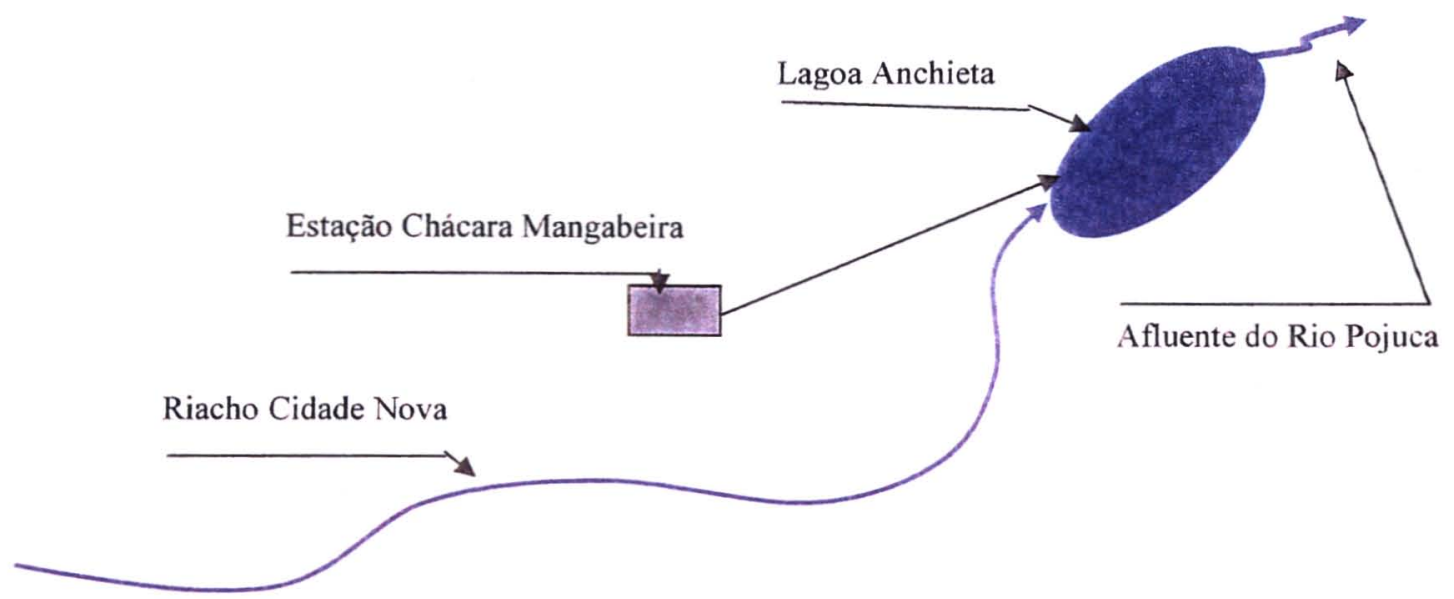

A estação de tratamento do esgoto Chácara da Mangabeira foi projetada para atender a um equivalente populacional de 765 pessoas com consumo percapita de 120 1/hab/dia, 
carga orgânica de esgoto de $38,25 \mathrm{~kg}$ de $\mathrm{DBO} /$ dia, correspondente a uma vazão média de $1.45 \mathrm{l} / \mathrm{s}$ (ESTEIO ENGENHARIA E COMÉRCIO LTDA 1990). O tratamento do esgoto sanitário projetado é a nível secundário. Estão ligados ao sistema 153 imóveis, com uma população total de 765 habitantes, gerando uma vazão média de 1,45 1/s e uma carga orgânica de aproximadamente $40,0 \mathrm{~kg}$ de DBO/dia (SANTIAGO et al 2001; EMBASA/UNF ${ }^{7}$ ).

A estação de tratamento Chácara da Mangabeira é constituída de tratamento preliminar (gradeamento e desarenador), seguido de tratamento primário e secundário através de dois DAFAs em série com o efluente tratado sendo lançado no Riacho Cidade Nova, afluente do Riacho Lagoa Grande, contribuinte do Rio Pojuca, conforme Foto 14 e Figura 2.19.

Os parâmetros básicos de projeto foram:

Carga orgânica: Afluente $\mathrm{Ca}=305.32 \mathrm{mg} \mathrm{DBO}_{5} /$, equivalente a $38,25 \mathrm{~kg} \mathrm{DBO}_{5} / \mathrm{dia}$;

Efluente $\mathrm{Ca}=27,48 \mathrm{mg} \mathrm{DBO}_{s} / 1$, equivalente a $3,44 \mathrm{~kg} \mathrm{DBO}_{5} /$ dia.

Vazões afluentes: Máxima $=2,34 \mathrm{l} / \mathrm{s}$; Média $=1,45 \mathrm{l} / \mathrm{s} ;$ Minima $=0,98 \mathrm{l} / \mathrm{s}$.

Vazões efluentes: Considerou as mesmas vazões afluentes.

Eficiència $=91,0 \%$ em remoção de DBO;

Tempo de detenção: DAFA 1 $=06: 00 \mathrm{~h}$; DAFA 2 $=06: 00 \mathrm{~h}$; Total $=12: 00 \mathrm{~h}$.

Remoção de coliformes: não informado (ESTEIO ENGENHARIA E COMÉRCIO LTDA. 1990)

Quanto à operação do tratamento foram previstas limpezas da grade de retenção de sólidos grosseiros diariamente, da caixa de areia a cada 15 dias, remoção de $3,98 \mathrm{~m}^{3}$ de lodo em dois DAFAs em série a cada 20 dias, fundamentado em análises físicoquímicas. Inicialmente, o lodo removido era descarregado em leitos de secagem e

\footnotetext{
Relatóno de Controle de Qualidade das Plantas de Tratamento do esgoto sanitário de Feira de Santana e corpo receptor. $2001,2002$.
} 
removido com 30 dias de desidratação. Atualmente, o lodo é removido e transportado, por meio de caminhão High Velocity, para a estação Contorno.

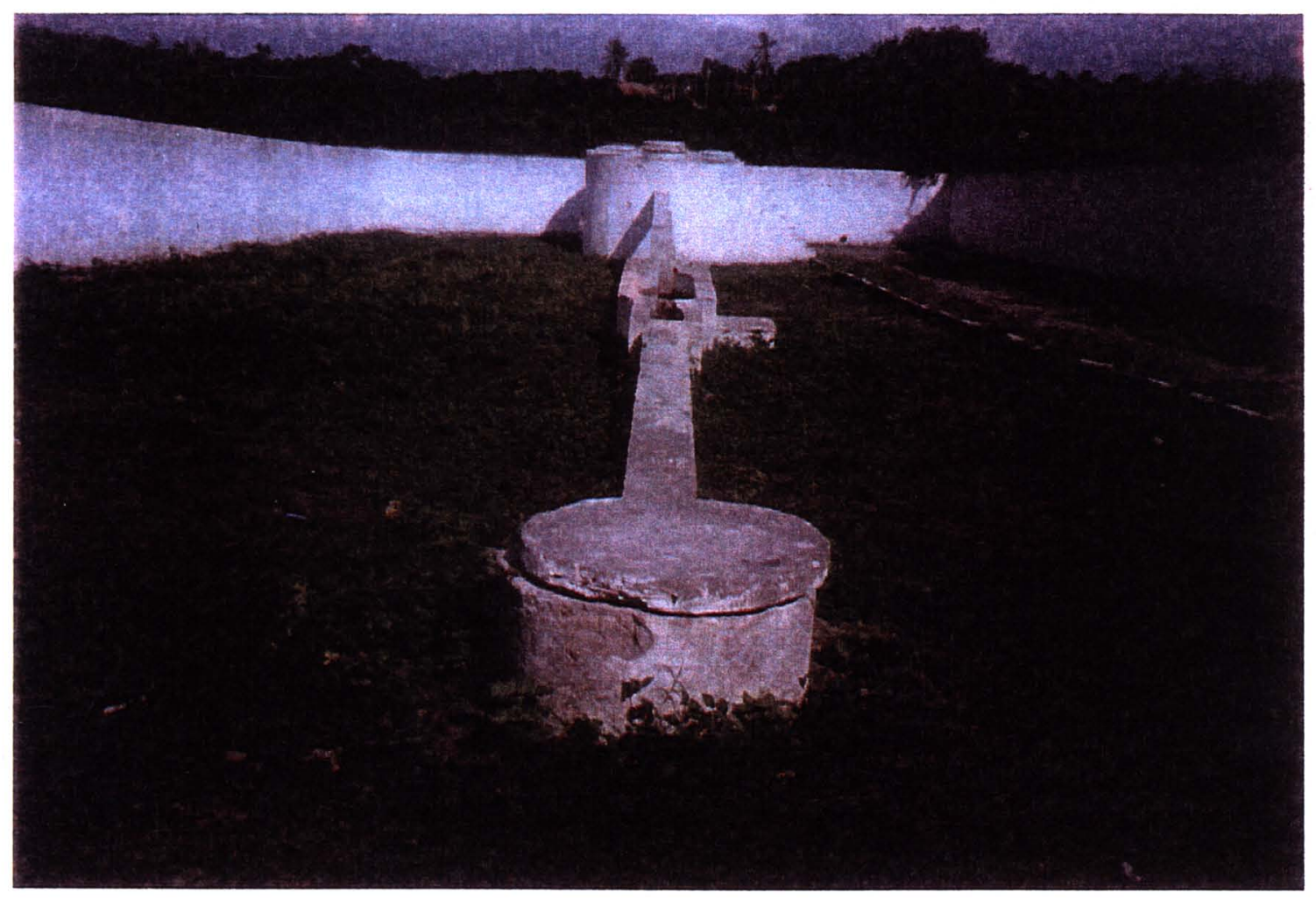

Foto 14. ETE Chácara da Mangabeira. 


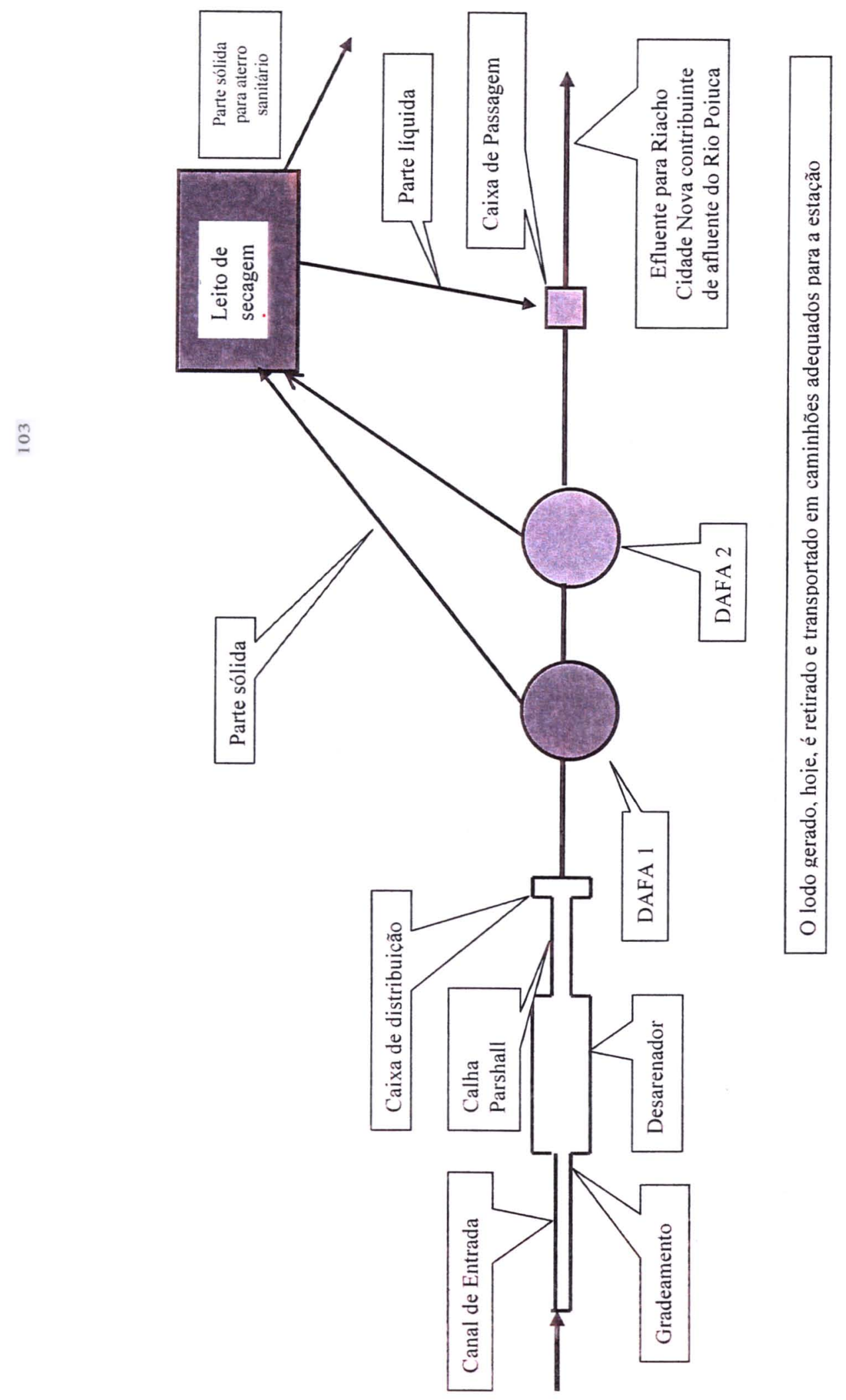

空 


\section{Comunidade e Estação Subaé}

A comunidade que tem seus esgotos tratados na estação Subaé localiza-se a nordestesudeste da cidade de Feira de Santana com início nas proximidades do centro da Cidade e seguindo na direção sul chegando às proximidades da comunidade de Limoeiro. Engloba os bairros: Brasília; Serraria Brasil (parte); Eucalipto; Jomafa; Tomba (parte); Santa Mônica, CAIC, Fraternidade e os conjuntos residenciais Jomafa, Luis Eduardo Magalhães, Fraternidade e Feira VII.

É constituída de pessoas com renda familiar das mais variadas possíveis, numa faixa de I a 40 salários mínimos ou mais. A comunidade dispõe dos serviços públicos de abastecimento de água tratada implantados desde cinqüenta e dois anos, até os mais recentes há cerca de dois anos e esgotamento sanitário em fase de implantação. A coleta e o transporte dos esgotos estão sendo feitos através de coletor predial e de rede pública coletora. O destino final do efluente tratado é o Rio Subaé, conforme Figura 2.20 que deságua na Baia de Todos os Santos. A drenagem pluvial é favorecida, em parte, pela topografia e o escoamento é realizado por meios das calhas das ruas que conduzem as águas pluviais a galerias e/ou a canais a céu aberto que cortam as comunidades citadas e contribuem para o rio Subaé. As ruas destas comunidades, aproximadamente metade, não são pavimentadas e a coleta do lixo é feita três vezes por semana nas áreas residenciais no entorno do centro, nas áreas periféricas duas vezes por semana, no centro e área comercial, diariamente, exceto aos domingos. Nas áreas periféricas, é comum encontrar lixo jogado nas calhas de drenagem pluvial, nas ruas e em terrenos baldios.

O sistema de tratamento de esgoto sanitário da ETE Subaé foi projetado para atender a um equivalente populacional de 171.203 pessoas em primeira etapa, consumo percapita de $208 \mathrm{l} / \mathrm{hab} / \mathrm{dia}$, coeficiente de retorno de 0,8 e carga orgânica de esgoto de $8.178 \mathrm{~kg}$ de DBO /dia, correspondente a uma vazão média de 329,96 1/s e DBO de $286,86 \mathrm{mg} / 1$, com tratamento do esgoto sanitário projetado a nivel secundário (META SERVIÇO DE 
ENGENHARIA LTDA 1998a, 1998b). Até o momento, só foram interligados aproximadamente 3.500 imóveis com população estimada em 16.100 habitantes.

Figura 2.20 Esquema do lançamento do esgoto sanitário da estação Subaé

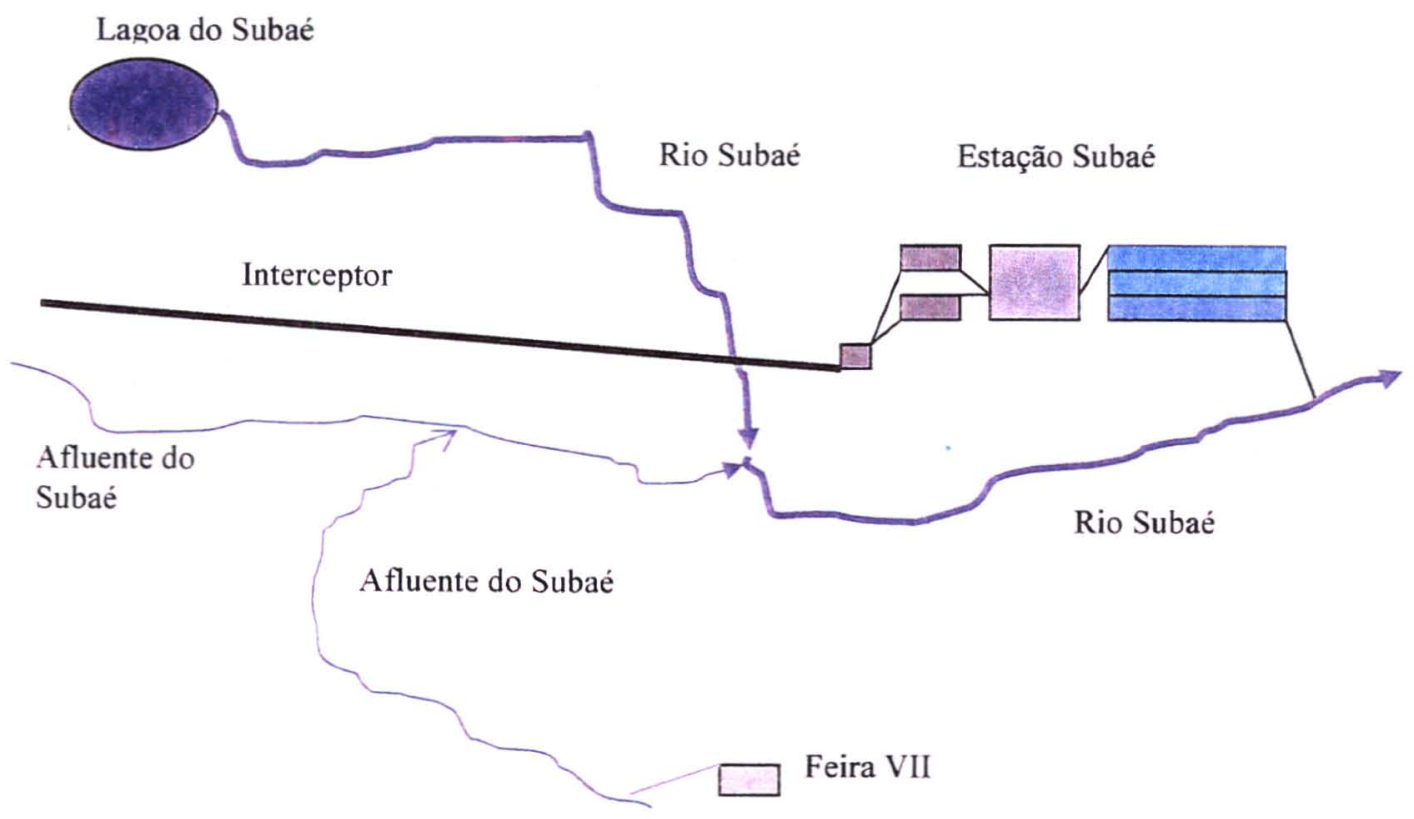

A estação de tratamento Subaé é constituída por tratamento preliminar (gradeamento e desarenador), seguido de tratamento primário e secundário através de dois DAFAs em paralelo (com captação do lodo para o leito de secagem), seguido de uma lagoa aerada e uma lagoa facultativa em série. O efluente tratado é lançado no Rio Subaé Foto 15 e Figura 2.21 .

Os parâmetros básicos de projeto foram ( $1^{\mathrm{a}}$. Etapa):

Carga orgânica: Afluente $\mathrm{Ca}=286,86 \mathrm{mg}$ de $\mathrm{DBO}_{5} / 1$, equivalente a $8.178,0 \mathrm{~kg} \mathrm{DBO} 5$ /dia; Efluente $\mathrm{Ca}=21,17 \mathrm{mg}$ de $\mathrm{DBO}_{5} / 1$, equivalente a $603,5 \mathrm{~kg} \mathrm{DBO} / /$ dia.

Vazões afluentes: Máxima $=592,93 \mathrm{l} / \mathrm{s}$; Média $=329,96 \mathrm{l} / \mathrm{s}$; Mínima =197,98 1/s.

Vazões efluentes: Considerou as mesmas vazões afluentes.

Eficiência $=92,6 \%$ em remoção de $\mathrm{DBO}$; 
Tempo de detenção: DAFA $=6: 18 \mathrm{~h}$; Lagoa aerada facultativa $=72: 00 \mathrm{~h}$; Lagoa acultativa tipo pistão $=96: 00 \mathrm{~h}$; Total $=174: 18 \mathrm{~h}(7,2625$ dias $)$.

Eficiência em remoção de DBO (\%):

DAFA $=70,0 ;$ Lagoa aerada facultativa $=54,0 ;$ Lagoa facultativa tipo pistão $=$ 46,0 ;

Total $=96,0 \mathrm{~h}$.

Eficiência em remoção de Coliforme (\%):

$\mathrm{DAFA}=90,0 ;$ Lagoa aerada $=90,0 ;$ Lagoa Facultativa tipo pistão $=99,5$

Total $=99,995 \mathrm{~h}$.

Remoção de coliformes: de $10^{7}$ para 5,7 x $10^{2}$ (META SERVIÇO DE ENGENHARIA LTDA 1998a, 1998b)

Quanto à operação do tratamento, foram previstas limpezas da grade de retenção de sólidos grosseiros diariamente, da caixa de areia a cada 10 dias ou quando a quantidade de areia chegar a uma determinada altura, remoção de $44,51 \mathrm{~m}^{3}$ de lodo diariamente dos dois DAFAs em paralelo, para os leitos de secagem, e para a $1^{\mathrm{a}}$ etapa. No momento, não existem os leitos de secagem, logo, o lodo gerado está sendo removido e transportado para a estação Contorno.

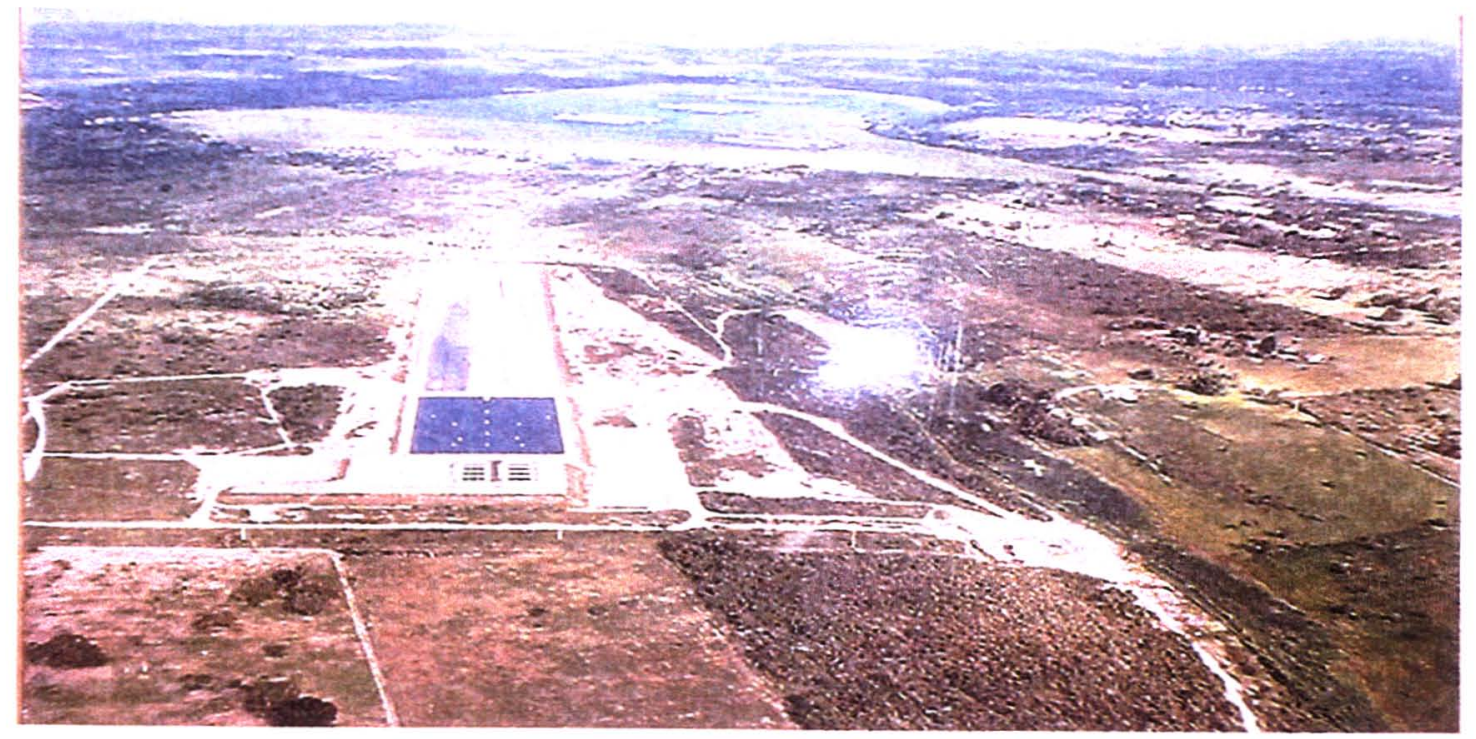

Foto 15. ETE Subaé. 


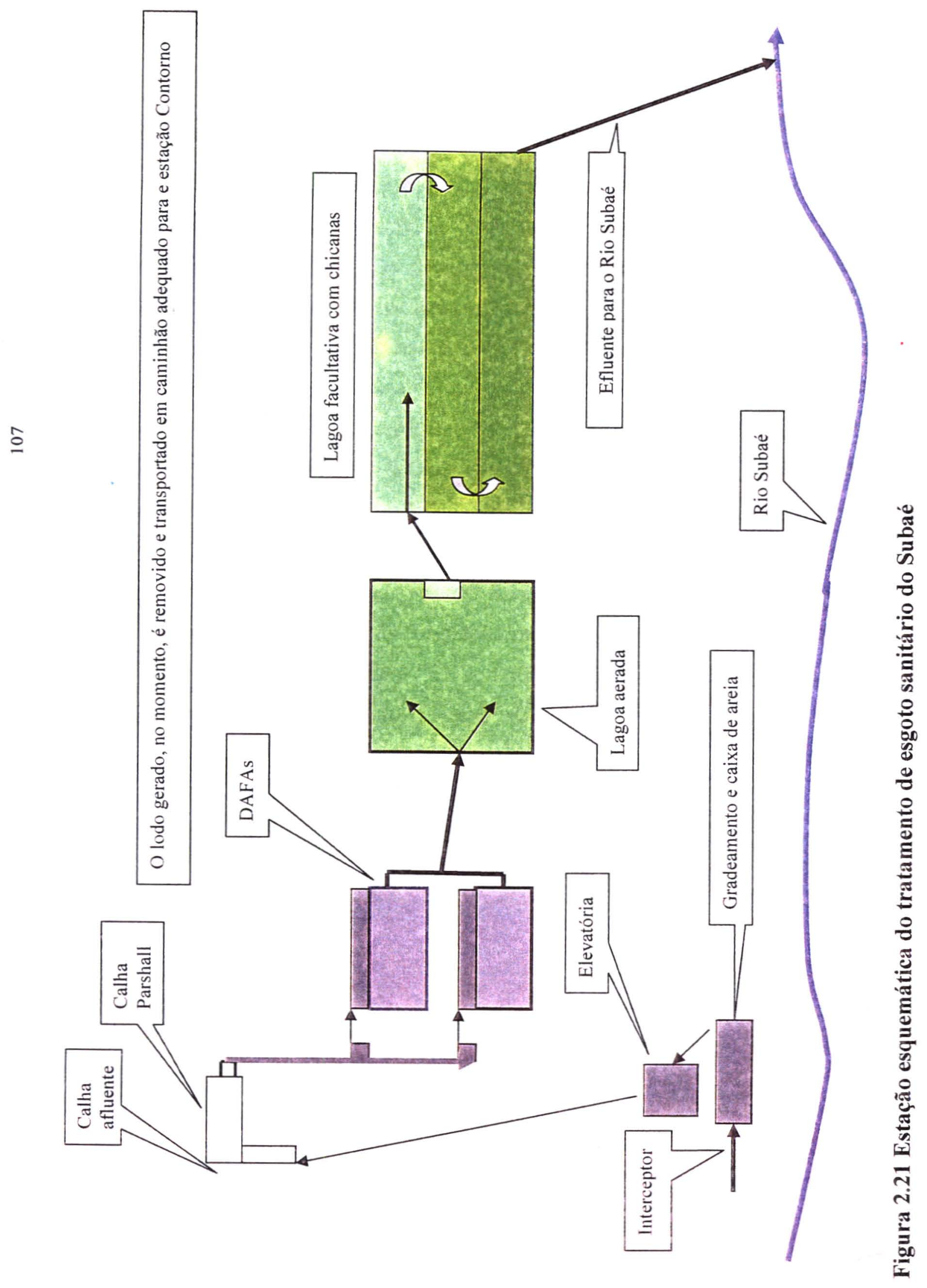


Em Feira de Santana, existem dez estações de tratamento de esgotos sanitários e, até o momento, só $33,5 \%$ da população são atendidas, porém, com capacidade para atendimento de $61,4 \%$ da população já implantada. O número elevado de estações para esse atendimento baixo $(33,5 \%)$ decorre de três situações: Feira de Santana está localizada em um platô divisor de águas de três bacias hidrográficas (Pojuca, Jcuipe e Subaé), com escoamento das águas do centro para as periferias, logo, o esgotamento sanitário segue a mesma tendência da topografia, ou seja, a geografia da área impôs a implantação do sistema de esgotamento sanitário por bacia. Já se encontram implantadas, em parte, as bacias do Jacuípe (ETE Contorno) e Subaé (ETE Subaé), que são estações de porte médio; A implantação do sistema de transporte e tratamento da bacia do Subaé é recente e parte relativa à coleta está em andamento, portanto não atingindo a população esperada. O sistema financeiro de habitação do Governo Federal impõe que a implantação de um empreendimento habitacional só ocorra se houver solução sanitária para o esgoto e, como, em Feira de Santana, muitos dos empreendimentos habitacionais do Governo estão localizados em área onde não existia sistema de esgotamento sanitário, foi obrigatória a implantação de sistemas próprios, ou seja, que atendessem, apenas, aos empreendimentos. 


\section{HIPÓTESE}

No Brasil, muitas estações de tratamento de esgotos sanitários são projetadas para atender exigências ambientais quanto à remoção da carga orgânica (DBO - Demanda Bioquímica de Oxigênio) e não removem microorganismos patogênicos (bactérias, vírus, helmintos e protozoários) nas quantidades necessárias para assegurar que o efluente não cause transtornos aos possiveis usuários dos corpos receptores, logo, não se considera a questão de saúde pública na maioria dos projetos. Esta pesquisa trabalha com a hipótese de que os processos de tratamento de esgotos sanitários não removem várias espécies de parasitas humanos dos afluentes das estações de tratamento, proporcionando riscos para os usuários que utilizam as águas a jusante dos lançamentos dessas estações.

\section{OBJETIVOS}

\subsection{Objetivo geral}

Caracterizar os afluentes e efluentes de quatro estações de tratamento de esgotos sanitários de Feira de Santana, avaliar os resultados quanto à eficiência do tratamento em remoção de carga orgânica, coliformes e patogênicos no processo, visando identificar possíveis condições de exposição a patógenos dos usuários a jusante dos pontos de lançamentos que podem resultar em riscos à saúde.

\subsection{Objetivos específicos}

- Caracterizar, fisica, química e biologicamente os esgotos sanitários antes e após o tratamento, em quatro estações da cidade de Feira de Santana;

- Verificar se há prevalência de helmintos e protozoários nas comunidades atendidas pelos diferentes sistemas de esgotamento sanitário investigados, visando identificar possíveis doenças causadas por parasitas do intestino humano presentes nessas comunidades;

- Fazer estudo comparativo entre as quatro estações de tratamento quanto à eficiência em remoção da carga orgânica e biológica; 
- Avaliar a remoção qualitativa de helmintos e protozoários parasitos do intestino humano, nas estações de tratamento de esgotos;

- Identificar situação de riscos para a saúde dos usuários que utilizam as águas a jusante dos lançamentos das estações de tratamento de esgotos sanitários. 


\section{METODOLOGIA}

A pesquisa desenvolvida refere-se a um estudo analítico com o objetivo de investigar e testar a hipótese formulada, através de experimentos, em quatro estações de tratamento de esgotos sanitários de Feira de Santana.

\subsection{Passos da metodologia}

\subsubsection{Levantamento documental}

Foram pesquisados os arquivos da EMBASA em Feira de Santana e em Salvador na busca de informações operacionais e dos projetos das unidades de tratamento de esgotos sanitários de Feira de Santana, bem como dos fatos históricos e eventos relevantes deste municipio.

\subsubsection{Levantamento bibliográfico}

Foram feitos levantamentos nas bibliotecas da Faculdade de Saúde Pública (USP); da CETESB - Companhia de Tecnologia em Saneamento Ambiental (SP); da SABESP - Companhia de Saneamento Básico do Estado de São Paulo; da UEFS Universidade Estadual de Feira de Santana; da APEB - Arquivo Público do Estado da Bahia; da ABES - Associação Brasileira de Engenharia Sanitária (Seção Bahia); da EMBASA - Empresa Baiana de Águas e Saneamento S. A. (Salvador); Departamento de Saúde Pública (UFBA); no IBGE (Escritório de Feira) e do pesquisador.

\subsubsection{Observações de campo}

Para compreender melhor as comunidades e as estações de tratamento de esgotos sanitários dessas comunidades, foram feitas observações de campo tais como: tipos de imóveis e de atividades presentes no bairro; padrão das residências; sistemas de drenagem pluvial, sistema de limpeza urbana; situação das estruturas de retenção de areia, retenção de sólidos grosseiros, medição de vazão, descarga, extravasor, equipamentos, estado físico e manutenção geral das estações de tratamento de esgotos sanitários. 


\subsubsection{Pesquisa pela Internet}

Foram feitas pesquisas pela Internet ao DATASUS; IWA - International Water Association; WHO - Word Health Organization (US); EPA - Environmental Protection Agency of United States; Water Environmental Research (US); OPS Organização Pan-americana de Saúde; CRA- Centro de Recursos Ambientais. Órgão da Secretaria de Planejamento do Estado da Bahia.

\subsubsection{Seleção da amostra}

Estudar as dez estações de tratamento de esgotos sanitários existentes no município de Feira de Santana, por periodo de um ano, seria o desejado, porém inviável visto que os recursos disponiveis não eram suficientes para realizar a quantidade de análises necessárias para todas essas ETEs. Considerando-se essa limitação, resolveu-se estudar quatro estações de tratamento de esgotos sanitários de Feira de Santana, estações estas que, no global, são representativas de todas as existentes atualmente.

Para selecionar as quatro estações estudadas neste projeto de pesquisa, foram observados os critérios que seguem:

- As estações devem ter características diferentes entre si para representar a diversidade;

- Os parâmetros de projeto das estações devem estar bem definidos para permitir comparar o resultado de campo com o previsto em projeto;

- As estações de tratamento de esgotos sanitários devem estar em operação há mais de dois anos, para garantir que a ETE se encontre em plena operação;

- As comunidades atendidas pelas estações de tratamento de esgotos sanitários devem ser possiveis de caracterização de forma geral;

- As características das comunidades atendidas pelas estações de tratamento devem ser diferentes, se possivel, para verificação das condições adversas apresentadas pelas comunidades;

Seguindo os critérios definidos, foram selecionadas as estações de tratamento de esgotos sanitários Homero Figueiredo, Viveiros "A", Lagoa Grande e Contorno. 
A estação Contorno foge um pouco dos critérios definidos acima, entretanto foi selecionada porque representa atendimento a uma população superior a 100.000 habitantes do municipio de Feira de Santana, sendo que a população atendida por essa unidade tem características bastante diversas das demais e vários hospitais e clínicas contribuem com seus esgotos para essa ETE.

\subsubsection{Definição dos parâmetros a serem pesquisados}

Os parâmetros selecionados para levantamento de informações das estações de tratamento de esgoto sanitário foram:

Físicos: Temperatura do ambiente, temperatura dos esgotos afluente e efluente, $\mathrm{pH}$ dos esgotos afluente e efluente e vazão afluente às ETEs;

Quimicos: Demanda Bioquimica de Oxigênio - DBO e Demanda Química de Oxigênio - DQO;

Biológicos: Coliformes totais e fecais, ovos viáveis e larvas de helmintos e protozoários conforme relação a seguir.

Helmintos:

- Ascaris lumbricoides;

- Trycocephalus trichiurus;

- Strongyloides stercoralis;

- Ancylostoma duodenali;

- Enterobius vermiculares;

- Schistosoma mansoni;

- Hymenolepis nana;

- Hymenolepis diminuta;

- Taenia sp.;

Protozoários:

- Entamoeba histolytica;

- Entamoeba coli;

- Endolimax nana;

- Iodamoeba butschlii;

- Dientamoeba fragilis;

- Giardia lamblia. 


\subsubsection{Seleção dos pontos de coleta.}

Os pontos das estações de tratamento selecionados para coleta das amostras para avaliação das eficiências em remoção de matéria orgânica, de coliformes, de helmintos e protozoários foram: o ponto de entrada do esgoto à ETE (afluente) e o ponto de saída do esgoto da ETE (efluente). Esta selecção considerou que os resultados das análises das amostras obtidas nesses pontos permitem a verificação da eficiência real de cada estação, a comparação entre os valores dos parâmetros medidos e os valores utilizados para projeto das estações, a comparação entre as ETEs e a verificação quanto ao atendimento às condições sanitárias e ambientais na operação de cada ETE.

\subsubsection{Definição do período de amostragem}

O período de amostragem executado foi de cinqüenta e duas semanas, equivalente ao periodo de um ano, com freqüência de coleta semanal, para cada uma das quatro estações de tratamento de esgotos sanitários selecionadas. Terças feiras para os exames de $\mathrm{DBO}$, DQO e Coliformes e quartas feiras para os exames parasitológicos.

\subsubsection{Definição do tipo e hora da amostragem}

A amostragem ideal seria a composta, constituída de amostras coletadas de hora em hora, ou duas em duas horas, e armazenadas adequadamente para conservar todas as características do esgoto nas condições da hora da coleta.

Optou-se pela coleta pontual das amostras para cada ETE, no período das 08:00 às 10:00 horas da manhã nas terça feiras, para as análises de DBO, DQO e coliformes e nas quartas feiras, para análises de ovos viáveis e larvas de helmintos e protozoários pelas seguintes razões:

- Em levantamentos prévios efetuados nos afluentes as ETEs ViveirosA e Contorno, as vazões máximas verificadas ocorriam no período das 07:30 às 10:30h da manhã, seguidas por picos menores no período das $13: 00$ às $15: 30 \mathrm{~h}$ e da 18:00 às 21:00 $\mathrm{h}$; 
- Por ser o período onde as condições operacionais são as mais desfavoráveis, visto que das 08:00 às 10:00 h ocorrem as maiores contribuições, ou sejam, vazões acima da média ou vazão de pico;

- Porque os laboratórios só aceitavam as amostras para análises se chegassem até às 12:30 horas;

- Porque era a forma de amostragem mais econômica e possível de ser realizada com o pessoal disponível.

\subsubsection{Definição da quantidade de amostras}

a) Para as análises fisicas de temperatura, vazão e pH:

- Número de parâmetros: Foram medidos seis parâmetros fisicos para cada estação de tratamento, quatro no local e hora da coleta das amostras (temperatura do ambiente e temperaturas dos esgotos afluentes e efluentes e vazão afluente) e dois no laboratório ( $\mathrm{pH}$ dos esgotos afluentes e efluentes);

- Total dos dados levantados: 4 × $6 \times 52=1248$ dados.

b) Para as análises químicas de DBO e DQO:

- Número de parâmetros: foram levantados dois parâmetros por estação de tratamento: DBO e DQO;

- Número de amostras: foram coletadas duas amostras por estação de tratamento de esgotos, por dia de coleta;

- Total dos dados levantados: $4 \times 2 \times 2 \times 52=832$ dados;

c) Para os exames bacteriológicos:

- Número de parâmetros bacteriológicos: dois - coliformes fecais e coliformes totais

- Número de amostras: foram coletadas duas amostras em cada estação de tratamento de esgotos, por dia de coleta;

- Total de dados levantados: $4 \times 2 \times 2 \times 52=832$ dados.

d) Para os exames de Helmintos e Protozoários

- Número de amostras: foram coletadas duas amostras de esgotos em cada estação de tratamento, por dia de coleta; 
- Número de parasitas a serem pesquisados: foram pesquisados quinze parasitas por amostra, seis protozoários e nove helmintos.

- Total de dados levantados: $4 \times 2 \times 15 \times 52=6240$ dados.

$\mathrm{Na}$ hora e local da coleta das amostras, foi anotada a condição do tempo em termos de precipitação pluviométrica para auxiliar na avaliação dos dados levantados.

\subsubsection{Coleta de amostras, armazenamento e transporte.}

Todas as amostras foram coletadas por um auxiliar de laboratónio da Empresa de Saneamento do Estado da Bahia - EMBASA, com orientação e acompanhamento do pesquisador.

a) Análises de $\mathrm{DBO}$, $\mathrm{DQO}$ e Bacteriológicas.

Os critérios para coleta, armazenamento e transporte das amostras para as análises de $\mathrm{DBO}, \mathrm{DQO}$ e bacteriológicas foram os estabelecidos pelo Standard Methods For The Examination of Water and Wasterwater, $19^{\text {th }}$ Edition, 1995.

As amostras de $1000 \mathrm{ml}$ de esgoto dos respectivos pontos de coleta foram armazenadas em garrafas plásticas, acondicionadas em vasilhame de isopor e transportadas até o laboratório da UEFS para análises.

b) Exames de helmintos e protozoários parasitos do intestino humano As amostras de esgoto para os exames de helmintos e protozoários parasitos do intestino humano foram coletadas, armazenadas e transportadas conforme segue.

Tipos de recipiente:

- Plástico para o esgoto bruto;

- Coletor para "fezes/urina" para armazenar os resíduos da centrifugação das amostras para os exames de helmintos e protozoários. 
Lavagem dos recipientes:

De plástico:

- Com solução de ácido nítrico 1:1 e enxaguado com água destilada.

De coleta para "fezes/urina":

- Conforme fornecido pelas farmácias, para acondicionamento de fezes ou urina.

Volumes das amostras:

- $1000 \mathrm{ml}$ de esgoto bruto;

- $100 \mathrm{ml}$ de sedimentos e sobrenadantes obtidos com a centrifugação de $352 \mathrm{ml}$ da amostra de $1000 \mathrm{ml}$ do esgoto bruto.

Preservação das amostras para transporte

- As amostras de $1000 \mathrm{ml}$ do esgoto bruto, após coletadas em garrafas plásticas, foram colocadas em um vasilhame de isopor e transportadas até o laboratório da EMBASA, para centrifugação de parte da amostra.

- As amostras centrifugadas foram colocadas em coletor tipo fezes/urina, armazenadas em vasilhame de isopor e transportadas até o laboratório de parasitologia da UEFS, para as análises de protozoários e helmintos.

\subsubsection{Técnica de preparo das amostras para entrega ao laboratório para} exames de helmintos e protozoários parasitos do intestino humano

No laboratório da EMBASA, a amostra de $1000 \mathrm{ml}$ foi homogeneizada, retirados 352 $\mathrm{ml}$ de esgoto e centrifugados a $2500 \mathrm{rpm}$, durante 5 minutos. Os sobrenadantes resultantes das centrifugações foram desprezados na quase totalidade, e,posteriormente, foram recolhidos os sedimentos e colocados em coletores tipos "fezes/urina" em volume de $100 \mathrm{ml}$ juntamente com algum sobrenadante, e armazenados em vasilhame de isopor. 


\subsubsection{Determinações e Análises}

a) Determinação da temperatura.

As medições da temperatura ambiente e dos esgotos sanitários afluentes e efluentes às estações de tratamento foram executadas no momento da coleta das amostras, com termômetro de bulbo de mercúrio, divisão de escala de 1,0 grau.

b) Determinação do $\mathrm{pH}$

As determinações do $\mathrm{pH}$ dos esgotos afluentes e efluentes às estações de tratamento foram feitas com sonda específica, calibrada com solução tampão pH 4 e pH 7 da Haloquímica Industria e Comércio Ltda, no laboratório de Saneamento da UEFS, somente para as amostras das determinações de DBO e DQO.

c) Determinação da Vazão

Em todas as estações de tratamento selecionadas, existem calhas Parshall (medidor de regime crítico) construídas segundo padrões e recomendações técnicas adequadas. Nestas calhas e nos pontos certos, foram feitas medições das lâminas de esgoto com régua milimetrada e, através da equação de vazão para cada calha, calculou-se a vazão instantânea do escoamento. As equações da vazão função da altura da lâmina para as calhas de 3" e 12 " são: $Q=0,176$ $\mathrm{xh}^{1,547}$ e $\mathrm{Q}=0,690 \times \mathrm{h}^{1,522}$, respectivamente, sendo $\mathrm{h}$ em metros e $\mathrm{Q} \mathrm{em} \mathrm{m}^{3} / \mathrm{s}$ (AZEVEDO NETO e ALVAREZ, 1991).

d) Análises da DBO e DQO

As análises de DBO e DQO foram executadas no Laboratório de Saneamento da UEFS - Universidade Estadual de Feira de Santana, conforme estabelece o Standard Methods For The Examination of Water and Wasterwater, $19^{\text {th }}$ Edition, 1995) 
e) Análises de coliformes totais e fecais

Os exames para determinação de coliforme fecais e totais foram realizados no Laboratório de Saneamento da UEFS, segundo o Standard Methods For The Examination of Water and Wasterwater, $19^{\text {th }}$ Edition, 1995, pelo método cromogênico empregando Colilert. Devido à limitação da capacidade do laboratório e de recurso financeiro disponivel, definiu-se, previamente, a diluição adequada para as amostras para cada ponto de coleta e fez-se análise apenas para essa diluição, evitando-se custos adicionais com a execução de análises com diluições a maior e a menor, em relação à definida previamente.

f) Análises dos Helmintos e Protozoários parasitos do intestino humano

Os exames de ovos viáveis e larvas de helmintos e protozoários parasitos do intestino humanos, foram feitos no Laboratório de Parasitologia Humana da UEFS, através do método qualitativo de sedimentação espontânea por Hofmann, Pons e Janer (NEVES, 2001), considerando-se que, para estudos de parasitologia humana, o importante é determinar a presença ou ausência do parasita e, não, a quantidade.

\subsubsection{Avaliação dos resultados}

a) Condição de saúde doença das comunidades estudadas

A avaliação das condições de saúde das comunidades foi realizada com base nos resultados das análises dos parasitas existentes em amostras de esgotos afluentes às estações, considerando-se a presença ou ausência de parasitas.

b) Eficiência na remoção de Helmintos e Protozoários parasitos do intestino humano

Com os resultados dos exames dos parasitos do intestino humano, helmintos e protozoários, fez-se a avaliação da eficiência do tratamento, comparando-se as freqüências da presença desses parasitos no afluente e efluente à ETE. Não se manteve o mesmo padrão adotado para avaliação dos coliformes porque os exames realizados para os microorganismos citados acima foram, apenas, qualitativos, visto que esse é o procedimento normalmente utilizado nos 
laboratórios de patologia clínica, pois, para o diagnóstico clínico de um paciente, é suficiente verificar se existe ou não o agente patogênico.

A avaliação entre estações de tratamento foi feita comparando-se os resultados das freqüências de helmintos e protozoários encontrados para os afluentes e efluentes destas.

c) Eficiência em remoção de DBO, DQO e Coliformes

Para os resultados de DBO, DQO, Coliformes totais e fecais calcularam-se as médias e os respectivos desvios padrão dos valores resultantes das análises realizadas nas amostras coletadas para cada estação do ano e, admitindo-se desvios de mais ou menos 1,96 padrão em relação às médias, verificaram-se os resultados que ficaram fora da faixa, expurgando-se os mesmos. Com a nova amostra repetiram-se os procedimentos anteriores até enquadrar todos os dados nos limites estabelecidos.

As avaliações das eficiências na remoção de $\mathrm{DBO}, \mathrm{DQO}$, coliformes totais e fecais foram feitas com base no decréscimo dos resultados obtidos nas análises de $\mathrm{DBO}, \mathrm{DQO}$ e bacteriológicas entre o afluente e o efluente para cada estação de tratamento de esgoto.

d) Eficiência real e de projeto das estações de tratamento de esgotos estudadas

A eficiência do tratamento de esgotos verificada em cada ETE foi comparada com a eficiência prevista em projeto, avaliando-se a adequação do projeto e a operação, para cada uma das quatro estações de tratamento de esgoto estudadas.

e) Adequação do tratamento com a Legislação

A qualidade do efluente das estações de tratamento quanto à remoção de DBO e coliformes fecais foi comparada com o padrão estabelecido nas 
NT002 da Resoluções 2288 (CEPRAM 2000) e Resolução n 20 (CONAMA 1986).

f) Levantamento das condições de risco à saúde dos usuários de jusante dos lançamentos das ETEs

Os levantamentos das condições potenciais de risco à saúde dos usuários dos corpos receptores dos esgotos tratados foram realizados através de comparações dos valores obtidos nas análises bacteriológicas e parasitológicas dos efluentes das estações com os padrões para água (corpo receptor) estabelecidos na Resolução n 20 (CONAMA 1986) e Portaria 1469 (MS 2001), que substitui a Portaria 36 (MS 1997), considerando-se os usos atribuídos à água desses corpos d'água.

Neste trabalho, entende-se por eficiência de remoção em porcentagem:

- Eficiência pontual: a diferença entre o resultado do afluente e respectivo resultado do efluente dividido pelo valor do afluente e multiplicado por cem, conforme amostragem simples executada entre 8:00 e 10:00h do dia;

- Eficiência média do período: a diferença entre a soma do resultado dos afluentes e a soma dos resultados dos efluentes, para o periodo considerado, multiplicado por cem, conforme amostragem simples executada entre 8:00 e 10:00h do dia;

- Eficiência total da amostragem: a diferença entre a soma do resultado dos afluentes e a soma dos resultados dos efluentes, para o período considerado, multiplicado por cem, conforme amostragem simples executada entre 8:00 e 10:00h do dia. 


\section{RESULTADOS E DISCUSSÃO}

\subsection{Geral}

Os resultados das investigações realizadas nas estações de tratamento de esgotos sanitários Homero Figueiredo, Lagoa Grande, Viveiros A e Contorno foram subdivididos em quatro períodos distintos correspondendo às estações do ano: Primavera de 23/09/01 a 20/12/01 (Tabelas 9.1 a 9.16 em anexos); Verão de 21/12/01 a 20/03/02 (Tabelas 9.17 a 9.32 em anexos); Outono de 21/03/02 a 20/06/02 (Tabelas 9.33 a 9.48 em anexos) e Inverno 21/06/02 a 22/09/02 (Tabelas 9.49 a 9.64 em anexos).

Os dados apresentados nas Tabelas 9.1 a 9.64 (em anexos) não foram todos os obtidos nas análises realizadas nos laboratórios. Dos resultados obtidos nas análises, foram avaliados e considerados como aceitáveis aqueles que seguem uma distribuição normal, com probabilidade de aceitação da amostra de 95\%, conseqüentemente, limite superior igual ao VM (Valor Médio) + 1,96 x Sd (Desvio padrão) e limite inferior VM (Valor Médio) - 1,96 x Sd (Desvio padrão). O par de dados, valores relativos ao afluente e ao efluente, encontrados fora dos limites estabelecidos na faixa acima foram rejeitados, se encontram em branco na tabela, para não afetar o resultado médio dos parâmetros pesquisados de cada periodo estudado, mesmo que somente um deles se encontre fora da faixa, ou seja, se o resultado do afluente ou o correspondente para o efluente se encontrar fora da faixa, rejeitam-se os dois.

Quanto às linhas sem resultados, e de cor cinza, existentes nas Tabelas 9.1 a 9.64, se explica porque as análises não foram realizadas em decorrência de feriados na Universidade Estadual de Feira de Santana; de ponto facultativo na EMBASA; de doença de técnico responsável pela coleta; e da falta de produtos químicos no Laboratório de Saneamento da UEFS. Estes fatos ficaram mais evidentes no verão (25/12/02 a 20/03/03) e, se comparados com os demais periodos (primavera, outono e inverno), verifica-se que os resultados daquela época ficaram prejudicados em quantidades. 
Os resultados bacteriológicos aparecem em alguns valores com sinal de maior, tanto para o afluente, quanto para o efluente, enquanto os valores médios, desvio padrão e limites superior e inferior não apresentam sinais, visto que as quantidades observadas tanto para o afluente, como para o efluente, são, aproximadamente, iguais e, considerando-se que se trata de esgoto sanitário com valores da ordem de $10^{7}-10^{8}$ para coliformes totais e $10^{6}-10^{7}$ para coliformes fecais, o valor com sinal de maior deve ficar multiplicado por 10. Logo, os valores em termos de percentuais de remoção são da mesma ordem de grandeza.

Os resultados das análises de helmintos e protozoários parasitos do intestino humano são qualitativos e foram apresentados com base na freqüência da presença desses microrganismos nas amostras analisadas.

Os resultados per-capitas calculados para as comunidades mostram que os hábitos quanto a consumo de água mudaram após a massificação da micromedição da água pela Empresa Baiana de Águas e Saneamento S. A.

\subsubsection{Temperatura e pH no ambiente das comunidades e das estaçōes pesquisadas}

Pelas Tabelas 6.1, 6.2, 6.3 e 6.4 verifica-se que as temperaturas médias dos ambientes das quatro ETEs pesquisadas variaram muito pouco para uma mesma estação do ano. Estas variações devem-se às altitudes dos ambientes e horas das medições das temperaturas, encontrando-se dentro do esperado para a região de Feira de Santana. A temperatura máxima ocorreu no verão com registros de $32{ }^{\circ} \mathrm{C}$ na estação Homero Figueiredo, $31^{\circ} \mathrm{C}$ na Lagoa Grande e $29^{\circ} \mathrm{C}$ nas estações Viveiros-A e Contorno. A temperatura minima registrada foi de $21^{\circ} \mathrm{C}$, no inverno, para todas as estações de tratamento pesquisadas. Observa-se que as medições das temperaturas ocorreram entre 08:00h e 10:00h.

Analisando-se o $\mathrm{pH}$, verifica-se que, para o afluente e o efluente, em termos de valor médio, e para uma mesma estação do ano, houve pequena variação para a mesma estação de tratamento. $\mathrm{O}$ pH médio afluente ficou maior que o $\mathrm{pH}$ médio efluente 
para as ETEs Lagoa Grande e Viveiros-A. A ETE Homero Figueiredo teve pH médio afluente menor que o pH médio efluente no verão, outono $\mathrm{e}$ inverno $\mathrm{e}$, aproximadamente, o mesmo valor na primavera. Para a ETE Contorno, o pH médio afluente e efluente foi, aproximadamente, o mesmo para as quatro estações do ano.

Para a estação Homero Figueiredo, a média mínima e a média máxima do pH relativa ao ano foram 6,9 e 7,5 para o afluente e 7,4 e 7,7 para o efluente. Para a estação Lagoa Grande 7,3 e 7,7 para o afluente e 7,0 e 7,1 para o efluente. Para a estação Viveiros-A 7,2 e 7,5 para o afluente e 6,9 e 7,2 para o efluente. E para a estação Contorno foram 7,1 e 7,3 para o afluente e 7,2 e 7,4 para o efluente. Não se registra correspondência entre a média máxima afluente e a média máxima efluente para uma mesma estação do ano como deveria ocorrer, bem como entre a média mínima afluente e a média minima efluente.

Tabela 6.1 - Temperaturas e pH registrados nos pontos de amostragem, na hora da coleta das amostras, na ETE Homero Figueiredo.

\begin{tabular}{l|c|c|c|c|c}
\hline \multirow{2}{*}{$\begin{array}{l}\text { Parâmetros } \\
\text { Estações do ano }\end{array}$} & \multirow{2}{*}{$\begin{array}{c}\text { Temperatura } \\
\text { Ambiente }\end{array}$} & \multicolumn{2}{|c|}{ Temperatura do esgoto } & \multicolumn{2}{c}{ pH do esgoto } \\
\cline { 3 - 6 } & & Afluente & Efluente & Afluente & Efluente \\
\hline Primavera & & & & & \\
\hline Média & 24,2 & 24,1 & 24,2 & 7,5 & 7,4 \\
\hline Desvio Padrão & 1,7 & 0,6 & 0,7 & 0,3 & 0,2 \\
\hline Valor máximo & 26,0 & 25,0 & 26,0 & 8,0 & 7,8 \\
\hline Valor mínimo & 24,0 & 23,0 & 23,0 & 7,1 & 7,2 \\
\hline Verão & & & & & \\
\hline Média & 27,3 & 25,7 & 25,7 & 7,1 & 7,7 \\
\hline Desvio Padrão & 2,5 & 2,0 & 2,0 & 0,4 & 0,3 \\
\hline Valor máximo & 32,0 & 29,0 & 29,0 & 7,6 & 8,4 \\
\hline Valor mínimo & 24,0 & 24,0 & 24,0 & 6,7 & 7,4 \\
\hline Outono & & & & & \\
\hline Média & 25,4 & 24,3 & 24,3 & 6,9 & 7,6 \\
\hline Desvio Padrão & 0,9 & 0,7 & 0,7 & 0,3 & 0,2 \\
\hline Valor máximo & 26,0 & 25,0 & 25,0 & 7,5 & 7,9 \\
\hline Valor mínimo & 25,0 & 23,0 & 23,0 & 6,3 & 7,2 \\
\hline Inverno & & & & & \\
\hline Média & 22,1 & 23,1 & 23,0 & 7,4 & 7,6 \\
\hline Desvio Padrão & 1,0 & 0,3 & 0,0 & 0,2 & 0,5 \\
\hline Valor máximo & 24,0 & 24,0 & 23,0 & 8,1 & 8,4 \\
\hline Valor minimo & 21,0 & 23,0 & 23,0 & 7,1 & 6,9 \\
\hline
\end{tabular}


Tabela 6.2 - Temperaturas e pH registrados nos pontos de amostragem, na hora da coleta das amostras, na ETE Lagoa Grande.

\begin{tabular}{l|c|c|c|c|c}
\hline Parâmetros & Temperatura & \multicolumn{2}{|c|}{ Temperatura do esgoto } & \multicolumn{2}{c}{ pH do esgoto } \\
\cline { 3 - 6 } Estações do ano & Ambiente & Afluente & Efluente & Afluente & Efluente \\
\hline Primavera & & & & & \\
\hline Média & 24,5 & 24,2 & 24,2 & 7,7 & 7,1 \\
\hline Desvio Padrão & 1,4 & 0,6 & 0,6 & 0,5 & 0,2 \\
\hline Valor máximo & 27,0 & 25,0 & 25,0 & 8,2 & 7,4 \\
\hline Valor mínimo & 22,0 & 23,0 & 23,0 & 6,6 & 6,9 \\
\hline Verão & & & & & \\
\hline Média & 27,0 & 25,8 & 25,8 & 7,4 & 7,1 \\
\hline Desvio Padrão & 2,1 & 1,9 & 1,9 & 0,4 & 0,2 \\
\hline Valor máximo & 31,0 & 29,0 & 29,0 & 8,2 & 7,5 \\
\hline Valor mínimo & 25,0 & 24,0 & 24,0 & 6,9 & 6,9 \\
\hline Outono & & & & & \\
\hline Média & 24,7 & 24,3 & 24,3 & 7,3 & 7,0 \\
\hline Desvio Padrão & 1,1 & 0,5 & 0,5 & 0,2 & 0,1 \\
\hline Valor máximo & 27,0 & 25,0 & 25,0 & 7,7 & 7,2 \\
\hline Valor mínimo & 23,0 & 24,0 & 24,0 & 6,9 & 6,7 \\
\hline Inverno & & & & & \\
\hline Média & 23,2 & 23,6 & 23,6 & 7,5 & 7,0 \\
\hline Desvio Padrão & 1,6 & 0,7 & 0,7 & 0,4 & 0,3 \\
\hline Valor máximo & 27,0 & 25,0 & 25,0 & 8,4 & 7,8 \\
\hline Valor mínimo & 21,0 & 23,0 & 23,0 & 7,0 & 6,8 \\
\hline
\end{tabular}

Tabela 6.3 - Temperaturas e $\mathrm{pH}$ registrados nos pontos de amostragem, na hora da coleta das amostras, na ETE Viveiros-A.

\begin{tabular}{l|c|c|c|c|c}
\hline \multirow{2}{*}{$\begin{array}{l}\text { Parâmetros } \\
\text { Estações do ano }\end{array}$} & \multirow{2}{*}{$\begin{array}{c}\text { Temperatura } \\
\text { Ambiente }\end{array}$} & Temperatura do esgoto & \multicolumn{2}{c}{ pH do esgoto } \\
\cline { 3 - 6 } & & Afluente & Efluente & Afluente & Efluente \\
\hline Primavera & 25,0 & 24,2 & 24,2 & 7,5 & 7,2 \\
\hline Média & 1,7 & 0,6 & 0,6 & 0,2 & 0,3 \\
\hline Desvio Padrão & 27,0 & 25,0 & 25,0 & 7,8 & 7,6 \\
\hline Valor máximo & 22,0 & 23,0 & 23,0 & 6,9 & 6,7 \\
\hline Valor mínimo & & & & & \\
\hline Verão & 27,6 & 25,7 & 25,6 & 7,2 & 6,9 \\
\hline Média & 1,4 & 1,1 & 1,0 & 0,5 & 0,1 \\
\hline Desvio Padrão & 29,0 & 27,0 & 27,0 & 7,7 & 7,0 \\
\hline Valor máximo & 26,0 & 24,0 & 24,0 & 6,4 & 6,7 \\
\hline Valor mínimo & & & & & \\
\hline Outono & 24,8 & 24,5 & 24,5 & 7,2 & 6,9 \\
\hline Média & 1,3 & 0,8 & 0,8 & 0,4 & 0,2 \\
\hline Desvio Padrão & 27,0 & 26,0 & 26,0 & 7,6 & 7,2 \\
\hline Valor máximo & 23,0 & 23,0 & 23,0 & 6,3 & 6,6 \\
\hline Valor mínimo & & & & & \\
\hline Inverno & 22,8 & 23,8 & 23,8 & 7,5 & 6,9 \\
\hline Média & 1,6 & 0,9 & 0,9 & 0,5 & 0,4 \\
\hline Desvio Padrão & 27,0 & 26,0 & 26,0 & 8,5 & 7,7 \\
\hline Valor máximo & 21,0 & 23,0 & 23,0 & 7,1 & 6,6 \\
\hline Valor mínimo & & & & &
\end{tabular}


Tabela 6.4 - Temperaturas e $\mathrm{pH}$ registrados nos pontos de amostragem, na hora da coleta das amostras, na ETE Contorno.

\begin{tabular}{l|c|c|c|c|c}
\hline \multirow{2}{*}{$\begin{array}{l}\text { Parâmetros } \\
\text { Estações do ano }\end{array}$} & $\begin{array}{c}\text { Temperatura } \\
\text { Ambiente }\end{array}$ & \multicolumn{2}{|c|}{ Temperatura do esgoto } & \multicolumn{2}{c}{ pH do esgoto } \\
\cline { 3 - 6 } & & Afluente & Efluente & Afluente & Efluente \\
\hline Primavera & & & & & \\
\hline Média & 25,5 & 24,6 & 24,6 & 7,3 & 7,4 \\
\hline Desvio Padrão & 1,7 & 0,7 & 0,7 & 0,1 & 0,2 \\
\hline Valor máximo & 28,0 & 26,0 & 26,0 & 7,5 & 7,9 \\
\hline Valor mínimo & 23,0 & 24,0 & 24,0 & 7,2 & 7,3 \\
\hline Verão & & & & & \\
\hline Média & 27,3 & 26,0 & 26,0 & 7,1 & 7,3 \\
\hline Desvio Padrão & 1,7 & 1,4 & 1,4 & 0,3 & 0,2 \\
\hline Valor máximo & 29,0 & 28,0 & 28,0 & 7,7 & 7,5 \\
\hline Valor mínimo & 56,0 & 24,0 & 24,0 & 6,8 & 7,0 \\
\hline Outono & & & & & \\
\hline Média & 25,1 & 24,8 & 24,7 & 7,1 & 7,2 \\
\hline Desvio Padrão & 1,6 & 0,8 & 0,9 & 0,1 & 0,2 \\
\hline Valor máximo & 27,0 & 26,0 & 26,0 & 7,3 & 7,5 \\
\hline Valor mínimo & 23,0 & 24,0 & 23,0 & 6,9 & 6,9 \\
\hline Inverno & & & & & \\
\hline Média & 22,9 & 23,6 & 23,5 & 7,3 & 6,3 \\
\hline Desvio Padrão & 1,6 & 0,7 & 0,7 & 0,3 & 0,3 \\
\hline Valor máximo & 27,0 & 25,0 & 25,0 & 8,1 & 7,9 \\
\hline Valor mínimo & 21,0 & 23,0 & 23,0 & 7,0 & 7,0 \\
\hline
\end{tabular}

O pH encontra-se dentro do esperado para todas as ETEs e para as estações do ano. A ETE Homero Figueiredo está com pH médio efluente maior em relação ao afluente, as ETES Lagoa Grande e Viveiros-A estão com pH efluente menor que o afluente e, para a ETE Contorno, o pH efluente e afluente são, aproximadamente, iguais, não houve variação. Entretanto, em todas as ETEs o pH médio ficou muito próximo do neutro $(\mathrm{pH}=7)$.

Conforme Tabelas 6.1 a 6.4 verifica-se, também, que, para o esgoto afluente, o maior valor médio de $\mathrm{pH}$ foi 8,5 , registrado no inverno e ocorrido na estação Viveiros-A; o menor valor de $\mathrm{pH}$ foi 6,3 , registrado no outono e ocorrido nas estações Viveiros-A e Homero Figueiredo. Para o efluente, têm-se 8,4 como maior valor de pH na estação Homero Figueiredo, registrado no inverno e outono, e 6,6 como menor valor de $\mathrm{pH}$, na estação Viveiros-A e registrado no verão e no outono. 


\subsection{Comunidade e ETE Homero Figueiredo}

\subsubsection{Condição de saúde-doença da comunidade}

A comunidade Homero Figueiredo dispõe dos serviços de abastecimento de água e esgotamento sanitário desde a instalação do sistema em 1993, bem como de coleta de lixo e drenagem pluvial adequados e é constituída de pessoas com renda familiar média na faixa de 2 a $4 \mathrm{SM}$. Nos esgotos sanitários afluentes à ETE Homero Figueiredo, foram identificados helmintos e protozoários em todas as estações do ano.

Das amostras pesquisadas no afluente da ETE Homero Figueiredo foram encontrados os helmintos: Ascaris lumbricoides $7,7 \%$ na primavera e $25 \%$ no inverno; Strongyloides stercoralis $53,3 \%$ na primavera, $83,3 \%$ no verão, $91,7 \%$ no outono e $83,3 \%$ no inverno; Ancylostoma duodenali $46,2 \%$ na primavera, $16,7 \%$ no verão, $33,3 \%$ no outono e $41,7 \%$ no inverno. Quanto aos protozoários, foram encontrados: a Entamoeba histolytica $23,1 \%$ no inverno e $33,3 \%$ no verão, outono e inverno; a Entamoeba coli $69,2 \%$ na primavera, $50,0 \%$ no verão, $66,7 \%$ no outono e $50,0 \%$ no inverno; a Endolimax nana $15,4 \%$ na primavera, $16,7 \%$ no verão e outono e $58,3 \%$ no inverno; a Iodamoeba butschlii $30,8 \%$ na primavera, $50,0 \%$ no verão, $25,0 \%$ no outono e $16,7 \%$ no inverno e a Giárdia lamblia $23,1 \%$ na primavera, $50,0 \%$ no outono e $66,7 \%$ no inverno, conforme Tabela 6.5 .

Pelos resultados obtidos, conforme apresentado na Tabela 6.5, verifica-se que não foram encontrados os helmintos Enterobius vermicularis, Schistosoma mansoni, Hymenolepis nana, Hymenolepis diminuta e Taenia sp, em nenhuma amostra pesquisada e que para os parasitas presentes, de maneira geral, não se pode concluir que há maior ou menor incidência nesta ou naquela estação do ano.

Estes achados indicam que pessoas da comunidade são portadoras desses microrganismos parasitas do intestino, que podem ser provenientes muito provavelmente de portadores sãos, ou mesmo de pessoas doentes. Essas pessoas 
podem ser portadoras de microrganismos porque desconhecem suas condições de saúde ou porque não têm acesso aos serviços de saúde.

Tabela 6.5 Freqüência de amostras com presença de helmintos e protozoários no esgoto sanitário da Comunidade Homero Figueiredo medida no afluente à ETE.

\begin{tabular}{l|l}
\hline Microrganismo & Freqüência de amostra de esgoto encontrada com
\end{tabular} presença de helmintos e protozoários, do total pesquisado

\begin{tabular}{|c|c|c|c|c|}
\hline & Primavera & Verão & Outono & Inverno \\
\hline & $\%$ do total & $\%$ do total & $\%$ do total & $\%$ do total \\
\hline \multicolumn{5}{|l|}{ Helmintos } \\
\hline Ascaris lumbricoides & 7,7 & - & - & 25,0 \\
\hline Trycocephalus trichiurus & - & - & - & - \\
\hline Strongyloides stercolaris & 53,8 & 83,3 & 91,7 & 83,3 \\
\hline Ancylostoma duodenali & 46,2 & 16,7 & 33,3 & 41,7 \\
\hline Enterobius vermicularis & - & - & - & - \\
\hline Schistosoma mansoni & - & - & - & - \\
\hline Hymenolepis nana & - & - & - & - \\
\hline Hymenolepis diminuta & - & - & - & - \\
\hline Taenia sp. & - & - & - & - \\
\hline \multicolumn{5}{|l|}{ Protozoários } \\
\hline Entamoeba histolytica & 23,1 & 33,3 & 33,3 & 33,3 \\
\hline Entamoeba coli & 69,2 & 50,0 & 66,7 & 50,0 \\
\hline Endolimax nana & 15,4 & 16,7 & 16,7 & 58,3 \\
\hline Iodamoeba butschlii & 30,8 & 50,0 & 25,0 & 16,7 \\
\hline Dientamoeba fragilis & - & - & - & - \\
\hline Giárdia lamblia & 23,1 & - & 50,0 & 66,7 \\
\hline
\end{tabular}

6.2.2 Eficiência de remoção de helmintos e protozoários na ETE Homero Figueiredo

Nos resultados relacionados na Tabela 6.6, verifica-se que no efluente da ETE Homero Figueiredo, constituída de DAFAs em série com uma lagoa facultativa, só foram identificados o helminto Strongyloides stercolaris, no outono, com freqüência de $8,3 \%$ e o protozoário Entamoeba coli, na primavera, com freqüência de 7,7\%, em relação ao número de análises realizadas no periodo.

Pelos resultados obtidos, conforme apresentado na Tabela 6.6, verifica-se que de maneira geral, não se pode concluir que há maior ou menor incidência desses parasitos nesta ou naquela estação do ano. 
Para o tipo de montagem de ETE empregado no tratamento (tempo de detenção total de 269:12h), verifica-se que a eficiência se mostrou muito boa, entretanto, ainda passam helmintos e protozoários, Strongyloides stercolaris e a Entamoeba coli.respectivamente, logo, há riscos para a saúde dos usuários da água do corpo receptor a jusante do lançamento dos efluentes tratados nesta ETE.

Tabela 6.6 Freqüência de amostras com presença de helmintos e protozoários no efluente da ETE Homero Figueiredo.

\begin{tabular}{l|c|c|c|c}
\hline \multirow{2}{*}{ Microrganismo } & \multicolumn{4}{|c}{$\begin{array}{l}\text { Freqüência de amostra de esgoto encontrada com } \\
\text { presença de helmintos e protozoários, do total pesquisada }\end{array}$} \\
\cline { 2 - 5 } & Primavera & Verão & Outono & Inverno \\
\cline { 2 - 5 } & $\%$ do total & $\%$ do total & \% do total & $\%$ do total \\
\hline Helmintos & & & & \\
\hline Ascaris lumbricoides & - & - & - & - \\
\hline Trycocephalus trichiurus & - & - & - & - \\
\hline Strongyloides stercolaris & - & - & 8,3 & - \\
\hline Ancylostoma duodenali & - & - & - & - \\
\hline Enterobius vermicularis & - & - & - & - \\
\hline Schistosoma mansoni & - & - & - & - \\
\hline Hymenolepis nana & - & - & - & - \\
\hline Hymenolepis diminuta & - & - & - & - \\
\hline Taenia sp. & - & - & - & - \\
\hline Protozoários & & & & - \\
\hline Entamoeba histolytica & - & - & - & - \\
\hline Entamoeba coli & 7,7 & - & - & - \\
\hline Endolimax nana & - & - & - & - \\
\hline Iodamoeba butschlii & - & - & - & - \\
\hline Dientamoeba fragilis & - & - & - & - \\
\hline Giárdia lamblia & - & - & - & - \\
\hline
\end{tabular}

6.2.3 Eficiência de remoção de $\mathrm{DBO}_{5}$ e DQO na ETE Homero Figueiredo e adequação à Legislação e ao projeto.

Pela Tabela 6.7, verifica-se que o maior valor médio de $\mathrm{DBO}_{5}$ do esgoto afluente ocorreu no outono $(655,0 \mathrm{mg} / \mathrm{l})$ e o menor na primavera $(570,9 \mathrm{mg} / \mathrm{l})$ com remoção entre o afluente e efluente de $89,1 \%$ e $79,0 \%$ respectivamente. No verão, a remoção média de $\mathrm{DBO}_{5}$ foi de $82,2 \%$ e no inverno $83,9 \%$. Pelo tipo de sistema de tratamento empregado na montagem da ETE (DAFA em série com lagoa) esperava-se remoção da carga orgânica maior no verão e menor no inverno, devido à influência da luminosidade e temperatura. Entretanto, verifica-se que no verão ocorre maior 
produção de algas na lagoa e maior contribuição de águas pluviais no sistema de coleta e transporte dos esgotos em relação ao inverno. Estes fatores podem ter influenciado no resultado verificado. Entretanto, segundo MARA (1995) apud VON SPERLING (1996c), de 60 a 90\% dos sólidos em suspensão de lagoas facultativas são de algas e cada $1,0 \mathrm{mg}$ de alga gera aproximadamente $0,45 \mathrm{mg}$ de $\mathrm{DBO}_{5}$. Logo, para cada $1 \mathrm{mg} / \mathrm{l}$ de sólidos em suspensão, no efluente das lagoas facultativas, as algas são capazes de gerar de 0,3 a $0,4 \mathrm{mg} / \mathrm{l}$ de $\mathrm{DBO}_{5}$ e devido à incerteza quanto à abordagem citada é prática se desconsiderar a DBO das algas facultativas, ou dos sólidos em suspensão, no efluente de lagoas facultativas. Considerando o exposto, as algas não são as maiores responsáveis pelo resultado apresentado.

O valor mínimo de $\mathrm{DBO}_{5}$ afluente registrado ( $300 \mathrm{mg} / \mathrm{l}$ ) ocorreu no inverno, quando deveria ter sido na primavera e/ou verão em decorrência da diluição maior da matéria orgânica pelas águas pluviais. Este parâmetro $\left(\mathrm{DBO}_{5}\right.$ mínima) não se manteve com a mesma variação da $\mathrm{DBO}_{5}$ média, nas estações do ano, ou seja, para o menor valor médio, registro do menor valor mínimo, ou para o maior valor médio, registro do maior valor mínimo, houve certa incoerência dos resultados. O valor máximo de $\mathrm{DBO}_{5}$ registrado foi de $1100 \mathrm{mg} / \mathrm{l}$ em $\mathrm{OD}$, no outono, muito superior ao esperado. Para os valores máximos de $\mathrm{DBO}_{5}$ registrados nas estações do ano, verifica-se que seguem a mesma variação média da $\mathrm{DBO}_{5}$, ou seja, para o menor valor médio calculado registrou-se o menor valor máximo de $\mathrm{DBO}_{5}$ e para o maior valor médio calculado registrou-se o maior valor máximo de $\mathrm{DBO}_{5}$, havendo coerência dos resultados Tabela 6.7.

Para a primavera e verão, estações mais quentes do ano na região de Feira de Santana, foram registrados os menores valores médios de $\mathrm{DBO}_{5}$ e $\mathrm{DQO}$ e coincidem com o maior consumo de água, bem como períodos com ocorrência de chuvas torrenciais, aumentando a parcela de contribuição de esgoto pluvial, proporcionando maior diluição dos esgotos, conseqüentemente menor valor de $\mathrm{DBO}$, conforme apresentado na Tabela 6.7. 
Analisando-se a DQO (Tabela 6.7), verifica-se que o maior valor afluente ocorreu no outono (1383,3 mg/l) e o menor na primavera (1013,8 mg/l) com remoções de $72,8 \%$ e $51,5 \%$ respectivamente. Houve correspondência entre as variações médias de DQO com as variações médias de $\mathrm{DBO}_{5}$, (para as quatro estações). Quanto aos valores máximos de $\mathrm{DQO}$, verifica-se que seguem a mesma variação média da $\mathrm{DBO}_{5}$, entretanto, para os valores mínimos não se observa essa concordância.

Tabela 6.7 Valores médios de $\mathrm{DBO}_{5}$ e DQO encontrados no esgoto da ETE Homero Figueiredo.

\begin{tabular}{l|r|r|r|r|r|r|r|r}
\hline & Afluente & Efluente & Remoção & $\begin{array}{c}\text { Remoção } \\
\%\end{array}$ & Afluente & Efluente & Remoção & $\begin{array}{c}\text { Remoção } \\
\%\end{array}$ \\
\hline Primavera & & & & & & & & \\
\hline Média & 570,9 & 119,8 & 451,1 & 79,0 & 1013,8 & 491,3 & 522,5 & 51,5 \\
\hline Valor máximo & 760,0 & 180,0 & 625,0 & & 1345,0 & 981,0 & 909,0 & \\
\hline Valor mínimo & 360,0 & 55,0 & 230,0 & & 509,0 & 73,0 & 109,0 & \\
\hline Verão & & & & & & & & \\
\hline Média & 620,0 & 105,7 & 514,3 & 82,2 & 1231,4 & 469,6 & 761,9 & 62,1 \\
\hline Valor máximo & 860,0 & 190,0 & 810,0 & & 1555,0 & 711,0 & 978,0 & \\
\hline Valor mínimo & 500,0 & 50,0 & 375,0 & & 933,0 & 222,0 & 600,0 & \\
\hline Outono & & & & & & & & \\
\hline Média & 655,0 & 69,2 & 585,8 & 89,1 & 1383,3 & 376,2 & 1007,2 & 72,8 \\
\hline Valor máximo & 1100,0 & 240,0 & 1065,0 & & 2933,0 & 500,0 & 2489,0 & \\
\hline Valor mínimo & 360,0 & 20,0 & 305,0 & & 578,0 & 150,0 & 222,5 & \\
\hline Inverno & & & & & & & & \\
\hline Média & 630,0 & 103,8 & 526,3 & 83,9 & 1304,7 & 430,9 & 873,8 & 67,0 \\
\hline Valor máximo & 900,0 & 205,0 & 730,0 & & 1745,0 & 675,0 & 1236,0 & \\
\hline Valor mínimo & 300,0 & 15,0 & 285,0 & & 730,0 & 225,0 & 420,0 & \\
\hline
\end{tabular}

Pela Tabela 6.8, verifica-se que a razão $\mathrm{DQO} \mathrm{DBO}_{5}$ para a ETE Homero Figueiredo, obtida para a época do verão e inverno é da ordem de dois, para o outono, $5 \%$ superior a $2,0 \mathrm{e}$, para a primavera, $11 \%$ inferior a 2,0 . $\mathrm{O}$ valor esperado para esgoto bruto doméstico está na faixa de 1,7 a 2,4 (VON SPERLING 1996a). Entretanto, verifica-se que a segunda maior razão ocorreu no inverno, quando nessa época o esperado era o menor valor porque a decomposição verificada entre a coleta e a entrada à ETE, nesse período, é menor que para os demais.

Tabela 6.8 Razão da DQO / $\mathrm{DBO}_{5}$ afluente à ETE Homero Figueiredo

\begin{tabular}{c|c|c|c}
\hline Primavera & Verão & Outono & Inverno \\
\hline 1,78 & 1,99 & 2,11 & 2,07 \\
\hline
\end{tabular}


Segundo VON SPERLING (1996c), o valor da $\mathrm{DBO}_{5}$ para esgoto doméstico é da ordem de $300 \mathrm{mg} / \mathrm{l}$, calculado com base no valor per-capita de $180 \mathrm{l} / \mathrm{hab} / \mathrm{dia}$ e carga orgânica de $54 \mathrm{~g} / \mathrm{hab} /$ dia. Os valores médios encontrados $(570,9 \mathrm{mg} / \mathrm{l}$ na primavera, $620,0 \mathrm{mg} / \mathrm{l}$ no verão, $655,0 \mathrm{mg} / \mathrm{l}$, no outono e 630,0 no inverno) foram pouco inferiores ou superiores ao previsto em projeto $(588,85 \mathrm{mg} / \mathrm{l})$. A comunidade Homero Figueiredo é quase que totalmente residencial, com pequenos estabelecimentos comerciais que não são geradores de esgotos diferentes do doméstico, logo os valores médios de $\mathrm{DBO}_{5}$ encontrados para as estações do ano fogem a essa realidade. Entretanto, observa-se que o consumo de água praticado pela comunidade está ocorrendo em quantidade inferior à prevista em projeto, em decorrência do uso mais racional dado à água; que a carga orgânica no esgoto permanece a mesma: e que as amostras de esgotos foram coletadas no horário de maior atividade residencial. Estes fatos mostram que o valor médio da $\mathrm{DBO}_{5}$ aumenta em relação ao indicado na literatura. O valor per-capita de água praticado na comunidade foi da ordem de $70 \mathrm{l} / \mathrm{hab} / \mathrm{dia}$, estimado com base em dados reais de consumo, levantados nos registros dos clientes da EMBASA - Empresa Baiana de Águas e Saneamento S.A.

O projeto da ETE Homero Figueiredo previa remoção de $93,2 \%$ da $\mathrm{DBO}_{5}$, para uma população total de 9.790 habitantes. Entretanto, só foram implantados imóveis para uma população de 7.340 habitantes, logo a ETE encontra-se com $25 \%$ de folga em termos de capacidade de remoção da carga orgânica. A remoção da carga orgânica prevista em projeto não foi comprovada na prática, pois as eficiências médias do tratamento obtidas para a remoção de $\mathrm{DBO}_{5}$ para as vazões no entorno do pico, foram inferiores à prevista em projeto, para as quatro estações do ano. As possíveis causas para essa ocorrência são: construção das unidades de tratamento com dimensões inferiores às de projeto; parâmetros maiores que os reais utilizados no projeto; operação inadequada das unidades de tratamento; horário em que foram efetuadas as medições (de 08:00 a 10:00) não ser representativo da operação do sistema; e combinação inadequada das unidades para a remoção de carga orgânica. As dimensões das unidades do sistema de tratamento foram checadas e estão coerentes com as de projeto. Os parâmetros usados no projeto foram os 
recomendados na literatura e a operação segue o recomendado em projeto, estando fundamentada em análises físico-químicas, ou seja, são feitas limpezas da grade e caixa de areia sempre que necessário, e remoção do lodo digerido periodicamente, observando-se os limites mínimos e máximos de $0,25-1,0 \mathrm{ml} / \mathrm{l}$ de sólidos sedimentáveis no efluente. Como justificativa para os resultados operacionais apresentados restam: parâmetros recomendados pela literatura maiores que os reais para a região de Feira de Santana; tipos de unidades de remoção de carga orgânica e forma de combinação inadequada, alguma falha operacional não identificada e hora da medição da eficiência não representativa da média diária da operação.

A remoção média de carga orgânica no outono, inverno e verão medida por meio da $\mathrm{DBO}_{5}$ foi superior ao estabelecido na NT002 da Resolução 2288 (CEPRAM 2000) que limita ao mínimo de $80 \%$ do valor da $\mathrm{DBO}_{5}$ de entrada, para o tipo de ETE que atende a construções residenciais populares, caracteristicas desse bairro. Entretanto, o valor médio de remoção para o período da primavera foi ligeiramente inferior ao limite mínimo estabelecido.

\subsubsection{Eficiência de remoção de coliformes na ETE Homero Figueiredo e adequação à Legislação}

$\mathrm{Na}$ Tabela 6.9, verificam-se que os coliformes totais afluentes e efluentes no outono, em média, foram os menores valores registrados, ou seja, $2,2 \times 10^{7} \mathrm{NMP} / 100 \mathrm{ml} \mathrm{e}$ $1,7 \times 10^{6} \mathrm{NMP} / 100 \mathrm{ml}$, respectivamente, com eficiência de remoção de 92,3\%, menor media registrada em relação às demais estações. Na primavera, registram-se os maiores valores médios $1,9 \times 10^{8} \mathrm{NMP} / 100 \mathrm{ml}$ e $7,8 \times 10^{6} \mathrm{NMP} / 100 \mathrm{ml}$ para afluente e efluente da ETE, respectivamente, com eficiência de remoção de $95,9 \%$. Entretanto, a maior porcentagem média de remoção de coliformes totais ocorreu no verão, com $98,3 \%$. Os valores de remoção de coliformes totais foram superiores a $90 \%$, para as quatro estações do ano. Houve correspondência entre os valores registrados do afluente com o efluente, para as quatro estações do ano, ou seja, maior valor médio de coliformes totais afluentes com maior valor médio de coliformes totais efluentes, menor valor de coliformes totais afluentes com menor valor de coliformes totais efluentes, coerência dos resultados. 
Quanto aos coliformes fecais, Tabela 6.9, verifica-se que os menores valores médios registrados para o afluente e efluente da ETE ocorreram no outono, correspondendo a $1,8 \times 10^{7} \mathrm{NMP} / 100 \mathrm{ml}$ e $5,2 \times 10^{5} \mathrm{NMP} / 100 \mathrm{ml}$, respectivamente, com $97,1 \% \mathrm{de}$ eficiência de remoção. Os maiores valores médios registrados de coliformes fecais

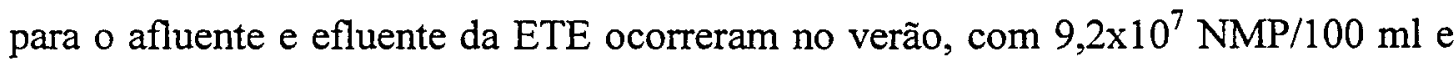
$6,6 \times 10^{5} \mathrm{NMP} / 100 \mathrm{ml}$, respectivamente, representando $99,3 \%$ de eficiência de remoção, que corresponde ao maior valor médio encontrado para as estações do ano. Não se manteve proporcionalidade entre os valores médios de coliformes fecais encontrados para o afluente em relação ao efluente, nas quatro estações do ano, bem como não houve proporcionalidade entre coliformes fecais e totais afluentes.

Também não houve proporcionalidade entre os valores máximos registrados para coliformes fecais na entrada e saída da ETE, o mesmo ocorrendo para os valores mínimos, nas quatro estações do ano.

Tabela 6.9 Valores de Coliformes Totais e Fecais encontrados na ETE Homero Figueiredo.

\begin{tabular}{l|r|r|r|r|r|r|r|r}
\hline \multirow{2}{*}{ PARÁMETROS } & \multicolumn{3}{|c|}{ Coliformes Totais NMP/100ml } & \multicolumn{3}{c}{ Coliformes Fecais NMP/100ml } \\
\cline { 2 - 10 } & Afluente & Efluente & Remoção & $\begin{array}{c}\text { Remoção } \\
\%\end{array}$ & Afluente & Efluente & Remoção & $\begin{array}{c}\text { Remoção } \\
\%\end{array}$ \\
\hline Primavera & & & & & & & & \\
\hline Média & $1,9 \times 10^{8}$ & $7,8 \times 10^{6}$ & $1,8 \times 10^{8}$ & 95,9 & $4,2 \times 10^{7}$ & $2,4 \times 10^{6}$ & $4,1 \times 10^{7}$ & 98,4 \\
\hline Valor máximo & $2,3 \times 10^{8}$ & $2,3 \times 10^{7}$ & $2,3 \times 10^{8}$ & & $9,2 \times 10^{7}$ & $1,2 \times 10^{7}$ & $9,1 \times 10^{7}$ & \\
\hline Valor mínimo & $2,3 \times 10^{7}$ & $1,1 \times 10^{6}$ & $2,1 \times 10^{7}$ & & $1,1 \times 10^{7}$ & $9,2 \times 10^{5}$ & $9,9 \times 10^{6}$ & \\
\hline Verão & & & & & & & & \\
\hline Média & $1,3 \times 10^{8}$ & $2,1 \times 10^{6}$ & $4,9 \times 10^{7}$ & 98,3 & $9,2 \times 10^{7}$ & $6,6 \times 10^{5}$ & $9,1 \times 10^{7}$ & 99,3 \\
\hline Valor máximo & $2,3 \times 10^{8}$ & $5,1 \times 10^{6}$ & $2,3 \times 10^{8}$ & & $1,6 \times 10^{8}$ & $1,1 \times 10^{6}$ & $1,6 \times 10^{8}$ & \\
\hline Valor mínimo & $2,3 \times 10^{7}$ & $1,1 \times 10^{6}$ & $2,1 \times 10^{7}$ & & $2,3 \times 10^{7}$ & $2,2 \times 10^{5}$ & $2,3 \times 10^{7}$ & \\
\hline Outono & & & & & & & & \\
\hline Média & $2,2 \times 10^{7}$ & $1,7 \times 10^{6}$ & $2,0 \times 10^{7}$ & 92,3 & $1,8 \times 10^{7}$ & $5,2 \times 10^{5}$ & $1,7 \times 10^{7}$ & 97,1 \\
\hline Valor máximo & $2,3 \times 10^{7}$ & $5,1 \times 10^{6}$ & $2,3 \times 10^{7}$ & & $2,3 \times 10^{7}$ & $1,6 \times 10^{6}$ & $2,3 \times 10^{7}$ & \\
\hline Valor mínimo & $1,2 \times 10^{7}$ & $2,2 \times 10^{5}$ & $6,9 \times 10^{6}$ & & $5,1 \times 10^{6}$ & $1,1 \times 10^{5}$ & $5,0 \times 10^{6}$ & \\
\hline Inverno & & & & & & & &. \\
\hline Média & $4,4 \times 10^{7}$ & $1,8 \times 10^{6}$ & $4,2 \times 10^{7}$ & 95,8 & $1,8 \times 10^{7}$ & $1,1 \times 10^{6}$ & $1,6 \times 10^{7}$ & 94,0 \\
\hline Valor máximo & $2,3 \times 10^{8}$ & $3,6 \times 10^{6}$ & $2,3 \times 10^{8}$ & & $2,3 \times 10^{7}$ & $2,3 \times 10^{6}$ & $2,3 \times 10^{7}$ & \\
\hline Valor mínimo & $2,3 \times 10^{7}$ & $1,1 \times 10^{5}$ & $2,1 \times 10^{7}$ & & $6,9 \times 10^{6}$ & $1,1 \times 10^{5}$ & $4,6 \times 10^{6}$ & \\
\hline
\end{tabular}

Os resultados médios de remoção de coliformes fecais registrados atendem ou superam o valor mínimo estabelecido na NT002 da Resolução 2288 (CEPRAM 
2000), ou seja, reduzir de $10^{7}$ para $10^{6}$. Entretanto, se não ocorrer diluição adequada no corpo receptor, essa redução não é suficiente para garantir qualidade à água para consumo humano, mesmo com tratamento. Inclusive, não removendo coliformes, outros microrganismo patogênicos podem estar presentes nesses efluentes.

Para garantir a qualidade da água do corpo receptor do efluente da ETE Homero Figueiredo como de Classe 2, conforme preconizado pela Resolução $\mathrm{n}^{\circ} 20$ (CONAMA 1986), ou seja, reduzir o número de coliformes fecais para valor igual ou inferior a 1.000 NMP/100 ml, faz-se necessário que a vazão média do corpo receptor seja 2400 vezes superior à vazão média desse efluente, caso não haja qualquer poluição a montante, sendo que a água com este valor de coliformes fecais só pode ser utilizada sem tratamento prévio para usos bem específicos. Para consumo humano, faz-se necessário tratamento completo. Como a vazão do riacho receptor dos esgotos da ETE Homero Figueiredo é da ordem de cinco vezes a vazão efluente da ETE, no período de maior vazão, logo este corpo receptor torna-se impróprio para qualquer dos usos mais nobres, principalmente, para consumo humano.

\subsection{Comunidade e ETE Lagoa Grande}

\subsubsection{Condição de saúde doença da comunidade}

A comunidade Lagoa Grande dispõe dos serviços de abastecimento de água e esgotamento sanitário desde a instalação do sistema em 1991, coleta de lixo e drenagem pluvial adequadas e é constituída de pessoas com renda familiar na faixa de 5 a 12 salários mínimos. Nos esgotos sanitários afluentes à planta de tratamento dessa comunidade, foram identificados helmintos e protozoários em todas as estações do ano.

Pela Tabela 6.10 verifica-se que houve presença, em todas as estações do ano, dos helmintos Strongyloides stercoralis (freqüências de $69,2 \%$ na primavera, $83,3 \%$ no verão, $91,7 \%$ no outono, $100 \%$ no inverno) e Ancylostoma duodenali (freqüências $100 \%$ na primavera, $83,3 \%$ no verão, $66,7 \%$ no outono, $58,3 \%$ no inverno); prevalência, em algumas estações do ano, do Ascaris lumbricoides (freqüências de 
15,4\% na primavera, $16,7 \%$ no verão, $8,3 \%$ no inverno); e Trycocephalus trichiurus (freqüências de $7,7 \%$ na primavera, $8,3 \%$ no outono). Quanto aos protozoários, verifica-se que, em todas as estações do ano, houve presença da Entamoeba histolytica (freqüências de $7,7 \%$ na primavera, $33,3 \%$ no verão, $25,0 \%$ no outono e $33,3 \%$ no inverno); Entamoeba coli (freqüências de $38,5 \%$ na primavera, $66,7 \%$ no verão, $58,3 \%$ no outono, $75,0 \%$ no inverno); Endolimax nana (freqüências de $7,7 \%$ na primavera, $33,3 \%$ no verão, $33,3 \%$ no outono, $16,7 \%$ no inverno); Iodamoeba butschlii (freqüências de $23,1 \%$ na primavera, sem registro no verão, $16,7 \%$ no outono, 41,7\% no inverno); e Giárdia lamblia (freqüências de 53,8\% na primavera, $33,3 \%$ no verão, $8,3 \%$ outono, $25,0 \%$ no inverno). Os helmintos Enterobius vermicularis, Schistosoma mansoni, Hymenolepis nana, Hymenolepis diminuta e a Taenia sp. bem como o protozoário Dientamoeba fragilis não foram identificados em nenhuma amostra examinada durante todo o ano.

Tabela 6.10 Freqüência de amostras com presença de helmintos e protozoários no esgoto sanitário da Comunidade Lagoa Grande medida no afluente à ETE.

\begin{tabular}{|c|c|c|c|c|}
\hline \multirow[t]{3}{*}{ Microrganismo } & \multicolumn{4}{|c|}{ Freqüência encontrada no afluente do esgoto a ETE } \\
\hline & Primavera & Verão & Outono & Inverno \\
\hline & $\%$ do total & $\%$ do total & $\%$ do total & $\%$ do total \\
\hline \multicolumn{5}{|l|}{ Helmintos } \\
\hline Ascaris lumbricoides & 15,4 & 16,7 & - & 8,3 \\
\hline Trycocephalus trichiurus & 7,7 & - & 8,3 & - \\
\hline Strongyloides stercolaris & 69,2 & 83,3 & 91,7 & 100 \\
\hline Ancylostoma duodenali & 100 & 83,3 & 66,7 & 58,3 \\
\hline Enterobius vermicularis & - & - & - & - \\
\hline Schistosoma mansoni & - & - & - & - \\
\hline Hymenolepis nana & - & - & - & - \\
\hline Hymenolepis diminuta & - & - & - & - \\
\hline Taenia sp. & - & - & - & - \\
\hline \multicolumn{5}{|l|}{ Protozoários } \\
\hline Entamoeba histolytica & 7,7 & 33,3 & 25,0 & 33,3 \\
\hline Entamoeba coli & 38,5 & 66,7 & 58,3 & 75,0 \\
\hline Endolimax nana & 7,7 & 33,3 & 33,3 & 16,7 \\
\hline Iodamoeba butschlii & 23,1 & - & 16,7 & 41,7 \\
\hline Dientamoeba fragilis & - & - & - & - \\
\hline Giárdia lamblia & 53,8 & 33,3 & 8,3 & 25,0 \\
\hline
\end{tabular}

Estes achados indicam que pessoas da comunidade são portadoras desses microrganismos parasitas do intestino, provenientes muito provavelmente de 
portadores sãos ou, mesmo, de pessoas doentes. Essas pessoas podem ser portadoras de microrganismo porque desconhecem suas condições de saúde ou porque não têm acesso aos serviços de saúde.

Pelos resultados obtidos, conforme apresentado na Tabela 6.10, verifica-se que, de maneira geral, não se pode concluir que há maior ou menor incidência de helmintos ou protozoários nesta ou naquela estação do ano. Entretanto, considerando-se um microorganismo específico, há tendência de crescimento em freqüência da primavera para o inverno, para o caso do Strongyloides stercolaris, enquanto a freqüência do Ancylostoma duodenali decresce da primavera para o inverno.

\subsubsection{Eficiência da remoção de helmintos e protozoários na ETE Lagoa Grande}

Nos resultados relacionados na Tabela 6.11, verifica-se que nas amostras analisadas do efluente da estação de tratamento de esgoto sanitário Lagoa Grande, constituída por DAFAs em série, foram identificados presença dos helmintos Ascaris lumbricoides (freqüência $23,1 \%$ na primavera, $16,7 \%$ no verão), Strongyloides stercolaris (freqüências de $53,8 \%$ na primavera, $50 \%$ no verão, $100 \%$ no outono, $83,3 \%$ no inverno), Ancylostoma duodenali (freqüências de $30,8 \%$ na primavera, $33,3 \%$ no verão, $16,7 \%$ na primavera, $25,0 \%$ no inverno) Enterobius vermicularis (freqüências de 7,7\% na primavera), Schistosoma mansoni (freqüência de $8,3 \%$ no inverno), Hymenolepis nana (freqüência $15,4 \%$ na primavera).

Quanto aos protozoários, foram identificados no efluente da ETE (Tabela 6.11) Entamoeba histolytica (freqüência de $23,1 \%$ na primavera), Entamoeba coli (freqüências de $53,8 \%$ na primavera, $50 \%$ no verão, $58,3 \%$ no outono, $66,7 \%$ no inverno), Endolimax nana (freqüências de 7,7\% na primavera, 16,7 \% no verão, $50,0 \%$ no outono, $66,7 \%$ no inverno), Iodamoeba butschlii (freqüências de $7,7 \%$ na primavera, $8,3 \%$ no outono, $8,3 \%$ no inverno), e Giárdia lamblia (freqüências de $7,7 \%$ na primavera, $23,3 \%$ no verão, $25 \%$ no outono e inverno).

Estes resultados mostram que uma ETE constituída de digestores anaeróbios em série não é eficiente para remoção de helmintos e protozoários. Estes microrganismos passam pelo sistema de tratamento e chegam ao corpo receptor, logo, há riscos para a 
saúde dos usuários das águas desse corpo receptor a jusante do lançamento dos efluentes.

Tabela 6.11 Freqüência de amostras com presença de helmintos e protozoários no esgoto efluente da ETE Lagoa Grande.

\begin{tabular}{|c|c|c|c|c|}
\hline \multirow[t]{3}{*}{ Microrganismo } & \multicolumn{4}{|c|}{ Freqüência encontrada no efluente do esgoto a ETE } \\
\hline & Primavera & Verão & Outono & Inverno \\
\hline & $\%$ do total & $\%$ do total & $\%$ do total & $\%$ do total \\
\hline \multicolumn{5}{|l|}{ Helmintos } \\
\hline Ascaris lumbricoides & 23,1 & 16,7 & - & - \\
\hline Trycocephalus trichiurus & 7,7 & - & 8,3 & - \\
\hline Strongyloides stercolaris & 53,8 & 50,0 & 100 & 83,3 \\
\hline Ancylostoma duodenali & 30,8 & 33,3 & 16,7 & 25,0 \\
\hline Enterobius vermicularis & 7,7 & - & - & - \\
\hline Schistosoma mansoni. & - & - & $=$ & 8,3 \\
\hline Hymenolepis nana & 15,4 & - & - & - \\
\hline Hymenolepis diminuta & - & - & - & - \\
\hline Taenia sp. & - & - & - & - \\
\hline \multicolumn{5}{|l|}{ Protozoários } \\
\hline Entamoeba histolytica & 23,1 & - & - & - \\
\hline Entamoeba coli & 53,8 & 50,0 & 58,3 & 66,7 \\
\hline Endolimax nana & 7,7 & 16,7 & 50,0 & 66,7 \\
\hline Iodamoeba butschlii & 7,7 & - & 8,3 & 8,3 \\
\hline Dientamoeba fragilis & 7,7 & 23,3 & 25,0 & 25,0 \\
\hline Giárdia lamblia & 53,8 & 33,3 & 8,3 & 25,0 \\
\hline
\end{tabular}

6.3.3 Eficiência de remoção de $\mathrm{DBO}_{5}$ e DQO na ETE Lagoa Grande e adequação à Legislação e ao projeto

Pela Tabela 6.12, verifica-se que o maior valor médio da carga orgânica afluente à ETE Lagoa Grande ocorreu no inverno (628,3 mg de $\left.\mathrm{DBO}_{5} / \mathrm{l}\right)$ e o correspondente valor médio do efluente foi de $152,9 \mathrm{mg}$ de $\mathrm{DBO}_{5} / \mathrm{l}$, com eficiência de remoção média da carga orgânica de $75,7 \%$. O menor valor médio da carga orgânica afluente ocorreu na primavera $\left(526,9 \mathrm{mg}\right.$ de $\left.\mathrm{DBO}_{5} / \mathrm{l}\right)$ com efluente de $121,9 \mathrm{mg}$ de $\mathrm{DBO}_{5} / \mathrm{l}$, conseqüentemente, $76,9 \%$ de eficiência de remoção da carga orgânica.

O valor máximo de $\mathrm{DBO}_{5}$ registrado corresponde a $820 \mathrm{mg} / \mathrm{l}$ em $\mathrm{OD}$, ocorrido no inverno, contra o valor mínimo de $320 \mathrm{mg} / \mathrm{l} \mathrm{em} \mathrm{OD,} \mathrm{também} \mathrm{registrado} \mathrm{no} \mathrm{inverno.}$ O valor minimo observado não está coerente com o esperado, pois, no inverno, o consumo de água é menor com conseqüente menor diluição, portanto, concentração 
maior da $\mathrm{DBO}_{5}$. Para o caso de Feira de Santana o esperado é o registro do menor valor de $\mathrm{DBO}_{5}$ na primavera ou no verão.

Os valores médios de $\mathrm{DBO}_{5}$ apresentados na Tabela $7.12(526,9 \mathrm{mg} / 1$ na primavera, $577,1 \mathrm{mg} / \mathrm{l}$ no verão, $615,0 \mathrm{mg} / \mathrm{l}$ no outono e $628,3 \mathrm{mg} / 1$ no inverno) estão acima do valor estimado em projeto $415,8 \mathrm{mg}$ de $\mathrm{DBO}_{5} / \mathrm{l}$. Estes valores superiores ao previsto em projeto decorrem do consumo menor de água em relação ao esperado. A demanda média diária de água registrada é da ordem de 90 1/hab/dia. Quanto à eficiência de remoção da carga orgânica, verifica-se que as médias registradas para as estações do ano ( $76,9 \%$ na primavera, $74,9 \%$ no verão, $71,6 \%$ no outono e $75,7 \%$ no inverno) foram inferiores à prevista em projeto, que é de $91 \%$.

Tabela 6.12 Valores médios de $\mathrm{DBO}_{5}$ e DQO encontrados no esgoto da ETE Lagoa Grande

\begin{tabular}{l|r|r|r|r|r|r|r|r}
\hline & PARÁMETROS & \multicolumn{3}{|c|}{ DBO5, $(\mathrm{mg} / \mathrm{l})$} & \multicolumn{4}{c}{ DQO (mg/l) } \\
\hline Primavera & & & & & & & \\
\hline \\
\hline Média & 526,9 & 121,9 & 405,0 & 76,9 & 1181,0 & 406,7 & 774,3 & 65,7 \\
\hline Valor máximo & 740,0 & 195,0 & 660,0 & & 2181,0 & 1236,0 & 2036,0 & \\
\hline Valor mínimo & 380,0 & 55,0 & 245,0 & & 436,0 & 109,0 & 327,0 & \\
\hline Verão & & & & & & & & \\
\hline Média & 577,1 & 145,0 & 432,1 & 74,9 & 1167,9 & 507,8 & 660,0 & 56,5 \\
\hline Valor máximo & 700,0 & 160,0 & 565,0 & & 1333,0 & 689,0 & 733,0 & \\
\hline Valor mínimo & 520,0 & 135,0 & 360,0 & & 978,0 & 333,0 & 555,2 & \\
\hline Outono & & & & & & & & \\
\hline MÉDIA & 615,0 & 174,6 & 440,4 & 71,6 & 1360,0 & 512,0 & 848,0 & 62,4 \\
\hline Valor máximo & 720,0 & 300,0 & 545,0 & & 2044,0 & 911,0 & 1533,0 & \\
\hline Valor mínimo & 460,0 & 140,0 & 315,0 & & 1022,0 & 244,0 & 378,0 & \\
\hline Inverno & & & & & & & & \\
\hline Média & 628,3 & 152,9 & 475,4 & 75,7 & 1138,9 & 390,5 & 748,4 & 65,7 \\
\hline Valor máximo & 820,0 & 205,0 & 650,0 & & 1700,0 & 650,0 & 1175,0 & \\
\hline Valor mínimo & 320,0 & 15,0 & 305,0 & & 581,0 & 181,0 & 334,0 & \\
\hline
\end{tabular}

Analisando-se a DQO afluente à ETE Lagoa Grande, conforme apresentado na Tabela 6.12, verifica-se que o maior valor médio afluente ocorreu no outono ( 1360,0 $\mathrm{mg} / \mathrm{l}$ ) e o menor valor médio foi $1138,9 \mathrm{mg} / \mathrm{l}$ em OD, na primavera, com remoção de $62,4 \%$ e $65,7 \%$ respectivamente. Houve correspondência entre a média de DQO e a média de $\mathrm{DBO}_{5}$, no verão. Para as demais estações do ano, não se verificou a 
correspondência, ou seja, o menor valor registrado de DQO ocorreu no inverno para nada menos que o maior valor médio de $\mathrm{DBO}_{5}$, o segundo maior valor médio de $\mathrm{DQO}$ ocorreu na primavera, justamente com o menor (quarto) valor médio de $\mathrm{DBO}_{5}$.

Quanto à razão entre $\mathrm{DQO}$ e $\mathrm{DBO}_{5}$ afluente, conforme Tabela 6.13, verifica-se que é da ordem de $11 \%$ superior a dois para a primavera e outono, igual a 2,0 no verão, e $10 \%$ menor que 2,0 no inverno. Tais valores obtidos encontram-se na faixa esperada para esgoto doméstico bruto, que segundo VON SPERLING (1996a) deve estar na faixa de 1,7 a 2,4 . O valor menor para o inverno é coerente, visto que no inverno a temperatura média cai e a decomposição da matéria orgânica, possível de ocorrer na rede, é menor que para as outras estações do ano.

Tabela 6.13 Razão entre $\mathrm{DQO}$ e $\mathrm{DBO}_{5}$ encontrada no afluente à ETE Lagoa Grande

\begin{tabular}{c|c|c|c}
\hline Primavera & Verão & Outono & Inverno \\
\hline 2,24 & 2,02 & 2,21 & 1,81 \\
\hline
\end{tabular}

Segundo VON SPERLING (1996c) o valor da $\mathrm{DBO}_{5}$ para esgoto doméstico é da ordem de $300 \mathrm{mg} / \mathrm{l}$, calculado com base no valor per-capita de $180 \mathrm{l} / \mathrm{hab} / \mathrm{dia}$. Os valores médios encontrados $(526,9 \mathrm{mg} / 1$ na primavera, $577,1 \mathrm{mg} / 1$ no verão, 615,0 $\mathrm{mg} / \mathrm{l}$ no outono e 628,3 no inverno) foram superiores aos previstos em projeto $(415,77 \mathrm{mg} / \mathrm{l})$. A comunidade Lagoa Grande é totalmente residencial e os valores médios de $\mathrm{DBO}_{5}$ encontrados para as estações do ano fogem a essa realidade. Entretanto, observa-se que o consumo de água praticado pela comunidade está ocorrendo em quantidade inferior à prevista em projeto, em decorrência do seu uso mais racional. O valor per-capita de água praticado na comunidade é da ordem de 90 1/hab/dia, estimado com base em dados reais de consumo, levantados nos registros dos clientes da EMBASA - Empresa Baiana de Águas e Saneamento S.A.

Considerando-se que não houve variação da quantidade de pessoas para a comunidade em relação à prevista em projeto, que a carga orgânica diária afluente à ETE permanece aproximadamente a mesma do projeto, independente do consumo de água, e que as amostras de esgotos foram coletadas no horário de maior atividade residencial conclui-se que o valor médio da $\mathrm{DBO}_{5}$ é maior em relação ao indicado na literatura. 
O projeto da ETE Lagoa Grande previa uma eficiência de remoção da $\mathrm{DBO}_{5}$ de $91,0 \%$, para uma população total de 3.200 habitantes. Como foram implantados e ocupados todos os imóveis previstos nessa comunidade, a ETE encontra-se operando com a capacidade de projeto. Entretanto a eficiência esperada não é comprovada na prática, ou seja, a eficiência verificada é inferior à prevista em projeto, conforme verificado para as quatro estações do ano. As possíveis causas desse evento são: construção das unidades de tratamento com dimensões inferiores às de projeto; operação inadequada das unidades de tratamento de esgoto; parâmetros maiores que os reais utilizados no projeto; horário em que foram efetuadas as coletas (de 08:00 a 10:00) não ser representativo do dia e operação do sistema. Entretanto, as dimensões das unidades foram checadas e estão coerentes com as de projeto; os parâmetros usados no projeto foram os recomendados na literatura; a operação segue o recomendado em projeto e o fundamentado em análises fisico-químicas, incluindo-se limpeza da grade e caixa de areia sempre que necessário e remoção do lodo digerido periodicamente, observando os limites mínimos e máximos de $0,25-1,0 \mathrm{ml} / \mathrm{l} \mathrm{de}$ sólidos sedimentáveis no efluente. Como possíveis justificativas para os resultados operacionais apresentados restam: parâmetros recomendados pela literatura maiores que os reais para a região de Feira de Santana; tipos de unidades de remoção da carga orgânica e forma de combinação dessas unidades, inadequadas; alguma falha operacional não identificada e horários das medições não representativo da média diária da operação.

Os valores médios de remoção da $\mathrm{DBO}_{5}$, para as quatro estações do ano, foram inferiores ao valor mínimo estabelecido na Resolução 2288 (CEPRAM 2000), que define o limite mínimo de eficiência de remoção em $80 \%$ para o tipo de empreendimento (residencial popular). A eficiência de remoção da carga orgânica verificada na ETE Lagoa Grande, em relação ao limite minimo estabelecido na referida Resolução, foi de $93,5 \%$. 


\subsubsection{Eficiência de remoção de coliformes na ETE Lagoa Grande e adequação à}

\section{Legislação}

$\mathrm{Na}$ Tabela 6.14, verifica-se que, em média, o maior valor de coliformes totais afluentes à ETE Lagoa Grande ocorreu na primavera e equivale a 2,0 x $10^{8} \mathrm{NMP} / 100$ ml. Para a mesma estação do ano os coliformes efluentes correspondem a $1,7 \times 10^{7}$ $\mathrm{NMP} / 100 \mathrm{ml}$, com eficiência de remoção de $90,8 \%$. O menor valor afluente foi $1,4 \mathrm{x}$ $10^{8} \mathrm{NMP} / 100 \mathrm{ml}$, no verão, com $2,0 \times 10^{7} \mathrm{NMP} / 100 \mathrm{ml}$ para o efluente, com $85,6 \%$ de eficiência de remoção, menor valor de eficiência encontrado.

Quanto aos coliformes fecais, conforme apresentado na Tabela 6.14, verifica-se que - maior valor médio afluente à ETE Lagoa Grande ocorreu no inverno, correspondendo a $1,0 \times 10^{8} \mathrm{NMP} / 100 \mathrm{ml}$, tendo para o efluente $9,1 \times 10^{6} \mathrm{NMP} / 100$ $\mathrm{ml}$ com eficiência de remoção de $90,1 \%$. O menor valor médio afluente foi registrado no verão, correspondendo a $2,6 \times 10^{7} \mathrm{NMP} / 100 \mathrm{ml}$, tendo para o efluente de $8,1 \mathrm{x}$ $10^{6} \mathrm{NMP} / 100 \mathrm{ml}$, com eficiência de remoção de $67,5 \%$, menor valor médio registrado de eficiência de remoção de coliformes fecais. O maior valor médio de eficiência de remoção de coliformes fecais foi $90,8 \%$, registrado na primavera.

Tabela 6.14 Valores de coliformes totais e fecais encontrados na ETE Lagoa Grande.

\begin{tabular}{|c|c|c|c|c|c|c|c|c|}
\hline \multirow[t]{2}{*}{ PARAMETROS } & \multicolumn{4}{|c|}{ Coliformes Totais NMP $/ 100 \mathrm{ml}$} & \multicolumn{4}{|c|}{ Coliformes Fecais NMP/100ml } \\
\hline & Afluente & Efluente & Remoção & $\begin{array}{c}\text { Remoção } \\
\%\end{array}$ & Afluente & Efluente & Remoção & $\begin{array}{c}\text { Remção } \\
\%\end{array}$ \\
\hline \multicolumn{9}{|l|}{ Primavera } \\
\hline Média & $2,0 \times 10^{8}$ & $1,7 \times 10^{7}$ & $1,8 \times 10^{8}$ & 91,2 & $5,4 \times 10^{7}$ & $4,9 \times 10^{6}$ & $4,9 \times 10^{7}$ & 90,8 \\
\hline Valor máximo & $2,3 \times 10^{8}$ & $2,3 \times 10^{7}$ & $2,2 \times 10^{8}$ & & $2,3 \times 10^{8}$ & $9,2 \times 10^{6}$ & $2,3 \times 10^{8}$ & \\
\hline Valor mínimo & $2,3 \times 10^{7}$ & $2,3 \times 10^{6}$ & $0,0 \times 10^{0}$ & & $9,2 \times 10^{6}$ & $1,1 \times 10^{6}$ & $1,8 \times 10^{6}$ & \\
\hline \multicolumn{9}{|l|}{ Verão } \\
\hline Média & $1,4 \times 10^{8}$ & $2,0 \times 10^{7}$ & $1,2 \times 10^{8}$ & 85,6 & $2,6 \times 10^{7}$ & $8,1 \times 10^{6}$ & $1,7 \times 10^{7}$ & 67,5 \\
\hline Valor máximo & $2,3 \times 10^{8}$ & $2,3 \times 10^{7}$ & $2,2 \times 10^{8}$ & & $5,1 \times 10^{7}$ & $1,2 \times 10^{7}$ & $4,7 \times 10^{7}$ & \\
\hline Valor minimo & $3,6 \times 10^{7}$ & $1,2 \times 10^{7}$ & $1,3 \times 10^{7}$ & & $1,1 \times 10^{7}$ & $3,6 \times 10^{6}$ & $0,0 \times 10^{\circ}$ & \\
\hline \multicolumn{9}{|l|}{ Outono } \\
\hline Média & $1,8 \times 10^{8}$ & $2,1 \times 10^{7}$ & $1,6 \times 10^{8}$ & $\overline{88,6}$ & $2,9 \times 10^{7}$ & $8,8 \times 10^{6}$ & $2,1 \times 10^{7}$ & $\overline{69,2}$ \\
\hline Valor máximo & $2,3 \times 10^{8}$ & $2,3 \times 10^{7}$ & $2,1 \times 10^{8}$ & & $6,9 \times 10^{7}$ & $1,6 \times 10^{7}$ & $6,2 \times 10^{7}$ & \\
\hline Valor mínimo & $1,1 \times 10^{7}$ & $9,2 \times 10^{6}$ & $1,8 \times 10^{6}$ & & $1,1 \times 10^{7}$ & $5,1 \times 10^{6}$ & $4,1 \times 10^{6}$ & \\
\hline \multicolumn{9}{|l|}{ Inverno } \\
\hline Média & $1,5 \times 10^{8}$ & $1,8 \times 10^{7}$ & $1,4 \times 10^{8}$ & 88,5 & $1,0 \times 10^{8}$ & $9,1 \times 10^{6}$ & $9,2 \times 10^{7}$ & 90,1 \\
\hline Valor máximo & $2,3 \times 10^{8}$ & $2,3 \times 10^{7}$ & $2,1 \times 10^{8}$ & & $2,3 \times 10^{8}$ & $2,3 \times 10^{7}$ & $2,2 \times 10^{8}$ & \\
\hline Valor mínimo & $2,3 \times 10^{7}$ & $2,3 \times 10^{6}$ & $2,1 \times 10^{7}$ & & $1,1 \times 10^{7}$ & $2,2 \times 10^{6}$ & $8,8 \times 10^{6}$ & \\
\hline
\end{tabular}


Os resultados de remoção de coliformes fecais equivalem ao valor mínimo estabelecido na NT002 da Resolução 2288 (CEPRAM 2000), ou seja, baixar de $10^{7}$ para $10^{6}$. Entretanto, essa redução é insuficiente para garantir a qualidade da água do corpo receptor para consumo humano se não houver diluição adequada, mesmo com tratamento. Se não se removem coliformes em percentual adequado, outros microrganismos patogênicos podem estar presentes nesses efluentes. Quanto a helmintos e protozoários já se sabe que a ETE não remove totalmente esses parasitos.

\subsection{Comunidade e ETE Viveiros-A}

\subsubsection{Condição de saúde doença da comunidade}

A comunidade Viveiros-A dispõe dos serviços de abastecimento de água $\mathrm{e}$ esgotamento sanitário desde a instalação do sistema em 1992, dos serviços de coleta de lixo e drenagem pluvial adequados e é constituída de pessoas com renda familiar entre 0 a 2 SM. Nos esgotos sanitários afluentes à estação de tratamento foram identificados helmintos e protozoários em todas as estações do ano.

Conforme Tabela 6.15 verifica-se que houve presença, em todas as estações do ano, dos helmintos Ascaris lumbricoides (freqüências de 15,4\% na primavera, 16,7\% no verão, 33,3\% no outono, 25,0\% no inverno); Strongyloides stercoralis ( $46,2 \%$ na primavera, $83,3 \%$ no verão, $91,7 \%$ no outono, $83,3 \%$ no inverno) e o Ancylostoma duodenali ( $69,2 \%$ na primavera, $83,3 \%$ no verão, $25,0 \%$ no outono e inverno). Quanto aos protozoários, foram encontrados, em todas as estações do ano, a Entamoeba histolytica (freqüências de $15,4 \%$ na primavera, $33,3 \%$ no verão, $75,0 \%$ no outono e 16,7\% no inverno), Entamoeba coli (freqüências de $76,9 \%$ na primavera, $66,7 \%$ no verão, $50,0 \%$ no outono, $83,3 \%$ no inverno), Endolimax nana (freqüências de $15,4 \%$ na primavera, $33,3 \%$ no verão, $25,0 \%$ no outono, $41,7 \%$ no inverno), Iodamoeba butschlii (freqüências de $30,8 \%$ na primavera, $66,7 \%$ no outono, 33,3\% no inverno) e Giárdia lamblia (freqüências de $30,8 \%$ na primavera, $33,3 \%$ no verão, $16,7 \%$ no inverno).

Estes achados indicam que pessoas da comunidade são portadoras desses microrganismos parasitas do intestino, provenientes muito provavelmente de 
portadores sãos, ou mesmo de pessoas doentes. Essas pessoas são portadoras de microrganismo porque desconhecem suas condições de saúde ou porque não têm acesso aos serviços de saúde.

$\mathrm{Na}$ Tabela 6.15 verifica-se, também, que os helmintos Enterobius vermicularis, Schistosoma mansoni, Hymenolepis diminuta e a Taenia sp. bem como o protozoário Dientamoeba fragilis não foram identificados em nenhuma amostra examinada e que, de maneira geral, não se pode concluir que há maior ou menor incidência de helmintos ou protozoários nesta ou naquela estação do ano.

Tabela 6.15 Freqüência de amostras com presença de helmintos e protozoários na Comunidade Viveiros-A medida no afluente à ETE.

\begin{tabular}{|c|c|c|c|c|}
\hline \multirow[t]{3}{*}{ Microrganismo } & \multicolumn{4}{|c|}{ Freqüência encontrada no afluente do esgoto a ETE } \\
\hline & Primavera & Verão & Outono & Inverno \\
\hline & $\%$ do total & $\%$ do total & $\%$ do total & $\%$ do total \\
\hline \multicolumn{5}{|l|}{ Helmintos } \\
\hline Ascaris lumbricoides & 15,4 & 16,7 & 33,3 & 25,0 \\
\hline Trycocephalus trichiurus & - & - & - & - \\
\hline Strongyloides stercolaris & 46,2 & 83,3 & 91,7 & 83,3 \\
\hline Ancylostoma duodenali & 69,2 & 83,3 & 25,0 & 25,0 \\
\hline Enterobius vermicularis & - & - & - & - \\
\hline Schistosoma mansoni & - & - & - & - \\
\hline Hymenolepis nana & - & - & - & - \\
\hline Hymenolepis diminuta & - & - & - & - \\
\hline Taenia sp. & - & - & - & - \\
\hline \multicolumn{5}{|l|}{ Protozoários } \\
\hline Entamoeba histolytica & 15,4 & 33,3 & 75,0 & 16,7 \\
\hline Entamoeba coli & 76,9 & 66,7 & 50,0 & 83,3 \\
\hline Endolimax nana & 15,4 & 33,3 & 25,0 & 41,7 \\
\hline Iodamoeba butschlii & 30,8 & - & 66,7 & 33,3 \\
\hline Dientamoeba fragilis & - & - & - & - \\
\hline Giórdia lamblia & 30,8 & 33,3 & - & 16,7 \\
\hline
\end{tabular}

Pelos resultados registrados, conforme Tabela 6.15 , constata-se que os helmintos Strongyloides stercolaris tem altas freqüências no verão, outono e inverno e freqüência média na primavera, o Ancylostoma duodenali com freqüências altas na primavera, verão e abaixo da média no outono e inverno, o Ascaris lumbricoides com freqüências abaixo da média nas quatro estações do ano. Quanto aos protozoários verifica-se que a Entamoeba histolytica tem freqüências abaixo da média na primavera, verão e inverno e alta freqüência no outono, a Entamoeba coli com freqüências acima da média (alta) na primavera, verão e inverno e média no outono, 
a Endolimax nana e a Giárdia lamblia com freqüências abaixo da média para todas as estações do ano e a Iodamoeba butschlii com freqüência alta no outono e abaixo da média na primavera e inverno.

\subsubsection{Eficiência de remoção de helmintos e protozoários na ETE Viveiros-A}

Nos resultados relacionados na Tabela 6.16, verifica-se que no efluente da ETE Viveiros-A, constituída de DAFAs em série, foram identificados os helmintos Ascaris lumbricoides (freqüências $30,8 \%$ na primavera, $16,7 \%$ no outono e no verão), Strongyloides stercolaris (freqüências de $23,1 \%$ na primavera, $83,3 \%$ no verão, $25 \%$ no outono, $41,7 \%$ no inverno), Ancylostoma duodenali (freqüências de $15,4 \%$ na primavera, $16,7 \%$ no verão e no outono, $8,3 \%$ no inverno) Enterobius vermicularis (freqüências de $7,7 \%$ na primavera), Schistosoma mansoni (freqüência de $7,7 \%$ na primavera) e Hymenelopis dimunuta ( $8,3 \%$ no outono).

Tabela 6.16 Freqüência de amostras com presença de helmintos e protozoários no efluente da ETE da Comunidade Viveiros-A.

\begin{tabular}{|c|c|c|c|c|}
\hline \multirow[t]{3}{*}{ Microrganismo } & \multicolumn{4}{|c|}{ Freqüência encontrada no efluente do esgoto a ETE } \\
\hline & Primavera & Verão & Outono & Inverno \\
\hline & $\%$ do total & $\%$ do total & $\%$ do total & $\%$ do total \\
\hline \multicolumn{5}{|l|}{ Helmintos } \\
\hline Ascaris lumbricoides & 30,8 & - & 16,7 & 16,7 \\
\hline Trycocephalus trichiurus & - & - & - & - \\
\hline Strongyloides stercolaris & 23,1 & 83,3 & 25,0 & 41,7 \\
\hline Ancylostoma duodenali & 15,4 & 16,7 & 16,7 & 8,3 \\
\hline Enterobius vermicularis & 7,7 & - & - & - \\
\hline Schistosoma mansoni & 7,7 & - & - & - \\
\hline Hymenolepis nana & - & - & - & - \\
\hline Hymenolepis diminuta & - & - & 8,3 & - \\
\hline Taenia sp. & - & $=$ & - & - \\
\hline \multicolumn{5}{|l|}{ Protozoários } \\
\hline Entamoeba histolytica & 15,4 & 16,7 & 16,7 & 58,3 \\
\hline Entamoeba coli & 92,3 & 83,3 & 83,3 & 83,3 \\
\hline Endolimax nana & 23,1 & 66,7 & 25,0 & 8,3 \\
\hline Iodamoeba butschlii & 30,8 & - & 25,0 & 50,0 \\
\hline Dientamoeba fragilis & - & - & - & - \\
\hline Giardia lamblia & 38,5 & 33,3 & 41,7 & 33,3 \\
\hline
\end{tabular}

Foram identificados, também, os protozoários Entamoeba histolytica (freqüências de $15,4 \%$ na primavera, 16,7 no verão e outono, $58,3 \%$ no inverno), Entamoeba coli (frequêencias de $92,3 \%$ na primavera, $83,3 \%$ no verão e outono e inverno), Endolimax 
nana (freqüências de $23,1 \%$ na primavera, $66,7 \%$ no verão, $25,0 \%$ no outono, $8,3 \%$ no inverno), Iodamoeba butschlii (freqüências de $30,8 \%$ na primavera, $25,0 \%$ no outono e $50 \%$ no inverno) e Giärdia lamblia (freqüências de $38,5 \%$ na primavera, $33,3 \%$ no verão, $41,7 \%$ no outono, $33,3 \%$ no inverno).

Estes resultados mostram que uma ETE constituída de digestores anaeróbios (DAFA) em série não é eficiente para remoção de helmintos e protozoários. Estes microrganismos passam pelo sistema de tratamento e alcançam o corpo receptor, representando, dessa forma, riscos para a saúde dos usuários a jusante do lançamento dos efluentes.

\subsubsection{Eficiência de remoção de $\mathrm{DBO}_{5}$ e DQO na ETE Viveiros-A e adequação à} Legislação e ao projeto

Pela Tabela 6.17, verifica-se que o maior valor médio de $\mathrm{DBO}_{5}$ afluente à ETE ocorreu no inverno $(538.3 \mathrm{mg} / \mathrm{l})$ com registro de $95,3 \mathrm{mg} / \mathrm{l}$ em OD para o efluente e remoção de $82,3 \%$. O menor valor médio de $\mathrm{DBO}_{5}$ afluente foi registrado no outono, correspondente a $446.7 \mathrm{mg} / \mathrm{l}$ em OD, com $80,4 \mathrm{mg} / \mathrm{l}$ em OD para o efluente e eficiência de remoção de $82,0 \%$. A menor eficiência em remoção da carga orgânica ocorreu no verão $(73,7 \%)$ e a maior no Inverno $(82,3 \%)$.

Tabela 6.17 Valores médios de $\mathrm{DBO}_{5}$ e DQO encontrados na ETE Viveiros-A.

\begin{tabular}{|c|c|c|c|c|c|c|c|c|}
\hline \multirow[t]{2}{*}{ PARÁMETROS } & \multicolumn{4}{|c|}{$\mathrm{DBO}_{5}(\mathrm{mg} / \mathrm{l})$} & \multicolumn{4}{|c|}{$\mathrm{DQO}(\mathrm{mg} / \mathrm{l})$} \\
\hline & Afluente & Efluente & Remofá & \begin{tabular}{|l|}
$\%$ \\
Remoção \\
\end{tabular} & Afluente & Efluente & Remoça & $\begin{array}{l}\% \\
\text { Remoçã̃o }\end{array}$ \\
\hline \multicolumn{9}{|l|}{ Primavera } \\
\hline Média & 486,7 & 110,0 & 376,7 & 77,4 & 1036,3 & 339,6 & 696,6 & 67,2 \\
\hline Valor máximo & 720,0 & 230,0 & 720,0 & & 1890,0 & 872,0 & 1636,0 & \\
\hline Valor mínimo & 290,0 & 0,0 & 90,0 & & 509,0 & 36,0 & 146,0 & \\
\hline \multicolumn{9}{|l|}{ Verão } \\
\hline Média & 520,0 & 136,7 & 383,3 & 73,7 & 1184,8 & 403,7 & 781,2 & 65,9 \\
\hline Valor máximo & 740,0 & 160,0 & 590,0 & & 1644,0 & 489,0 & 1156,0 & \\
\hline Valor mínimo & 200,0 & 100,0 & 55,0 & & 355,0 & 267,0 & 88,0 & \\
\hline \multicolumn{9}{|l|}{ Outono } \\
\hline Média & 446,7 & 80,4 & 366,3 & 82,0 & 1050,1 & 263,7 & 786,4 & 74,9 \\
\hline Valor máximo & 680,0 & 105,0 & 595,0 & & 1555,0 & 489,0 & 1200,0 & \\
\hline Valor mínimo & 220,0 & 60,0 & 150,0 & & 711,0 & 66,6 & 222,0 & \\
\hline \multicolumn{9}{|l|}{ Inverno } \\
\hline Média & 538,3 & 95,3 & 443,0 & 82,3 & 1116,9 & 280,4 & 836,5 & 74,9 \\
\hline Valor máximo & 820,0 & 175,0 & 725,0 & & 1700,0 & 550,0 & 1450,0 & \\
\hline Valor mínimo & 80,0 & 10,0 & 70,0 & & 693,0 & 125,0 & 514,0 & \\
\hline
\end{tabular}


Os valores médios de $\mathrm{DBO}_{5}$ registrados na Tabela 6.17 para as estações do ano foram $486,7 \mathrm{mg} / \mathrm{l}$ na primavera, $520,0 \mathrm{mg} / 1$ no verão, $446,7 \mathrm{mg} / \mathrm{l}$ no outono, 538,3 $\mathrm{mg} / \mathrm{l}$ no inverno e foram inferiores ao valor previsto em projeto $(587,1 \mathrm{mg} / \mathrm{l})$. A média anual da eficiência de remoção verificada na ETE Viveiros-A foi de $82 \%$, enquanto a eficiência prevista em projeto foi de $96 \%$.

Quanto à DQO, verifica-se que o maior valor afluente ocorreu no verão (1184,8 $\mathrm{mg} / \mathrm{l}$ ) com valor médio para o efluente de $407,3 \mathrm{mg} / \mathrm{l}$ e remoção de $65,9 \%$. O menor valor médio afluente ocorreu na primavera $(1036,3 \mathrm{mg} / \mathrm{l})$ com valor médio efluente de $339,6 \mathrm{mg} / \mathrm{l}$ e remoção de $67,2 \%$.

Pela Tabela 6.18, verifica-se que as razões registradas de $\mathrm{DQO} \mathrm{DBO}_{5}$ afluentes à ETE Viveiros-A para a primavera, verão e outono foram $6,5 \%, 12,5 \%$ e $17,5 \%$ superiores a 2,0, respectivamente, e para o inverno aproximadamente 2,0 . O valor esperado para esgoto bruto doméstico está na faixa de 1,7 a 2,4 (VON SPERLING 1996a). Considerando-se que, na rede coletora de esgoto dessa comunidade, não existem lançamentos regulares de esgotos diferentes do doméstico, de conhecimento da Empresa Operadora do serviço, e que o tempo de permanência do esgoto na rede coletora e interceptor é pequeno, esperavam-se valores menores para as razões entre a DQO e $\mathrm{DBO}_{5}$.

Mesmo com os valores altos da razão entre a $\mathrm{DQO}$ e a $\mathrm{DBO}_{5}$, verifica-se coerência do resultado apresentado para o inverno em relação aos valores encontrados para as demais estações do ano, visto que, no inverno, a decomposição do esgoto na rede ocorre com menor intensidade em decorrência da temperatura mais baixa nessa estação.

Tabela 6.18 Razão entre DQO e $\mathrm{DBO}_{5}$ para a ETE Viveiros-A

\begin{tabular}{c|c|c|c}
\hline Primavera & Verão & Outono & Inverno \\
\hline 2,13 & 2,25 & 2,35 & 2,07 \\
\hline
\end{tabular}

Segundo VON SPERLING (1996c), o valor da $\mathrm{DBO}_{5}$ para esgoto doméstico é da ordem de $300 \mathrm{mg} / \mathrm{l}$, calculado com base no valor per-capita de $180 \mathrm{l} / \mathrm{hab} / \mathrm{dia}$, os 
valores médios encontrados $(486,7 \mathrm{mg} / \mathrm{l}$ na primavera, $520,0 \mathrm{mg} / 1$ no verão, 446,7 $\mathrm{mg} / \mathrm{l}$ no outono e 538,3 no inverno) foram inferiores ao previsto em projeto $(587,1$ $\mathrm{mg} / \mathrm{l})$. A comunidade Viveiros-A é totalmente residencial e os valores médios de $\mathrm{DBO}_{5}$ encontrados para as estações do ano fogem a essa realidade. Entretanto, observa-se que: o consumo de água praticado pela comunidade está ocorrendo em quantidade pouco superior à prevista em projeto, porém inferior à usada para a estimativa da $\mathrm{DBO}_{5}$; a carga orgânica produzida pela comunidade permanece a mesma, apesar da variação para mais do consumo de água em relação ao previsto em projeto; as amostras de esgotos foram coletadas no horário de maior atividade residencial e estes fatos mostram que o valor médio da $\mathrm{DBO}_{5}$ pode ser inferior em relação ao indicado na literatura. O valor per-capita de água praticado na comunidade foi da ordem de 85 1/hab/dia, estimado com base em dados reais de consumo, levantados nos registros dos clientes da EMBASA - Empresa Baiana de Águas e Saneamento S.A.

O projeto da ETE Viveiros-A previa remoção de $96,0 \%$ da $\mathrm{DBO}_{5}$, para uma população total de 3.560 habitantes e foram implantados e ocupados todos os imóveis previstos, logo, a ETE encontra-se operando com a capacidade de projeto. Entretanto a eficiência de remoção de carga orgânica esperada não foi comprovada na prática, ou seja, a eficiência média anual verificada é inferior à prevista em projeto, pois, as eficiências médias do tratamento na remoção de $\mathrm{DBO}_{5}$ para as quatro estações do ano foram inferiores à prevista em projeto. As causas possíveis são: construção das unidades de tratamento com dimensões inferiores às de projeto; parâmetros maiores que os reais utilizados no projeto; operação inadequada das unidades de tratamento; horário em que foram efetuadas as coletas (de 08:00 a 10:00) não ser representativo da operação do sistema; combinação inadequada das unidades de remoção de carga orgânica. As dimensões das unidades do sistema de tratamento foram checadas e estão coerentes com as de projeto, os parâmetros usados no projeto foram os recomendados pela literatura, a operação segue o recomendado em projeto e o fundamentado em análises físico-químicas, ou seja, são feitas limpezas da grade e caixa de areia sempre que necessário e remoção do lodo digerido periodicamente, observando-se os limites mínimos e máximos de $0,25-1,0 \mathrm{ml} / \mathrm{l}$ de sólidos 
sedimentáveis no efluente, etc. Como justificativa para os resultados operacionais restam: parâmetros recomendados pela literatura maiores que os reais para a região de Fiera de Santana; tipos de unidades de remoção de carga orgânica e forma de combinação dessas unidades inadequadas; alguma falha operacional não identificada; e hora da medição da eficiência não representativa da média diária da operação.

Os resultados de remoção relativos a $\mathrm{DBO}_{5}$ para o outono e inverno foram superiores ao mínimo estabelecido na NT002 da Resolução 2288 (CEPRAM 2000), que limita ao mínimo de $80 \%$ do valor da $\mathrm{DBO}_{5}$ de entrada, para o tipo de ETE que atende a construções residenciais populares, características desse bairro. Entretanto, os valores médios de eficiência de remoção de $\mathrm{DBO}_{5}$ para o período da primavera e verão foram inferiores ao limite mínimo estabelecido.

\subsubsection{Eficiência de remoção de coliformes na ETE Viveiros-A e adequação à Legislação}

$\mathrm{Na}$ Tabela 6.19, verifica-se que o maior valor médio de coliformes totais afluentes ocorreu no verão, correspondente a $1,7 \times 10^{8} \mathrm{NMP} / 100 \mathrm{ml}$, com registro para o efluente de $1,3 \times 10^{7} \mathrm{NMP} / 100 \mathrm{ml}$ e eficiência de remoção de $93,3 \%$. O menor valor médio registrado de coliformes totais afluente foi de $1,3 \times 10^{8} \mathrm{NMP} / 100 \mathrm{ml}$ com registro para o efluente de $1,5 \times 10^{7} \mathrm{NMP} / 100 \mathrm{ml}$ e eficiência de remoção de $88,9 \%$. Entretanto a maior porcentagem média de eficiência de remoção ocorreu no outono $\operatorname{com} 93,5 \%$.

Quanto aos coliformes fecais, conforme Tabela 6.19, verifica-se que o maior valor médio ocorreu no inverno, correspondente a $8,5 \times 10^{7} \mathrm{NMP} / 100 \mathrm{ml}$, com registro 1,3 $\times 10^{7} \mathrm{NMP} / 100 \mathrm{ml}$ para o efluente e eficiência de remoção de $85,0 \%$. O menor valor médio de coliformes fecais registrados ocorreu na primavera, correspondente a 3,8 $\mathrm{x}$ $10^{7} \mathrm{NMP} / 100 \mathrm{ml}$, com registro de $4,3 \times 10^{6} \mathrm{NMP} / 100 \mathrm{ml}$ para o efluente e remoção de $88,6 \%$. A maior eficiência de remoção de coliforme fecal ocorreu no verão $90,1 \%$. 
Tabela 6.19 Valores de Coliformes Totais e Fecais encontrados na ETE Viveiros-A.

\begin{tabular}{|c|c|c|c|c|c|c|c|c|}
\hline \multirow[t]{2}{*}{ PARÁMETROS } & \multicolumn{4}{|c|}{ Coliformes Totais NMP/100ml } & \multicolumn{4}{|c|}{ Coliformes Fecais NMP/100ml } \\
\hline & Afluente & Efluente & Remoçẵo & $\begin{array}{l}\% \\
\text { Remocão }\end{array}$ & Affuente & Efluente & Remoção & $\begin{array}{l}\% \\
\text { Remocão }\end{array}$ \\
\hline \multicolumn{9}{|l|}{ Primavera } \\
\hline Média & $1,4 \times 10^{8}$ & $1,2 \times 10^{76}$ & $1,3 \times 10^{8}$ & 91,3 & $3,8 \times 10^{7}$ & $4,3 \times 10^{6}$ & $3,4 \times 10^{2}$ & 88,6 \\
\hline Valor máximo & $2,3 \times 10^{8}$ & $2,3 \times 10^{7}$ & $2,1 \times 10^{8}$ & & $1,6 \times 10^{8}$ & $9,2 \times 10^{6}$ & $1,6 \times 10^{8}$ & \\
\hline Valor mínimo & $2.3 \times 10^{7}$ & $2,2 \times 10^{6}$ & $1,3 \times 10^{7}$ & & $3,6 \times 10^{6}$ & $2,3 \times 10^{5}$ & $3,4 \times 10^{6}$ & \\
\hline \multicolumn{9}{|l|}{ Verão } \\
\hline Média & $1,7 \times 10^{8}$ & $1,3 \times 10^{7}$ & $1,6 \times 10^{8}$ & 93,3 & $4,9 \times 10^{7}$ & $4,9 \times 10^{6}$ & $4,4 \times 10^{7}$ & 90,1 \\
\hline Valor máximo & $2,3 \times 10^{8}$ & $2,3 \times 10^{7}$ & $2,2 \times 10^{8}$ & & $9,2 \times 10^{7}$ & $9,2 \times 10^{6}$ & $8,5 \times 10^{7}$ & \\
\hline Valor mínimo & $5,1 \times 10^{7}$ & $5,1 \times 10^{5}$ & $3,5 \times 10^{\prime}$ & & $1,1 \times 10^{7}$ & $2,2 \times 10^{6}$ & $7,4 \times 10^{6}$ & \\
\hline \multicolumn{9}{|l|}{ Outono } \\
\hline Média & $1,6 \times 10^{8}$ & $1,0 \times 10^{7}$ & $1,5 \times 10^{8}$ & 93,5 & $4,2 \times 10^{7}$ & $5,2 \times 10^{6}$ & $3,7 \times 10^{7}$ & 87,6 \\
\hline Valor máximo & $2,3 \times 10^{8}$ & $2,3 \times 10^{7}$ & $2,2 \times 10^{8}$ & & $9,2 \times 10^{\prime}$ & $2,3 \times 10^{7}$ & $6,9 \times 10^{7}$ & \\
\hline Valor mínimo & $5,1 \times 10^{7}$ & $3,6 \times 10^{6}$ & $4,4 \times 10^{7}$ & & $6,9 \times 10^{6}$ & $1,1 \times 10^{6}$ & $4,7 \times 10^{6}$ & \\
\hline \multicolumn{9}{|l|}{ Inverno } \\
\hline Média & $1,3 \times 10^{8}$ & $1,5 \times 10^{7}$ & $1,2 \times 10^{8}$ & 88,9 & $8,5 \times 10^{7}$ & $1,3 \times 10^{7}$ & $7,2 \times 10^{7}$ & 85,0 \\
\hline Valor máximo & $2,3 \times 10^{8}$ & $2,3 \times 10^{7}$ & $2,2 \times 10^{8}$ & & $2,3 \times 10^{8}$ & $2,3 \times 10^{7}$ & $2,1 \times 10^{8}$ & \\
\hline Valor mínimo & $2,3 \times 10^{7}$ & $9,2 \times 10^{5}$ & $1,3 \times 10^{7}$ & & $9,2 \times 10^{6}$ & $1,1 \times 10^{5}$ & $4,1 \times 10^{\circ}$ & \\
\hline
\end{tabular}

Os resultados de remoção de coliformes fecais mantiveram-se no limite mínimo estabelecido na NT002 da Resolução 2288 (CEPRAM 2000), ou seja, baixar de $10^{7}$ para $10^{6}$ para a primavera, verão e outono. No inverno, houve eficiência de redução de coliformes fecais, entretanto, manteve-se em $10^{7}$ tanto para o afluente como para o efluente à ETE Viveiros-A. Entretanto, se não ocorre diluição adequada do efluente da ETE no corpo receptor, a redução de coliformes verificada não é suficiente para garantir qualidade da água para consumo humano, mesmo com tratamento. Não se removendo coliformes, outros microrganismos patogênicos podem estar presentes nesses efluentes. Quanto a helmintos e protozoários, já era esperado que a ETE não removesse totalmente esses parasitos.

\subsection{Comunidade e ETE Contorno}

\subsubsection{Condição de saúde doença da Comunidade}

Parte da comunidade Contorno dispõe do serviço de abastecimento de água desde 1951 e de esgotamento sanitário desde a implantação da $1^{a}$ etapa do sistema em 1982 e a outra parte entre 1982 a 1994. A comunidade também dispõe dos serviços de limpeza urbana e drenagem pluvial adequados e a renda familiar varia de menos de 1 $\mathrm{SM}$ e mais de $40 \mathrm{SM}$. Nos esgotos sanitários afluentes à ETE Contorno foram 
identificados helmintos e protozoários em todas as estações do ano, conforme Tabela 6.20 .

Pela Tabela 6.20, verifica-se que houve presença em todas as estações do ano dos helmintos Ascaris lumbricoides (freqüências de 23,1\% na primavera, 50,0\% no verão, $16,7 \%$ no outono, 33,3\% no inverno); Strongyloides stercoralis $(53,8 \%$ na primavera, $50,03 \%$ no verão, $66,7 \%$ no outono e inverno) e o Ancylostoma duodenali ( $76,9 \%$ na primavera, $66,7 \%$ no verão, $41,7 \%$ no outono e inverno), bem como incidência de Hymenolepis nana (16,7\% no inverno) e de Hymenolepis diminuta $(16,7 \%$ no verão).

Tabela 6.20 Freqüência de amostras com presença de helmintos e protozoários na Comunidade Contorno medida no afluente à ETE.

\begin{tabular}{|c|c|c|c|c|}
\hline \multirow[t]{3}{*}{ Microrganismo } & \multicolumn{4}{|c|}{ Freqüência encontrada no afluente do esgoto a ETE } \\
\hline & Primavera & Verão & Outono & Inverno \\
\hline & $\%$ do total & $\%$ do total & $\%$ do total & $\%$ do total \\
\hline \multicolumn{5}{|l|}{ Helmintos } \\
\hline Ascaris lumbricoides & 23,1 & 50,0 & 16,7 & 33,3 \\
\hline Trycocephalus trichiurus & - & - & - & 75,0 \\
\hline Strongyloides stercolaris & 53,8 & 50,0 & 66,7 & 66,7 \\
\hline Ancylostoma duodenali & 76,0 & 66,7 & 41,7 & 41,7 \\
\hline Enterobius vermicularis & - & - & - & - \\
\hline Schistosoma mansoni & - & - & - & - \\
\hline Hymenolepis nana & - & - & - & 16,7 \\
\hline Hymenolepis diminuta & - & 16,7 & - & - \\
\hline Taenia sp. & - & - & - & - \\
\hline \multicolumn{5}{|l|}{ Protozoários } \\
\hline Entamoeba histolytica & 23,1 & - & 25,0 & 16,7 \\
\hline Entamoeba coli & 53,8 & 100,0 & 33,3 & 75,0 \\
\hline Endolimax nana & - & - & 41,7 & 8,3 \\
\hline Iodamoeba butschlii & 53,8 & 66,7 & 50,0 & 41,7 \\
\hline Dientamoeba fragilis & - & - & - & - \\
\hline Giárdia lamblia & 23,1 & 33,3 & 16,7 & 41,7 \\
\hline
\end{tabular}

Quanto aos protozoários, foi verificada presença em todas as estações do ano da Entamoeba coli (freqüências de $53,8 \%$ na primavera, $100 \%$ no verão, $33,3 \%$ no outono, $75,0 \%$ no inverno), Iodamoeba butschlii (freqüências de $53,8 \%$ na primavera, $66,7 \%$ no verão, $60,0 \%$ no outono, $41,7 \%$ no inverno) e Giárdia lamblia (freqüências de $23,1 \%$ na primavera, $33,3 \%$ no verão, $16,7 \%$ no outono, $41,7 \%$ no 
inverno) e incidência da Entamoeba histolytica (freqüências de 23,1\% na primavera, $25,0 \%$ no outono e $16,7 \%$ no inverno) e Endolimax nana (freqüências de $41,7 \%$ no outono, $8,3 \%$ no inverno).

A presença de helmintos e protozoários nos esgotos afluentes à ETE Contorno indicam que pessoas da comunidade são portadoras desses microrganismo parasitas do intestino, ou dos esgotos das clínicas e hospitais, ou de pessoas doentes. Essas pessoas podem ser portadoras de microrganismo porque desconhecem suas condições de saúde, não têm acesso aos serviços de saúde, ou porque os médicos não tratam.

Os helmintos Enterobius vermicularis, Schistosoma mansoni e a Taenia sp. bem como o protozoário Dientamoeba fragilis não foram identificados em nenhuma amostra examinada durante todo o ano. Pelos resultados obtidos, verifica-se que existe variação sazonal da freqüência tanto dos helmintos quanto dos protozoários presentes nos esgotos da comunidade Contorno.

\subsubsection{Eficiência de remoção de helmintos e protozoários na ETE Contorno}

Nos resultados relacionados na Tabela 6.21, verifica-se que, no efluente da estação de tratamento de esgoto sanitário Contorno, formada por lagoas aeradas seguidas de decantação e lagoa facultativa, existem presenças dos helmintos Ascaris lumbricoides (freqüência de $15,4 \%$ na primavera), Strongyloides stercolaris (freqüência de $8,3 \%$ no outono e inverno), Ancylostoma duodenali (freqüência de $23,1 \%$ ), Hymenolepis nana (freqüência $7,7 \%$ na primavera) e dos protozoários Entamoeba histolytica (freqüência de $23,1 \%$ na primavera, $16,7 \%$ no verão, $25,0 \%$ no inverno), Entamoeba coli (freqüências de $23,1 \%$ na primavera, 8,3\% no outono, $50,0 \%$ no inverno), Endolimax nana (freqüências de $16,7 \%$ no verão, $25,0 \%$ no outono), Iodamoeba butschlii (freqüência de 7,7\% na primavera) e Giárdia lamblia (freqüências de $7,7 \%$ na primavera, $50,0 \%$ no verão, $8,3 \%$ no outono, $16,7 \%$ no inverno). 
Para o tipo de ETE aqui estudada, verifica-se que ainda passam helmintos e protozoários, havendo, conseqüentemente, riscos para a saúde dos usuários a jusante do lançamento dos efluentes

Estes resultados mostram que a ETE Contomo, constituída de lagoas aeradas, decantação e lagoa facultativa em série, com tempo de detenção relativamente alto 86:00h - ainda não é eficiente na remoção de helmintos e protozoários. Estes microrganismo passam pelo sistema de tratamento e chegam ao corpo receptor.

Tabela 6.21 Freqüência de amostras com presença de helmintos e protozoários no efluente da ETE da Comunidade Contorno.

\begin{tabular}{|c|c|c|c|c|}
\hline \multirow[t]{3}{*}{ Microrganismo } & \multicolumn{4}{|c|}{ Freqüência encontrada no efluente do esgoto a ETE } \\
\hline & Primavera & Verão & Outono & Inverno \\
\hline & $\%$ do total & $\%$ do total & $\%$ do total & $\%$ do total \\
\hline \multicolumn{5}{|l|}{ Helmintos } \\
\hline Ascaris lumbricoides & 15,4 & - & - & - \\
\hline Trycocephalus trichiurus & - & - & - & - \\
\hline Strongyloides stercolaris & - & & 8,3 & 8,3 \\
\hline Ancylostoma duodenali & 23,4 & - & - & - \\
\hline Enterobius vermicularis & - & - & - & - \\
\hline Schistosoma mansoni & - & - & - & - \\
\hline Hymenolepis nana & 7,7 & - & - & - \\
\hline Hymenolepis diminuta & - & - & - & - \\
\hline Taenia sp. & - & - & - & - \\
\hline \multicolumn{5}{|l|}{ Protozoários } \\
\hline Entamoeba histolytica & 23,1 & 16,7 & - & 25,0 \\
\hline Entamoeba coli & 23,1 & - & 8,3 & 50,0 \\
\hline Endolimax nana & - & 16,7 & 25,0 & - \\
\hline Iodamoeba butschlii & 7,7 & - & - & - \\
\hline Dientamoeba fragilis & - & - & - & - \\
\hline Giárdia lamblia & 7,7 & 50,0 & 8,3 & 16,7 \\
\hline
\end{tabular}

\subsubsection{Eficiência de remoção de $\mathrm{DBO}_{5}$ e DQO na ETE Contorno e adequação à} Legislação e ao projeto

Pela Tabela 6.22, verifica-se que o maior valor médio de $\mathrm{DBO}_{5}$ afluente à ETE foi registrado no outono - $541,7 \mathrm{mg} / 1 \mathrm{em}$ OD - quando se registrou para o efluente valor médio de $119,6 \mathrm{mg} / \mathrm{l}$ em OD com redução média de $77,9 \%$, menor valor registrado para a ETE. $\mathrm{O}$ menor valor médio de $\mathrm{DBO}_{5}$ afluente registrado para a ETE 
corresponde $442,5 \mathrm{mg} / \mathrm{l}$ em OD na primavera, cujo efluente médio foi de $83,9 \mathrm{mg} / 1$ de OD e remoções $81,0 \%$, maior valor para a ETE. Pelo tipo de montagem de ETE (Lagoa aerada, decantador secundário, recirculação de parte do lodo para a lagoa aerada, remoção de parte do lodo para leito de secagem e lagoa facultativa) esperavase maior eficiência. Entretanto, segundo MARA (1995) apud VON SPERLING (1996c), de 60 a 90\% dos sólidos em suspensão de lagoas facultativas são de algas e cada $1,0 \mathrm{mg}$ de alga gera aproximadamente $0,45 \mathrm{mg}$ de $\mathrm{DBO}_{5}$. Logo, para cada 1,0 mg/l de sólidos em suspensão, no efluente das lagoas facultativas, as algas são capazes de gerar de 0,3 a $0,4 \mathrm{mg} / \mathrm{l}$ de $\mathrm{DBO}_{5}$ e, devido à incerteza quanto à abordagem citada é prática se desconsiderar a DBO das algas, ou dos sólidos em suspensão, no efluente de lagoas facultativas.

O valor máximo de $\mathrm{DBO}_{5}$ foi registrado na primavera - $680,0 \mathrm{mg} / 1$ - e o valor mínimo no inverno - $200 \mathrm{mg} / \mathrm{l}$. Esperava-se o inverso na região de Feira de Santana, ou seja, mínimo no verão ou primavera e máximo no inverno devido às chuvas torrenciais e maior consumo de água nas residências no verão ou primavera.

Tabela 6.22 Valores médios de $\mathrm{DBO}_{5}$ e DQO encontrados na ETE Contorno

\begin{tabular}{l|r|r|r|r|r|r|r|r}
\hline PARÁMETROS & \multicolumn{3}{|c|}{$\mathrm{DBO}_{5}(\mathrm{mg} / \mathrm{l})$} & \multicolumn{3}{|c}{ DQO (mg/1) } \\
\hline Primavera & & & & & & & & \multicolumn{1}{c}{$\begin{array}{c}\text { Afluente } \\
\text { efluente }\end{array}$} \\
\hline Média & 442,5 & 83,9 & 358,6 & 81,0 & 1112,3 & 325,1 & 787,2 & 70,8 \\
\hline Valor máximo & 680,0 & 120,0 & 565,0 & & 1745,0 & 836,0 & 1309,0 & \\
\hline Valor mínimo & 180,0 & 15,0 & 145,0 & & 582,0 & 89,0 & 254,0 & \\
\hline Verão & & & & & & & & \\
\hline Média & 457,1 & 94,3 & 362,9 & 79,4 & 1040,9 & 399,7 & 641,2 & 61,6 \\
\hline Valor máximo & 640,0 & 115,0 & 550,0 & & 1288,0 & 466,6 & 822,0 & \\
\hline Valor mínimo & 300,0 & 80,0 & 210,0 & & 622,0 & 244,0 & 378,0 & \\
\hline Outono & & & & & & & & \\
\hline Média & 541,7 & 119,6 & 422,1 & 77,9 & 1134,0 & 504,7 & 629,4 & 55,5 \\
\hline Valor máximo & 640,0 & 225,0 & 515,0 & & 1689,0 & 822,0 & 1222,0 & \\
\hline Valor mínimo & 300,0 & 70,0 & 230,0 & & 556,0 & 222,0 & 67,0 & \\
\hline Inverno & & & & & & & & \\
\hline Média & 491,7 & 101,3 & 390,4 & 79,4 & 1198,3 & 375,2 & 823,2 & 68,7 \\
\hline Valor máximo & 660,0 & 135,0 & 445,0 & & 2254,0 & 725,0 & 1782,0 & \\
\hline Valor mínimo & 200,0 & 10,0 & 65,0 & & 544,0 & 235,0 & 272,0 & \\
\hline
\end{tabular}


Considerando-se que a ETE está recebendo esgoto de uma população superior à prevista em projeto, que a carga orgânica prevista em projeto foi inferior à real e que uma das lagoas aeradas foi retirada de operação durante a realização da pesquisa, duas semanas, no verão, e três, no outono, para manutenção da estrutura, é possível que sejam estas as causas da eficiência real ser menor que a eficiência prevista em projeto, nas quatro estações do ano. Observa-se que a aeração do esgoto foi compensada quando uma das lagoas foi retirada de carga, de forma que o valor do oxigênio dissolvido na lagoa aerada foi mantido como anteriormente. Nesta condição, o que se verificou na prática foi a redução do tempo de detenção.

Pela Tabela 6.22, verifica-se que o maior valor médio de DQO encontrado para o afluente ocorreu no inverno, correspondente a $1198,3 \mathrm{mg} / \mathrm{l} \mathrm{em} \mathrm{OD}$, e o valor correspondente para o efluente foi de $375,2 \mathrm{mg} / \mathrm{lem} \mathrm{OD}$, com eficiência de remoção de $68,7 \%$. O menor valor médio de DQO afluente ocorreu no verão $-1040,9 \mathrm{mg} / \mathrm{lem}$ OD - tendo para DQO no efluente $399,7 \mathrm{mg} / \mathrm{l}$, conseqüentemente, eficiência de remoções de $61,6 \%$. Estes valores estão coerentes com o esperado para a região de Feira de Santana.

Quanto a $\mathrm{DQO}$ e a $\mathrm{DBO}_{5}$ afluentes à ETE Contorno (Tabela 6.23), verifica-se que para a primavera, verão, outono e inverno as razões de $\mathrm{DQO} / \mathrm{DBO}_{5}$ obtidas ficaram em $25,5 \%, 13,5 \%, 4,5 \%$ e $22,0 \%$ superior a 2,0 , respectivamente. $O$ valor esperado para esgoto bruto doméstico está na faixa de 1,7 a 2,4 (VON SPERLING 1996a). Os resultados mostram certa distorção para a primavera, em relação ao esperado, e em relação às demais ETEs pesquisadas. Considerando-se que o tempo de permanência do esgoto bruto na rede coletora e interceptor do sistema Contorno é bem maior do que o tempo de permanência nos demais sistemas de coleta e transporte das ETEs estudadas, conclui-se que as razões $\mathrm{DQO} / \mathrm{DBO}$ maiores são em decorrência da decomposição de parte da carga orgânica biodegradável na rede e/ou de possível carga orgânica não biodegradável lançada no sistema Contorno.

Tabela 6.23 Razão entre DQO/ $\mathrm{DBO}_{5}$ para a ETE Contorno

\begin{tabular}{c|c|c|c}
\hline Primavera & Verão & Outono & Inverno \\
\hline 2,51 & 2,27 & 2,09 & 2,44 \\
\hline
\end{tabular}


Segundo VON SPERLING (1996c), considerando-se que o valor da $\mathrm{DBO}_{5}$ para esgoto doméstico é da ordem de $300 \mathrm{mg} / 1$, calculado com base no valor per-capita de 180 1/hab/dia e carga orgânica de $54 \mathrm{~g} / \mathrm{hab} / \mathrm{dia}$, os valores médios encontrados (442,5 $\mathrm{mg} / \mathrm{l}$ na primavera, $457,1 \mathrm{mg} / 1$ no verão, $541,7 \mathrm{mg} / \mathrm{l}$ no outono e 491,7 no inverno) foram superiores ao previsto em projeto $(380,0 \mathrm{mg} / \mathrm{l})$. A comunidade Contorno é constituída de residências, clínicas, hospitais, restaurantes, comércios diversos, postos de combustiveis e estabelecimentos públicos e os valores médios de $\mathrm{DBO}_{5}$ encontrados para as estações do ano fogem a essa realidade. Entretanto, observa-se que: o consumo de água praticado pela comunidade está ocorrendo em quantidade inferior à prevista em projeto; a carga orgânica foi aumentada devido ao aumento da população atendida pelo sistema; as amostras de esgotos foram coletadas no horário de maior atividade residencial. Estes fatos mostram que o valor médio da $\mathrm{DBO}_{5}$ pode ser superior em relação ao indicado na literatura. O valor per-capita de água consumida na comunidade não foi possível ser estimado com precisão como foi feito para as demais comunidades, devido ao tamanho da população e à diversidade de usos da água. $\mathrm{O}$ valor per-capita foi calculado só para uma amostra de residências da comunidade Contorno, com valor da ordem de 120 1/hab/dia, com dados levantados nos registros dos clientes da EMBASA - Empresa Baiana de Águas e Saneamento S.A.

O projeto da ETE Contorno previa remoção de $94,7 \%$ da $\mathrm{DBO}_{5}$, para uma população total de 90.000 habitantes e a ETE encontra-se operando com a capacidade superior à de projeto em mais que $21 \%$, ou seja, para uma população estimada de 114.412 hab, com clínicas, hospitais, comércios diversos, oficinas, órgãos públicos, pequenas indústrias e postos de combustiveis. Evidentemente que a eficiência esperada não foi comprovada na prática, pois as eficiências médias do tratamento obtidas para a remoção de $\mathrm{DBO}_{5}$ foram, para as quatro estações do ano, inferiores às previstas em projeto. As causas possiveis para essa ocorrência são: construção das unidades de tratamento com dimensões inferiores às de projeto; parâmetros maiores que os reais utilizados no projeto; operação inadequada das unidades de tratamento; o horário em que foram efetuadas as medições (de 08:00 a 10:00 h) não ser representativo da 
operação do sistema; combinação inadequada das unidades de remoção de carga orgânica e carga orgânica com aplicação superior à prevista em projeto. As dimensões das unidades foram checadas e estão coerentes com as do projeto, os parâmetros usados foram os recomendados pela literatura bem como a operação que, também, foi fundamentada em análises físico-químicas. Foram efetuadas limpezas da grade e caixa de areia sempre que necessárias, removendo-se $\mathrm{p}$ lodo digerido periodicamente, com a combinação adequada das unidades de remoção de carga orgânica. Como justificativa para os resultados operacionais esperados, restam: parâmetros recomendados pela literatura maiores que os reais para a região de Feira de Santana, alguma falha operacional não identificada, hora da medição da eficiência não representativa da média diária (08:00 - 10:00 hs) e ETE operando com sobrecarga.

O resultado da remoção média de carga orgânica na primavera, medida por meio da $\mathrm{DBO}_{5}$, foi superior ao valor estabelecido na NT002 da Resolução 2288 (CEPRAM 2000) que limita ao minimo de $80 \%$ do valor da $\mathrm{DBO}_{5}$ de entrada, para esse tipo de ETE. Para o verão, outono e inverno, a remoção média foi inferior ao estabelecido na referida Resolução. Entretanto, pelo projeto, verifica-se que a carga orgânica estimada foi de $380 \mathrm{mg} / \mathrm{l}$ em $\mathrm{DBO}_{5}$, muito inferior ao valor médio encontrado, correspondente a $480 \mathrm{mg} / \mathrm{l}$. A eficiência real verificada para e ETE foi de $81,0 \%$ na primavera, $79,4 \%$ no verão, $77,9 \%$ no outono, $79,4 \%$ no inverno, com média anual de $79,4 \%$, valor este inferior à estabelecida em projeto de $94,6 \%$.

\subsubsection{Eficiência de remoção de coliformes na ETE Contorno e adequação à}

\section{Legislação}

$\mathrm{Na}$ Tabela 6.24, verifica-se que o maior valor médio de coliformes totais afluentes à ETE ocorreu no verão, correspondente a $1,9 \times 10^{8} \mathrm{NMP} / 100 \mathrm{ml}$, e para efluente o valor de $1,6 \times 10^{7} \mathrm{NMP} / 100 \mathrm{ml}$, com eficiência de remoção de $91,4 \%$. O menor valor médio registrado, de coliformes totais, para o afluente foi de $1,5 \times 10^{8} \mathrm{NMP} / 100 \mathrm{ml}$, no inverno, com eficiência de remoção de $91,4 \%$. A maior remoção de coliformes totais ocorreu na primavera $(92,2 \%)$ e a menor, no outono $(90,4 \%)$. 
Quanto aos coliformes fecais, conforme Tabela 6.24, verifica-se que o menor valor médio afluente à ETE foi registrado para o verão, correspondendo a $7,1 \times 10^{7}$ $\mathrm{NMP} / 100 \mathrm{ml}$, com o correspondente valor para o efluente de $8,2 \times 10^{6} \mathrm{NMP} / 100 \mathrm{ml}$ com remoção de $88,4 \%$. O menor valor médio registrado para o afluente ocorreu no outono $-4,2 \times 10^{7} \mathrm{NMP} / 100 \mathrm{ml}$ - tendo para o efluente o valor médio de $6,0 \times 10^{6}$ $\mathrm{NMP} / 100 \mathrm{ml}$ com remoção média de $85,7 \%$, menor valor médio registrado no periodo da pesquisa. A maior eficiência de remoção de coliformes fecais ocorreu na primavera.

Os resultados de remoção de coliformes fecais atende ao valor limite mínimo estabelecido na NT002 da Resolução 2288 (CEPRAM 2000), ou seja, baixar em ordem de grandeza de $10^{7}$ para $10^{6}$. Entretanto, essa redução não é suficiente para garantir a qualidade da água do corpo receptor para consumo humano, mesmo com tratamento, se não houver a diluição adequada. Se não se removem coliformes, outros microrganismos patogênicos podem estar presentes nos efluentes. Quanto a helmintos e protozoários já era esperado que a ETE não removesse totalmente esses parasitas.

Tabela 6.24 Valores de Coliformes Totais e Fecais encontrados na ETE Contorno.

\begin{tabular}{|c|c|c|c|c|c|c|c|c|}
\hline \multirow[t]{2}{*}{ PARÂMETROS } & \multicolumn{4}{|c|}{ Coliformes Totais NMP/100ml } & \multicolumn{4}{|c|}{ Coliformes Fecais NMP/100ml } \\
\hline & Afluente & Efluente & Remoça & $\begin{array}{l}\% \\
\text { Remocáo }\end{array}$ & Afluente & Efivente & Remaçăa & $\begin{array}{l}\% \\
\text { Remacaso }\end{array}$ \\
\hline \multicolumn{9}{|l|}{ Primavera } \\
\hline Média & $1,6 \times 10^{8}$ & $1,3 \times 10^{7}$ & $1,5 \times 10^{8}$ & 92,2 & $4,5 \times 10^{7}$ & $3,6 \times 10^{6}$ & $4,1 \times 10^{7}$ & 92,0 \\
\hline Valor máximo & $2.3 \times 10^{8}$ & $2,3 \times 10^{7}$ & $2,3 \times 10^{8}$ & & $1.2 \times 10^{8}$ & $9,2 \times 10^{6}$ & $1,2 \times 10^{8}$ & \\
\hline Valor minimo & $2,3 \times 10^{7}$ & $1,1 \times 10^{6}$ & $2.1 \times 10^{7}$ & & $9,2 \times 10^{6}$ & $9,2 \times 10^{5}$ & $5,9 \times 10^{6}$ & \\
\hline \multicolumn{9}{|l|}{ Verão } \\
\hline Média & $1,9 \times 10^{8}$ & $1,6 \times 10^{7}$ & $1,7 \times 10^{8}$ & 91,4 & $7,1 \times 10^{7}$ & $8,2 \times 10^{6}$ & $6,3 \times 10^{7}$ & $\overline{88.4}$ \\
\hline Valor máximo & $2,3 \times 10^{8}$ & $2,3 \times 10^{7}$ & $2,2 \times 10^{8}$ & & $1,6 \times 10^{8}$ & $1,6 \times 10^{7}$ & $1,4 \times 10^{8}$ & \\
\hline Valor mínimo & $1,2 \times 10^{8}$ & $5,1 \times 10^{\circ}$ & $1,0 \times 10^{8}$ & & $2,0 \times 10^{7}$ & $1.1 \times 10^{6}$ & $1,6 \times 10^{7}$ & \\
\hline \multicolumn{9}{|l|}{ Outono } \\
\hline Média & $1,5 \times 10^{8}$ & $1,5 \times 10^{7}$ & $1,4 \times 10^{8}$ & 90,4 & $4,2 \times 10^{7}$ & $6,0 \times 10^{\circ}$ & $3,6 \times 10^{7}$ & $\overline{85,7}$ \\
\hline Valor máximo & $2,3 \times 10^{8}$ & $2,3 \times 10^{7}$ & $2,2 \times 10^{8}$ & & $6,9 \times 10^{7}$ & $2.3 \times 10^{7}$ & $6,5 \times 10^{7}$ & \\
\hline Valor mínimo & $6,9 \times 10^{7}$ & $3,6 \times 10^{6}$ & $4,6 \times 10^{7}$ & & $2,2 \times 10^{7}$ & $1,1 \times 10^{\circ}$ & $1,8 \times 10^{7}$ & \\
\hline \multicolumn{9}{|l|}{ Inverno } \\
\hline Média & $1,5 \times 10^{8}$ & $1,3 \times 10^{7}$ & $1,3 \times 10^{8}$ & 91,4 & $6,8 \times 10^{7}$ & $6,5 \times 10^{6}$ & $6,2 \times 10^{7}$ & $\overline{90,4}$ \\
\hline Valor máximo & $2,3 \times 10^{8}$ & $2,3 \times 10^{7}$ & $2,3 \times 10^{8}$ & & $2,3 \times 10^{8}$ & $2,3 \times 10^{7}$ & $2,1 \times 10^{8}$ & \\
\hline Valor mínimo & $2,3 \times 10^{7}$ & $2,3 \times 10^{6}$ & $2,1 \times 10^{7}$ & & $1,2 \times 10^{7}$ & $1,2 \times 10^{6}$ & $1,1 \times 10^{7}$ & \\
\hline
\end{tabular}


Para garantir a qualidade da água do corpo receptor do efluente da ETE Contomo como de Classe 2, conforme preconiza a Resolução $n^{\circ} 20$ (CONAMA 1986) faz-se necessário que a vazão mínima do mesmo seja da ordem de 2400 vezes superior à vazão média do esgoto efluente à ETE, se não houver qualquer poluição a montante do ponto de lançamento, o que não ocorre.

\subsection{Comparação entre as estações de tratamento}

\subsubsection{Quanto à remoção de $\mathrm{DBO}_{5}$}

Analisando-se a Tabela 6.25, verifica-se que a ordem decrescente de eficiência das Estações de Tratamento de Esgotos na remoção de $\mathrm{DBO}_{5}$, em média anual, é a seguinte: Homero Figueiredo (83,6\%); Contorno (79,4\%); Viveiros-A (78,9\%) e Lagoa Grande (74,8\%). Quanto ao tempo de detenção, como função da eficiência em remoção de $\mathrm{DBO}_{5}$, verifica-se que a ordem permanece a mesma, do maior tempo de detenção para o menor. ETEs Homero Figueiredo (269:12h), Contorno (86:00 h); Viveiros-A (20:00h); e Lagoa Grande (12:12h). Pelos resultados, verifica-se, também, que para as ETEs que funcionam sem sobrecarga - com a carga prevista em projeto - a eficiência aumenta com o aumento do tempo de detenção, Lagoa Grande $(\mathrm{Td}=12: 12 \mathrm{~h}, \mathrm{Ef}=74,9 \%)$ e Viveiros-A $(\mathrm{Td}=20: 00 \mathrm{~h}, \mathrm{Ef}=78,9 \%)$.

Nos processos aeróbios, a decomposição da carga orgânica é mais completa que nos processos anaeróbios. A decomposição predominante na ETE Contorno é aeróbia enquanto na Homero Figueiredo é anaeróbia, logo, a remoção maior de $\mathrm{DBO}_{5}$ verificada na ETE Homero Figueiredo em relação à ETE Contorno, justifica-se pelo fato de que a ETE Contorno encontra-se subdimensionada para a atual carga de $\mathrm{DBO}_{5}$ recebida, está operando com sobrecarga superior a $21 \%$ em relação à de projeto e a ETE Homero Figueiredo encontra-se com folga de $25 \%$ na sua capacidade prevista em projeto.

ETEs constituídas de um reator anaeróbio têm eficiência de remoção de $\mathrm{DBO}_{5}$ na faixa de 70 - 80\% (SOUZA e VIEIRA 1986; VIEIRA 1996; LEITE e AISSE 1998). As estações Lagoa Grande e Viveiros-A apresentaram efiçiências na faixa citada 
acima, entretanto, são constituídas de dois digestores em série e, pelo projeto, a eficiência final é o resultado da remoção total verificada nos dois digestores. Pelos resultados apresentados, há divergência em relação ao resultado esperado, o que indica que o segundo digestor pode não estar produzindo a eficiência esperada conforme projeto, ou seja, o segundo digestor da série, possivelmente, não garante a mesma eficiente do primeiro.

\subsubsection{Quanto à remoção de coliformes}

Avaliando-se a remoção de coliformes fecais (Tabela 6.25), em termos de média anual, verifica-se que a ordem das eficiências das ETEs foi a mesma da remoção de $\mathrm{DBO}_{5}$, ou seja, Homero Figueiredo (97,2\%); Contorno $(89,1 \%)$; Viveiros-A $(87,8 \%)$ e Lagoa Grande (79.4\%). Pelo projeto, só na ETE Contorno foi prevista remoção de coliformes, e não consta o valor da remoção para a ETE Homero Figueiredo. No caso da ETE Contomo, a remoção de coliformes não foi comprovada na prática, possivelmente em decorrência da carga orgânica real aplicada ser superior à do projeto e do tempo de detenção, pequeno $(86: 00 \mathrm{~h})$. Quanto à remoção de coliformes totais, verifica-se que houve permuta de posição entre a Contorno e Viveiros-A.

\subsubsection{Quanto à remoção de helmintos e protozoários}

Quanto à eficiência na remoção de helmintos e protozoários, verifica-se que nenhuma das ETEs é completamente segura. Entretanto, pelas Tabelas 6.27, $6.28 \mathrm{e}$ 6.28, pode-se aferir que a ETE Homero Figueiredo apresenta-se muito mais eficiente que as demais, visto que a presença de helmintos só ocorreu no outono (Strongyloides stercolaris freqüência de $8,3 \%$ das amostras pesquisadas) e de protozoários na primavera (Entamoeba coli freqüência de 7,7\% das amostras pesquisadas). A folga na carga orgânica aplicada e o tempo de detenção bem maior que o das demais estações são as causas da eficiência superior desta em relação às outras.

A ETE Contorno é a segunda melhor em remoção de helmintos, bem como de protozoários (Tabela 6.28 e 6.29). Estes resultados são em decorrência da mesma ter, na seqüência final do tratamento dos esgotos, lagoa facultativa em série com outras 
unidades de remoção de carga orgânica e o segundo maior tempo de detenção (86:00h).

Segundo LEITE e AISSE (1998), em lagoas com dois compartimentos e tempo de detenção total de 20 dias, a remoção de protozoários é completa, e em lagoas com 10 dias de detenção, a de helmintos é total. A ETE Homero Figueiredo constituída de DAFA (10:00 h de detenção) em série com lagoa facultativa (259:12 h de detenção) não foi inteiramente eficiente quanto à remoção de helmintos (Tabela 6.27 e 6.28). Com relação à de protozoários já era esperada a ineficiência indicada. 


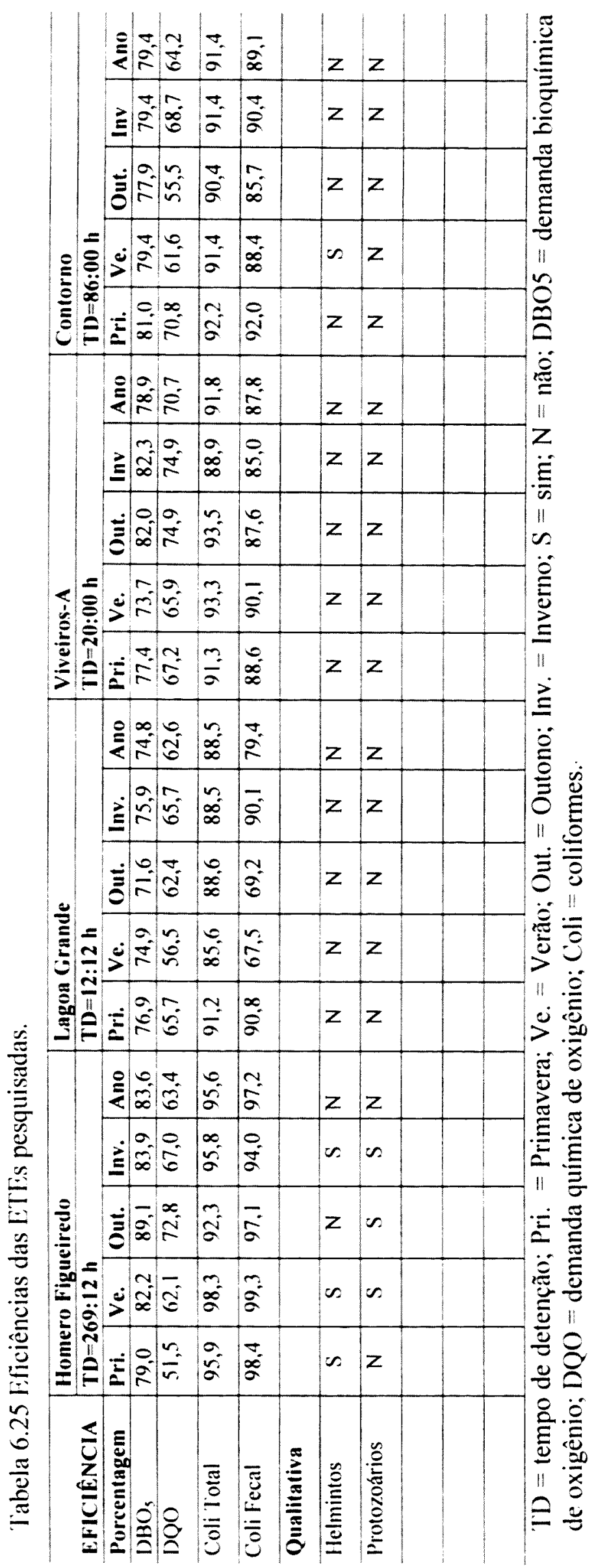




\begin{tabular}{|c|c|c|c|c|c|c|c|c|c|c|c|c|c|c|c|c|c|c|c|c|}
\hline \multirow{5}{*}{ 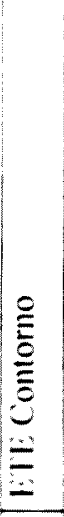 } & \multirow{5}{*}{ 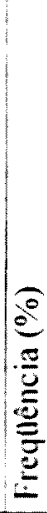 } & $\bar{E}$ & & $\stackrel{\vec{n}}{\mathrm{n}}$ & 离 & ह & $\begin{array}{l}\infty \\
\infty \\
\infty\end{array}$ & 1. & . & 7 & & $F$ & 1 & & $\underline{\underline{x}}$ & ह & 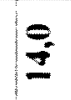 & $\frac{2}{\sigma}$ & & $\stackrel{2}{i}$ \\
\hline & & $\geqq$ & & $\hat{m}$ & 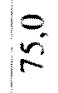 & 8 & $\frac{F}{F}$ & 1 & & 6 & & ' & - & & 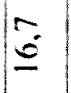 & 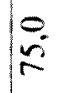 & $\infty$ & $=$ & ' & $=$ \\
\hline & & $\bar{\Xi}$ & & $\underline{6}$ & ' & 8 & $\frac{F}{\bar{\sigma}}$ & 1 & ' & ' & & ' & & & $\begin{array}{l}0 \\
\text { in } \\
\text { s. }\end{array}$ & $\vec{m}$ & $\bar{\sigma}$ & $\begin{array}{l}0 . \\
8\end{array}$ & ' & 6 \\
\hline & & $>$ & & 官. & & : & 8 & , & ' & ' & & 6 & & & , & $\Xi$ & & 8 & . & 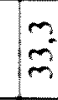 \\
\hline & & $\Xi$ & & $\bar{\theta}$ & ' & $\begin{array}{l}\infty \\
\hat{n}\end{array}$ & 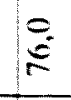 & ' & ' & : & & ' & & & $\overline{\tilde{N}}$ & a & " & $\begin{array}{l}\infty \\
\tilde{\omega}\end{array}$ & & $\overline{\hat{i}}$ \\
\hline \multirow{5}{*}{ 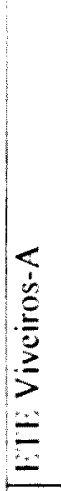 } & \multirow{5}{*}{ 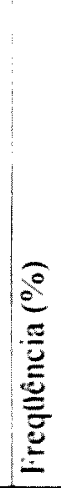 } & $\sum^{\infty}$ & & $\hat{\tilde{\nu}}$ & $\xi$ & $\frac{\infty}{\delta}$ & $\ddot{z}$ & $\cdot$ & ' & ' & & . & . & & 翌 & $a^{\infty}$ & $\begin{array}{l}\ddot{N} \\
\ddot{d}\end{array}$ & 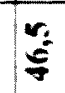 & ' & $=$ \\
\hline & & $\geqq$ & & $\underset{i}{0}$ & ' & $\infty$ & $\begin{array}{l}0 \\
\ddot{\sim} \\
\sim\end{array}$ & & ' & ' & & ' & & & 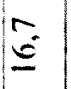 & $\frac{2}{\infty}$ & $\frac{r}{\sigma}$ & $\ddot{m}$ & & $\hat{0}$ \\
\hline & & 志 & & $\frac{m}{2}$ & ' & $\frac{1}{a}$ & $\begin{array}{l}0 \\
\ddot{i} \\
\ddot{i}\end{array}$ & & - & ' & & ' & & & $\begin{array}{l}0 \\
\therefore\end{array}$ & $\ddot{8}$ & $\begin{array}{l}0 \\
\ddot{\sim}\end{array}$ & 8 & & ' \\
\hline & & $j^{\circ}$ & & 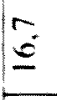 & ' & $\frac{m}{\infty}$ & $\vec{\infty}$ & & ' & ' & & . & & & $\Leftrightarrow$ & 8 & $m$ & $\cdot$ & & $\stackrel{m}{m}$ \\
\hline & & 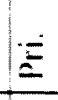 & & $\vec{z}$ & , & フֶ. & 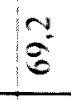 & & ' & ' & & ' & ' & & $\vec{z}$ & E & 它: & $\overbrace{\infty}^{\infty}$ & : & $\stackrel{\infty}{\stackrel{\infty}{\circ}}$ \\
\hline \multirow{5}{*}{ 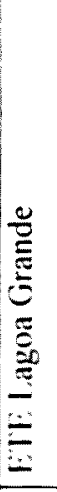 } & \multirow{5}{*}{ 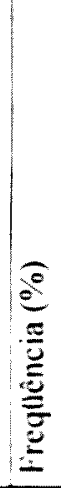 } & 运 & & 2 & $\because$ & 0 & $\stackrel{5}{\check{0}}$ & ' & . & . & & . & ' & & $\frac{2}{2}$ & $\bar{x}$ & 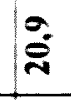 & $\vec{\pi}$ & ' & $\stackrel{N}{\equiv}$ \\
\hline & & $\geqq$ & & $\infty$ & ' & $\underline{\Xi}$ & $a_{\infty}$ & 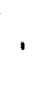 & ' & ‘ & & . & & & $\frac{m}{m}$ & $\begin{array}{l}0 \\
\sim\end{array}$ & 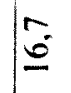 & $\bar{\sigma}$ & & $\ddot{\sim}$ \\
\hline & & $\doteq$ & & & $\ddot{\infty}$ & $\frac{1}{a}$ & 8 & 1 & ' & ' & & ' & 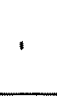 & & $\begin{array}{l}0 \\
\text { i } \\
\text { in }\end{array}$ & $\begin{array}{l}3 \\
\infty \\
\infty\end{array}$ & $\frac{m}{m}$ & $\underline{6}$ & . & $\infty$ \\
\hline & & $\dot{~}$ & & 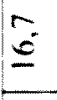 & . & $\infty$ & $\tilde{\infty}^{2}$ & , & ' & & & . & . & & $\approx$ & 8 & 2 & ' & . & $m$ \\
\hline & & $1=$ & & $\underline{\ddot{u}}$ & $=$ & $\frac{3}{8}$ & $\Xi$ & . & , & . & & . & . & & $\approx$ & $\infty$ & $\approx$ & $\overline{\hat{N}}$ & . & $\infty$ \\
\hline \multirow{5}{*}{ 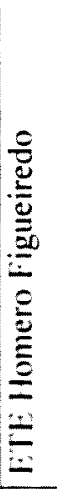 } & \multirow{5}{*}{$\frac{0}{0}$} & 这 & & 2 & ' & 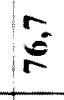 & $\stackrel{2}{2}$ & ' & ' & ' & & ' & & & స్ & है: & $\ddot{\ddot{n}}$ & $\stackrel{\sim}{\sim}$ & ' & 2 \\
\hline & & $\geqq$ & & $\begin{array}{l}0 \\
\text { i. } \\
\text { in }\end{array}$ & ' & $\ddot{\infty}$ & $\frac{F}{\bar{\sigma}}$ & ' & ' & ' & & . & & & $\hat{m}$ & $\ddot{n}$ & $\vec{m}$ & $\underline{0}$ & ' & 5 \\
\hline & & $\doteq$ & & , & ' & $\frac{1}{\sigma}$ & $m^{2}$ & ' & . & ' & & ' & & & $\vec{m}$ & 8 & $\underline{0}$ & i & , & 宫 \\
\hline & & $\sum$ & & 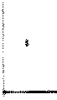 & ' & $\stackrel{m}{\infty}$ & $\tilde{0}$ & ' & . & . & & . & . & & 2 & $\stackrel{0}{\circ}$ & $\Xi$ & 8 & & . \\
\hline & & $\equiv$ & & 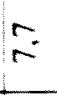 & . & $\infty$ & $\dddot{c}$ & , & . & . & & , & & & $\overline{\mathrm{i}}$ & 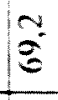 & $\vec{\square}$ & $\stackrel{\infty}{\equiv}$ & & $\overline{2}$ \\
\hline & 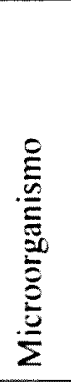 & & 总 & 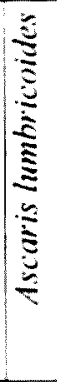 & 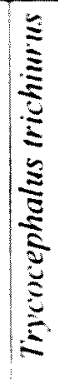 & 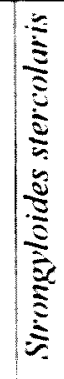 & 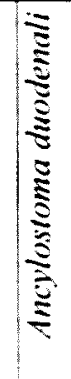 & 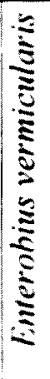 & 音 & 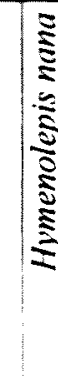 & (1) & 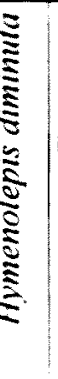 & $\stackrel{5}{\vdots}$ & 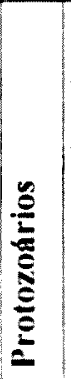 & 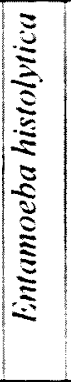 & & 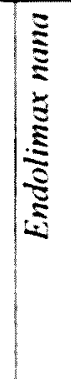 & 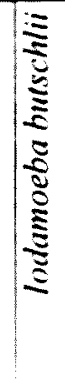 & 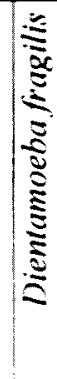 & 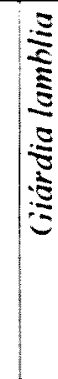 \\
\hline
\end{tabular}




\begin{tabular}{|c|c|c|c|c|c|c|c|c|c|c|c|c|c|c|c|c|c|c|c|c|}
\hline \multirow{5}{*}{\multicolumn{2}{|c|}{ 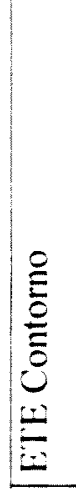 }} & \multirow{5}{*}{ 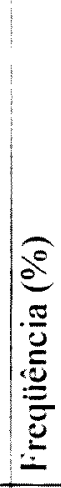 } & $\bar{\Sigma}$ & & $F$ & ' & $=$ & $\Leftrightarrow$ & ' & ' & $\ddot{3}$ & ' & ' & & $\underline{\underline{c}}$ & $\frac{m}{n}$ & 2 & 2 & 1 & $\underline{2}$ \\
\hline & & & $\geqq$ & & ' & 1 & $\varkappa^{\prime}$ & ' & & ' & ' & ' & ' & & $\begin{array}{l}0 \\
\approx\end{array}$ & 离 & ' & ' & ' & 0 \\
\hline & & & $\doteq$ & & ' & ' & $\infty$ & ' & ' & ' & ' & ' & ' & & ' & 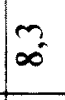 & $\begin{array}{l}0 \\
\approx \\
\sim\end{array}$ & 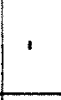 & ' & $m$ \\
\hline & & & $>$ & & ' & ' & ' & ' & ' & ' & ' & ' & ' & & $\underset{0}{0}$ & ' & 6 & ' & ' & Ö \\
\hline & & & $\doteq$ & & 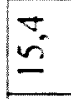 & ' & ' & $\overline{\hat{n}}$ & ' & ' & 2 & . & ' & & $\bar{i}$ & $\overline{\tilde{N}}$ & ' & $\therefore$ & ' & $\approx$ \\
\hline \multirow{5}{*}{\multicolumn{2}{|c|}{ 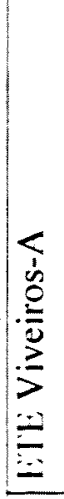 }} & \multirow{5}{*}{ 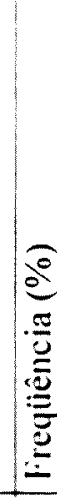 } & $\bar{\Sigma}$ & & $\underline{x}$ & 1 & $\approx$ & $\underset{ \pm}{ \pm}$ & $\dddot{n}$ & $\dddot{2}$ & ' & 2 & 1 & & $\stackrel{2}{\sim}$ & 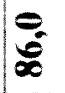 & $\stackrel{\check{N}}{\sim}$ & ๙্- & 1 & $\stackrel{2}{m}$ \\
\hline & & & $\geqq$ & & $\ddot{0}$ & . & $\bar{\sigma}$ & $\tilde{\infty}_{0}$ & ' & ' & ' & ' & ' & & $\begin{array}{l}m \\
\infty\end{array}$ & $\frac{m}{\infty}$ & $\infty^{2}$ & 吾 & ' & $\ddot{m}$ \\
\hline & & & $\dot{\Xi}$ & & 0 & , & $\begin{array}{l}0 \\
\approx \\
\sim\end{array}$ & 6 & ' & ' & ' & $\infty$ & 1 & & 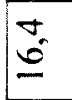 & $\frac{m}{\infty}$ & $\begin{array}{l}0 \\
i\end{array}$ & $\begin{array}{l}0 \\
i\end{array}$ & , & $\frac{\gamma}{\sigma}$ \\
\hline & & & $>^{j}$ & & ' & I & $\frac{\partial}{\infty}$ & 8 & ' & ' & ' & ' & 1 & & 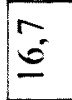 & $\frac{3}{\infty}$ & 6 & ' & ' & $\vec{m}$ \\
\hline & & & $\equiv$ & & $\stackrel{\infty}{=}$ & , & $\bar{j}$ & $\underline{\ddot{0}}$ & $\approx$ & $\approx$ & ' & ' & 1 & & $\begin{array}{l}\ddot{2} \\
\ddot{2}\end{array}$ & $\frac{2}{2}$ & $\overline{\tilde{i}}$ & $\ddot{\infty}$ & ' & $\approx$ \\
\hline \multirow{5}{*}{\multicolumn{2}{|c|}{ 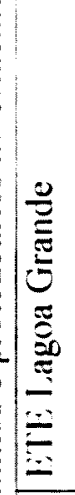 }} & \multirow{5}{*}{ 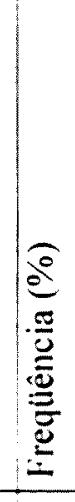 } & 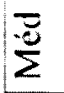 & & $z^{2}$ & ' & $\frac{\vec{T}}{\sigma}$ & $\stackrel{\sim}{\sim}$ & $\dddot{m}$ & ' & $\ddot{i}$ & ' & 1 & & $\Rightarrow$ & $\bar{x}$ & $\frac{1}{2}$ & $\Rightarrow$ & ' & 产 \\
\hline & & & $\geqq$ & & ' & ' & $\tilde{\infty}$ & $\begin{array}{l}0 \\
i \\
i\end{array}$ & $\infty$ & ' & ' & ' & ' & & ' & 8 & 6 & $\infty$ & ' & $\begin{array}{l}0 \\
\sim\end{array}$ \\
\hline & & & $\dot{\bar{\Xi}}$ & & ' & ' & $\Xi$ & $\underline{0}$ & & ' & ' & ' & 1 & & ' & $\begin{array}{l}2 \\
\infty \\
\infty \\
n\end{array}$ & $\begin{array}{l}0 \\
8 \\
8\end{array}$ & $\infty^{2}$ & ' & $\begin{array}{l}0 \\
\text { i }\end{array}$ \\
\hline & & & j & & 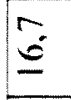 & ' & हे & $\ddot{m}$ & & ' & ' & ' & 1 & & ' & 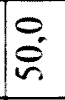 & 6 & ' & ' & 3 \\
\hline & & & $\doteq$ & & $\bar{i}$ & ' & $\infty$ & 㐫 & & ' & $\begin{array}{l}\vec{\sigma} \\
\ddot{2}\end{array}$ & ' & 1 & & $\bar{i}$ & $\infty$ & $\approx$ & $\pi$ & ' & $\cong$ \\
\hline \multirow{5}{*}{ 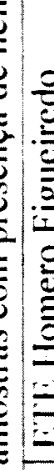 } & \multirow{5}{*}{ 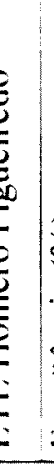 } & \multirow{5}{*}{ 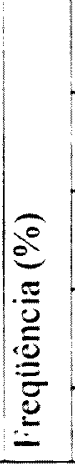 } & $\Sigma$ & & ' & ' & 3 & ' & ' & ' & ' & ' & 11 & & ' & 2 & 1 & ' & ' & ' \\
\hline & & & $\geqq$ & & ' & ' & ' & ' & & ' & 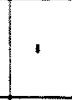 & ' & ' & & ' & ' & ' & ' & ' & \\
\hline & & & $\ddot{\Xi}$ & & ' & ' & $\infty$ & ' & ' & ' & ' & ' & ' & & ' & ' & ' & ' & ' & 1 \\
\hline & & & $\geq^{j}$ & & ' & ' & 1 & ' & 1 & ' & ' & ' & ' & & ' & ' & ' & ' & ' & ' \\
\hline & & & $\Xi$ & & ' & , & 1 & , & , & ' & . & , & ' & & . & $\approx$ & I & , & ' & , \\
\hline & & 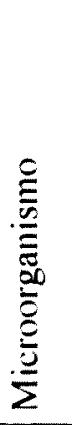 & & 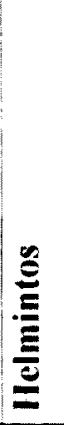 & 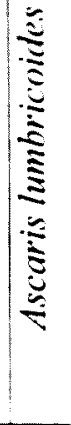 & 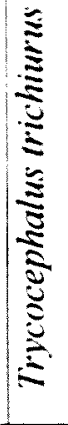 & 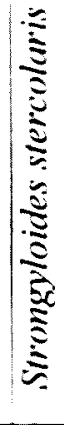 & 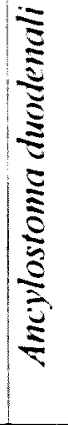 & 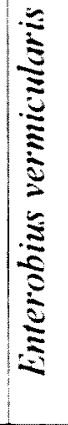 & 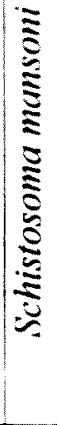 & 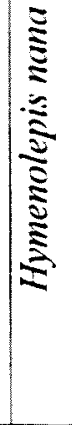 & 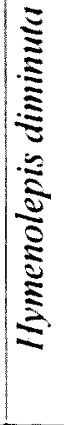 & 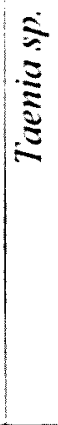 & 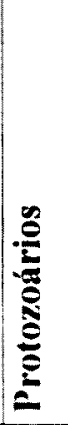 & & 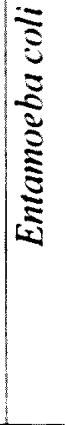 & 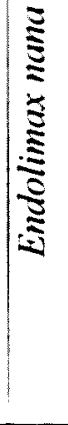 & 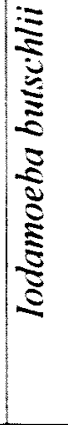 & 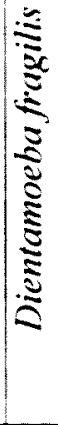 & \\
\hline
\end{tabular}




\begin{tabular}{|c|c|c|c|c|c|c|c|c|c|c|c|c|c|c|c|c|c|c|c|c|}
\hline \multirow{10}{*}{\multicolumn{2}{|c|}{ 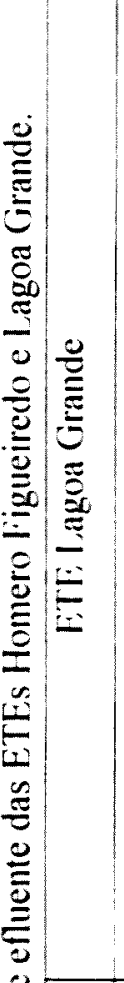 }} & \multirow[b]{2}{*}{$\sum^{\frac{a}{2}}$} & $\sum$ & & 2 & ' & $\frac{8}{7}$ & W & 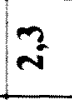 & 1 & $\dddot{i}$ & ' & ' & & $\Rightarrow$ & $\bar{x}$ & $\frac{1}{2}$ & $\Rightarrow$ & ' & बें \\
\hline & & & $\sum$ & & 2 & 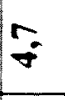 & 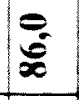 & F́ & ' & ' & ' & I & ' & & 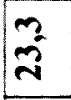 & $\bar{c}$ & बें & in & ' & लิ \\
\hline & & $\cong$ & $\sum$ & & & & $\frac{m}{\infty}$ & $\begin{array}{l}0 \\
i\end{array}$ & $\infty$ & ' & ' & ' & & & 1 & 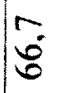 & 6 & $\infty$ & ' & $\begin{array}{l}0 \\
\tilde{n}\end{array}$ \\
\hline & & 㐫 & $\sum$ & & 2 & ' & $\Xi$ & $\begin{array}{l}\infty \\
\infty \\
\infty\end{array}$ & ' & . & ' & & & & $\frac{2}{m}$ & $\begin{array}{l}0 \\
i\end{array}$ & 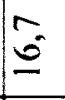 & $\bar{z}$ & ' & $\begin{array}{l}0 \\
i\end{array}$ \\
\hline & & $\cong$ & $\equiv$ & & & , & $\S$ & 5 & . & ' & ' & & & & ' & $\mid \begin{array}{l}m \\
\infty \\
\infty\end{array}$ & 离 & $\infty$ & ' & $\ddot{5}$ \\
\hline & & 三 & $\sum$ & & : & $\infty$ & $\frac{1}{5}$ & 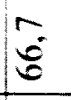 & ' & ' & ' & & 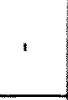 & & $\begin{array}{l}\sigma \\
i\end{array}$ & $\begin{array}{l}m \\
\infty \\
\infty\end{array}$ & $\ddot{m}$ & 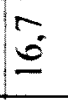 & . & $\infty$ \\
\hline & & & $\equiv$ & & 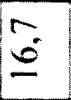 & ' & $\ddot{\theta}$ & $\ddot{m}$ & ' & ' & ' & & ' & & . & 官 & $\ddot{6}$ & ' & ' & $\ddot{\sigma}$ \\
\hline & & 袺 & $\sum$ & & 6 & ' & $\frac{2}{\infty}$ & $\frac{2}{\infty}$ & ' & ' & ' & . & 1 & & $m$ & 8 & $m$ & ' & ' & $m$ \\
\hline & & 这 & $\equiv$ & & $\bar{a}$ & ! & $\begin{array}{l}\infty \\
\infty \\
\infty\end{array}$ & 文 & ' & 1 & $\begin{array}{l}\ddot{0} \\
\ddot{0}\end{array}$ & ' & . & & $\overline{\tilde{i}}$ & $\infty$ & $\therefore$ & $\approx$ & ' & $\approx$ \\
\hline & & E & $\sum$ & & $\overrightarrow{0}$ & $\approx$ & 8 & $\Xi$ & ' & ' & ' & ' & ' & & $\approx$ & $\begin{array}{l}n \\
\infty\end{array}$ & 2 & $\overline{\hat{j}}$ & ' & $\infty$ \\
\hline$E$ & & $\Xi$ & E & & ' & 1 & 3 & ' & ' & ' & ' & ' & ' & & ' & $a^{2}$ & ' & ' & ' & ' \\
\hline & & $\sum$ & $\frac{E}{2}$ & & $a^{2}$ & ' & 8 & $\frac{2}{m}$ & ' & ' & ' & ' & ' & & $\begin{array}{l}y \\
\tilde{m}\end{array}$ & $\frac{6}{8}$ & aे & $\frac{a}{2}$ & ' & 孚: \\
\hline & & $\supseteqq$ & $\sum_{\text {I }}^{\equiv}$ & & ' & ' & ' & & ' & ' & ' & 1 & 1 & & ' & ' & ' & ' & ' & ' \\
\hline $\bar{\Xi}$ & 을 & 焉 & E & & ci & ' & $\frac{2}{\infty}$ & $\equiv$ & ' & ' & ' & 1 & 1 & & $\frac{m}{m}$ & 官 & 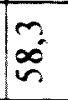 & 6 & ' & 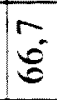 \\
\hline$\stackrel{\Xi}{\Xi}$ & $\frac{5}{0}$ & 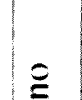 & $\equiv$ & & ' & : & $\infty$ & ' & ' & ' & ' & ' & ' & & ' & ' & ' & ' & ' & ' \\
\hline 0 & 竞 & 京 & E & & ' & & $\frac{1}{0}$ & 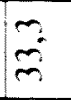 & ' & ' & ' & ' & ' & & $\frac{3}{3}$ & 8 & É & $\begin{array}{l}0 \\
\sim\end{array}$ & ' & $\ddot{8}$ \\
\hline$\Xi$ & $\overline{5}$ & & $\equiv$ & & ' & ' & ' & . & ' & ' & ' & & ' & & ' & & ' & ' & ' & ' \\
\hline \pm & & $\sum^{\frac{\pi}{2}}$ & $\sum$ & & 1 & ' & $\frac{m}{\infty}$ & 6 & ' & ' & ' & ' & ' & & $\frac{2}{m}$ & : & 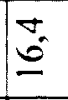 & $\ddot{\circ}$ & 1 & ' \\
\hline 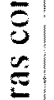 & & $\frac{5}{2}$ & 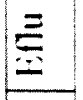 & & , & ' & ' & 1 & ' & ' & ' & & . & & ' & 2 & . & , & ' & ' \\
\hline$\leqq$ & & 莽 & $\equiv$ & & 2 & ' & $\frac{x}{\sigma}$ & 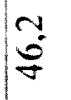 & ' & & 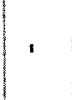 & & & & $\overline{\hat{i}}$ & $\frac{1}{8}$ & $\vec{\sigma}$ & $\stackrel{x}{\infty}$ & ' & $\bar{j}$ \\
\hline 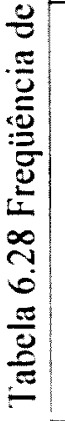 & 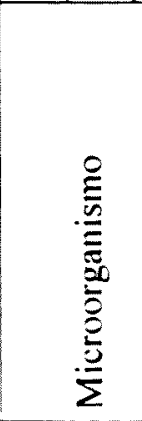 & & & 总 & 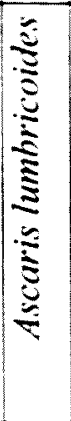 & 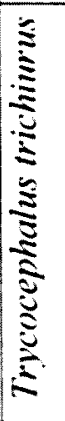 & 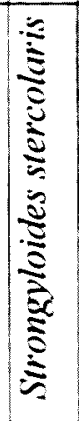 & 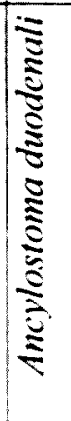 & 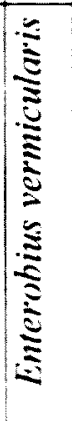 & 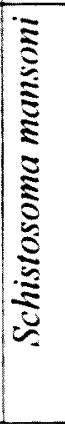 & 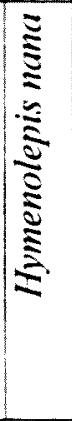 & 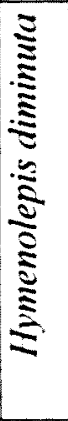 & $\underset{\Xi}{\vdots}$ & 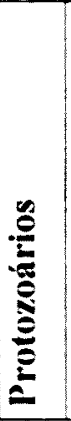 & 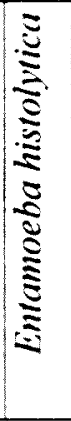 & 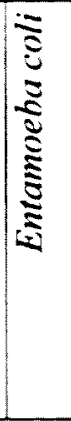 & 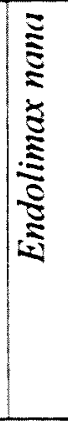 & 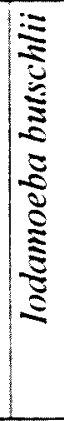 & 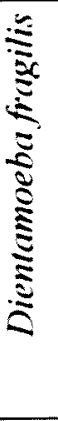 & 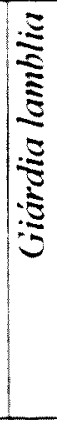 \\
\hline
\end{tabular}




\begin{tabular}{|c|c|c|c|c|c|c|c|c|c|c|c|c|c|c|c|c|c|c|c|c|}
\hline \multirow{10}{*}{ 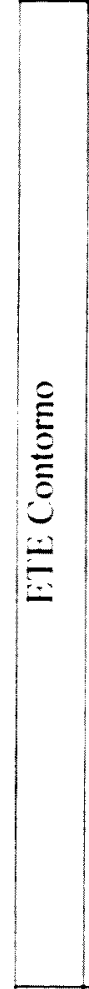 } & \multirow{10}{*}{ 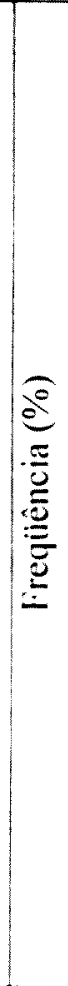 } & \multirow{2}{*}{ 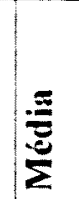 } & \multirow{2}{*}{\begin{tabular}{|l|}
$\sum$ \\
$\mathbf{S}$ \\
$\sum$ \\
$Z$
\end{tabular}} & & $F$ & ' & $\frac{5}{5}$ & $\Rightarrow$ & ' & ' & 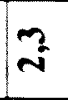 & ' & I & & $\underline{0}$ & 2 & 2 & $\ddot{n}$ & 1 & 3 \\
\hline & & & & & $\stackrel{a}{i}$ & 言 & $\frac{\sigma}{8}$ & $\begin{array}{l}x \\
v \\
v\end{array}$ & ' & ' & $F$ & $F$ & I & & $\begin{array}{l}0 \\
\infty\end{array}$ & है & 吾 & $\frac{1}{\infty}$ & ' & $\stackrel{a}{N}$ \\
\hline & & $\cong$ & $\equiv$ & & & & $\infty$ & & & & & & & & $\begin{array}{l}0 \\
\tilde{i}\end{array}$ & $\begin{array}{l}0 \\
\ddot{8}\end{array}$ & & & & 10 \\
\hline & & 㐫 & $\stackrel{\equiv}{\Sigma}$ & & $\hat{m}$ & $\begin{array}{l}0 \\
0 \\
i\end{array}$ & 8 & $\frac{F}{\dot{\sigma}}$ & ' & ' & 6 & ' & , & & 6 & $\begin{array}{l}0 \\
i\end{array}$ & $\infty$ & $\frac{\gamma}{\sigma}$ & ' & F \\
\hline & & $\supseteqq$ & $\equiv$ & & ' & ' & $\infty$ & 1 & ' & ' & ' & . & ' & & 1 & $m^{\prime}$ & $\begin{array}{l}0 \\
\sim \\
\sim\end{array}$ & ' & ' & $\infty$ \\
\hline & & $\bar{\Xi}$ & 妾 & & $E$ & 1 & 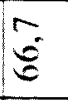 & $\bar{\sigma}$ & ' & ' & ' & ' & ' & & $\begin{array}{l}0 \\
\sim \\
\sim\end{array}$ & $\ddot{m}$ & $\bar{F}$ & $\ddot{8}$ & 1 & $\Xi$ \\
\hline & & & $\equiv$ & & ' & ' & . & ' & ' & ' & ' & ' & . & & 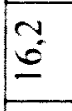 & ' & $\ddot{0}$ & I & ' & $\ddot{\ddot{n}}$ \\
\hline & & $\sum^{\check{\Xi}}$ & 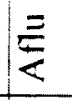 & & $\begin{array}{l}0 \\
\dot{n}\end{array}$ & ' & $\ddot{8}$ & $\hat{8}$ & ' & ' & ' & $\sigma^{\circ}$ & ' & & ' & 8 & , & $\hat{8}$ & ' & $\dot{m}$ \\
\hline & & 童 & E & & $\ddot{\theta}$ & ' & 1 & $\overline{\vec{v}}$ & ' & ' & $\approx$ & , & , & & $\overline{\vec{j}}$ & $\bar{i}$ & ' & 2 & ' & 2 \\
\hline & & 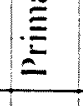 & $\sum$ & & $\vec{i}$ & ' & $\begin{array}{l}\infty \\
n \\
n\end{array}$ & $\underset{\leftarrow}{0}$ & : & ' & . & ' & . & & $\bar{i}$ & $\infty$ & ' & $\begin{array}{l}\infty \\
\tilde{\omega}\end{array}$ & , & $\overline{\vec{v}}$ \\
\hline & & $\equiv$ & $\sum_{\Sigma}^{E}$ & & 0 & ' & $\frac{1}{2}$ & $\underset{\dot{u}}{8}$ & $\ddot{n}$ & $\stackrel{2}{i}$ & ' & 3 & ' & & $\frac{a}{2}$ & $\infty$ & $\begin{array}{l}0 \\
0 \\
i\end{array}$ & ָू & 1 & rू \\
\hline & & $\bar{\Sigma}$ & $\sum$ & & 今े & ' & $\begin{array}{l}\infty \\
0 \\
0\end{array}$ & $\frac{\partial}{\sigma}$ & ' & 1 & I & I & ' & & 今ू & $\hat{0}$ & $\begin{array}{l}0 \\
\tilde{i} \\
\tilde{y}\end{array}$ & $\begin{array}{l}r_{2} \\
6 \\
0\end{array}$ & . & I \\
\hline & & $\stackrel{一}{\varrho}$ & $\sum_{\underline{I}}^{\Xi}$ & & $\underline{6}$ & ' & $\frac{F}{\bar{\sigma}}$ & $\infty$ & & & & & & & $\begin{array}{l}m \\
\infty \\
\infty\end{array}$ & $\hat{\infty}$ & $\infty$ & $\ddot{8}$ & ' & $\dot{m}$ \\
\hline & & $\stackrel{0}{\text { D }}$ & $\sum$ & & $\begin{array}{l}0 \\
\approx \\
\approx\end{array}$ & ' & $\frac{m}{\infty}$ & $\begin{array}{l}\dot{n} \\
\dot{n}\end{array}$ & ' & ' & ' & ' & I & & $\underline{E}$ & $\hat{\infty}$ & $\frac{F}{\bar{\sigma}}$ & $\vec{m}$ & . & 6 \\
\hline 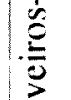 & $\frac{\Xi}{\tilde{J}}$ & $\supseteqq$ & 湴 & & 6 & & i & $\underline{0}$ & ' & ' & ' & $\hat{\infty}$ & . & & 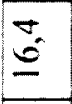 & $\frac{2}{\infty}$ & $\vec{n}$ & $\begin{array}{l}0 \\
\infty \\
\infty\end{array}$ & ' & $\bar{F}$ \\
\hline$\underset{\Xi}{\check{E}}$ & $\stackrel{\overline{\bar{g}}}{\overline{\bar{\Xi}}}$ & $\stackrel{\Xi}{\Xi}$ & 衣 & & $\hat{m}$ & ' & $\frac{1}{0}$ & $\begin{array}{l}\vec{y} \\
\text { in }\end{array}$ & ' & ' & ' & ' & 1 & & 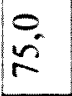 & Ö. & $\begin{array}{l}0 \\
0 \\
\sim\end{array}$ & 8 & ' & , \\
\hline$\because$ & $1-$ & & 宓 & & ' & 1 & $\frac{2}{\infty}$ & $\hat{6}$ & ' & ' & ' & . & ' & & $\underline{6}$ & $\omega_{2}^{2}$ & $\sqrt{8}$ & ' & ' & $\ddot{m}$ \\
\hline & & $>$ & $\underset{\sum}{\Sigma}$ & & $\underline{0}$ & & $\hat{\infty}^{2}$ & 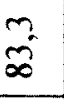 & ' & ' & ' & ' & ' & & $m$ & 8 & $\hat{m}$ & ' & ' & $\stackrel{m}{m}$ \\
\hline & & $\stackrel{5}{2}$ & $\equiv$ & & $\begin{array}{l}\infty \\
0 \\
0\end{array}$ & ' & $\bar{i}$ & $\vec{v}$ & $\pi$ & 2 & ' & ' & 1 & & $\underline{\tilde{v}}$ & $\hat{a}$ & $\overline{\hat{i}}$ & 恶 & ' & $\infty$ \\
\hline & & 玹 & $\sum$ & & $\ddot{\square}$ & 1 & $\stackrel{2}{\circ}$ & $\begin{array}{l}z \\
g\end{array}$ & ' & . & ' & . & & & 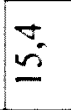 & iे & $\vec{\sim}$ & $\dot{\rho}_{\infty}^{\infty}$ & ' & $\infty$ \\
\hline & 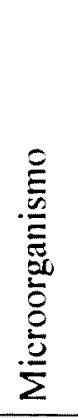 & & & 总 & 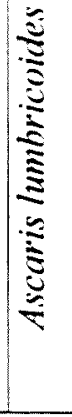 & 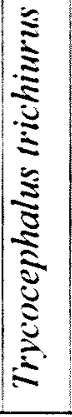 & 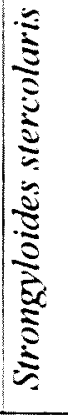 & 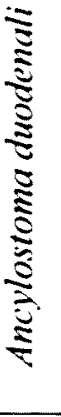 & 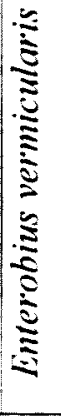 & 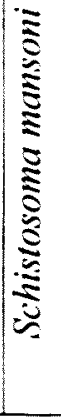 & 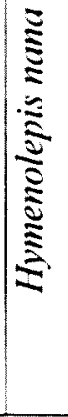 & 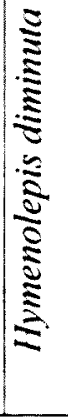 & 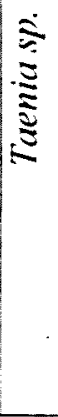 & 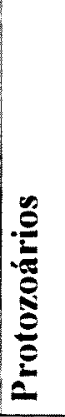 & 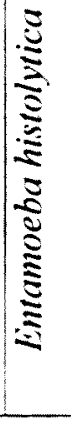 & 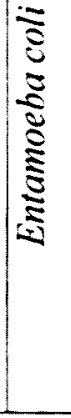 & 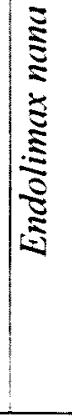 & 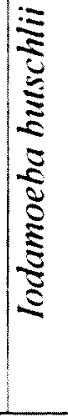 & 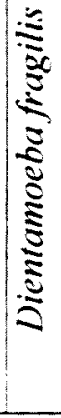 & 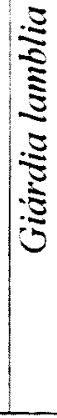 \\
\hline
\end{tabular}




\subsection{Levantamento das situações de risco à saúde dos usuários de jusante dos lançamentos das ETEs Homero Figueiredo, Lagoa Grande, Viveiros- A e Contorno}

De acordo com a Resolução n $^{\circ} 20$ (CONAMA 1986), corpo d'água de Classe 1 não pode ter mais que 200 coliformes fecais em $100 \mathrm{ml}$ em suas águas, de Classe 2 até 1.000 coliformes fecais em $100 \mathrm{ml}$ e de Classe 3 até 4.000 coliformes fecais em $100 \mathrm{ml}$. Corpos dágua de Classe 1 e 2 podem ser utilizados para abastecimento doméstico após tratamento; para recreação de contato primário; para irrigação de hortaliças que são comidas cruas e de frutas que se desenvolvem rente ao chão e são ingeridas cruas com casca: e para criação natural e/ou intensiva de espécies destinadas à alimentaçào humana (aqüicultura). Corpos d'água de Classe 3 podem ser usados para abastecimento doméstico após tratamento convencional, para dessedentação de animais e irrigação de culturas arbóreas, cerealíferas e forrageiras.

Giardia lamblia e outros protozoários, bem como helmintos, parasitos do intestino humano, são lançados nos corpos receptores dos efluentes das ETEs Homero Figueiredo (Riacho do Barão); Lagoa Grande (Riacho Lagoa Grande); Viveiros-A (Riacho do Fato) e Contorno (Riacho Principal) juntamente como coliformes fecais, em quantidades da ordem de $10^{6}$ por $100 \mathrm{ml}$. Segundo LEITE e AISSE (1998), o tempo de sobrevivència de Salmonelas e de outras bactérias patogênicas é o mesmo dos coliformes. logo, a probabilidade é grande de existirem, também, bactérias patogênicas nesses corpos d’água, devido ao lançamento de esgotos tratados das ETES estudadas.

Água para consumo humano, considerada potável, não pode apresentar nenhum valor de Escherichia coli ou coliformes termotolerantes (coliformes fecais), conforme definida na Portaria 1469 de 29/12/2000 (MS 2001) que substitui a Portaria 36 de 19/01/1990 (MS 1997).

Coliformes fecais da ordem de $10^{6} \mathrm{NMP} / 100 \mathrm{ml}$ estão muito acima do limite estabelecido para corpos hídricos de Classe $3\left(4 \times 10^{3} \mathrm{NMP} / 100 \mathrm{ml}\right)$, o qual, mesmo 
assim, ainda pode ser utilizado para abastecimento humano após tratamento convencional, para dessedentação de animais e para irrigação de culturas arbóreas, cerealifera e forrageira.

Segundo Mc CANN (1999), as barreiras de uma estação de tratamento de água podem não ser seguras quanto à passagem do Cryptosporidim parvum, da Giardia lamblia e de outros microrganismo patogênicos. Assim, as águas dos corpos receptores das ETEs Homero Figueiredo, Lagoa Grande, Viveiros-A e Contorno não são seguras para consumo humano sem tratamento, representando riscos para a saúde de seus usuários.

O uso dessas águas para irrigação representa risco, por duas razões: uma, pelo contato direto de seus usuários e outra, pelo consumo de hortaliças e frutas irrigadas com as águas desses córregos.

A pesca nessas águas também é uma atividade de risco pelo contato direto que se estabelece entre a água e o pescador, e pelo consumo do pescado sem o cozimento adequado, pois este pode estar contaminado com agentes patogênicos retidos nas escamas.

A utilização desses recursos hídricos para atividades de recreação de contato primário também representa atividade de risco à saúde humana, considerando-se que existem helmintos e protozoários, parasitos do intestino humano, bem como as altas concentrações de coliformes fecais. Conseqüentemente, há a probabilidade da presença de outras bactérias e patógenas nessas águas.

Os usuários de jusante dos corpos hídricos que recebem os efluentes das quatro estações de tratamento de esgotos sanitários, direta ou indiretamente, fazem parte de um grupo potencial de risco quanto aos agravos à saúde, representados por doenças parasitárias do intestino humano. Este grupo contribui para a permanência e disseminação dessas doenças nessas e, mesmo, em outras comunidades que contam com os serviços de abastecimento de água e esgotamento sanitário. 


\section{CONCLUSÕES}

\subsection{Estação Homero Figueiredo}

A ETE Homero Figueiredo encontra-se operando com folga de $25 \%$ em relação à carga orgânica definida em projeto. Essa estação apresentou melhor rendimento na remoção de $\mathrm{DBO}_{5}$, coliformes fecais, helmintos e protozoários em relação às demais estudadas. Quanto à $\mathrm{DBO}_{5}$, o esgoto fica enquadrado no padrão aceitável pela NT002 da Resolução 2288 (CEPRAM 2000), para o verão, outono e inverno e com resultado muito próximo para a primavera. Quanto à remoção de coliformes fecais os esgotos enquadram-se no padrão estabelecido na NT002 da Resolução 2288 (CEPRAM 2000) para as quatro estações do ano (primavera, verão, outono e inverno).

No afluente à ETE, os helmintos Strongyloides stercolaris e o Ancylostoma duodenali foram identificados em todas as estações do ano. Quanto aos protozoários pesquisados, a Dientamoeba fragilis não foi encontrada em nenhuma das estações do ano, a G. lamblia o foi em três estações (primavera, outono e inverno) e os demais protosoários estudados estiveram presentes durante todo o ano (E. histolytica, E. coli, E. nana e I. butschlii). A presença desses microorganismos no afluente à ETE caracteriza que pessoas da comunidade são portadores sãos, ou doentes.

Por dispor de digestor anaeróbio em série com lagoa facultativa e tempo de detenção de 269:12 h (11,22 dias) a ETE Homero Figueiredo apresentou resultado satisfatório quanto à remoção de helmintos e protozoários, em relação às demais estações estudadas.

Os resultados da operação da ETE Homero Figueiredo mostraram-se superiores às demais estações estudadas, quanto à capacidade de remoção de coliformes fecais. No entanto, o valor médio calculado de coliformes fecais para o efluente ficou muito acima do desejado. Para não configurar risco sanitário na utilização das águas do corpo receptor (após tratamento para alguns usos), seria necessário que o Riacho do 
Barão apresentasse vazão 2.400 vezes maior que a do efluente da ETE para que ocorresse diluição do esgoto tratado, mantendo o corpo receptor enquadrado como Classe 2, conforme Resolução $n^{\circ} 20$ (CONAMA 1986), o que não ocorre na realidade local.

Como a ETE Homero Figueiredo não remove protozoários e helmintos na sua totalidade nem coliformes no padrão desejado, os usuários de jusante do corpo dágua receptor (riacho do Barão) ficam submetidos a situação de riscos de agravos à saúde devido à utilização da água desse córrego sem o devido tratamento, já que o fazem para as atividades de banho, irrigação de culturas e dessedentação de animais.

A razão DQO/DBO dessa ETE encontra-se conforme os valores indicados na literatura, ou seja, na faixa de $1,7-2,4$. Como os valores encontrados estão próximos de dois, isto significa que o esgoto é predominantemente de origen residencial e não ocorre decomposição considerável, entre a coleta e a entrada à estação de tratamento.

\subsection{Estação Lagoa Grande}

A ETE Lagoa Grande encontra-se operando no limite da carga orgânica prevista em projeto. Apresentou o menor rendimento em remoção de carga orgânica - DBO estando o efluente, nas quatro estações do ano, abaixo do padrão aceitável estabelecido na NT002 da Resolução 2288 (CEPRAM 2000). O efluente da ETE Lagoa Grande está sendo lançado no corpo receptor (riacho Lagoa Grande) em desacordo à referida resolução.

Os helmintos Ascaris lumbricoides, Trycocephalus trichiurus, Strongyloides stercolaris e o Ancylostoma duodenali foram identificados no afluente à ETE, bem como os protozoários E. histolytica, E. coli, E. nana, I. butschlii e a Giárdia lamblia. A presença desses microorganismos no afluente à ETE caracteriza que pessoas da comunidade são portadores sãos, ou doentes. 
Entre os helmintos encontrados no efluente à ETE em todas as estações do ano, temos o Strongyloides stercolaris e o Ancylostoma duodenal. Em apenas algumas duas estações, o Ascaris lumbricoides, o $T$. trichiurus, o $E$. vermicularis o $\mathrm{S}$. mansoni e a H. nana. Quanto aos protozoários, temos a E. coli, E. histolytica, E. nana e a $G$. lamblia em todas as estações do ano e em algumas a I. butschlii e a $E$. histolytica.

A ETE dispõe de digestores anaeróbios em série, operando com o menor tempo de detenção (12:12h) das quatro estudadas e não apresentou bons resultados quanto à remoção de helmintos e protozoários no tratamento do esgoto sanitário, como já era esperado.

Como a ETE Lagoa Grande não remove helmintos e protozoários nem coliformes no padrão desejado, os usuários de jusante do corpo dágua receptor (riacho Lagoa Grande) estão submetidos a situação de riscos de agravos à saúde devido à utilização da água desse córrego sem o devido tratamento, já que o fazem para atividades de banhos, irrigação de culturas e dessedentação de animais.

A ETE Lagoa Grande comporta-se como o esperado quanto à capacidade de remoção de coliformes fecais do esgoto sanitário. Atende à NT002 da Resolução 2288 (CEPRAM 2000), entretanto, os valores médios de coliformes fecais registrados para o efluente ficaram muito acima do desejado. Para não configurar risco sanitário na utilização das águas do corpo receptor (após tratamento para alguns usos) seria necessário que o mesmo (riacho Lagoa Grande) apresentasse vazão 9.100 vezes maior que a do efluente da ETE para que ocorresse a diluição do esgoto tratado, mantendo-se o mesmo enquadramento como Classe 2, conforme Resolução $n^{\circ} 20$ (CEPRAM 1986), o que não corre.

A razão DQO/DBO dessa ETE encontra-se conforme valores indicados na literatura, na faixa de 1,7 a 2,4. Como os resultados são superiores a 2,0 para a primavera, verão e outono, é provável que o processo de decomposição do esgoto sanitário ocorra entre a coleta e a entrada à estação de tratamento. 


\subsection{Estação Viveiros $\mathrm{A}$}

A ETE Viveiros-A encontra-se operando no limite da carga orgânica prevista em projeto e apresentou rendimento intermediário em remoção de $\mathrm{DBO}_{5}$ em relação às demais estações estudadas. Quanto à $\mathrm{DBO}_{5}$, o esgoto efluente a ETE Viveiros-A ficou abaixo do padrão aceitável pela NT002 da Resolução 2288 (CEPRAM 2000), para a primavera e verão, e acima do padrão, para o outono e inverno.

A ETE Viveiros-A comporta-se como esperado quanto à capacidade de remoção de coliformes fecais. Atende a NT002 da Resolução 2288 (CEPRAM 2000) para a primavera, verão e outono e remoção abaixo, para o inverno. Os valores médios registrados no efluente ficaram muito acima do desejado. Para não configurar riscos sanitários na utilização das águas do corpo receptor (após tratamento para alguns usos) seria necessário que o mesmo apresentasse vazão 13.000 vezes maior que a do efluente da ETE, para que ocorresse a diluição do esgoto tratado, mantendo-se o mesmo enquadrado como Classe 2, conforme Resolução n 20 (CONAMA 1986), o que não ocorre na prática.

Os helmintos $A$. lumbricoides, $S$. stercolaris e o A. duodenali foram identificados no afluente à ETE, bem como os protozoários E. histolytica, E. coli, E. nana, I. butschlii e a Giárdia lamblia. A Dientamoeba fragilis não foi encontrada em nenhuma das estações do ano. A presença desses microorganismos no afluente à ETE caracteriza que pessoas da comunidade são portadores sãos ou doentes.

Os helmintos presentes em todas as estações do ano no efluente da ETE foram $S$. stercolaris, A. duodenali e o A. lumbricoides. Quanto aos protozoários foram encontrados em todas as estações do ano a $E$. coli, E. histolytica e a $E$. nana.Em algumas estações, a I. butschliie e a G. lamblia.

Por dispor de digestores anaeróbios em série e tempo de detenção de 20:48h a ETE Viveiros-A não apresentou bons resultados na remoção de helmintos e protozoários confoeme já esperado. 
Como a ETE não remove helmintos e protozoários e nem coliformes no padrão desejado, os usuários de jusante do corpo d'água receptor (riacho do Fato) estão submetidos a situações de riscos de agravos à saúde devido à utilização da água desse riacho sem o devido tratamento, já que o fazem para atividades de banho e de dessedentação de animais.

A razão DQO/DBO encontra-se acima do esperado para esgoto doméstico na primavera, verão e outono e coerente no inverno. Como a razão de DBO/DQO é maior que 2,0 deve estar ocorrendo decomposição do esgoto entre a coleta e a entrada à ETE, ou existe lançamento de esgoto orgânico não biodegradável na rede coletora.

\subsection{Estação Contorno}

A ETE Contorno encontra-se operando acima do limite da carga orgânica prevista em projeto, em mais de $21 \%$. Mesmo operando com carga orgânica acima da capacidade nominal, apresentou o segundo maior rendimento em relação às ETEs estudadas. Quanto à $\mathrm{DBO}_{5}$, o efluente da ETE Contorno ficou abaixo do padrão aceitável pela NT002 da Resolução 2288 (CEPRAM 2000), no verão, outono e inverno e acima, na primavera. Entretanto, a média de remoção de $\mathrm{DBO}_{5}$ anual fica muito próxima do limite mínimo aceitavel pela NT002 da Resolução 2288 (CEPRAM 2000).

Os helmintos $A$. lumbricoides, $S$. stercolaris e o Ancylostoma duodenali foram identificados no afluente à ETE durante todo o ano, bem como os protozoários $E$. coli, I. butschlii e a Giárdia lamblia. E em duas e três estações, a E. nana, E. histolytica, respectivamente. A Dientamoeba fragilis não foi encontrada em nenhuma das estações do ano. A presença desses microorganismos no afluente à ETE caracteriza que pessoas da comunidade são portadores sãos ou doentes desses microrganismos. 
A ETE Contorno, com tempo de detenção de $86: 00 \mathrm{~h}$ ( 7,0 vezes maior que o tempo de detenção da ETE Lagoa Grande e 4,7 vezes maior que o tempo de detenção da ETE Viveiros-A), não apresentou resultados melhores que os destas estações (com tempo de detenção de $12: 12 \mathrm{~h}$ e $20: 48 \mathrm{~h}$ respectivamente) quanto à remoção de coliformes fecais e totais. Quanto à de protozoários e helmintos, opera melhor que as ETEs referidas (Lagoa Grande e Viveiros-A) e pior que a ETE Homero Figueiredo, como esperado.

Os helmintos presentes em todas as estações do ano no efluente da ETE foram Ancylostoma duodenal, Strongyloides stercolaris e o Ascaris lumbricoides. Quanto aos protozoários, foram encontrados em todas as estações do ano a Entamoeba coli, Iodamoeba butschlii e a Giardia lamblia. Em algumas estações do ano a Entamoeba histolytica e Endolimax nana.

A ETE Contorno não se comporta como o esperado em projeto quanto à capacidade de remoção de coliformes fecais do esgoto sanitário. Atende à NT002 da Resolucão 2288 (CEPRAM 2000), entretanto, os valores médios de coliformes fecais registrados para o efluente ficaram muito acima do desejado. Para não configurar riscos sanitários na utilização das águas do corpo receptor (riacho Principal) seria necessário que o corpo receptor apresentasse vazão 8.200 vezes maior que a vazão do efluente da ETE, para diluir o esgoto tratado e manter o mesmo como de Classe 2, conforme Resolução n 20 (CONAMA 1986). Observa-se que a vazão desse corpo receptor, durante a maior parte do ano, é infeior à do efluente da ETE.

Como a ETE Contorno não remove helmintos, protozoários e coliformes no padrão desejado, os usuários de jusante do corpo dágua receptor (riacho Principal) estão submetidos a situação de riscos de agravos à saúde devido à utilização da água desse riacho sem o devido tratamento, já que o fazem para atividades de banho, irrigação de culturas, dessedentação de animais e recreação de contato primário.

A razão $\mathrm{DQO} / \mathrm{DBO}$ dessa $\mathrm{ETE}$ encontra-se acima da faixa indicada na literatura para esgotos residenciais $(1,7-2,4)$ para a primavera e inverno, e na faixa, para as demais 
estações do ano. Os esgotos da comunidade Contorno decompõem-se, em parte, entre a coleta e a chegada à ETE e recebem carga de esgoto orgânico não biodegradável na rede, justificando o resultado.

\subsection{Geral}

Nas quatro ETEs estudadas, evidenciou-se a persença de helmintos e protozoários, parasitos do intestino humano, nos esgotos sanitários das respectivas localidades, nas quatro estações do ano. Este fato indica que há, nas populações estudadas, portadores, sintomáticos ou assintomáticos, desses agentes patogênicos e que os esgotos sanitários veiculam tais agentes no ambiente.

Nenhuma estação de tratamento de esgoto pesquisada apresentou-se completamente segura quanto à remoção de helmintos, protozoários e coliformes, logo, o tratamento dos esgotos sanitários, configurado nos diferentes sistemas estudados, não garante efluentes com qualidade adequada para lançamento em corpos d'água utilizados para distintos usos como: consumo humano; banho; atividades de recreação de contato primário, irrigação de culturas e dessedentação de animais.

Os valores per-capita de consumo de água calculados para as comunidades estudadas indicam que os hábitos das pessoas dessas comunidades mudaram quanto ao gasto de água, após a implantação de micromedição, pela Empresa Bahiana de Águas e Saneamento S. A., o que monitorou a redução de tal consumo.

A pesquisa do Criptosporidium, que consegue passar pelas barreiras de estações de tratamento de água e resistir a dosagens baixas de cloro residual, não foi possivel devido a limitações do laboratório de parasitologia humana da UEFS. O uso das águas dos corpos receptores das ETEs pesquisadas, mesmo com tratamento convencional, pode colocar os usuários em situação de risco de agravo à saúde, riscos estes aumentados se tais águas não sofrerem tratamento, como ocerre. 
Os helmintos predominantes nos efluentes das ETEs foram o S. stercolaris, $A$. duodenali e A. lumbricoides. Quanto aos protozoários a predominância ficou para a E. coli, E. nana, G. lamblia, E. histolytica e I. butschlii.

Como existem tais organismos no esgoto sanitário afluente e no efluente, não é só tratamento que resolve. Há necessidade de outras ações, como educação sanitária, para o uso adequado do sistema e para mudança de hábitos, de higiene, por exemplo.

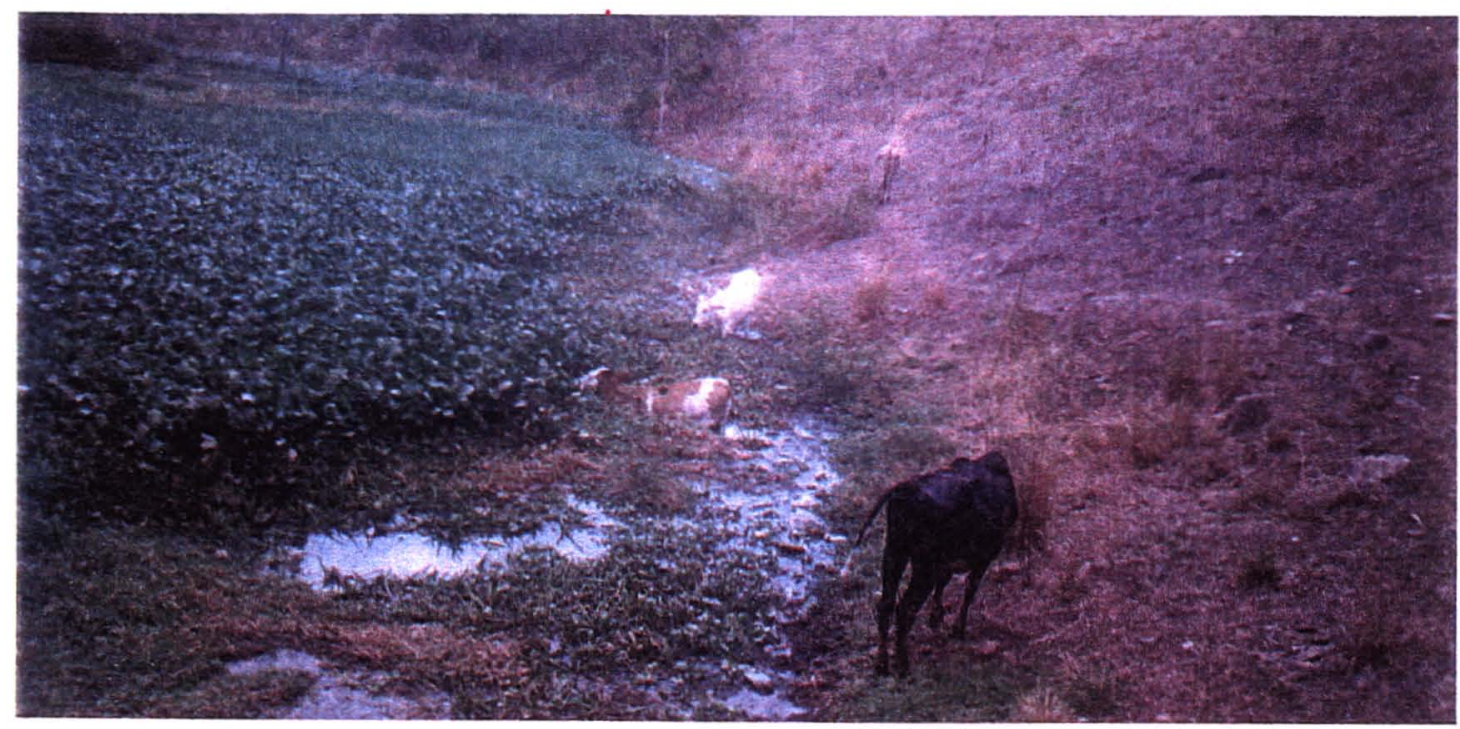

Foto 16. Dessedentação de animais (Gado) no Riacho Principal, a jusante da descarga da ETE Contorno.

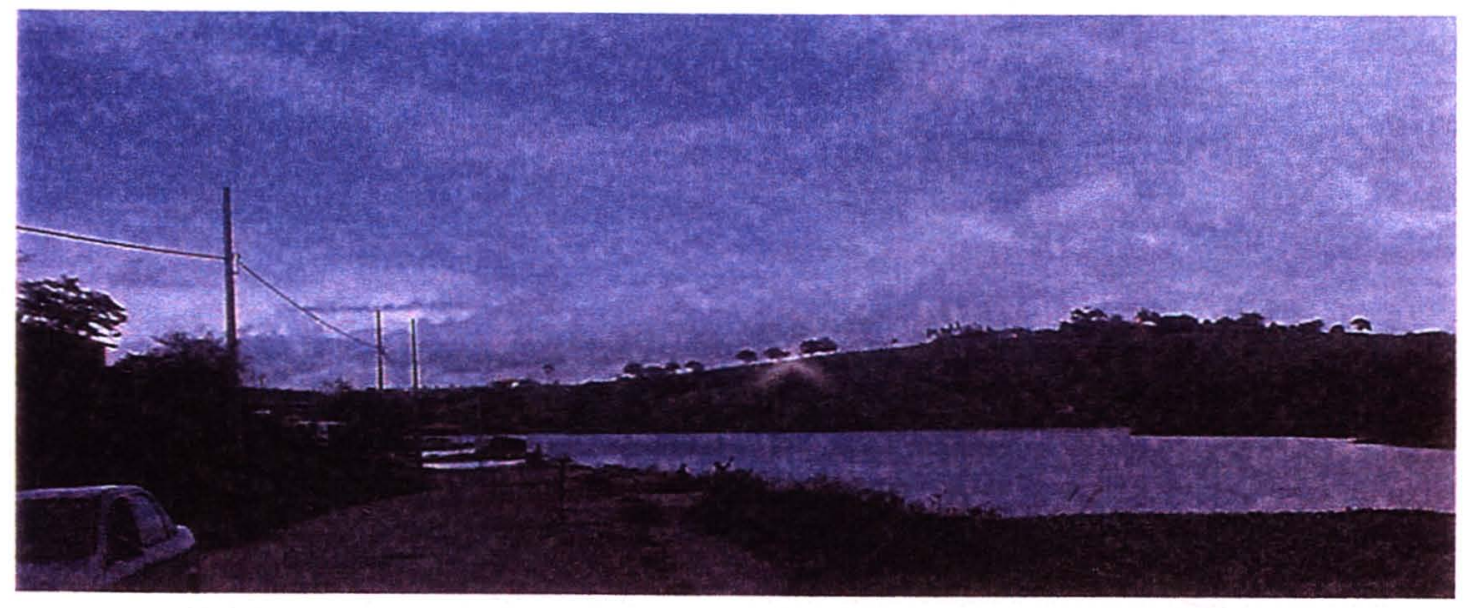

Foto 17 Pescador na área de descarga do Riacho Principal na Bacia da Barragem de Pedra do Cavalo. 


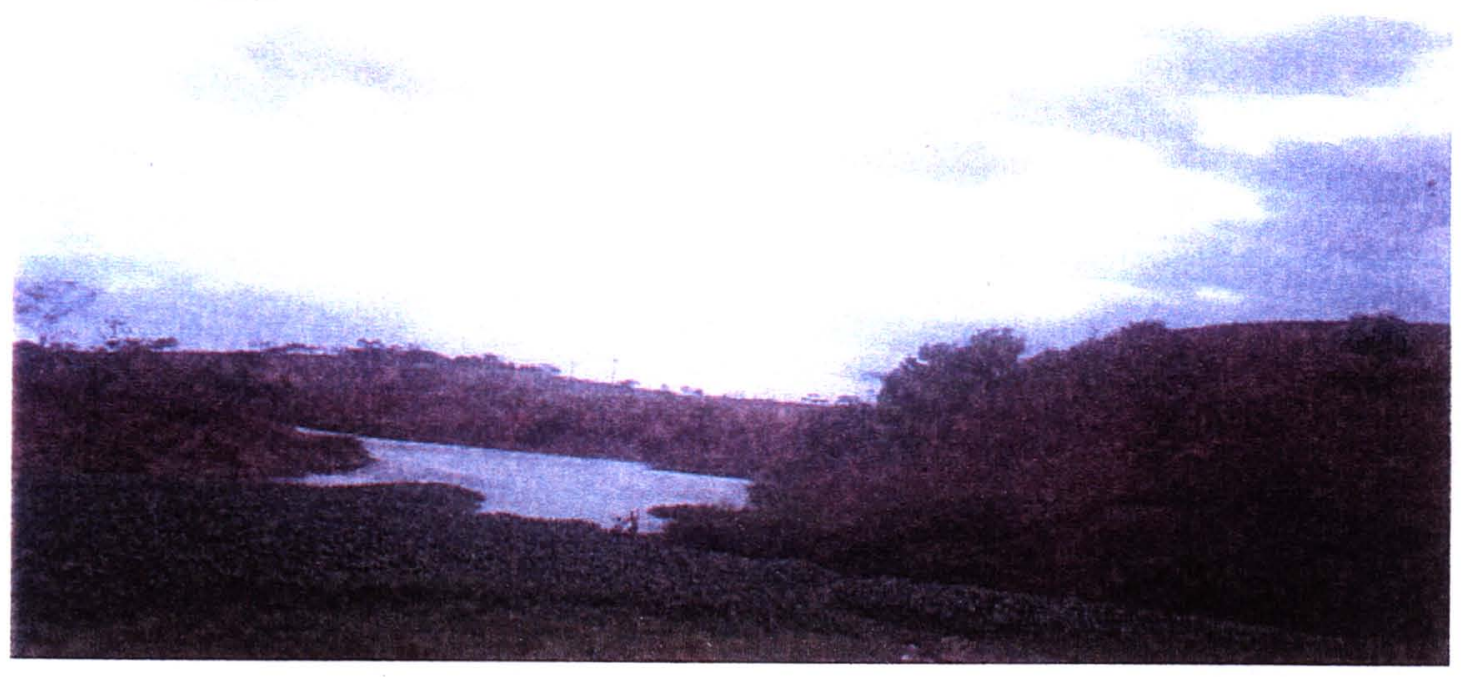

Foto 18. Pescador na área de descarga do Riacho Principal, na Bacia da Barragem Pedra do Cavalo.

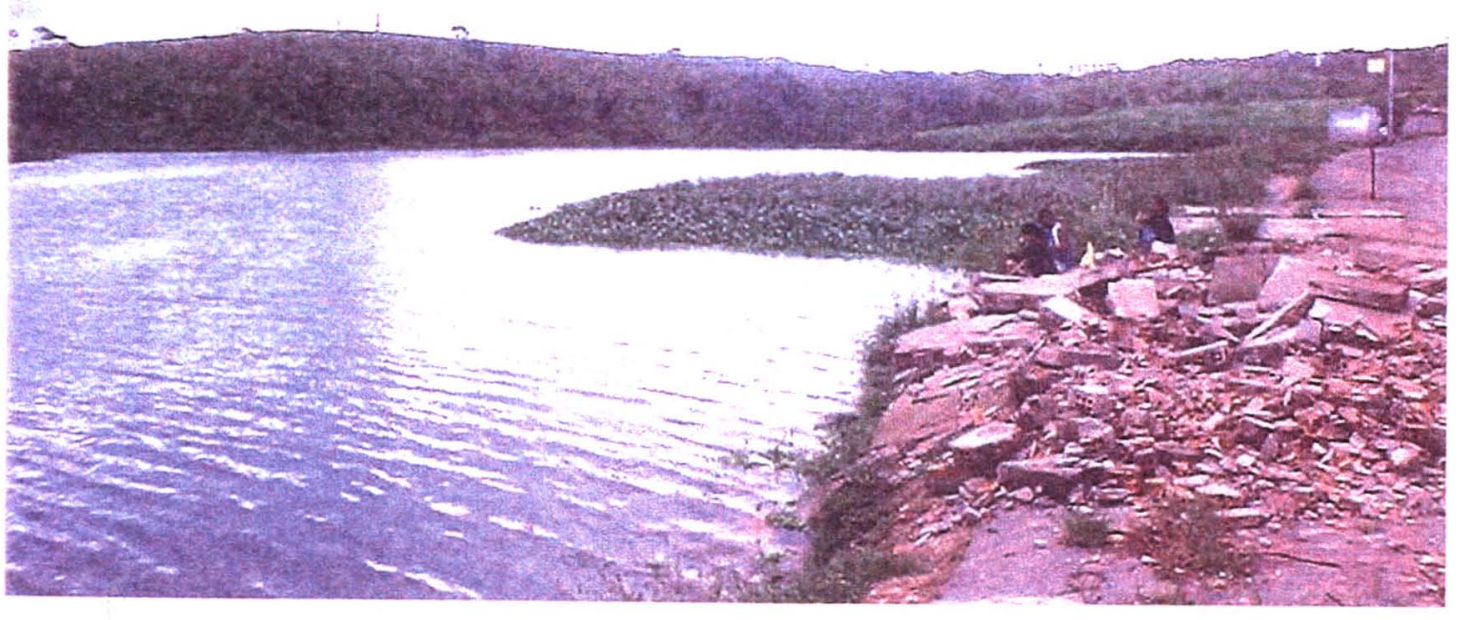

Foto 19. Pescador na área de descarga do Riacho Principal, na Bacia da Barragem Pedra do Cavalo. 


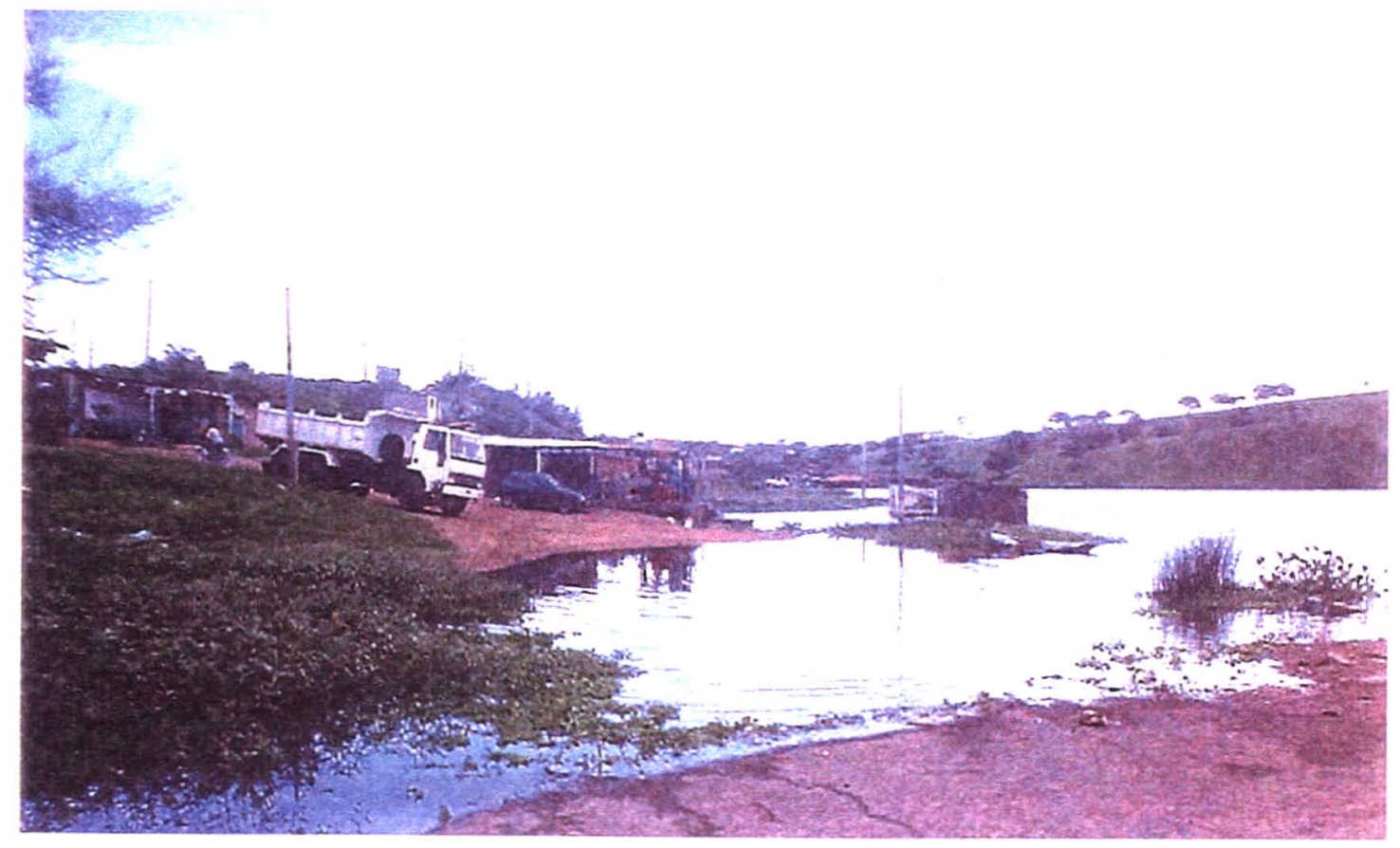

Foto 20. Área de utilização de contato primário, banho, na Bacia da Barragem de Pedra do Cavalo, no ponto da descarga do Riacho Principal.

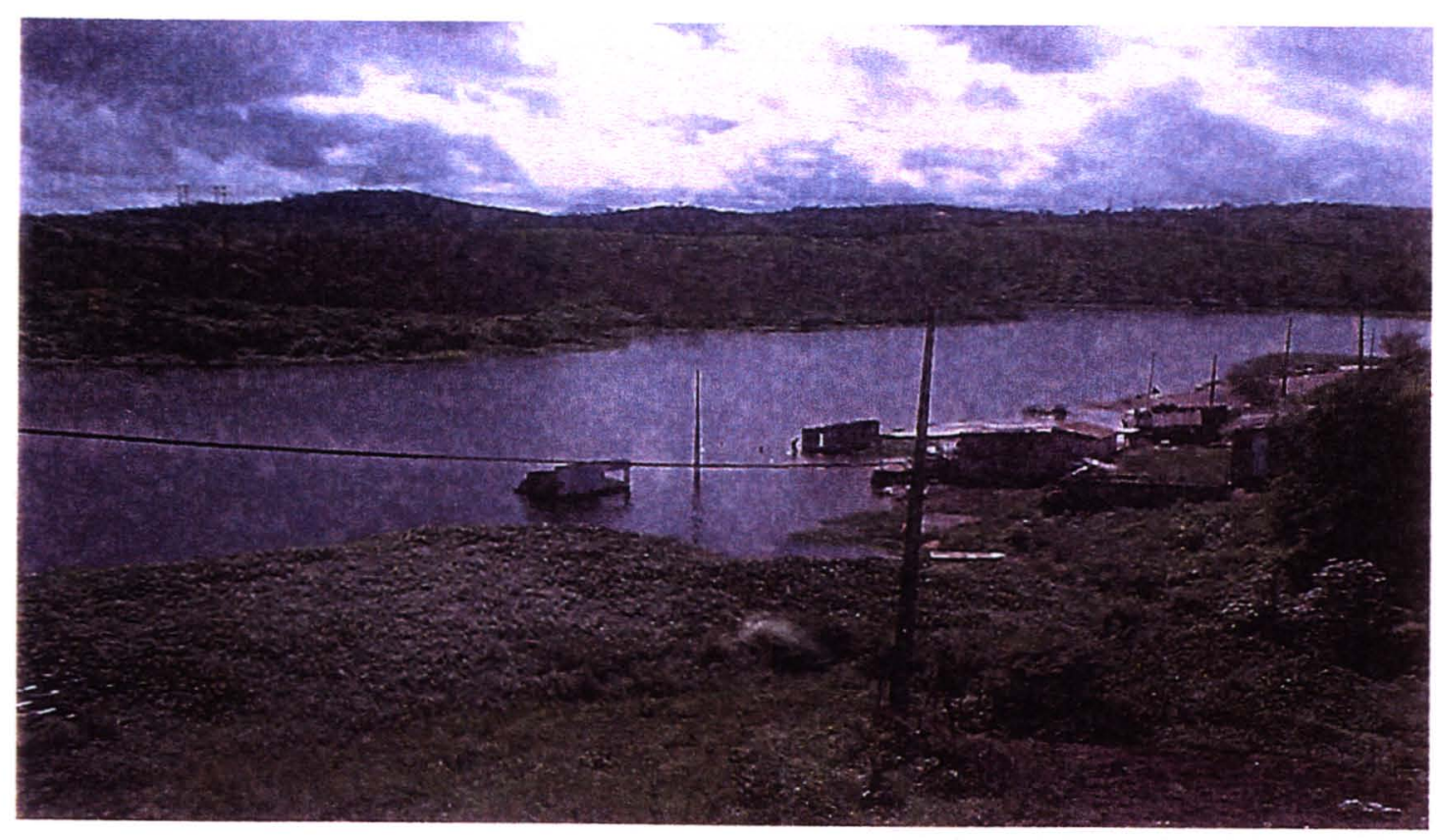

Foto 21. Área de utilização de contato primário, banhao, na Bacia da Barragem Pedra do Cavalo, nas proximidades da descarga do Riacho Principal. 


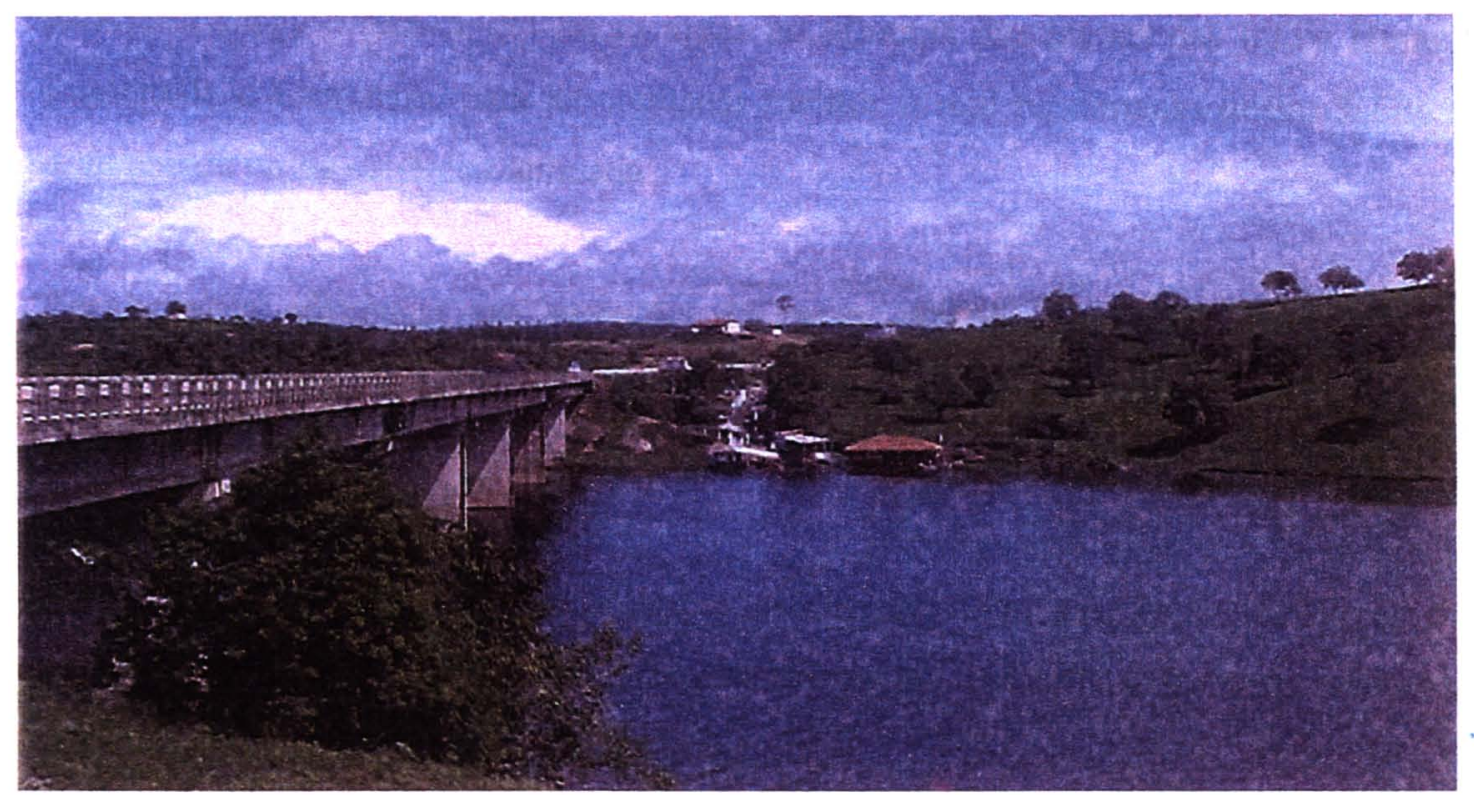

Foto 22. Área de utilização de contato primário, banho, na Bacia da Barragem Pedra do Cavalo, junto à BR 116 Sul, adjacente à descarga do Riacho Principal.

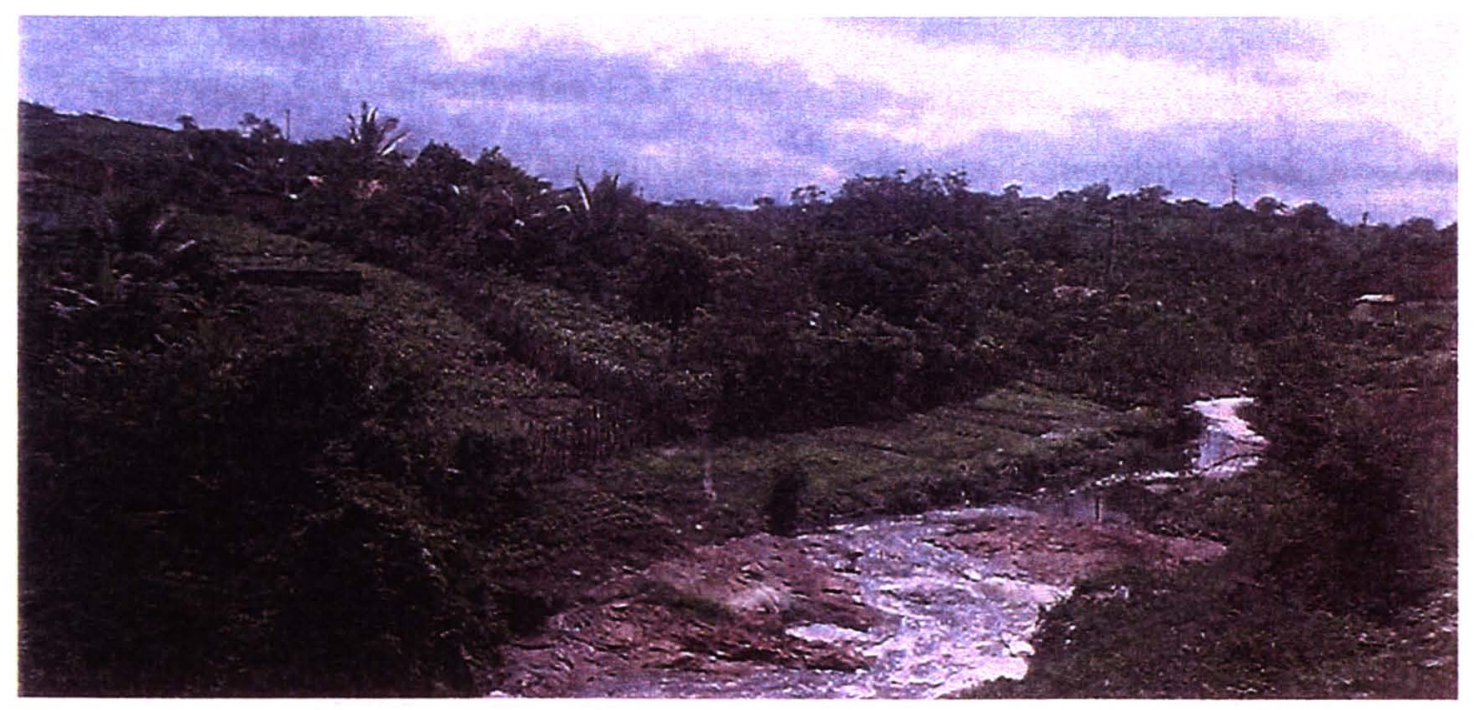

Foto 23. Uma área de plantação irrigada, nos períodos de estiagem, com utilização da água do Riacho Principal, a jusante da descarga da ETE Contorno. 


\section{RECOMENDAÇÕES}

Avaliar a carga orgânica devida às algas no efluente das lagoas das ETEs Homero Figueiredo e Contorno, para se conhecer melhor o real rendimento destas ETEs na remoção da carga orgânica aplicada.

Recalcular a eficiência em remoção da carga orgânica das ETEs para a carga orgânica aplicada e a vazão, mantendo os demais parâmetros e dimensões de projeto conforme execução.

Rever os parâmetros usados em projeto com base nos dados de eficiências levantados para as ETEs, para a vazão medida e a carga real aplicada, bem como rever os procedimentos operacionais.

Avaliar as pessoas das comunidades que recebem os serviços de abastecimento de água e esgotamento sanitário, quanto à condição de portador sintomático ou assintomático de helmintos e protozoários parasitos do intestino humano, tratá-las, visando eliminar a veiculação desses microorganismos no ambiente.

Complementar o tratamento das ETEs que foram projetadas para remover a carga orgânica, e que apresentam baixa eficiência na remoção de helmintos e protozoários parasitos do intestino humano e de coliformes fecais, tomando-as mais eficientes, ou seja, eliminando a veiculação desses parasitos, para o ambiente, através dos esgotos tratados.

Estudar as comunidades relativas às ETEs pesquisadas visando levantar a rota de veiculação e dissieminação desses parasitos entre a população se: de portadores sãos da comunidade, de alimentos contaminados, do uso de outras fontes de água contaminadas ou transmitidos de pessoa para pessoa. 
Divulgar para a Secretaria Municipal de Saúde do municipio de Feira de Santana, e para a Universidade Estadual e comunidades interessadas, os resultados obtidos na pesquisa visando a adoção de medidas mais eficientes de saneamento. 


\section{REFERÊNCIAS BIBLIOGRÁFICAS}

Aisse M. M. Padrões de Qualidade Ambiental: Discussão de Alguns Parâmetros Relacionados ao Lançamento de Efluentes Líquidos e a Qualidade dos Corpos d'água Receptores. SANEARE 1998; 8 (8): 39-49.

Al-Layla M. A., Ahmad S. e Middlebrooks E. J. Handbooks of Wastewater Collection and Treatment: principles and practice. New York \& London: Garland Publishing, Inc; 1980.

Amabis J. M., Martho G. R. e Mizuguchi Y. Biologia: Os seres vivos. Segunda edição. São Paulo: Editora Moderna; 1989.

Andrade Neto C. O. de. Sistemas Simples para Tratamento de Esgotos Sanitários: Experiência Brasileira. Rio de Janeiro: ABES - Associação Brasileira de Engenharia Sanitária e Ambiental; 1997.

Andraus S., Borges J. C., Medeiros M. L. B. de, Toledo E. B. S. Sobrevivência de Bactérias Entéricas de Lodo de Esgoto, em Solo Agrícola. SANEARE. 1997; 8 (8): 6670 .

Andreoli C. V., Bonnet B. R. P., Fernandes F., Souza M. L. de P. Efetividade da Avaliação de Impacto Ambiental no Brasil na Área de Saneamento. SANEARE. 1995; $3(3): 31-38$.

[Anonymus] Coluna Vida Feirense. Folha do Norte 1923 abril 7.

APEB - Arquivo Público do Estado da Bahia. Sessão Província / Presidência da Província. Correspondências recebidas Feira de Santana, Série Saúde/Epidemia março 5361. 
Araujo R. A. et. al. Caderno Feirense - Meio Ambiente Parte I: Serviços Públicos de

Saneamento, Abastecimento de Água e Esgotamento Sanitário. In: Anais do $\mathbf{1}^{\circ}$ Seminário Sobre o Desenvolvimento de Feira de Santana; 1984 dez 18-20; Feira de Santana, Bahia, Brasil. INTERURBE - Companhia de Desenvolvimento Urbano e Articulação Municipal, 1985. p.15-29.

Azevedo Neto J. M. de. Lagoas de Estabilização $2^{a}$ Edição. São Paulo: CETESB Companhia Estadual de Tecnologia de Saneamento Básico e de Controle de Poluição da Águas, 1975.

- Tanque séptico: Conhecimentos atuais. Engenharia Sanitária $1985 \mathrm{a} ; 24(2): 222-229$.

. Aspectos construtivos de lagoas de estabilização. DAE 1985b;

$45(140): 44-49$.

Azevedo Neto J. M. e Alvarez G. A. Manual de Hidráulica. Volume II. $7^{\mathrm{a}}$ edição, $4^{\mathrm{a}}$ reimpressão. São Paulo: Editora Adgard Blucher Ltda; 1991.

Baréa L. C. Tratamento de Esgoto Doméstico Utilizando Reatores Tipo UASB. SANEARE 1994; 2 (2): 18-20.

Bennett J. V., Homberg S. D., Rogers M. F. and Soloman S. L. Infectious and parasitic diseases American Journal Preventative Medical; 1987. 55: p.102-114.

Bernard M. A. Land disposal of sewage effluent: appraisal of health effects of pathogenic organism. J. Am. Water Work Assoc 1973; 85: 432. 
Branco S. M. Hidrobiologia Aplicada à Engenharia Sanitária. São Paulo: Companhia de Tecnologia de Saneamento Ambiental - CETESB; 1978.

BRASIL. Lei $n^{\circ}$ 6938, de 31 de Agosto de 1981. Dispões sobre a Política Nacional do Meio Ambiente, seus fins e mecanismos de formulação e aplicação, e dá outras providências. Senado Federal Direito Administrativo Tema: Água, Brasília, 1997a. Caderno Legislativo 001/97: p.231-244.

BRASIL. Lei $n^{\circ} 9433$ de 08/01/1997. Institui a Política Nacional de Recursos Hídricos, cria o Sistema Nacional de Gerenciamento de Recurso Hídrico, regulamenta o inciso XIX do artigo 21 da Constituição Federal, e altera o artigo $1^{\circ}$ da Lei 8001 de 13 de março de 1990 que modifica a Lei 7990, de 28 de dezembro de 1989. Senado Federal Direito Administrativo Tema: Água, Brasília, 1997b. Caderno Legislativo 001/97: p.231-244.

BRASIL. Lei no 9984 de 17 de junho de 2000. Dispõe sobre a criação da Agencia Nacional de Águas - ANA, entidade federal de implantação da Política Nacional de recursos Hídricos e de coordenação do Sistema Nacional de Gerenciamento de Recursos Hídricos, e da outras providências: Disponivel em: < URL: http://www.lei.adv.br/9984-00.html [2003, Maio].

Brasil A. L. (Coordenadora) et al. Agência inicia atividades a partir de 2001. BIORevista Brasileira de Saneamento e Meio Ambiente 2000a; XI (16): 15.

. Águas: Recurso político estratégico. BIO-Revista Brasileira de Saneamento e Meio Ambiente 2000b; XI (16): 17.

. Águas: Ação preventiva. BIO-Revista Brasileira de

Saneamento e Meio Ambiente 2000c; XI (16): 17. 
- Águas Subterrâneas. BIO-Revista Brasileira de Saneamento e Meio Ambiente 2000d; XI (16): 25 - 31.

- Recursos Hídricos: Especialistas ao encontro de

mudanças no panorama mundial. BIO - Revista Brasileira de Saneamento Ambiental 2000e; XI (16): 33-38.

. Economia de água. BIO-Revista Brasileira de

Saneamento e Meio Ambiente. 2001; XI (18): 17-37.

- Água - o ouro do século XXI. BIO Revista

Brasileira de Saneamento e Meio Ambiente. 2002; XI(21):20-34.

Bringhenti J. R. Efeitos da Codisposição de Lodos de Tratamento de Esgotos em Aterros Sanitários - Estudo em Lisímetros. São Paulo; 1999. [Dissertação Apresentado ao Departamento de Saúde Ambiental da Universidade de São Paulo].

Brito E. R. de e Alves F. C. Descontaminação de fossas sépticas por bacteriófagos. Engenharia Sanitária 1984; 23 (2): $163-167$.

Brito E. R. de. A experiência do uso de Bacteriófagos em Fossa Séptica.Engenharia Sanitária $1986 ; 25(1): 50-51$.

Câmara M. P. A. Caderno Feirense - Raizes Históricas de Feira de Santana. In: Anais do $1^{\circ}$ Seminário Sobre o Desenvolvimento de Feira de Santana; 1984 dez 18-20; Feira de Santana, Bahia, Brasil. INTERURBE - Companhia de Desenvolvimento Urbano e Articulação Municipal, 1985.p.7-33.

Campos J. R. e Dias H. G. Potencialidades do Filtro Anaeróbio. DAE 1989; 49 (154): 29-33. 
CEPRAM - Conselho Estadual de Meio Ambiente da Bahia. Resolução 2288 de 28 de abril de 2000. Aprova a Norma Técnica NT-002/2000 que estabelece os padrões de lançamento para efluentes sanitários nos corpos hídricos situados na Região Metropolitana de Salvador - RMS e demais municípios do Estado da Bahia, gerados a partir da implantação de empreendimentos habitacionais. Diário Ofícial do Estado da Bahia, Salvador, 03 de maio de 2000.

Coelho P. M. S. Schistosoma mansoni. In: Neves D. P. Parasitologia Humana. São Paulo. Atheneu; 1998. p.280-291.

CONAMA - Conselho Nacional do Meio Ambiente do Brasil. Resolução n ${ }^{\circ} 20$, de 18 de junho de 1986. Estabelece a Classificação das Águas. Diário Oficial da República Federativa do Brasil, Brasília, 30 de jul. 1986. p. 11356.

CONCREMAT - Engenharia e Tecnologia S. A. Feira de Santana: Estudo de Impacto Ambiental das Instalações de Tratamento de Esgotos. Feira de Santana, 1992.

CONCREMAT - Engenharia e Tecnologia S. A. Projeto Executivo da Nova Planta de Tratamento de Esgoto: Contorno. Feira de Santana; 1993.

CONSTRUTORA CELl Ltda. Projeto de Esgotamento Sanitário: Conjunto Habitacional Lagoa Grande. Feira de Santana; 1989.

CONSTRUTORA ERG Ltda. Projeto de Esgotamento Sanitário: Conjunto Habitacional Elza Azevedo. Feira de Santana; 1992.

COPLAN S. A. - Construção e Planejamento. Plano de Desenvolvimento Local Integrado de Feira de Santana; 1968. 
Costa H. M. de A. Helmintos. In: Neves D. P. Parasitologia humana. $9^{a}$ ed. São Paulo: Atheneu; 1998. p.201-211.

Costa H. M. de A. Helmintos. In: Neves D. P. Parasitologia humana. $10^{a}$ ed. São Paulo: Atheneu; 2000.

Crespo P. G. Tratamento dos esgotos uma questão de bom senso. Engenharia Sanitária. 1989; 28 (2): 89.

Driver C. H. et. al. Assessment of the effectiveness and effects of land disposal methodologies of waste water management. Washington: Department of the Army Corps of Engineers; 1972.

Edberg S. C., Piscitelli V., Cartter M. Phenotypic characteristics of coliform and noncoliform bacteria from a public water supply compared with regional and national clinical species. Appl. Environ. Microbial 1986; 52: 474-478.

EPA - Environmental Protection Agency. Process design manual land treatment of municipal wastewater Cincinnati. Ohio; 1981.

EPA- Environmental Protection Agency. Health effects of land application of municipal sludge $1985 ; 15: 1-85$.

ERGON Engenharia Ltda. Projeto de Esgotamento Sanitário: Conjunto Viveiros A, B e C. Feira de Santana; 1990.

ESTEIO Engenharia e Comercio Ltda. Projeto de Esgotamento Sanitário: Conjunto Habitacional Chácara da Mangabeira. Feira de Santana; 1990. 
Faria C. M. Ocorrência de enterovirus na Bacia do Jacui In: Anais do $15^{\circ}$ Congresso Brasileiro de Engenharia Sanitária e Ambiental; 1989 St. 17-22; Belém-Pa, Brasil. 2 (IV): p236-246.

Ferreira F. A. G. Moderna Saúde Pública. 5ed. Lisboa: Fundação Calouste Gulbenkian; 1982. v.1. 721p.

Figueiredo R. F. de. Tratamento de esgotos pelo processo de escoamento superficial no solo. DAE 1985; 45 (140): 62 - 66.

Fricker C. and Clancy J. Crypto's protocol prospects. WQI - Water Quality International 1998; May/June: 11.

Gasi T. M. T. Removal of pathogenic microorganisms from USB reactor effluent by chlorination. In: Proceedings of the International Symposium on Anaerobic Digestion. Tilche A \& Rozzi A. (ed) Porter - papus, Bologna Monduzzi Editore, 1988. pp 875-878.

Remoção de Microorganismos em Reatores Anaeróbios de Fluxo Ascendente e Manta de Lodo Operado com Esgoto Doméstico. São Paulo; Agosto 1991 [Dissertação apresentada à Faculdade de Saúde Pública da Universidade de São Paulo para obtenção de título de Mestre em Saúde Pública da Universidade de São Paulo].

Geldreich E. E. Sanitary Significance of Faecal Coliforms in the Environment. US Federal Water Pollution Control Administration. Washington, DC, 1966; Report WP-20-3.

HABITACIONAL Construções S. A. Projeto de Esgotamento Sanitário: Conjunto Habitacional Parque Cajueiro. Feira de Santana; 1990. 
Hamcock C. M, Rose J. B., and Callahan. Crypto and Giardia in US groundwater. Journal Water Work Association 1998; 90 (3): 58-61.

Heller L, Costa A. M. L. M. da e Barros R. T. de V. Saneamento e o Município. In: Barrois R. T. de, Chernicharo C. A. de L.; Heller L., Sperling M. Von, editores. Manual de Saneamento e Proteção Ambiental para os Municípios volume 2. Belo Horizonte: Minas Gerais. Escola de Engenharia de da UFMG 1995; p.14-15.

Heller L. Saneamento e Saúde. Brasília: Organização Pan-Americana da Saúde e Organização Mundial da Saúde 1997; 97p.

Heller L. (Coordenador). Água potável: esforço de todos. BIO - Revista Brasileira de Saneamento e Meio Ambiente 1998; Ano IX; (7): 9-11.

Heller L., Vieira M. B. C. M., Brito L. L. A. de e Machado P. M. R. Verificação da Ocorrência de Cistos de Giárdia, Oocistos de Cryptosporidium e Indicadores Bacterianos nos Esgotos Sanitários da Bacia do Ribeirão Arruda, Belo Horizonte MG. [Apresentado no IX SILUBESA - Simpósio Luso-Brasileiro de Engenharia Sanitária e Ambiental; 2000].

Hofer E. \& Vicente A. C. P. Coliformes fecais em água de esgoto. I. Resistência a antibióticos, metais pesados e colicinogenia. Engenharia Sanitária 1989; 28 (1): 54 57.

Houaiss A., Casanovas C. F. de F., Davidovich E. Lankszner L. e Geiger P. Rio de Janeiro: Grande Enciclopédia Delta Larousse. Delta S. A.; 1978. v6p2699.

Huffman D. E. F. and Rose J. B. Emerging waterborne pathogens. WQI - Water Quality International 1998; Nov./Dez: 14-18. 
IBGE - Instituto Brasileiro de Geografia e Estatistica. Dados populacionais do Censo de 2000. Unidade de Feira 2000.

Juliano N. M. A. Aspectos legais e institucionais associados à gestão ambiental. São Paulo: EPUSP, 1996. 67P.

Kottek S. S. Gems from the Talmud: public health I - Water supply. Israel Jounal of Medical Sciences 1995; 31 (4): 255-256.

Leite B. Z., Aisse M. M. Pós-Tratamento de Efluentes de Reatores Tipo Ralf em Lagoas de Estabilização. SANEARE 1998; 9 (9): 58-66.

Leite A. C. R. Ancylostomatidae. In: Neves D. P. Parasitologia Humana. São Paulo. Atheneu; 1998. p.280-291.

Lewis W. J. Et al. O risco de poluição do lençol freático por sistemas de disposição local de esgotos. Brasília: Ministério do Desenvolvimento Urbano e Meio Ambiente / Programa das Nações Unidas para o Desenvolvimento; 1986.

Lima A. O., Soares J. B., Greco J. B., Galize J e Cançado J. R. Métodos de Laboratório Aplicados à Clínica. $5^{\text {a }}$ ed. Rio de Janeiro: Guanabara Koogan; 1977.

Lima C. L. S. de; Braz V. N.; Rivera I. G. Pesquisa de coliforme e estreptococos fecais em um ambiente aquático protegido. Engenharia Sanitária e Ambiental 1999; 4 (3 e 4): $127-132$.

Lima F. F., Dacach N. G. e Sena O. Projeto de Abastecimento de Água para as Cidades de Feira de Santana, Conceição da Feira e São Gonçalo. SESEB Secretaria de Engenharia Sanitária do Estado da Bahia; 1969. 
Lisle J. T. and Rose J. B. Cryptosporidium contamination of water in the USA and UK: a mini review. Journal water supply and Reseache Technology. 1995. 44: p.103.

Macedo L. A. A. de e Rocha A. A. Lançamento de esgotos em manguezais. Considerações sobre aspectos ecológico-sanitários na ilha de São Luís, MA. DAE 1985; 45 (140): $67-72$.

Mc Cann B. Pathogens in surface Water catchments. Water 21 - IWA - International Water Association 1999; Nov/Dez: 15.

Meccia M. C. Caderno Feirense: Desenvolvimento Econômico de Feira de Santana. In: Anais do $1^{\circ}$ Seminário Sobre o Desenvolvimento de Feira de Santana; 1984 dez 18 20; Feira de Santana, Bahia, Brasil. INTERURBE - Companhia de Desenvolvimento Urbano e Articulação Municipal, 1985.

Mello Jorge M. H. P. e Gotlieb S. L. D. As Condições de Saúde no Brasil: Retrospectiva de 1979 a 1995. Rio de Janeiro: FIOCRUZ; 2000. 280p.

Mendonça S. R. Tópicos Avançados em Sistemas de Esgotos Sanitários. Rio de Janeiro: ABES - Associação Brasileira de Engenharia Sanitária e Ambiental; 1987.

Meta Serviços de Engenharia Ltda. Projeto Executivo do SES de Feira de Santana Bacia do Subäé 1998a. Tomo I.

Meta Serviços de Engenharia Ltda. Projeto Executivo do SES de Feira de Santana Bacia do Subaé 1998b. TomolI Volume I: .

Metcalf \& Eddy. Wastwater Engineering: Treatment Disposal Reuse. Second Editon. Rio de Janeiro: McGraw-Hill, Inc.1991. 
Mims C., Playfair J., Roitt I., Wakelin D., Williams R. Microbiologia Médica. $2^{\mathrm{a}}$ ed. São Paulo: Manole Ltda 1999. p. 253-286.

Mota S. Introdução à Engenharia Ambiental 1ª. Edição. Rio de Janeiro: ABES Associação Brasileira de Engenharia Sanitária e Ambiental; 1997.

MS - Ministério da Saúde. Portaria 36, de 19/01/1990: dispões sobre os procedimentos e responsabilidades relativas ao controle e vigilância da qualidade da água para consumo e seus padrões de potabilidade, e da outras providências. Senado Federal Direito Administrativo Tema: Água, Brasília, 1997. Caderno Legislativo 001. p.570-581.

MS - Ministério da Saúde do Brasil. Portaria 1469 de 29 de dezembro de 2000. Estabelece os procedimentos e responsabilidades relativas ao controle e vigilância da qualidade da água para consumo e seus padrões de potabilidade, e da outras providências. Diário Oficial da República Federativa do Brasil, Brasília, 10 de janeiro de 2001. No 7-E, Seção 1, p.26.

Neves D. P. Parasitologia humana. $9^{a}$ ed. São Paulo: Atheneu; 1998.

Neves D. P. Parasitologia humana. 10ª ed. São Paulo: Atheneu; 2000.

Nunes C. W. Desempenho dos Sistemas de Tratamento de Esgotos na SRN Superintendência Regional Nordeste do Paraná. SANEARE 1998; 5 (5): 9- 12.

Oliveira R. de. Contribuição ao Estudo de Tanques Sépticos. Paraíba, Campina Grande; 1983. [Dissertação de Mestrado - Universidade Federal da Paraíba].

OYAMA FIGUEIREDO Construções e Empreendimentos Ltda. Sistema de Esgotamento Sanitário: Conjunto Habitacional Homero Figueiredo, Arco Ires e Alvorada. Feira de Santana; 1992. 
Paganini W.da S. Disposição de esgoto no solo, através de escoamento à superfície com utilização de gramíneas: avaliação do processo quanto aos aspectos sanitários, operacionais, construtivos e de manutenção. São Paulo; 1996. [Dissertação de Mestrado Apresentada à Faculdade de Saúde Pública da Universidade de São Paulo, Departamento de Saúde Ambiental, para a obtenção do título de "Mestre em Saúde Pública"].

Pahren A. R. et al. Health risks associated with land application of municipal sludge. Journal Water Pollution Control Federation. September, 1979.

Paoletti R. Ubatuba usa fossa anaeróbia contra esquistossomose. Engenharia Sanitária $1984 ; 23(2): 156$.

Pereira L. O. Schistosoma mansoni. In: Neves D. P. Parasitologia Humana. São Paulo. Atheneu; 1998. p.280-291.

Pescod M. B. Investigation of Rational Effluent and Stream Standards for Tropical Countries. Bangkok: Asian Institute of Tecnology, 1974.

Pessoa S. B. e Martins A V. Pessoa: Parasitologia Médica. $11^{\text {a }}$ Ed. Rio de Janeiro: Guanabara Koogan S. A.; 1982.

Pinto M. A. T. e Onoyama M. T. Remoção de matéria orgânica, fósforo e nitrogênio de esgotos domésticos utilizando o processo de lagoa de taxa alta. DAE. 1991; 51: 6-13.

Poppino R. E. Feira de Santana. Salvador 1968.

Rocha A. A. Aspectos ecológicos do filtro biológico. DAE 1985; 45 (140): 40 - 43. 
Rochelle P. A. Detection of Protozoa in Environmental Water Samples. In: Environmental Molecular Microbiology: Protocols and Applications. Horizon Scientific Press, Wymondham, England; 2001. p. 91-114,.

Rosen G. Uma história da saúde pública. São Paulo: HUCITEC; 1994. 423p.

Rothenberg R. E. Medicina e Saúde: Guia Prático. Sexta edição. São Paulo: Abril Cultural; 1979. Vol. 3 p.688.

Sampaio A. de O. e Campos J. R. Desinfecção de esgotos sanitários com utilização de radiação ultravioleta. DAE 1985; 45 (140): 101 - 108.

Santiago A. A. C.; Lacerda Neta Z. F. de; Oliveira E. S.; Lima F. J. F. e Coura L. R. AlA - Auto-Avaliação para o Licenciamento Ambiental dos Sistemas de Esgotamento Sanitário da Unidade de Negócio de Feira de Santana - UNF EMBASA - Ba. SENAI/CETIND 2001: 1 e 2.

Santos M. J. M. dos. O Saneamento no Brasil. Engenharia Sanitária 1989; 28 (2): 86 88.

Sibiya J. B. Sanitation in Developing Countries. In: Proceeding of a workshop on training held in Lobatse; 1980 Aug 14-20; Lobatse, Brotswana p 68-70.

Silva S. A. \& Mara D. D. Tratamentos Biológicos de Águas Residuárias - Lagoas de Estabilização. Rio de Janeiro: ABES - Associação Brasileira de Engenharia Sanitária e Ambiental; 1979.

Silva A. J. M. Terra de sã Natureza: A Construção do Ideal de Cidade Saudável em Feira de Santana (1833 - 1920). Feira de Santana; 1997. [Monografia do curso de 
Especialização em Teoria e Metodologia da História como pré-requisito parcial para obtenção do grau de especialista, Universidade Estadual de Feira de Santana - Bahia]

Simonsen R. C. História Econômica do Brasil (1500 a 1820), $7^{\mathbf{x}}$. Edição. Companhia Editora Nacional/MEC 1977; p151.

Sogayar M. I. T. L e Guimarães S. Giárdia Lamblia. In: Neves D. Parasitologia Humana. $10^{2}$ ed. São Paulo: Atheneu; 2000 p.107-127.

Souza M. E. de e Vieira S. M. M. Uso do reator UASB para tratamento de esgoto sanitário. DAE 1986; 46 (145): $165-168$.

Standart Methods for the Examination of Water and Wastewater - WPCF $19^{\text {a }}$ Edition 1995.

Sussman M. E. coli in human and animal disease In: The virulence of Escherichia coli: reviews and methods. London, Academic Press 1985; p. 7-46.

Tate 1978, apude EPA-Environmental Protection Agency. Health effects of land application of municipal sludge; 1985.

TECNOSAN ENGENHARIA S. A. Feira de Santana Sistema Integrado de Abastecimento de Água: Relatório Técnico Preliminar. EMBASA - Empresa Baiana de Águas e Saneamento S. A. 1981

Vasconcelos N. V. e Abreu R. M. de. A qualidade das Águas no Alto Tietê. DAE 1991; $51: 8$. 
Vieira S. M. M. e Além S. P. Resultados de Operação e Recomendações para Projetos de Sistema de Decanto - digestor e Filtro Anaeróbio para tratamento de Esgoto. DAE 1983; (135): 51-57.

Vieira S. M. M. Tratamento de Esgoto Domestico por reator anaeróbio de fluxo ascendente e manta de lodo - reator UASB. São Paulo; 1996. [Tese apresentada à Faculdade de Saúde Pública da Universidade de São Paulo].

Villar R., Hirano C. O., Magalhães T., Regal J. e Eleutério C. E. Padrão de qualidade da água de novo na berlinda. Bio - Associação Brasileira de Engenharia Sanitária e Ambiental 1997; Ano IX, (4): 39-41.

Vitor R. W. de A. Protozoa. In: Neves D. P. Parasitologia humana. 10 a ed. São Paulo: Atheneu; 2000. p. 24-26.

Von Sperling M. Critérios e dados para uma seleção preliminar de sistemas de tratamento de esgotos. BIO - Associação Brasileira de Engenharia Sanitária e Ambiental 1994; Encarte, Ano III, (1): 7 - 21.

- Princípios do Tratamento Biológico de Águas Residuárias:

Introdução à qualidade das águas e ao tratamento de esgotos $2^{2}$ edição. Belo Horizonte: Departamento de Engenharia Sanitária e Ambiental DESA Universidade Federal de Minas Gerais; 1996a. v.1.

Princípios do Tratamento Biológico de Águas Residuárias:

Princípios básicos do Tratamento de esgotos. Belo Horizonte: Departamento de Engenharia Sanitária e Ambiental DESA Universidade Federal de Minas Gerais; 1996 b. v.2. 
- Princípios do Tratamento Biológico de Águas Residuárias:

Lagoas de estabilização. Belo Horizonte: Departamento de Engenharia Sanitária e Ambiental DESA Universidade Federal de Minas Gerais; 1996c. v.3.

- Associação entre a legislação de qualidade da água (resolução

CONAMA 20/86) e a seleção de processos de tratamento de esgotos. Engenharia Sanitária Ambiental 1998; 3: 69.

WHO-World Health Organization. The international drinking water supply and sanitation decade: review of mid-decade progress. Geneva 1987. 25p.

Wiendl W. G. Processos eletrolíticos para depuração de esgotos - Uma revisão secular. DAE 1985; 45 (140): $50-54$.

Zulauf W. Ubatuba usa fossa anaeróbia contra esquistossomose. Engenharia Sanitária 1984; 23 (2): 156. 
ANEXOS 
Os resultados físico-químicos, bacteriológicos e parasitológicos obtidos na primavera, para as Estações Homero Figueiredo, Lagoa Grande, Viveiros-A e Contorno, estão apresentados nas Tabela 9.1 a 9.16 


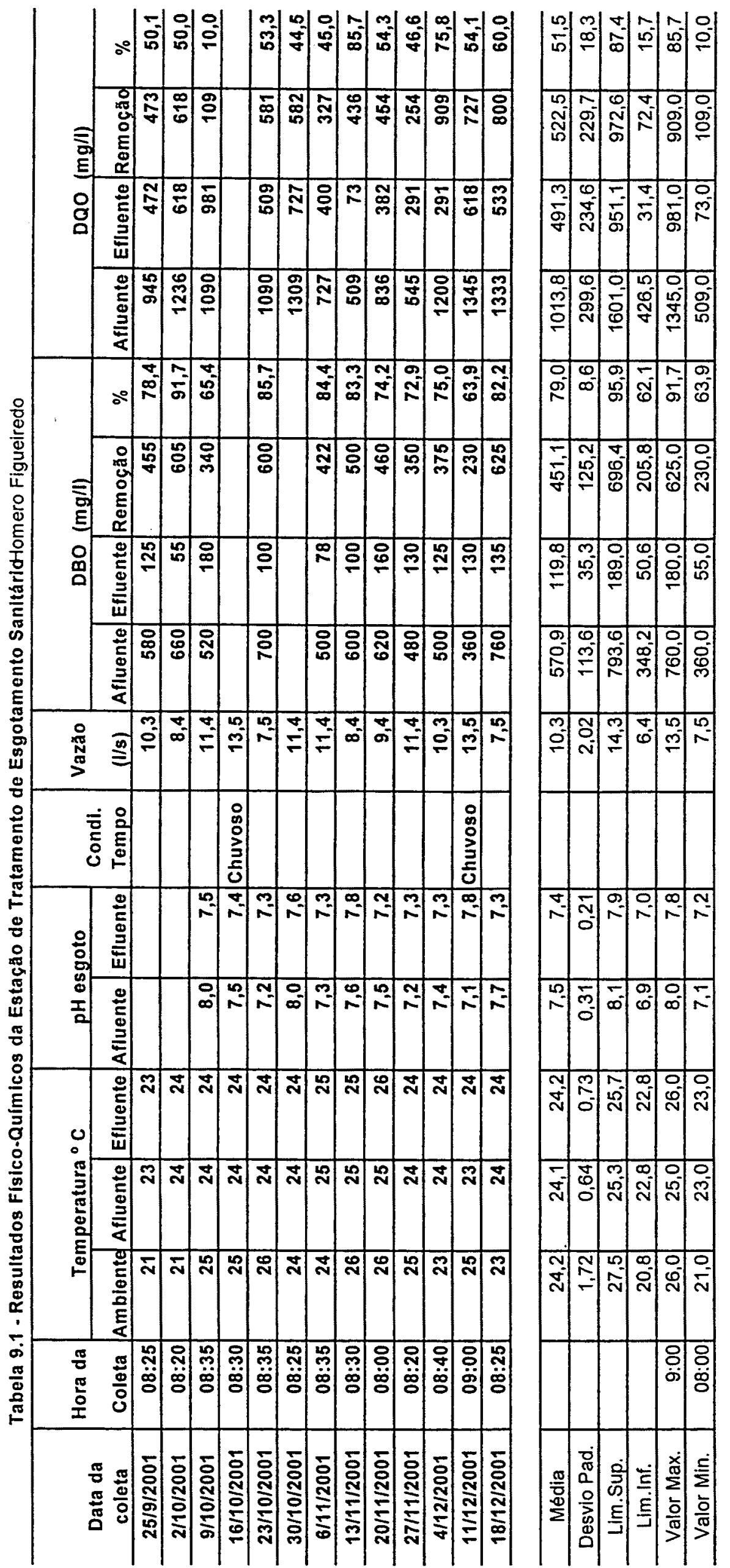




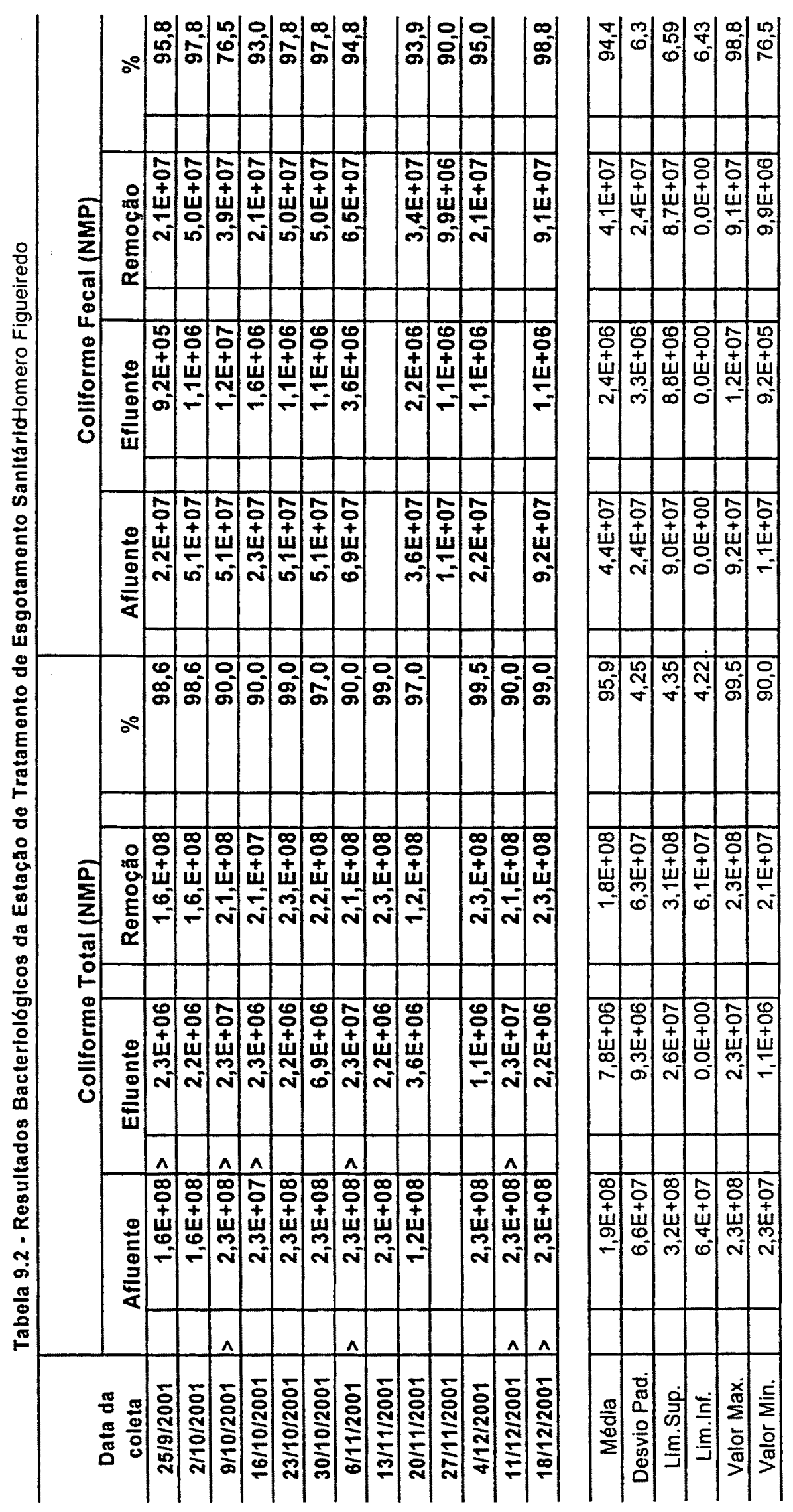




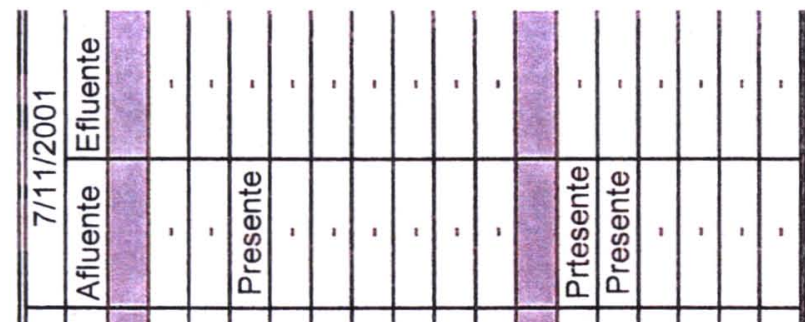
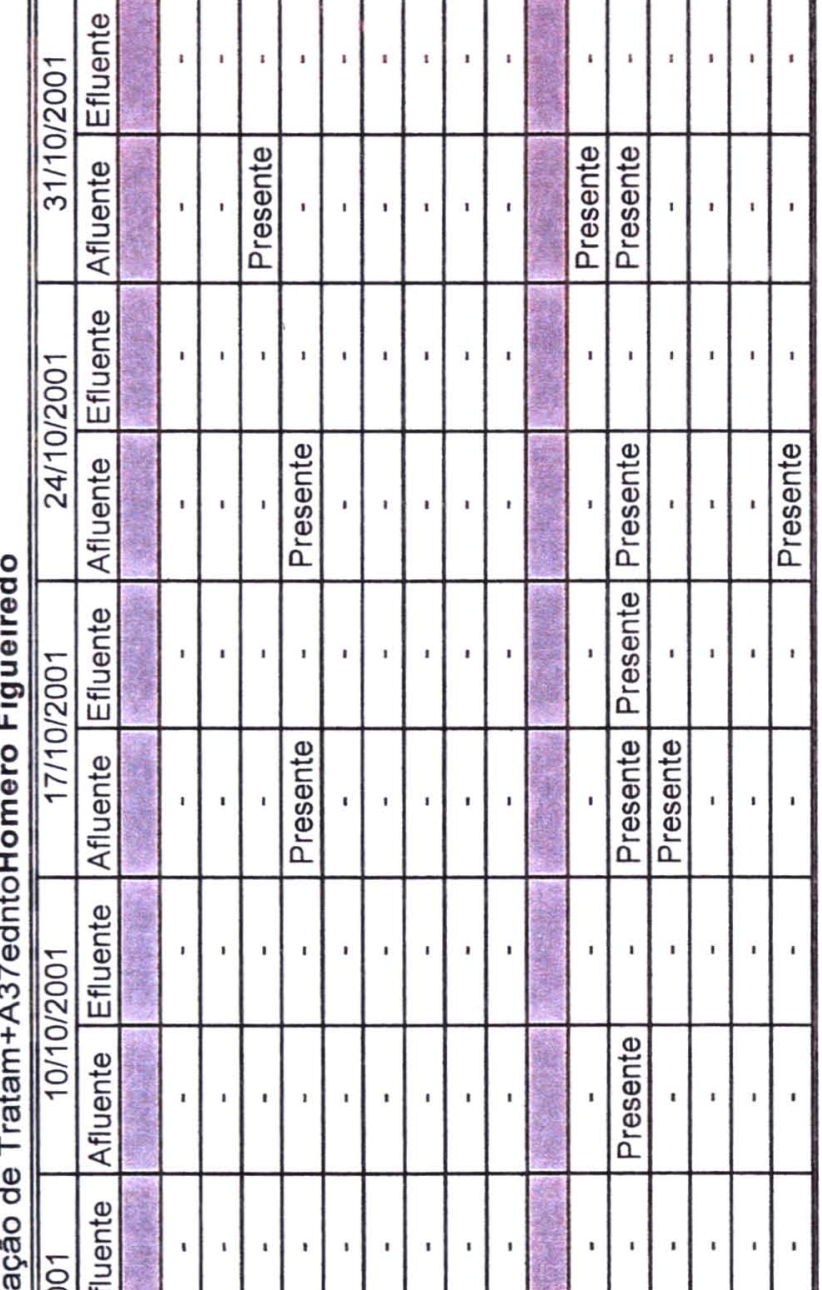

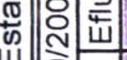

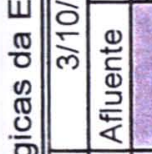

紊

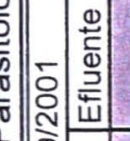

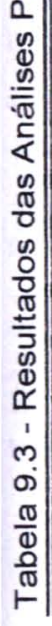

$\stackrel{\oplus}{ \pm}$

竞

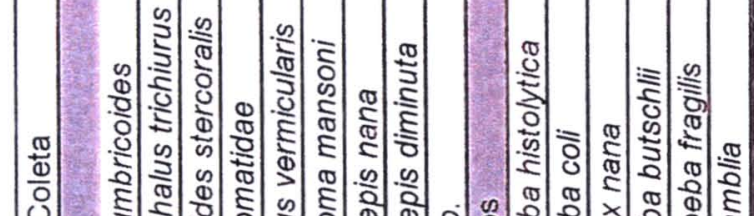

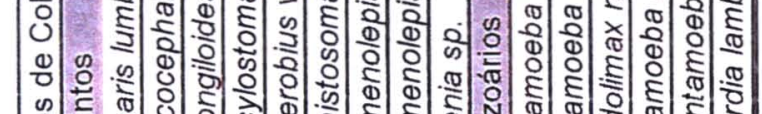

()

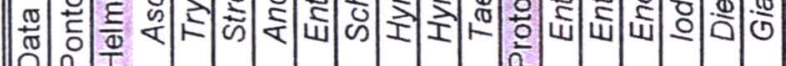

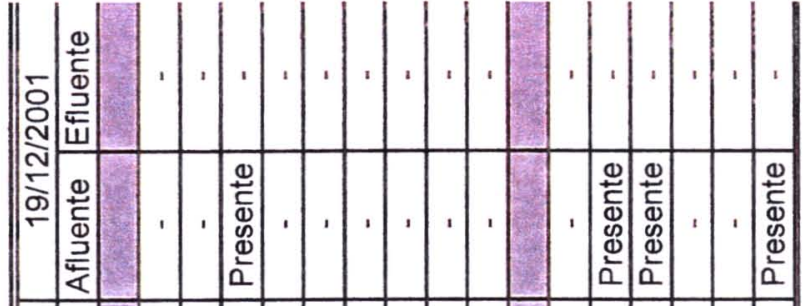

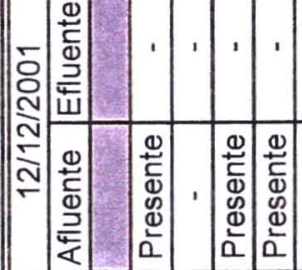

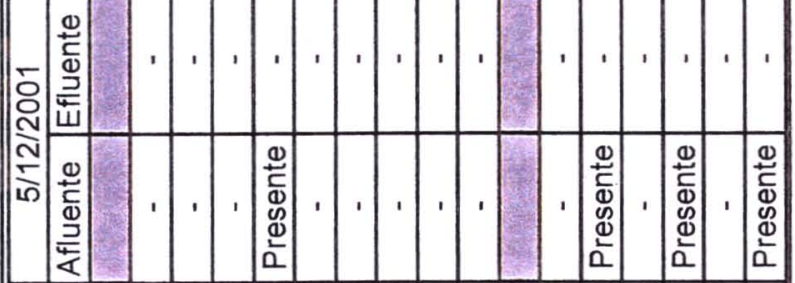

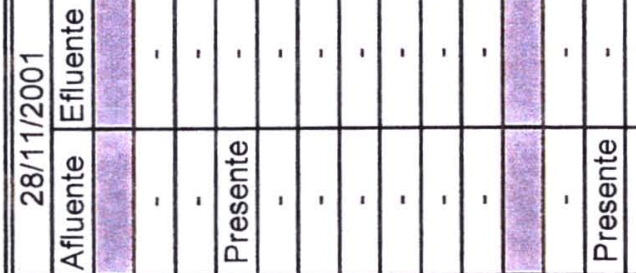

(ำ

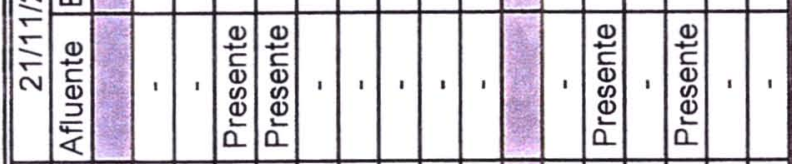

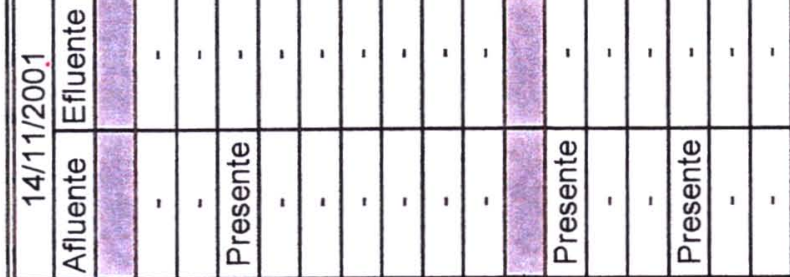

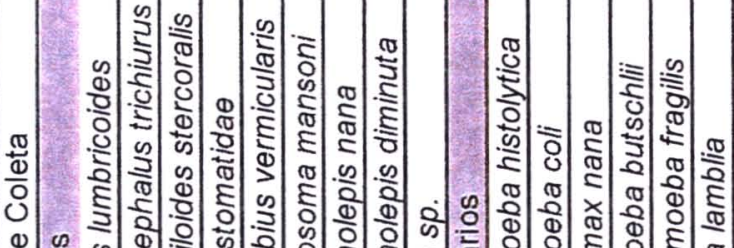

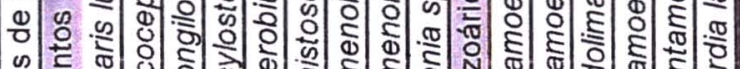

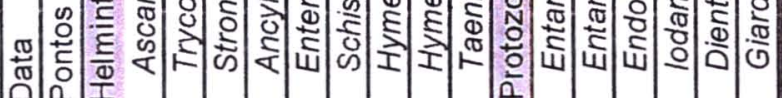




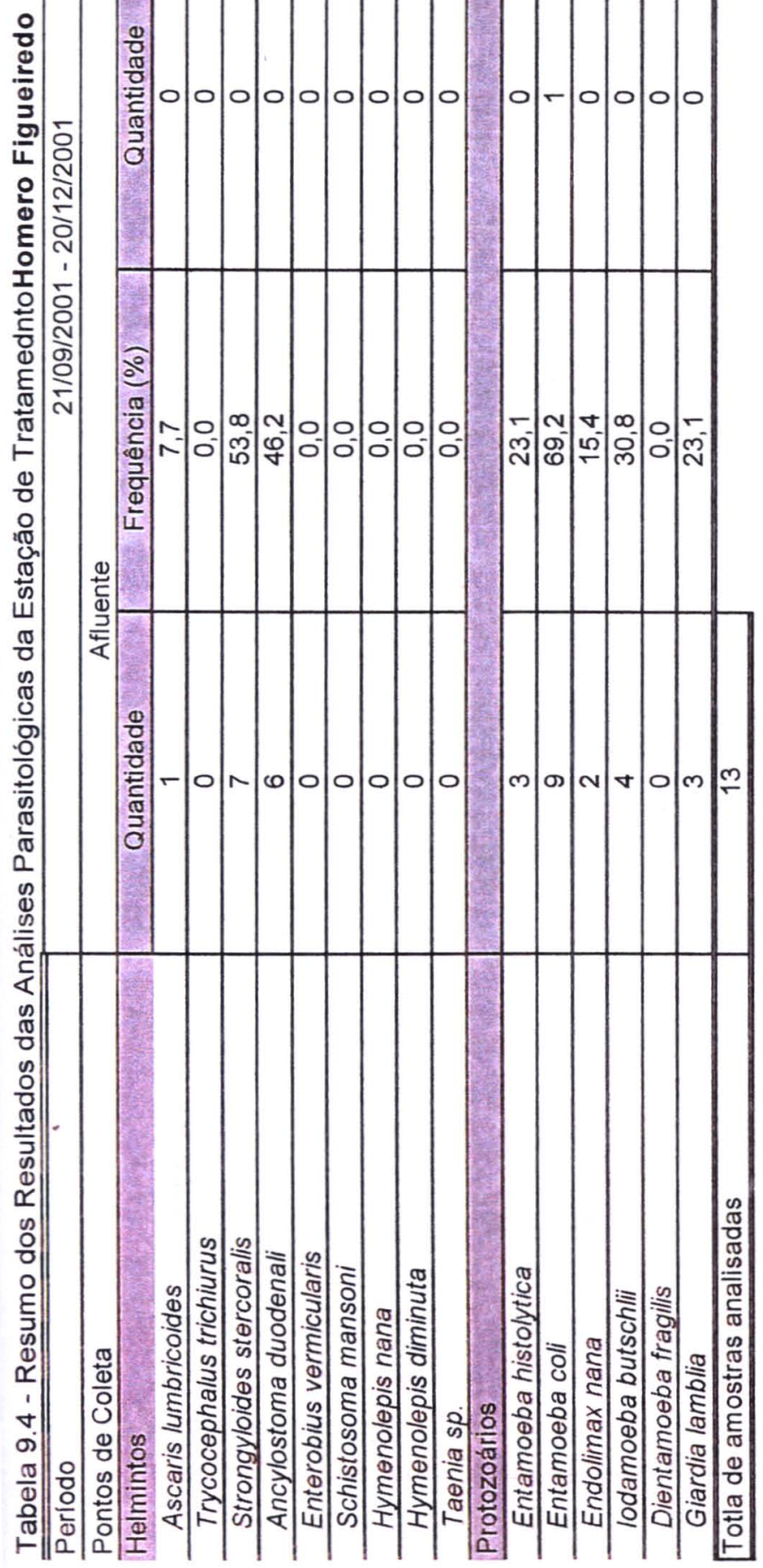




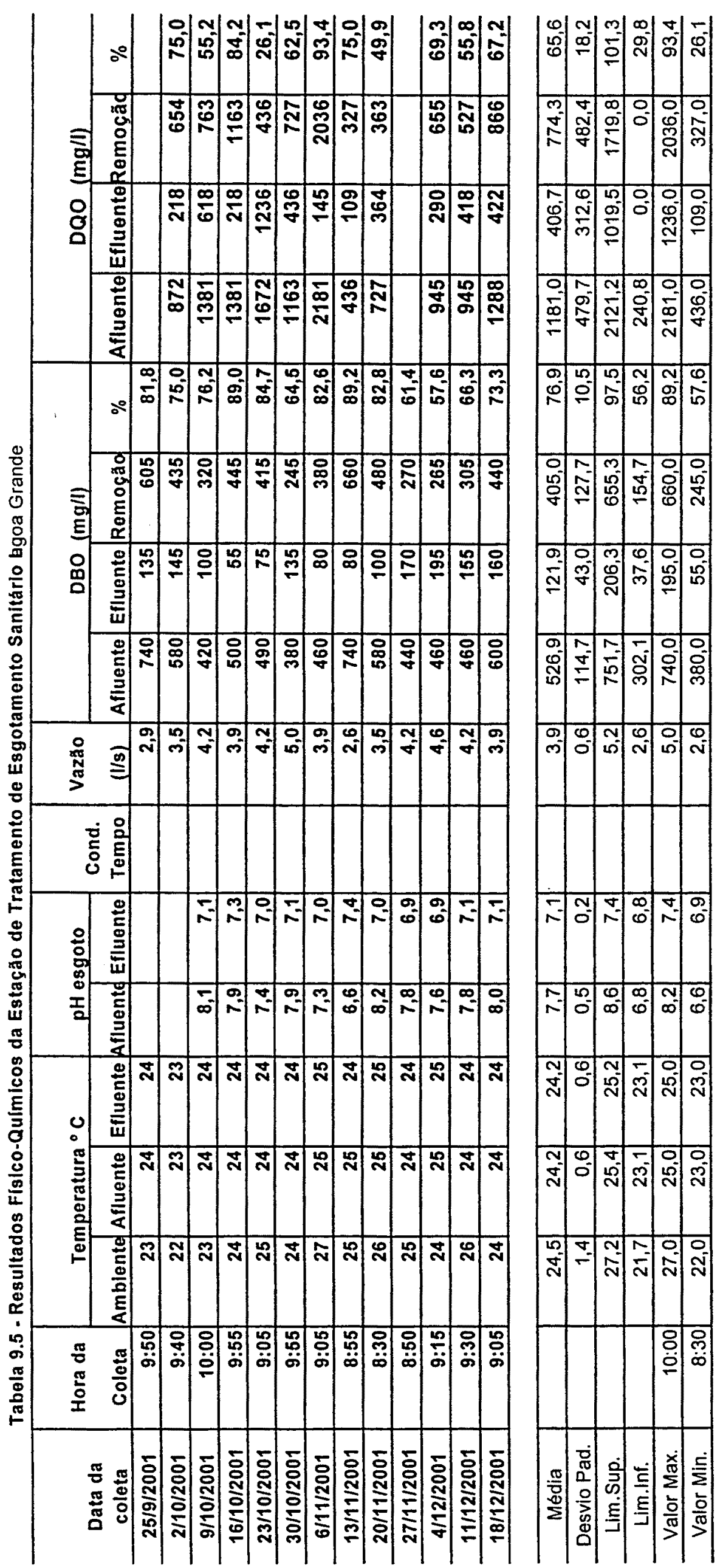




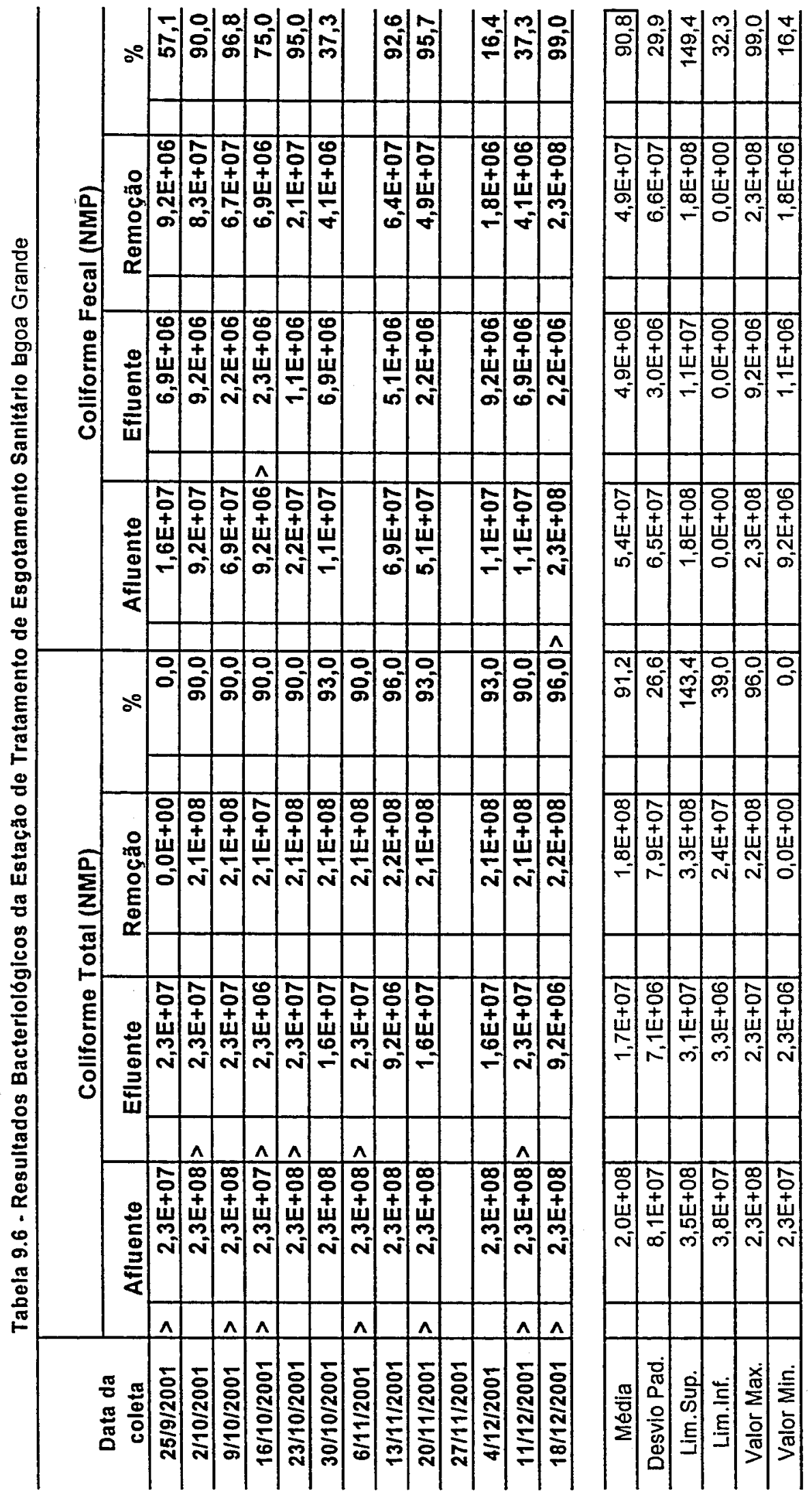



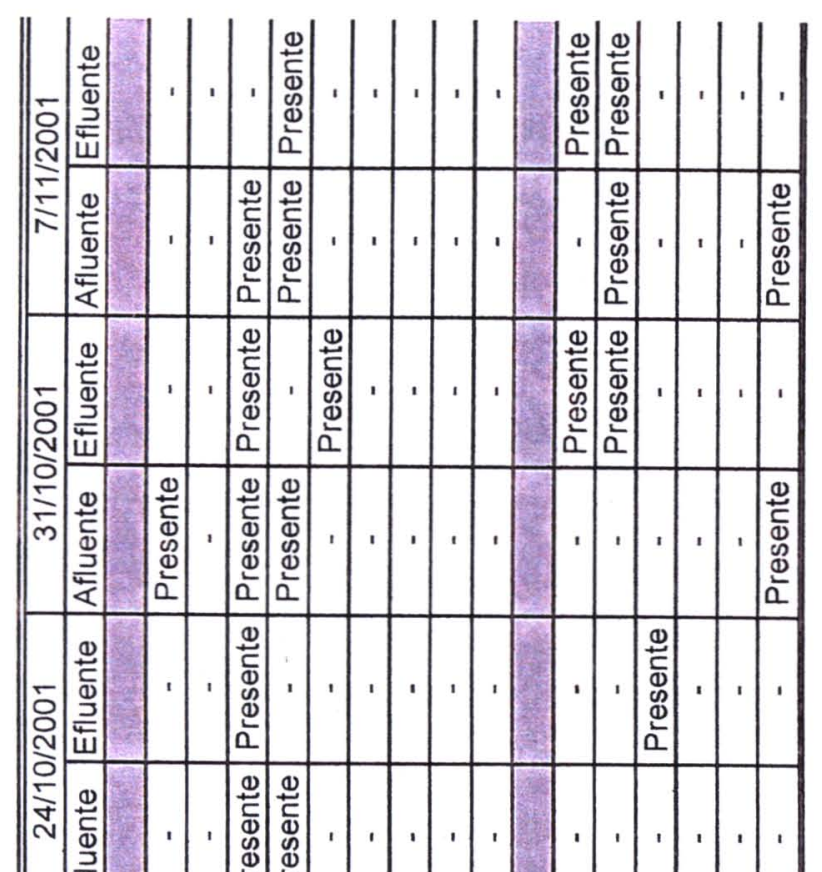

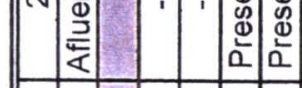
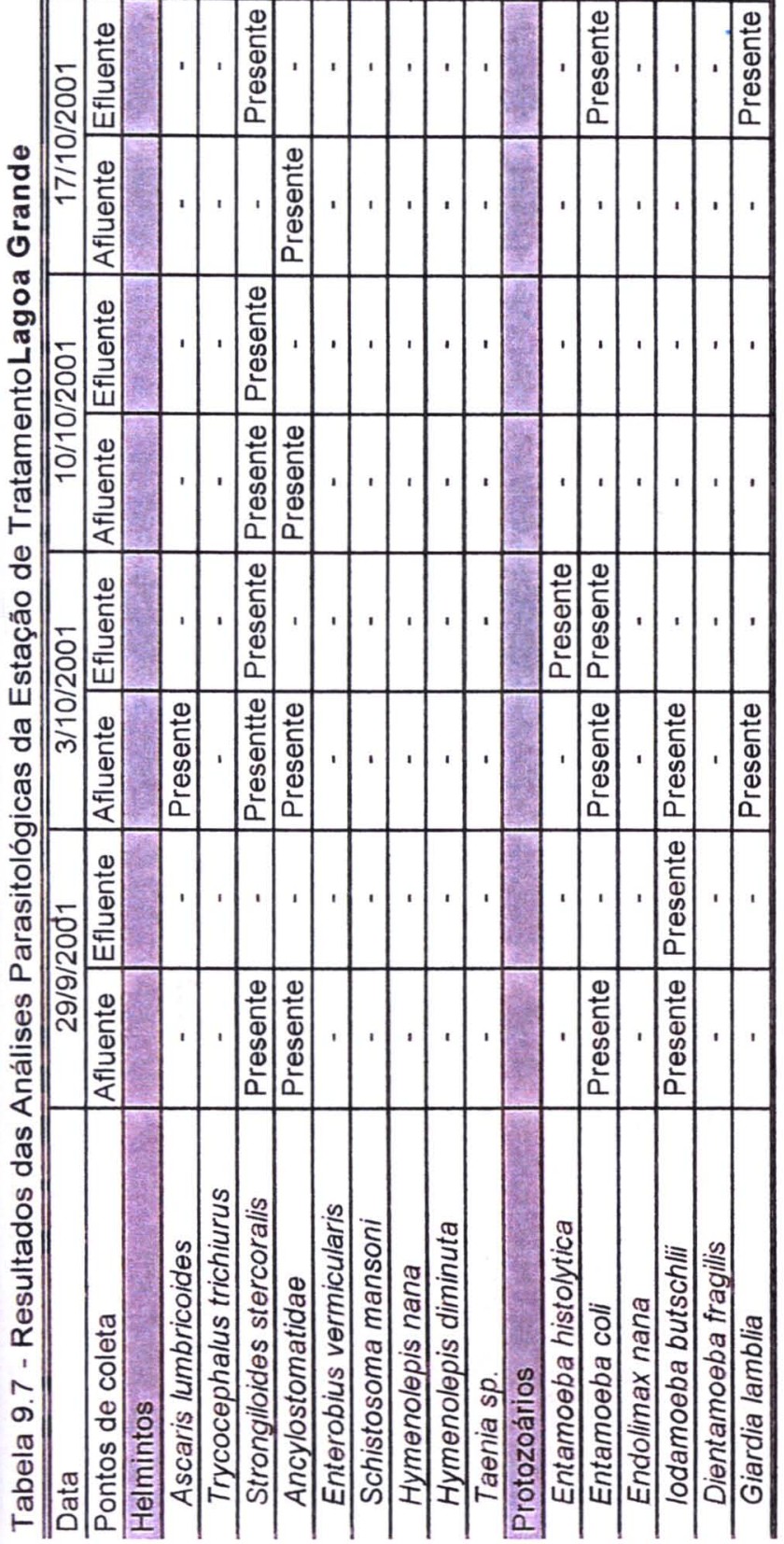
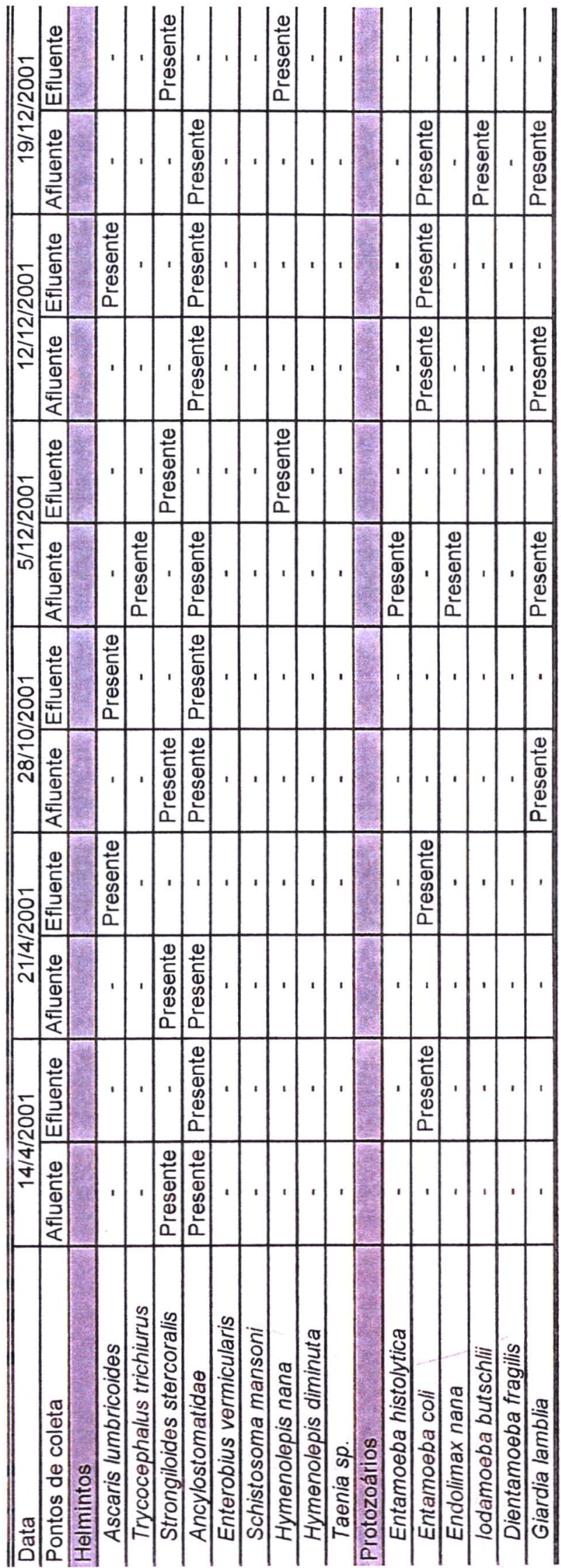


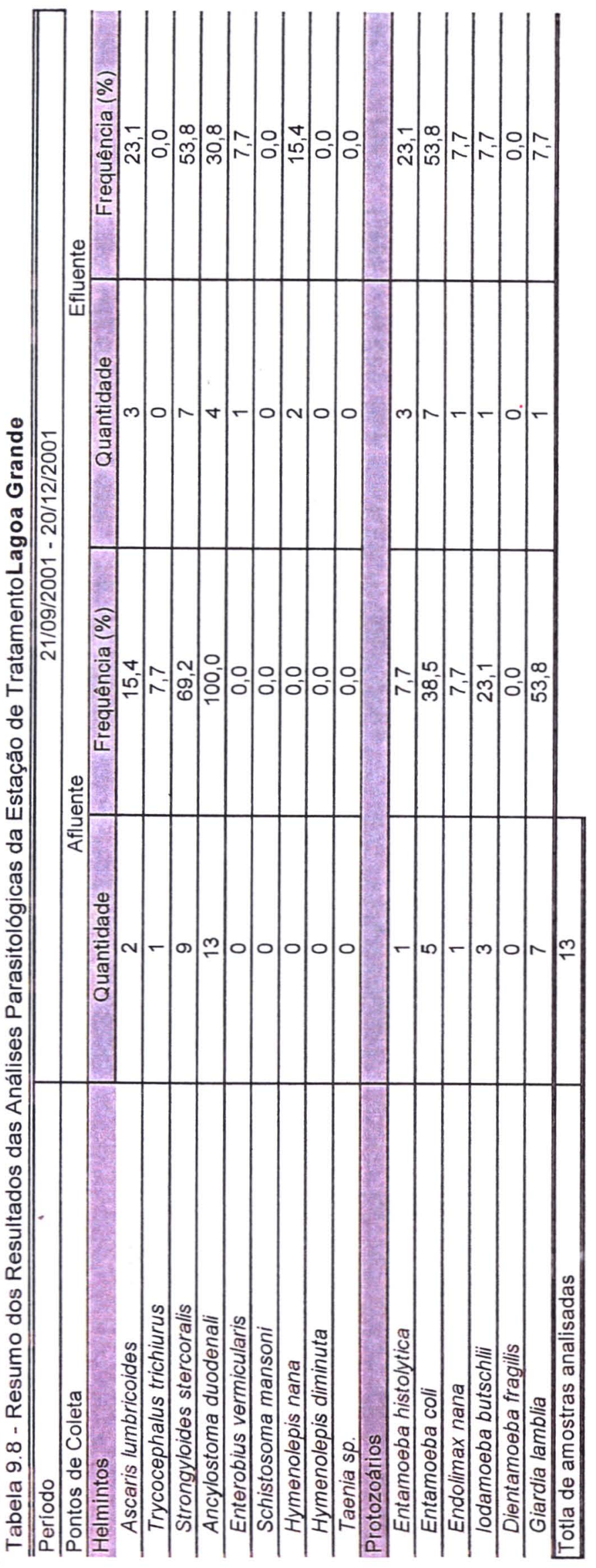




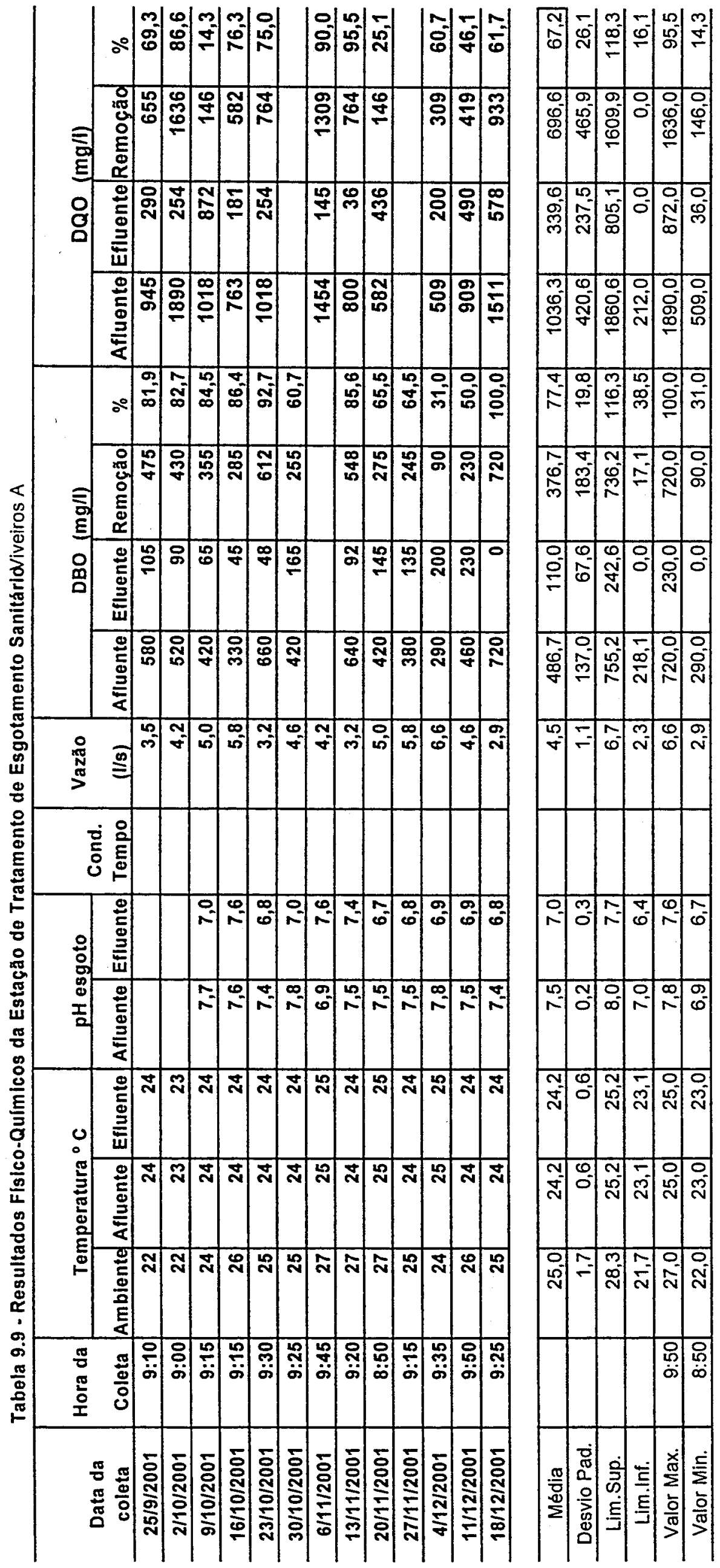




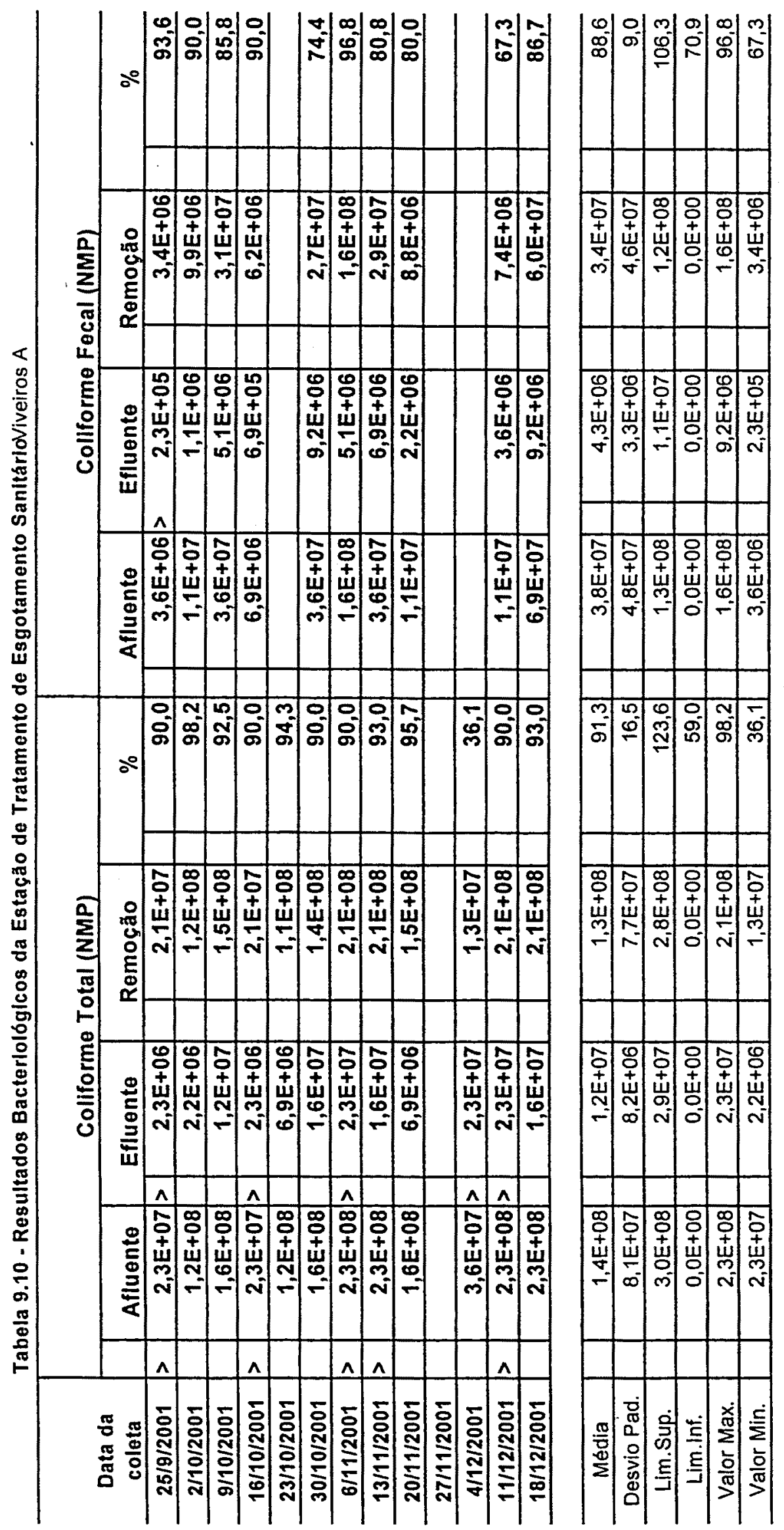



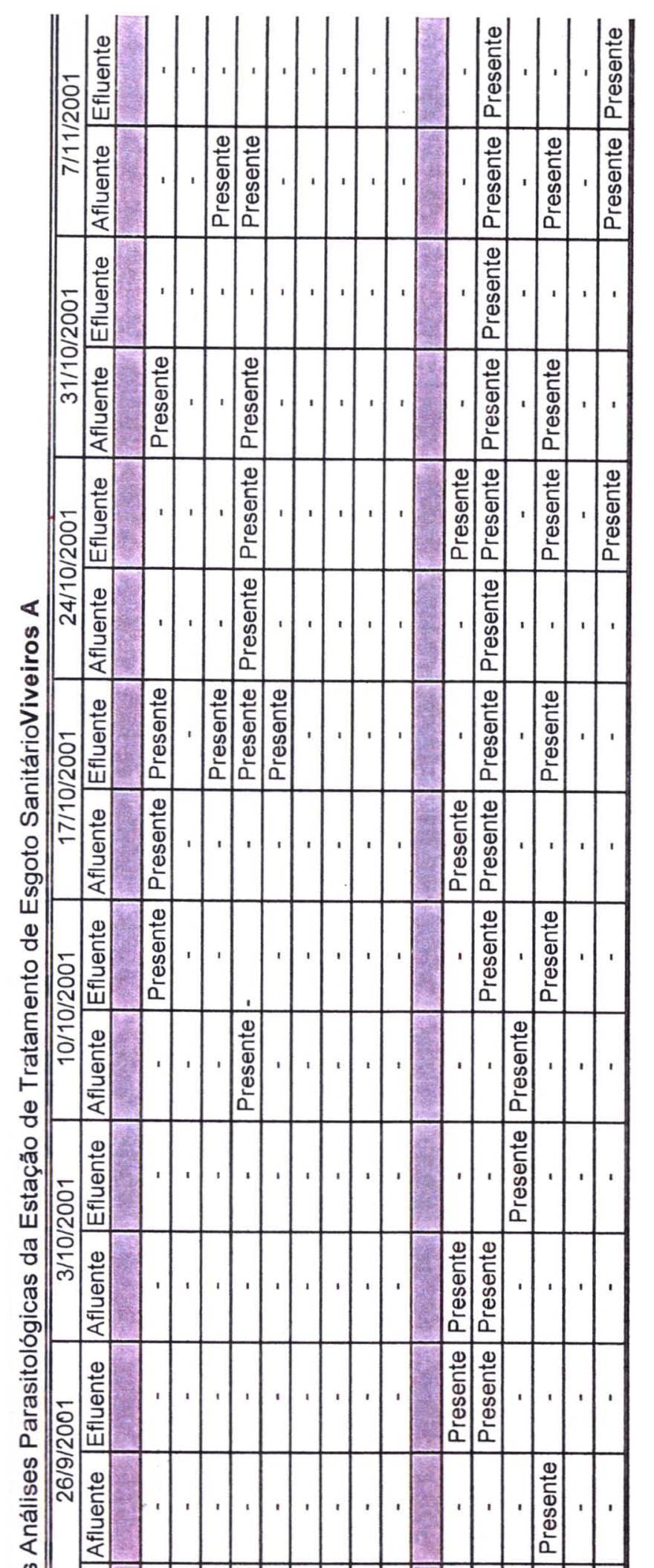

ำ

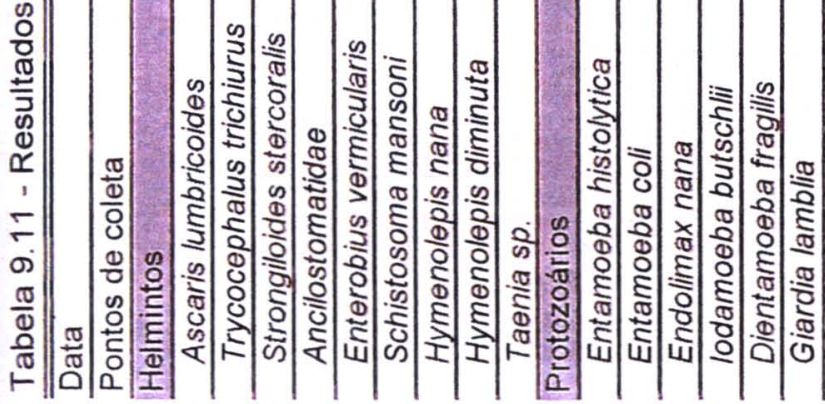

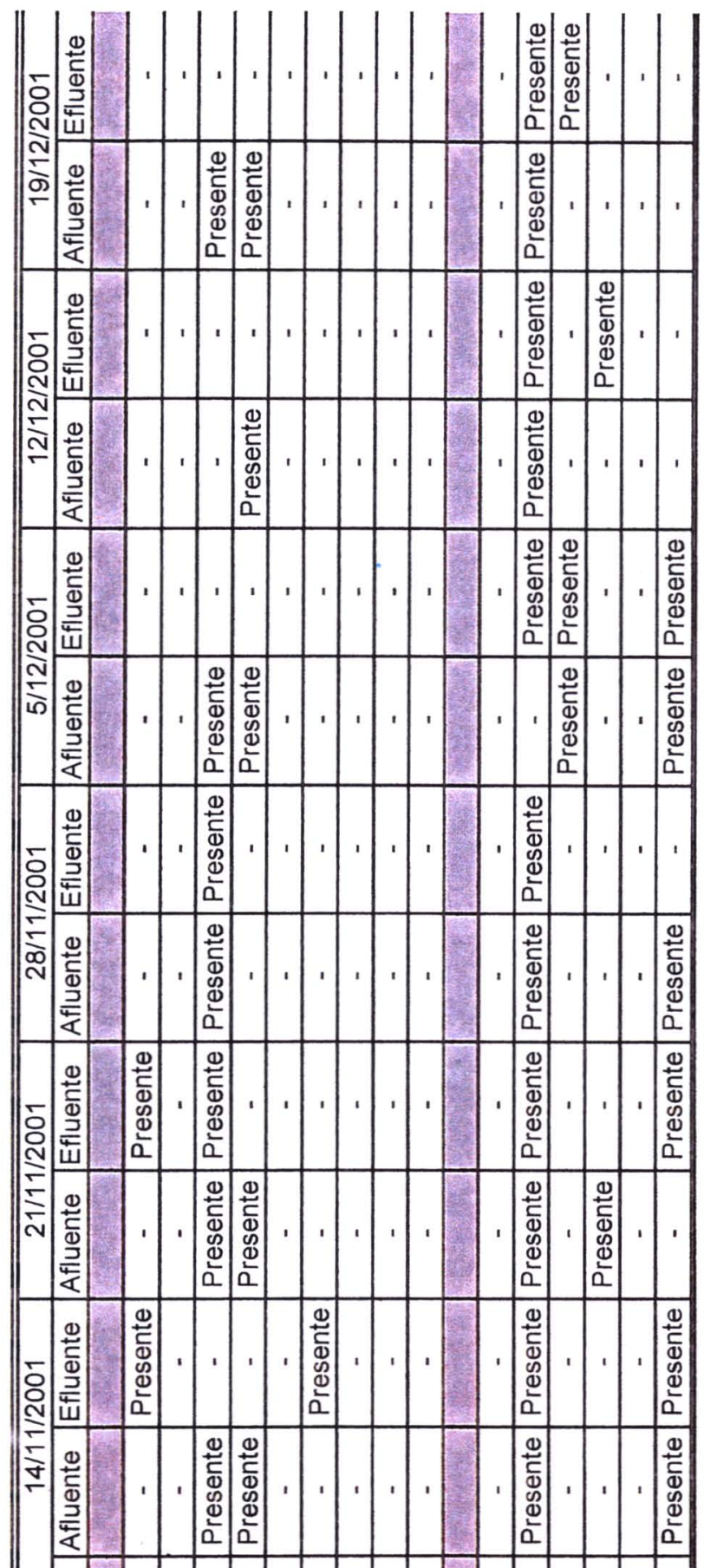

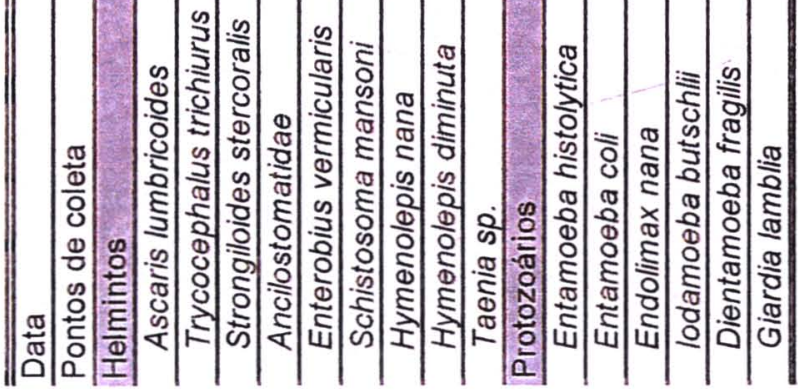




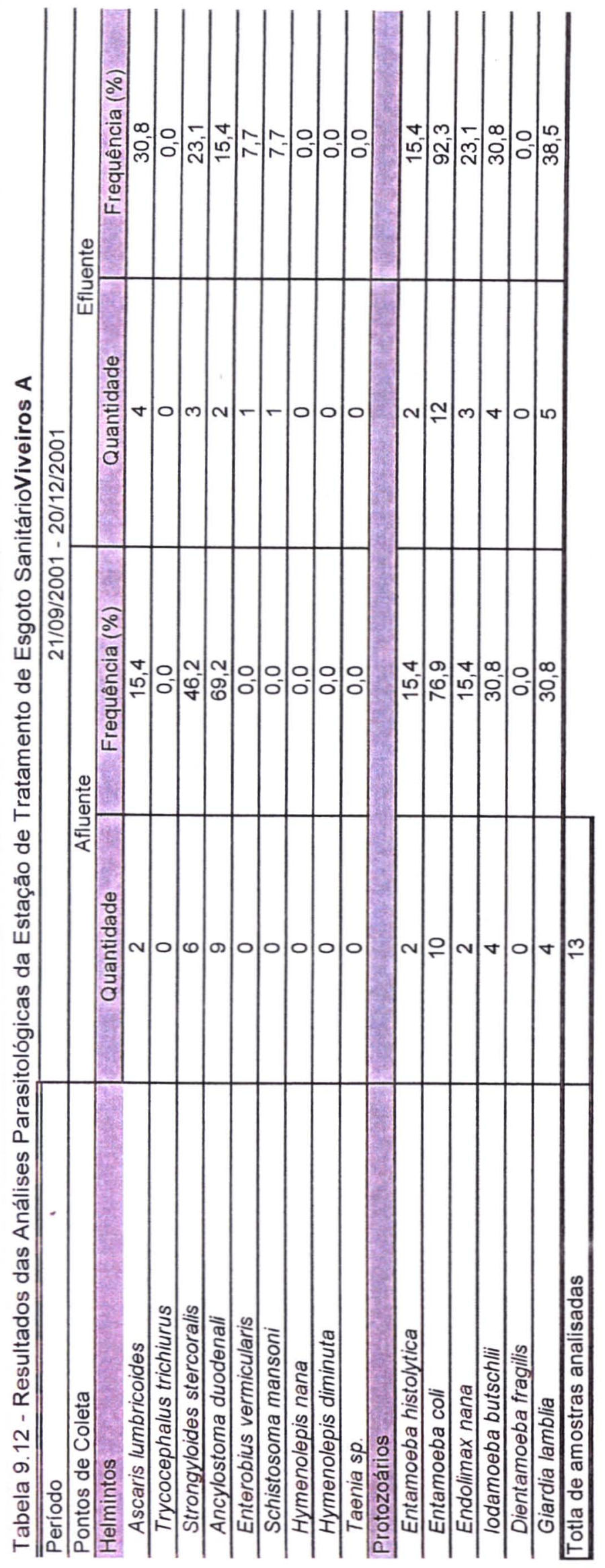




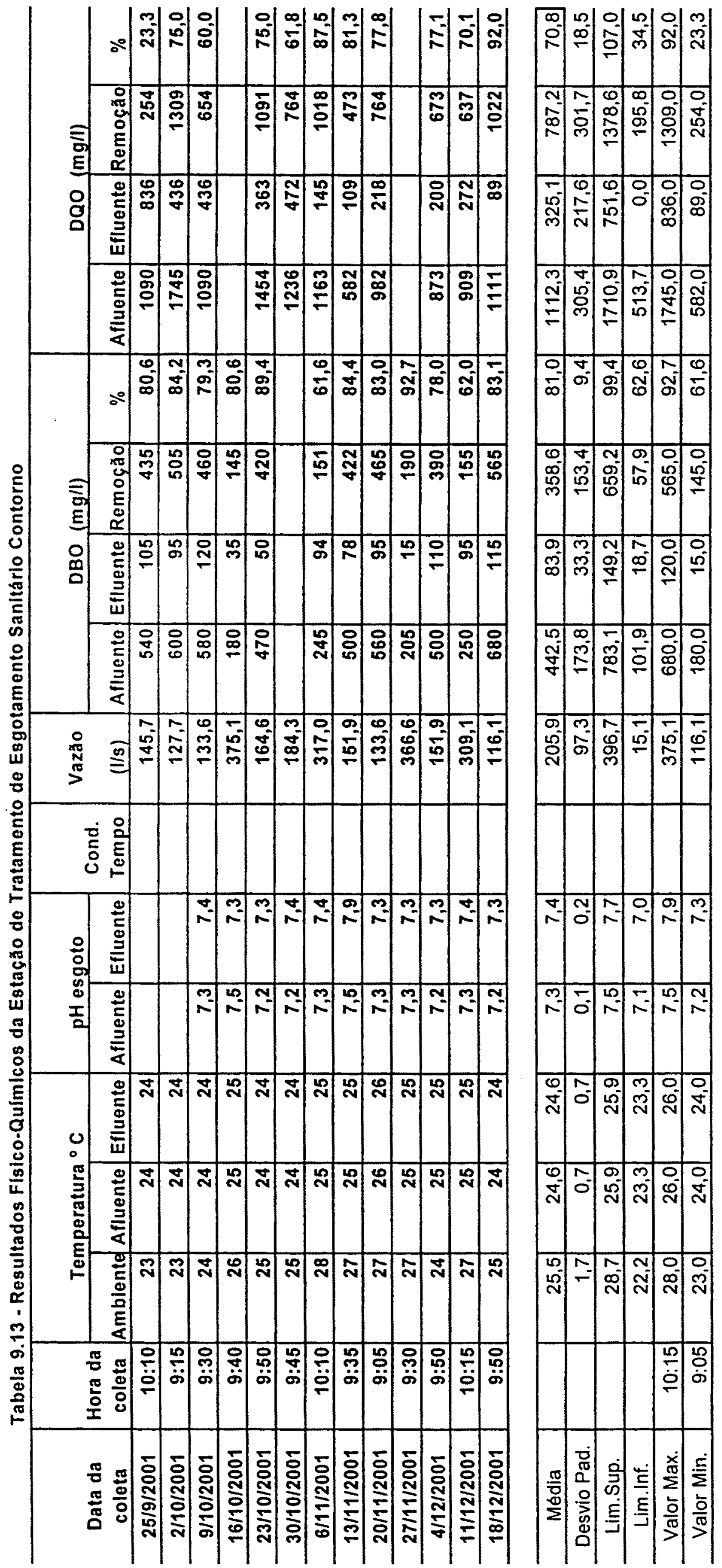




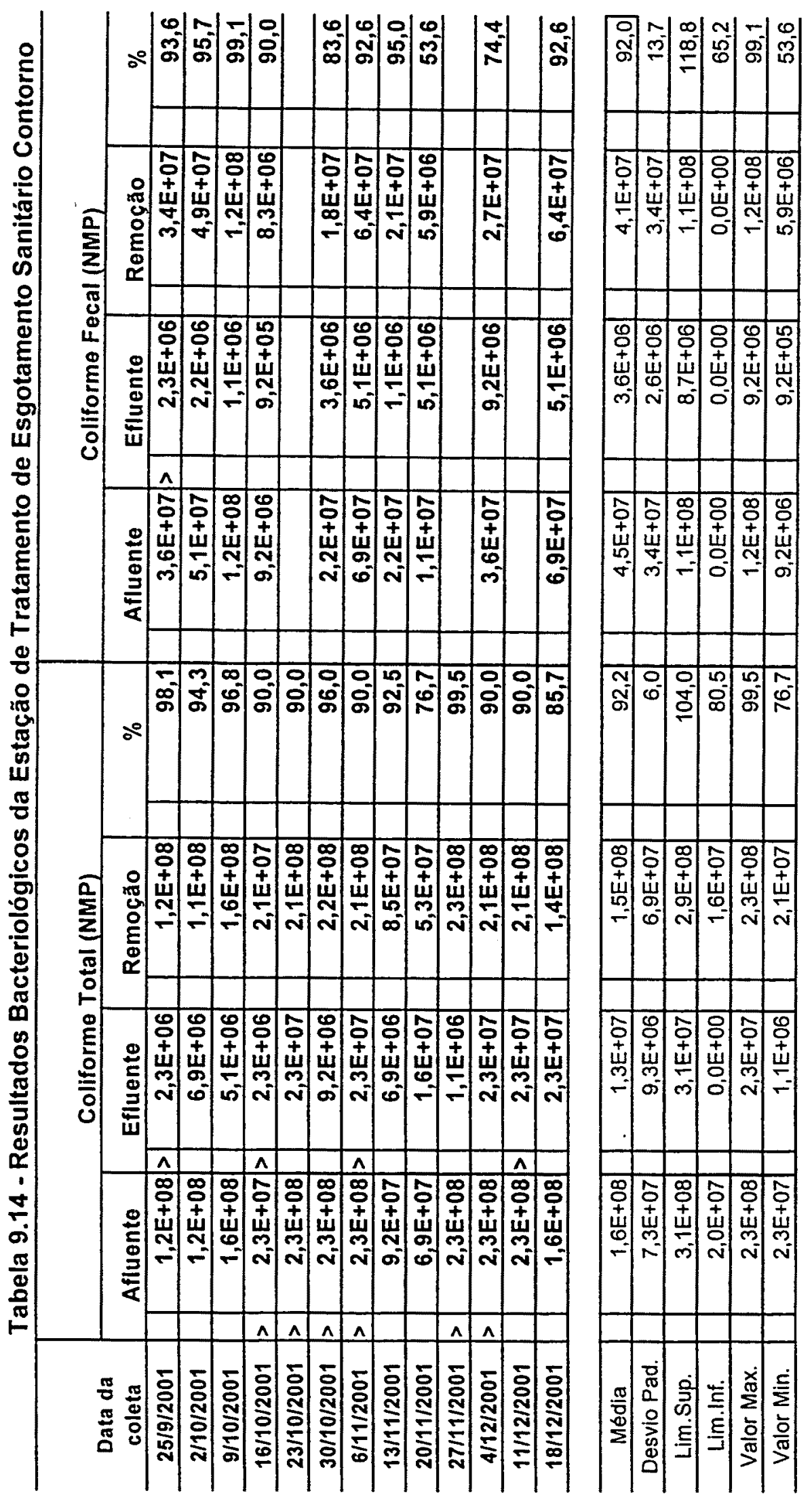



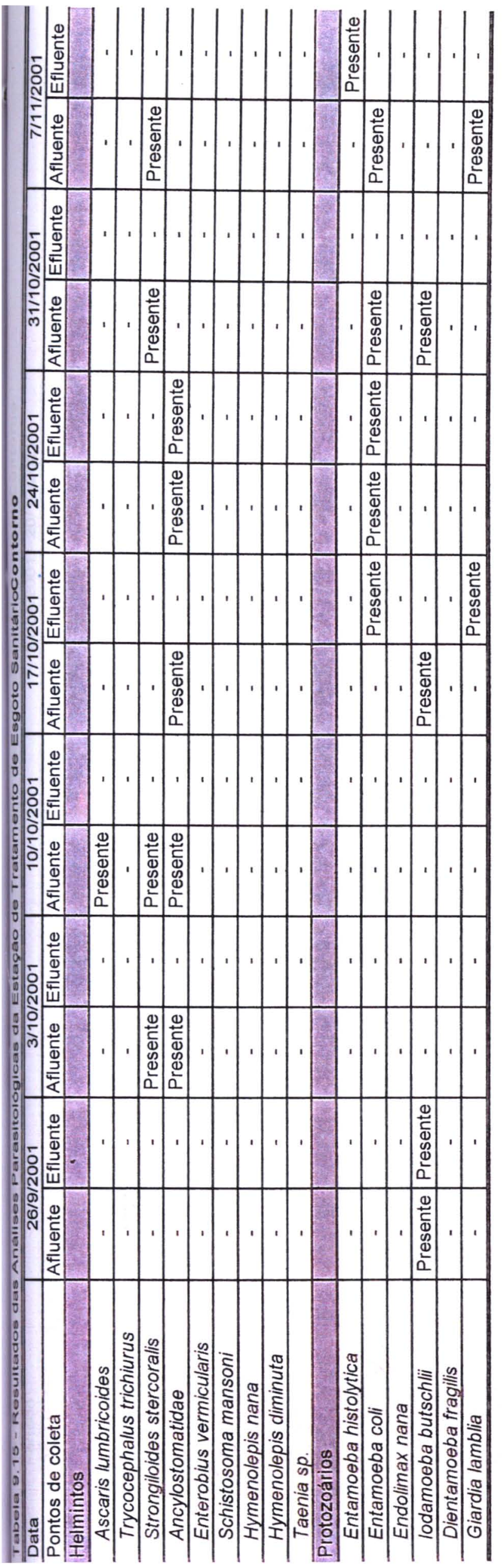
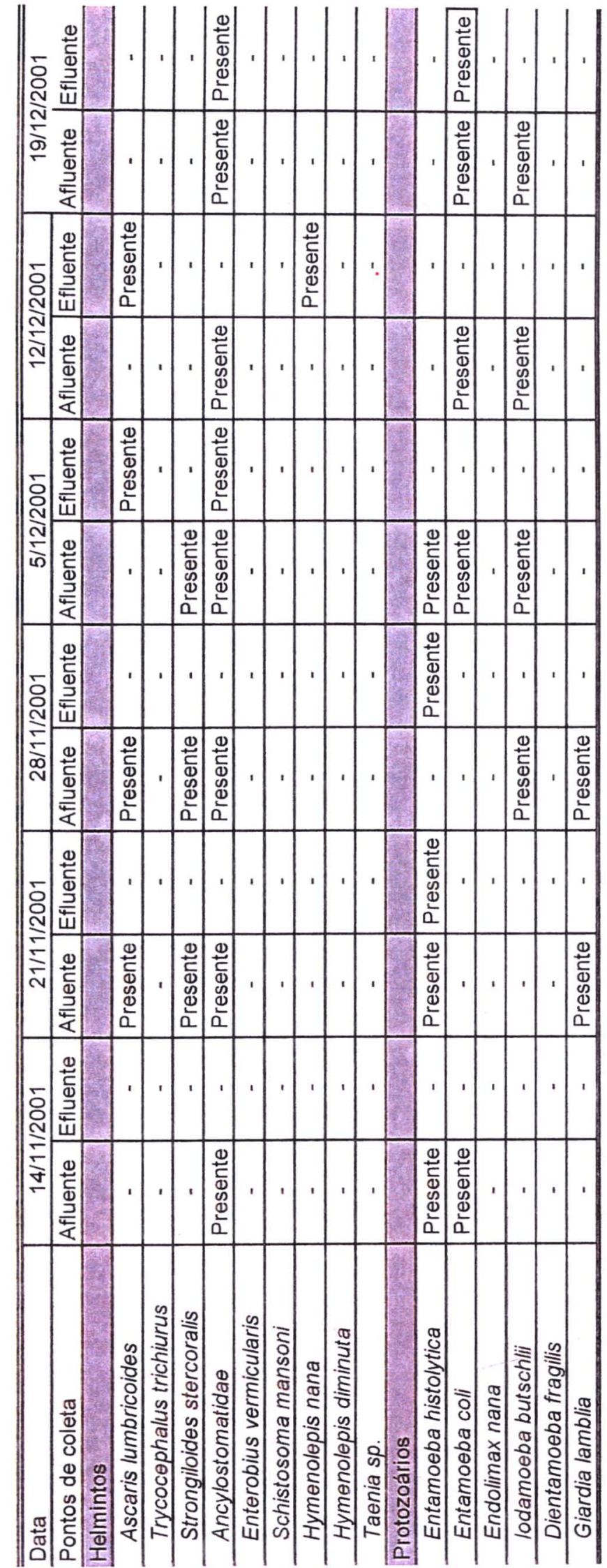


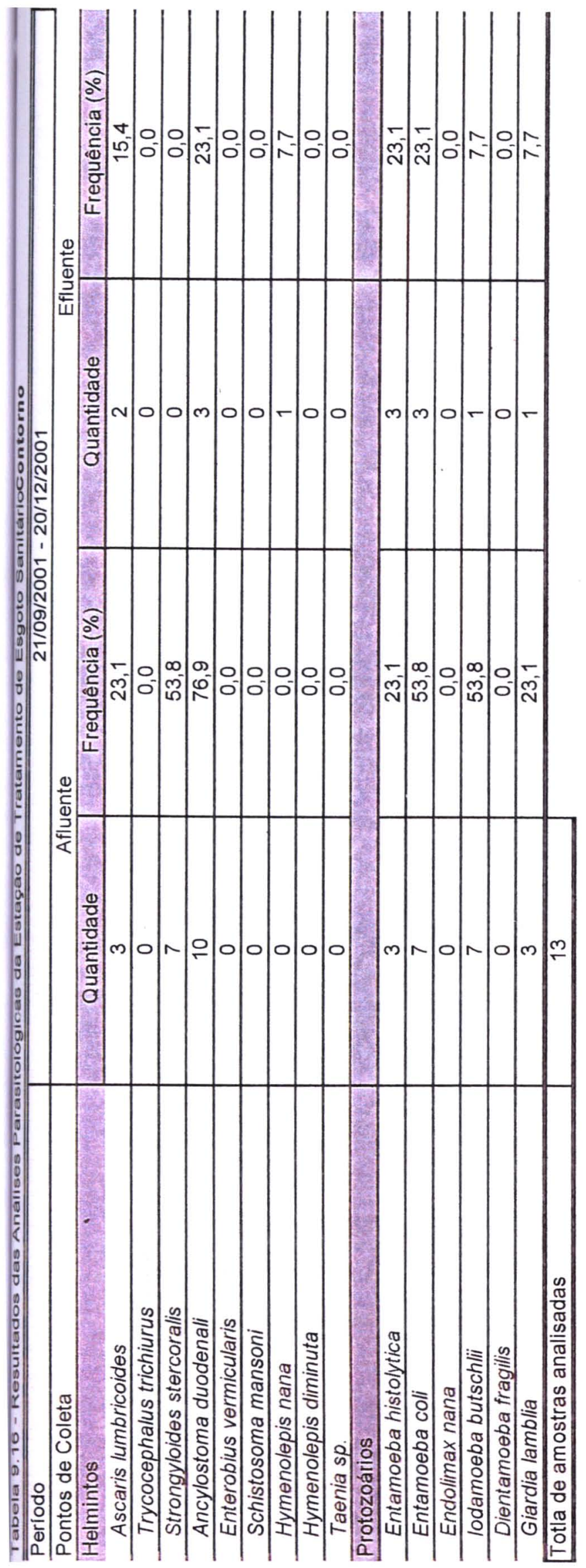


Os resultados físico-químicos, bacteriológicos e parasitológicos obtidos no verão, para as Estações Homero Figueiredo, Lagoa Grande, Viveiros-A e Contorno, estão apresentados nas Tabelas 9.17 a 9.32 . 


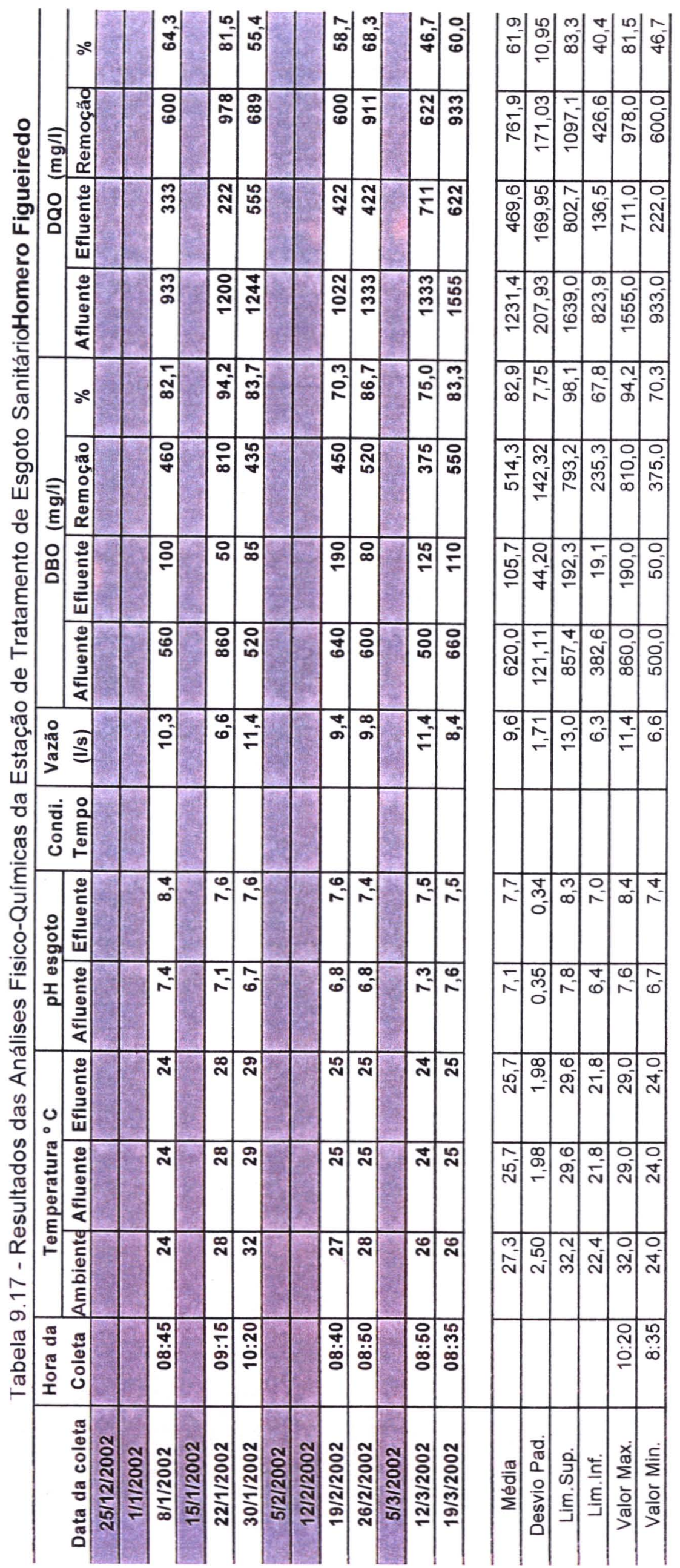




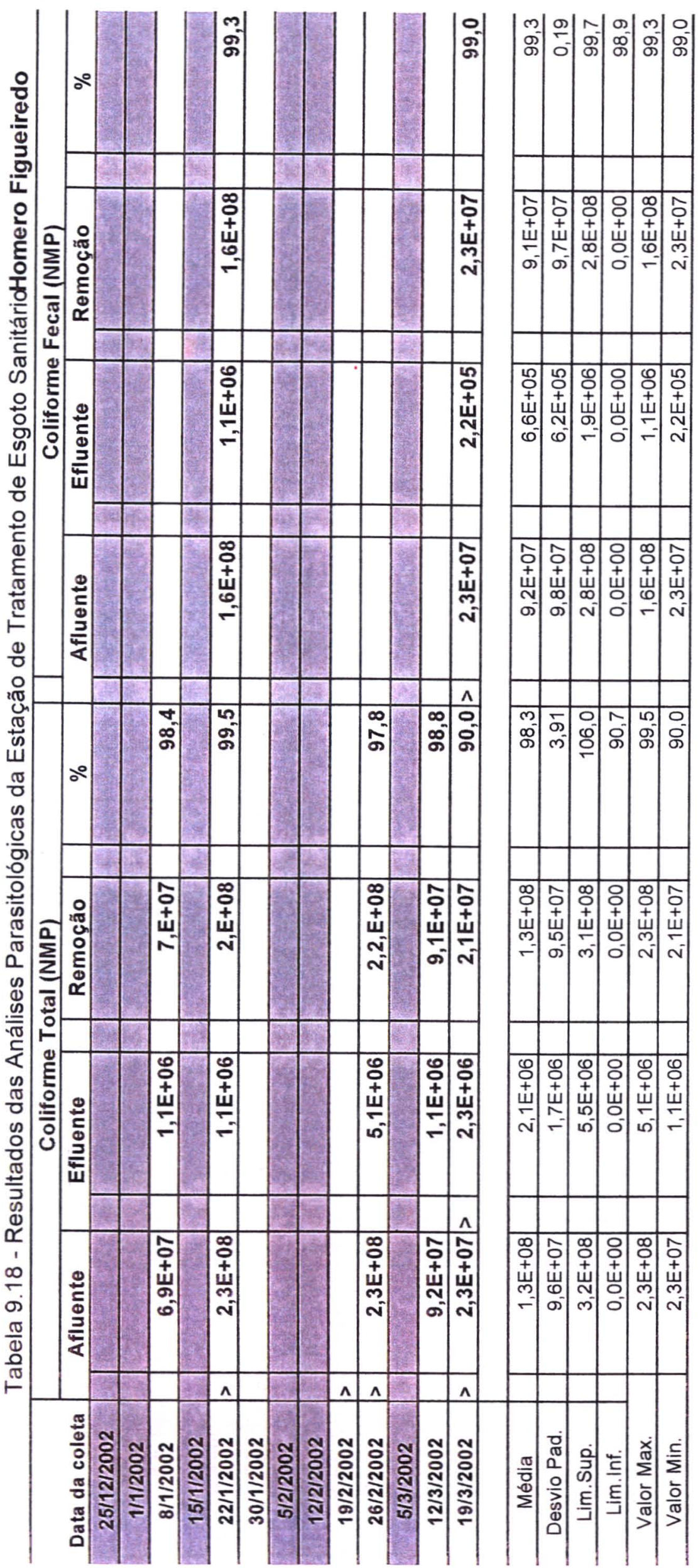



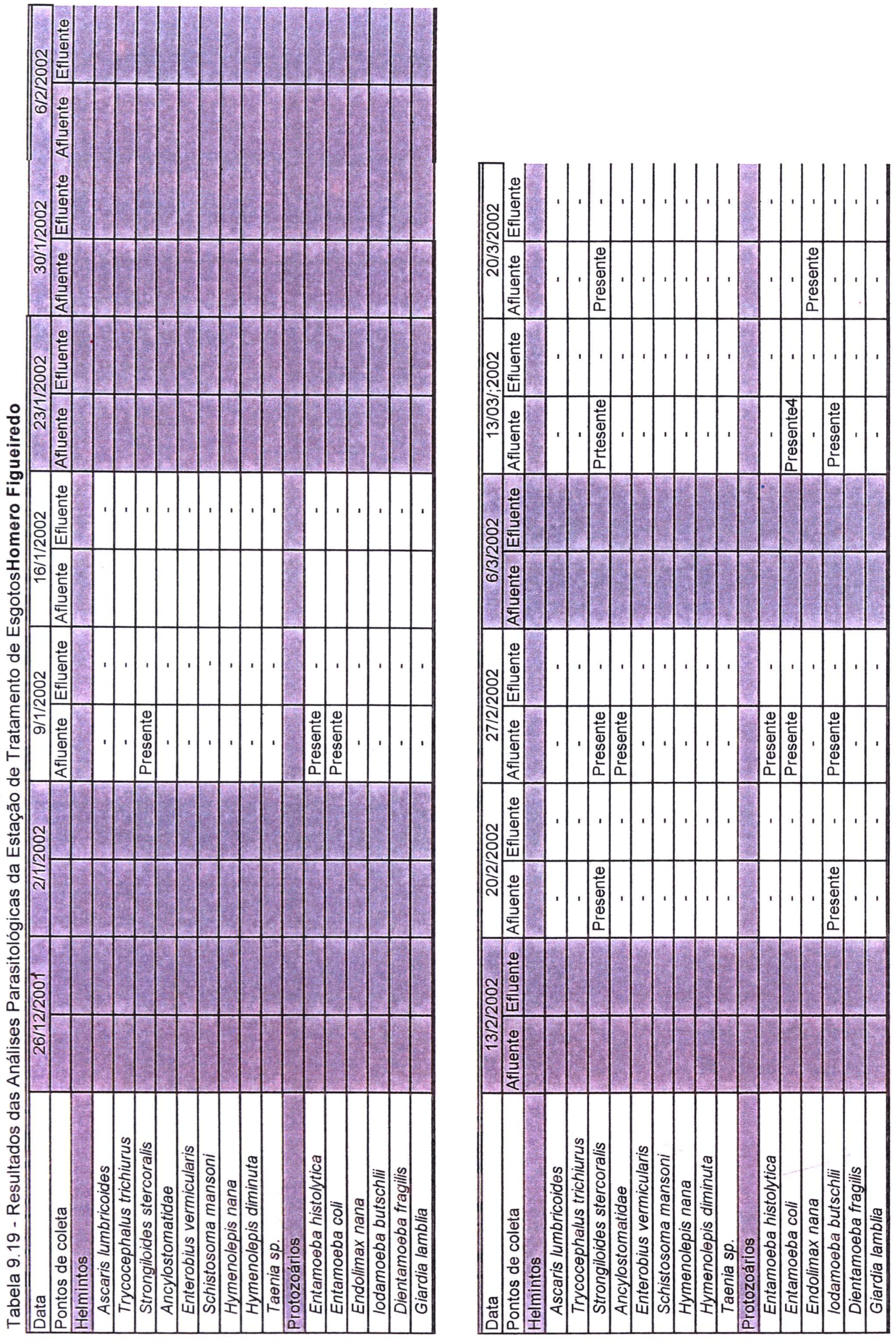


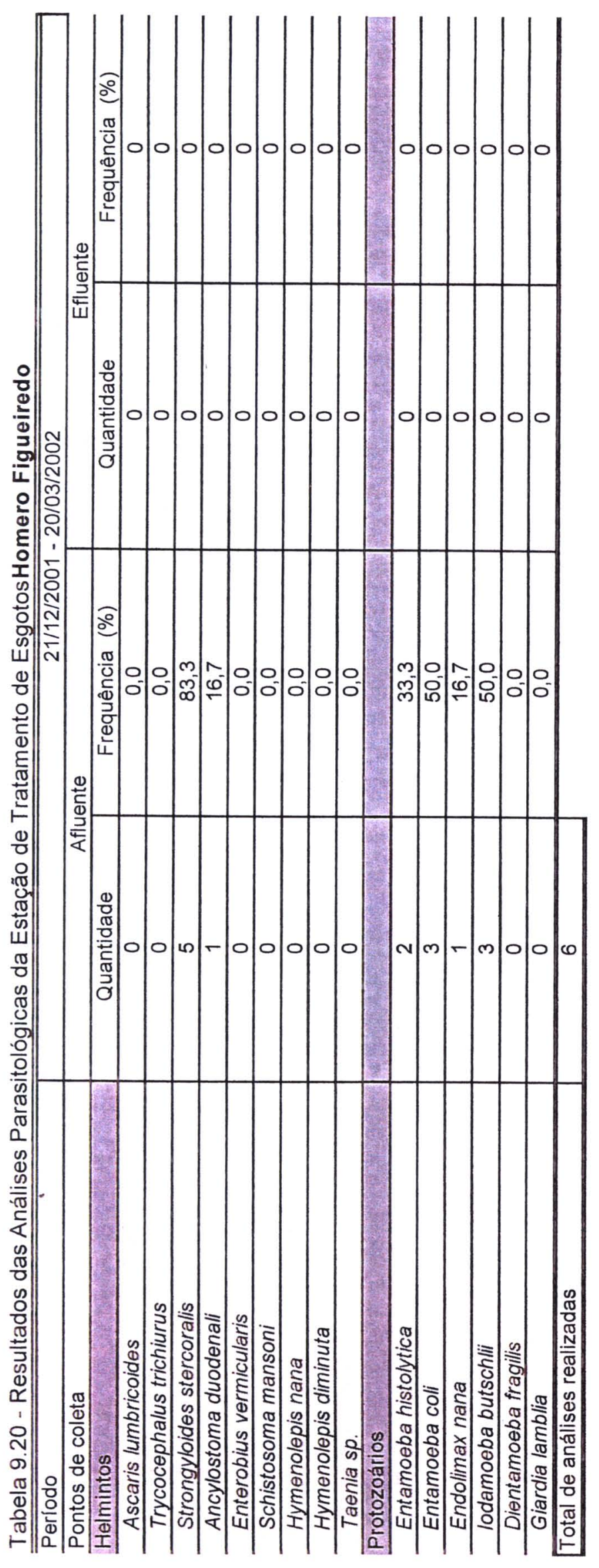




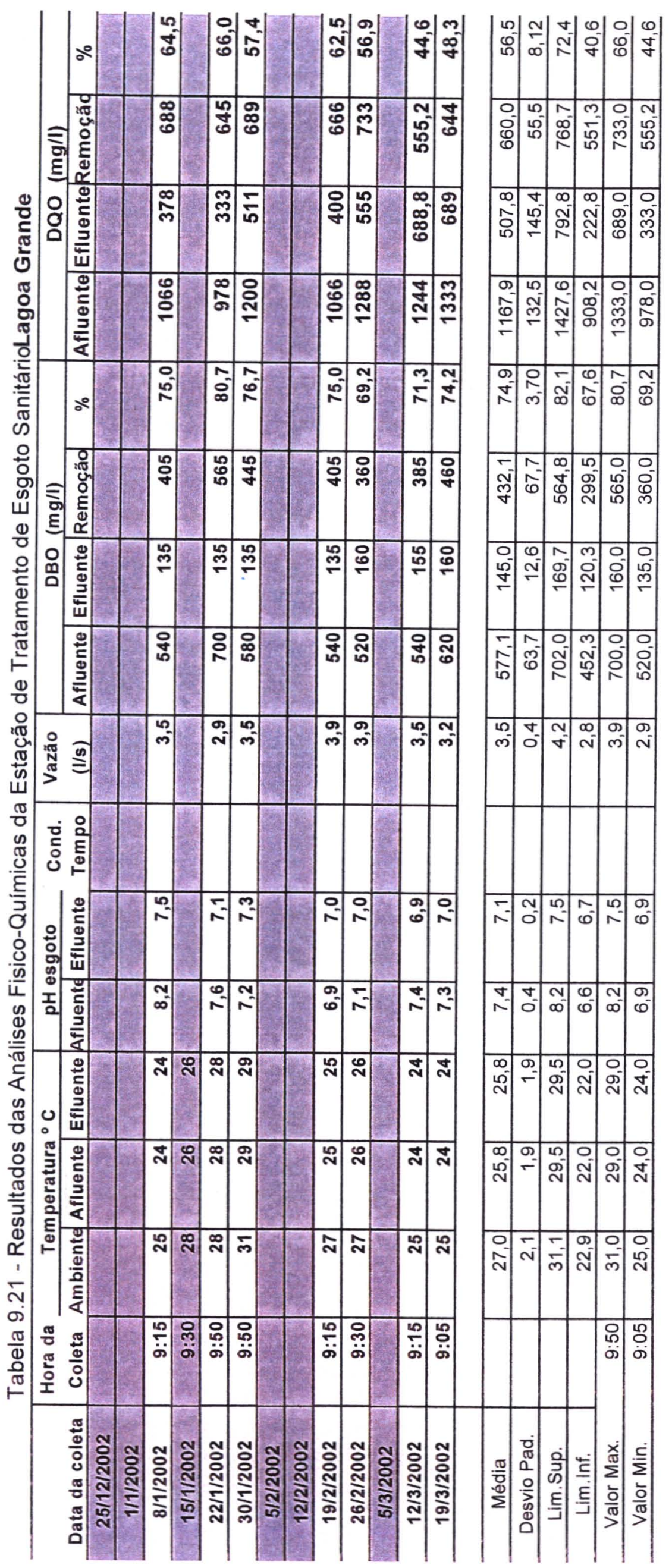




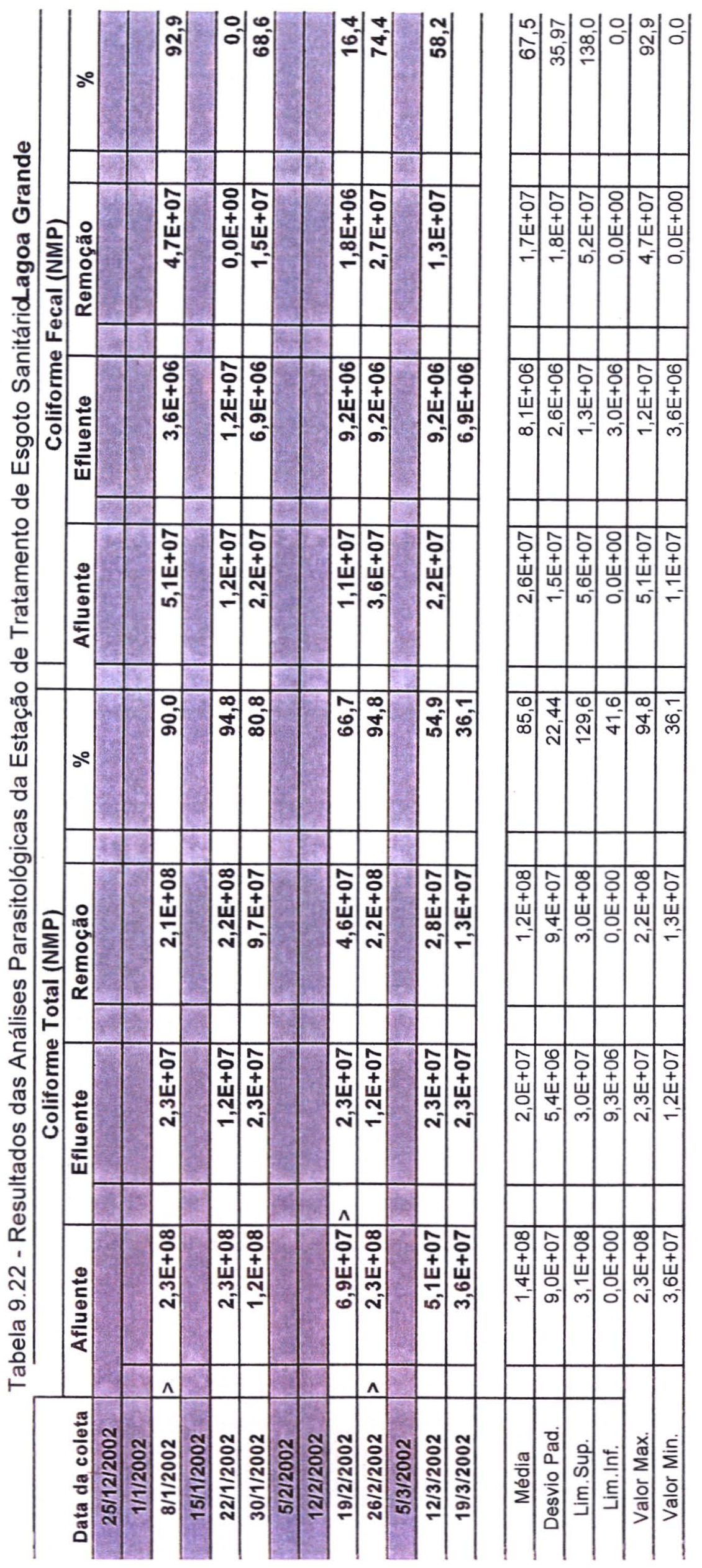



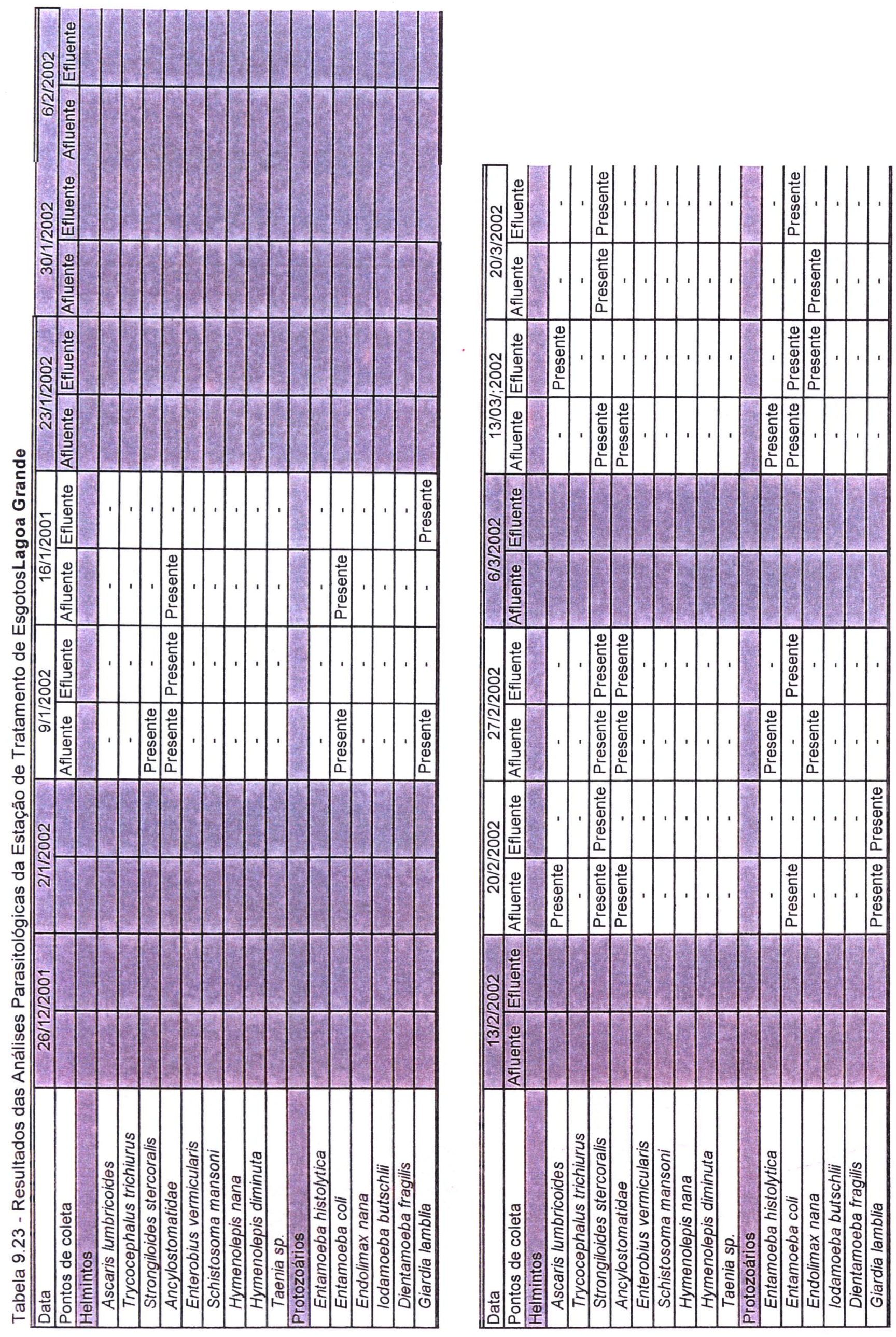


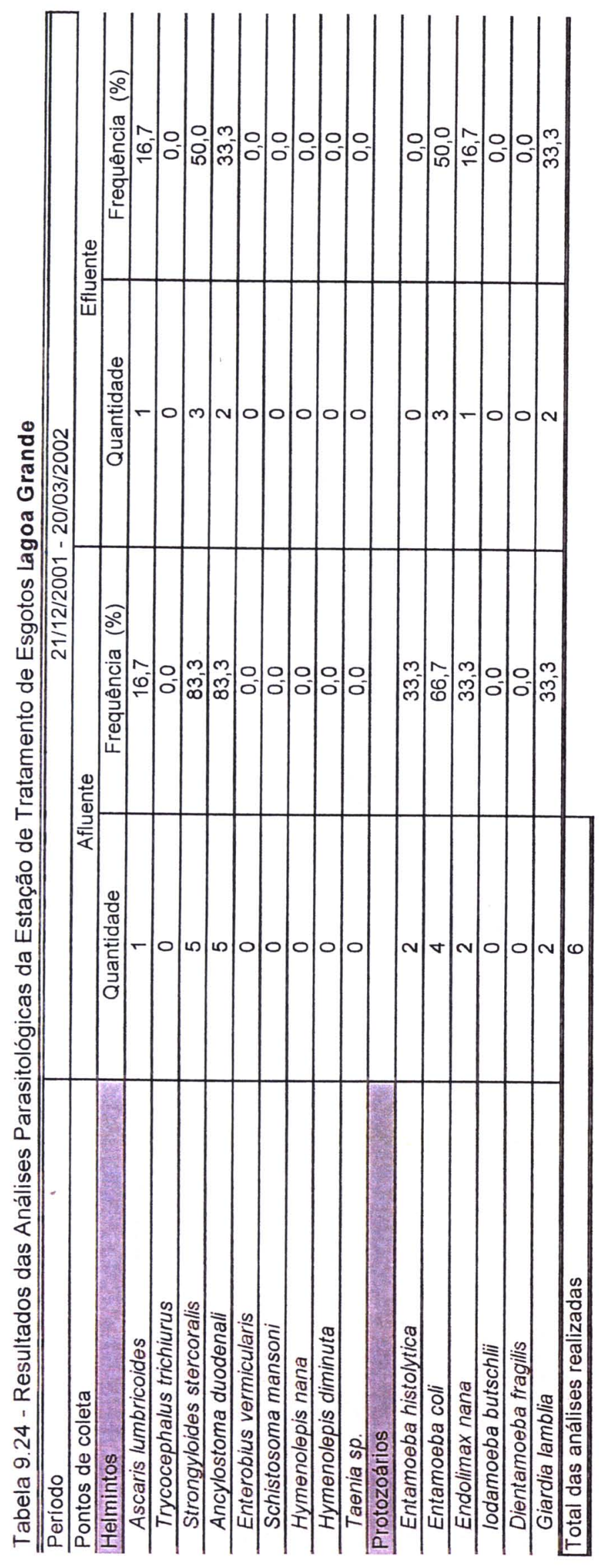




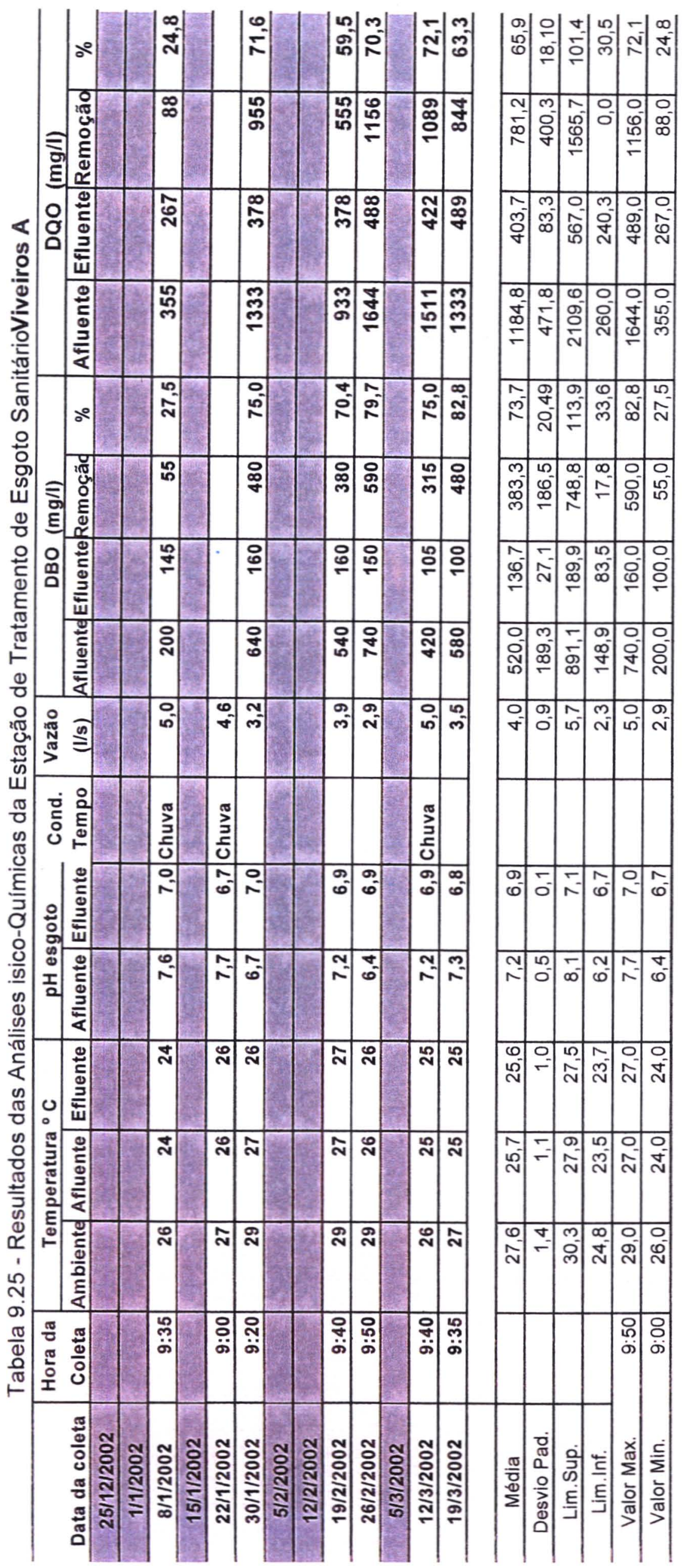




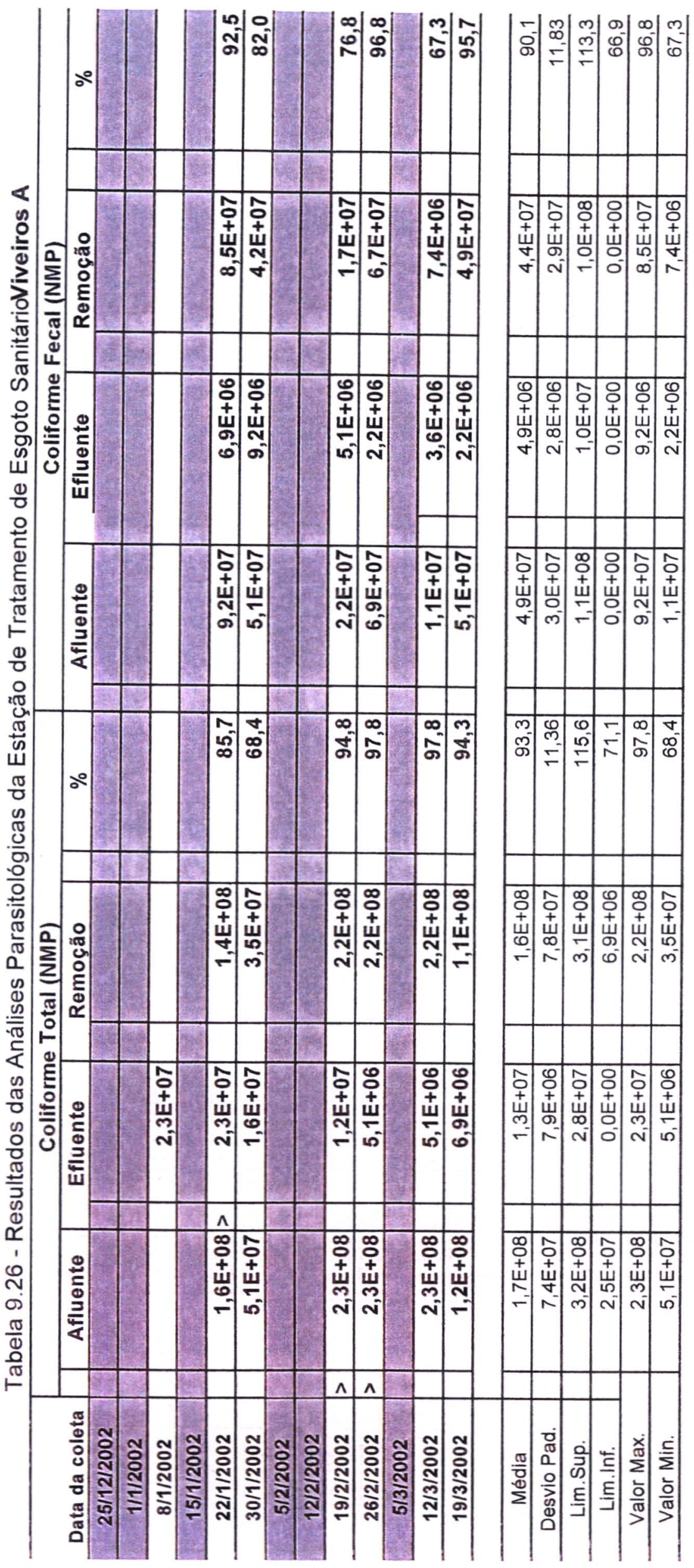



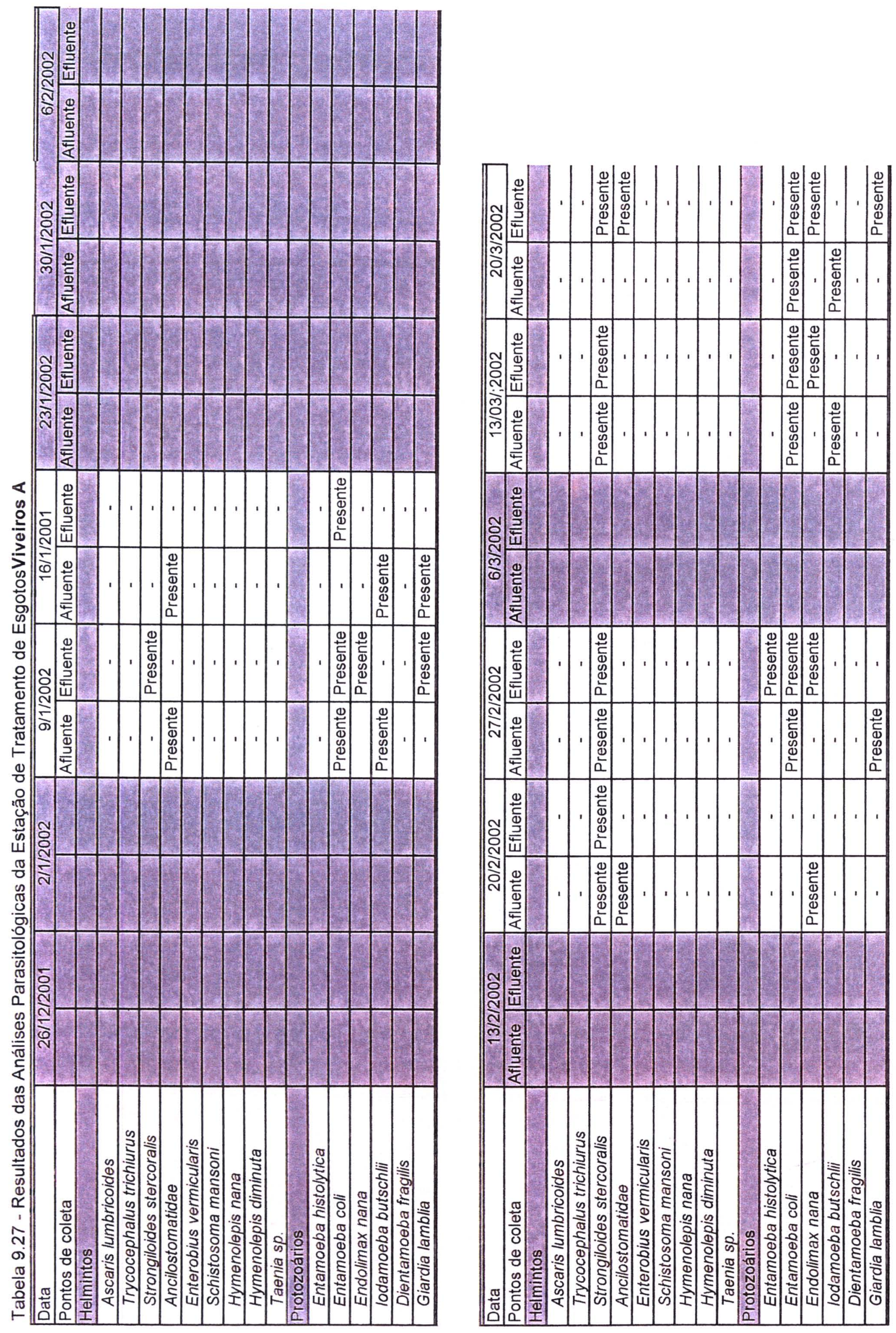


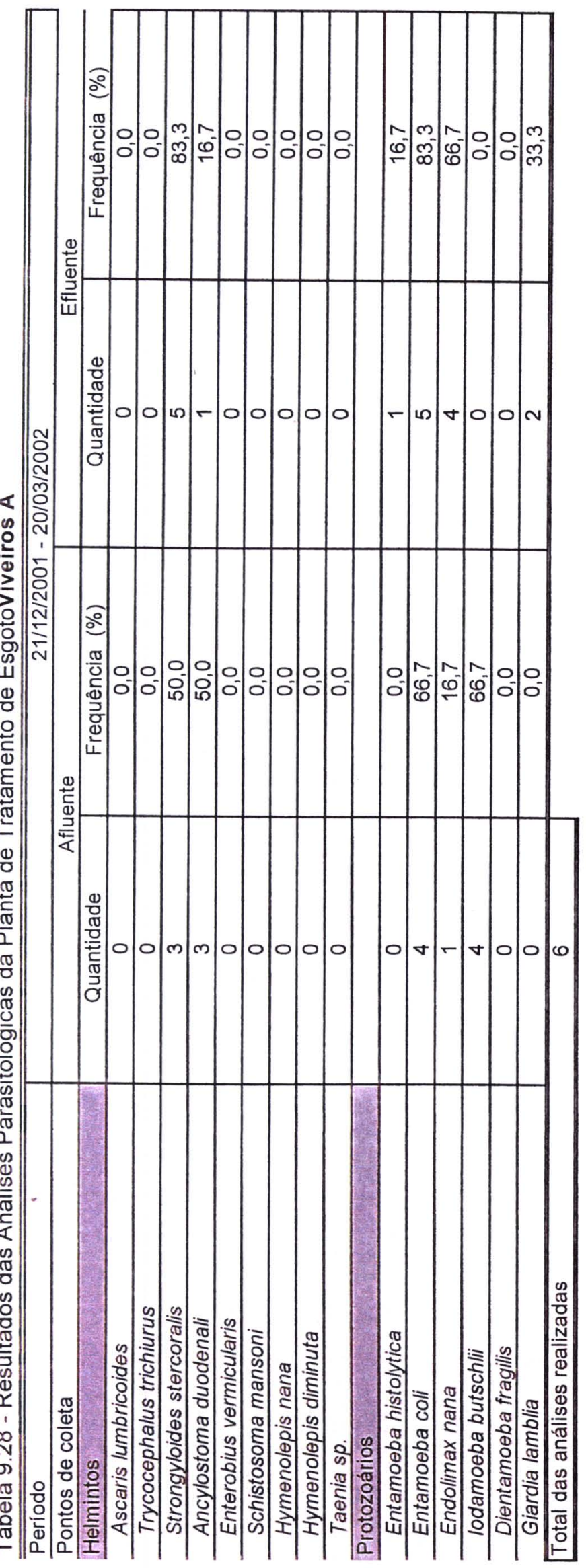




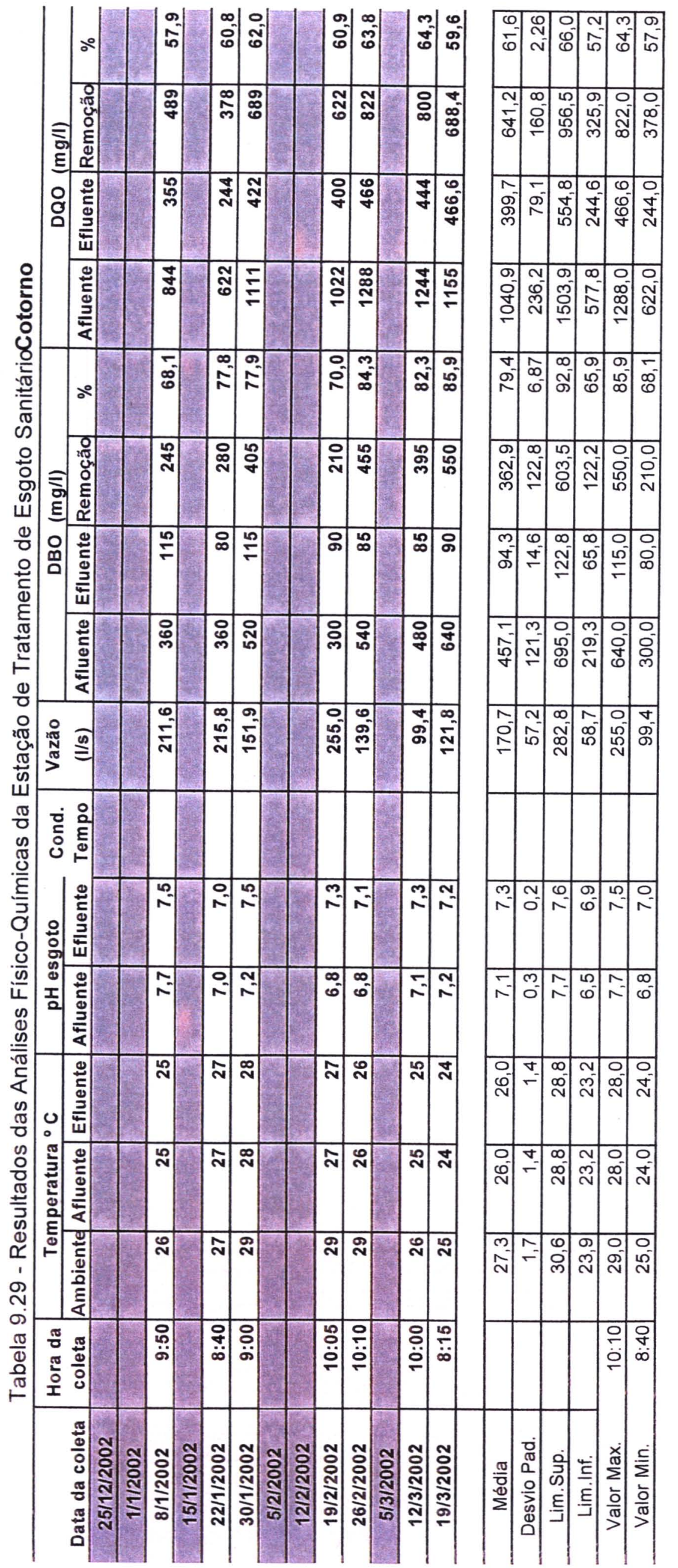



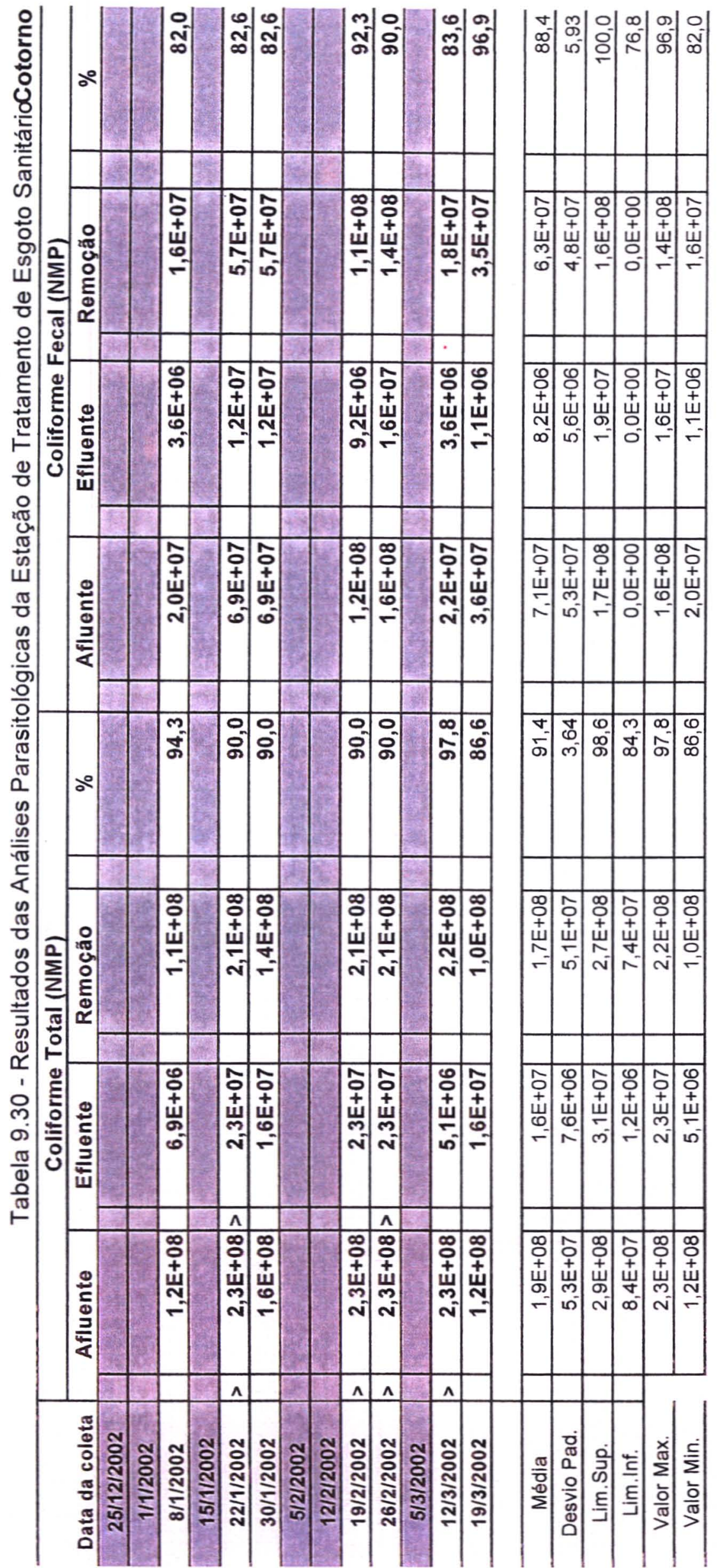
.
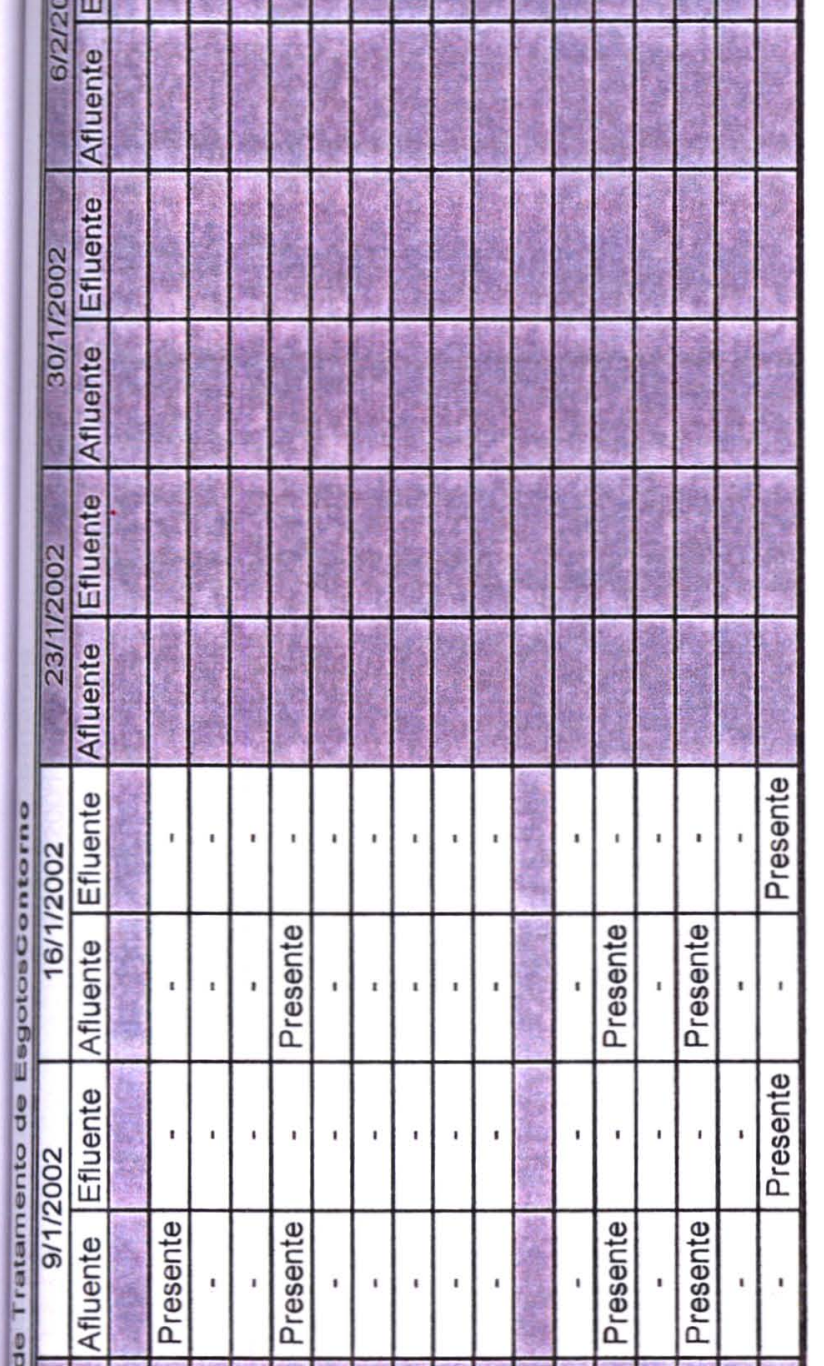

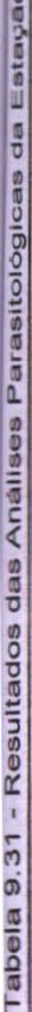

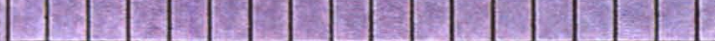

$-$

간

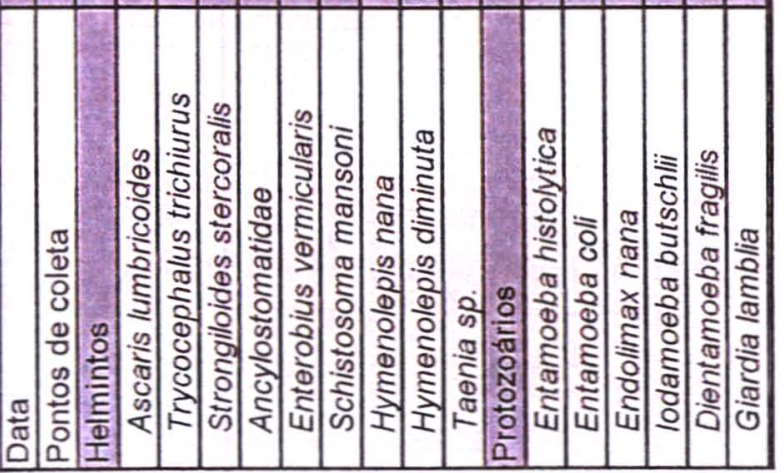

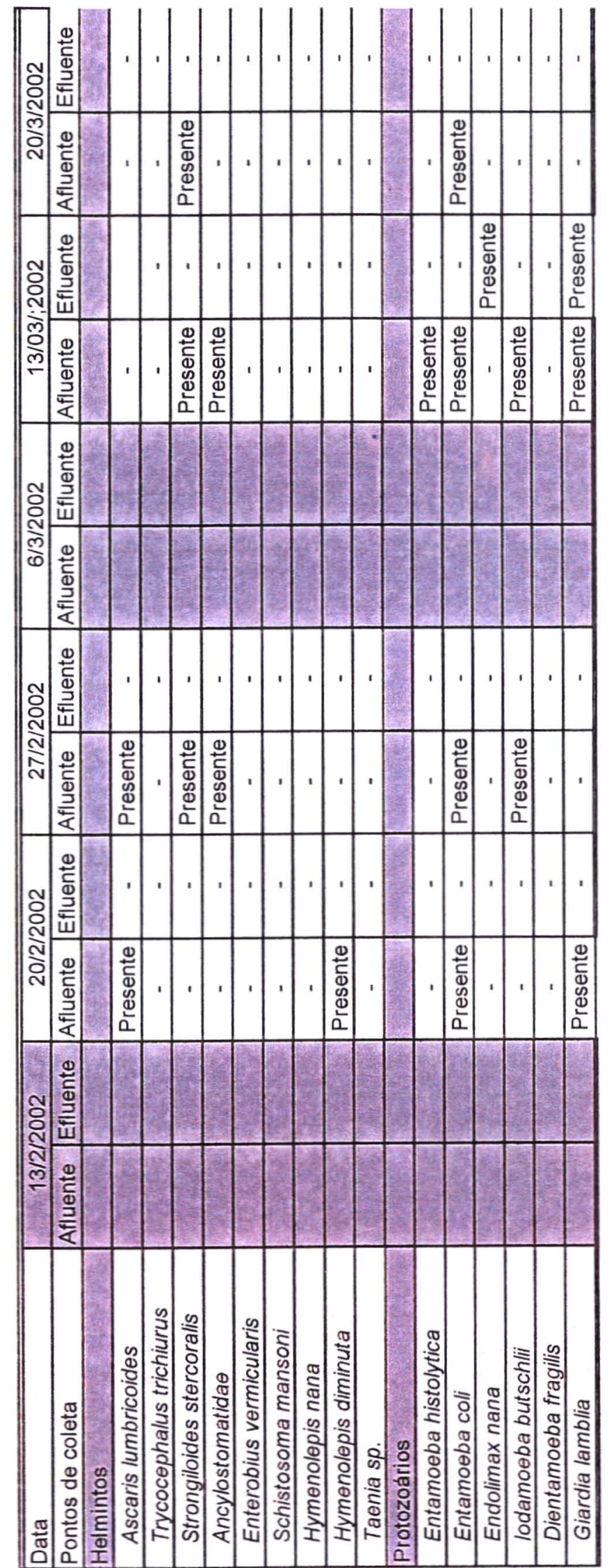




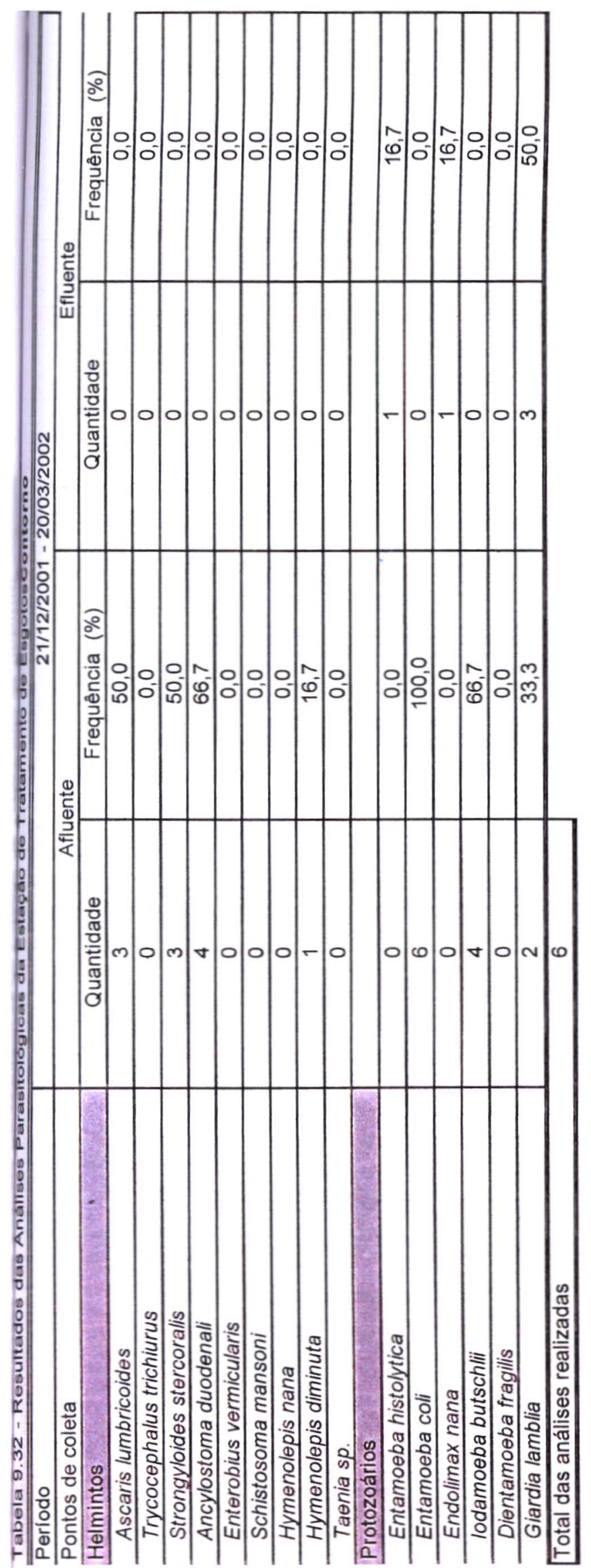


Os resultados físico-químicos, bacteriológicos e parasitológicos obtidos no outono, para as Estações Homero Figueiredo, Lagoa Grande, Viveiros-A e Contorno, estão apresentados nas Tabelas 9.33 a 9.48 . 


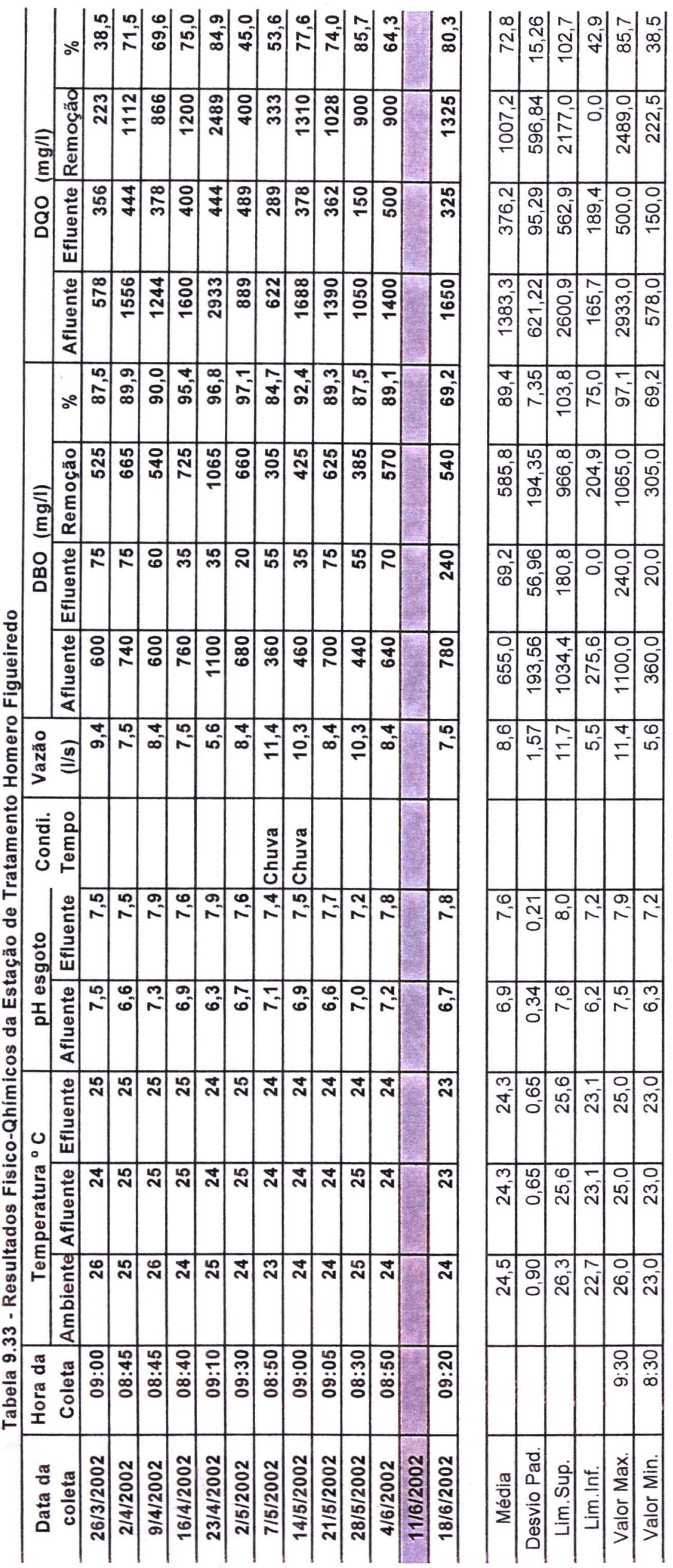




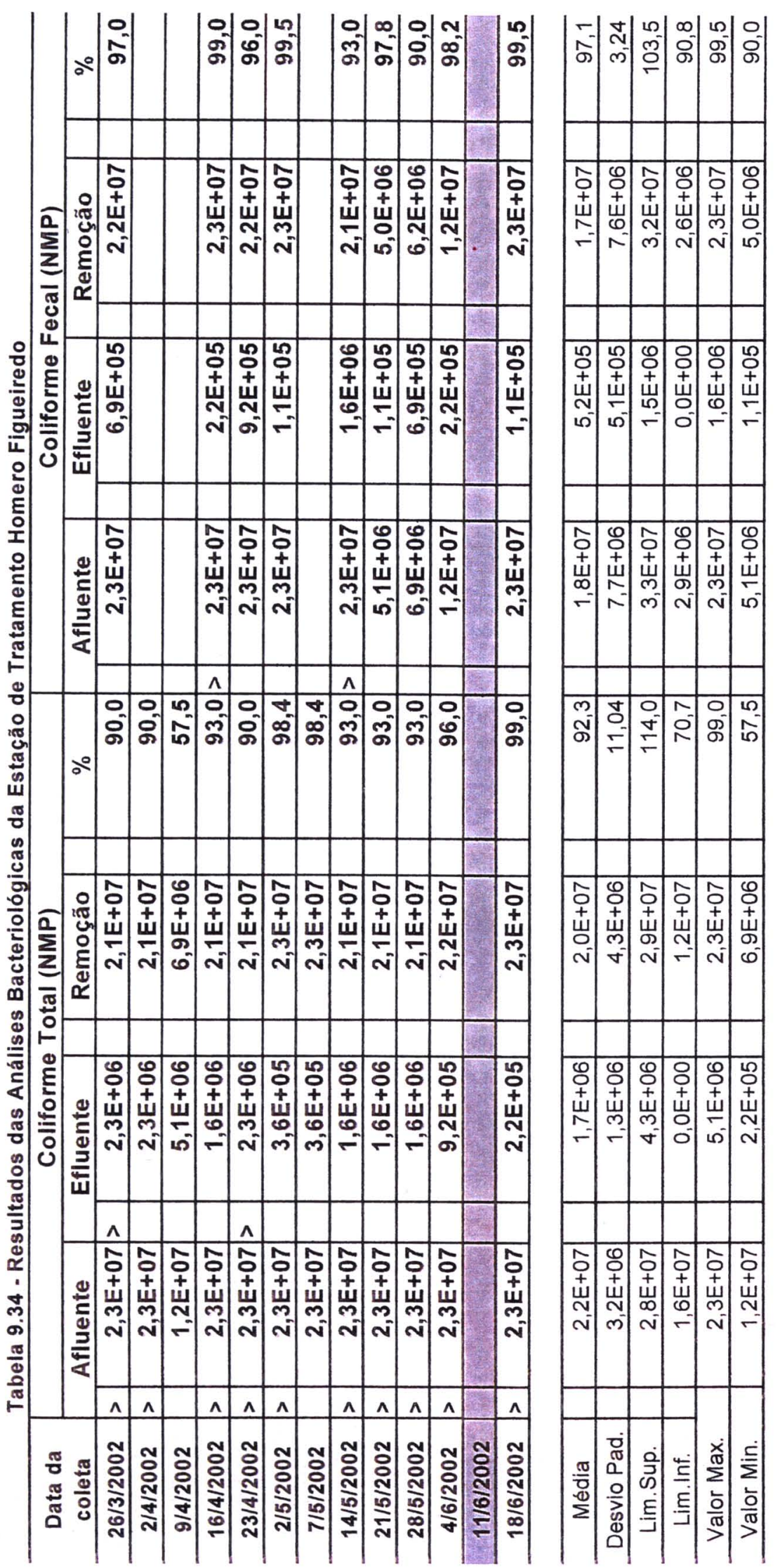




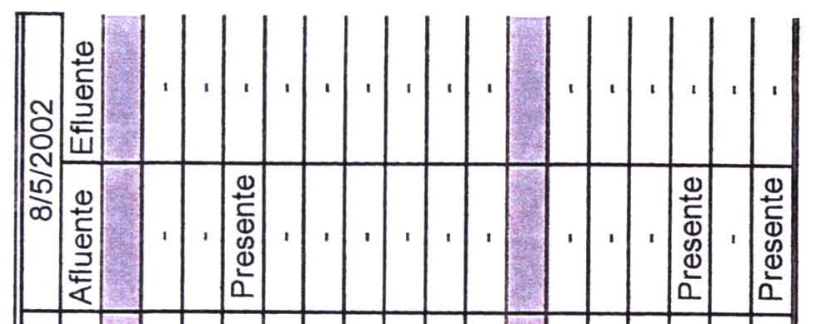

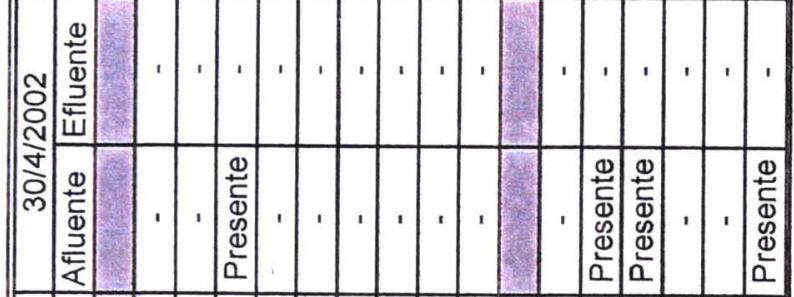

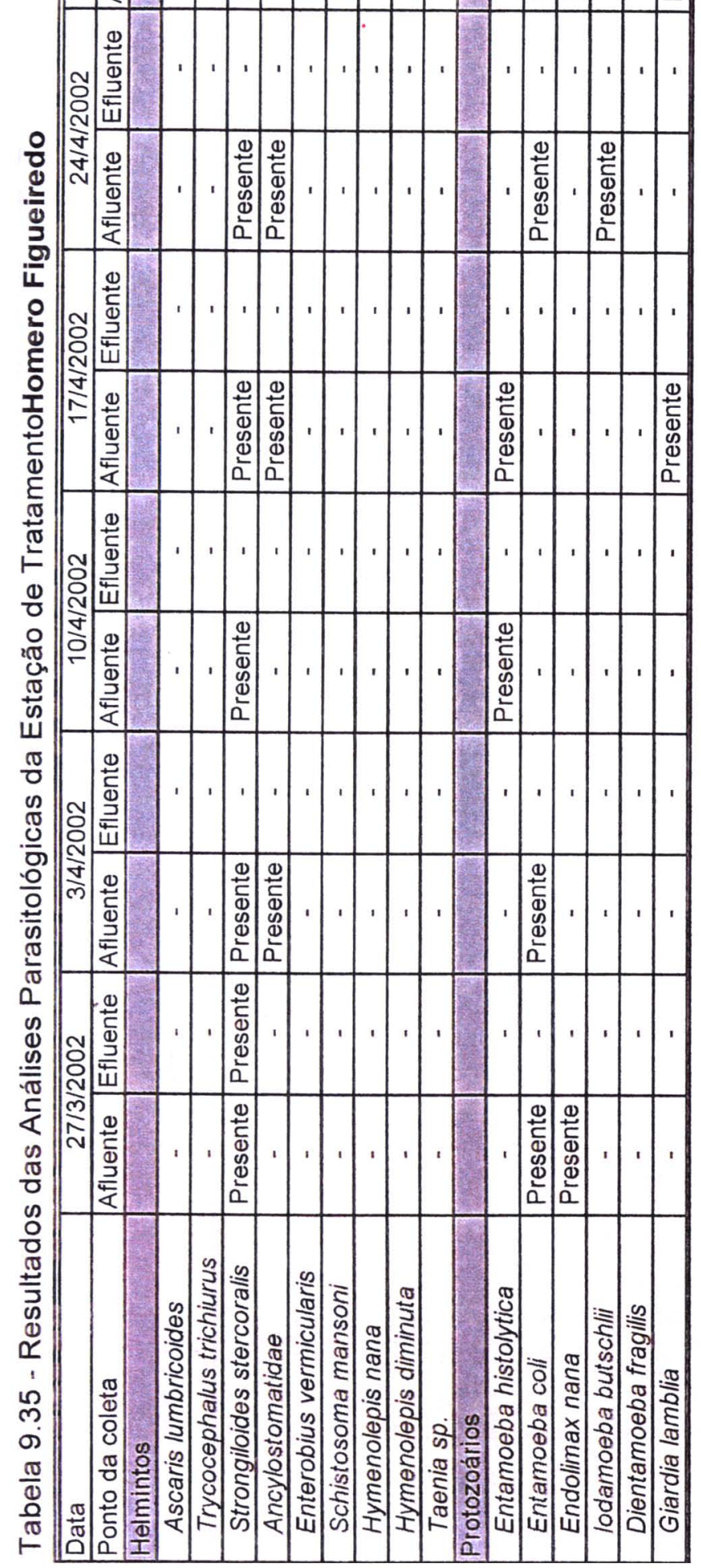

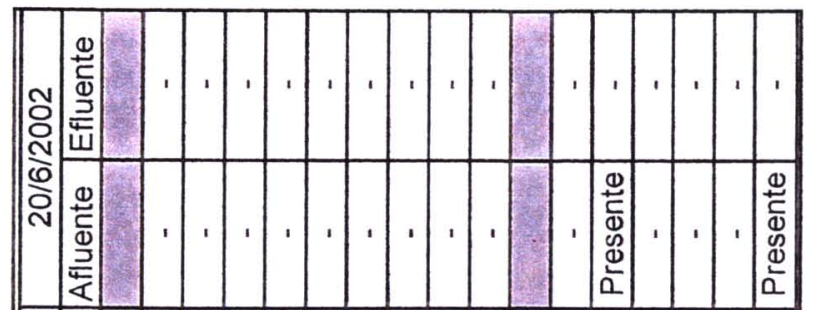
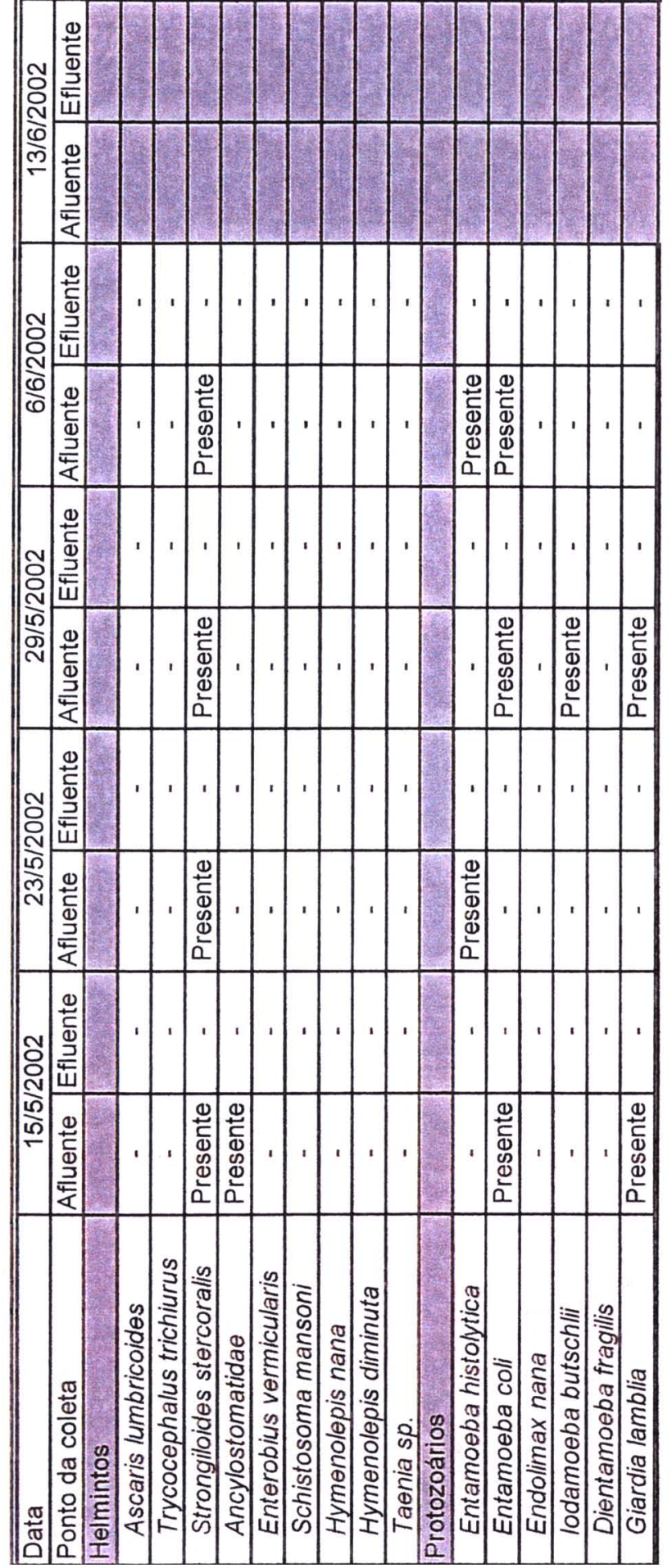


$$
\text { E }
$$




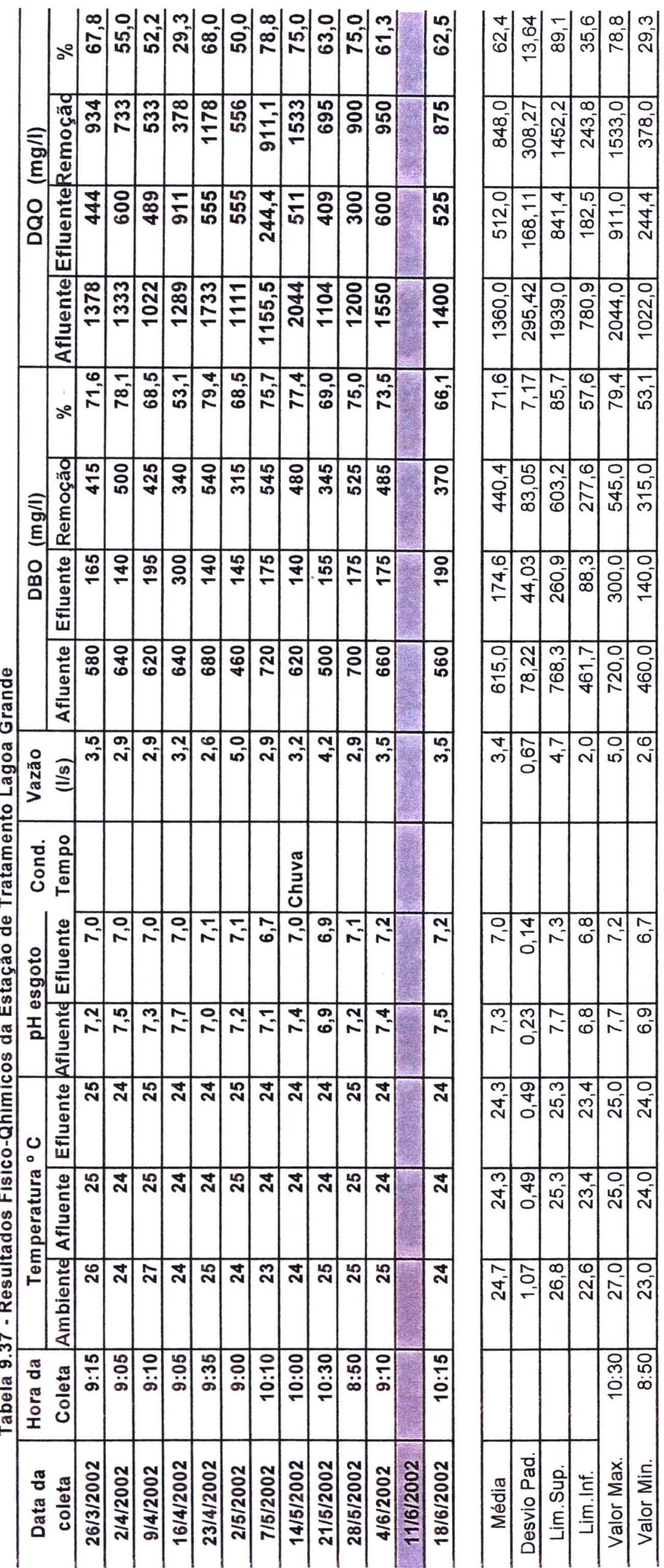




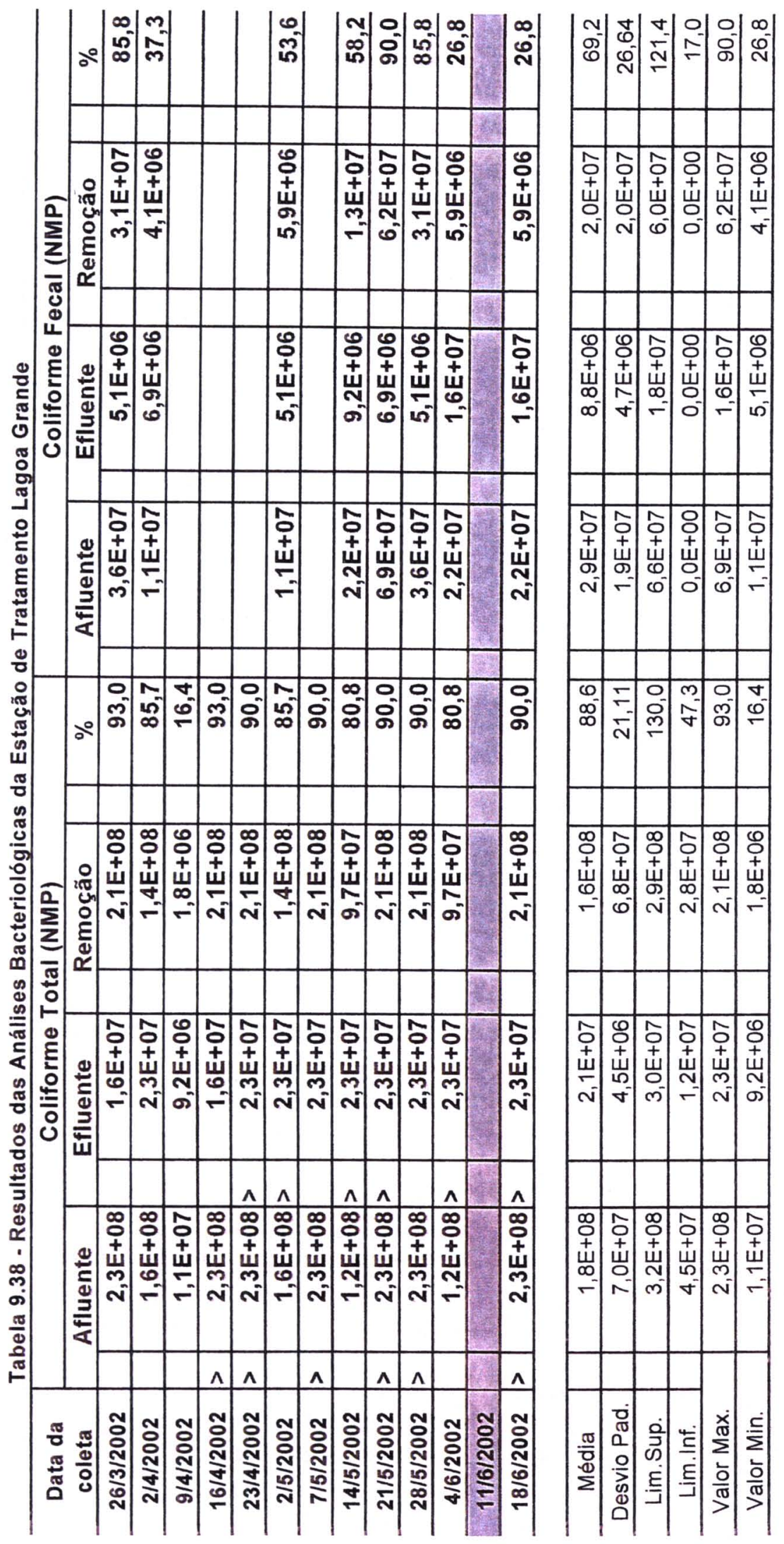



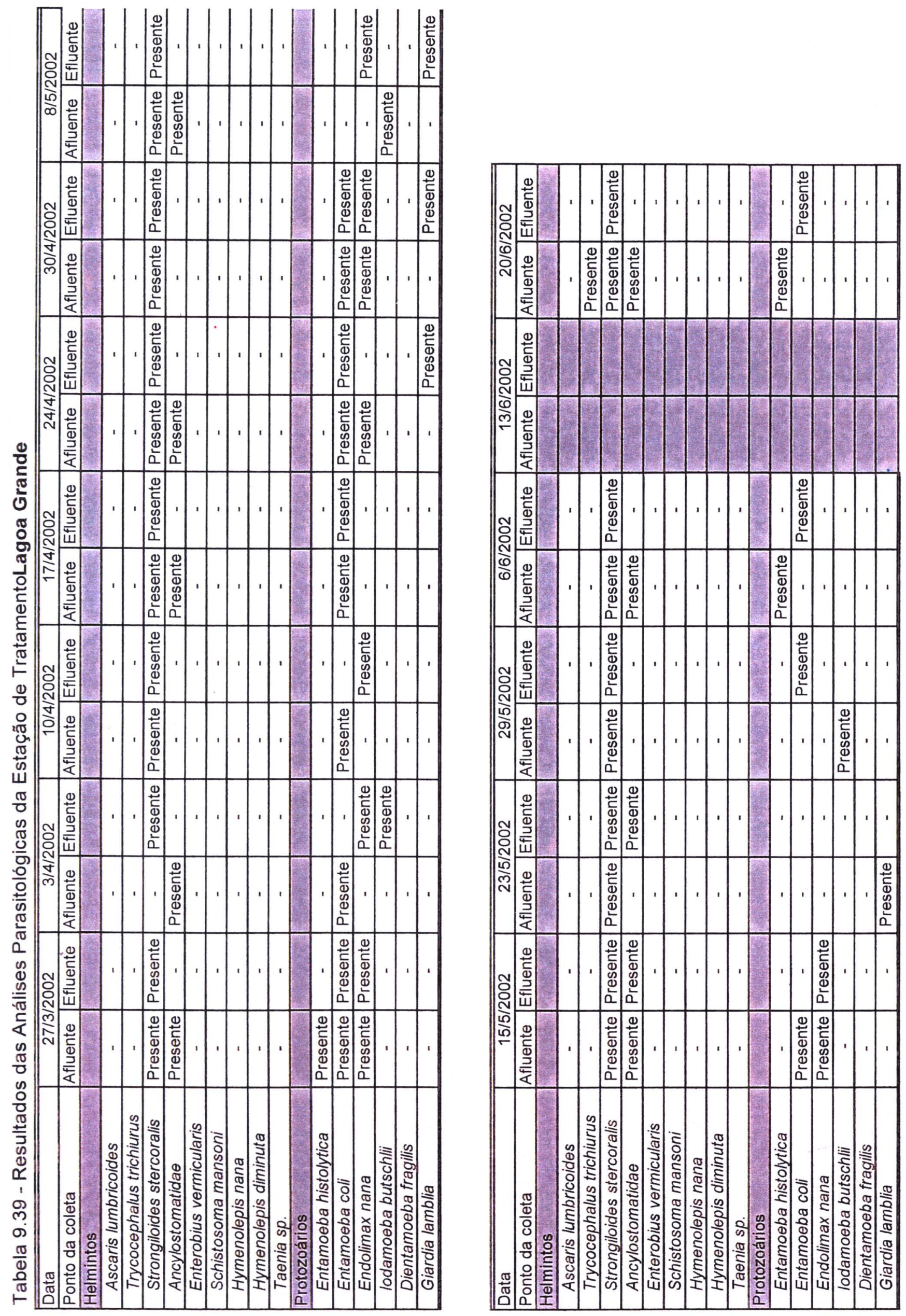

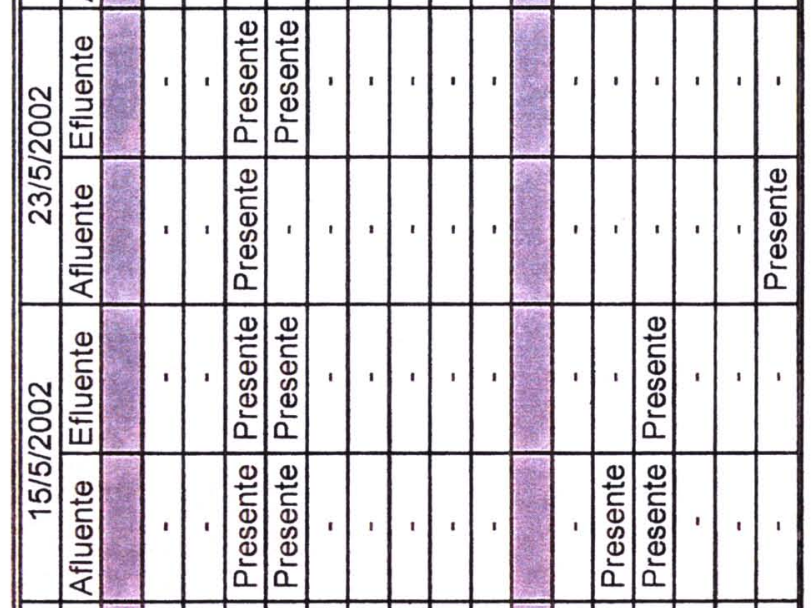

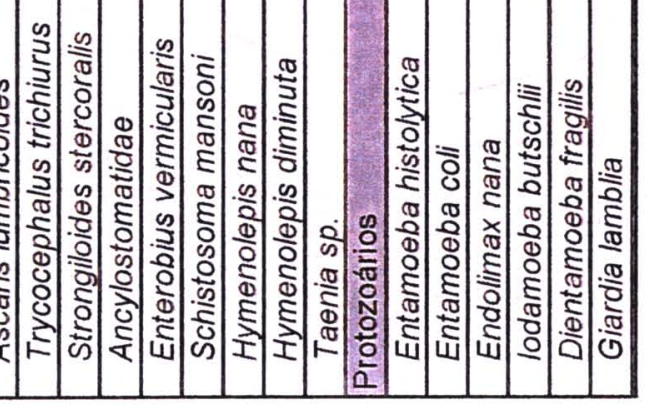



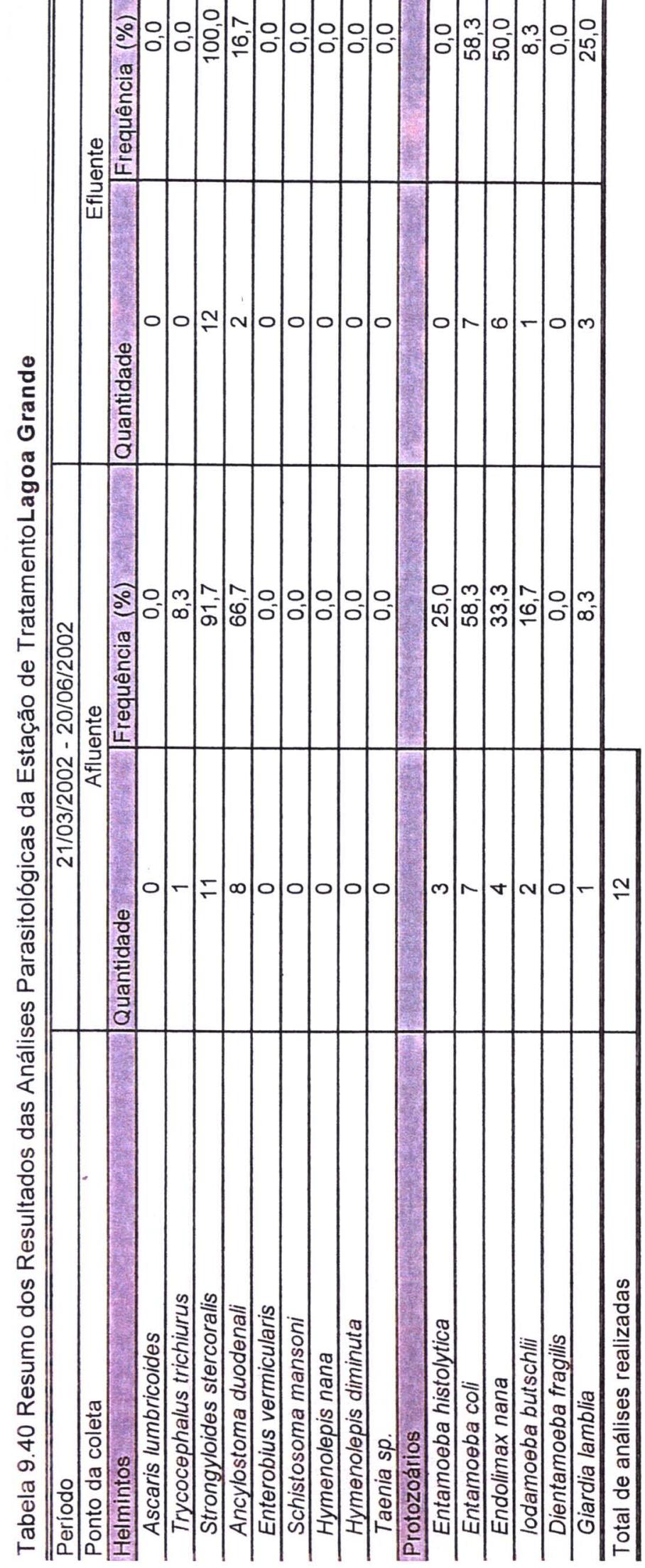


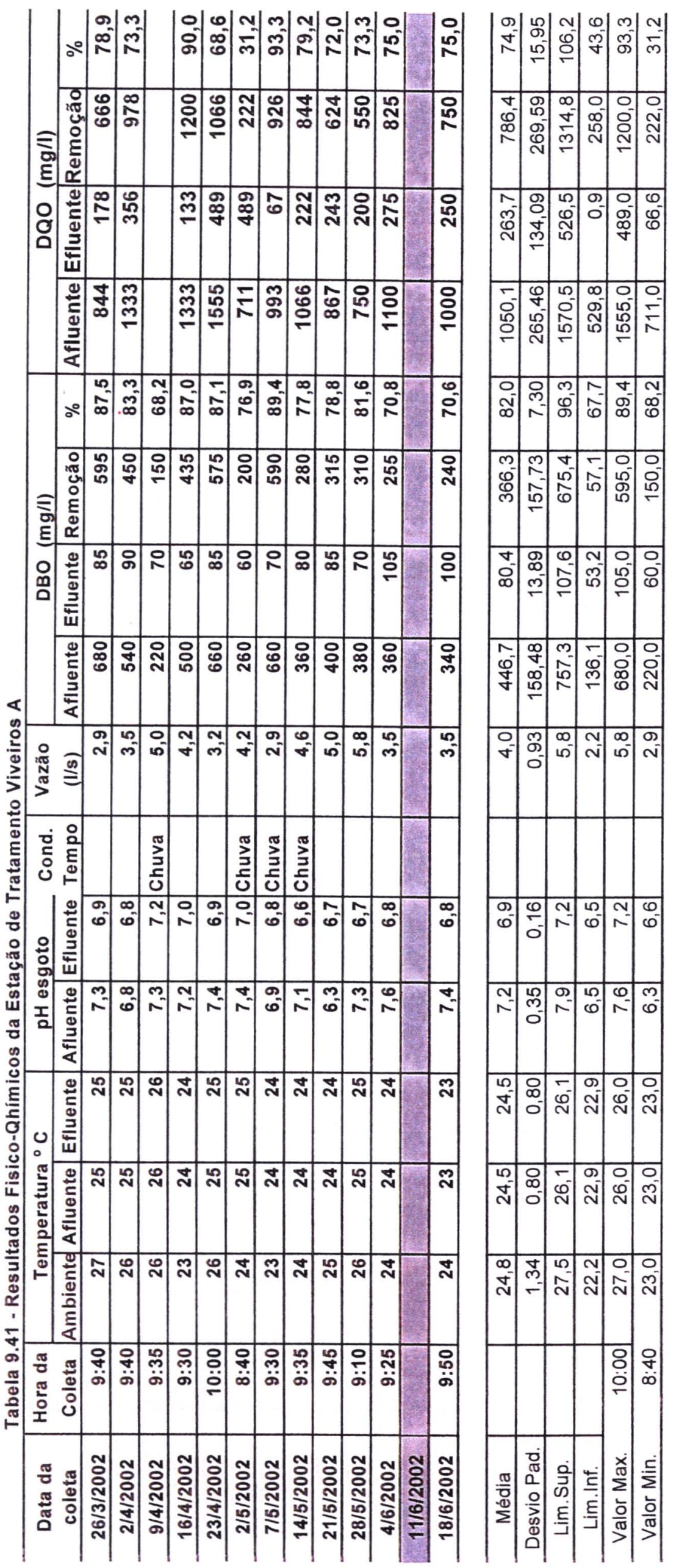




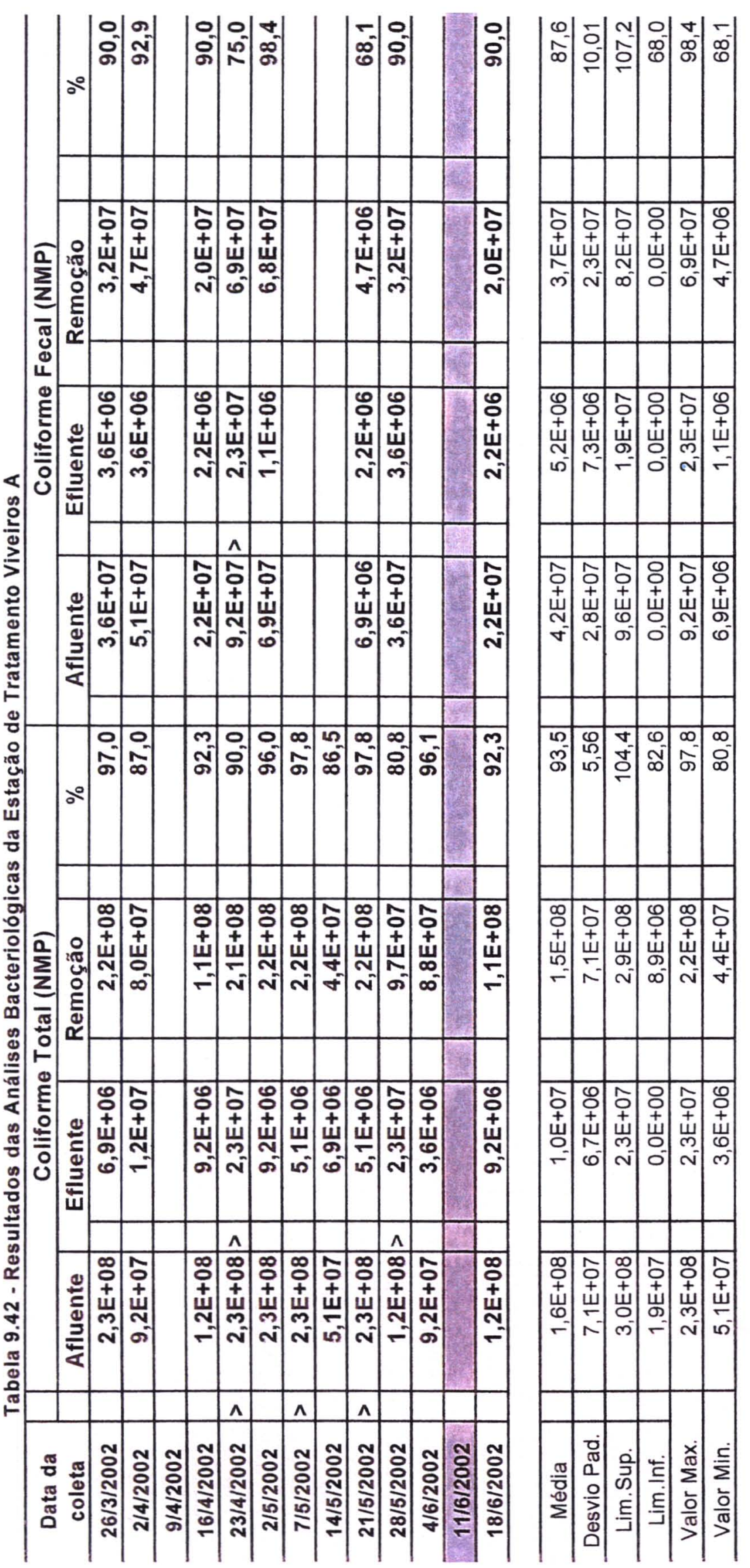




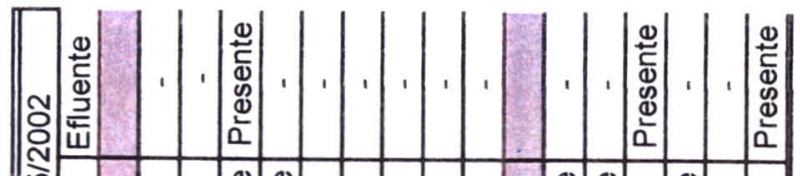

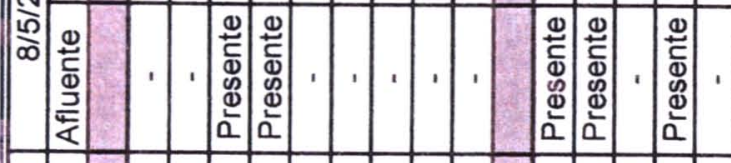

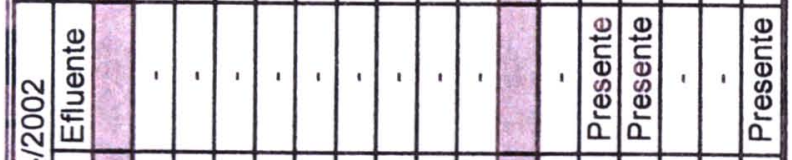

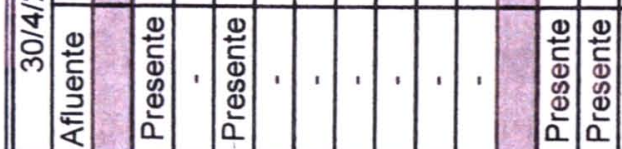

觪
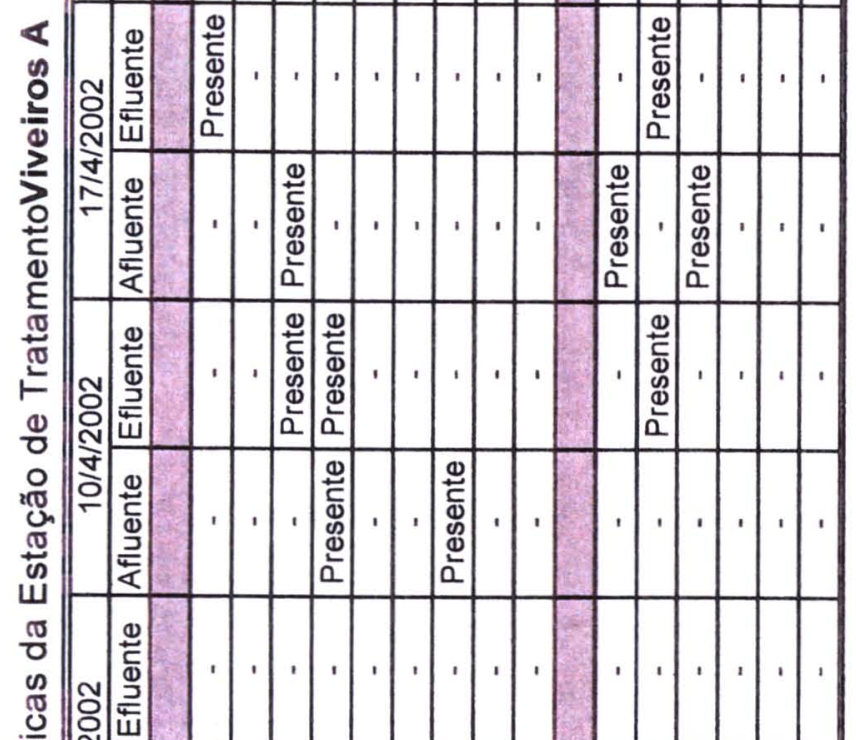

을

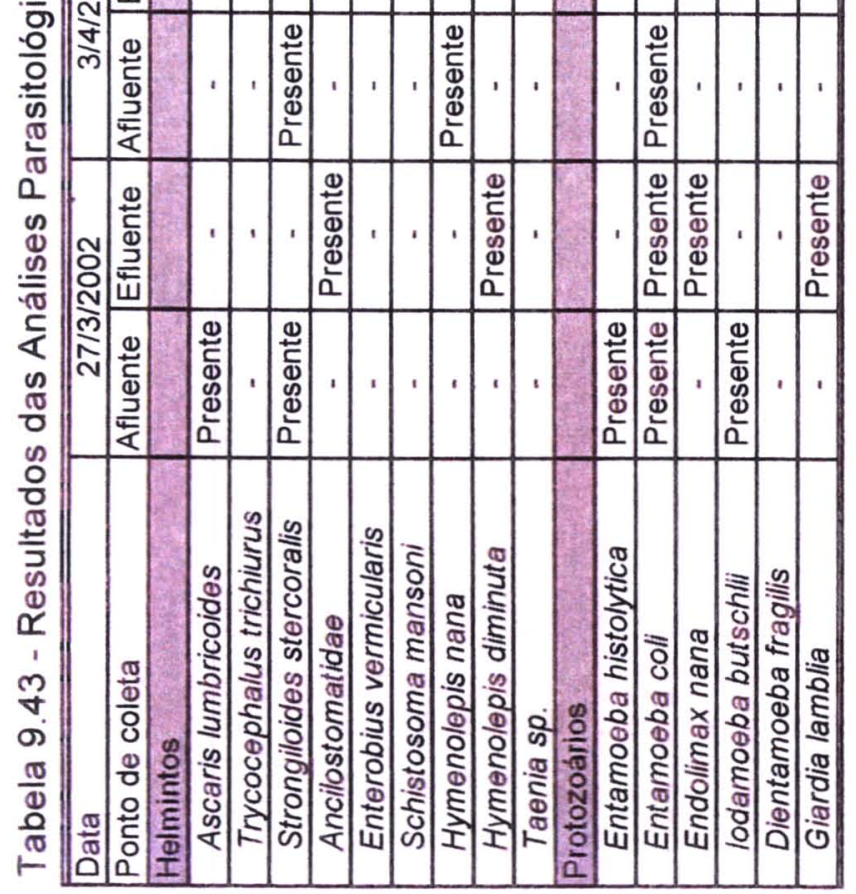

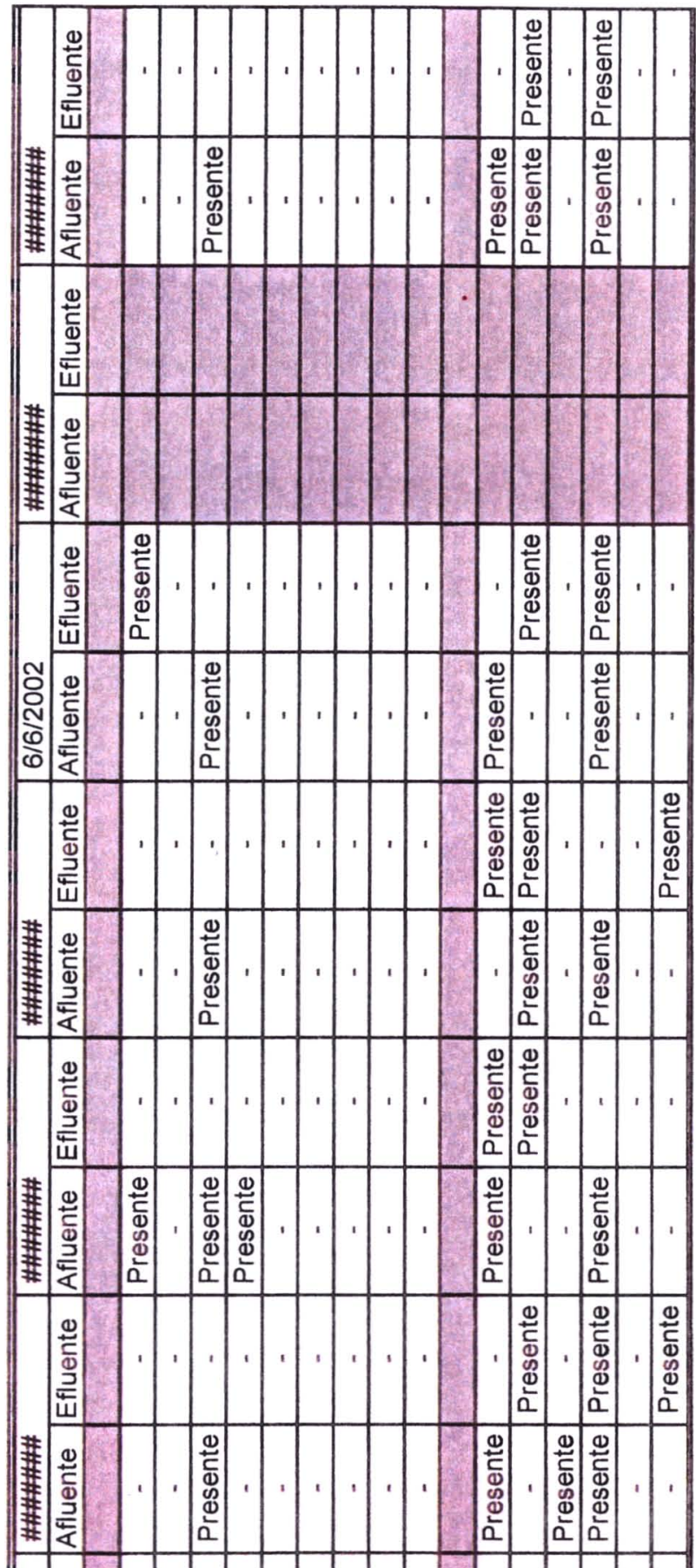

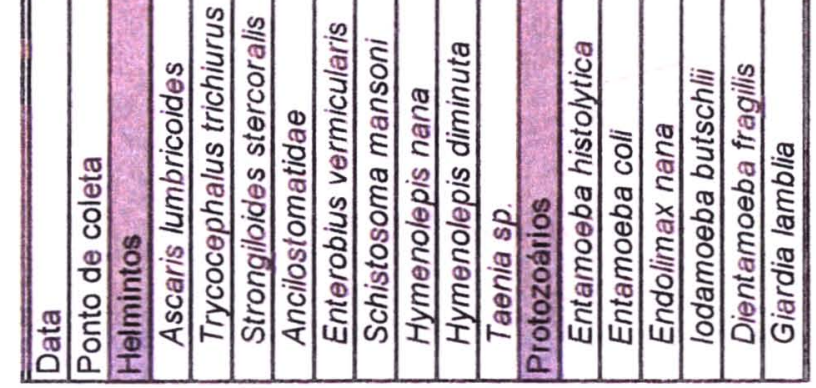




$$
\text { W }
$$




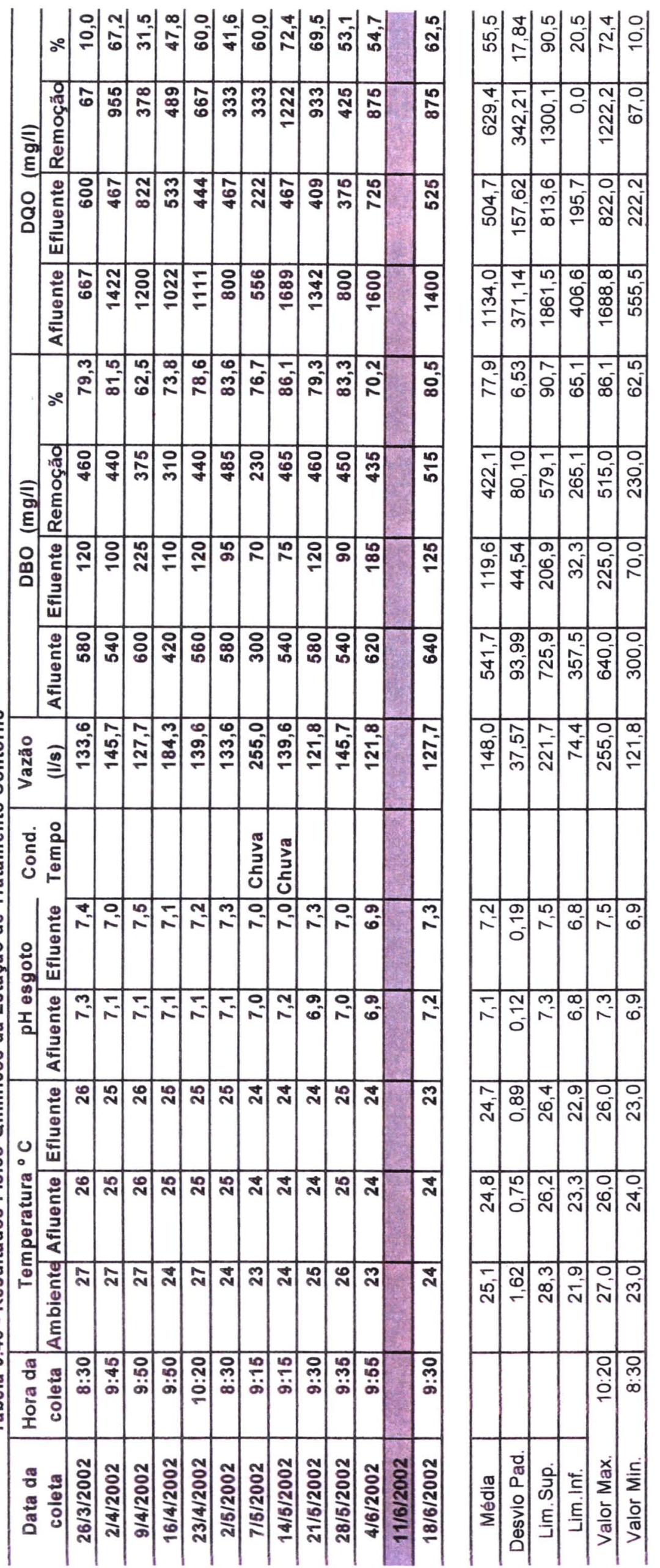




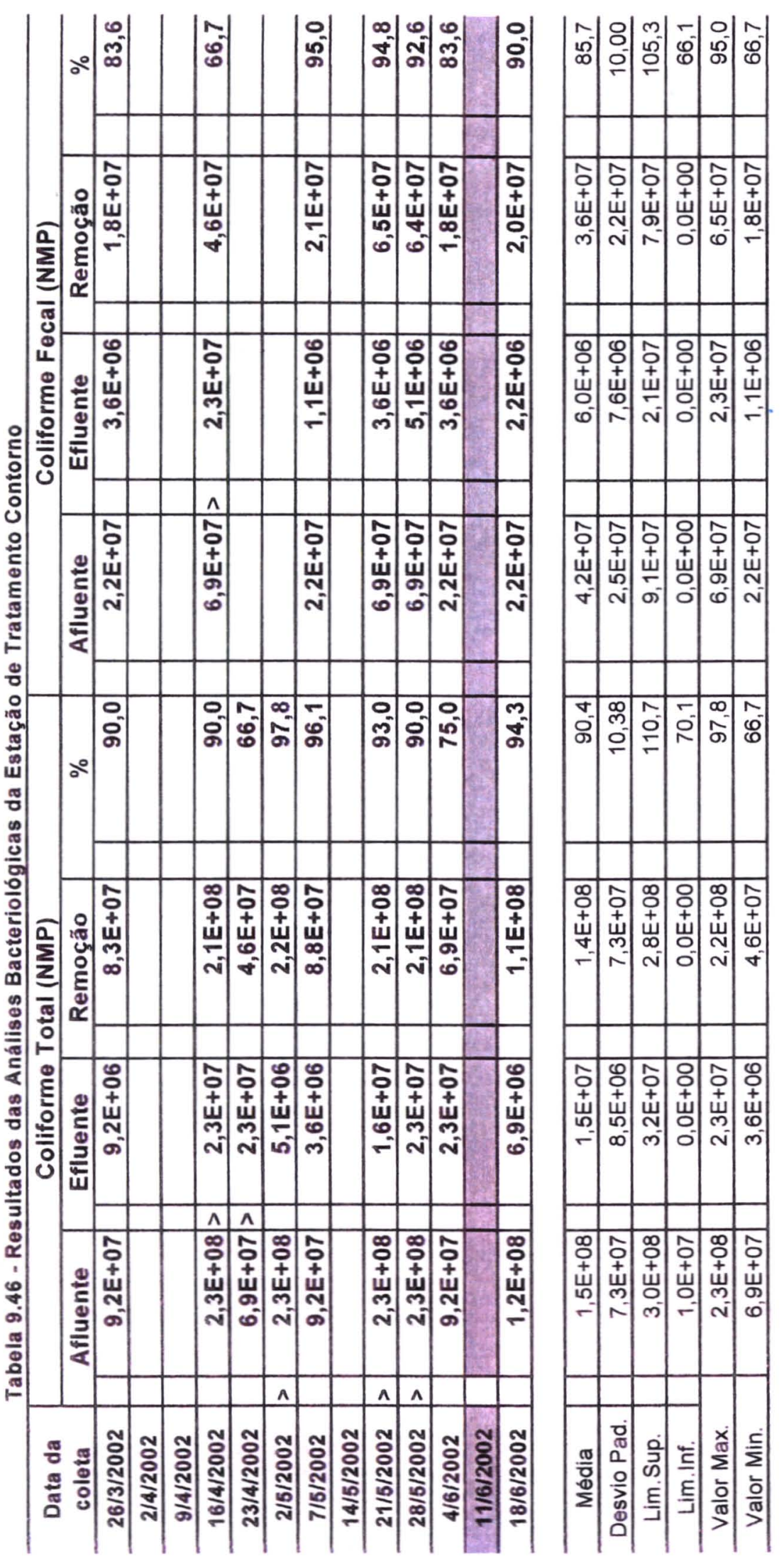




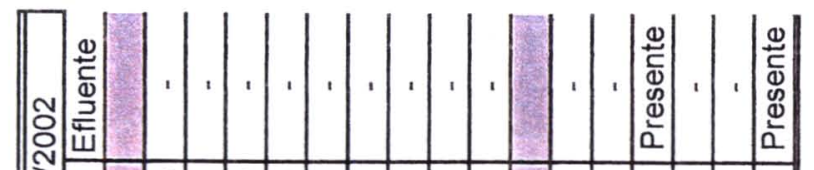

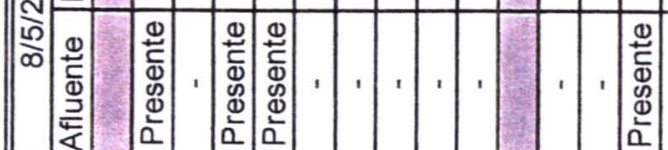

ำ

음

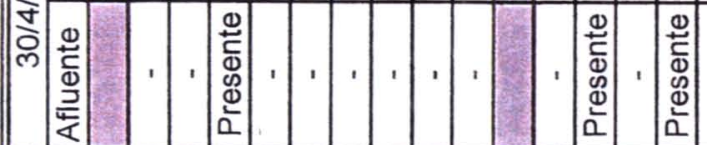
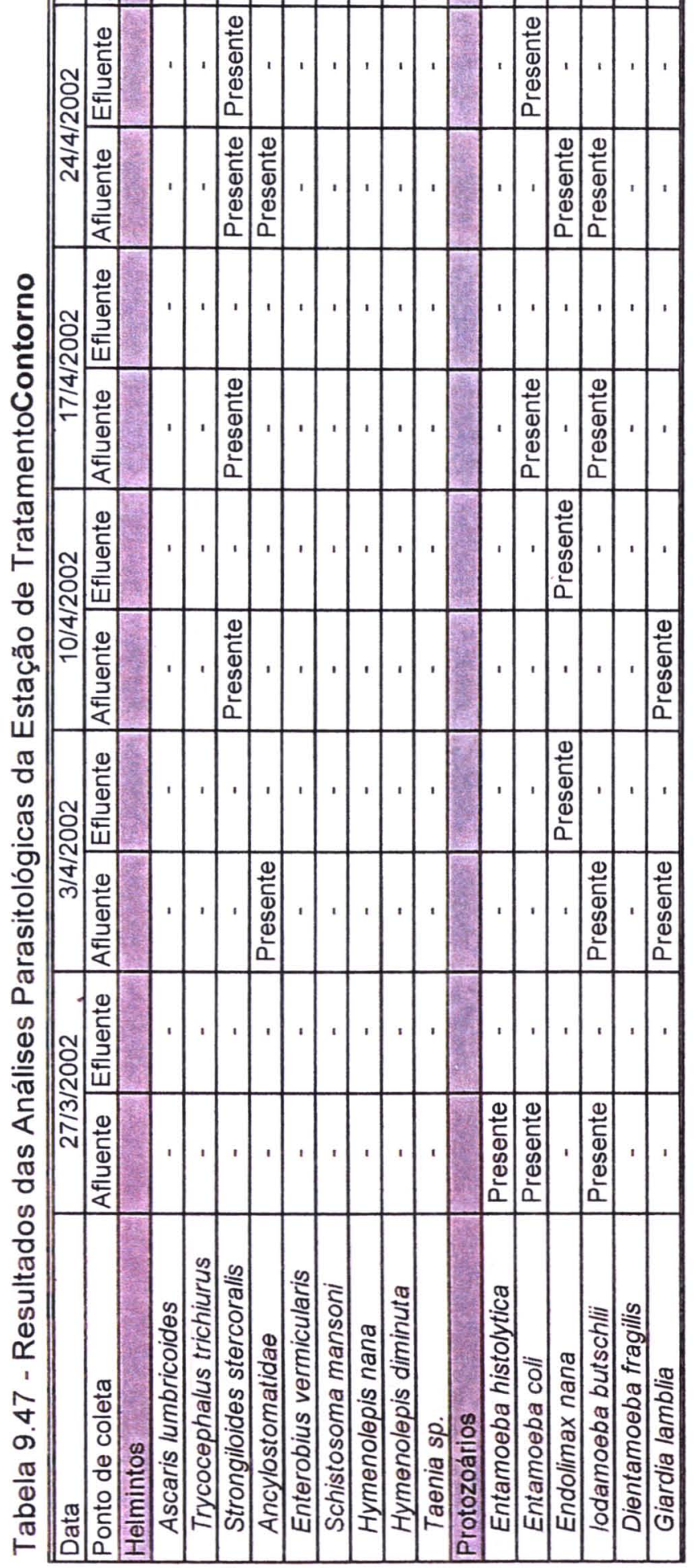
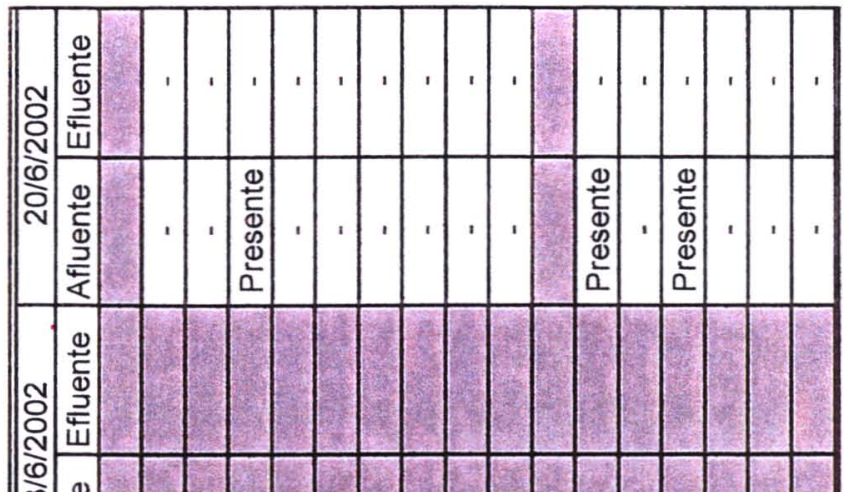

ले

(

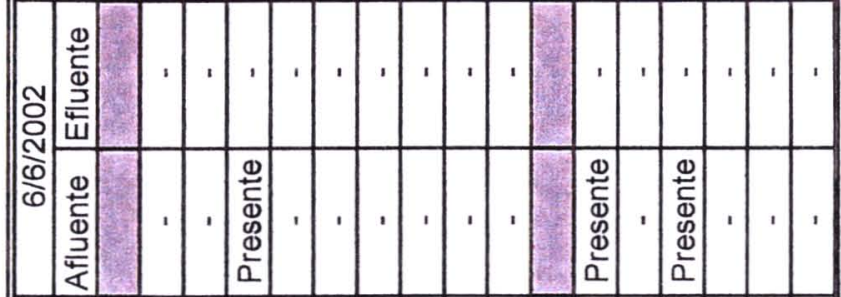

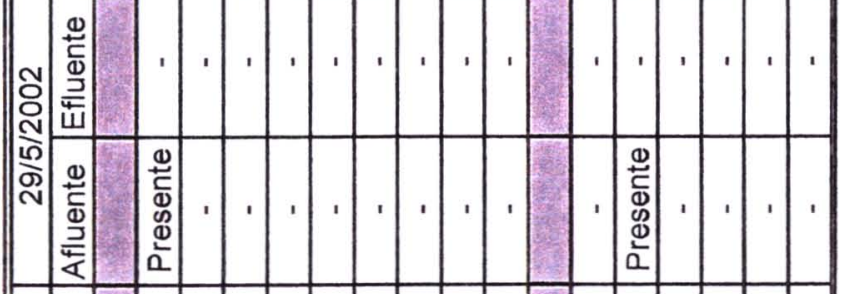

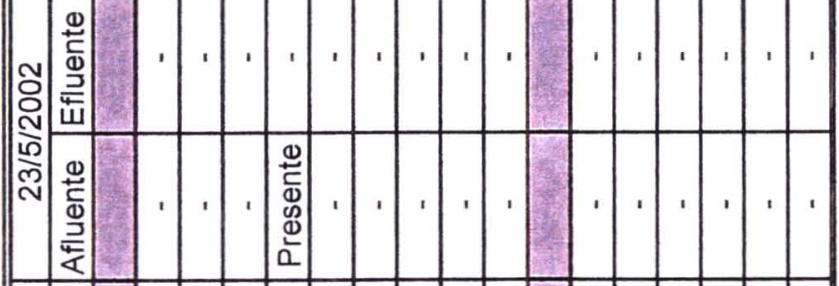
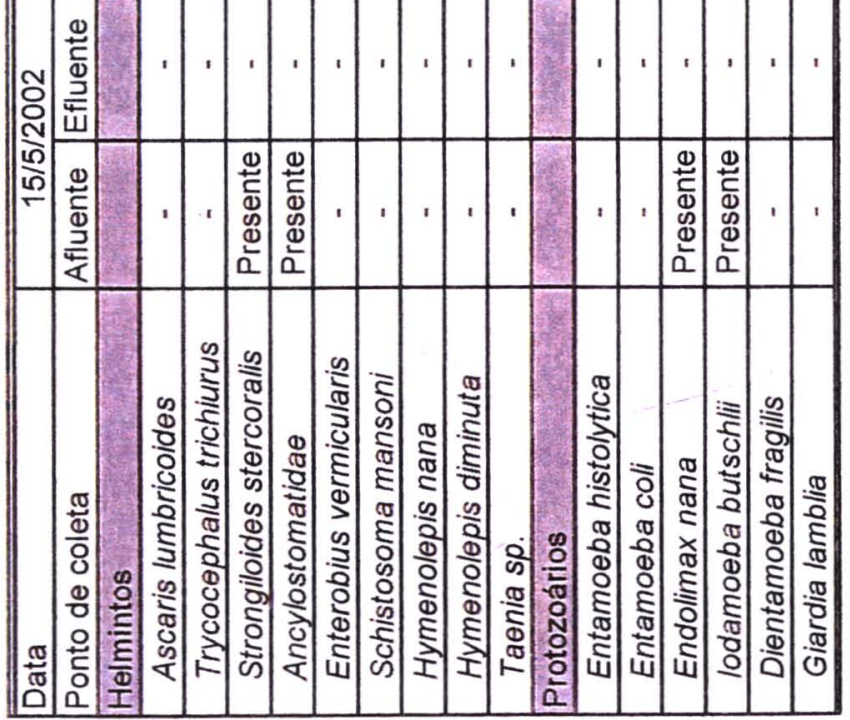


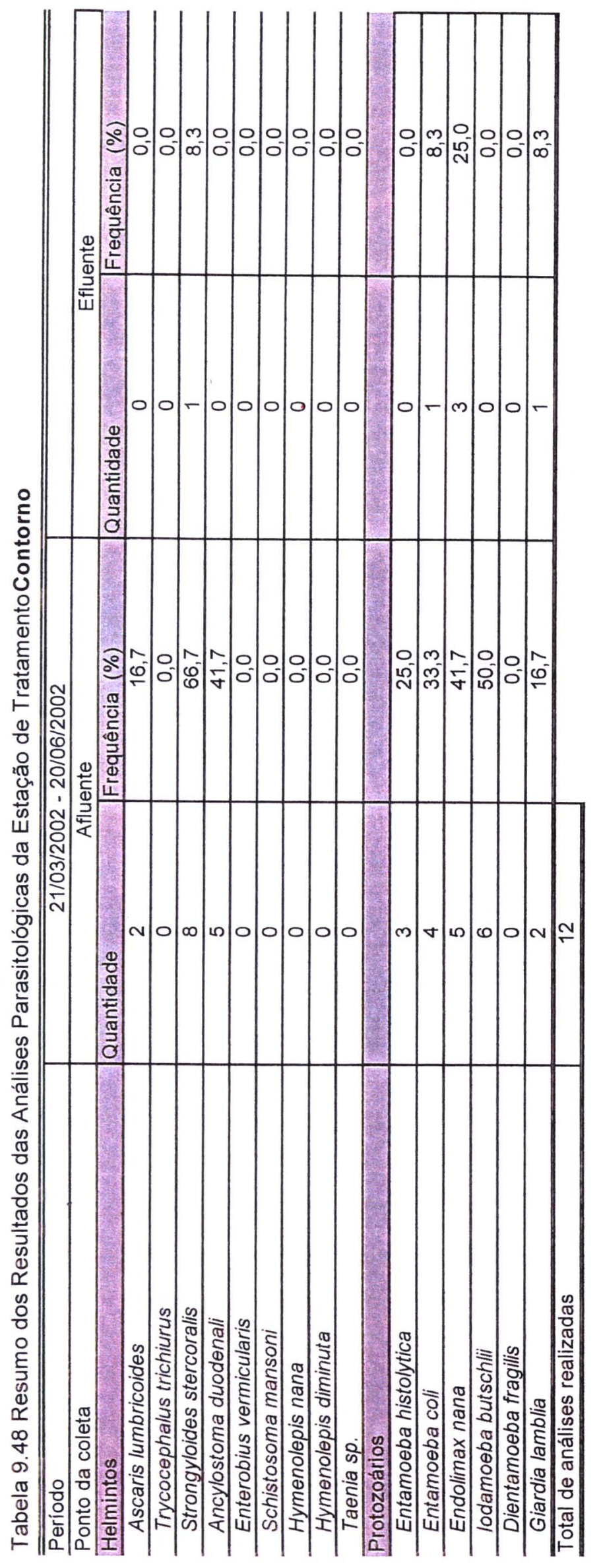


Os resultados físico-químicos, bacteriológicos e parasitológicos obtidos no inverno, para as Estações Homero Figueiredo, Lagoa Grande, Viveiros-A e Contorno, estão apresentados nas Tabelas 9.49 a 9.64. 


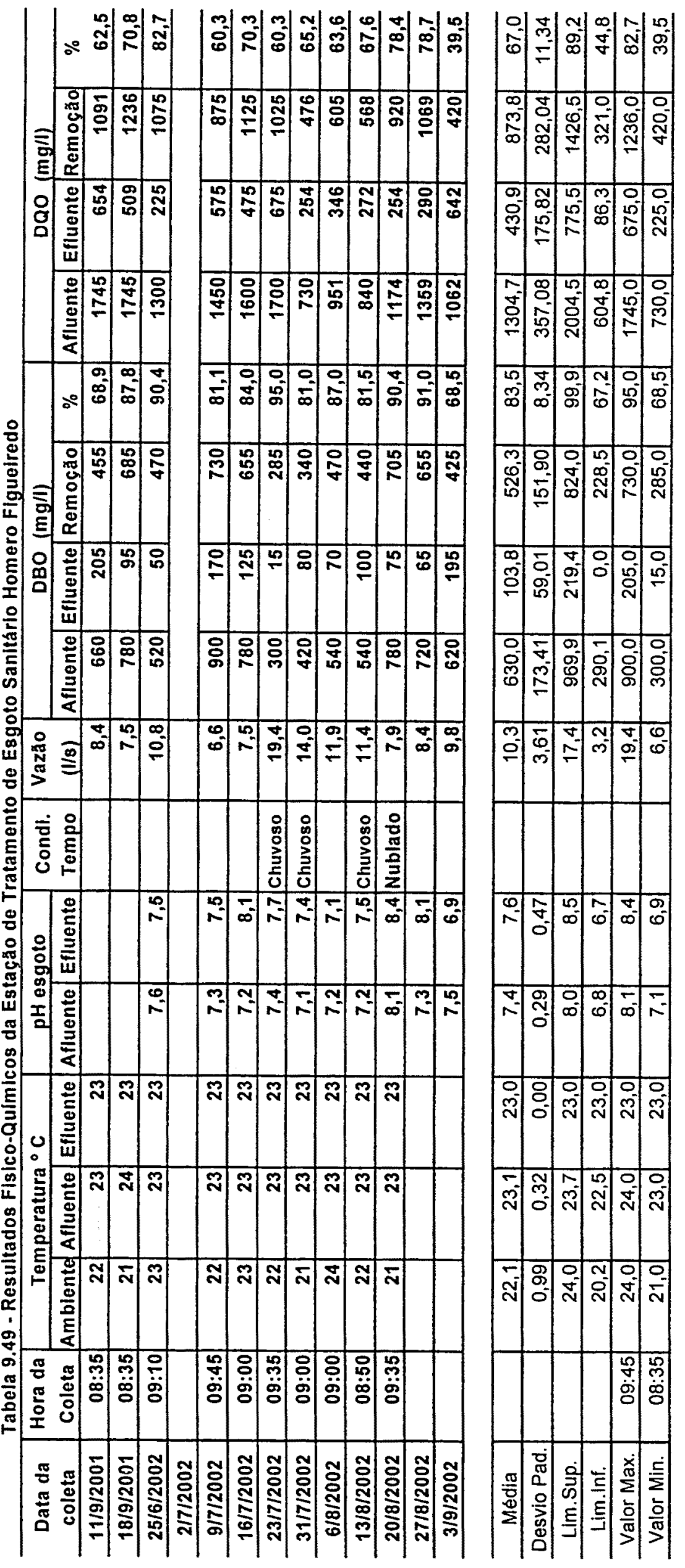




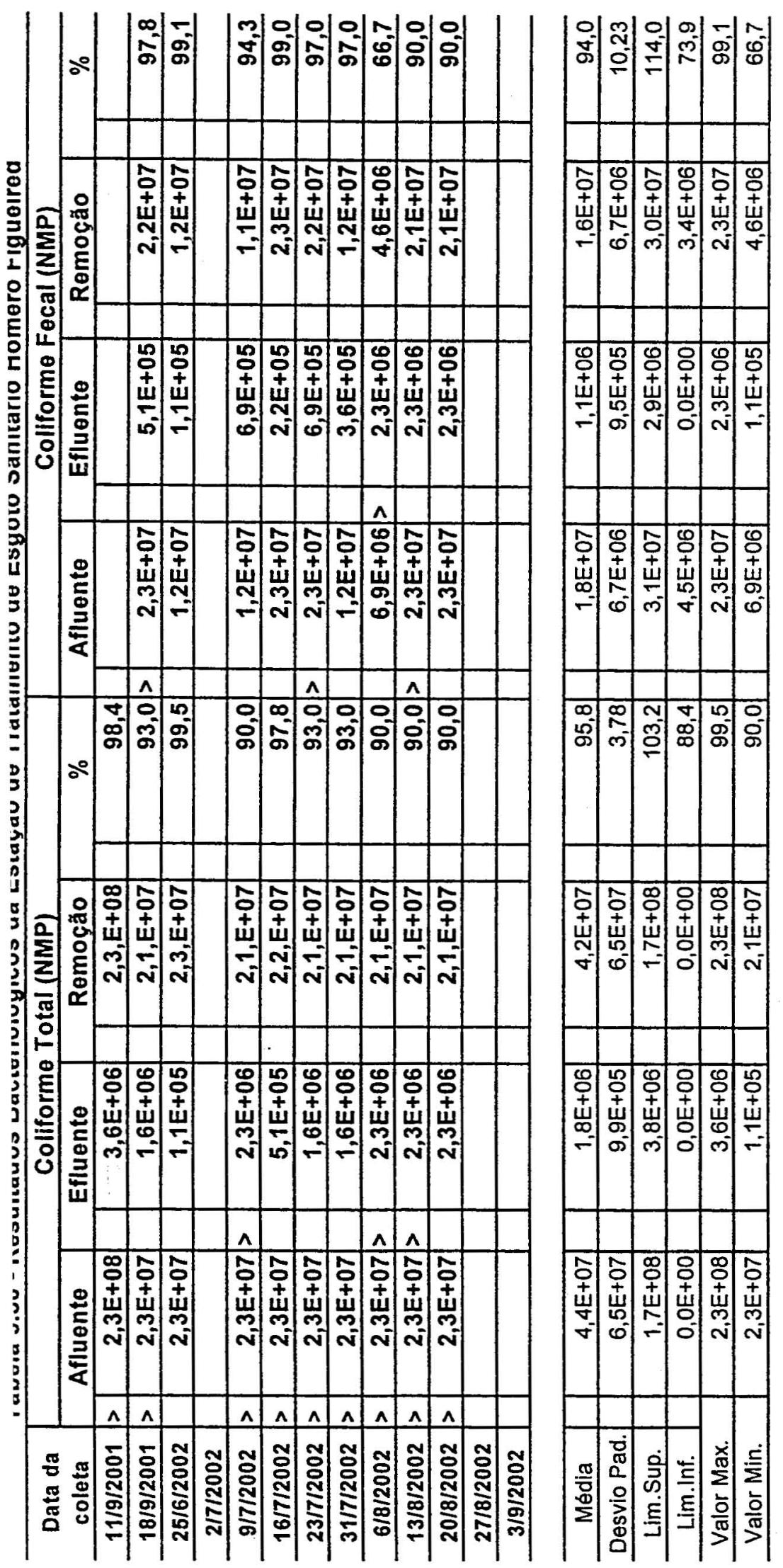


ํํำ

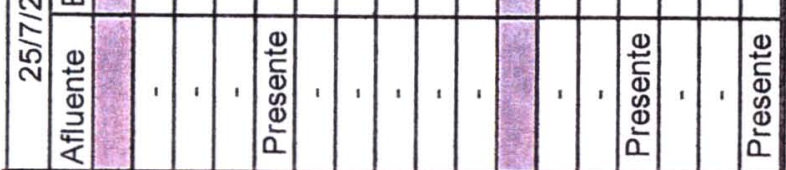

\section{}
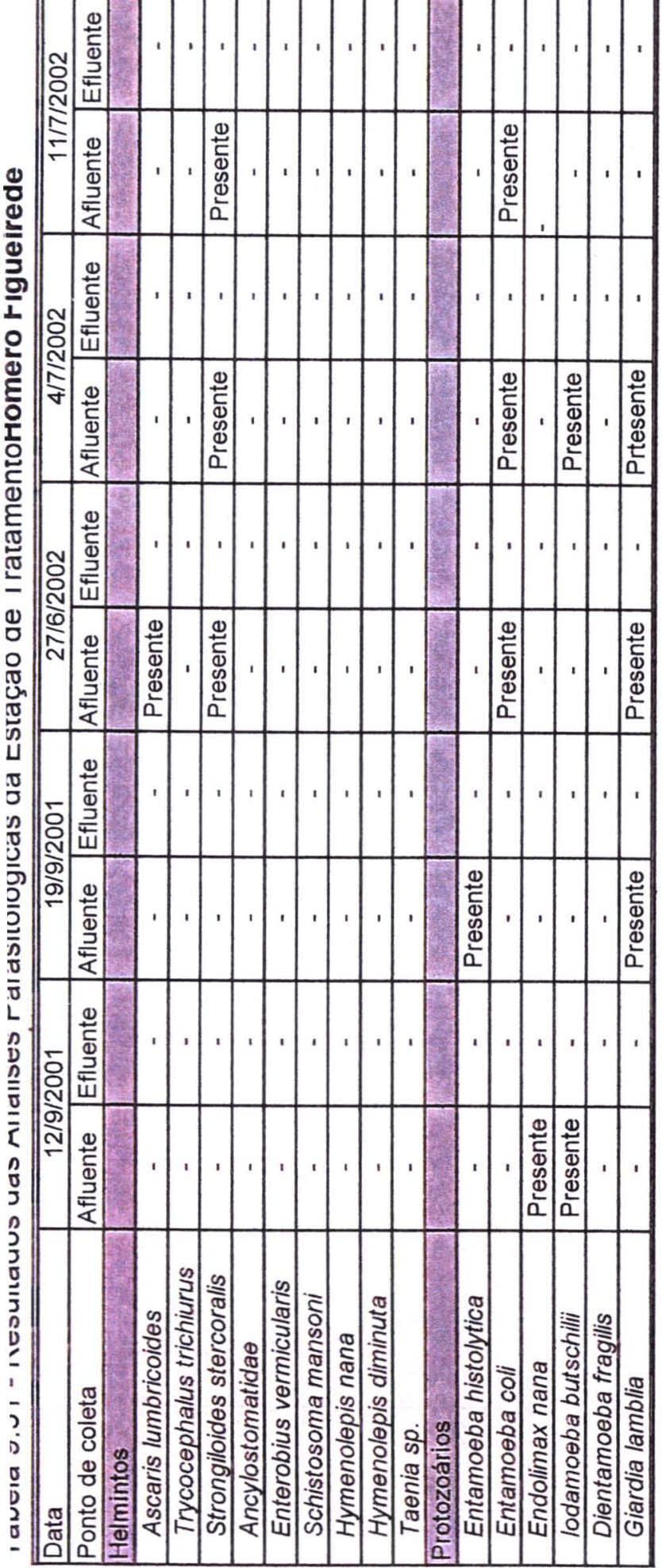
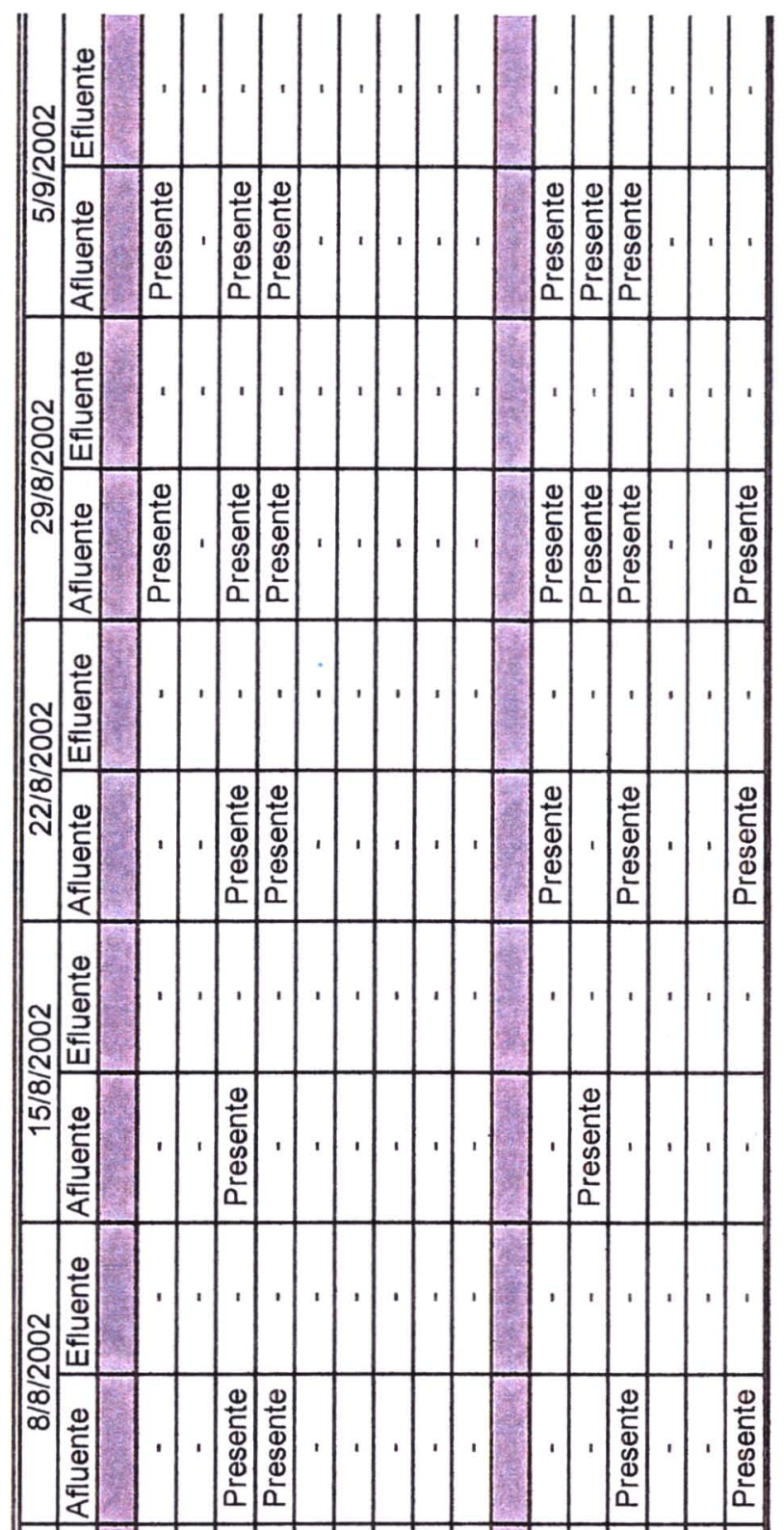

\begin{tabular}{|c|c|c|c|c|c|c|c|c|c|c|c|c|}
\hline ऽ & ' & & 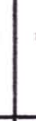 & 1 & ' & ' & & 1 & & & & 1 \\
\hline 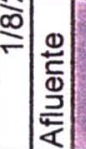 & I & & & & ' & 1 & & & 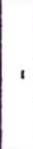 & & & $\square$ \\
\hline
\end{tabular}

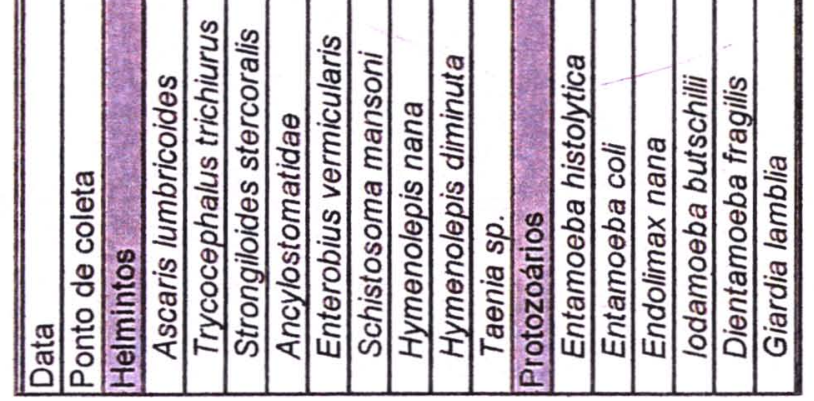




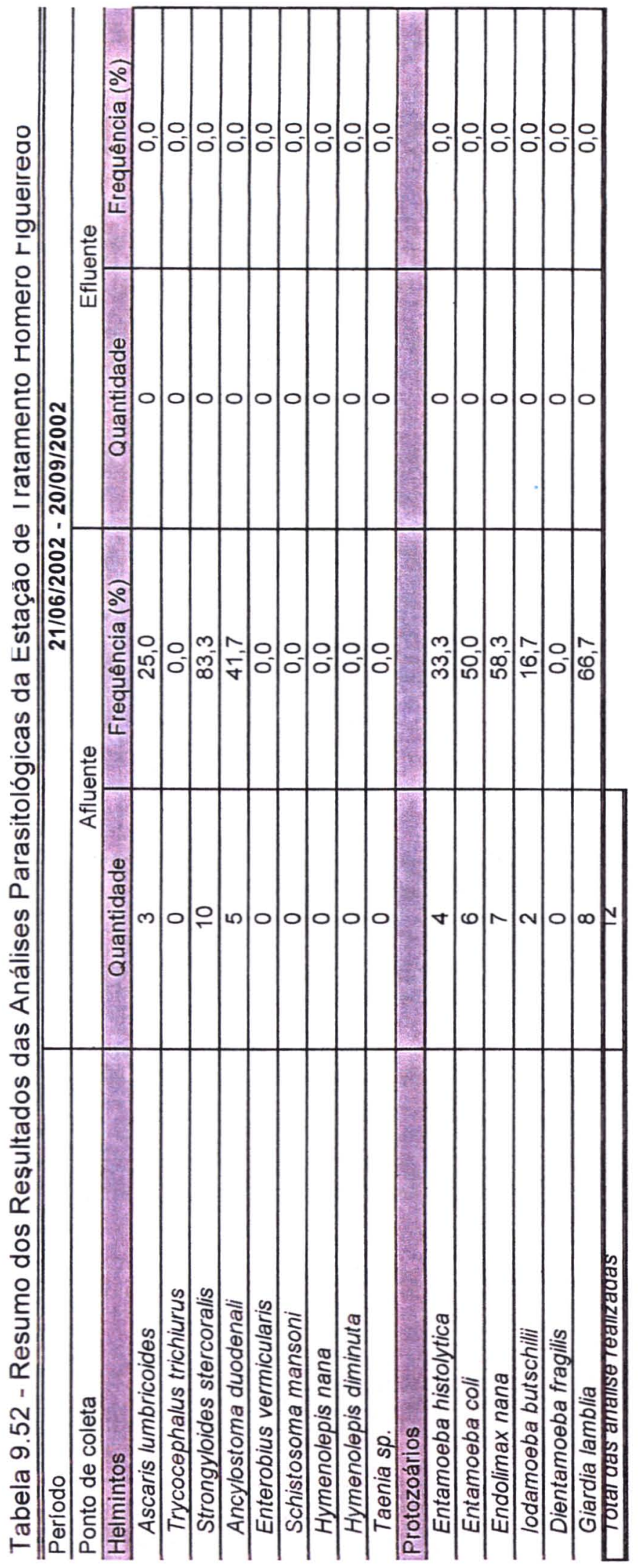




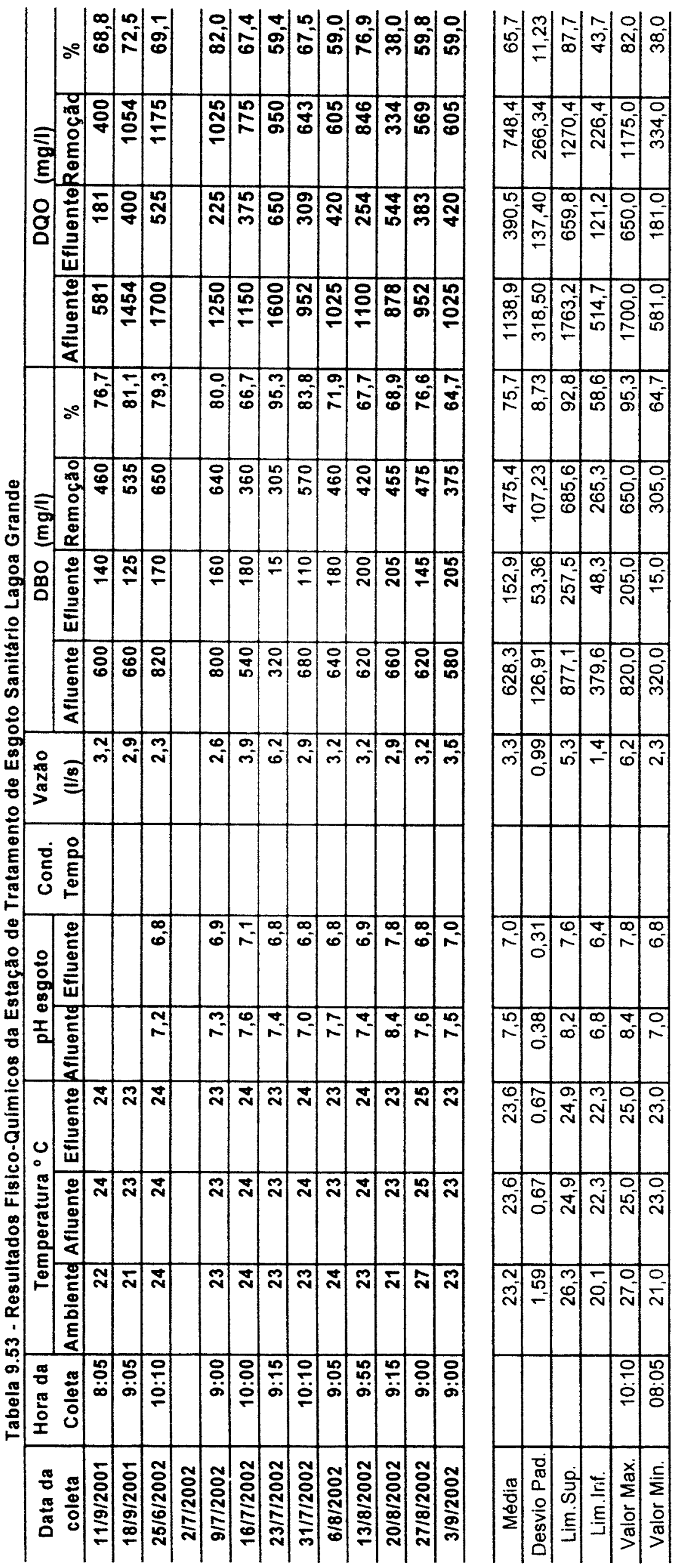




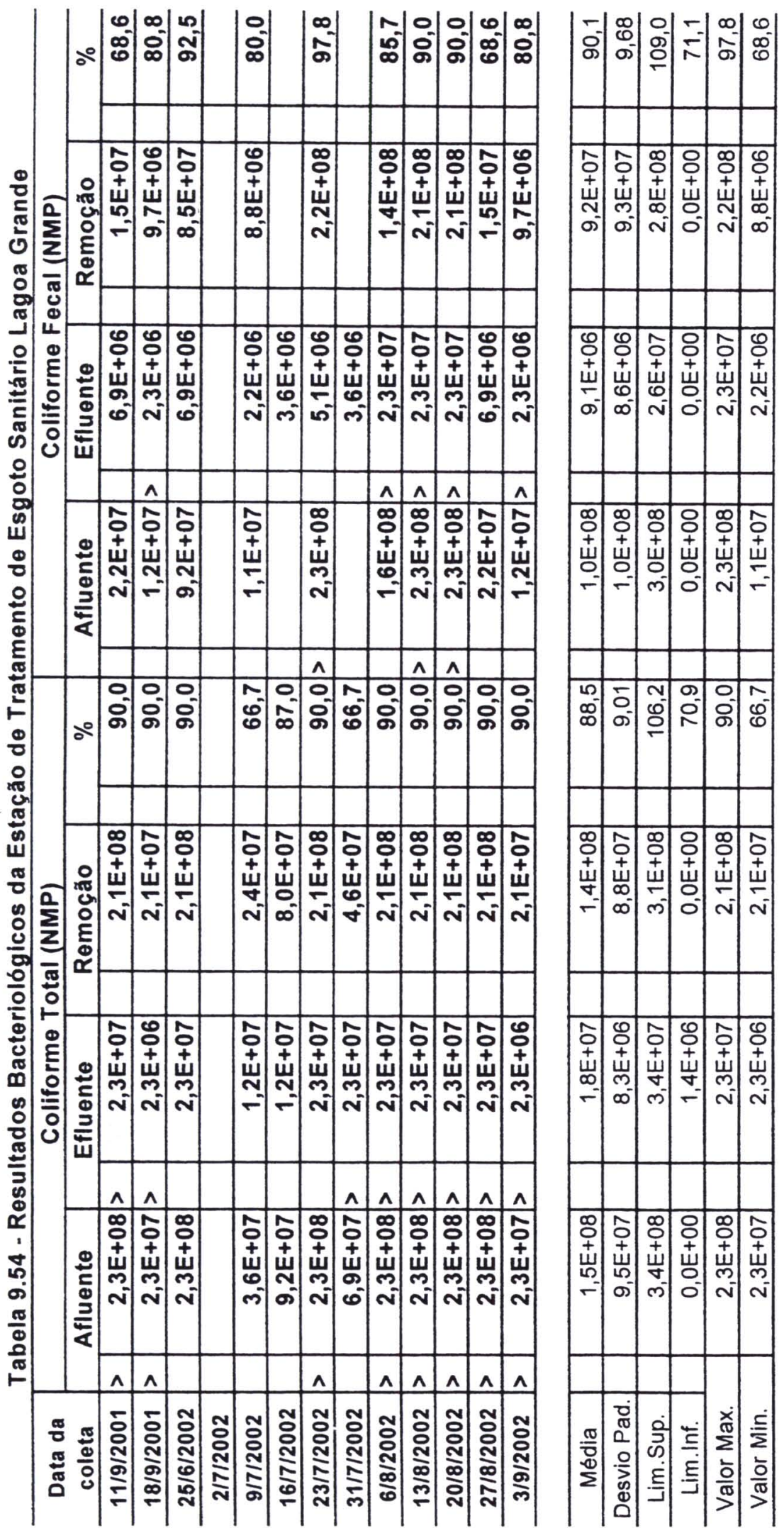




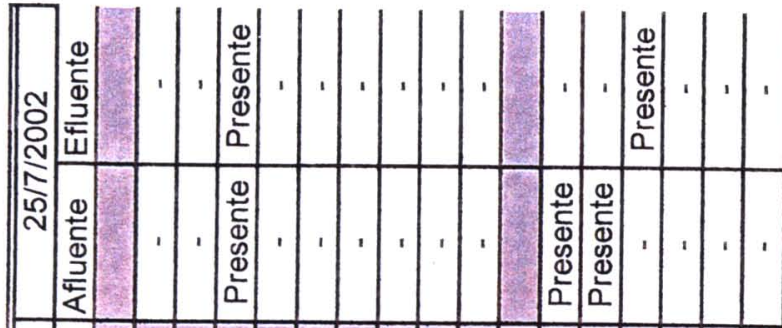
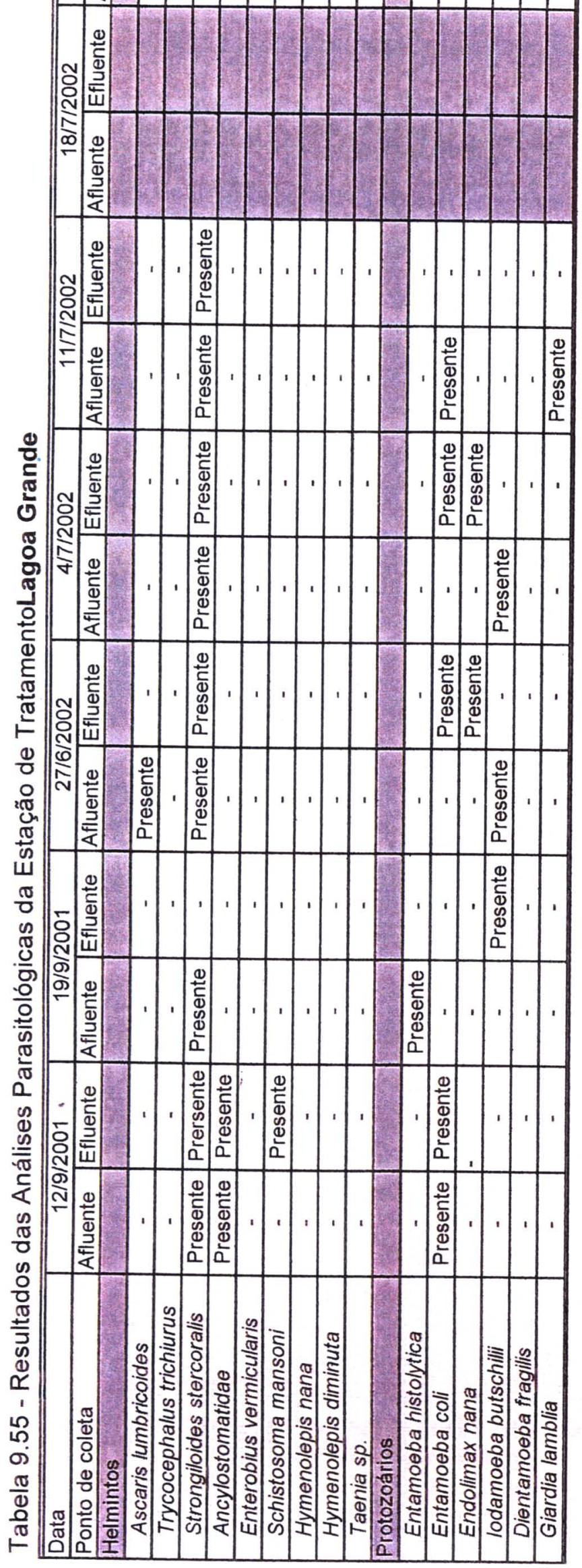

\begin{tabular}{|c|c|c|c|c|c|c|c|c|c|c|c|c|c|c|c|}
\hline & 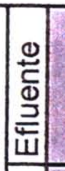 & & & 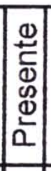 & & 11 & & 1 & 11 & & 1 & & & & 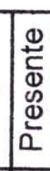 \\
\hline & 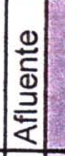 & & & 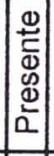 & 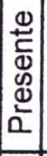 & & 1 & ' & 11 & & & 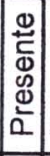 & 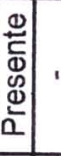 & & 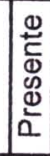 \\
\hline & 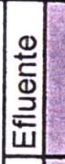 & ' & & 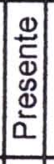 & & 1 & & & '] & & & 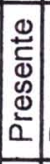 & 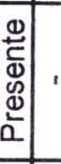 & & 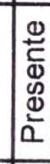 \\
\hline & 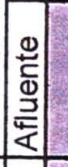 & & & 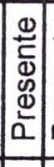 & 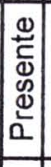 & & 1 & ' & 1 & & 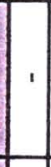 & 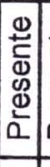 & 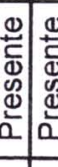 & & 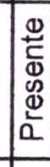 \\
\hline ్ָ & 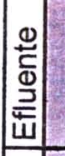 & ' & & 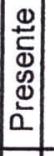 & 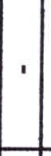 & & 1 & ' & ' & & & 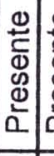 & & & 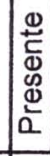 \\
\hline 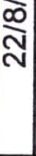 & 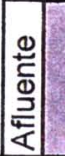 & ' & & 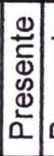 & & & & . & ' & & & 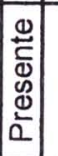 & ' & & 11 \\
\hline & 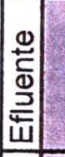 & ' & & 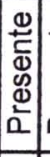 & & & 1 & & ' & & & 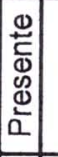 & ' & & ' \\
\hline 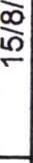 & \begin{tabular}{|l|} 
\\
$\frac{0}{2}$ \\
$\frac{2}{0}$ \\
$\frac{3}{4}$ \\
\end{tabular} & ' & & 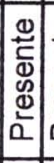 & 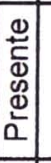 & & & & ' & & & 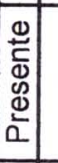 & 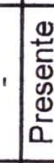 & & \\
\hline & 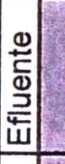 & & ' & & 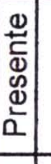 & & & 1 & ' & & & 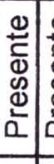 & & & 1. \\
\hline $\begin{array}{l}\infty \\
\infty \\
\infty\end{array}$ & 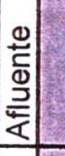 & & & 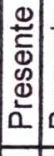 & 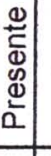 & & & ' & ' & & 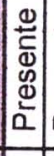 & 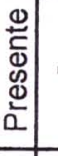 & & & 1 \\
\hline & 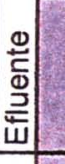 & & & 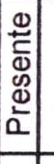 & & & ' & & ' & & & 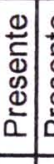 & & & ' \\
\hline$\stackrel{\infty}{\sim}$ & \begin{tabular}{|l|}
\multirow{2}{*}{} \\
\multirow{2}{\Phi}{} \\
\end{tabular} & I & & 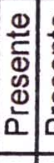 & 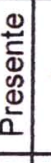 & & & & & & 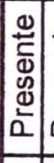 & 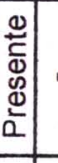 & & & 1 \\
\hline$\subseteq$ & 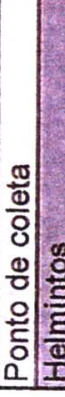 & $\frac{\substack{\vdots \\
\frac{1}{5}}}{\frac{c}{2}}$ & $\begin{array}{l}0 \\
\frac{5}{7} \\
\frac{5}{5} \\
\frac{0}{0}\end{array}$ & 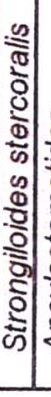 & 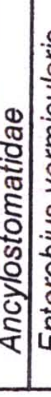 & : & : & 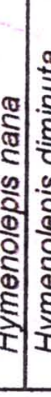 & 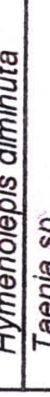 & 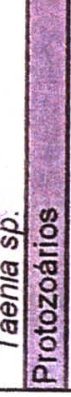 & 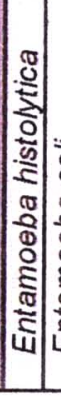 & 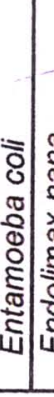 & t: & 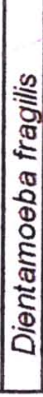 & 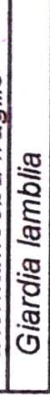 \\
\hline
\end{tabular}




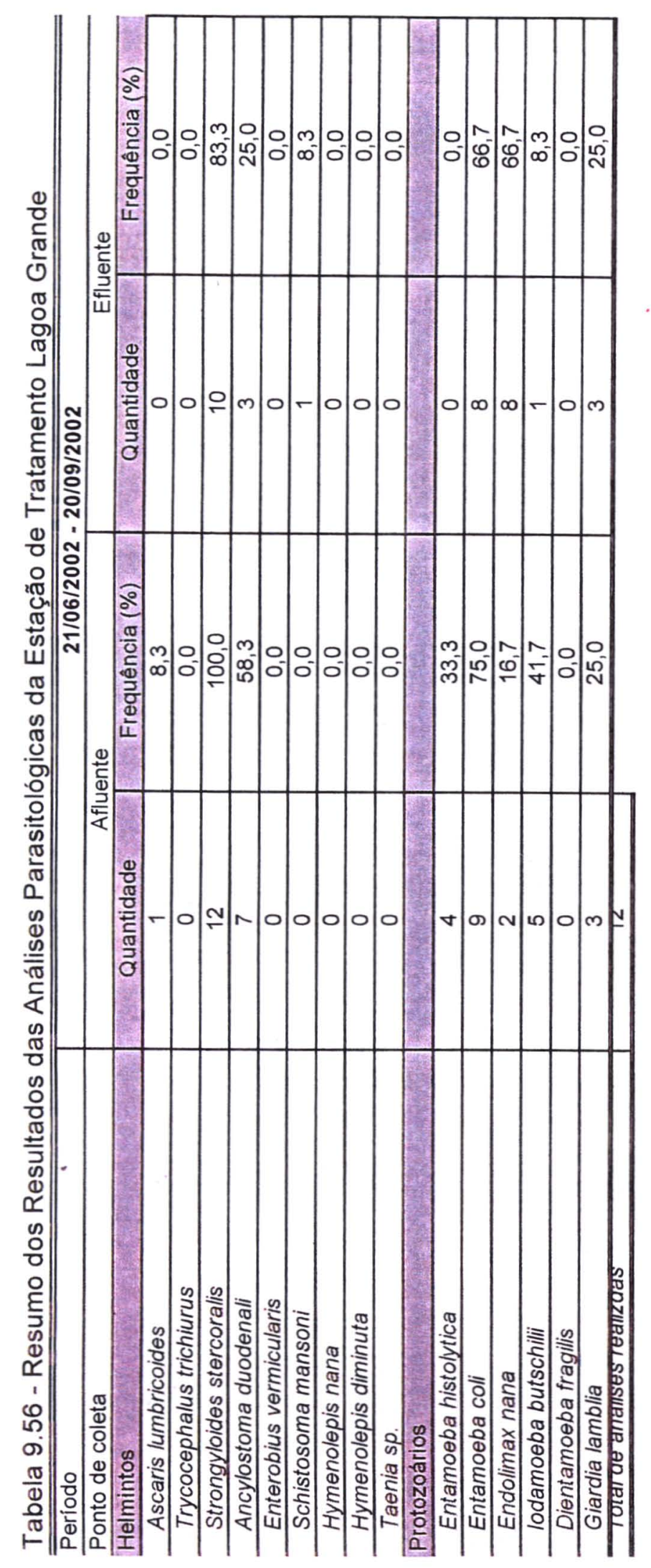




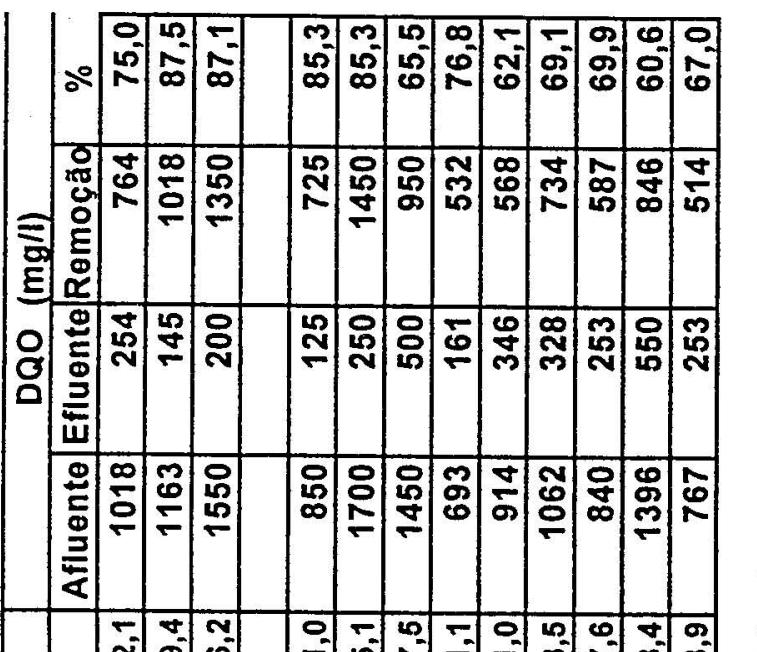
$\therefore$ 일 충

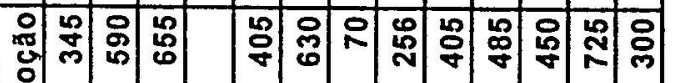

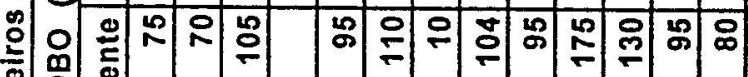
$\stackrel{\infty}{\geq}$

은

क

总

. $>$

응

릉 릉

판

(8)

닌

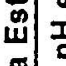

:

흫

인

잉

을

을

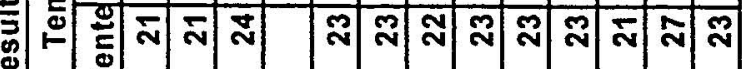

苗

造

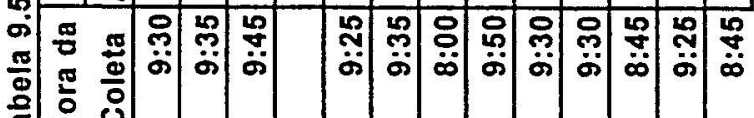

I 0

ฐ

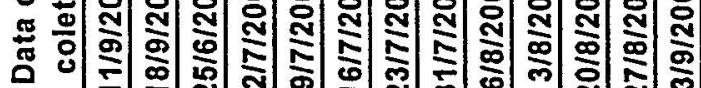

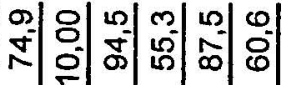

(0)

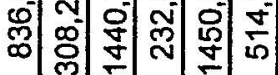

- ल० 00

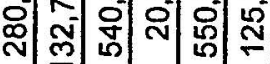

काल 0 응

뒬 लु

ल는

กี่

ㅊํ응응

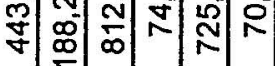

m 9070

का

ल 0000

命

न

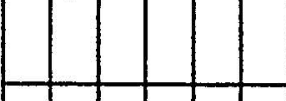

क

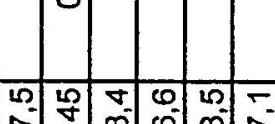

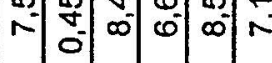

$\infty$ -

స్ $0^{-}$N N

$\infty-1000$

งิโั กิ กิ กิ

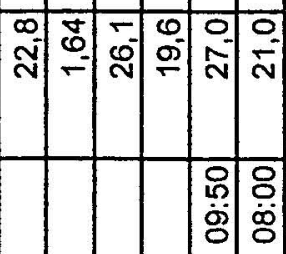

$ه$ 造

의의 की

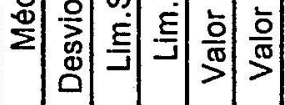




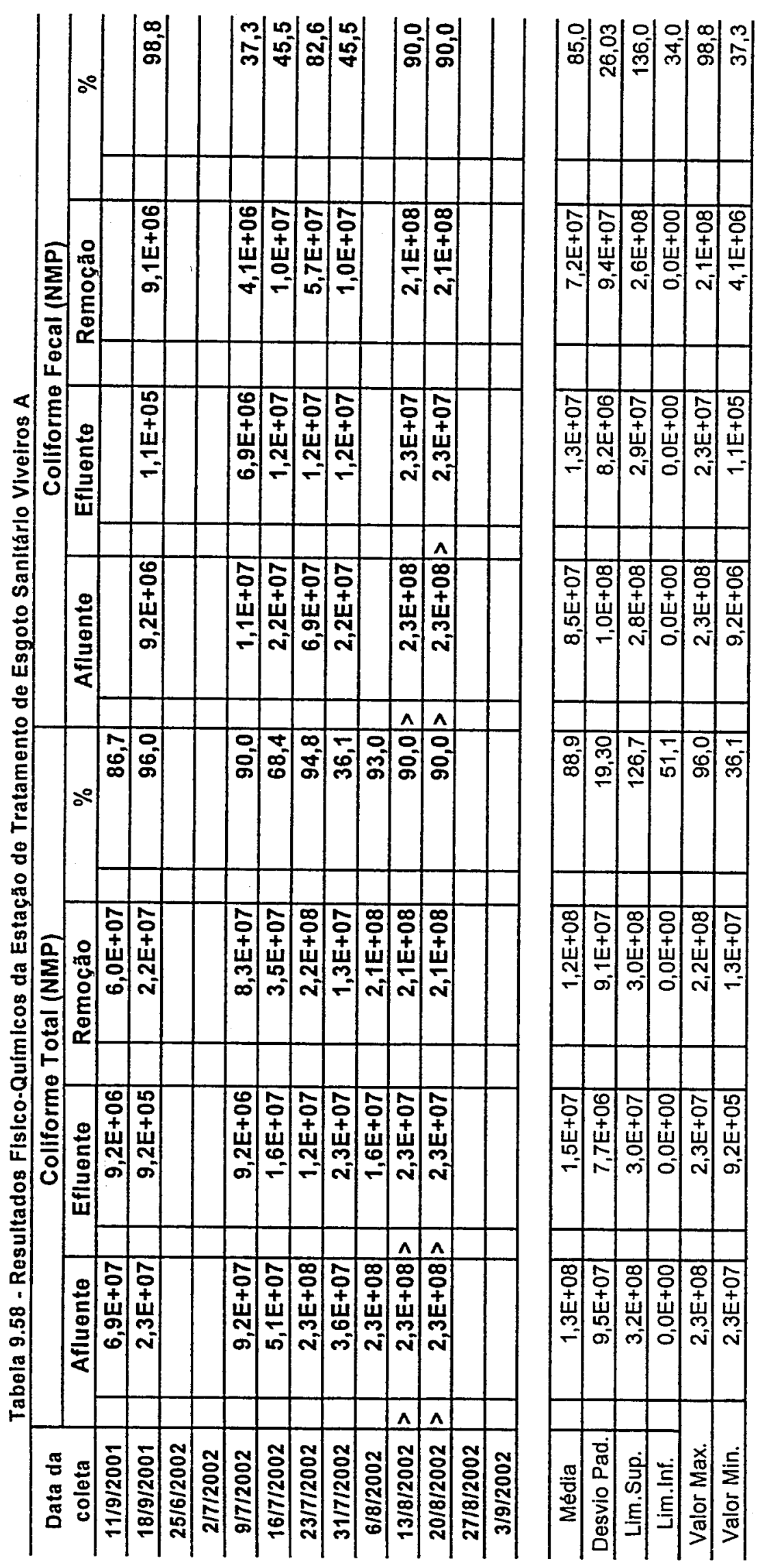




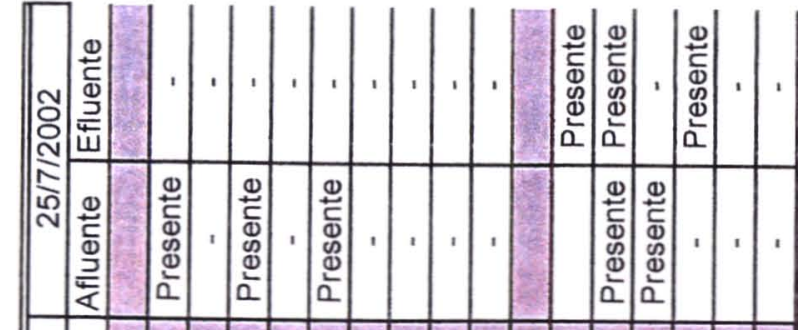

$\stackrel{\frac{\Phi}{c}}{\frac{\Phi}{2}}$

승

- $\frac{\Phi}{\frac{\pi}{\Phi}}$

产

ป

W्ञ

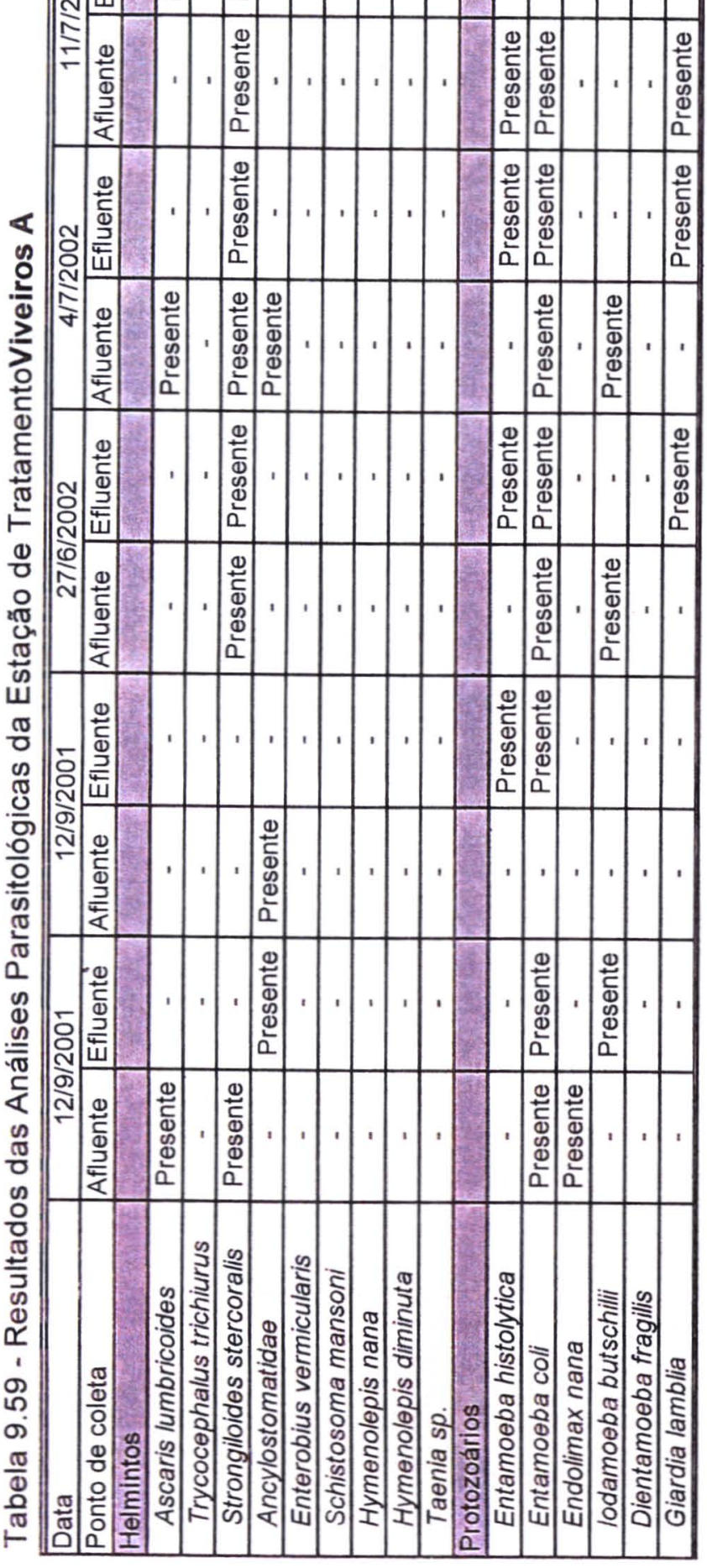

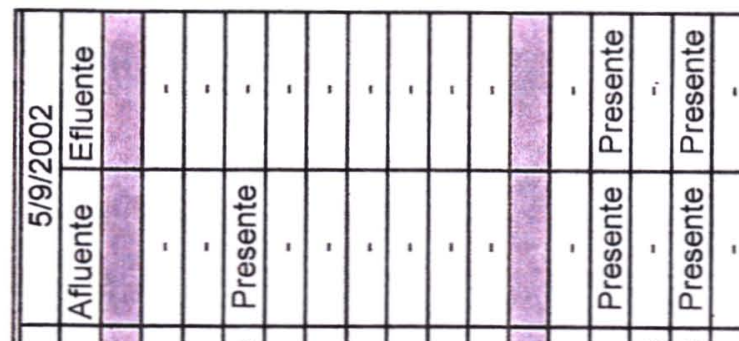

\begin{tabular}{|c|c|c|c|c|c|c|c|c|}
\hline 焉 & t & , & & ' & 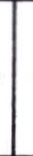 & & 8 & 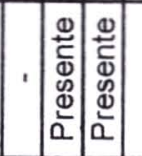 \\
\hline
\end{tabular}

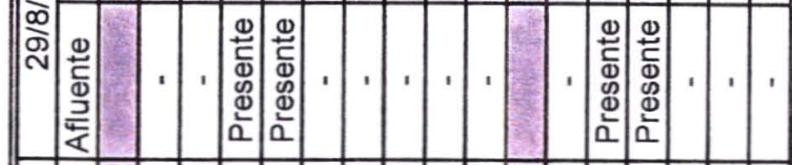

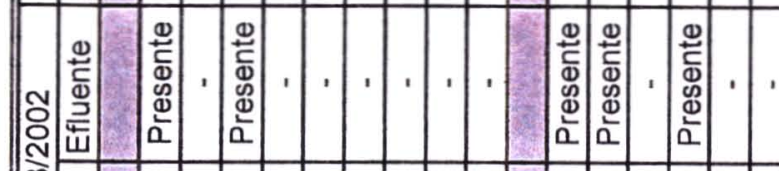

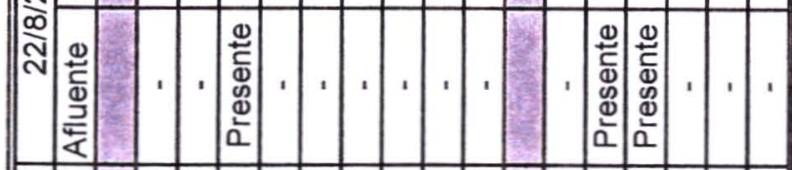

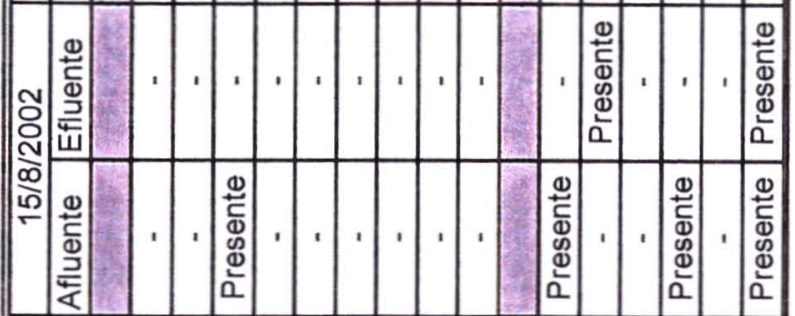

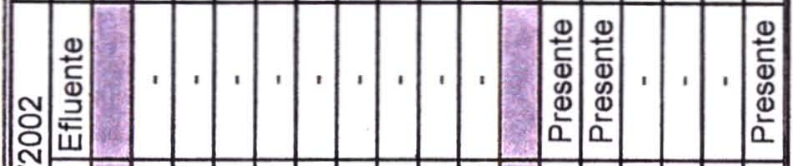

$\infty$

$\infty$

竞

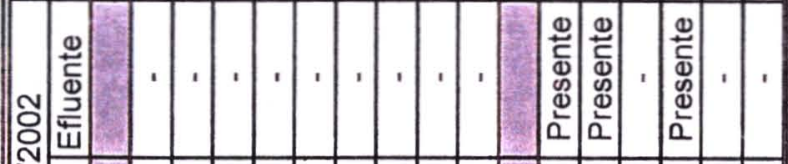

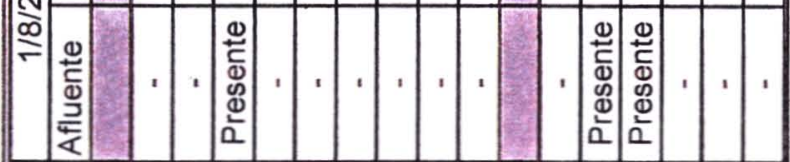

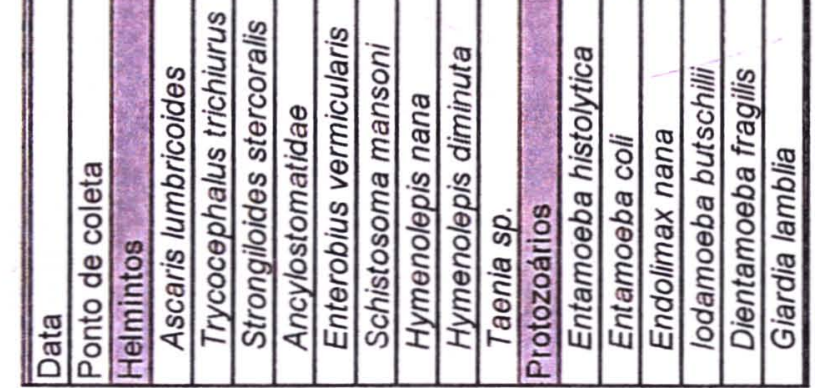




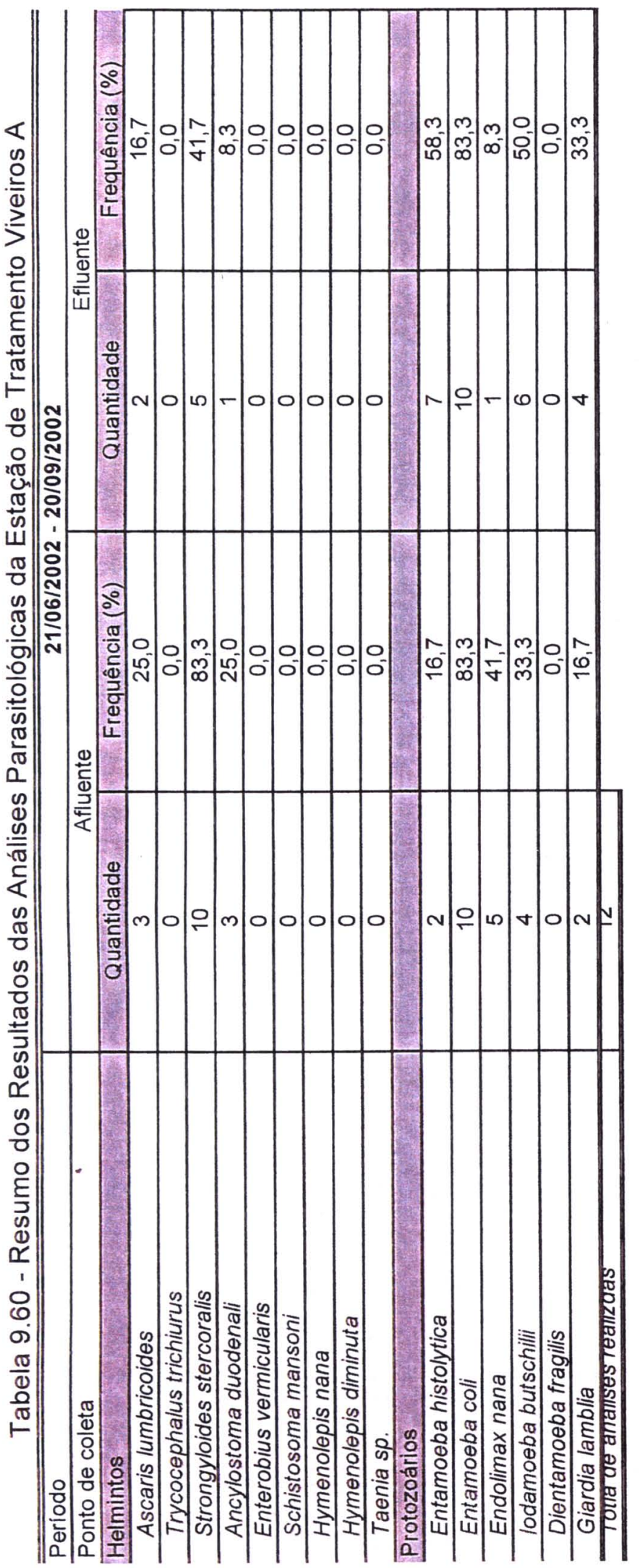




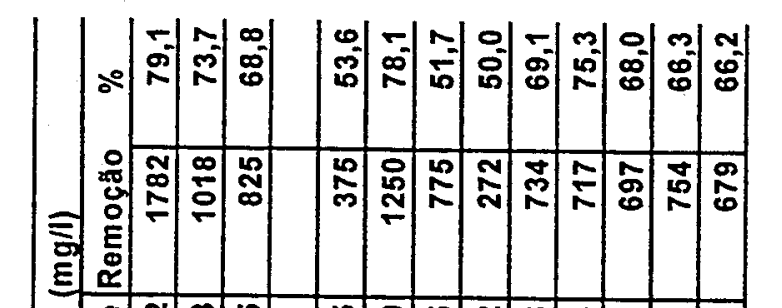

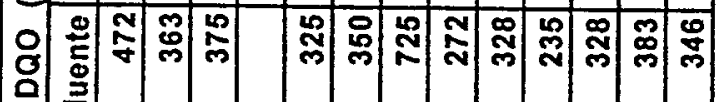
娄

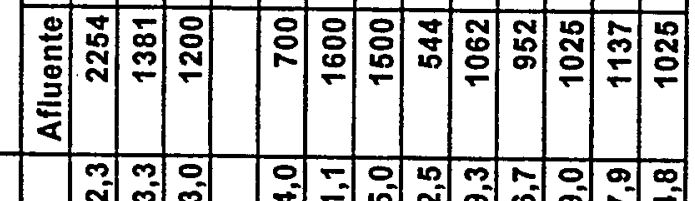

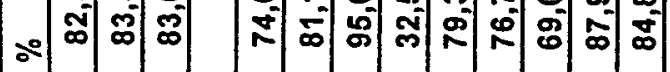

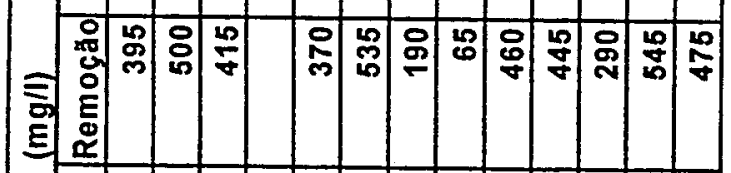

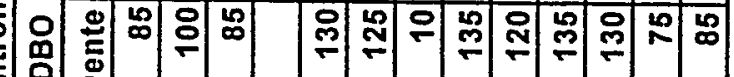

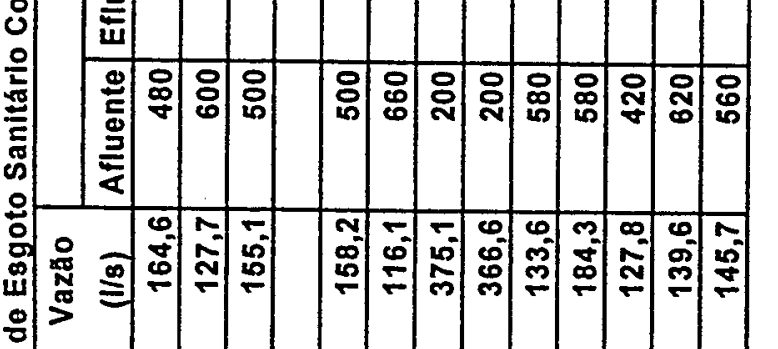
突

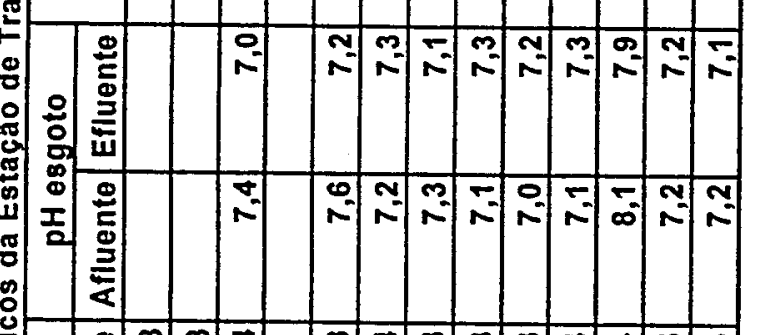

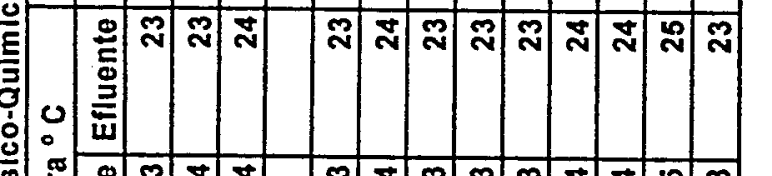

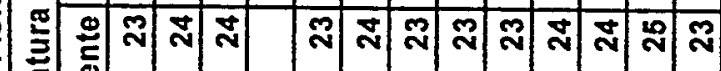

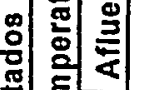

: $\stackrel{0}{\mathbf{\alpha}}$

$\frac{\pi}{0}$

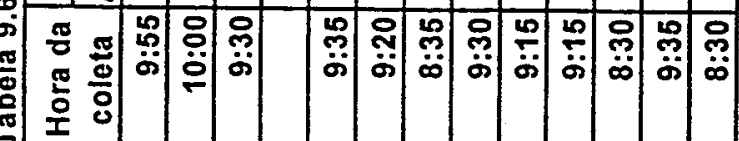

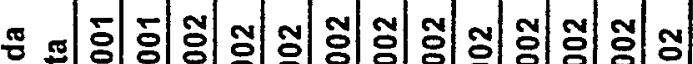

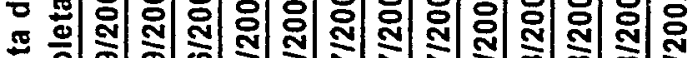

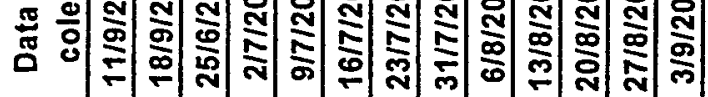

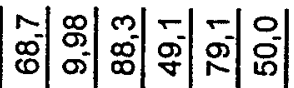

ㄴ. 零

N m

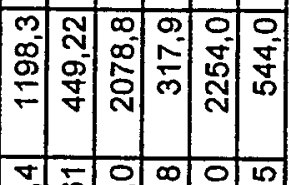
苟

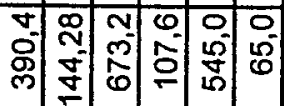
m 은

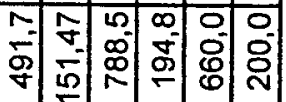

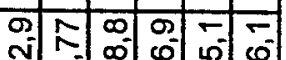
灾

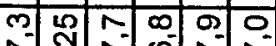
$N$ Nón

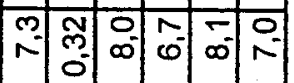
ద

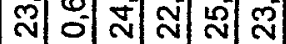

0 न क ल 00 ฟั

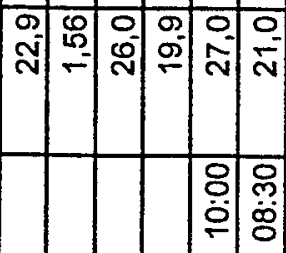

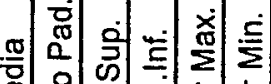

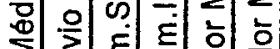

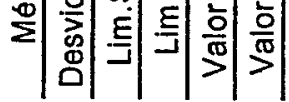




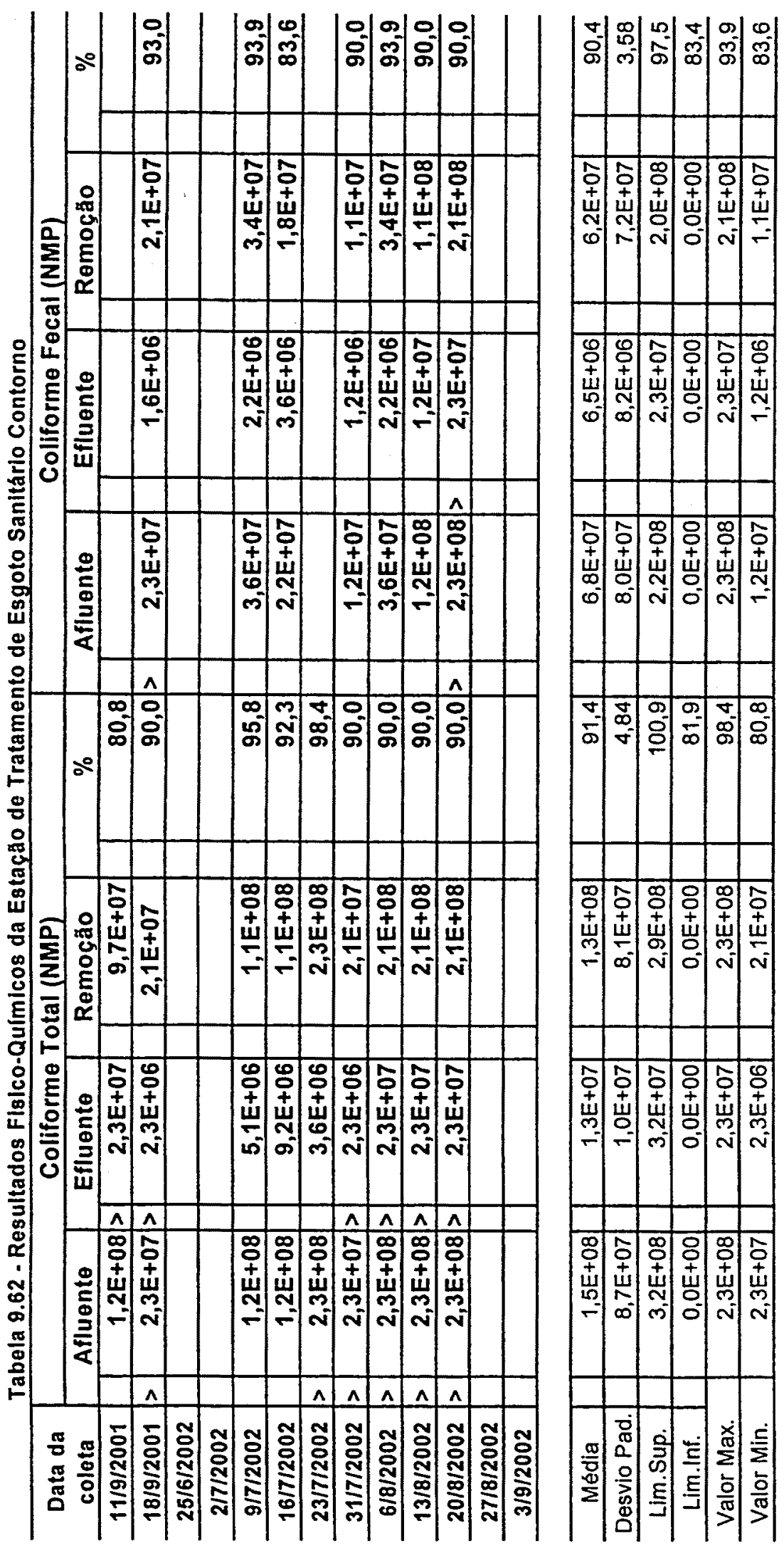


|
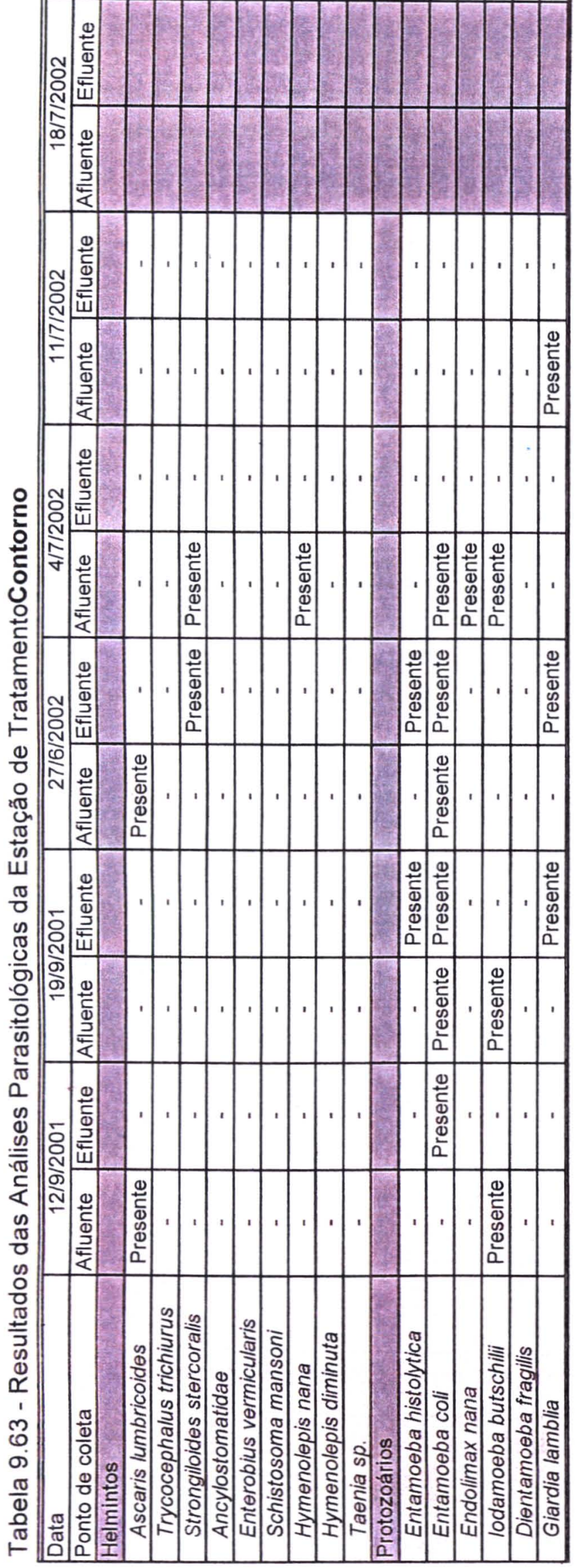

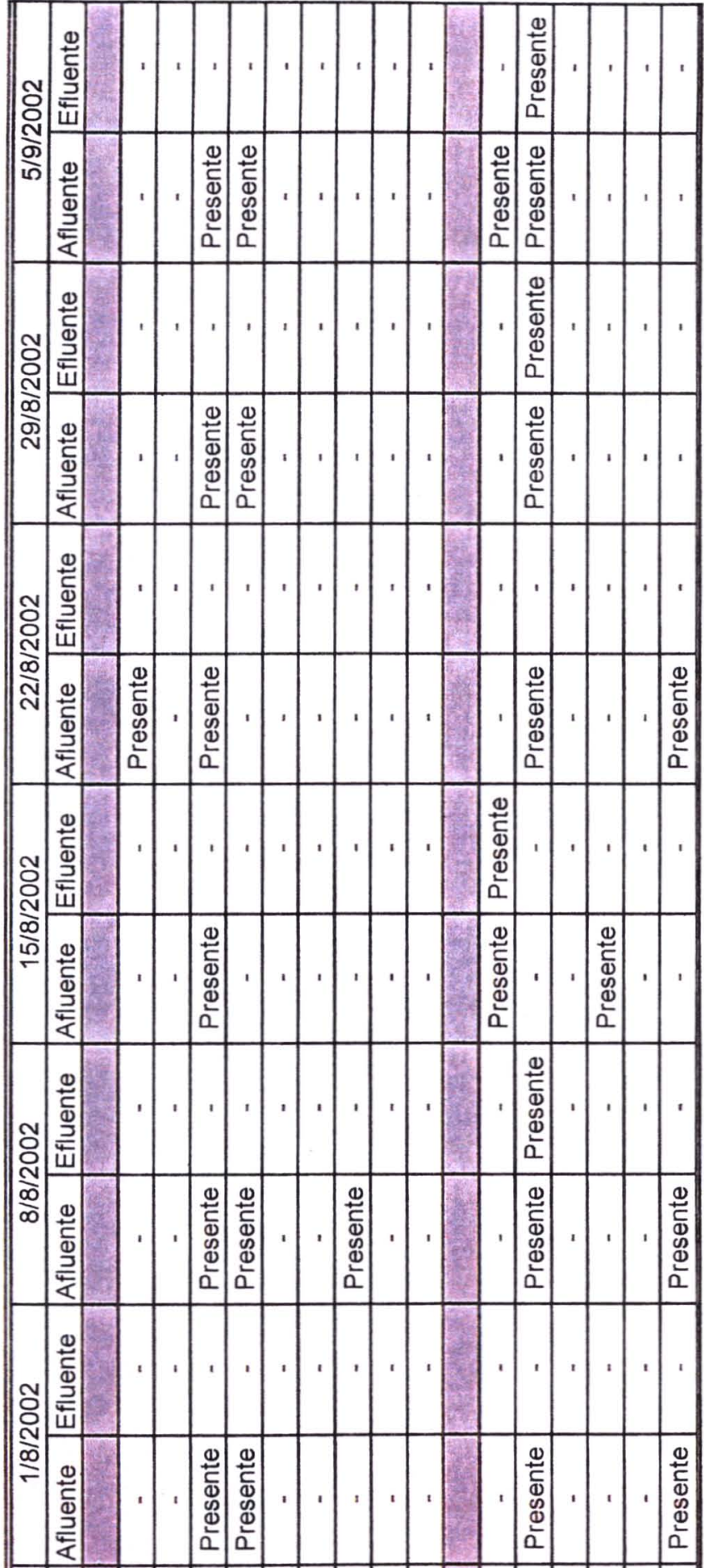




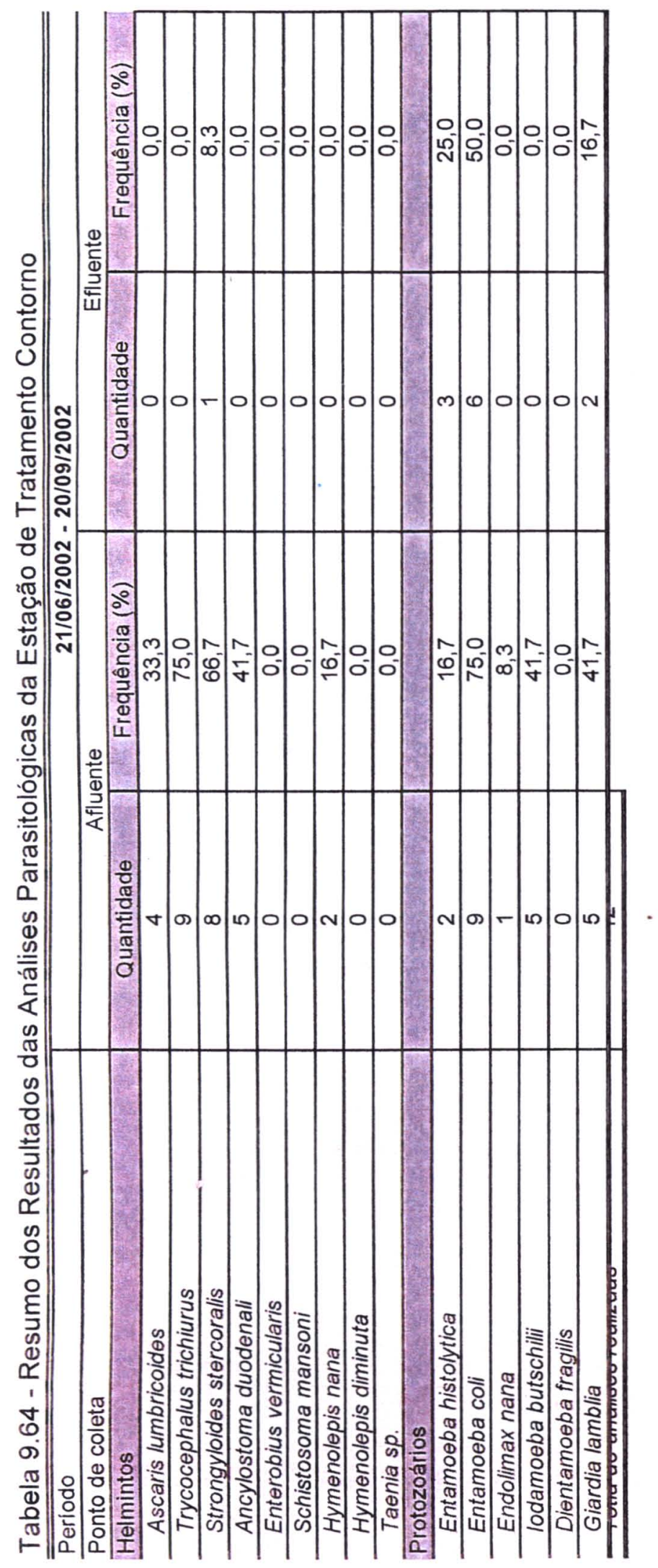

